

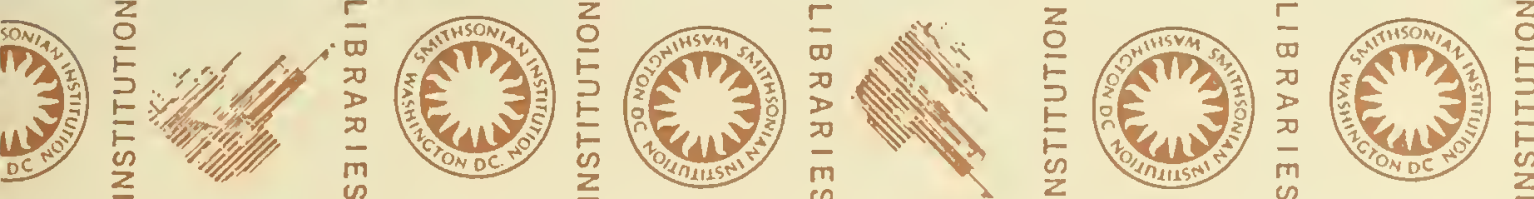

(I)

\section{(1)}
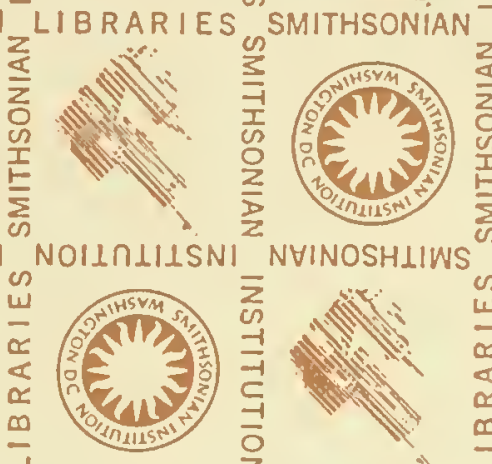

S 1 Y 84817 LIBRARIES
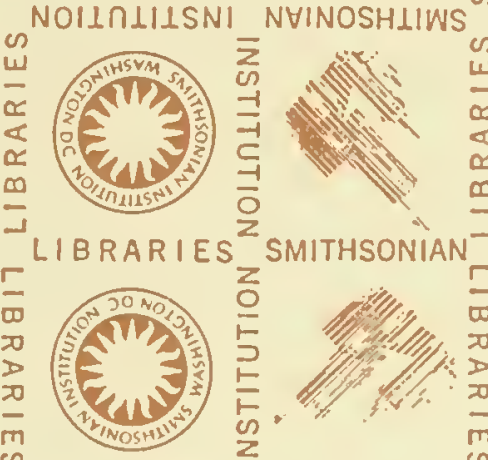
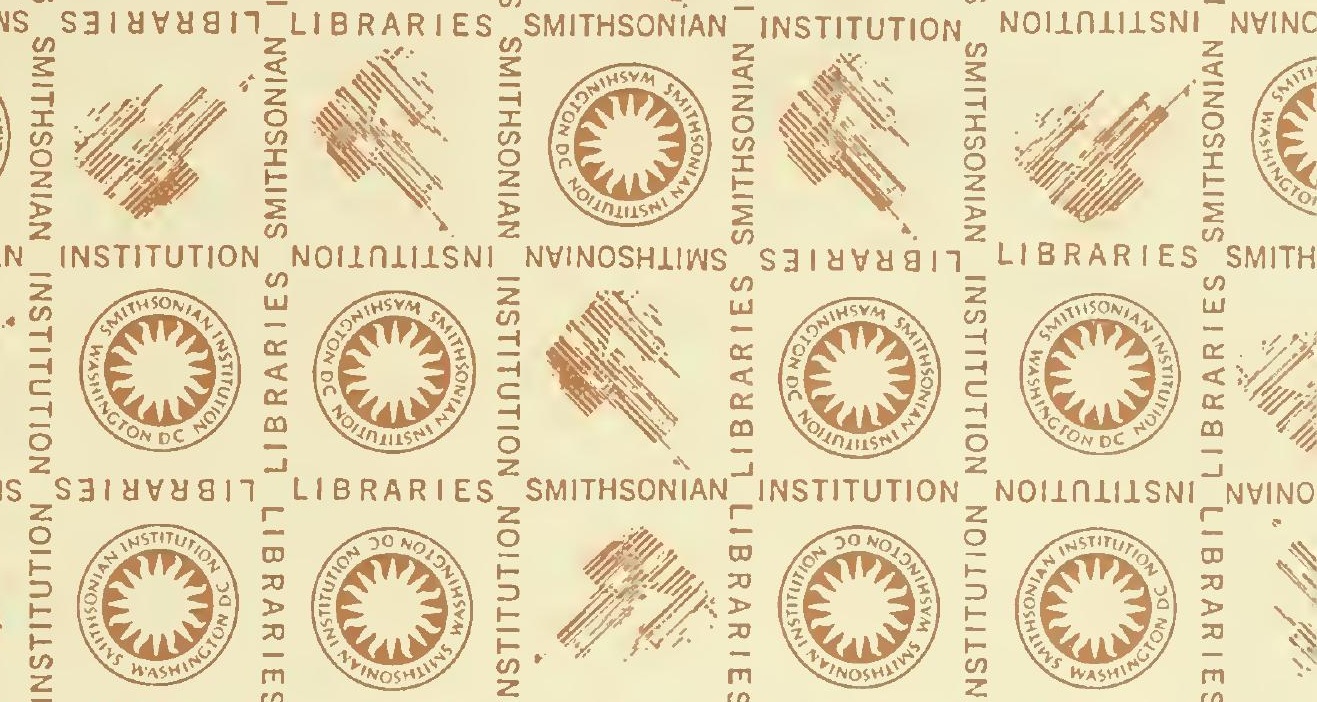

ARIES SMITHSONIAN
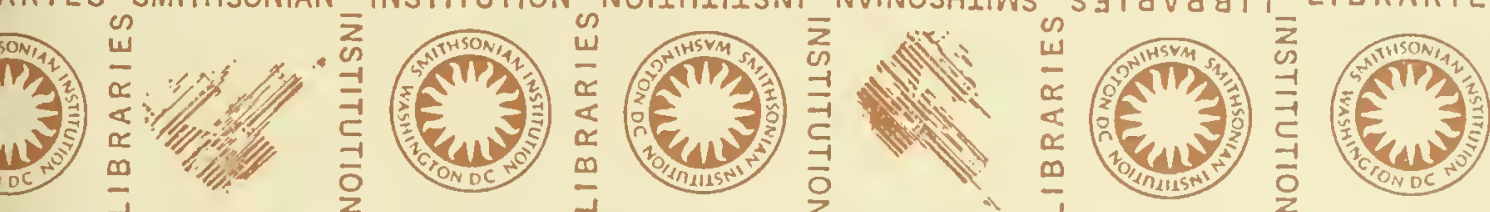

IILSNI NVINOSHLIWS
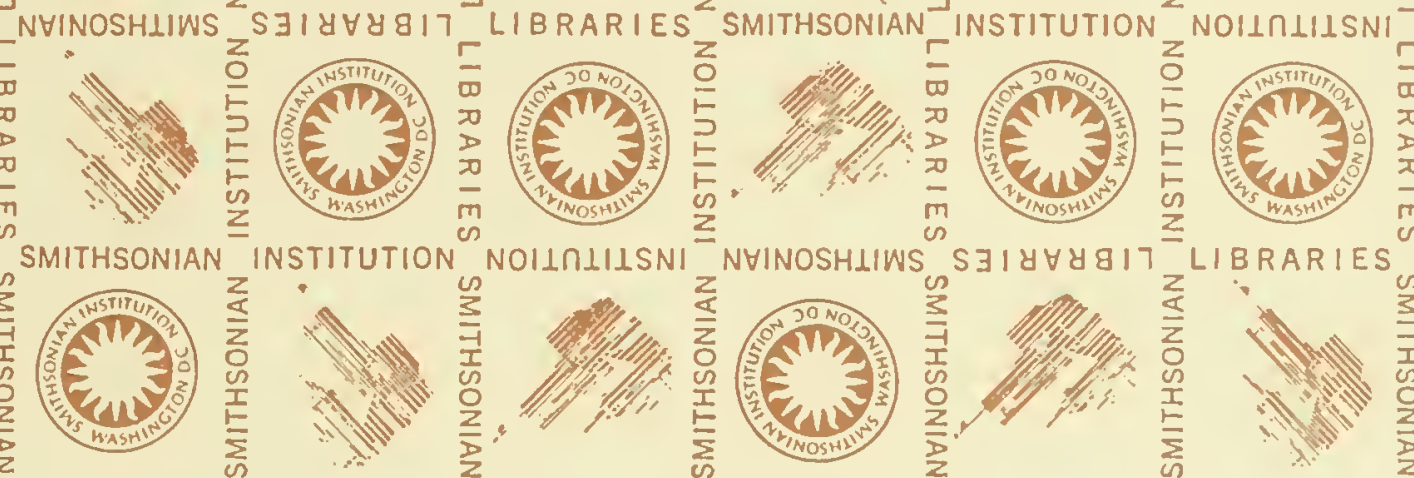

\section{在}
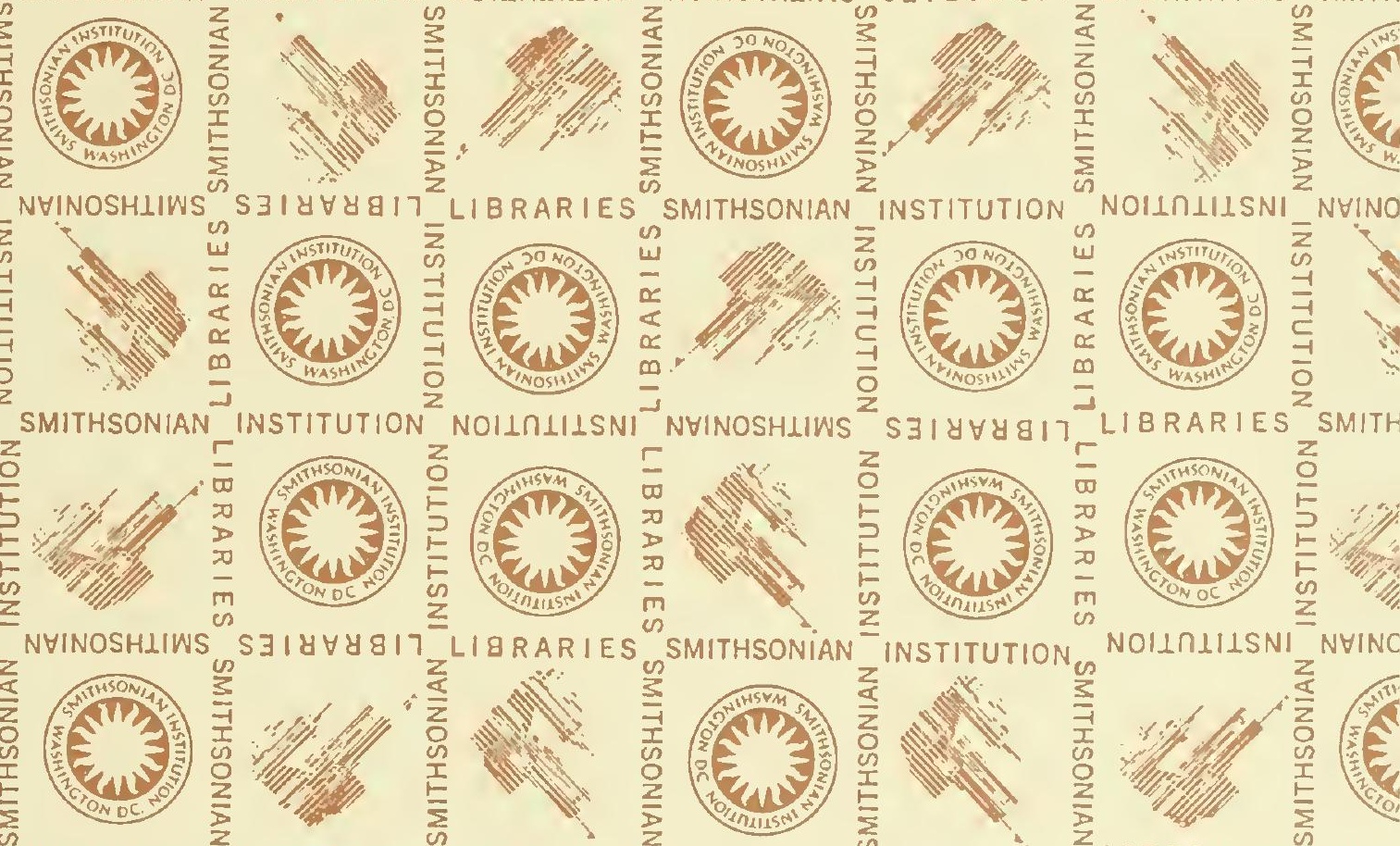

ARIES SMITHSONIAN
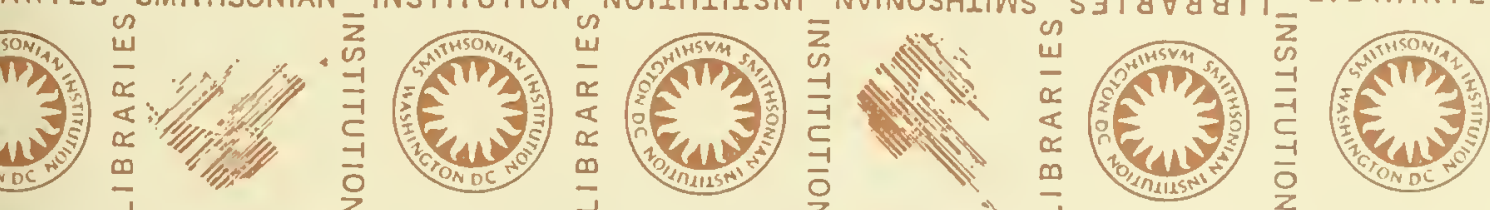

IIISNI NYINOSHLIWS

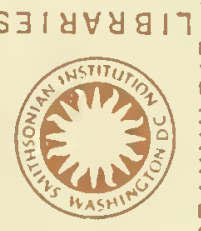

LIBRARIES
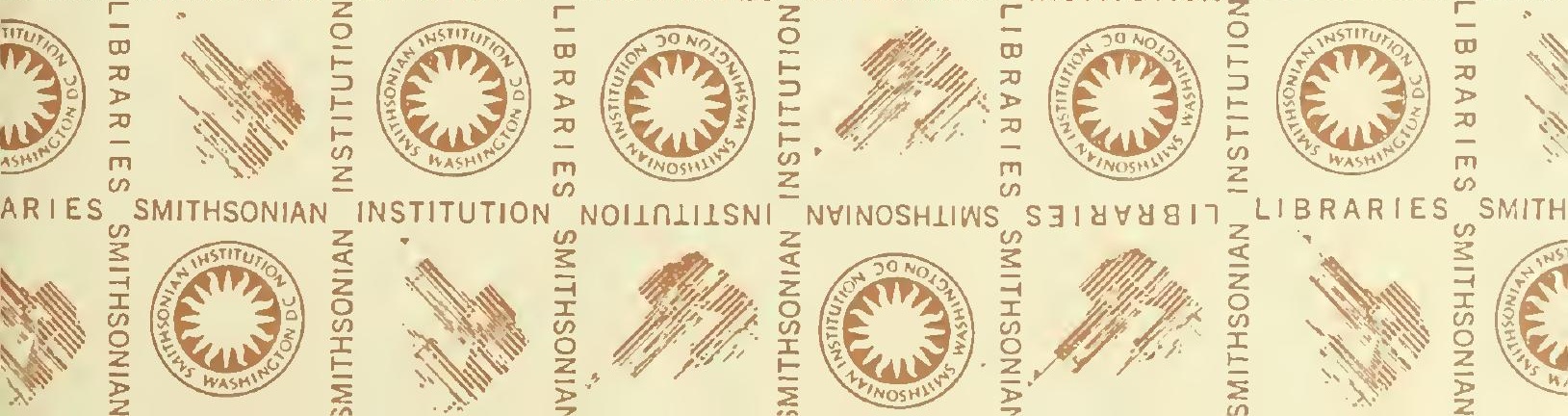



\section{UNIVERSITY OF CALIFORNIA PUBLICATIONS}

Note.- The Unlversity of Callfornia Publications are offered in exchange for the publycations of learned socleties and institutions, universities, and libraries. Complete ists of all the publications of the University will be sent upon request. For sample coples, lists of publications or other information, address the MANAGER OF THE UNIVERSITY PRESS, BERKELEY, CALIFORNIA, U. S. A. All matter sent in exchange should bo addressed to THE EXCHANGE DEPARTMENT, UNIVERSITY LIBRARY, BERKELEY, OALIFORNIA, U. S. A.

\section{WILLIAM WESLEY \& SONS, LONDON}

Agent for the series in American Archaeology and Ethnology, Betany, Geology, Physlology, and Zoology.

ZOOLOGY.-W. E. Ritter and C. A. Kofoid, Editors. Price per volume, \$3.50; beginning with vol. 11, $\$ 5.00$.

This series contains the contributions from the Department of Zoology, from the Marine Iaboratory of the Scripps Institution for Blological Research, at La Jolla, California, and from the California Museum of Vertebrate Zoology in Berkeley.

Cited as Univ. Calif. Publ. Zool.

Volume 1, 1902-1905, 317 pages, with 28 plates $\$ 3.50$

Volume 2, 1901-1906, xvii + 382 pages, with 19 plates .................................................. \$3.50

Volume 3, 1906-1907, 383 pages, with 23 plates ............................................................. \$3.50

Volume 4, 1907-1908, 400 pages, with 24 plates .............................................................. \$3.50

Volume 5, 1908-1910, 410 pages, with $3 \pm$ plates ........................................................... \$3.50

Volume 6, 1908-1911, 478 pages, with 48 plates ............................................................. \$3.50

Volume 7, 1910-1912, 446 pages, with 12 plates............................................................. \$3.50

Volume 8, 1911, 357 pages, with 25 plates .................................................................... \$3.50

Volume 9, 1911-1912, 365 pages, with 24 plates ............................................................... \$3.50

Volume 10, 1912-1913, 417 pages, with 10 plates .......................................................... \$3.50

Volume 11, 1912-1914, 538 pages, with 26 plates .......................................................... \$5.00

Volume 12, 1913-1916, 558 pages, with 22 plates ............................................................... \$5.00

Volume 13, 1914-1916, 529 pages, with 39 plates .............................................................. \$5.00

Volume 14, 1914-1918, 452 pages, with 60 plates ................................................................ \$5.00

Volume 15. 1915-1916, 360 pages, with 38 plates ............................................................. $\$ 5.00$

Volume 16, 1915-1917, 522 pages, with 46 plates ................................................................. \$5.00

Volume 17, 1916-1918, 545 pages, with 24 plates ................................................................. \$5.00

Vol. 17. 1. Diaguosis of Seven New Mammals from East-Central Callfornia, by Joseph Grinnell and Tracy I. Storer. Pp. 1-8.

2. A New Bat of the Genus Ifyotis from the High Sierra Nevada of Callfornia, by Hilda Wood Grinnell. Pp. 9-10.

Nos. 1 and 2 in one cover. August, 1916

3. Spelerpes platycephalus, a New Alpine Salamander from the Yosemite National Park, Califorula, by Charles Lewis Camp. Pp. 11-14. Septem. ber, 1916

4. A New Spermophile from the San Jcaquin Valley, Callfornia, with Notes on Ammospermophitus nelsoni nelsoni Merriam, by Walter P. Taylor. Pp. 15-20, 1 figure in text. October, 1916

5. Habits and Food of the Roadrunner in Callfornia, by Harold C. Bryant. Pp. 21-58, plates 1-4, 2 figures in text. October, 1916

6. Description of Bufo canorus, a New Toad from the Yosemite National Park, by Charles Lewis Camp. Pp. 59-62, 4 figures in text. November, 1916......

7. The Subspecles of Sceloporus occidcntalis, with Description of a New Form from the Sierra Nevada and Systematic Notes on Other California Lizards, by Charles Lewis Camp. Pp. 63-74. Decemher, 1916

8. Osteological Relationships of Three Species of Beavers, by F. Harvey Holden. Pp. 75-114, plates 5-12, 18 text figures. March, 1917

9. Notes on the Systematic Status of the Toads and Frogs of California by Charles Lewis Camp. Pp. 115-125, 3 text flgures. February, 1917 ..

10. A Distributlonal List of the Amphiblans and Reptiles of Calffornia by Joseph Grinnell and Charles Luwis Camp. Pp. 127-208, 14 figures in text. July, 1917 


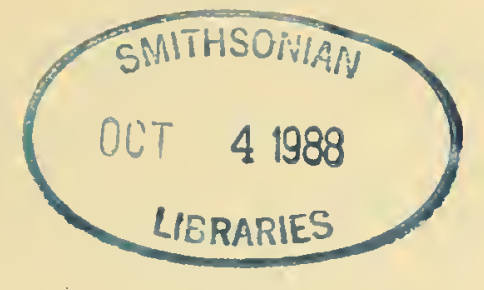

A QUANTITATIVE AND STATISTICAL STUDY OF THE PLANKTON" OF THE SAN JOAQUIN RIVER AND ITS TRIBUTARIES IN AND NEAR STOCKTON, CALIFORNIA, IN 1913/

BY

WINFRED EMORY ALLEN 
University of California Publications in Zoology Tol. 22, No. 1, pp. 1-292, pls. 1-12, 1 text figure Issued June 25, 1920 


\section{CONTENTS}

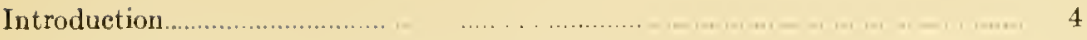

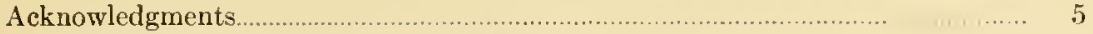

General features of San Joaquin River basin........................................... 6

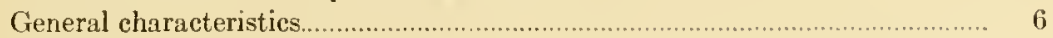

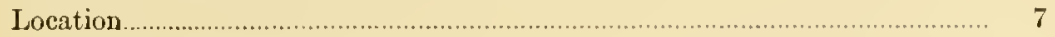

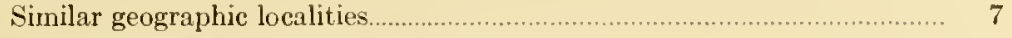

Geographic areas of middle California ................................................. 7

Size and form of Sau Joaquin drainage area......................................... 7

Forest areas........................................................................... 8

Rainfall.......................................................................................... 8

Important tributaries of San Joaquin River............................................. 8

The lings River.................................................................. 8

The Mlerced River................................................................... 9

The Tuolumne River................................................................... 9

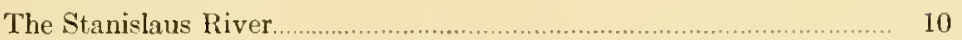

The Calaveras River................................................................... 10

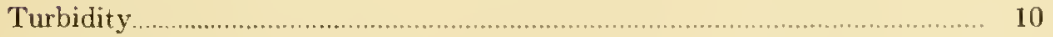

River couditions near Stockton ................................................................ 11

Relation of Stockton to tide-water .......................................................... 11

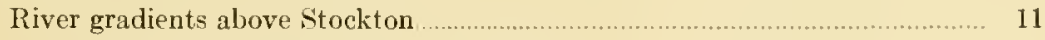

Opportunities for plankton development .......................................... 11

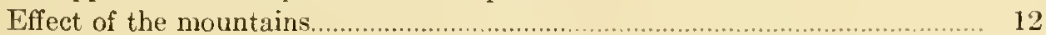

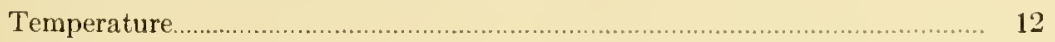

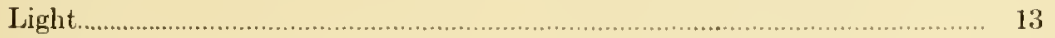

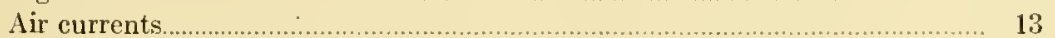

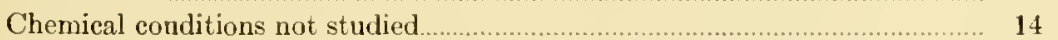

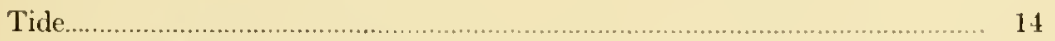

Aquatic and marginal vegetation ........................................................... 14

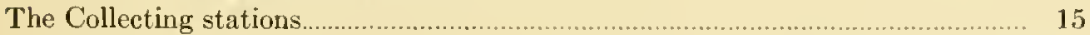

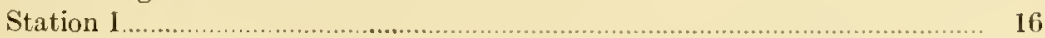

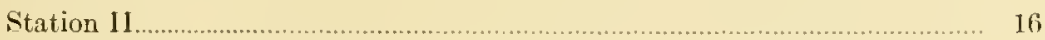

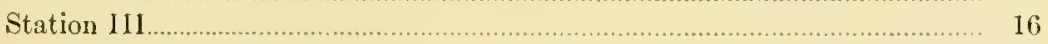

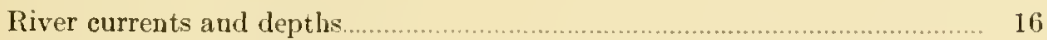

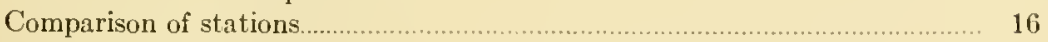

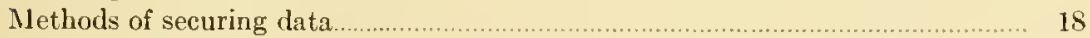

Time of collecting .......................................................................... 18

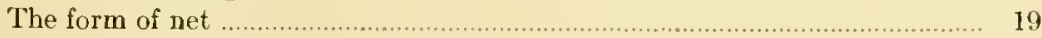

The amount of haul ........................................................................... 20

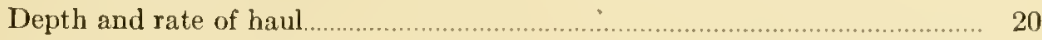

Records.................................................................................... 20

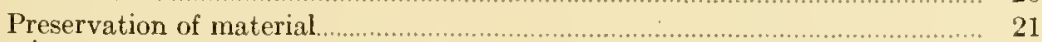

Tests of salinity............................................................................. 21

Measurement of volume................................................................ 22

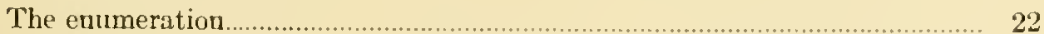

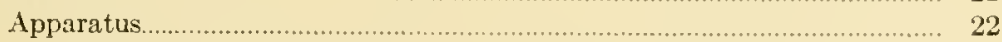

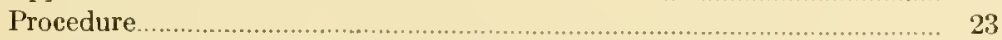

Standard concentration ........................................................... 23

Method of filling Sedgwick-Rafter cell........................................ 23 
PAGE

Miking and recording the count. .......................... 23

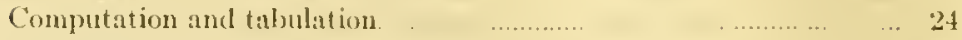

Identification of forms.

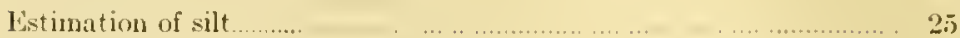

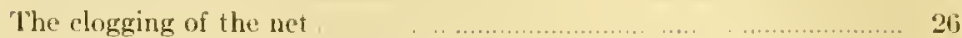

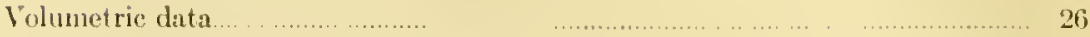

Organisms found in Sin Joaquin plankton .......................................... 27

Definitions, .. ....

Component forms.

The principal types of fresh water plinkton .............. . . . ......... 28

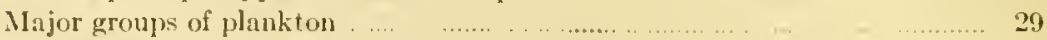

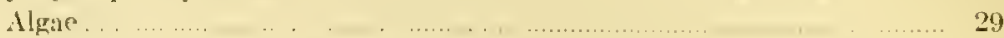

Zooplankton ........ .............

Totals of major groups $\ldots \ldots \ldots \ldots \ldots$

Comparison with similar groups of Illinois forms.......... . 32

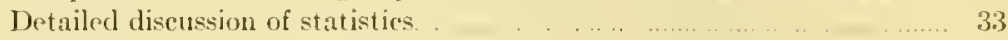

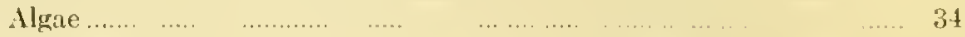

Bacteriaceac ........ , ... . ............ . . . . . 34

Schizophyceac .................................................. 34

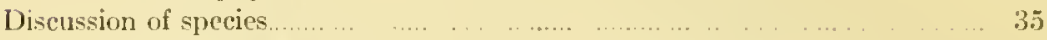

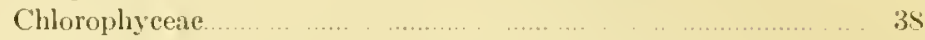

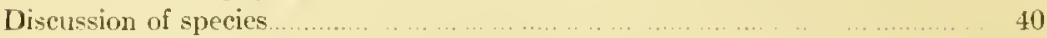

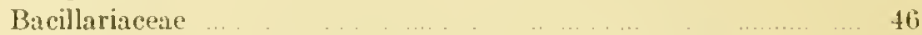

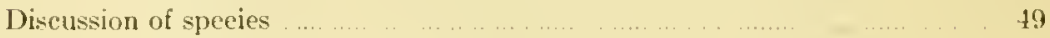

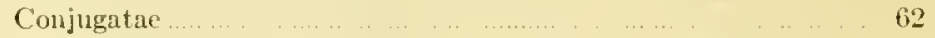

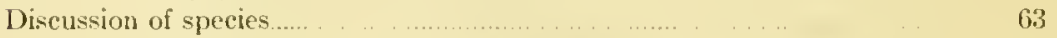

Chlorophyll bearing organisms and Mastigophora....

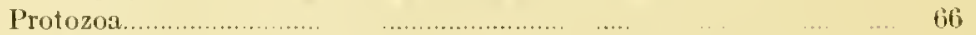

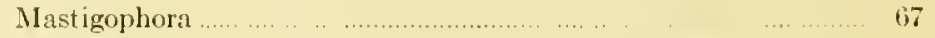

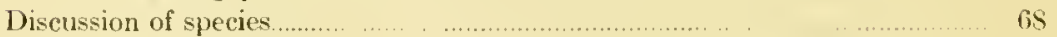

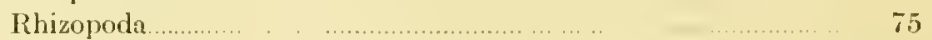

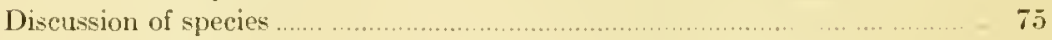

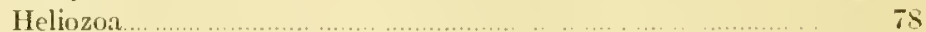

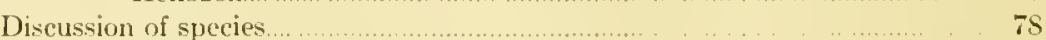

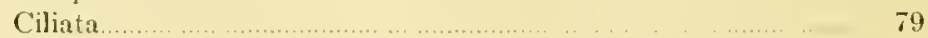

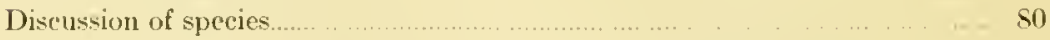

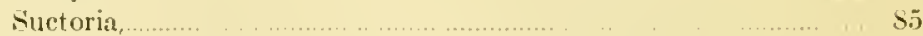

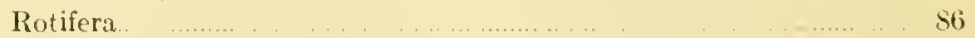

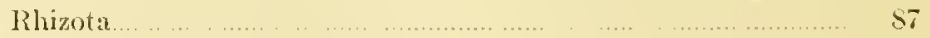

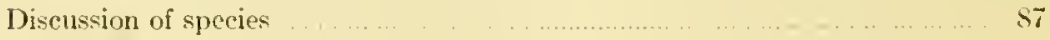

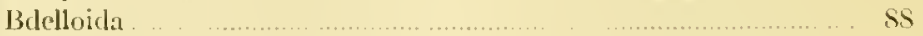

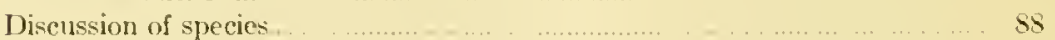

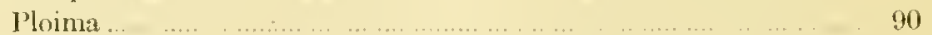

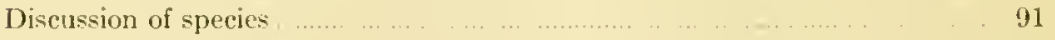

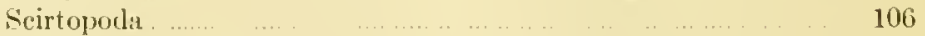

Gastrotricha ...................................... 106

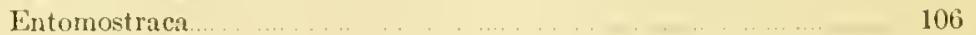

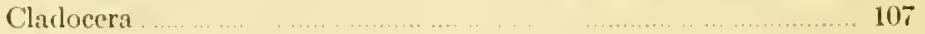

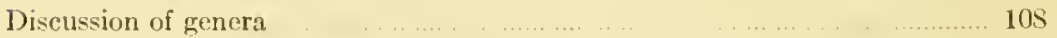

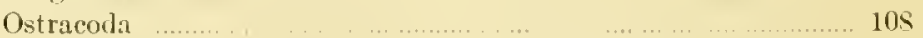

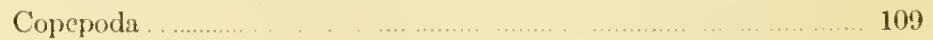


Discussion of genera.

PAGE Malacostraca.

109

Miscellaneous

The daily series

Summary.

114

The hourly series

116

Conclusion......

117

Addendum.

124

Tables 1 to 8

125

Literature cited.

Plates 


\section{INTRODUCTION}

The biology of fresh water is an attractive field for investigation both from the standpoint of ecology and lirom that of its practieal bearings on the problems of fisheries. The fresh water plankton with its varying components forms a hiological complex, or association of both plant and amimal forms which have an intimate relation not only each to the others, but also to the varying factors of their enviroment, sueh as light, temperature, organie and inorganie substances in solution, and to seasonal change attenclant upon the rum-off from the watershed.

Thas survey of San Franciseo bay undertaken by the Lnitud states Burean of Fisheries in 1912-13 in eoopperation with the University of California afforded an opportunity to initiate a survey of the plankton of the Sin Joatuin River, one of the principal tributaries of that lay. My position at Stockton as teaches of biology in the ITigh school afforded some laboratory facilities and also a location near the head of tidewater where the nltimate contributions of the stream of the bay conld be examined and where a variety of conditions were present, ineluding hoth the main chamel, and backwaters with varying rates of flow, as well as a canal much enriehed by sewage.

The author is eonseions not only of the serious and baftling diffienties that attend sucl an attempt at a contimuous piece of work but also of the errors which inevitably ereep in, especially in the initial stages of such an enterprise. These erross are, however, in the main, distributed throughout the data and do not necessarily invalidate onr conclusions. Sueh erors as occur in taxonomy are due to laek of the speceialist 's knowledge of nomenelature and symonymy, and of his eritical skill in the fince distinctions of speeies and subspeeies. The species as I lave lecorded them are at least gronjes of recognizably. similar organisms. The largest souree of significant error in this ceological stuly is the not improbable inchusion in such groups, of small numbers of less abundant or rare speeies of elosely similar form. 


\section{ACKNOWLEDGIENTS}

This investigation owes its origin to the eommittee in eharge of the survey of San Franeiseo Bay, of whieh Professol Charles A. Kofoid, is chairman, and was undertaken under the anspices of the United States 13nrean of Fisheries, to which I am indebted for equipment of nets and supplies.

Both Dr. F. B. Sumner and Waldo K. Selmitt, sueeessive naturalists of the Tnited States Steamship "Albatross," have lent their eneonragenent to my efforts and have also titrated some water samples. For literature, or assistanee in seeuring it, sineerest thanks are hereby given to Professor S. A. Forbes, of the Illinois State Laboratory of Natural History, to the Aiehigan State Fish Commission, to Professor II. W. Conn of Comnectieut, to Professor H. B. Ward of the University of Illinois, to Dr. Vincente Izquierdo of Santiago, Chile, to the Inited States Geological Survey, to the Chief of Engineer's of the United States War Department, to Professor F. E. Clements of the University of Minnesota, to Dr. William F. Allen of the University of Iimnesota, and to the Library of the Eniversity of Minnesota, to Dr. C. Dwight Marsh of the United States Bureau of Plant Industry, to Mr. H. K. Harring of the United States Bureau of Standards, to Professor C. J. Elmore, Grand Island, Nebraska, to Dr. B. W. Evermann of the Califomia Aeademy of Seimee, to Professor E. A. Birge of the University of Wiseonsin, and to Professor C. A. Fiofoid of the University of California.

Dr. Marsh and Mr. Harring have also very kindly made some identifieations of copepods and rotifers. Very material aid has been given by Mr. F. P. Higby of the California State Hospital at Stoekton, who has given full use of his weather reeords; and to Mr. Lawrence Backes of Stockton for photographie views of the stations. Above all it should be sail that whatever value there may be in the presont paper is largely dependent upon the adviee, encouragement and assistanee of Professor C. A. Kofoid; and upon the painstaking eare with which Mrs. W. E. Allen has computed, reeorded and preserved most of the data as they came to hand. Inasmueh as Professor. Kofoid 's report on the Illinois River has been in eonstant use for reference and guidanee it has been used liberally for suggestive ontline of discussion. Many of its generalizations and eonelusions are assumed 
as applying here, but some points will reeeive special notice for the murpose of comparing eonditions there and here when the data will permit.*

\section{GENERAL FEATURES OF THE SAN JOAQUIN RIVER BASIN}

The writer laas sot yet had sufficient opportunity to collect detailed information on this topie. The California report by Clapp and Henshaw (1909), to the United States Geologieal Survey, upon the surface water supply gives an excellent discussion of the most important features and it forms the main basis for this present bricf discussion.

\section{GENERAL CIIARACTERISTICS}

Two points of difference from the typieal river basin in its latitude are interesting elaracteristics of the San Joaduin. First, its drainage is northwestward away from the equator. Second, it consists throughout of a rather deep trough with comparatively abrupt sides and umusually flat bottom, the level of which is repeatedly broken by the deltas of tributaries entering in most cases very nearly at right angles. The land surface.varies markedly in character with the differences in these tributaries, but with a constant tendency to the formation of swamps and marshes at the lower points through the deposit of the lighter organie matter not left in the tributary deltas. This condition is very prominent from some distance above Stockton on to the month of the river. Stockton itself is on the eastern border of an area of swampy peat land through which the course of the river ean be maintained only by extensive systems of levees. Even then great stretches of the lower levels are inundated each year, and Stockton has the peremial prohlem of escaping from floods.

It is quite evident from the foregoing that the lower valley as a whole is fertile, with a deep soil of good texture. The lower part is fairly well settled but there is as yet no adequate control of the water supply and an extensive area is practically undeveloped. The few eities are small and far apart. None of them is so situated as to cause any appreciable contamination of the river water near Stockton. The whole basin is under the direet influence of the "dry" and "wet" seasons. With its low levels, this results in sluggish, almost stagnant flow of the main river during the first, and a brisk flow during the run-oft of flood waters incident to the second.

* This paper is published by permission of Dr. H. M. Smith, commissioner of the United States Bureau of Fisheries. 


\section{LoCATION}

\section{SIMILAR GEOGRAPHIC LOCALITIES}

The San Joaquin River lies in about the same latitude as the larger part of the Mediterranean Sea, the headwaters of the Tigris and Euphrates, and a considerable portion of the Hoang Ho, both of headwaters and lower reaches. It extends northwest from about $35^{\circ}$ to $38^{\circ}$ $\mathrm{N}$. latitude between $118^{\circ}$ and $122^{\circ} \mathrm{W}$. longitude. The main basin lies on the isotherm of $60^{\circ} \mathrm{F}$. Similar average temperature conditions are found in the Potomac region of the United States, along the northern border of the Mediterranean Sea and in north central China near the coast. Stoekton lies in latitude $37^{\circ} 57^{\prime} 30^{\prime \prime} \mathrm{N}$., longitude $121^{\circ} 17^{\prime} 30^{\prime \prime}$ W. and on isotherm $60^{\circ}\left(15.5^{\circ} \mathrm{C}\right)$. The altitude at the steamer landing in mid-city is sixteen feet, according to Mr. A. L. Miner, assistant city engineer.

\section{GEOGRAPHIC AREAS OF MIDDLE CALIFORNIA}

The part of California containing the San Joaquin system is a region of great diversity, but it is quite distinetly composed of three parallel strips of country. There is the Coast Range at or near the western border of the state, the central plain known as the San Joaquin Valley, and the Sierra on the eastern border. The part with which we are immediately concerned is comprised in the eastern slopes of the Coast Range, 4,000 square miles, the valley, 12,700 square miles, and the western slopes of the Sierra, 16,000 square miles. The range of altitude is from near sea level in the lower valley through some hundreds and thousands of feet in the Coast Range and the Sierra foothills up to over 14,000 feet in the High Sierra. The gradient is slight leugthwise of the valley, very steep, commonly twenty to forty feet to a mile, to the Coast Range, and generally moderate to the Sierra, averaging nearly five feet to a mile.

\section{SIZE AND FORM OF SAN JOAQUIN DRAINAGE AREA}

The total length of the San Joaquin River is near 350 miles, 125 miles from the High Sierra to the main valley and 225 miles thence to the outlet into Suisun bay, 50 miles from San Francisco. All the important tributaries are from the Sierra slopes, which consist mainly of granites and metamorphic roeks, sedimentary and igneous. The slopes of the other side are mostly sandstone, shale and conglomerates. 
The ditferenees in gradient partly canse an asymetery of the valley floor which is male prominent by the differences of the streams on the two sides. Since the streans on the east side are larger. they have built larger deltas with a witer spuend as they eross the lighter, longer slopes. Deltas from the two sides have united across the valley, cutting off the Tulare hasin. For this reason water from the large streans at the heat of the valley does not reach the San Joaquin River, except in years of unusual rainfall. Thus about one-fourth of the main basin is practieally separated from the rest and this sonthern area rarely has any influence on northern conditions.

\section{FOREST AREAS}

There is no important forest eover in the main valley. Some of the higher gromel in the Coast Range bears shrubbery and light timber. The Sierra foothills are usually well covered with grass, brush and scattering trees. Alove the foothills is heav timber to 10,000 feet. above which none oceurs. The famous Sequoias oceur in this region. National forests oceny about 65 per cent of the Sierra slopes.

\section{RAINFALL}

The anmual rainfall varies from five to twenty inches from sonth to north along the valley. The west slope has light rainfall with similar increase northwest. The Sierra slopes show heavier precipitation aceording to altitude, but with similar inerease to northward.

\section{IMPORTANT TRIBUTARIES OF SAN JOAQUIN DRAINAGE AREA}

In addition to the foregoing consideration of the main river and the basin as a whole it is worth while to include some points concerning three or four of the principal tributaries which may have some recognizable influence at Stockton.

\section{THE KINGS RIVER}

The King's River is the most southerly tributary that has any ordinary connection with the San Joaquin. Its relation is rather peculiar sinee its delta forms a large part of the barrier entting off the T'ulare Lake Basin from the main valley. This delta has been built in such a way as to calry the entipe flow of the Kings River to the San Joaquin thuring low water, but most of the flood waters go to Tulare Lake. The altiture near the entrance of the San Joaquin is about 175 feet accorting to Clapp and Henslaw (1911). 
King's River basin has fifty miles of Sierra divide as its eastern border, with some altitules above 14,000 feet. Its length is about sixty miles in the mountains, with an area approximating 1,840 square miles. The river sonree eonsists of many little glacial lakes at the edge of glaciers and perpetual snow. The length of the river to the month of its eañon is nearly 85 miles.

The basin as a whole is very rough and irregular, the head espeeially including the most rugged region in the Sierra. Nearly all the tributaries 'mu through glaeial cañons cut through solid granite. Several of the latter are 2,000 or 3,000 feet deep. The whole formation is granitic.

The larger part of the basin is well forested up to 10,000 feet Most of it is in the National Forest Reserve. Precipitation ranges from eight to ten inches in the San Joaquin. Valley to fifty or sixty inches in the high altitudes. Most of the precipitation of this basin is in the form of snow.

\section{The Merced River}

The Merced River drains an area sixty-five miles in length from Mount Lyell on the Sierra divide (13,090 feet) down to the San Joaquin River. This ineludes a total of 1,200 square miles. The river itself is about 135 miles in length, with four or five tributaries of some importance, including the famous Yosemite Creek. Though the Yosemite Valley is the most remarkable, there are other parts of the basin very rough and broken, with many waterfalls and glaeiated regions. Abont 850 square miles of the upper part of the basin is ineluded in national forests, thongh there is little growth alove 12,000 feet. The anmual precipitation in the San Joaquin Valley near the mouth of the Merced sixty or seventy miles from Stoekton, is ten to fifteen inches and it ranges throngh twenty-five inehes in the foothills to about sixty inches near the divide. Even in the monntains this precipitation oceurs mainly in the rainy season, mostly as snow, the melting of which is most rapid in May and June.

\section{The Tuolunne River}

The Tuolumne River traverses a basin 105 miles long, two-thirds of which is in the mountains. The mountainous portion is about 1,680 square miles in area. This river is 150 miles long, about 80 miles of whieh is through a deep eañon eut down into solid granite. This eañon drains numerous glaeial lakes at the Sierra divide, and the upland meadows shightly lower down. The basin as a whole is 
very rough, with bare, glaciated roeks of granite in the upper parts. Altitudes vary from 300 feet in the foothills to 12,000 or 13,000 feet at the divide. Upper parts have no forests, but there is a median belt heavily forested with coniferous trees. The lower region has only grass and brush, usually. There is about 1,200 square miles of National Forest in the mountains. Precipitation is about ten inches per annum in the region near the junction with the San Joaquin, 25 or 30 miles from Stockton. It ranges to sixty inches at high altitudes where most is snow, the greater part of which disappears in spring.

\section{The Stanislaus River}

The Stanislaus River has a long, narrow basin, about 75 miles in length and an area of somewhat over 950 square miles. The length of the river is about 120 miles, 80 miles in the mountains. The source is mainly in glaeial lakes about the divide and the mouth is about 20 miles above Stockton. The general character of the basin is quite similar to that of the Tnolumne.

\section{The Calaveras Rrver}

The Calaveras River flows near Stockton and empties six or seven miles below the city. It has some influence in flood season on account of the overflow, but in this case its influence would be much the same as that of those already mentioned since the flood waters of all are essentially similar. Furtlermore, the flood waters of the Calaveras are largely kept from the San Joaruin above Stockton by an enormous levee forming the so-ealled "diverting canal."

\section{TURBIDITY}

The turbidity of the water of the San Joaquin in the vicinity of Stockton at all times of the year is very characteristic. In the river ehannel this is obviously due to fine silt during the flood season but the plankton is the principal source in the sluggish water of late fall. Water in some of the sloughs sometimes becomes elear enough to reveal objects at a depth of six or eight feet. 


\section{RIVER CONDITIONS NEAR STOCKTON}

\section{Relition of Stockton to Tidewater}

In this connection it is doubtless worth while to reconsider the points already mentioned which have most obvious relation to Stoekton conditions. First, we may emphasize the fact of the low gradient. Since the steamer landing at Stockton is only sixteen feet above sea level the water level nust be only abont eight fect above sea level for a considerable part of each year. Stockton is about one hundred miles from the Golden Gate, so the gradient to the sea is only about 0.08 foot to the mile. This must account in large measure for the range of the tide, which sometimes shows a difference of something over three feet between high and low water in Stockton Chamnel.

\section{River Gridiext Aboye Stockton ·}

In the other direction, we find a rise to one hundred and seventyfive feet above sea level at the mouth of Kings River, probably about two hundred miles above Stockton. Assuming this distance as an approximation, we find the gradient above Stockton to arerage a little more than 0.8 foot to the mile. As might be expected from such a low gradient, there is a great deal of swamp land thronghont the distance. Formerly there was annual flooding of this low area during the wet season, with a good deal of deposit of silt and stirring up of organie matter, much of which came from the death of plants and animals in the preceding dry season. The definite limitation and constant alternation of dry and wet seasons, together with the proximity of the mountains, must have had a very marked influence on plankton production in the low lands under such conditions.

\section{OPPORTUNITIES FOR PLANKTON DEVELOPMENT}

Recently more and more of these low lands have been reelaimed and protected by levees. The run-off is thus materially hastened in flood season and there is much less opportmnity for plankton development than Kofoid has found for the Illinois River. There is also the further consideration that most eases in which impounding of the water occurs, show rapid evaporation after river subsidence, with great destruction of organisms before they have opportunity to get into the river channel. Unfortmnately, definite informatiou as to areas still open and details of their seasonal history are not available. 
At any rate, it seems that one explanation of the apparent numerieal deficiency in plankton modnetion as compared with the llinois nay be that there is less imponded water ready to develop and discharge flankton, and that there are no frecuently ocenring minor floods to wash ont these areas. It should be stated, howerer, that 1913 was an 11 usually dry year; henee the flood conditions were not typieal for this region.

\section{EFFECT OF THE MOUNT.INS}

The mountains probably have just as much influenee on plankton in the river as does the elaracter of the bottom lands. The Coast Range has no very extensive influence. In the main it is rather against flankton production. The slopes are steep and the run-off torrential during the heavy rains. There are not many natural reservoirs snch as either swamps or lakes, and the surfaee water is soon lost. Conseguently very little plankton is contributed to the San Joaquin from these western tributaries. In fact most of them are dry through a large jart of the year and the water they eontribute in time of flood is so full of silt as to hamper rather than hinder plankton prounction in the main river.

\section{TEMPERATIRE}

The Sierra Nevala seems to affeet produetion in two rather important ways. First, temperature in their run-off is rather low for either quantity or variety of plankton in the higher areas during most of the year. On the other hand, there are few places for impounding the water in the lower areas and the streams move too rapidly for mueh development even on the emparatively low gradients of the foothills, Hence there is no very great eontribution of plankton from any tributary. Second, the snows, glaeiers, forests, lakes and swamps of the higher region all together constitute an enormous series of reservoirs which hold much of the water in check, not only greatly prolonging the flood season, but giving a remarkably even distribution of flood water over a period of weeks or even months. The effeet of this is evidently twofold, inasmueh as the volume of water hastens the flow of the river and so may retard production, while at the same time it keeps many of the slonghs and swamps suffieiently filled to maintain a rapid plankton output. This period of flood from the Sicrra often overlaps the period of floods in the valley due to the winter rains. In other eases it follows or is continnous with the same. Hence there are a few rises and subsidences of the floods, almost every year, some of wheh are cffective in elearing ont the sloughs and giving 
basis for a new plankton crop. The combined flood periods usually extend from late December to about July, after whieh there is gradnal subsidence to the low-water conditions of sluggish flow and partial stagnation. It should be said that the term "flood" is here user to inehde all stages of water at Stoekton which are high enough to keep a distinet current in the river.

The mean anmul temperature of the valley, stated as $15.5^{\circ} \mathrm{C}$, does not give a very good idea of the real eonditions at Stockton. For one thing, the range in temperature in every twenty-four hours is considerable throughont the year. The nights are almost invariably cool even in late summer and by far the larger number of days become ruite warm. The average range for the year is about $8^{\circ} \mathrm{C}$ and is about $3^{\circ} \mathrm{C}$ in winter and $12^{\circ} \mathrm{C}$ in summer. On the other hand, the seasonal range is not so very great. Tery rarely a high temperature near $40^{\circ} \mathrm{C}$ is reached in summer and a low temperature of about $-10^{\circ} \mathrm{C}$ in winter. On the whole, there is good reason for thinking that temperature fluetuations in the San Joaquin River Basin have less influence than some other conclitions on the general plankton production.

\section{LIGHT}

Of course the fluctuations in available light are of great importanee. These fluctuations are dependent on a number of conditions, such as the seasonal changes in lengtl of kays, turbidity of the water, elondiness, and agitation by wind. All these influences are most adverse during the winter months, eoineident with adverse temperature, so that it is ahmost impossible to prove which is most responsible for seareity of plankton at that time.

As already stated, the turbidity of the waters in the Stoekton region is very great and fairly eonstant. During the greater part of the first six months of the year this is evidently due mainly to very fine silt. During the rest of the year the high organie content seems to have some influence. Although the net with its brass parts was a rather' conspicuons object in elear water, it was never visible one meter' below the surface at any station. There are, however, no data available for acenrate determination or comparison of turbidity.

\section{Air Currents}

Since Stockton is in a low region adjacent to extensive swamp areas and waterways, it is considerably affected by fog and elouds. The exclusion of light from this canse is quite important in the course of 
the year. Being loeated almost opposito the Golden Gate, this region is also under almost daily influence of distinct air enrents. 'These are very frequently strong enough to make the water surface quite rongh and there is scarcely a diay that it is not made ripply for some hours. This also causes important loss of light throughout the year.

\section{Chenicaid Conditions Not Studied}

No definite clata are available as to the chemical composition of San Joaquin waters. Hence disenssion of this important factor must be deferred.

\section{TIDE}

The ocean ticle is very much in evidence at Stockton, but the available data are not aclapted to satisfactory study. The extreme range is about three feet, but that does not ocenr very often. The only loeal records were those from a private tide-guage kept by Dixon Brothers Transportation Company. These records were made very irregnlarly in eommetion with the movement of their barges and cannot be used with much confidence in this discussion.

\section{Aquatic and Mlargin.ll Vegetation}

No definite study has been made of the aquatic and marginal vegetation of this section. The ocasional dredging of all larger waterways has kept down such growths in the places most accessible locally. Hence the following list must be regarded as incomplete. It is certainly inadequate so far as the typical delta flora is coneerned.

Chara sp. oceurs abundantly in some of the ditches and narrow waterways. It has not been observed in the river or in the larger canals, possibly because of the dredging. Where found it furnishes extensive lodging places for myriads of microseopic animals and plants.

Duckweeds, probably Lemna gibba L. and Lemna minor L., are very conspienous in the fall in quiet nooks and ditehes.

Typha latifolia L. is very abundant in a few places and is frequently foumd in small groups along any water margins.

Alisma plantago $\mathrm{L}$. is said to be common.

Sagittaria is common and three species at least ocemr in this region. Apparently s. latifolia Willd is most frequent, thongh s. greggii J. G. Smith, and s. sanfordii Greene are more characteristic of the locality.

Crtica holosericea Nutt. is very abundant on most undisturbed levees and water margins. 
Jussiaea californica fills some quiet sloughs and eanals with an almost impenetrable mass of stems.

Scirpus lacustris L., is by far the most conspicuous plant in the marshes and shallow waters from one end of the valley to the other.

Carcx marcida Boott. covers large areas of ground where the soil remains saturated though not completely submerged through most of the year.

Ancmopsis californica Hook. occurs in temporary marshes and is peculiar to the rainy season.

The most abundant willows are Salix nigra Marsh., S. lasiolepis Benth., and S. fuviatilis Nutt. Although abundant by natural propagation, they are frequently planted along the levees to help to hold the dirt in place.

Populus fromonti Wats. is common along the water courses, but not abundant.

Rumcx salicifolius Wats. is conspicnous in marshy ground, especially in the heavy loam and peat soils. $R$. occidentalis Wats. and $R$. Crispus are also prominent.

Polygomum amphibium L. occurs in the ditches and narrow waterways. So far as observed, it furnishes remarkably good shelter for minute animals and plants.

Ranunculus aquatilis $\mathrm{L}$. is exceedingly abundant in small areas at times, forming dense mats in shallow water.

Nasturtium officinalis is reported as common, but it has not been observed by the present writer.

\section{THE COLLECTING STATIONS}

Three collecting stations were used. Plate 20 Station I was located in Stockton Channel at the foot of Yosemite street. This is abont one mile and three-quarters from the river; fon hundred yards from Mormon Channel outlet and three-fourths of a mile from the steamer. landing at the head of Stockton Chainnel. There was a good deal of sewage coming down this channel. Normon Channel was an open cesspool during most of the year. Hence this station seemed to be fairly typical for the study of organisms in dilute sewage.

Station $I 1$ was in the river, from four hundred to eight hundred yards above Stockton Channel, and it represented as nearly natural yiver conditions as conk be found in this section.

Station III was in Smith Caual abont fonr hundred yards from the river. There was a small amount of sewage conning down this 
canal from the outskints of the eity. There was also a small slough about one hundred yards from the place of colleeting. 'The general similarity to river conditions was well marked.

Station IV was not used in this series.

Stoekton Chamel and Smith (anal are more subject to disturb)ance by frevaling wimls than is the river. Smith Canal being shallowest, Station III was probably most affected.

Stockton Chamel was vastly more disturled by river traffic than cither of the other stations. Smith Canal was rarely affected in this way. Station II, in the river, was probably not stirred np one-tentl as much as Station 1.

The turbidity of the water was least at Station III during 1913, and greatest at Station 11. Bnt Station III was never clear and the turbidity was not much less than at Station $I$.

Since the times of taking the temperatures at the various stations varied by an hour or more, an acenrate comparison is impossible. The olserver, however, always expected to find the highest temperatures at Station 1, and the lowest at Station 1 I and something between these at Station III.

There was no vegetation of consequenee near Station $I$, but the levees were heavily covered at both the others. No aquatic vegetation occurs at any of the stations.

\section{River Currexts ind Deptils}

Tilal enrents were sometimes very notieeable at all the stations, but strong currents of any sort were very rare exeept at Station II. where they were noticeable for several months during the spring and early summer. The highest estimate placed on the rate of the river (nn'ent in 1913 was four miles per honl. River transportation men, notably Captain Cury of the Island Transportation Company, say that five miles per hour is often reached during the hearier floods.

The least depth of water noted at the stations at low tiele was about one and one-half meters at Station I, two and onc-lialf meters at Station II and one meter at Station III.

\section{COMP.IRISON OF S'T.ITIONS}

The general form of the three chammels is somewhat different. The becl in all eases seems to be a clay with variable superimposed ooze. Stockton Chammel is a straight eanal ending blindly at the steamer landing, two and one-fourth miles from the river. It is nearly the same width thronghont, prohably two hmucled feet on the average. 


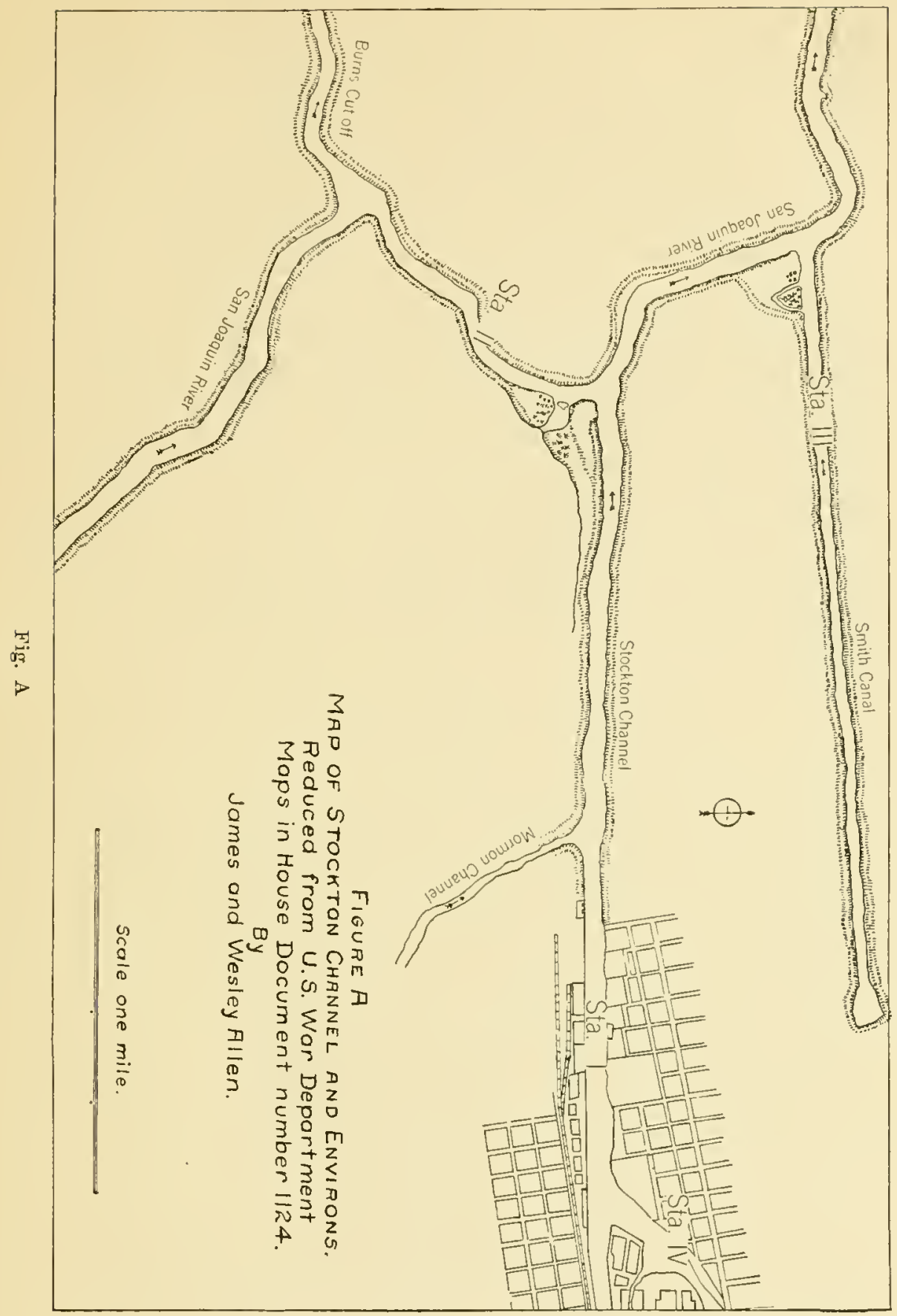


Its flow is westward. Molmon Chandel empties into it about half way up on the south side. Miner Chamel, after traversing the eity as an open diteh, empties into it through Meleod 's Lake about three hnudred yarks from the steamer landing. Mleleod's Lake is merely a broad slough some four hundred yards in length. It was almost filled with arks and boat houses during 1913. All sorts of rubbish ant refuse were dumped into Miner Channel and MleLeod's Lake at that time, ineluding some servage from factory drains and some refuse from the tannery".

The river channel is very crooked. The general direetion is northeast for about one mile ahove Station II. At Station II it is nearly east, but within another half mile it has turned to the west. The width is kept fairly uniform ly dredging and it probahly averages one humdred and twenty feet near the station.

Smith Canal is a straight ehamel about sixty feet wide and two miles long, ending abruptly at the northwest eity limits. An open ditch aeross the northern elge of the eity earried waste water from eertain gas wells and some sewage direetly into its upper end, during most of 1913. This diteh was also partly filled with rubbish and garbage.

\section{IIETIIODS OF SECURING DATA}

\section{Tine of Collecting}

Most of the collections at Stations II and III were taken at sevenday intervals, at week ends. There was oeeasional variation of a day or two. Collections at Station I were made twiee a week. The midweek colleetion was usually on Wednesday. In a few eases there was a ehange of a day or two in the interval, but there was no failure to make two collections in any week.

One series of claily eolleetions was taken in Stoekton Chamnel for one month in July and August. Another series of hourly collections was taken for twelve hours in Smith Canal about one mile from the river. The plankton eontent was slightly different from that of the regular station in Smith Canal, but this was not realized at the time the series was being taken. The difference is not great enough to prevent instrutive eomparison.

The time of day at whieh eolleetions were taken was very variable. Most of the midweek eolleetions were taken after school in the late afternoon. Most of the week end collections at all stations were taken in the forenoon. 


\section{The ForM of NeT}

The first few eollections in January were obtained with a temporary net made of used mill silk. But a net, of number 25 new bolting silk, was put into use on January 15, 1913, and was used continnously to January 1,1915 . There were occasional changes of drain cups.

The net was eonstructed after a plan suggested by Professor C. A. Kofoid. Outspread, its general form is that of a very broad and short truneaterl cone, the base having a total circumference of 166.65 centimeters and the apex 17.59 centimeters. The slant length is 60 eentimeters. In order to avoid the awkwardness of such a shape, eight equal folds are made lengthwise and thrir uper edges closed. The inmer points of the folds are then fastened directly to a brass ring of proper size. The onter points of the folds and an mnfolded part between each two is bound by buteher's linen to a slightly conical brass plate with an opening in the midale whieh will pass just 10,000 eubie centimeters of water for each meter hauled, i.e., 100 square centimeters area. The convex surface of this subeonical plate is kept ontermost, so that in hanling the water may all pass away flom the opening, except that which is in the column immediately before it.

A small brass eylinder is fitted into the small end of the net and fastened there by butcher"s linen. Smooth grooves on the outer surface of the eylinder, near eaclı end, serve for securing it to the net as well as for attaehing the drain cup to the distal end.

This drain eup is made of the same silk as the net. It is a very simple pocket, abont 5 centimeters deep, made of two semicircular pieces sewed together by the cirenlar edges. The straight edges thus form the top of the cup, just large enough to slip over the end of the brass cylinder. The size was not kept quite uniform but the filtering surface of this etrp avel'aged about 100 square eentimeters in 1913. A draw string of white tape is run around the margin of the cup and fastened by a small hook and eye, such as is used by dressmakers. The draw string makes it possible to slip the eup over the cylinder emi without tearing. The hook and eye, when properly adjusted, makes a very secure fastening, easily and ruickly opened or closed.

The total net surface before shrinkage was 5,527.20 square eentimeters, not inchding the drain eup. 'The total filtration opening as calculated from mierometer measurements was 690.9 square centimeters. This gives a filtration ontlet somewhat more than six times 
the area of the inlet to the net. Before using, the net was plaeed in warm, soapy water and gently rinsed in ordor to induce uniform slivinkage.

The drain eup was removed after eaeh haul and the contents washed off into a small pail. Some organisms elung very tenacionsly to the net and ressels. 'This was especially true of the stentors and some rotifers. The rater in the pail was strained through a silk eup at the end of the eollection.

\section{THE AMOUNT OF HiUL}

The standard eolleetion eovered an aggregate haul of twenty-five meters. Sometimes it was not possible to make a full eolleetion. On a few oceasions the light was too poor to make a full midweck eolleetion. At these times it was usually possible to take half the usnal haul. On still fewer oecasions the silt elogged the net so barly in the river that only about ons-fifth of a staudard colleetion was taken. Even so it seemed that the net would surely break before it drained. Dranage of the net was always hastened ly shaking the net slightly or by working it with the fingers.

Most hauls at Station I were at the deptly of three meters; at Station II, four meters, and at Station III, two meters. Sometimes five meters conld be taken at Station II. On the other land there were times when only one meter conld be taken at Station III. MIost hauls in the river were taken while drifting. Mlost hauls in Stockton Channel and Smith Canal were taken while at anchor. Exeept on one oeeasion all lanks were matle by the same person. The net was always hauled as neary as possible at sueh a speed that it would just fail to throw water from its mouth as it broke the surfaee. This was about one-half meter per second. All hauls were as nearly vertical as possible. No particular effort was made to get in midstream at any time. In faet some rolleetions were taken neal the bank beeanse of deeper water there. A few eolleetions were taken from boat landings when the writer's motor boat was not in working order.

\section{RECORDS}

Reeords were kept of the temperature of air and water at each station. The air temperature was taken first and it was always taken in the shade without much motion. The water temperature was taken by holding the luulb from one to three inehes below the surface of the 
water and reading while in that position. Temperature was forgotten once during the year and on a few occasions it was taken at some distance from the point of collection. This was usually when there was a high wind that made any appreciable variation improbable.

The condition of the tide was lecorded when it could be detected. Dixon Brothers' Tide Record is of some value for comparison, but it is so fragmentary that it cannot be depended upon. Corrections for this locality from the United States Tide Tables are of some value.

Records were kept of cloudiness, rain, fog, wind, roughness of the water, etc., at the time collections were being taken.

The hour and mimute of collection was regularly recorded, usually at beginning and end.

\section{Preservation of M.iterilles}

The collections were preserved in formalin in four-ounce, corkstoppered bottles of the so-called vaselinetype. The formalin was not measured accurately, but it was intended to be from 6 to 10 per cent. The stronger solutions were used for the heavier collections. The formalin for one collection was forgotten until two days after it was taken, but so far as known that is the only serious error. The total number of collections during 1913 is 242 . The year 1913 was very dry with very little flood water at any station. On the contrary, the water was unusually low much of the time. For this reason it would not show the local plankton range and distribution most typically. But there were some features strikingly similar to river conditions in other parts of the world, and it will make a good basis of comparison with 1914 which was a wet year.

\section{Tests OF S.ILINITY}

In spite of the low water it is not at all probable that sea water ever had any influence here except in causing tides. Surface samples of San Joaquin River water were taken at Station II at about the twentieth of each month. These samples were titrated for chlorine content by the scientific staff of the U. S. S. "Albatross" and their report is presented herewith. It is given in parts of chlorine per 1000 .

\begin{tabular}{|c|c|c|c|}
\hline Jan. 19. & 0.0280 & July 19 & 0.0800 \\
\hline Feb. $19 .$. & 0.0745 & Aug. 21. & 0.0964 \\
\hline Mar. 29 ......................... & 0.1025 & Sept. 21 .. & 0.1764 \\
\hline Apr. 26 & 0.1680 & Oet. 19. & 0.2352 \\
\hline May $24 \ldots \ldots \ldots \ldots \ldots . . . . . . . . . .$. & 0.0032 & Nov. $22 \ldots$ & 0.6600 \\
\hline June 21 & 0.0072 & Dee. $30 \ldots$. & 0.1404 \\
\hline
\end{tabular}


The most probable explanation of the variation shown is that the incoming tide earried some of the poltuted Stockton Channel water up stream when the natural stream flow was very weak. No other tests of the ehemieal eomposition of water at any station are available.

\section{Meisurement of Tolude}

In order to measure the mass of material secured in the eollections, a Bausch and Lomb hand eentrifuce was nsed. The sedimentation tubes were graduated to tenths of a cubic centimeter. This machine makes 23 revolutions to each turn of the erank. After a few trials it was decided to run at 54 turns per minute. While no amount of practice made mniform speed possible, the average was kept at about 1300 revolutions per minute. The time of running was four minntes. Experience indicated that this was a little longer time than necessary, but it was molertaken with the intention of compensating for any possible inacenacy due to rariation in rate. Since this indicated only the mass of material held by the net, it was necessary to make some supplementary test to determine as nearly as possible what volume went through. Only two or three such tests were made because of the pressnre of other duties, lont the indieation from filter paper tests is that the net sometimes retains only one-tenth of the mass of material aetually present in the water. This material is often composed prineipally of silt.

\section{The Enumer.tion}

After considerable experiment, the eonut of the organisms in the catches was begm in September, 1914. Sinee the time arailable was nearly always at night, almost all the comting was done by artificin light from an ordinary 60-watt, frosted, incanclescent globe. Only rarely was it possible to make two comnts in one day. Hence the enumeration was not finished mutil the night of June $18,1915$.

\section{APPARATUS}

The mieroseope nsed throughont was a Spencer with 16 millimeter objective and $8 x$ ocular. It was equipped with a quiek serew substage ant a Spencer meeluanieal stage. The Whipple oenlar mierometer and the Rafter counting cell were used. Its largest square covered 1.1 sfuare millimeters with the above lens equipment, so that the labor of ealenlating was slightly increased by the fractional area. 


\section{PROCEDURE}

\section{Standard CONCentration}

In preparation for eounting, all eatehes were first brought to a volume of 100 eubic eentimeter's by addition of water or, in a few eases, by decanting some fluid. If the coneentration was too great at this volume, dilution was made to 400 or 800 or 1,600 eubic eentimeters. No other quantities were used beeause the inerease in diffienlty of eomputation would offset the difficulty in counting. This was dne to the fact that the above quantities were nsed often enough to make the formation of eomputing tables useful for them.

\section{Metrod of Filling Sedgwick-Rafter Cell}

In the process of filling the eell after thorough mixing a little more than 1 eubie eentimeter was taken quickly into a pipette. The eell was then filled as rapidly as possible nutil the eover slipped into place. This never oecurred completely until there was a slight exeess of fluid. The exeess was immediately taken baek into the pipette, leaving the eover glass flat. The possibility of some error is evident, but experiment indieated that this method gave more even distribution in the eell than any other and that errors were not appreeiably more frequent than those attending other methous. The method was followed throughout the whole series and every detail was handled by the writer, so that there must have been praetieal uniformity. This wonld eertainly rednee the signifieanee of any error which may have been ineident to the method.

\section{Making and Recording the Count}

After filling the cell satisfaetorily, a rapid survey was always taken in order to estimate the relative amomnts of plankton and nonplankton. The estimate was then reeorded in percentage of silt. With these preliminaries completed, the work of eounting was begun, fifty fields being always counted. This made a total of 60.5 cubie millimeters. Counting was begun on the proximal side of the slide at point 32 on the lateral scale of the mechanical stage. The field next to the wall of the cell was not eounted, but the next five were taken eonseentively. This proeess was repeated at point 16 , then at point 80 on the proximolistal scale at the right end of the cell, followed by point 87. Points 16 and 32 distal, 87 and 80 left, were then taken in order. The detail eomnt was eompleted by ten fields from point 15 to 
27 in the median line of the eerl. The whole count was completed by rmming over exaetly laalf of the eell looking for strays and for a check on larger organisms which miglit be irregular in distribution. After a year's experience the writer is inclined to think that twenty-five or thirty fields would he snffieient for the detailed comnt in viow of thr half-slicle check. At any rate he is satisfied that the possibility of rror in comnting will rest elsewhere than on the methor of selecting areas for connting. It might be said too, that the year's experience indieates that the method of filling the cell gives as mniform distribution of plankton in the eell as ean be hoped for in any ease.

The method of reeording the count was almost miform. Mrs. Allen sat near the microscope and wrote down names or mate elicek marks as the names were ealled. In two or three eases about half the eateh was reeorded by the writer while himself counting. On about ten occasions he recorded as much as ten fields in like manner. These were the only exceptions. Occasionally the witer called the name of one planktont when another was intended, the mistake being noticed because it did not somnd right. It is altogether probable that some such mistakes were made which were not notieed. In addition to this, of course, we must recognize the presence of elerical errors not humanly avoidable in sneh a mass of material. It can only be said that all jeasonable precantion has been taken to avoid them.

\section{Compltation and Tabulation}

After recording, the comts were eomputed for a full cubic meter, and then tabulated by key sheets, such as suggested by Professor Kofoid in his lllinois report. From these shects they were finally transferred to the statistical tables.

\section{IDENTIFICATION OF ForMs}

Identification of speeies, or even genera, was very diffienlt in many eases. This was due to several conditions. First, the preserved planktont was often very different in appearance from the living specimen. Seenond, many kinds had very marked tendeney to coherence or agghtination in formaklehyle. Third, many of the smaller organisms were hidden wholly or in part by silt or by larger organisms. Fourth, many different organisms have the same appearanee in very roung stages; they also resemble mature stages of simpler forms. Fifth, distinctive eharacters were frecuently invisible in the position found in the Rafter cell. Sixth, many forms were not sufficiently 
figured and described in the literature immediately available for use. Seventh, much of the acenrate identifieation of plankton forms wonld require long time and careful work, even for specialists in the varions groups. The writer was hampered by lack of time and experience in identifieation in all groups. Eighth, the synonymy is confusing. This, however, is rather an aggravation than a difficulty in the sense of the foregoing.

This list certainly seems imposing as stated. As against it, the following facts should be noted. First, that more than one year was spent in studying the living materials, with both 16 millimeter and 4 millimeter objectives, before there was any attempt to count. In this way, suffieient familiarity was obtained with many forms to enable identification even in much contracted, distorted and broken conditions. Second, that most of the names as finally applied meant something definite to the writer, even though there might be error in their specifie application. While this fact is unfortmate for the speeialist who may wish to know exactly what species are present, it surely leaves the possibility of drawing some valuable conclusions as to seasonal ehanges, plankton rhythms, and relative numbers. Third, there were enough prominent planktonts, easy to identify, to make a good foundation for a report on plankton characteristies of this region at sueh stations as were seleeted. Fourth, those planktonts hardest to identify were mostly of the kind which would be largely lost through the meshes of the net, or which were adventitions and so of minor importance in solution of the greater problems of plankton production and distribution. Fifth, the various totals are not much affected by specific errors of identification.

\section{Estimation OF Silt}

In estimating the percentage of silt, the same possibility of error was noticed as that mentioned by Kofoid (1908), i.e., some of the material, being flocenlent in character, would appear unduly prominent in the Rafter cell: whereas, the compression of the centrifuge wonld make it relatively small in the volumetric record. While it seems probable that differences in the stations and in seasonal conditions give this error some real importance, there appears to be no way of avoiding it. There may be some compensation in the fact that with larger quantities of sediment there is usually a larger proportion of heavy materials, thus making the compressible materials less conspicuous. 
'Tie Clugging of the Netet

The elogering of the net is undoubtedly an important factor affecting the catch and it was also quite variable uncler 1913 conditions here. Hence some designation of its proballe condition is very desirable. In spite of this it was finally teeided to ignore it tor 1913 at least. This is beeause too few filter paper, or other supplementary, eatches have bern made to give adecpuate ground for estimation.

\section{VOLUMETRIC DATA}

There is not a great deal to say on this topie as yet. The main points are distinetly shown by plate 1 and table 6 . The two most interesting points, in the light of such investigations elsewhere, are that only Station I shows a very distinet rernal pulse and that the autumnal pulses are most prominent at all stations. This statement needs some qualification since there was a higher maximm shown at Station 1 in Mareh than in the fall. This vernal pulse was, however, so very abuptly developed, and the antumnal so very gradually, that it seems natural to assign the greater importance to the latter. At neither of the other stations does the rernal pulse compare in magnitude with the antumnal. Indeed, at Station 11I, there is no well marked, vernal pulse.

It is worthy of note that volumes appear least variable at Station I and most so at Station II. It might, at first thonght, seen that this was owing to the miformity of food supply at Station I, causer by the constant inflow of sewage thronghont the year. Closer examination of the reeords suggests, however, that variation in speed of eurrents in the river, together with the dilution due to flood waters is more potent. This estimate of the importanee of the eurrent as a faetol is supported by collections made in the San Joaquin River near Fresno, California, in Angust, 1916. Although this was the season for maximum oeenrrence of plankton at Stockton, not enough was taken by the net at Frosno to be measurable volumetrically with any acenracy. Since the emrent at Fresno is abont as rapid in the dry season as at Stoekton in flood season, it seems certain that it has a profonnd influence. Still the importanee of the uniform food supply at Station I must not be minimized. 
The whole series of collections for 1913 is now (1916) in the permanent possession of the Department of Zoology of the University of California.

\section{ORGANISAIS FOUND IN SAN JOAQUIN PLANKTON}

\section{DEFINITIONS}

Professor Krofoid 's definitions are followed as closely as possible, although only a few terms will be used. This report designates only three types of planktons, i.e., the continmous, the periodic and the adventitious. No eloser distinction is advisable in view of the writer's laek of definite knowledge of life histories of various species. There has becn no difficulty about the application of the general term "plankton" to the typically mixed population of minute living things found in these colleetions, because there was no case observed in which the plant or aninal seemed distinctly out of place. It might be rare, and perhaps evidently ill-fitting, but in no way eould its presence be regarded as surprising. Hence it beeomes perfectly natural to apply the term collectively to all the organisms found.

\section{Component Forms}

A total of 471 planktonts was listed during the year, though only 396 were recorded from the preserved material. The number of species present was doubtless much greater. Those not recorded were found only in the living material and in small numbers. Of those recorded, some forms which might be distinet species were placed together in one because they could not be distinguished during the count. This laek of distinction was sometimes duc to the inadequate preservation or to the rarity or to the diffienlty of identifying specifie characters while counting. Others were placed together because the writer's acquaintance with them was not suffieient for definite recognition. Very many were simply referred to the genus without attempt at species segregation because identifieation was too difficult to be undertaken in the time available. The question of probability of proper identification will be taken up in the detailed discussion of each form. 


\section{THE PRINCIIAL TIPES OF FRESH WATER PLANITON}

Among the 396 forms recorded and eounted in the preserved material, 201 were thought to be positively identified as to genus, of whieh number 107 were also satisfietory as to speeies. The generie designation of most of the remaining 195 forms was regarded as probably corret thougl some were merely referred to the nearest possible genus or speeies aceording to the information at luand. The following table gives the general distribution of these forms among the three stations.

\begin{tabular}{|c|c|c|c|}
\hline & $\begin{array}{l}\text { At three } \\
\text { stations }\end{array}$ & $\begin{array}{l}\text { At two } \\
\text { stations }\end{array}$ & $\begin{array}{l}\text { At one } \\
\text { station }\end{array}$ \\
\hline 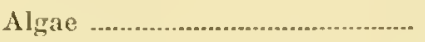 & 90 & 29 & 53 \\
\hline Protozoa & 56 & 26 & 37 \\
\hline Rotifera & 44 & 11 & 26 \\
\hline Crustacea & 8 & 2 & 2 \\
\hline Miscellaneous ............................. & 3 & 1 & 8 \\
\hline Total & 201 & 69 & 126 \\
\hline
\end{tabular}

As might be expected of those found at only two stations most are from stations I and II. Those found at only one station are of the rarer, less conspienous kinds.

This table shows the main charaeteristies mentioned by Fofoid (1908) as distinguishing fresh water from marine plankton. It may be well to enumerate his main points as verified in the present study. The plankton consists of eryptogams and invertebrates, with some orders missing and the other's very variable in numbers of representatives. Larval forms are very few and the number of invertebrate groups much less than that of the sea. The small size of organisms in fresh water is also a conspienous feature. There are no large erustaceans, no eoelenterates, no mature mollusks, few worms, no tmineates or radiolarians, to make diversity such as that of the sea. In spite of the smaller size of the organisms in fresh water their total mass is mueh greater than that in the sea. The highest amount reeorded here is 18 eubic centimeter's per cubic meter; the smallest 0.2s cubic centimeters per enbic meter; while a typieal marine produet is stated as 0.12 to 0.48 eubie eentimeter per eubie meter. The San Joaruin produetion noted was taken from net hauls only, the maximm from Stockton Channel, the minimum from Smith Canal. Filter paper catches show ten times the recorded volume in some eases. 


\section{Miajor Groups of Plankton}

ALGAE

No plants higher than the algae have been found in these collections. Very few bacteriaceae were found because of their small size. Tery few sehizophyceac were eonspicuous in 1913, though the number's of individuals were sometimes large and the total quantity sufficicnt in late summer to give characteristic eolor to the water's. Bacillariaceae were always present and usually in large numbers. Many of them are doubtless adventitious. Chlorophyceae were not prominent, though some were present throughout the year. The conjugatae were not represented by many species and the numbers were few.

\section{ZOOPLANKTON}

Almost all the zooplanktonts found were included in the three groups Protozoa, Rotifera and Entomostraca. Other types of animals are decidedly rare.

Amongst the Protozoa, Ciliata and Mastigophora predominate. The group Mastigophora is meant to inelude the same organisms as comprised under that head by Kofoid (1908), i.e., "all green and brown flagellates, sometimes elassified with the Chlorophycene and Phaeophyceae." Rhizopoda were usually present but in small number's. Hcliozoa were rare except for one or two smaller forms which kept up rather large totals for the group. Suctoria were rare. No Sporozoa were recognized. Ciliata were distinetly more notieeable in the dilute sewage of Stockton Channel than at either of the other stations.

The Rotifera were even more prominent inhabitants of Stockton Channel than the ciliate Protozoa, but their numerical superiority may have been due to larger size and consequent capture by the net. The numerical differenee at the other stations was not very marked. There is no question that their consiferable size and large numbers entitle them to the leading place among analytic organisms assigned by Kofoid (1908) to the Illinois Rotifera. The greater abundance in the sewage laden water is, however, rather against his suggestion that they may be found to be more characteristic of river than of lake plankton. Local conditions indicate sewage or at least organic 
content as being a deeiding factor. Apparenty, most of the sprecies recorded here are to be regarded as nomal constiturnts of the local flankton.

With the exerption of three or four specimens of Giammans found on two different dates, and of a fow miscellaneous forms, the Entomostraca are far the largest of the local planktonts. While much less munerous on the whole than they were in the Jllinois River, they undoubtedly play a large part in the life of our waters. Copepoda, thomgh lareal forms, are distinctly in the aseruclant, with Cladocera somewhat seattering and Ostracoda harely represented. Ilost of the forms foumc appear to be true planktonts. In fact, rypris, the sole member of the Ostracolat, is the only gents which is evidently alventitious.

Turbliaria, Oligochaeta, IJexapoda, Iydrachuida, Gastrotricha and Pryozoa barely find rejuesentation at any station. Their influenee in the plankton is negligible.

\section{TOTALS OF MAJOR GROUPS}

The following table of averages (text table $\mathrm{I}$ ) will serve to indicate in some measure the proportionate representation in the San Joaquin plankton of the most typical constituent groups. As already noted olsewhere, 1913, was a comparatively dry year so that the prodnetion in most anses was probably below normal. The fignres given are the result of the comnt of individnals, except in the case of colonial forms such as Bacillaria. symura and Sconclesmus where the colonies ouly were counted. The small mmbers as compared with Kofoid's similar table (1908) for the Illinois plankton of 1898 is mainly the to the fact that all San Joaruin enumerations are from silk net collections, whereas many of his were from filter paper eatches. Our table ineludes all recorded forms whether satisfactorily ilentified or not. It shonld be noted that in the total of syntletie organisms Sehizoplyyecae are inchuded beeause they do sone of that work. All of the Mastigophora are also inehded beeanse there was not sufficient aconaintance with them to distinguish synthetic and analytic forms and it was miderstood that most of them found here were syntlietic. The averages are computed on the basis of 104 eatches for Station I, 52 for Station 11 and 51 for Station III. The daily and hourly series are not inchuded in the general disenssion except as incidentally reforred to. They require separate disenssion. 
Text Table 1.-Total P'lanktonts by Major Grodps

$$
\begin{gathered}
\text { Number } \\
\text { of } \\
\text { forms }
\end{gathered}
$$

Total Phytoplanktonts. $\quad 85$

Bacteriaceac.

Chizophyceas 15

Chlorophyceae..... $\quad 15$

Bacillariaceae .... 47

Conjugatae.

Total Zooplanktonts .... 141

Mastigophora $\quad 25$

Rhizopoda............... 13

Heliozoa.................. 5

Ciliati ................. 29

Sictoria

Total Plotozoa ...... 7.5

Rhizota P

Bdelloida.

Ploina

Total Rotifern $\quad 5.5$

Cladocera... 3

Copepoda

Total Entomostraca

Niscellaneous

Totial planktonts

Synthetic. enumerated

Analytic.

$-\frac{\text { Total }}{\text { Station I }}_{\text {Average }}^{\text {S }}$

$2,720,5,56,600$ $1,696,364$

$166,755,145$

188, 417,098

$2,351,342,460$

$12,651,930$

$1,102,116,740$

$355,691,226$

$17,402,19 \mathrm{~S}$

$35,583,488$

$98,463,242$ 79,296

$540,219,450$

156,992

$36,328,460$

$467,115,946$

$503,601,39 \mathrm{~S}$ 400.992

$57,856,500$

$58,257,492$

38,400

$3,822,973,340$

$3.104,857,862$

$718,115,478$

$\begin{array}{rr}\text { Average } & \begin{array}{r}\text { Number } \\ \text { of } \\ \text { forms }\end{array} \\ 26,162,100 & 97 \\ 16,310 & 1 \\ 1,603,414 & 18 \\ 1,811,722 & 13 \\ 22,609,062 & 59 \\ 121,653 & 9 \\ 10,597,272 & 110 \\ 3,705,569 & 20 \\ 167,325 & 9 \\ 370,995 & 5 \\ 946,762 & 16 \\ 762 & 3 \\ 5,194,416 & 53 \\ 1,509 & 3 \\ 349,312 & 6 \\ 4,491,499 & 34 \\ 4,842,320 & 43 \\ 3,855 & 4 \\ 556,312 & 3 \\ 560,167 & 7 \\ 369 & 7 \\ 36,759,372 & 207 \\ 29,854,420 & \ldots . \\ 6,904,952 & \ldots \ldots\end{array}$

207

$20,554,120$

$6,904,952$

162,100

….
Station II

\begin{tabular}{rr}
\hline \multicolumn{1}{c}{ Total } & \multicolumn{1}{c}{ Average } \\
$2,216,347,625$ & $42,622,065$ \\
$1,035,072$ & 19,905 \\
$67,219,364$ & $1,292,680$ \\
$77,972,944$ & $1,499,479$ \\
$2,052,872,514$ & $39,478,317$ \\
$17,247,734$ & 331,687 \\
$229,332,166$ & $4,410,230$ \\
$136,713,846$ & $2,629,112$ \\
$7,842,488$ & 150,817 \\
$13,376,096$ & 257,232 \\
$23,291,269$ & 447,909 \\
467,776 & 8,995 \\
$181,691,474$ & $3,494,065$ \\
$1,933,424$ & 37,181 \\
$2,449,472$ & 47,105 \\
$41,559,652$ & 799,224 \\
$45,942,549$ & 883,510 \\
384,000 & 7,384 \\
770,768 & 14,822 \\
$1,154,768$ & 22,206 \\
543,376 & 10,449
\end{tabular}

$\begin{array}{rr}2,445,679,794 & 47,032,295 \\ 2,352,026,402 & 45,231,275 \\ 93,653,392 & 1,801,023\end{array}$

Text Table 1. - Total Planktonts by Major Groeps-Continued

number

Number
of
forms

$\begin{array}{cc}\text { Total Phytoplanktonts. } & 93 \\ \text { Bacteriaceac.. .... } & \mathbf{1}\end{array}$

Schizophycea ....... 16

Chlorophycene ....... 13

Bacillariaceae ........ 55

Conjugatae.

Total Zoöplanktonts..... 108

Mastigophora ......... 25

Rhizopoda............. 11

Heliozoa.

Ciliata.

Suctoria

Total Protozoa

Rhizota

Bdelloida

Ploima

Total Rotifera......... 39

Cladocera

Copepoda.................

Malacostraca

Total Entomostraca

Miscellaneous

Total Planktonts

enumerated ........

Synthetic

Analytic

201

......

Total $_{\text {Station III }}^{\text {Average }}$ f

$2,090,812,294$

116,992

$99,810,742$

$91,241,112$

$1,878,169,822$

$21,443,626$

$253,153,822$

$134,216,822$

$14,706,624$

$14,003,600$

$22,003,692$

409,984

15. 340,722

$1,539,421$

$2,897,100$

$61,996,492$

$66,433,016$

469,040

$7+2,032$ 20

$1,211,092$

\begin{tabular}{|c|c|c|}
\hline & Dai & \\
\hline & Total & Average \\
\hline 53 & $1,018,801,028$ & $32,864,549$ \\
\hline 1 & 115,392 & 3,722 \\
\hline 12 & $80,574,044$ & $2,599,163$ \\
\hline 11 & $67,560,712$ & $2,179,378$ \\
\hline 25 & $869,719,232$ & $25,055,459$ \\
\hline 4 & 831,648 & 26,827 \\
\hline 61 & $335,441,120$ & $10,820,681$ \\
\hline 14 & $57,450,320$ & $1,853,429$ \\
\hline 4 & $3,155,872$ & $101, \mathrm{~S} 02$ \\
\hline 2 & $19,193,826$ & 619,156 \\
\hline 6 & $40,485,331$ & $1,306,075$ \\
\hline 26 & $120,294,352$ & $3,880,462$ \\
\hline 3 & $3,745,752$ & 120,831 \\
\hline 27 & $165,007,160$ & $5,322,812$ \\
\hline 30 & $168,752,912$ & $5,443,643$ \\
\hline 2 & 230,400 & 7,432 \\
\hline 2 & $46,141,056$ & $1,4 \mathrm{SS}, 421$ \\
\hline 4 & $46,371.456$ & $1,495,853$ \\
\hline 1 & 22,400 & 723 \\
\hline 114 & $1,354,242,14 \mathrm{~S}$ & $43,685,230$ \\
\hline & $1,076,257,348$ & $34,717,97 \mathrm{~S}$ \\
\hline - & $277,984,800$ & $8,967,252$ \\
\hline
\end{tabular}

168,992 
Text Table 1.-Total l'Lañktonts br Major Groups-Conduded

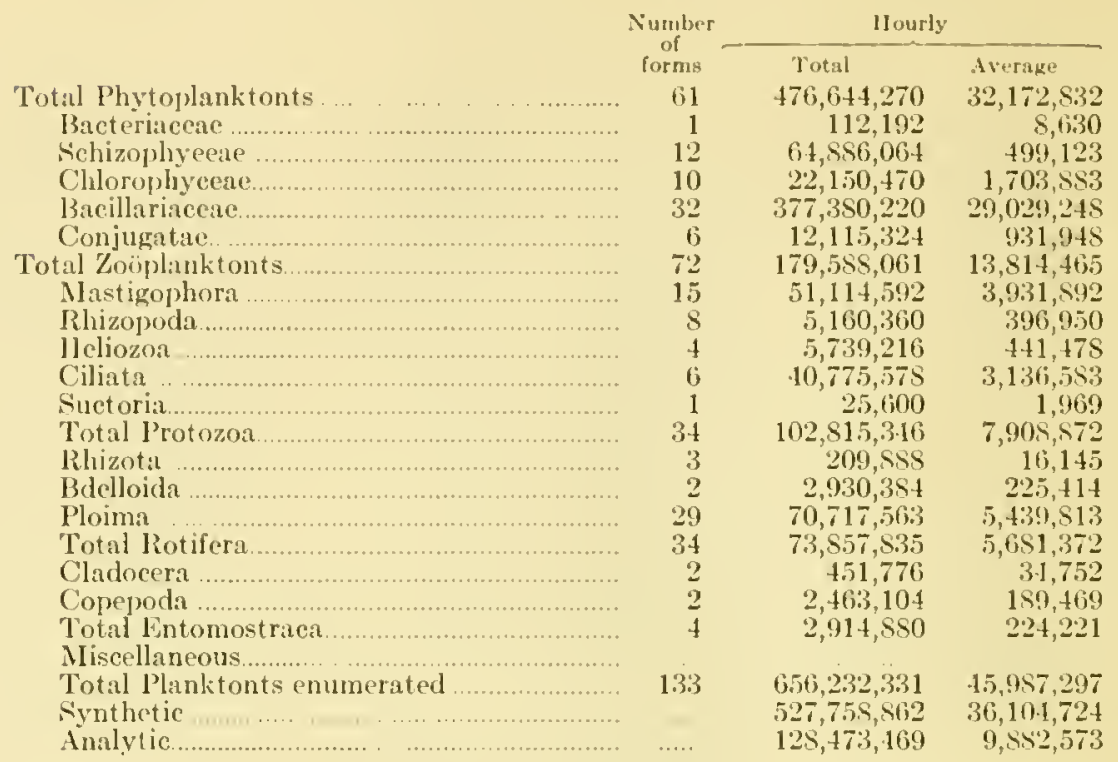

\section{COMPARISON WITH ILLINOIS FORMS}

As in the ease of the Illinois River, this table shows plants to be more numerous than animals, though they are generally smaller. The disprarity in numbers is shightly different being, in recorded oreler of stations $2.5,9$, and 9 to 1 , instead of 5 to 1 as in the Illinois River. The preponderance of Rotifera and Protozoa over Entomostraci is less marlied than in Illinois, being $8.5,45$, and 50 to 1 ; and 9, 180, and 151 to 1 , respectively. The numbers of Rotifera and Protozoa are not markedly different from each other in Stoekton Chamel thongh Protozoa are four or five times as numerons as Rotifera at the other two stations. In Stockton Channel synthetic organisms are relatively few even among plants proper. In this place the prineipal food of the zooplankton, therefore, is probably furnished by the Bacteriaceae and other saproplytic plants. For this reason the forms of plankton usually rated as important in more or less lirect support of a fish fam are few in kinds if not in numbers, although there is a conspiruous animal popmlation.

At Station I, Copepoda (ineluding immature forms) ontumuber Cladocera abont 18 to 1 , but only ahont 2 to 1 at Station II and 1.5 to 1 at Station III. Protozoa are 1210, 500, and tot to 1 of the Cladocera, distributed as follows: Rhizopods 45, 22, and 32 to 1 , 
Ciliata 236, 64, and 45 to 1, Mastigophora 927, 361, and 292 to 1. Cladocera are outnumbered by plants 6540,6090 , and 4555 to 1 . Diatoms are responsible for most of this with 5652, 5640, and 2314 to 1 . Schizophyeeae appear at 400,185 , and 217 to 1 and Chlorophyeege 452, 214, and 198 to 1 .

The most striking features of these results when eompared with those of Kofoid (1908) are two in number. First, there is the remarkable number of Copepoda in Station I. Seeond, the astonishingly small number of synthetic organisms and of Protozoa at all stations, in proportion to the number of Cladoeera. Since Cladocera are almost all eaught in the adult stage and since they are almost all retained by the silk net, they present very good ground for eomparison of plankton eatehes everywhere. Henee the numbers of Cladoeera, the laek in numbers of other organisms and the results of the few, filter paper catches point eonelusively to the faet that the numerical and volnmetrie study of plankton ealls for absolute filtration, high magnification and a laborious teehnique aderuately to represent the sourees of food, and the interrelations of the organisms of the plankton.

\section{DETAILED DISCUSSION OF STATISTICS RECORDED BY THE AUTHOR}

\section{Prefatory}

Tables and plates have been prepared to show in numerieal or graphie form the various facts of distribution and oceurrence which are or may be reekoned as important. This eommentary is intended to elueidate and amplify sueh records and to serve espeeially as a guide to the details of observation or eonelusion concerning whieh the writer is eertain or meertain. Averages, when given for each organism in numbers per cubie meter will be given for each station on the basis of 104 eolleetions at Station I, 52 at Station II and 51 at Station III. Averages are only used beeanse there is no other way of making a general numerieal eomparison in brief form. Temperatures, in degree Centigrade, are given both for surface water and for air. While the latter may be unnecessary it was thought that it might help to give an idea of the conditions locally.

Numbers of planktonts are recorded in units for the same reasons of eonsistency and eonvenience as those mentioned by Kofoid (1908). There is not the slightest intention to imply fietitions accuraey by unit expression. Those who prefer can read the reeord in "round numbers." The writer himself rarely gives any thought to more than the first three figures of a number. 


\begin{abstract}
Algae
Bacteriaceae

Members of this group were uncuestionably abundant both in mumbers and kinls, but they were rery rarely retained by the silk net. In fact, Spivillum undula was the only representative recorded from Stockton Channel, the station most favorable for Baeteria and giving most evidence of their presence. The average number there, 16,310 , is ridienlonsly small in view of the general conditions and in eonsideration of the filter paper collections which indicated a total volume of eatch ahout ten times as great as that found in the silk net eatehes. The relatively great numbers of Cladocera and Copepoda also serve to emphasize the fact that the large portion of the plankton population is very freqently beyond the reach of the usunl methods of observation. Silk net methods can never be more than suggestive of the proluetivity of the waters since they must deal mainly with the giants of the plankton. For that reason, an extended discussion of the Bacteriaceac cannot be undertaken for this scries. It might be said, however, that general conditions inclieate a maximum production of Bacteria in late summer along with the other grouls.

Beggiaton and Micrococcus were only recorded from Stations II and III, and then only once, but they were probably common at all stations.
\end{abstract}

$\begin{array}{cccccc}c & & \\ & \text { Schizophyceac } & & \\ & \text { Station I } & \text { Station II } & \text { Station III } & \text { Daily } & \text { 1Ionrly } \\ \text { Number of forms................. } & 15 & 15 & 15 & 15 & 7 \\ \text { Average per cubic meter ....... } & \mathbf{1 , 6 0 3 , 4 1 4} & 1,292,680 & 1,957,661 & 2,599,163 & 499,123\end{array}$

This group was most conspicuous at all stations in July, Angust and Septemher, when it gave a peculiar color and appearance to the water, but it harl some representation thronghont the year. Anabacna. Nostoc and Oscillatorin were generally most prominent. Some of the smaller forms were probably represented but not identified. Some small forms were also probably confused with other gronps. The group, as a whole, does not seen aceording to record to be of quite so great imprortance as in the Illinois, but this apparent lack is doubt. less due to eseape throngly the net. The color of the water alone would suggest that mulel of the material is lost. It is then, not only safe to say that the group is valuable in furnishing food for othel 
organisms, but also that it probably holds a high place in working " the organic content of the water. Identification, even of genera, was frequently rather difficult in this group, although there was not often any question as to their belonging to the Schizophyeeae. Names as reeorded are to be regarded as suggestive rather than positive. Eyferth's Einfachste Lebcnsformen and Tilden's Winncsota Algae were the guides mainly used.

\section{Discussion of Species}

Anabacna spp.

$$
\begin{array}{ccccc}
\text { Station I } & \text { Station II } & \text { Station III } & \text { Daily } & \text { Hourly } \\
57,600 & 317,644 & 437,967 & 245,139 & 1,531,949
\end{array}
$$

Average

Not clearly distingnished from Nostoc, straight filaments being the characteristic nsually eonsidered indicative. Inehdes some Aphanizomcnon. Found oeeasionally throughout the year. Abundant only in July, August and September, at all stations, in a water temperature ranging from $23.5^{\circ} \mathrm{C}$. to $28^{\circ} \mathrm{C}$. Largest number reeorded at Station I on July 12, Station II on August 9, and Station III on July 19.

Aphanocapsa spp.

Average

Station I Station II Station III Daily Hnurly $117,381 \quad 84,916 \quad 74,329 \quad 441,469 \quad 187,647$

Nost of the colonies eounted under this name probably belong under Clathrocystis and Hicrocystis. There were probably few, if any Aphanocapsa present. The characteristies of Aphanocapsa were not muderstood until the count had gone too far for revision. Since Clathrocystis and Hicrocystis were also more or less subject to confusion it was thought best to let the record for 1913 stand under this head. The maximum production occurs at about the same time as that of Microcystis at all stations. Hence the error probably affects nothing but the question of species distribution. Clathrocystis does not appear on the reeord though now known to be present and it might be well to transfer the Aphanocapsa count to that heading. The late summer maximum, oceuring in higher temperatures and the sudden fall in numbers in colder waters suggests the characteristies of Clathrocystis as noted by Kofoid (1908) in Illinois.

Coclosphacrium kiützingianum Naeg. Recorded three times from Station III and once from each of the other stations. Very small numbers in all eases. Ilentifieation not positive. 
Glococopsa conglomrrata lïitz.

dierage Station 1 Station II Station I11 Iraily LIourly

Recorded only in July and Angust at all stations. Identifiention not positive. Abundant throngh daily and hourly series and in considerabla numbers for the few times taken in the regular series. Howerer, not an important factor so far as these catches indicate. Losses through net probably heavy.

$\begin{array}{lccccc}\text { Crlococapsa spp. } & \text { Stition I } & \text { Station II } & \text { Station III } & \text { 1)aily } & \text { IInurl. } \\ \text { Average ........ } & 197,400 & 141,594 & 181,426 & 520,660 & 539,132\end{array}$

Probably several species are inchuded muler this heading. They are found at all stations throughout the year though most abundant in. July and August. Losses through the net were probably very heary and the genns must play an important part in local waters. Identification considered probable though some confusion affeeted the count at times.

Gomphosphacra aponina Kig.

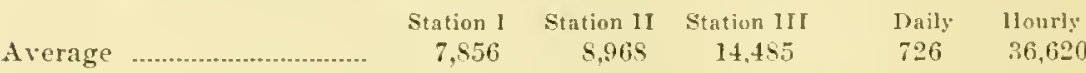

Identification uneertain. Ocenrence at irregular intervals throughout the rear at all stations. Numbers small.

Inactis tinctoria Agardh

$\begin{array}{cccccc} & \text { Station 1 } & \text { Station 1I } & \text { Station 111 } & \text { Daily } & \text { Homrly } \\ \text { Average ............................ } & 532,790 & 215,65.3 & 594,302 & 0 & 10.5,7 ! 12\end{array}$

Identification uncertain. None recorded until Angust. Very few after October at any station. Numbers large while present. Heary loss through net probable. Evidently of considerable importance in the planliton while present.

Merismopedium glaucus Ehrbg.

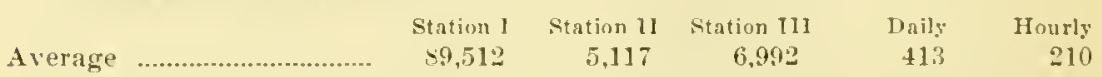

Identification satisfactory. Losses throngh net rery heary. Numbers fairly large in November and Decenber. Rarely recorded earlier in year. Small size nakes it easy to overlook even when present.

Mirrocystis sp.

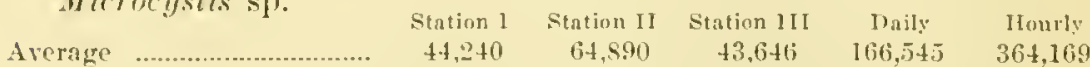

Identification satisfactory. Count probably too low on account of confusion of some colonies with other forms. Found occasionally 
thrnghout the year at all stations. Nuch more abundant in July, August and September. Loss through net certainly very great. An important member of the plankton, but net catches do not afford a good basis for diseussion of its distribution.

\begin{tabular}{|c|c|c|}
\hline & $\begin{array}{l}\text { Station } \\
156,435\end{array}$ & $\begin{array}{c}\text { Station II } \\
301.283\end{array}$ \\
\hline
\end{tabular}

All the plants included under this head were filaments of the contorted type. The count gives the number of filaments in some eases thongh usually fragments of colonies constituted the units. Whole colonies were rarely, if ever, found. Possibly three or four species are inchded in this enumeration. Nostoc appeared occasionally thronghout the year and became quite prominent in July, Angust and September. In view of the fragmentary condition of the colonies it is probable that the loss through the net was considerable.

Oscillatoria formosa. Bory.

$\begin{array}{lccccc} & \text { Station I } & \text { Station II } & \text { Station 1II } & \text { Daily } & \text { Hourly } \\ \text { Average } & 2,037 & 45,699 & 2,205 & & \end{array}$

Identification meertain. This form occurled more often at Station II where it was recorded frequently thronghont the year, reaching its maximum in June. It does not seem to be very important since its size makes it improbable that loss through the net was very great.

\section{Oseillatoria spp. \\ Station I Station II Station III Daily Hourly Average $\begin{array}{lllll}210,437 & 32,323 & 49,941 & 299,126 & 105,792\end{array}$}

Probably three or four species are included under this heading. Found occasionally throughont the year but distinctly a summer form. Maximnm in Angust. Oscillatoria of all kinds were nearly always found in single filaments or fragments of filaments. Masses of filaments were rarely seen. This might be considered as supporting Kofoid's suggestion (1908) that physiological conditions may at times make Oscillatoria a temporary planktont. On the other hand it does not furnish very definite proof against the view that this form is an adventitious planktont, cast adrift by gas bubles or violent curlents.

Oscillatoria tenuis Agardh.

$$
\begin{aligned}
& \text { Station I Station II Station III Daily Hourly } \\
& \text { A verage _......................... } \quad 46,340 \quad 2,404 \quad 3,040 \quad 154,363 \quad 12,207
\end{aligned}
$$

Identification uncertain. Not a very prominent form. Gencral occurrence much the same as for the above mentioned species. 


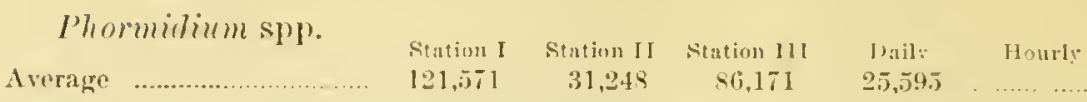

Probably inchudes more than one species. Genus uneertain also. Oecurrence oceasional throngh the year. Most abundant at Station I. Maximum in September. Not a very prominent planktont.

Stigonema sp.

Average

$\begin{array}{ccccc}\text { Station I } & \text { Stition II } & \text { Station III } & \text { Daily } & \text { HIoury. } \\ 1,317 & 45,665 & 8,831 & \ldots \ldots \ldots \ldots \ldots & \ldots \ldots \ldots \ldots \ldots \ldots\end{array}$

Identification very doubtful. Filaments always fragmentary. Nothing but vegetative cells seen. Roferred to Stigonema partly on aceonnt of ocasional lateral arrangement of two eclls in the filament. Never very prominent. Maximum in June at Station II where it was most often fomd. Apparently of little importance. Probably adventitions.

The following forms were recorded but once, at one or more stations, or else are listed because thought to be present in living material :

Calothrix sp. Recorded once at Station I.

Clat luneystis aeruginosa Kig.

Cylindlospermum comalum Wood.

Dactylococcopsis rhaphiclioides IIausg. Recorderl once at Station I. Glococapsa gelatinosa kïitz.

Lyngbya sp. Recorled once at Stations I and II.

Oncobyrsa rivularis Kutz. Recorled once at each station.

Rivnlaria sp. Recorderl once at Station 1.

Srmplocastrum sp. Recorded once at Station III.

Chlorophyccue

$\begin{array}{cccccc} & \text { Station } x & \text { Station } 1 \mathrm{l} & \text { Station XII } & \text { Daily } & \text { Hourly } \\ \text { Number of forms............... } & 15 & 14 & 17 & \mathrm{~S} & \mathrm{~S}\end{array}$

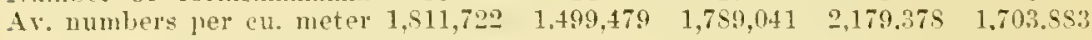

These averages indicate only about one-thirtieth of the numbe: found by liofoid (1908) in Illinois. Since, however, the main eontribution here was male by Actinastrum, Corlastrum. Pcdiasimm and scenedesmus it may be readily understood that losses through the net areomnt for most of the diflerence. The group was represented through the entire year, thongl the numbers were often very fer: Station I showed the peculiarity of a great increase in numbers in May and June, a deeline in .July and August, and another well sustained increase in September, October and November. Stations II and III showed only one eonspienons rise in mumbers, covering abont four months, from July to Oetober inclusive. The numbers ocenr- 
ring in other months were very small. It is quite diffieult to determine the cause of the two pulses at Station I as distinguished from the other two stations. It could hardly be temperature sinee that faetor remains too nearly eonstant during the period involved. The earlier increase in Nay might be aseribed to the more quiet water rich in organie matter, and the eontinnance through November might be aided by the sewage. The most probable explanations of the intermediate fall in numbers seems to be that predatory organisms may have been most prominent at that period or that stagnation of the sewage laden water hindered growth and multiplieation. The possibility of the last named factor being the more important is supported by the fact that inerease comes in September when there begins to be some relief from stagnation by inerease of supply from the momntain streams. This relief was not very great in 1913, however, nor is it very well marked in any year. The possibility of interference by other organisms is supported by the fact that the numbers present are mainly influenced by the numbers of scenedesmus, an organism very likely to be extensively used for food by some of the organisns of the zooplankton. Amongst the Cilinta. Torticrlla seems most likely to be responsible while Asplanchna is the most prominent of the Rotifera. But the Copcpoda are still more charaeteristie of this period and the summer decline of Scencdcsmus may be due mainly to their aetivity. Chlornphyceac were never very eonspienous in 1913 and they were outnumbered by diatoms 14 to 1 and by Mastigophora about 2 to 1 . Uncertainty as to the pereentages of losses of various forms throngh the net makes definite conclusion impossible.

The very interesting question eoneerning reeurrent pulses and their relation to lunar eycles, disenssed by Kofoid (1908), cannot be answered any more definitely here. It is elear from these net eatches that there are recurrent pulses (plates 1-5) at about three to six weeks intervals but there is nothing which warrants more than an indorsement of his provisional conclusion that there may be an inerease in number of chlorophyll bearing organisms to eorrespond with each recurrent inerease of light from the moon. It is altogether probable that this moblem cannot be solved until some one is able to carry a long series of daily eatehes, earefully timed, and by more acenrate methods than those of the silk net. Whether any filter method would suffiee is hard to say. It was hoped that the daily series earried for thinty-one days in 1913 would help to solve this problem but it presented no conchusive evidence. (Pl. 6.) 
Thirty forms were recorded in the comt and it was thought that several others were reognized in the living material. Certainly there were more species present. So far as net cateles inclicate, l'ediastrum was the learer both mumerieally and volumetrically, at Stations II and II1. At Station 1 it was not far different from serncdrsmus in numbers (coenobia counted) and of course, exceeded it in volume of catch. sccncdesmus was elearly second in importanee, Actinastrum

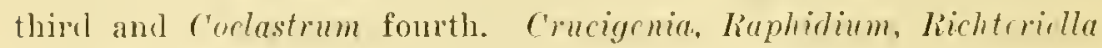
and schrocteria were frequently found. In view of the eommon oceurrence of Botryococcus in other places its scarcity here needs explanation. Failure to identify seems to be the most probable reason, though it may actually have been absent usually.

present methods do not show the dilute sewage water of Stockton Chamnel to be much more productive of chlorophyccae than the river. Hence such evizence as we get from this study only weakly supports Kofoid's suggestion (1908) that sewage laden waters favor the increase in numbers of the group. At any rate there is clear indication that the chlorophyccac contribute largely to the plankton at all stations.

\section{Discuission of Species}

Actinastrum hantzschii. Lagerh.

$\begin{array}{cccccc} & \text { Station I } & \text { Station II } & \text { Station III } & \text { Daily } & \text { Hourly } \\ \text { Average } & 51,050 & 216,851 & 257,954 & 36,939 & 392,439\end{array}$

Ifentification satisfactory. The combined averages of two varicties of this species are given here. They are reeorded separately in tables 1 to 5 . The only difference noted was in size, the one recorded as "large" being from two to four times as large as the typical form measured by length of the cell. As might be expected, it is largely responsible for the enormons average here as compared with the silk net average (338) in Illinois. Without it, however, the average is much greater, thus indicating a distinctly greater prevalence of the species here. It will be noticed too that Stockton Channel with its dilute sewage shows only about one-fourth of the average number's produced by the other stations. The typieal form was found oceasionally at all stations throughont the year and it also reacher its greatest abundance at the same three periods at all stations, i.e., Narch, June and September, the last slowing the maximum. The large variety came in late (April and May), produced a weak pulse in July, and strong pulses in August and October: it dropped out again in November. Apparently temperature affected it much more 
definitely than it did the typical form. Temperature is not the deciding factor, however, as is shown by the fact that this variety appeared last in the warmer water of Stockton Channel whence it also practically disappeared first. Its lower temperature linit seems to be about $14^{\circ} \mathrm{C}$. Stockton Channel was distinctly less favorable to the large form than to the typical form as is shown by the difference in numbers being greater there than at the other two stations (tables 1 to 3 ). Gradations in size between the two forms sometimes made sep. aration difficult. This species is evidently of considerable importance here.

Coelastrum microporum Naeg.

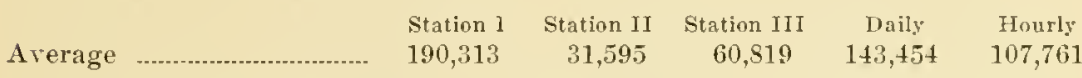

Identification satisfactory. Possibly includes at least two othel. species. Coenobia counted. Was not found at Stations II and III until July, and only five times before that at Station I. Maximum in September at all stations. Last appearance on December 14 at Station T, a month later tluan at the other places. Obviously favored by the slightly higher temperature of Stockton Channel. The difference in arerages also suggests a distinct preference for sewage watel. The maximum in September, when there was little disturbance of the waters, may indicate great susceptibility to action of strong currents and to rising and falling flood waters with their rapid changes in temperature. The September pulse is the only distinet one. In view of the enormous losses through the net, Coclastrum must be reckoned as an important planktont, though it is mainly limited to temperatures above $15^{\circ} \mathrm{C}$.

Crucigenia lauterbornii Schmidle.

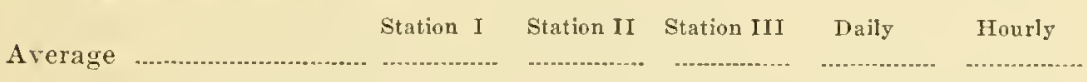

Identification fairly satisfactory. Recorded once from Station II, four times from Station III. Average of colonies for the rear at Station III, 14,771. Clearly too small for accurate stury by net methods. Occurrence in September and October.

Pcdiastrum boryanum Menegh.

$\begin{array}{crrrrr} & \text { Station I } & \text { Station II } & \text { Station III } & \text { Daily } & \text { Hourly } \\ \text { Average } & 9,913 & 41,265 & 72,153 & 12,612 & 37,474\end{array}$

Identification inexact. Coenobia with bicornate marginal cells but without intereellular spaces were counted under this head. Va- 
rious gralations and dliffermees in detail make it seem probable, as liofoid (1908) fouml in Illinois, that at laast two or three speeies may at times he pepresented in the comt.

Present throughont the year at all stations. Missing irregularly in aluost every month at Station I, less often at the ofluer two. Very few in Jannary and Deember. Distinctly more numerous at all stations than in Illinois. Sewage watel evilently less favorable for its development. All stations show a Mareb pulse of some moment and another in September. There is some evidenee of reenrent pulses eorresponding to lunar eyeles, strongest at Station II. Maxima in September at Stations I and II, October at Station III. The most cousistent reeord at Station I is in March and November, indieating a preference in sewage water for temperatures from $13^{\circ} \mathrm{C}$. to $19^{\circ} \mathrm{C}$. Since the only misses at Station II are in May, June and Deember the same inferenee might be drawn as to temperature if it were not for the faet that the representation was well sustained through August to November. Somewhat similar conditions were shown by Station III. At all stations the fluctuations were well marked at all seasons. This was even more true of the daily series at Station I (table 4) than of the regular series. The fluctuations of the first half year may be mainly due to rise and fall of flood waters. It is more diffienlt to aeconnt for those of the suceeding four months monder relatively stable eonditions.

Pcdiastrum duplex, Mleyen.

$\begin{array}{cccccc} & \text { Station I } & \text { Station II } & \text { Station III } & \text { Daily } & \text { Ifourly } \\ \text { Average } & \ldots \ldots \ldots \ldots \ldots \ldots \ldots \ldots \ldots . . . . . .301,913 & 686,539 & 837,875 & 703,005 & 1,613,919\end{array}$

Diagnosis inexact. All the coenobia with more or less bicornate marginal exlls showing distinet intereellular spaces were counted moler this head. The assemblage as a whole is fairly eonstant to a provisional type and is quite possibly a single species. It was also different fron the preceding form in its larger numbers, greater constancy of ocenrence and greater regularity of development. Then too, this species has a more mniform chronology at all stations. There is a vernal pulse with maximum in Mareh and an autumnal pulse with maximm in Oetober. The marked dechne after Mareh is evidently ehargeable in some way to flood conditions. The steady rise from July through Angust and September to the October maximmm is just as evidently due to warmer temperature and greater stability. 'Though $P$. duplex is m'esent at all stations through the whole year its optimm temperature is elearly near $20^{\circ} \mathrm{C}$. The eomparatively 
small numbers in Stoekton Channel indieate that mueh sewage is detrimental. By similar reasoning it might be eonehuled that Smith Canal (Station III) supported a larger number than the river (Station II) beeause more organie matter is benefieial up to a certain point. Sueh a conclusion is not entirely warranted, however, beeause the river has an open channel with some flow while the other is elosed at one end. This difference alone might amount to more than the organic content.

The indieation of recurrent eyeles dne to lunar influence is more distinet with this form than the preeeding though they are not at all regular even here (tables 1 to 3 ). The daily series shows an interesting suggestion of reeurrent pulses at intervals of four to six days (tal)le 4). In the hourly series (table 5), it appears that both $P$. boryanum and $P$. duplex reach maxima in the afternoon, suggesting diurnal influence of light and temperature. The data, however, do not wasrant a eonclusion. The hourly series needs extension.

There is no very definite relation of Pediastrum pulses to the volumetrie pulses.

\section{Pediastrum simplex Meyen.}

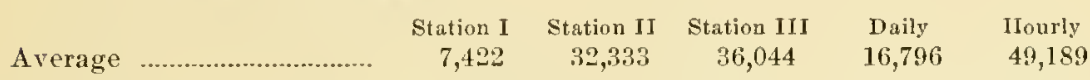

Identifieation fairly satisfaetory. Cocnobia having marginal eells with one median spine were eounted under this head. Probalsy only one species inehded. Fewer than either of the foregoing forms at all stations, exeept that it exeeds $P$. boryanum in both the daily and hourly series. Rare at Station I through the first six months, considerable numbers there in July, very few in Angust, maximnm in September, rare thereafter. Oeeurrence at the other two stations similar, except that the numbers were larger. So far as the records go they indieate the same general eharacteristies of distribution as mentioned for the foregoing speeies.

It is evident that Pediastrum is a very important genus, both numerieally and volumetrieally in the loeal plankton. The greater numbers here, as eompared with Illinois, indieate that local conditions are better suited to this gemus, but it is also true that this may have been an exceptionally favorable year. It is worth noting in this eomneetion that the representation of Pediastrum is proportionally greater here as eompared with other forms found in both seetions and this fact favors the view that it is really more characteristie of our plankton. 
Sinee the genus shows very distinet response to flood conditions, perhaps it is worth while to emphasize that point, especially in view of the fact that there are no reliable water gauge or tide records available. "The rapil deeline of numbers in March follows very closcly" on the arrival of the heary stream flow l'rom the monntains. The rapid rise in numbers in June is just as closely comnected with the disappearance of flood waters.

Raphidium polymorphum Fres.

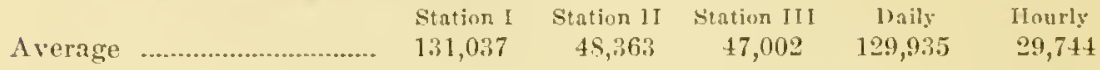

Diagnosis incxact. Probably includes two or more species. Occurrence rare in winter months at all stations. Thrives best in Stockton Channel (Station I). While the numbers are large at times the records are so fragmentary, particularly in view of the enormous numbers eseaping through the net, that no generalization can be made. There is, however, some support for Kofoid's observation (1908) that the organism has an optimum temperature above $15^{\circ} \mathrm{C}$. Furthermore the larger numbers in Stockton C'hannel indicate the benefits of sewage.

Richetriclla botryoides Lemm.

$\begin{array}{cccccc} & \text { Station I } & \text { Station II } & \text { Station III } & \text { I) } \\ \text { Average } & 5,723 & 20,806 & 27,499 & \text { Hourly }\end{array}$

Identification satisfactory. Oecurrence at very irregular intervals at all seasons of the year and at all stations. Rather large numbers at times. Records too seant to warrant eonchusions. Percentage . eaptured evidently very small.

Scencdesmus obliquus Kütz.

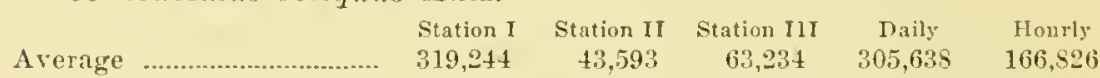

Diagnosis sometimes confused on aceount of apparent intergradations. May perhaps include two or three species. Rare in January and February. Few in Mareh, April, May and December at all stations. Maximum in June at Station I, althongh the numbers are best sustained there through September and October. Other stations also show greater constancy in that period. Terual pulse very shight so far as silk net can show. A rerage silk net eatch in Illinois was given by Kofoid (1908) as 673. 'The largest Stockton C'lannel eatch is about 500 times as great. If the silk net only captures a fraction of 1 per ecnt of the Scencdcsmus present the numbers there were certainly cnormous. In spite of the losses through the net it is at least safe to say that sewage and moderate temperature, $15^{\circ} \mathrm{C}$. to $20^{\circ} \mathrm{C}$. are 
espeeially favorable to this form. There are reenrent pulses apparently but the meertainty as to the percentage of the population on reeord makes all such points unreliable.

Scenedesmus quadricauda Breb.

$\begin{array}{cccccc} & \text { Station I } & \text { Station II } & \text { Station III } & \text { Daily } & \text { Hourly } \\ \text { Average } & 772,520 & 224,775 & 363,308 & 786,615 & 366,203\end{array}$

Diagnosis sometimes eonfused by intergradations. Only a small pereentage in doubt. Losses throngh net certainly very heavy, probably over 99 per cent aecording to Kofoid's results (1908). Henee inferenees are to be made with cantion as in ease of the preceding speeies However, the greater eontimuity of the reeord for this speeies makes intelligent discussion possible.

A vernal pulse in March and an autmmnal pulse euminating in Oetober were quite well marked at Stations II and III. The vernal pulse is not elear at Station I and the autumnal maximum was reaehed in November. In no ease was there very heary representation nutil abont June. At Station I a distinct deehine through July and Angust suggests marked limitation by ligher temperatures. Sewage water with temperature between $15^{\circ} \mathrm{C}$. and $20^{\circ} \mathrm{C}$. is evidently nearly ideal for Sccnedesmus.

There is rather distinct indication of monthly pulses at all three stations (tables 1-3). These do not, however, eorrespond very closely with Pediastrum pulses, so it is hardly worth while to attempt to establish any connection with lunar eycles from present data.

This speeies was rarely absent from any station, never from Station I. Its appearanee there in large numbers through the winter months elearly marks it as perenuial in this locality. While the records of this and the preeding species are fragmentary so far as the whole population of the genms is eoneerned they show very clearly that the genus is of first rate importance in our waters throngh a large part of the year and especially where there is mueh organic matter.

Schroederia sctigcra Lemm.

$\begin{array}{cccccc} & \text { Station I } & \text { Station II } & \text { Station III } & \text { Daily } & \text { Hourly } \\ \text { Average } & 35,7 \mathrm{D4} & 4,099 & 5,343 & 43,587 & 16,276\end{array}$

Identification satisfaetory. Probably only small pereentage captured by the net. Only reeorded six times at Station III and three times at Station II. Irregnlar oeenrenee from last of April to end of year at Station I. Well represented through June and part of November. Not enough data to indieate more than a preferenee for dilute sewage. 
Sclcnastrum bibrainum Reinseh.

ldentification satisfactory. Recorded five times from Station I in small numbers. Once at Station 111. Evidently too small to be held by the net.

The following forms were recorded only once or twice in sinall numbers or else were noticed in living material.

Botryococus sp. Ouce at Stations II and III. May have been overlooked.

Bulbocliaete sp.

Cloolatelia ciliata. Lemm. Once at Station III.

Crueigenia qualrata Morr. Onee in daily series.

Crueigenia reetangnlaris Chod.

Crueigenia sp. Onee at Stations II and III.

Dimorylococens lunatus $\mathrm{A}$. Br.

1) raparnaldia plunısa Ag.

Golcukinia radiata Chod. Once at Stations I and III.

Lagerheimia wratislaviense Sehroed. Once at station I.

Lanterborniella elegantissima Schmidle. Onee at Stations I and II.

Monostroma sp. Once at Station III.

Nephroeytium agardhianum Nacg.

Plenroeoceus sp.

Sorastrum spinulosum Naeg.

Stigeoclonium (g) sp. Twiee at Stations I and II.

Tetrastrum sp. Onee at Station III.

Ulothrix sp. Twice at Station I. Doubtful identification.

\section{Bacillariaccae}

Plates $7-9$

Station I Station II Station III Daily Flourly $\begin{array}{cccccc}\text { Number of forms recoriled } 44 & 58 & 53 & 25 & 32 \\ \text { Av. number per eu. meter .....2:2,609,062 } & 39,478,317 & 36,526,559 & 25,055,459 & 29,029,248\end{array}$

The diatoms are distinetly the most abundant gromp of organisms in San Joaquin plankton so far as present methods show. Aceording to these records they outnumber Schizophyceae 14,33 and 18 to 1 ; Chlorophyceac 12, 28 and 21 to 1, and Mastigophora 6, 14 and 7 to 1 at Stations I, 11 and III respectively, thus making them appear to have a still more prominent place in the plankton than they had in Illinois. There were always some diatoms in every collection at all stations thronghout the year.

There was only one very distinct pulse at each station. At Station I this appeared in $\mathrm{Iay}$, while at the other stations, where it was larger but less abrupt, it came in August. There is no way of telling from these records whether this difference was due to better temperature or to more stable conditions at those times. The fact that Smith Canal 
resembles the river in temperature and is more like Stockton Channel in stabihity suggests a stronger influence of temperature. A glance at plates 7,8 and 9 shows a marked resemblance of all three stations in low production of diatoms through the first twenty and the last six weeks of the year. All show comparatively heavy production through all the intervening period though the culmination is more nearly median in this time at Stations II and III. This characteristic of distribution is common to all the algae. These major pulses are evidently composite though the exact location of their maxima may be due to single speeies. The diatoms as a group show more marked indication of pulses recurrent at approximately four weeks intervals than do any other algae.

One notable difference in the three stations is that the total production is less at Station I than at either of the others. Except for the difference in the location of the maxima this was shown throughout the year. The production in winter and spring is eontinuously less at Station I. Although the maximum came earlier it did not appear so abruptly nor decline so quickly as at both Station II and Station III. Serage seems to be detrimental, as does a temperature above $23^{\circ} \mathrm{C}$. However, it is not certain that temperature is the determining factor, for stagnation of the water probably has a deleterions effect nore quickly in sewage water than in water comparatively elean. It seems quite possible that simultaneous strong flood eurrents through Stockton Channel and the river would hold the maximum back to a similar date. Some light on this question may be expeeted from the 1914 series which covers a time of heavy flood. Again there is the possibility that predatory organisms, notably Entomostraea, cut down the supply of diatoms in spite of favorable conditions for development. The maximum for Entomostraca comes at the time of decline of produetion of diatoms in the summer (plates 3,9 ).

The fact noted by Kofoid (1908) that the volumetrie measure shows mainly the zoöplankton is especially important here because there is not suffieient check by other methods to give any idea of the relative loss of phytoplankton through the net. The diatom count eorresponds pretty elosely, in its rise and decline, to the volumetric reeord (plates $1,7,8,9$ ) at Station II and III but no very definite relation appears at Station $I$. This might be expected from the fact that a moment's examination gives one the impression that the Stockton Channel plankton is distinctly animal and the river plankton mainly plant. 
While the records of Station I might lead one to think there possibly were reproductive eyeles and snecessive rest periods as suggesterl by Kofoid (1908) the records for Stations 11 and III point rather the other way. The strong and somewhat rapid rise throngh June and July to a maximum in Augnst witle in similar deeline to the winter level suggests, indeed, that factors of the immediate external environment are responsible and that increase in numbers would continue indefinitely if the proper balance of temperatnre, food materials and natural enemies could be secured along with suffieient removal of injurious acemunlations.

The number of forms of diatoms listed (98) may seem unwarranted inasmueh as there conld be no hope of aeemrate determination of all the speeies present. The large list was the emmulative result of an effort to give expression to differenees noted. The futility of it was not realized until too late to change it easily. After all, it happens that there are only a few forms fonnd frequentiy and in great number's and most of these ean be approximately determined.

Twenty forms oceur at one or more stations with suffieient eontinuity to give the impression that they are true planktonts. These are Astcrionclla gracillima, Bacillaria paradora. Cyclotella spp. Cymatopleura solca, Cymbella affinis, Cymbclla cymbiformis. Cymbclla lumida, Fragillaria capucina, Gyrosigma lï̈zingii, Gyrosigma scalproides. Mrlosira gramulata, Melosira varians. Navioula alpestris, Navicula bacillum, Navicula gracitis, Nitzschin acicularis, Plourostanom pervulum, surirella sppe, Synchlra radians, and synertra ulna. Distinetly the most important of these are Asterionclla. Bacillaria. ('yclotella. Mclosira and Synedra, all of which are satisfaetorily determined as to genus, thongh the speeies are sometimes nncertain. Most of the other genera just mentioned are also believed to be eorrectly designated. Mneh of the speeifie determination is largely gress work for the inexperieneed observer under the combitions of counting. Fortmuately sueh errors do not materially affect the generalizations within reaeh of this present study. Sehönfeldt 's "Baeillariales" in the siussuasserfora Deutschlands series was the main depentenee for irlontification. 


\section{Discussion of Species}

Asterionella gracillima Heib.

$\begin{array}{cccccc} & \text { Station I } & \text { Station II } & \text { Station III } & \text { Daily } & \text { Hourly } \\ \text { Average …................................ } 344,375 & 1,743,406 & 1,381,583 & 3,516 & 12,206\end{array}$

Identification certain. Reeords show numbers of colonies. Average size of colonies at Station I was three, at Station II four, at Station III three. Two forms were noted, a typical and a large form. They were recorded separately in tables 1 to 5 though the above averages are for the two eombined. As in the ease of Actinastrum the two were alike except for size but the larger was usually only abont 50 per cent larger, rarely twiee as large. There were sometimes all gradations in size but in most cases the distinetion was plain. It will be notieed by reference to the tables that the pulses ran somewhat the same with both forms at all stations but that the large form appeared rather late at all stations and that it was only prominent in Nlay and Jnn's at Stations I and II, Jume at Station III. Perhaps this condition warrants the inference that the large form is favored by a tenperature above $20^{\circ} \mathrm{C}$. espeeially since the Jume maximum eomes at the highest temperature $\left(26.5 \mathrm{C}\right.$. and $29^{\circ} \mathrm{C}$. respectively at Stations II and III) and very nearly so at Station I $\left(22^{\circ} \mathrm{C}\right.$.).

Both forms were practically absent at all stations through July, August, September and October. Both reappear in November. The typieal form is abundant at all stations except during the four montlus just mentioned. At Station I it showed a strong pulse in January and a maximum pulse in Mareh. Another strong pulse came in December. At both of the other stations the maximum pulse came in February and a very strong pulse in December. If both forms be counted together, Station II is seen to have almost as large a pulse in June as in February. The combination also shows a very large pulse in June at Station III. The abrupt disappearance of both forms in Jnly at all stations must be tue to some other factor than temperature since the temperature ehange is neither abrupt nor very marked. Stagnation may have a strong deterrent influence. There are fairly well marked, reeurrent pulses at four to six weeks intervals at all stations.

Very few single cells of Aslcrionella were recorded. This ean be aceounted for in two ways: first, eseape through the net; second, confusion with other single cells. 
Amphiprora alata Kïitz.

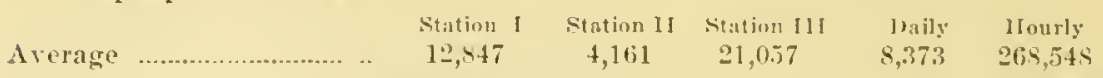

Identification satisfactory als to genus and probable as to species. A. ornala is probably inchuled in the connt at times, als it was sometimes found by the writer and was also idlutifierl in 1915 catches by Professor C. J. Fimore. Probably heary loss through the net. So far ats net eatrhes show it is not so very important. Ocenrence rather scattering at all stations though faily constant in latter part of the year at Station I. Maximum at Station I in May, at other stations in June.

Bacillaria paradora Gmel.

\begin{tabular}{|c|c|c|}
\hline & Station & \\
\hline
\end{tabular}

Identifieation positive. Colonit's usually large, henee probably very little loss throngh the net. Ocenrence seattering at Station I, fairly constant throngh the year at Station II and II where it was abundant throngh the seeond half year. Maximum in July at Station I, Angust 2 at Station II, and Angust 9 at Station III. Conspienous minor pulses in April and Deember at Station $11: \Delta$ pril. September and December at Station III. The sudden jump into prominence at Stations II and III in July and the reappearance at Station I, where it had been absent more than two months, seems to indicate favolable influence of stagnant water. Retardation by sewage is also indieated. IIgher tempratures may lave a bearing, though the temperature change is not nearly so abrupt as the change in numbers of Bacilluria. There are no very strong indications of reeurent pulses at any station, but Station II shows them slightly.

P. puradora is certainly one of the most important planktonts of the river" after the flood season. Colnnies containing less than ten individual cells were comparatively rare, certainly not more common than those consisting of more than twenty-five. It wonld he very safe to estimate the average number of eells eaptured at ten times the arerage reeorded for the colonies. This would bring $B$. puradora into the foremost rank of planktonts, minerieally, at Stations 11 and HI. Only Cyclot lla sp. and Mclosira gremulatu would elearly exeed it in 11 mbers by that reckoning. The other forms which might do so are not identified with sufficient certainty.

Cocconris prdiculus Ehrbg.

Detemination probable. May includr other species. Losses throngh net undoubtedy heary. According to the records not a very import- 
ant planktont. Ocenrs fire times at Station I, thirteen times at Station Il with a maximum of 105,792 at the end of May, and four times at Station III.

$\begin{array}{cccccc}\text { Cyclotella spp. } & \text { Station I } & \text { Station II } & \text { Station III } & \text { Daily } & \text { Hourly } \\ \text { A rerage } & \end{array}$

Genus identification certain. Probably includes three or more species, eertainly two. Impossible to distinguish speeies eompletely while eounting though the attempt was marle throughout the whole series for 1913. It was finally decided that more acenrate eonelusions were probable if all counts were thrown together. So few individuals are retained by the net that any conclusion must be taken with cantion even then. Present through the year in all collections at all stations. Wide range in size. Nost of them nearer the smaller limit as noted by Kofoid (1908).

Maximum numbers at Station I in .June, at both of the other stations in October. One minor pulse is of umusual interest because it falls on January 19 at all three stations (tables 1-3). There is no great change in temperature to account for it but it came after a week of cloudy weather with more or less rain on the five days immediately preeeding. It wonld seem that the condition of falling flood is responsible in this case. Possibly the June maximum at Station I can be explained in the same way. No such local conclitions apply in case of the Oetober maximum at Stations $1 \mathrm{I}$ and III. There was, however, about that time highel water than there had been for several weeks previous, dne to the inflow from momtain tributaries enlarged by the early mountain rains.

So far as our present records show, the optimum temperature seems to be nearer $20^{\circ} \mathrm{C}$. than $15^{\circ} \mathrm{C}$. as found by Kofoil (1908) in Illinois. Sewage contamination, stagnation and flood waters all appear to be factors of marked importance in determining maximal production of this diatom. There is no indication of a maximum corresponding to the volumetric maximum (plate 1 ) such as was observed in Illinois, but this may be due to the small numbers canght as compared with those escaping.

Cymatopleura solea Breb. Average $\begin{array}{ccccc}\text { Station I } & \text { Station II } & \text { Station III } & \text { Daily } & \text { Hourly } \\ 219 & 11,043 & 3,796 & \ldots \ldots \ldots \ldots \ldots \ldots & \ldots \ldots \ldots \ldots\end{array}$

Identifieation satisfactory. Recorded only six times at Station I, but found at intervals throngh whole year at other stations. Numbers 
rather small. Loss through net considerable. Maximum in May at Station II with a well defincd pulse. Maximum in August at Station III where there were no definite pulses. May be adventitious. Tumperatures at maxima were above $20^{\circ} \mathrm{C}$.

C'ymbclla affinis Kiitz.

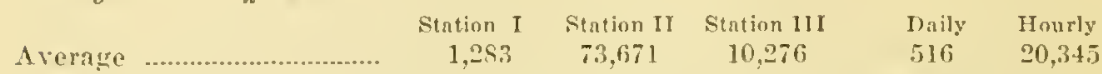

Identification unecrtain. This was a very small cymbella relatively few of which eonld have been retained by the net. Recorded only eleven times at Station I. Abundant in Mareh, April, May and Jume at Station II but missing in January, February and Decenber. Seattering in other montlis. Maximum on May 31 in a well developed pulse. Nlore irregular in oecurrence at Station III where the maximum eame in April. Prohably an important planktont numerieally. Evidently not favored by sewage.

Cymbclla cymbiformis Kïitz.

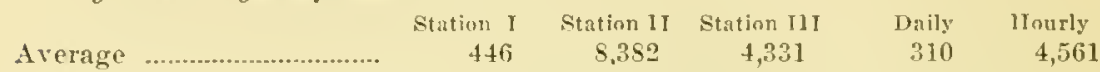

Identifieation meertain. Probably includes more than one speeies not distinguishable while eounting. Recorded thirteen times at wide intervals at Station I, in small numbers. Small numbers reeorded in every month of the year at Stations I and III with a fairly constant reeord throngh May and June at Station II. Apparently of minor importance.

rymbclla tumida Breb.

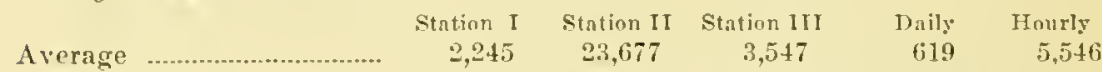

Identification mneertain. Probably inelndes more than one spreeies. Records seattering and in small numbers at Station I. Small numbers but fairly constant, May to September, at Station III. Reeorded in every month except January and September at Station II. Maximm in May. Probably of minor importance.

Epithemia ocellata Küitz.

Average $\begin{array}{ccccc}\text { Station I } & \text { Station II } & \text { Station III } & \text { Daily } & \text { Hourly } \\ 1,015 & 15,713 & 3,579 & 413 & 8,630\end{array}$

Trentifieation fairly satisfactory. Probably two other speeies included. Loss through net heary. Numbers small and records seattering at Stations I and III. Representation fairly constant at Station II exeept in Jannary, February and December. Maximum in May on a well marked pulse. May be adventitious sinee the maximum comes on the waters of the mountain flood. 
Fragillaria capucina Desm.

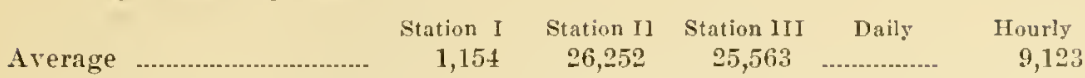

Identification satisfactory. Colonies usually rather large, seldom less than six cells. Most of the colonies probably retained, though loss of small colonies and single cells way have been heavy. Numbers very small at Station I and records few after April. Numbers larger and occurrence more constant at Stations II and III, though frequently missing there after $\Lambda$ ugnst. Maximum in May at both places. No other pulse of particular note. Apparently not very important.

\section{Fragillaria crotonensis Kitton.}

\begin{tabular}{|c|c|c|c|c|c|}
\hline & Station I & Station II & Station III & Daily & Hourly \\
\hline Average & 92 & 4,516 & 7,889 & 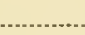 & \\
\hline
\end{tabular}

Identification satisfactory. Colonies not very large. Occurrence twice at Station I, seven times at Station II at wide intervals and nine times at Station III. The records at Station III are mainly in September, October and November. Evidently unimportant here in spite of considerable escape from net in catches.

Fragillaria spp.

Average Station I Station II Station III Daily Hourly

Probably most of those included under this lieading belonged to F. virescens. Occurrence only twice at Station I. Represented at Station II by some fairly large numbers widely scattered. Colonies small. Apparently adventitions.

Gomphonema constrictum Ehrbg.

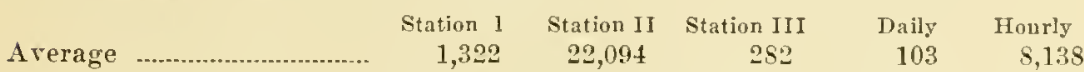

Identification uncertain. Numbers small. Losses through net heavy. Recorded seven times at Station I at irregular intervals. Well represented in May and Jume at Station II. Recorded seven times at Station III in very small numbers.

Gomphonema spp.

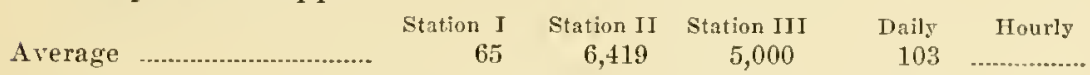

Under this heading are included some members of this group which could not be placed satisfactorily. Probably most of them were $G$. subcluvatum. Apparently there were five or six species of this genus observed at various times and it probably has some importance though it may be adventitious. 
Cryrosigma acuminatum líitz.

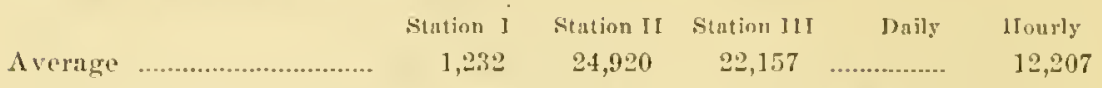

Identification uneertain. Recorded seven times at Station $I$ at wide intervals, twelve times at Station II and Station III. Grouper in August at Station III. Considering amount of loss throngh net may have some importanee though evidently adventitious.

Gyrosigma liitzingü Grum.

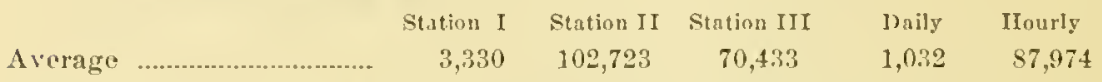

Identification probable. Losses through net very heavy. Recorded frequently in small numbers in every month exeept February, June, and July at Station I. Maximum there in September. Oecurred reagularly with only one or two breaks at Stations II and III. Naximum at Station II in late August in a well developed pulse. Mtaximum at Station $11 \mathrm{I}$ in late July at the beginning of a similar pulse which almost reached the maximum again at the same time with Station II. Minor pulses at from two to six weeks intervals through most of the year were rather prominent at both stations. Apparently this is a planktont of some importance thronghout the year sinee the pereentage retained by the net is undoubtedly small.

Gryrosigma scalproides Rabenh.

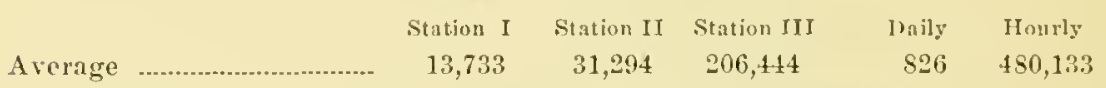

Identification satisfactory. May inelude G. spenerri W. Sm. Loss through net heavy. Reeords seattering at Station I espeeially in first seven months. Maximum in Angust with a well developed pulse. Recorded in every month up to September and not later, at Station II, with a sharp pulse in August. Reeorded every month after January and February at Station 11 I though seattering until late July. Very strong pulse in August reaching apex on Angust 23. Seems to be, like other Gyrosigma, a sasonal planktont favored by temperatures above $20^{\circ} \mathrm{C}$. and injured by sewage.

\section{Melosira granulata Ehrbg.}

Station I Station II Station 11 I Daily Hourly Average ............................ 2,305,175 $\quad 25,163,409 \quad 22,821.226 \quad 1,880,779 \quad 18,144,471$

Identifieation ertain. Mostly variety spinose. Loss through net high. Kofoid (1908) says about 98 per eent in Illinois and it is doubt- 
less nearly the same here. His observation that silk eatches showed the same seasonal routine as the filter catches makes it seem probable that we can use our connts here with some confidence in the conclusions they may indicate. $M$. granulata is recorded in every collection through the whole year at all stations. At all stations the numbers are comparatively small until April, though the million mark was reached a few times before that date at each. The earliest count of this size was at Station I in January. The maximum at all stations falls on September 6, after a considerable period of rather high temperatures. A temperature of $25^{\circ} \mathrm{C}$. or higher and stagnation of the water are at least two favorable factors in production. Since Station I has less than 10 per cent of the number at the other stations at that time it seems equally elear that sewage is detrimental. So far as the 1913 collections show, there is a rather definite growth period in September, though there are several prominent pulses through the warm season just as there were in Illinois. IIinor pulses at from two to six weeks intervals were quite prominent characteristics of the occurrence of this organism everywhere. The steady deche from the September maximnm in spite of oceasional minor pulses strongly supports Kiofoid's view that temperature is the most potent factor influencing production.

The time of maximum production corresponds fairly well with the time of greatest production of total plankton mass (plate 1), though the largest number is reached a little later. It is, however, coincident with the maximum of the total count of organisms. To this last total $M$. granulata contributes largely since it is the most abundant local planktont at Stations II and 111. Owing to its large numbers it also contributes a very considerable mass.

There was a good deal of variability in this species. Spines varied from very coarse, prominent projections to none. Granulation was very prominent in some cases, absent in others. There was a wide variation in size. This was so great that for a time a small form was listed as $M$. granulata $A$ and counted separately (tables 1-3). By so doing the main count was fairly well restricted to the more nearly typical gramulata and to the variety spinosa. Sometimes these seemed to be nearly equal in numbers but usually the spinous form was less noticed than the other.

Various encumbrances of the filaments were common. None of these were certainly identified. The only one eounted was a small Rotifer egg listed as Diurella sp., by guess. 
No effort was made to determine the average number of cells in a filament but it was mobably not less than five. The cells composing a filament were much longer in proportion to willth than they were figureal in the literature consulted. A common form about the time of maximum unmbers hacl eclls ahout five times as long as wide.

Volosira varians Ag.

\begin{tabular}{|c|c|c|c|c|c|}
\hline Arerage & $\begin{array}{c}\text { Stition I } \\
+682\end{array}$ & $\begin{array}{l}\text { Station II } \\
233,227\end{array}$ & $\begin{array}{c}\text { Statim III } \\
93 \text { sSt }\end{array}$ & $\begin{array}{l}\text { Daily } \\
\text { (ilg }\end{array}$ & $\begin{array}{l}\text { II ourly } \\
0,123\end{array}$ \\
\hline
\end{tabular}

Identification satisfactory. Losses through net heary. Occurrence at Station I quite irregular in small numbers, with a maximum in April. Main production at other stations in first six months, two or three misses after that time at hoth. Maximum at last of May in Station II after steady increase for several weeks. Maximum in Mareh at Station III, appearing rather abruptly. Recurrent pulses at two to six weeks intervals at both stations. A large September pulse is only indication of response to ennditions similar to those of $1 /$. gramulatu. In fact the most favorable temperature seems to be near $18^{\circ} \mathrm{C}$. or between $12^{\circ} \mathrm{C}$. and $20^{\circ} \mathrm{C}$. There is a strong pulse in late December at Station II which follows about a month of temperatures below $10^{\circ} \mathrm{C}$. Hence it is certain that the two species are distinctly different in the responses to temperature. While M. varians is overshadowed in produetiveness by $M$. gramulata, it is yet to be reckoned an important planktont here.

Navicula affinis Ehrbg.

ldentification doubtful. Losses through net heavy. Recorded eleven and eight times at Stations II and 111 respectively in rather small numbers. Not sufficient data for discussion.

Naricula alpestris Grun.

$\begin{array}{rrcccc} & \text { Station I } & \text { Station II } & \text { Station III } & \text { Daily } & \text { Hourly } \\ \text { Average …............................ } & 6,746 & 76,645 & 29,979 & 3,929 & 55,357\end{array}$

Iclentification doubtful. Losses throngh net very heary. Ocenrrence at Station I in small numbers and very seattering througl the year. Not much better record at Station III. Appears in Mareh at Stations II and III. Maximum at Station II on May 31 after two months of fairly steady increase, followed by slow decline to August. Scens to be favored by moving water. Its long continmed presence seems to indicate that it is a true planktont, and it is probals]y of considerable importance. 
Naricula bacillum Ehrbg.

Arerage

$\begin{array}{ccccc}\text { Station I } & \text { Station II } & \text { Station III } & \text { Daily } & \text { Ifourly } \\ 56,910 & 169,399 & 42,869 & 16,079 & 65,103\end{array}$

Identification doubtful. Percentage retained by net must be very small. It may seem a waste of time to list so many diatoms of meertain identity, especially of the smaller forms, but it is the writer's opinion that to do so may serve two purposes: first, to give a faint idea of the large number of forms present; seeoud, to show how very many forms there are beyond the reach of ordinary quantitative methods. For example the small diatom listed under this present heading was quite probably present in one hundred times the numbers reeorded, possibly more. It appears in April at all stations and is erratie in appearanee and numbers after that. The maximum appears in September at Station I and Station III but in June at Station II. In the eireumstanees no safe eonchsions ean be drawn from such a small organism.

\section{Nuricula didymu Ehrbg.}

Identification doubtful. Losses through net heary. Recorded once at Station I, ten times at Stations II and III, always in small numbers.

Naricula dubia Ehrbg.

Identifieation doubtful. Losses throngh net heavy. Recorded six times at Station I, four times at Station II and five times at Station III in small numbers.

Navicula gracilis Ehrbg.

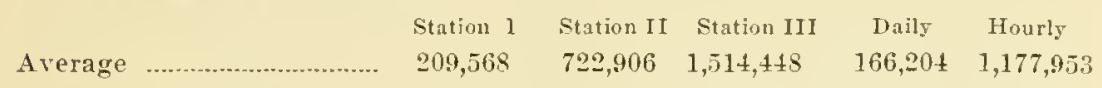

Identifieation uneertain. Losses through net very heavy. Recorded in every month at all stations. Maximum in August at all stations on a rather abrupt rise in numbers. Certainly farored by higher temperatures and quiet water but hindered by sewage. These points are shown by the remarkable derelopment at Station III with quiet water but with little sewage and by the faet that the large numbers shown by Station II through May probably eame from the washing out of some sloughs where there had been a time of quiet just preceding. Reeurrent pulses are fairly well marked. This form is evidently very important numerieally. The count may inelude several speeies. 


\section{Naricula sp.}

Under this head are included a number of forms thought to be Naricula. Sone of these were first reeorded as $N$. oblonga, N. pusilla, $N$. rhomboides and $N$. smithii, but the numbers were few and the identity meertain, so it was more eonvenient to place them this way. There is nothing of particular importanee to be olstained even from the combined record.

Naricula viridis Ehrlog.

$\begin{array}{cccccr} & \text { Station I } & \text { Station II } & \text { Station III } & \text { Daily } & \text { Ilourly } \\ \text { Average } & 169 & 27,659 & 4,488 & & 985\end{array}$

Identifieation satisfactory. Losses through net probably heary. Numbers very small at Stations I and III. Maximum in May at Station II where the numbers were larger and there were few eollections showing none. For purposes of discussion it is unfortumate that the only Navicula named with confidence presents too few numbers to warrant much attention.

Nitzschia acicularis Kiitz.

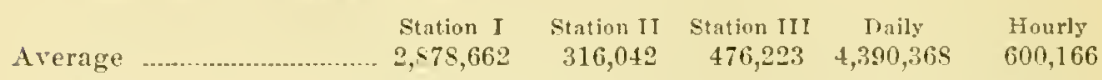

Identifieation satisfactory. Probahly very small pereentage retained by net. Present thronghout the year at all stations. Maxima in Jume at Stations I and II, in late August at Station III. Numbers well sustained through summer at all stations, with a conspicuons September pulse. Evichently a summer planktont favored by temperatures above $20^{\circ} \mathrm{C}$. Just as evidently favored by the sewage at Station I as shown by the enormous averages there in eomparison with the averages at other stations. Reeurrent pulses fairly well marked. Certainly of great numerieal importanee though its small size would keep the volumetric showing low.

\section{Nitzschia spp.}

Under this heading are disenssed forr or more speeies of Nitzschia all but one of whieh are doubtful as to identifieation. Nitzschia angularis was satisfactorily determined but $N$. sigma, sigmoidca and vermicularis were all somewhat doubtful, at least sometimes. They were all listed separately in the tables but the oeeurrence was so erratie and the probable losses from the net so heary that it hardly seemed wortly while to attempt to draw any eonelusions from the reeords of any of them. It might be noted, however, that all Nitzschia are favored by ligher temperatures, but that none of these do well in sewage, $\dot{N}$. 
acicularis being exceptional in that respect. It may also be the only true planktont, all the others being adventitious.

Pleurostauron pareulum Grun.

Average Station I Station II Station III Daily Hourly

$\begin{array}{lllll}34,372 & 261,925 & 149,609 & 310 & 28,521\end{array}$

Identification probable. Probably very small pereentage retained by net. Almost entirely absent from Station I through July, August and September. Few during last half of year. Maximum in May at Stations I and II and in March at Station III. Heavier representation in first half year at all stations. Hence it appears to be favored by flood waters and lower temperatures. Larger numbers at Station II and III indicate bad effects of sewage at Station I. Wust be of nnmerical importance.

Stauroneis phocniecnteron Ehrbg.

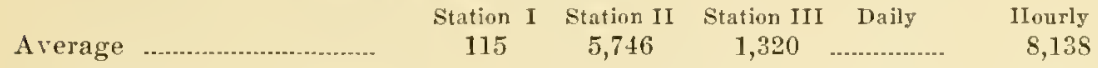

Identification satisfactory. Losses throngh net probably heary. Found at varions times of year at all stations but in small numbers. Recorded only six times at Stations I and III. Maximum in May at Station II. Probably adventitions.

Surivella spp.

$\begin{array}{cccccc} & \text { Station I } & \text { Station 11 } & \text { Station I1 I } & \text { Daily } & \text { Hourly } \\ \text { Average } & 14,270 & 753,747 & 404,242 & 12,303 & 305,82 \mathrm{~S}\end{array}$

Genns identifieation certain. Probably at least four species ineluded under this lieading. Losses through net heavy. Present throngh year at all stations. Maximum in Augnst at Stations II and III. The representation at Station I was light and seattering and though the maximum came in May it eannot be considered very important, especially since large pulses came at that time at the other stations. This planktont is evidently favored by temperatures abore $20^{\circ} \mathrm{C}$. and retarded by sewage. Both in numbers and volume it makes an important contribution to the plankton popnlation.

Synedra radians Kü̈tz.

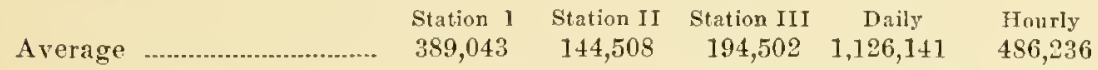

Identification donbtful. Probably very small percentage retained by net. This is one of those very small forms so difficult to handle in a count. Its appearance on the reeord at mid-July is simply due to the fact that its continned presence seemed to demand some definite notice. The ocenrrence before that date must be ignored beeause of 
failure to decide to record it. There is enough record to indieate that it is a wam weather form and not nearly so well pepresented in the colder' months.

Synedra ulna Ehrlog.

Average

Station I Station II Station III Daily IIourly

ldentification mnecrtain. l'rolably includes at least three or four other species with possibly some similar genera. This probably acconnts for the similarity of numbers and distribution at all stations. Maximm in August at Stations II and III, in Jume at station I with a large pulse in August. Certainly favored by higher temperatures. Losses through net heary. An important local planktont.

\section{Tabcllaria spp.}

Idnutification of genus satisfactory. Ocenrrence at all stations rare. Evidently unimportant here. It was thought that both $T$. fenestrala and $T$. flocculosa were reeognized a few times. This gemus is apparently no more at home here than Kofoid (1908) reported it to be in Illinois.

The following forms of Bacillariaceae were recorded only once or twien at the three stations, or were thought to be recognized in living material:

Amphora coffeaeformis Ag. Once, I and twice, 111.

Amphora sp. Once, I anil III.

Coceoneis placentula Elrog. Onee, Il.

Cocconeis s]).

Coscinortiscus sp. Onee Stations I and III and daily.

Cyilotella schroeteri Lemm. Once, I.

Crimbella helretica Kïtz. Onee, IJ and IJI.

Cymbella lanceolata Elirbg.

Cymbella jarra W. Sm. Twice, l, once at II and III.

Cyubella pusilla Grun.

Cymbella prostrata Berk.

Denticula sp.

Diatoma sp.

Diatoma vulgare Bory. Twice, $I$, once at III.

Diatomella sjo. Grev, Once, I and II.

Epithemia graulata Ehrbg.

Withemia sorex Küitz. Once, III.

Epithemia sp.

Fuithemia turgisla Ehrbg. Once, II.

Eunotia flexuosa Kütz. Once at Station I, twice at III.

Hunotia major W. Sm. Once, IIT.

Iunotia pectinalis Kütz.

Fragillaria mntabilis. 
Gomphonema acuminatum Ehrbg. Once, III.

Gomphonema olivaceum Lyngb. Twice, III.

Gomphonema subelavatum Grun.

Gyrosigma attenuatum Kütz. Ouce, III.

Mastogloia braunii Grun. Twice, II and III.

Mastogloia sp. Once, II.

Melosira subflexilis Kütz. Once, II.

Naricula helvetica J. Bruu. Once, III.

Navieula lanceolata Kütz. Once, II.

Navieula oblonga Kütz.

Navicula pusilla W. Sm.

Navicula rhomboides Ehrbg.

Navieula smithii Breb.

Nitzschia dubia IV. Sm. Once, II.

Nitzschia gracilis Hantzsch. Onee, III.

Pinuularia acrospluaeria Breb. Once, $11 \mathrm{I}$.

Pleurostauron obtusum Lagerst. Once, 1 and II.

Rhizosolenia longiseta Zach. Once, I and III.

Rhopalodia gibba O. Müll. Once, I, twice, II.

Rhopalodia paralella O. Müll. Once, 11 .

Stephanodiseus sp. Twice, I, once, II.

Surirella spiralis Kütz. Once, IT.

The following list of forms, identified by Professor C. J. Elmore of Grand Island College in Nebraska from material collected in 1915 and sent to him for naming, will prove of interest for comparison.

Achnanthes lanceolata (Breb) Grun.

Amphora ovalis.

Asterionella graeillima Heib.

Amphiprora ornata Bailey.

Bacillaria jaraıloxa Gmel.

Ceratoneis arcus Elir.

Cocconeis pediculus Ehr.

Cyclotella meneghiniana Kütz.

Cymatopleura solea (Breb) Grun.

Cymatopleura elliptica (Kütz) W. Sm.

Cymbella gastroiles Kïtz.

Cymbella lanceolata.

Cymbella pusilla.

Diploneis (Navienla) elliptiea.

Encyonema turgiłum (Greg) Grun.

Epithemia gibba (Ehr) Kiitz.

Epithemia ocellata Kütz.

Epithemia turgida Elır.

Ennotia robusta.

Fragilaria capueina Desm.

Gomphonema montanum.

Gomphonema constrictum Ehr.

Grrosigma kützingii (Grun) $\mathrm{Cl}$.

Gyrosigma parkerii.

Gyrosigma scalproiles (Rabenh) Cl. 
Gyrosigma spenterii (W. Sm) Cl.

Homoeoclarlia (Nitzschia) acicularis.

Ilomocoeladia amplioxys.

Ilomorocladie olotusa.

Homoeocladia sigma.

Homoeocladia speetabilis.

Ilomococladia tryblionella.

Melosira granulata (Ehr) Ralfs.

Melosira cremulata Ehr.

Melosira distans. Kütz.

Melosira varians Ag.

Navicula ambigua.

Navicula borealis.

Navicula eryptoephala kïitz.

Navicula iridis.

Navieula fulva.

Navieula ]anceolata Küt\%.

Navicula parva (Elir).

Navieula pupula Kütz.

Navicula pygmaea.

Navicula rhychoceplala Kütz.

Navicula viridis (Nitz) Kütz.

Nitzsuhia vermicularis Kiitz.

Olontilium elongatum (Ag) Kuntze.

Sphinetoeystis dibrilis.

Stauroneis anceps.

Stauroneis phoenicenteron.

Surirella hiseriata.

Surirella ovalis.

Surirella robusta.

Surirella spiralis.

Synedra acus Kïtz.

Synertra capitata.

Synerlra ralians Kütz.

Synedra ulua Ehr.

Tabellaria fenestrata Küitz.

\section{Conjugatae}

Number of forms listed...

$\begin{array}{cc}\text { Station I } & \text { Station I } \\ 10 & 15\end{array}$

Station III

13
Daily

Hourly

$121,653 \quad 331,687$
5
420,463
26,527
viduals per cubic meter
931,948

The representation for this gromp is mainly desmid but there

The representation for this gromp is mainly desmid but there

The representation for this gromp is mainly desmid but there were a few filamentous forms such as spirogyra included oecasionally. These latter occurred in snch small quantities, however, that they had no appreciable volumetrie effeet and the count serves to show their relative importance quite clearly. Including one form of Spirogyra there are seven species of Conjugatae listed here which will be given separate disenssion. Even among the desmids the mumber of individuals was not great. 


\section{Discussion of SPECiEs}

Clostcrium acerosum Ehrbg.

Average Station I Station II Station III Daily Hourly

Identifieation uncertain. I osses through net probably large. Occurrence rare, irregular and in small numbers at Station I. Found at almost all times of year at other stations. Maximum in September at hoth. Evidently favored by higher temperatures.

\section{Clostcrium acuminatum.}

Identifieation doubtful. Reeorded three times at Station II and five times at Station III.

Closterium rostratum Ehrbg.

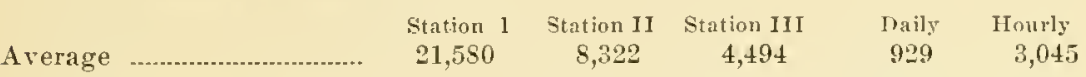

Identification satisfaetory. Lasses through net probably large. Reeorded only seven times at Station II, five times at Station III and ocenrence rare at Stațion I until late summer. Maximum at Station I in August. Distinetly a summer planktont. Apparently favored by sewage.

\section{Mougeotia sp.}

Average

$\begin{array}{ccccc}\text { Station I } & \text { Station II } & \text { Station III } & \text { Daily } & \text { Hourly } \\ 75,517 & 262,429 & 269,657 & 23,118 & 793,570\end{array}$

Identification of genus satisfactory. This was deeidedly the most abundant of the filamentous Conjugate. Rather prominent at all stations in July, August and September with maximum in last week of August or first of September. Not found often or in large numbers at other times. Favored by temperatures above $20^{\circ} \mathrm{C}$. and somewhat hindered in development by sewage.

Spirogyra protecta Wood.

Identification uncertain. Occurred once at Station I, five times at Station II and nine times at Station III. Never in very large numbers. So far as eatehes show it is unimportant in every way.

Staurastrum sp. A.

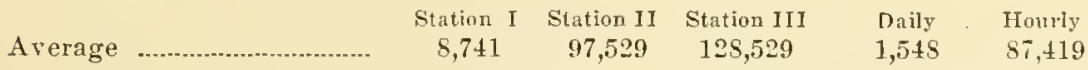

Genns eertain. Species description not found in any literature available. Only the more voluminous references at the University of 
Califormia have been eonsulted, however. This Staurastrum is the most delicate and graceful of any ever observed by the present writer. Losses through net probably very heavy. Oeemrenee as recorded at Station I, small in numbers and seatterexl: May is the only month yielding none. Nore abmndant at other stations but missing in Jannary and May. Maximum in September at all stations. This comes after sereral weeks of strong development at Stations 11 and III. Evidently favored by higher temperatures, $20^{\circ} \mathrm{C}$. or above, but hindered by sewage. Probably of considerable importance in summer.

\section{s'taurastrum spp.}

Arerage

$$
\begin{array}{ccccc}
\text { Station I } & \text { station II } & \text { Station III } & \text { Daily } & \text { Hourly } \\
3,566 & 35,901 & 37,335 & 526 & 12,207
\end{array}
$$

Probably three or more Staurastrum are ineluded under this heading. There were a large mumber of different kinds fouml at various times at different stations. All secm to be rather elosely eonfined to the warm season and to the water with least sewage.

The following forms of Conjugatae were reorded only once or twice or were thought to have heen recognized in living material.

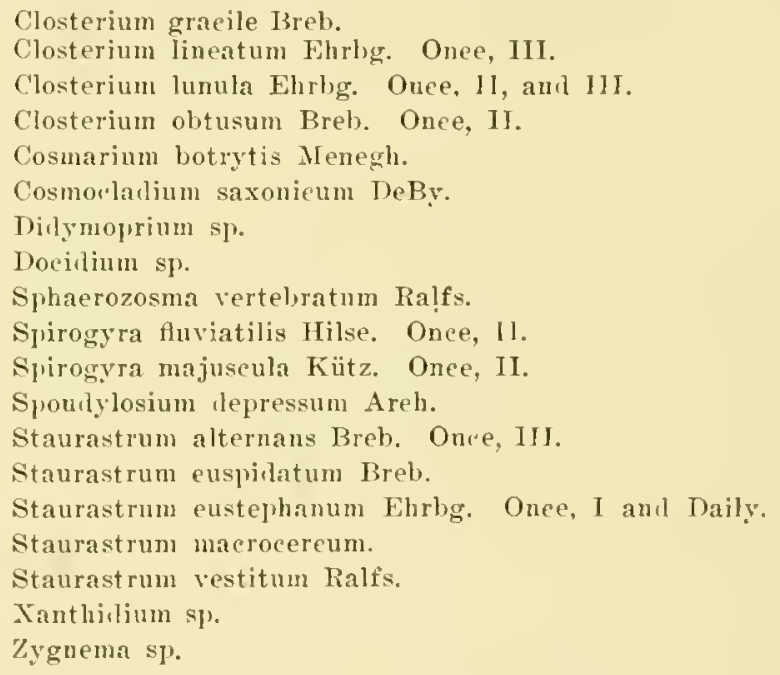

\section{CIILOROPHYLI, BEARING ORGANISMS}

So few flagellates were found that were clearly non-chlorophyll bearing, there was so much difficulty in separating the two types, and the eharacteristics of the Mastigophora so clearly resembled those 
of the algae, that it was finally decided to give a list of totals of algae (except Bacteriaeeae) plus Nastigophora under the heading of chlorophyll bearing organisms (tables 1-5). This plan was also followed with the graphs in plates 3 to 6 . A separate list of algae is given nnder headings of Total Phytoplanktonts (text table 1, P. 31), but no graph was made for it as the slight apparent difference did not seem to warrant it.

It will be noticed that this eombination shows marked coherence throngh the year. There is a rather prominent pulse in every montly through the first nine months at Stations I and II and in almost every month at Station III. There is steady increase in numbers from Mlay to September at Stations II and III followed by a steady decline to the end of the year, and at Station I the numbers were well maintained from Nay to September with a steady decline following. The most striking difference in the three stations eoncer'us the maxima. The maximum came in June at Station I and in September at the other two. The June maximum at Station I was due, however, to the enormous numbers of Cyelotella at that period. With Cyclotella exerting less influence on the totals or entirely omitted, the general features of occurrence look mueh the same at Station I as at the other two stations.

The response to higher temperatures is quite noticeable at all stations, the larger numbers being espeeially characteristic of the time from June to November when the temperature was nsually near or above $20^{\circ} \mathrm{C}$. This, however, is also the time at which there was least disturbance of the water.

The recurrent pulses were very striking and may be conveniently illustrated by Station II where the dates and intervals ran as follows: Jamary 19, three weeks to February 8, three weeks to Mareh 1, four weeks to Mareh 29, three weeks to April 19, four weeks to May 17 , three weeks to June 7 , three weeks to Jume 28 , five weeks to August 2, three weeks to Angust 23, two weeks to September 6, five weeks to October 11 , seven weeks to December 6 .

Flnetuations at Station II and III also showed a very close correspondence with the volumetric record. This is probably because the algae and Mastigophora furnished a large part of the volume at those stations (plates 1, 4,5). Sueh a conclusion is supported by the fact that there is no such correspondence at Station I where the Rotifera and Entomostraca furnisl mueh of the volume (pl. 1, 3). 
PROTOZOA

\begin{tabular}{|c|c|c|c|c|c|}
\hline & Station I & Station II & Station III & Daily & Hourly \\
\hline mher of forms recoriltel & 75 & 53 & 59 & 26 & 34 \\
\hline $\begin{array}{l}\text { verage number of indi- } \\
\text { viduals per cu. meter ....... }\end{array}$ & & $3,494,065$ & $3,634,131$ & $3,850,462$ & $7,908,873$ \\
\hline
\end{tabular}

'The number of forms recorded is 116 but that is eertainly considerably less than the real number of speeies. Identifieation was very diffienlt, not only of speeies but of genera. Many spereies were indistinguishable nuder conditions of counting and some that were recorded for a time were abandoned later when high power study showed how great the error was. Distortion of preserved material was a great factor affeeting aceuraey of counting of Protozoa. Even such strikingly different speeies as the two stentors, (S. coeruleus and S. niger) could not be separated with full eonfidence during the eount. For these reasons the list of Protozoa shows more often than that of algae names which include several forms within rather ill defined limits.

Notwithstanding the great diversity of eharaeteristies shown by several prominent protozoan planktonts, the distribution of totals throngh the rear at different stations deserves some attention. The totals of non-flagellated Protozoa at all stations agree in that there is light representation in January, February and December, witl an equally well elefined heary representation from May or July to miklNovember. Station I averages abont 60 per cent higher on its totals than either of the others but its maximum is only shightly greater. The maximum for Station I falls on August 13 but it is almost equalled by a similar pulse in November. The maximum for Station II comes on October 4 and for Station III on August 15, but the latter record is almost equalled hy a further pulse on Oetober 4 . There is then substantial agreenent of all stations in making the best showing as to large numbers and eontinuity of numbers in late summer and through autumn, when temperatures are rather high, the water quiet and the organic content great.

The inclusion of the Mastigopliora with the Protozoa almost destroys the definiteness referred to above. Such a eombination shows at Station I a fairly well marked pulse in January, another in Mareh and another in April, followed by a steady increase up to the maximum on September 9. There were then two moderate pulses on the dechine, which was otherwise fairly steady to the encl of the year. At 
Station II there were prominent pulses in Jannary, Febrnary. Narch, May, July and Oetober, while at Station III the prominent pulses came in February, March, April, July, August, September and October. It is thus apparent that the combined history is considerably different at the different stations and that the inclusion of the Mastigophora destroys the colerence of the Protozoa as a group. The totals are given both with and withont the Mastigophora in tables 1 to 5 and the reader may suit himself with the list of his preference. See also Plates 12-14.

\begin{tabular}{cccccc}
\multicolumn{7}{c}{ Mastigophora } \\
& Station I & Station II & Station III & Daily & 1Iourly \\
Number of forms recorded & 33 & 30 & 31 & 20 & 20 \\
Av. number per cu. meter... $3,708,569$ & $2,629,112$ & $2,631,702$ & $1,853,429$ & $3,931,592$
\end{tabular}

Almost all of the Mastigophora were too small to be retained by the silk net to any great extent. This is probally the main reason for the fact that the averages recorded are exceeded from twenty-five to forty times by Kofoid's averages (1908) in Illinois. It is certainly true that other factors might be expected to operate, as mentioned before in this paper, but this is so obviously sufficient in itself to account for the difference that it seems useless to inquire further.

Nastigophora were present at all stations throughont the year, although the numbers were quite small for the first few eatches. This may be partly due to the fact that the net used before Jamary 15 was of slightly larger mesh than the regnlar number 25 which was ready by that date. By far the larger proportion of the flagellates came in the last six months, even December showing much more than Jnne. There were, however, two or three strong pnlses in Jamnary and February at all stations. IIence the general indication seems to be that quiet water or even stagnation is about as important as temperature in controlling prodnction. The greater numbers at Station I also indicate that sewage is favorable to this group. The maximm at Station I was reached in September, at Station II in Octoher and at Station III in November. These dates are largely due to Chromulina sp., a form very unreliable for suggesting conclusions, both on account of its small size and the mncertainty of identification.

The recurrent pulses of Mastigophora were not so distinct as they were in the case of the total chlorophyll bearing organisms. The semi-weekly collections at Station I seem to obscure them rather than make them more distinct. At any rate the intervals vary from eleven to forty days in a rather indefinite way. Indications at the other 
two stations are not much better. Evidently we have again too much influence of chromulina in the record. Since the only otluer flagellate showing very large immbers is Trachclomonas, itself very small, it seems hardly worth while to attempt any conchusions from net colleetions.

\section{Discussion of Species}

C'cratium himudinclla O. F. Miill.

Identification satislactory. Loss through net probably very heavy. Occurrence rare and in small numbers, four times at Station $I$ in September and Oetober. Five times at Station II in June, July, Angust and September. Three times at Station III in July, September and Oetober.

\section{C'cremonas crassicuuda Duj.}

Identification satisfactory. Loss throngh net very heary. Oceurrence rare and in small numbers. Recorded at Station I nine times at wide intervals from July to the end of the year. Twice at Station II in July and September. Five times at Station III in June, August and September.

\section{Cercomonas sp.}

Identification of genus doubtful. Recorded seven times at Station I in August and September, and onee at Station III.

\section{rhlamydomonas sp.}

Identification of genus donbtful. Recorded eight times at Station I from July to Deeember, five times at Station II from May to Oetober and twice at Station III in February and May.

Chromulina spp.

Identification uncertain. May include various minnte genera not readily distinguished while counting. Percentage jetained by net surely very small. Found in every month at all stations but oceasionally not recorded in the first half year. Constantly present after July. Maxinum at Station I on September 13, Station II on Oetober 26, and Station III on Noveruber 22. Evidently favored by warm and quiet water and not much affeeted by sewage. 


\section{Cryptomonas sp.}

Identification doubtful. May be confused with some other forms. Loss through net heavy. Recorded at Station I in considerable mumbers in latter part of year. Only once at Station II and four times at Station III. Distinctly favored by sewage and low temperature but relatively indifferent to quiet water by this showing, which agrees pretty well with Kofoid's findings (1908) in Illinois.

Dinobryon sertularia Ehrbg.

Average

Station I Station II Station III Daily Hourly $11,4 \$ 1 \quad 9,993$

1dentification of species frequently uncertain. Loss throngh net probably large. Occurrence rare at Station $I$ and in small numbers of colonies at that. Recorded eleven times at Station II in four, well marked groups at the last of Mareh and May, first half of Jume and through most of November. Maximum in May and June. Recorded frequently at Station III from Mareh to July and again in November. Absent at other times. Favored by cooler water or flood time and hindered by sewage. Although the numbers here were small the distribution resembles that reeorded for Illinois most remarkably. On the present showing it cannot be regarded as a very important planktont here. While not followed very far, the general impression given by the condition of the colonies here leads to support of Kofoid's contention (1908) that the synonymy of this species has been needlessly extended and that all the variant forms might be included under one species name with advantage.

Eudorina clegans Ehrbg.

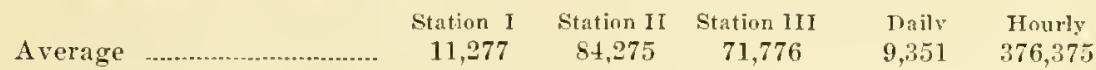

Identification usually certain. Found throughout the year at Stations II and III with only six seattered periods of absence at each. Numbers much smaller and absenees more apparent at Station I where it was only twice recorded in May, entirely absent in Angust and most of September, last half of Oetober and first half of November. Evidently deleted by sewage. Maximum in October at this station, on August 9 at Station II and III. Contrary to the Illinois record the period of greatest abundance in our river is in the warmest season and almost at greatest stagnation. The complete absence at Station I at this time, however, may throw some light on the Illinois situation. Either the sewage is more injurious to this organism in 
warmer wather or "lse its enemies multiply faster under snch conditions and so keep it down. 'The substantial agreement of Stations 11 and 111 mpon such a point in opposition to Station I makes it almost eertain that sewage or organic content is in some way a more influential factor than temperature in the warmer season. There are some indications of recurent pulses at all stations but they cannet be radily followed through the year. Parasitized colonies were lres. quently fouml, especially through the warm season. Eudorina is evidently a more important planktont here than in lllinois exerpt at Station 1 where it is about the same.

One experience in collecting at Station I gives some interesting evidence as to the ocemronce of swarms. The regular eolleetion was taken near shore from the boat lunling, one morning about $S$ o elork. On examination of the living material under the mieroscope after reaching home it was found to contain umsual ruantities of Eudorina. It seemed a farorable time to make a sprecial collection to send to Professor Kofoid so another trip was made to the same spot ancl hauls taken as nearly as possible in the same way as before. Although there had been a time interval of less than two hours searenly any Eudorina conld be found anywhere about. Weather conditions had not changed and there had been no great disturbance of the water by boats as it was on a Sunday morning when the traffie was light.

Euglena deses Ehrbg.

Identification satisfactory. Loss through net heavy. Reeorded at Station I five times and onee at Station II.

Euglena viridis Ehrbg.

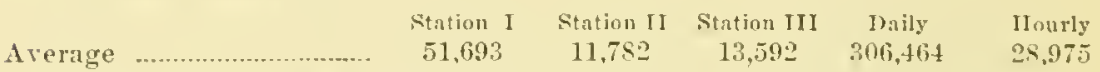

Identification satisfactory. Probably very small pereentage retained by met. Ocenrs mainly in summer and early fall at all stations. Maxinum in July at Station 1 and I1 I, June at Station II. Aplarently favored by sewage, quict water and temperatures above $20^{\circ} \mathrm{C}$. Information from silk net catches not reliable beyond this.

It minlinium nasutum St.

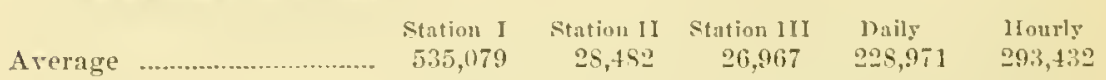

Identifieation doubtful. Very small pereentage rutained by net. Recorded only in last half of year at all stations, possibly beeanse not 
definitely distinguished before. Very few at any station after midOetober. Far more numerous at Station I than at either of the others. Certainly favored by temperatures near or above $20^{\circ} \mathrm{C}$. by quiet water and by sewage.

\section{Iallomonas sp.}

Identification of genus certain. Recorded three times at Stations $I$ and III in small numbers.

Pandorina morim Bory.

\begin{tabular}{|c|c|c|c|c|}
\hline . & $\begin{array}{r}\text { Station I } \\
2,752\end{array}$ & $\begin{array}{c}\text { Station II } \\
16,804\end{array}$ & $\begin{array}{c}\text { Station IIl } \\
15,457\end{array}$ & $\begin{array}{c}\text { Daily } \\
103\end{array}$ \\
\hline
\end{tabular}

Identification satisfactory in most cases. May sometimes inchude young colonies of Eudorina or Pleodorina. Probably some loss through net. Oceurrence at Station I frequent in small numbers through first three months, after that at irregular intervals usually several weeks apart. Fewest in warmer months. Maximmm on Mareh 26. At Station II most constant oeeurrenee was through February and Mareh in moderate numbers. IIaximum of 105,792 reached in each of the four months of June, July, August and September. At Station III fairly constant in February and Narch, November and December. Reeords grouped at irregular intervals between. Maximum in May. Although the records differ strangely at the three stations it seems fair to infer that sewage is deterrent, especially during stagnation but that warmer water's are favorable if stagnation could be avoided. It is possible, however, that the organism was not eaptured so constantly in warmer waters because those were the quiet waters, hence there were no currents to mix it through the whole body of water. If this be true it is easy to see that the net might at one time traverse a "swarm" of the organisms but miss it entirely at another time.

\section{Pcridinium cinctum Ehrlog.}

$\begin{array}{cccccc} & \text { Station I } & \text { Station II } & \text { Station III } & \text { Daily } & \text { Hourly } \\ \text { Arerage ….............................. } & 34,262 & 5,209 & 18,732 & \mathbf{1 1 1 , 3 2 4} & 12,207\end{array}$

Identification uncertain. Probably very small percentage retained by net. Occurrence rare in first lalf year at all stations. Recorded only six times at Station II and seven times at Station III. Evidently favored by sewage, since it ocenred frequently in rather large numbers at Station I from late June to late November. Naximum apparently in July with most consistent reeord in September. Evidently favored also by temperature of $20^{\circ} \mathrm{C}$. or over, and by quiet water. 


\section{P'cridinium sp.}

Identification of genus satisfactory. Species different from $P$. cinclum but not placel. Recorder four times at Station II three times at Station III.

Thacus pleuronectes Ntz.

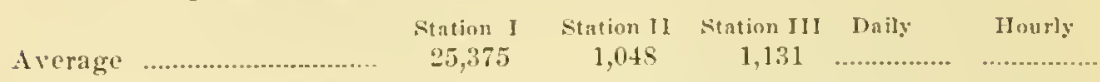

Identification questionable. Loss through net probably very heavy. Oceurrenee twice at Station 1 and thriee at Station III in small numbers. Recorded with only five exceptions at Station I through last three montlis of year. Nay have been overlooked before. Kofoid (1908) designates this genus ant this species as a summer planktont. The faihre of the record here to support fully this view may be tue to small size and conserguent inaccuracy with silk met catches.

\section{Platydorina caudata Kofoid.}

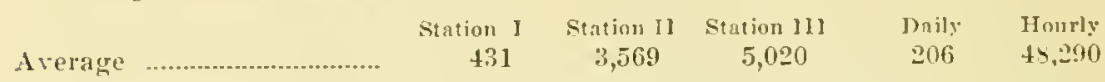

Identification positive. Loss throngh net considerable. Occurrence quite distinctly limited both by temperature and sewage. Recorded only six times at Station $I$, all at variable intervals from August 2 to November 1 and in very small numbers. Nine ocenrrences, mainly in Angust and September at each of the other stations. No case of ocenrence in temperature less than $17^{\circ} \mathrm{C}$. Maximmm at Station I on September 2, Stations II and III on September 13. Considering the small numbers and the short period of occurrence, the similarity of ocenrrence at the three stations is most remarkable. All stages of development were found and speeial collections were made for Professor Kofoid in order that he might study some features of development.

Plcodorina californica Shaw.

Average $\begin{array}{ccccc}\text { Station I Stntion II } & \text { Station III } & \text { 1):aly } & \text { 11ourly } \\ 123 & 21,231 & 6,282 & 113 & 67,751\end{array}$

Identification certain. Probably most of the matured colonies were retained by the net. Recorded only twice (in Angust) at Station I. Evidently strong sewage is deterrent though Kofoid (1908) mentions sewage as probably a factor leating to larger numbers in 1897 than in 1898. Station II showed the only consistent development of this organism. After being recorled in mid-June it was not found until tluree weeks later when it hegan an eight weeks periot of 
steady increase to a maximum on Angust 31, followed by a three weeks decline, after which there were three isolated records. Station III showed no distinct maximum but the nine catches were distributed over about the same period from July to mid-November. It scems clear enough then that too much organic matter, and possibly too great stagnation, is detrimental and that the optimum temperature is above $20^{\circ} \mathrm{C}$.

Pleodorina illinoisensis Kofoid.

ldentification uncertain. Probably some loss through net. Recorded once at Station I, twice at Station II and four times at Station IIl, all in small number's. A puzzhing thing about this form is that when examining fresh catches in 1913 the writer was sure he formd it frequently and in considerable numbers. Hence he was somewhat surprised at not finding it readily while counting. About the only conclnsion possible is that it is very hard to distinguish this form from Eudorina elegans in preserved material. Chodat (1902) and others would doubtless say that this fact supports their view that $P$. illinoisensis is only a stage of development of Eudorina.

\section{Pteromonas sp.}

Identification probable. Loss through net heavy. Occurrence irregular and rare. Recorded ten times at Station I between June 21 and October 8, three times at Station II and twice at Station III. Apparently favored by sewage, stagnation and higher temperatures.

\section{Spondylomorum quaternarium Ehrbg.}

Identification certain. Loss through net heavy. Oecurrence very rare in small numbers. Recorded twice at Station I, once at Station II.

Symura uvella Ehrbg.

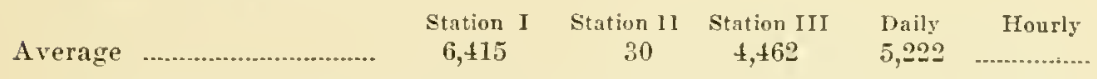

Identification uncertain. Colonies only counted. Loss through net probably very heavy. Ocenrrence greatest at Station I but at wide intervals there. Numbers recorded usually rather small. From our records it seems to do best at about $20^{\circ} \mathrm{C}$. Maximum at Station I in August. Also evidently favored by sewage and stagnation, since it is recorded only once at Station II and five times at Station 11 . Certainly much less important than in Illinois, even with full allowance for eseape through the net. 
Trachclomonas cuchlora Lemm.

\begin{tabular}{|c|c|c|c|c|}
\hline verag & $\begin{array}{l}\text { Station } \\
14,295\end{array}$ & $\begin{array}{c}\text { station } 11 \\
21,739\end{array}$ & $\begin{array}{c}\text { Station 111 } \\
30,180\end{array}$ & $\begin{array}{l}\text { In:ily } \\
7,032\end{array}$ \\
\hline
\end{tabular}

Identification uneertain. Small pereentage retained by net. Found frequently in first half year at all stations. Rare in second half year. Warner waters, sewage and stagnation seem to be doterrent, sinee numbers were smallest at Station I and during the period from June to Oetober.

Trachclomonas volgonsis Lemm.

Identification probable. Loss through not very heavy. Reeorded five times near last of year at Station $1 \mathrm{I}$ and six times at Station III.

Trachclomonas volvocina Ehrbg.

$\begin{array}{cccccc} & \text { Station I } & \text { stntion 1I } & \text { Station III } & \text { In:ily } & \text { Hourly } \\ \text { Average } & 268,091 & 134,297 & 180,692 & 179,473 & 512,684\end{array}$

Identifieation uneertain. Loss through net very heary. Reeorded in every month at all stations. Maximum at Station I on Angust 20, at Station II on September 13, and at Station III on August 31. While a number of minor pulses are readily distinguishable at all stations, the percentage of loss is too uneertain to eneourage conelusions. The maxima of the three stations coming so elose together lead to the idea that temperature is an important factor for this form and that it does best above $20^{\circ} \mathrm{C}$. The difference in averages listed above supports the view that sewage is bencfieial and this is strengthened by the faet that several eatches at Station I exeed the maxima at Station II and III. Stagnation seems favorable at all stations.

Tolvox aurcus Eirbg.

Identification satisfactory. Recorded only at Station II, five times in August and September.

\section{Volvox globator L.}

Identifieation satisfactory. Recorded only at Station III twiee, in September and December.

The following forms of Mastigophora were recorded only once or twice, or else they were thought to be present in fresh material:

Anthophysa sp. Once, I and Daily.

Chilomonas paramoecium Ehrbg.

Dinema sp. Once, III.

Diplosiga sp. All stations. Not counted because too small.

Diplosigopsis entzi France. Once, Il.

Euglena acutissima Lenm.

Gonium pectorale O. F. M. Once, II and III and Hourly. 
Gymnodinium sp.

Hyalobryon sp.

Mastigamoeba sp. Once, Station I, Station II and Hourly.

Oikomonas sp. Once, Station I.

Phacus longicauda Duj. Station I.

Salpingoeca sp.

Syncrypta sp. Once, Station II and III,

Uroglena volvox. Once, Station III and Hourly.

\section{Rhizopoda}

$\begin{array}{cccccc} & \text { Station I } & \text { Station II } & \text { Station III } & \text { Daily } & \text { Hourly } \\ \begin{array}{c}\text { Number of forms recorded } \\ \text { Arerage number of indi- }\end{array} & 13 & 14 & 17 & 7 & 9 \\ \quad \text { viduals per cubic meter } & 167,328 & 150,817 & 258,365 & 101,502 & 396,950\end{array}$

Rhizopoda, according to onr records are from five to ten times as numerous as in Illinois. This is probably erroneous, lowever, since Diffugia contributes mainly to this showing and the Diffugia count includes an unknown percentage of Tintinnidium. Conceding this error to be very large, it still seems safe to say that the Rhizopoda were at least as important as in Illinois where Kofoid (1909) gives them a high rank becanse they are bottom living forms, actually present in far greater numbers than the catch of floating forms could possibly indicate. This adventitions character is just as strongly marked here as there, since all the recorded forms are irregular in distribution and erratic in occurrence. The group as a whole contributes most during the warmer season. This might be expected as a result of greater activity of the animals rendering them more liable to dislodgment. Larger numbers produced would also mean larger numbers dislodged. Heavy food supply wonld also account for it in part because, as Kofoid (1908) says, it means greater oil and gas production in the body of the animal thus reducing the specific gravity.

\section{Discussion OF SPECIES}

Amoeba proteus Rösel.

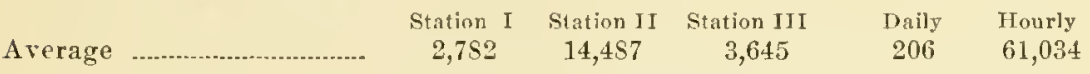

Identification uncertain. Probably includes several species. Amoeba proteus was the large form most frequently observed and so the name is used as being probably most frequently correct. Occurrence rather irregular at all seasons of the year. All stations agree in showing the largest numbers at ahout the height of the warm season, i.e., in Angust at Stations I and II and September at Station III. All show only very small numbers in cold weather. Larger numbers at Station 
II may be due not so much to fin rorable effeet of clean water as to the slight flow in the river tending to greater distodgment.

Amorba radiosa Duj.

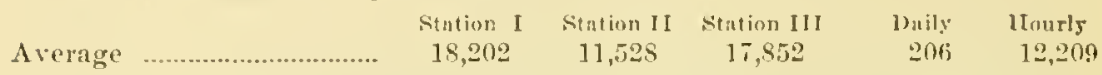

Identifieation satisfaetory. Losses through not probably great. Although Fofoid (1908) eounts A. radiosa with A. proteus, it is given separate listing here because it was the one form that seemed to be always elearly reeognizable under conditions of connting. Either singly or eombined the two forms were deeidedly more numerous than the combination was in Ihlinois, and this is true of all stations. A. rarliosa was not reeorded at any station until the last of $A$ pril. It leveloped a small pulse at Station I in May, disappeared entirely in July and Angust but reappeared in eonsiderable strength in September. The maximm eame in a strong abrupt pulse in late Octoher after which the form disappeared again showing only two small records in the rest of the year. At Station II there were two oeenrrenees in April and May, one (the maximum) in September and a small series of four reeords in Oetober and November. At Station III there were seattered records from July to a September maximum, a small group in Outober and November and one eatch in December. In spite of eonsiderable differences at the three stations the reeord shows a rather definite preference for water a little below the maximum temperature. The larger numbers at Station I indieate a preferenee for sewage. An almost equal nunber at Station III warns against too mueh eonficlenee in such a conelusion, however.

Arcella vulgaris Ehrbg.

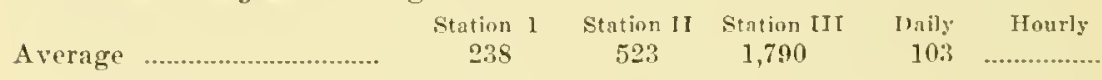

Identifieation of speeies meertain. Probably ineludes three or four speeies. Certainly there were marked differences in shells found. Not very important in our plankton so far as our reeords slow. Oeeurred only seven times at widely separated intervals at Station I, four times in April and June at Station II, and six times at wide intervals at Station III. Numbers always rather small. Is known to be very abundant in ditches near Stockton. Clearly adventitious.

Cyphoderia ampulla Leidy.

Identifieation probable. Reeorded five times at Station II, and four times at Station III in rather small numbers and at wide intervals. Clearly adventitions. 
Diffugia corona Wallich.

Identification uncertain. Recorded three times at Station I, six times at Station II and twice at Station III, always in small numbers.

Diffugia pyriformis $\mathrm{Py}$.

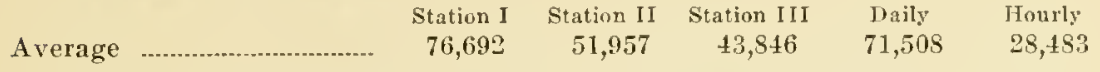

Identification uncertain. Surely includes several other species certainly includes some Codonclla and Tintinnidium which could not be readily distinguished while counting. This was especially true up to August before the presence of Tintinnidium and Codonclla was noticed. In view of this error the record for Diffugia cannot be regarded as trustworthy. The variations in form are bewildering at best. As the record stands, the maximum seems to fall in June at all stations and Station I shows the largest numbers.

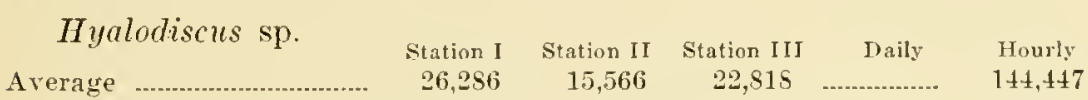

Identification very doubtful. This form was not recorded until late in the season because it was small and hard to diagnose. It was finally decided to record it simply for the purpose of calling attention to eonsiderable numbers of an organism frequently occurring which conld not be definitely designated. The condition of the records does not warrant conclusions.

Microgromia socialis $\mathrm{II}$, and L.

\begin{tabular}{|c|c|}
\hline (verace & Station \\
\hline
\end{tabular}

Identification uncertain. Probably heavy loss through net. Occurrence at Station I in every month except Jannary and Decomber. Found mainly at the other stations in July, August, September and October. Evidently favored by warm weather and deterred by sewage.

The following forms were rccorded only once or twice, or were thought to be present in fresh material:

Amoeba verrncosa Ehrbg. Once, II and III.

Diffngia aeuminata Ehrbg. Once, II and III.

Diflugia globulosa Duj. Once, I and twice at III.

Euglypha alveolata Duj.

Hyalosphenia cuncata St. Twice, I.

Ifyalosphenia papilio Leidy. Twice, 1, once, II and 111.

Nebela collaris Leidy. Once, III.

Pseudodifflugia graeilis Schlumbg. Once, III.

Quadrula symmetriea F. E. Seh. Onee, III and daily.

Trinema enchelys Ehrbg. Once, III. 


\begin{abstract}
II cliozon

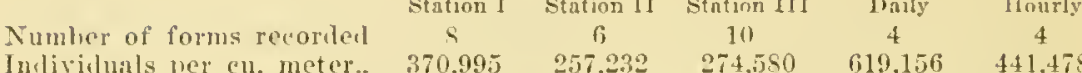

While there were only a few species of Ifeliozoa recorded the numbers of some of the smaller forms were quite large and so make the group somewhat important. The extreme fragility under manipulation makes letailed examination somewhat untrustworthy in results and also invalidates the eonnt more than in the other groups. Nevertheless the following records seem to be fairly satisfactory. Through some error in copring early lists, Nuclcaria and Vampyrella were included with Rhizopoda. The numbers do not seriously change the totals in the two groups, however; the totals for IIcliozoa have been left short by that mucl and the totals for Rhizopods show a corresponding exeess.
\end{abstract}

\title{
Discussion of SPECiEs
}

Heterophrys fockei Areh.

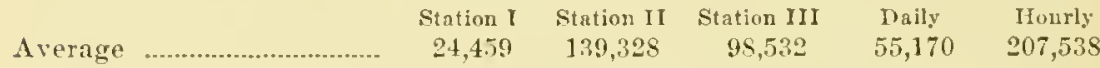

Identifieation uneertain. May inelude other species or other genera at times. Thonght to be nsually eorrect. Not recorded at any station before July. Not present at any after Oetober. One of the most definitely limited organisms on our records. Limited to a period of abont sixteen weeks with a peenliar break in the middle (last of Angust). This is a period in which the temperature was almost constantly above $20^{\circ} \mathrm{C}$. Maximm numbers on Angust 2 at Station I, Oetober 4, at Stations II and III. Smaller nmmbers at Station I indieate deterrent aetion of sewage.

II terophrys sp.

Probably not deserving separate listing though this faet was not discovered until too late to ehange casily.

Nuelcaria simplex Cienk.

$\begin{array}{cccccc} & \text { Station I } & \text { Station II } & \text { Station Ill } & \text { Taily } & \text { Hourly } \\ \text { Arerage ............................... } & 7,020 & 338 & 15,871 & 206 & 44,758\end{array}$

Identifieation uneertain. No records until late in the season, partly because overlooked until Oetober, partly beeause of indeeision as to advisability of reeording. It was finally deeided that some indieation of the presence of an organism possibly belonging under this speeies name was desirable. No conelusions ean safely be drawn as to distribution, however. 
Rap?idiophrys elegans II. \& L.

A verage

Station I Station II Station III Daily Hourly

$309,635 \quad 79,467 \quad 107,739 \quad 532,371 \quad 20,345$

Identification probable. First reeorded in April at Station I and Station III, in Nareh at Station II. Constant in oeeurrenee at Station I throngh June, Juy̌, August and November. Irregular at other times. Irregular at both the other stations exeept for a period throngh August and early September at Station II, late June and July at Station III. Evidently favored by higher temperatures and sewage, not so much by stagnation. From these records, seems to be a rather important eonstituent of onr plankton. This is somewhat different from the condition at Illinois where it appeared only as a constituent of back waters.

The following forms were recorded only once or twice or were thought to be present in living material.

Actinosphaerium eichornii Elırbg. Once, I and III.

Diploeystis sp.

Vampyrella sp. Once, III.

\begin{tabular}{lcccccc}
\multicolumn{7}{c}{ Ciliata } \\
& Station I & Station II & Station III & Daily & Hourly \\
Number of forms recorded & 32 & 22 & 25 & 9 & 10 \\
$\begin{array}{c}\text { Number of individuals } \\
\text { per cubie meter.........- }\end{array}$ & 946,762 & 447,909 & 431,445 & $1,306,075$ & $3,136,583$
\end{tabular}

Identifieation of eiliates was abont as unsatisfactory as was that of the Rhizopoda and Heliozoa. This was due partly to distortion of preserved specimens and partly to suall size. It is probable, however, that totals for the group are fairly aceurate.

Members of the group were always found thronghont the year, exeept for the first three and two collections at the first of the year at Stations II and III respectively. Unfortunately no general conelusions ean be stated with full confidence from the totals of Protozoa because Vorticclla sp. is too largely responsible for them. This was beeause Vorticella sp. was used as a sort of catchall for a miseellaneons assemblage of organisms which eould not be readily distinguished under conditions of counting. Most of these were elearly Vorticella (nearly all of the short stem type) but some eraspemonad flagellates and the like were undoubtedly counted in at times. In spite of these defects in the record, there is some reason for thinking that the group as a whole develops best in sewage water and in the higher temperatures with rather stable conditions. Since this does not agree very 
well with Kofoid's (1908) Illinois results and siner the net error is undoultedly great, too much importance must not be attached to suelı a suggestion.

Whatever the truth may be eonerming their distribution there is no question that the Ciliata exert a very marked influence amongst loeal planktonts, espeeially" in Stockton Chamel. The larger Ciliata are quite conspicuons in the catches there in the eolder months.

\section{Disceissiox OF SPECiES}

Aslienusia elegans Bloch.

Identifieation probable. Recorded only at Station I four times in small numbers. Thought to have been positively recognized in fresh material, lowever.

\section{Chilodon sp.}

Identifieation doultful. Reeorded four times at Station I and twice at Station II in small numbers.

Coleps hirtus Ehrbg.

Average

$\begin{array}{ccccc}\text { Station I } & \text { Station II } & \text { Station 11I } & \text { Daily } & \text { Fourly } \\ 7,338 & 3,052 & 4,149 & \ldots \ldots \ldots \ldots \ldots & \ldots \ldots \ldots \ldots \ldots . . .\end{array}$

Identification certain. Loss through net heavy. Probably also overlooked in counting sometimes. Reeorded ten times at Station I, five of which came in Deember. Recorded twice at Station II and once at Station III. Evidently favored by sewage and probably by temperature below $15^{\circ} \mathrm{C}$.

\section{Colpoda sp.}

Identification very doubtful. Recorded at Station I five times in very small numbers, once at Stations II and III.

\section{C'yclidium sp.}

\begin{tabular}{|c|c|c|c|c|c|}
\hline Average & $\begin{array}{c}\text { Station I } \\
29,530\end{array}$ & Station II & \multicolumn{2}{|l|}{ Stati } & \\
\hline
\end{tabular}

Identifieation unsatisfactory. Referred to this gemus purely on general resemblanee to figures in reference books. No undulating membrane was visible under conditions of eounting. Apparently a warm water form favored by sewage. Small pereentage retained by net. 
Didinium nasutum.

Average at Station I, 1,636.

Identification positive. Recorded sixteen times at Station 1 at irregular intervals January to April and in November. Only once at Station II and twice at Station III. Distinctly a cold water form. Probably heary loss through net.

Euplotes patella Ehrbg.

$\begin{array}{ccccc}\text { Station I } & \text { Station II } & \text { Station III } & \text { Daily } & \text { Hourly } \\ 38,100 & 7,350 & 8,068 & \ldots \ldots \ldots \ldots \ldots \ldots\end{array}$

A verage 38,100

Identification of species fairly certain. Recorded in first three and four months and the last two months at all stations. Far more numerous at Station I. Distinetly favored by sewage and low temperatures. Spling maximum on Narch 19 at Station I at $14.5^{\circ} \mathrm{C}$. Fall maximum on November 12 , at $17.5^{\circ} \mathrm{C}$. Disappearance in April at $20^{\circ} \mathrm{C}$, reappearance in October at $19^{\circ} \mathrm{C}$.

Euplotes sp.

Average at Station I, 3,567.

Recorded only twelve times at Station I (February 8-April 5), twice at Station 11 and three times at Station III. Showed same tendencies of distribution as preceding species. Probably variety of same.

Halteria grandinella O. F. Mïll.

$\begin{array}{ccccc}\text { Station I } & \text { Station II } & \text { Station III } & \text { Daily } & \text { Hourly } \\ 3,390 & - & 126 & 206 & 12,207\end{array}$

Average …......................... $3,390 \quad 126 \quad 206 \quad 12,207$

Identification probable. Loss tlurough net heavy. Recorded sixteen times in first three months and five times in the last three months at Station I, only five times at Station III. Apparently adventitious and not of much consequence here.

Hastatella radians Erlanger.

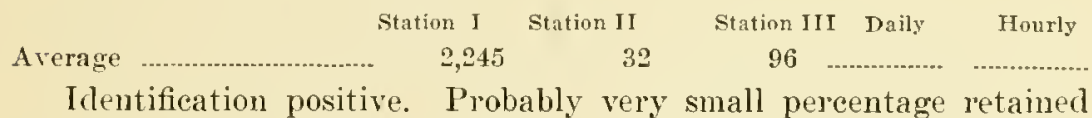
by net. Recorded fourteen times at Station I, once at Station II and twice at Station III, in February, Mareh, April and December. Distinctly a cold wate form and almost as distinctly favored by sewage. Notwithstanding its small size this form is so distinct in appearance and so little deformed by preservation that the count is umusually trustworthy. 
IIolophrya sp.

Average

Station I Station II Statim 11I Daily Hourly $109,113 \quad 76,816 \quad 103,775 \quad 140,4041 \quad 870,497$

Inlontification very lonbtful. This generic name was used as a catchall for a number of forms that might be referred to it without too great streteh of possibilities. T'hey were usually too mueh deformed in preservation to give any definite clue to affinities. About all that can be safely said is that the assemblage is favored by wamel waters and stagnation, probably also by sewage.

Paramoccium aurclia 0. F. Miiill.

Average

$$
\begin{aligned}
& \text { Station I Station Il Station III Daily Hourly } \\
& 10,931 \quad 1,415 \quad 94
\end{aligned}
$$

Identification satisfactory. Loss through net probably heary. Occurrence almost entirely limited to first two and last two months of the year. Hence distinctly a cold water form. Record at Station I fairly constant in periots mentioned, with a maximum in December. Numbers small and eateles rare at Station II and III. Evidently does best in sewage, probahly on aecount of quantities of bacteria for food.

Paramorcium bursaria Focke.

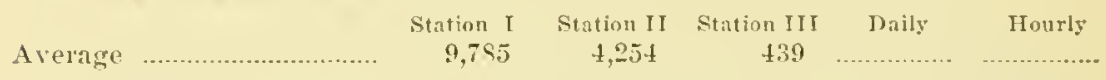

Identification uneertain. Probably should be inclnded with $P$. aureliu though there seemed to be some difference. Shows praetically same characteristics of distribution as the former species.

Paramoccium caudatum Ehrbg.

Identifieation satisfaetory. Althougl a few speemens of this type were found six times at Station I and onee at Station III, it was probably not. worth while to attempt separation. They are too few

\begin{tabular}{|c|c|c|c|c|c|}
\hline Plcuroncmasp. & Station I & Station II & Station III & Daily & Hourly \\
\hline
\end{tabular}
to siguify mueh.

Identification doubtful. Recorded thus as nearest possibility. Reeords indieate preference for sewage and cold water.

I'rorodon sp.

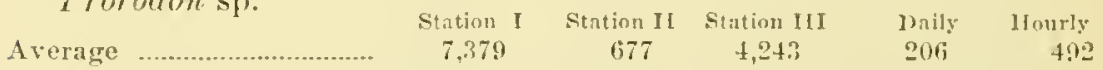

Identifieation uneertain. Occurrence almost entirely eonfined to first three months and last three months of the year, thus indieating the favorable influence of eold weather. Larger numbers at Station I were probably due to sewage. 
Stentor cocrulcus Ehrbg.

Arerage

$\begin{array}{cccc}\text { Station I. Station II } & \text { Station III Daily } & \text { Hourly } \\ 8,141 & 103 & 141 & 492\end{array}$

Identification usually satisfactory. Under conditions of comnting probably some confusion with $S$. niger and perhaps another species. This was beeause distortion in preservation made it almost impossible to use any distinetion exeept size in many eases, hence a small $S$. coerulcus might be mistaken for $s$. nigcr, or a large specimen of the latter might be mistaken for the former. Generally, however, the stouter body of $S$. cocrulcus showed plainly enongh to make it fairly certain. Oecurrence was almost confined to first fon months and December. Only two catches were reeorded at Station II and three at Station III. Clearly a cold water form almost limited to sewage or at least to water with heary organic eontent. Maximum ocenrred in Deember at Station I, althongh the eatehes were fairly constant over a period of four months from the first of the year. The maximum for this early period was in Jannary. Since it is absent at periods of greatest stagnation, this planktont is evidently more inflnenced by temperature than by that factor. The most farorable temperature seems to be at abont $10^{\circ} \mathrm{C}$. since the maxima just mentioned come at about that condition.

Stentor niger Ehrbg.

Average

Station I Strtion II Station III Daily Hourly $\begin{array}{llll}42,691 & 739 & 571 & \ldots \ldots \ldots \ldots\end{array}$

Identification satisfactory. Probably some loss through net. Also considerable loss of this and the preeding form throngh elinging to net, uteusils, ete. This form was first recorded as S. rocselii on aceount of the nuelens, but the delieacy and grace of form together with smoky color seem so strongly characteristic that it has finally been referred to $S$. niger. The decision to make the ehange was mainly due to Professor Kofoid's statement that melear charaeters are very unstable in this genus. They cannot be determined at least while counting.

Oecurrence at Station I runs later in spring and begins earlier in fall than that of $S$. cocrulcus. The numbers are very noticeably greater in the fresh material while the animals are active. The Jannary and December maxima fall on the same dates as those of $s$. cocruleus but there are strong pulses in April and May hy way of contrast. It seems safe to say then that both species have about the same optimum but that $S$. niger is able to endure a slightly higher. temperature $\left(20^{\circ}\right.$ C. $)$ and that it is less disturbed by flood conditions. 
Tintinnidium flucialile St.

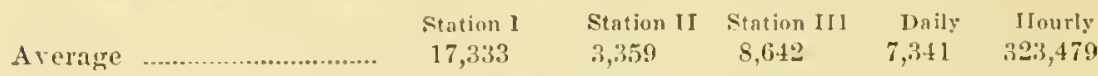

Irlentification uncertain. Loss through net probably heavy. For some reason (probably because intent on I)iffugia) the writer entirely overlooked this form and that of codonclla until attention was foreibly attrated by some living material in 1914. This was after the eomnt hat progressed almost through the first seven months of 1913, hence it was too late to reetify by reeomnting. It was also impossible at that late date to distinguish the three forms readily in preserved material. Tudoubtedly some Codonolla and a few Diffugia are ineluded umler the present head. It is also probable that Difflugia ineludes some of both Tintimidium and codonclla even after an attempt was male to differentiate them. C'odomella was not sueeessfully distinguished at all. The connt as it stands rields very imperfeet lesults. It appears certain, however, that Tintimidium does best in heary sewage. Sinee the river shows least of this species it is also probable that quiet water is favorable. So far as the evidenee goes, it serms that higher temperatures are best.

\section{Trichodina padiculus Elırbg.}

Average at Station I, 631.

Identifieation probable. Loss throngh net probably heary. Ocenrrenee at Station I almost entirely in first three and last three months. Reeorded only onee at Stations II and III. Small numbers everywhere. Surely a eold water form favored by sewage. Adventitions.

Torticclla longifilum Ehrbg.

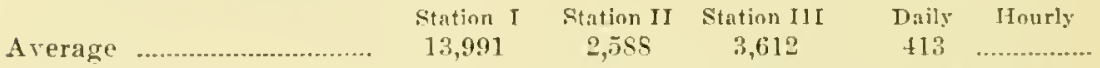

Identifieation doubtful. Count ineludes all individuals with very long and slender stalks. None were ever found attaehed to anything. Loss through net probably very heavy. Oecurrenee at Station I mainly in last three months. Catehes in small numbers and at widely separated and irregular intervals at other times and other stations. Evidently a eold water form doing hest in sewage and quiet waters.

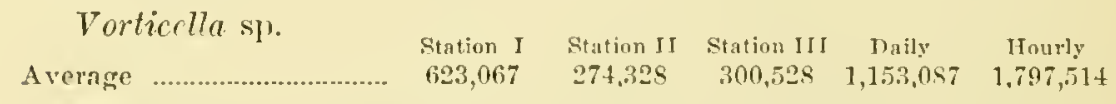

Identifieation mnertain. Probahly ineludes several speeies of short stemmed Torlicella and some eraspemonad flagellates attaehed to various objects. 
Those taken to be most typieal of this miseellaneous assemblage were found on the bodies and appendages of Entomostraca, especially Cyelops. Most of these were large enough to be fairly aceurately counted. In view of the miseellaneous character of the forms ineluded, it is nndesirable to draw definite conelusions. There is, however, a elear suggestion of preference for sewage ant quiet water. Highter temperatures are also distinetly favorable for the assemblage and this is in marked contrast to nearly all the other eiliates.

The following forms were reeorded only once or twice or else were thought to be observed in fresh material.

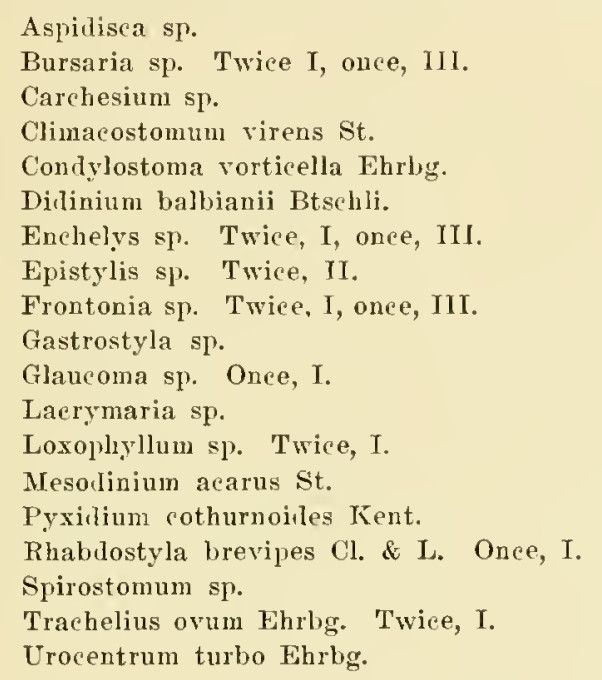

\section{Suctoria} Number of indi-

viduals per cubie meter $\quad 762 \quad 8,995 \quad 8,039 \quad \ldots \ldots \ldots \ldots \ldots . . . . \quad 1,969$

Only three forms were recorded from this group and they oeeurred at all three stations but mainly in the last three or four months of the year. In no ease were the numbers very large. While genera eould not be identified with much eonfidence, it yet seemed elear that the forms recorded were Suctoria and that the generie designation was probable. Inasmuch as none of the three forms appeared to be a true planktont and the numbers were few, it seems hardly neeessary to attempt detailed discussion. The most notable suggestion that ean be made is that sewage seems unfavorable to all three forms. The following are the three forms reeorded. See tables 1-5.

Acineta sp.
Folopliya sp.
Sphaerophrya sp. 
ROTIFERA

Plates $3-6$ and $15-17$.

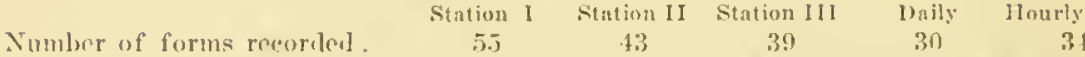
Indiviluals per cu, moter.. $4,542,320 \quad 893,510 \quad 1,302,609 \quad 5,443,643 \quad 5,6 \$ 1,37.2$

Eggs $31 \%$ Figgs $+5 \%$ Eggs $34 \%$ Eggs $29 \%$ Higgs $31 \%$

These averages are made from reeords which include males, fenales, rggs attached, a few records of free eggs, winter eggs, mate eggs and parasitized individuals. Further distinetions were not advisable beeanse of inability to earry them through the count with aceuraey.

Rotifera were foumd in every collection through the whole var at all stations. Only twiee in the whole year did the numbers fall below 75,000 per cubic meter at Stations II and III, and at no time was a smaller number than 200,000 recorded at Station I. This malies a remarkably consistent showing, espeeially ly way of eontrast with Illinois conditions as found by linfoid (1908). This consisteney is eren more striking than are the distinctly larger numbers found here at all stations. Both features are evidently due to the peculiar elimatic conditions of this region. There is agreement with Illinois records in the fact that minimum production occurred in winter and the maximum in warmer weather, thongh much later there than at Station 1. There is a difference in that the fluetuations were less extreme here, and that maxima oecurred in November at Stations II and III.

Recurrent pulses were fairly well marked at all stations though the intervals were quite variable. These pulses were not coineident with those of any other group. The maximum number of Rotifera did not eorrespond in time with the maximum mass production of plankton at any station nor did it agree with any othere gronp.

This group affords another illustration of a ease in whieh a single gemus exerts a remarkable influence on the whole group, the late maximum in Norember at Stations II and III being clue to Kratclla. Since, however, this same genus is largely responsible for throwing the Illinois maximum into May, perhaps those records and ours ean be compared with some faimess.

Catehes of 1,000,000 or near that mumber were rare at temperatures below $15^{\circ} \mathrm{C}$. About eighty-seven forms of Rotifera were listed.

The names used have been eleeked as elosely as possible to correspond with those indieated in Ilarring's Synopsis of the Rotatoria. 


\section{Rhizota}

Station I Station II Station III Daily Hourly

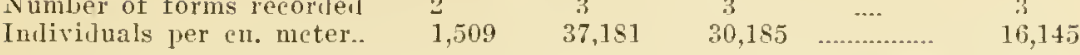

Practically all of the Rhizota found at any station were single individuals without tubes. Only two or three times were eolonial forms recorded and then only part of the colony was present. These faets serve to emphasize the alventitions charaeter of the Rhizota and to indieate that their presence in the plankton was due to broken anchorage. The large numbers at Stations II and III as compared with Station I suggest a decidedly deterrent inflnence of sewage.

\section{Disctrsion of Species}

Collothrea pelagica Rous.

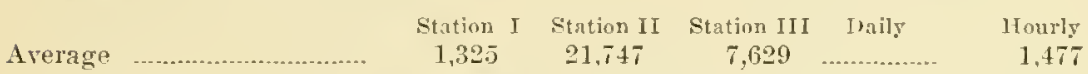

Identification meertain. May inchde two or three species, one of which is possibly C. mutabilis. The preserved condition does not permit of very aecurate judgment and the amimals were usually without tubes. So many of the tubes which were seen were of a slender type that it was thouglnt that they indieated the species designated. This form was only recorded at Station I six times (in small numbers), all in August, September and Oetober with the largest number in October. Oeenrrenee at Station II was from August 15 to Novem. ber 22. Most of the eatelies were fairly large and there were only two faihures to appear in that period. The largest number reeorded was in August, due probahly to some unusual disturbanee of the water by barges or dredges.

Attached eggs of this genus and almost entirely of this form were recorded with averages as follows: Station I, 18.5; Station II, 14.288; Station III, 15,332. Although certainly adrentitious, the eombined numbers of eggs and adnlts make this form of some importance in the local river plankton for a brief period. It is not adapted to life in sewage, however.

The following forms were reeorded only onee or twiee or were thought to be present in fresh material:

Collotheca ornata Ehrbg. Once, I and III.

Conochiloites dossnarius Hudson.

Conochiloides natans Seligo.

Conochilus hippocrepis Sehrank.

Conochilus unicoruis Rous. Once, II and III.

Cupelopagis rorax Leidy. Once, III.

Ptygura brevis Rous. 


\begin{abstract}
Bdelloida

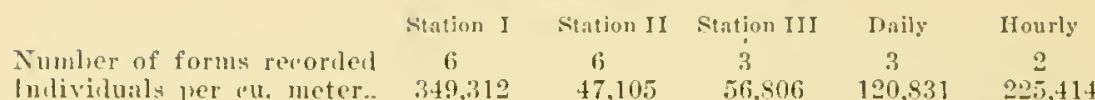

These large averages are perbaps mfair, inasmueh as they are largely influeneed by the assemblage of unidentifice forms which was assigned to the Bdelloida becanse it semed almost certain that all but a very few belonged to that gromp.

The only genus reeorded is Rotaria and it is itself a heary contributor to the plankton. P'robably some other genera ale inclucled, especially in the unidentified list. The larger numbers at Station I indicate a distinet preference for sewage, a condition directly opposite to that of the Rhizota. The representation in February ant Narch at Station $I$ is mueh heavier than at any other time of year, the maximmm falling on Mareh 12. This is very largely dne to the abumdance of Rotaria rotatoria. The maxima at Stations II and III eame in October and Angust respectively, due to the greater influence of the unidentified assemblage at those stations. It must be acknowledged that the data for this gromp do not lead to satisfactory eonelusions. Some of the diffieulty is due to the characteristies of the group and some to the diffieulty of identifieation in preserved material.
\end{abstract}

\title{
Discerssion of Species
}

Rotaria neptunia Elurbg.

\begin{tabular}{|c|c|c|c|c|}
\hline …………… & $\begin{array}{c}\text { Station I } \\
14,987\end{array}$ & $\begin{array}{c}\text { Station II } \\
2,331\end{array}$ & $\begin{array}{c}\text { Station III } \\
3,829\end{array}$ & $\begin{array}{l}\text { Daily } \\
1,961\end{array}$ \\
\hline & & & & \\
\hline
\end{tabular}

Identification usually positive. Oeeurrence most constant in cooler months of the year at all stations. Nneh more abundant at Station I, thus showing preference for sewage. Not reeorded in April, May and June at Station I and but rarely in July and September. Numbers small in Nareh, species well represented in other months. Maxinum number recorded twiee, Oetober 15 and November 5 at temperature of $18.5^{\circ} \mathrm{C}$., whieh is probably near the optimum. Small numbers in early January were probably dne to the temperature being bolow $10^{\circ} \mathrm{C}$. Flood conditions may be responsible for absence in A pril, May and June while high temperature accounts for it in July. The reason for absence in September after being reeorded in August is not clear.

While definite pulses were present, there is not mueh regularity of appearance. 
At Station II this form was reeorded in every month except February, April, May and June though the numbers were rather small thronghout and the eatehes mostly at irregular intervals. The maximum oeenred in Oetober at a temperature of $20^{\circ} \mathrm{C}$. and again at $17^{\circ} \mathrm{C}$. Conditions were much the same at Station III except that April, June and July were the only months withont eatches. This again supports the eonchsion that flood and higher temperatures are both deterrent factors. The maximm eame in October.

While the habits of this organism woukd lead one to think of it as really adventitious in the plankton, the large numbers here raise a definite ruestion as to the valiłity of that view. Can it be that this animal has adopted a free swimming labit under our loeal eonditions? Or are the general conditions so favorable for development that farorite haunts become rapidly overerowded thus foreing individuals temporarily into the plankton while seeking other quarters?

Rotaria rotatoria Pallas.

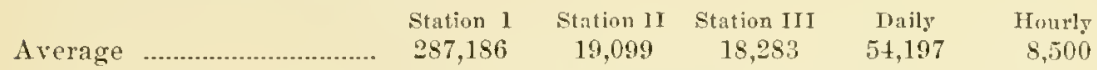

Identification meertain. Probably inchdes two or three other speeies and possibly other genera. So far as estimated from living material the above named speeies was more numerous; the others could not be distinguished from it while comnting. Ocemrenee in every month of the year at all stations, thongh rather light in April, May and first half of June at eaeh, and contiming so throngh June and July at Stations II and III. The maximum came in March at all three stations. The fairly rapid decline after the March maximmm was apparently due to the incoming mountain flood waters. There was a marked pulse in July at the disappearance of these flood waters. Higher temperatures undonbtedy kept the numbers down, however, and none of the pulses of the last half year reached the numbers common in the first quarter year. This, of course, is also some indieation that the eomparative stagnation of the last half year was less farorable than the distrrbed hydrographie eonditions of the first three months when there was enongh rainfall to eause eonsiderable local variation. Comparison with the 1914 condition when there was heavier rainfall may help to settle some of these questions. The $\mathrm{mm}$ bers elearly show that this form does best in sewage. There can be no question that it prefers temperatures below $20^{\circ} \mathrm{C}$. and the indica. tions are that it does best in waters slightly disturbed, as by local rains, but this eannot be settled now.

No other forms of Bdelloida were recorded. 


\begin{abstract}
Ploima
Number of forms recoleled Station I Station 11 Station IJl Daily Ilourly Individuals frer eu. meter.. $4,491,499 \quad 799,224 \quad 1,215,618 \quad 5,322,812 \quad 5,439,813$

I'loima were invariably present at all stations throughont the year. 'The averages given above inchule the eggs, of which there were ubout 30 pere ent at Station I and Station III and over 40 per cent at Station II. While the numbers were always rather large they were especially so in temperatures above $15^{\circ} \mathrm{C}$., the maximum at Station I ocenring in .June at a temperature of $22.5^{\circ} \mathrm{C}$, in November at Station $\left[1\right.$ at $19.5^{\circ} \mathrm{C}$., in November at Station $13 \mathrm{I}$ at $17^{\circ} \mathrm{C}$. A marked preference for sewage is proved by the excedingly large mumbers at Station I, median mumbers at Station III and smallest numbers at Station II. The large numbers in late summer and thronglont the autumn at all stations also indicate a favoralble effect of stagnation.

The fact that all the l'loima show strikingly uniform clatracteristies of seasonal distribution, noted by Lofoid (1908) in Illinois is strongly in evidence here, especially amongst the forms occurring throughout the year. Plates 3,4 and 5 give a graphic representation of the occurrence of the group as a whole (inclurling eggs) aceompanied by a similar graph for the chlorophyll bearers. This does not indieate any prominent relationship of the two groups. The following text table gives the more prominent pulses of lloimal at Station I (exclusive of eggs). Omission or inclusion of eggrs does not aftect the location of the pulses, hence eggs are not segregated from other records in totals at stations II and III.
\end{abstract}

Text Table 2. Station I

\begin{tabular}{|c|c|}
\hline Diate & No. \\
\hline a11. 15 & 259,268 \\
\hline eb. 2.3 & $2,6992,9+9$ \\
\hline pr. 19 & 6 \\
\hline Juile 25 & 13,7 \\
\hline Aug. $20 \ldots$ & $5,287,904$ \\
\hline Nov", $19 \ldots$ & 802,845 \\
\hline
\end{tabular}

\begin{tabular}{|c|c|}
\hline Date & No. \\
\hline I an. 29 & 567,096 \\
\hline Mar. $12 \ldots$. & $9,577,280$ \\
\hline May 11 & $9,9: 6,352$ \\
\hline July $12 \quad \ldots$ & $5,979,752$ \\
\hline Sept. $13 \ldots$ & $5,353,600$ \\
\hline Dee. 14 & 723,508 \\
\hline
\end{tabular}

\begin{tabular}{|c|c|}
\hline Date & No. \\
\hline Frl, 12 & $1,95,5,200$ \\
\hline Apre. 5 & $5,398,400$ \\
\hline June 3 & $4,359,472$ \\
\hline $11 y 26$ & $4,649,99.52$ \\
\hline et 8 & 7,105 \\
\hline
\end{tabular}

It may be sem that of the seventeen pulses noted in this table eight preceded chlorophyll and algal pulses by from three to twelve days, mslally three or four days. Coincidenee oceurred twice, and there were two cases in which ploiman pulses followed the others hy a frw days. In the other fire cases no definite relation appeared. It therefore seems that there is no such clearness of relationship of pulses of ploima and of chlorophyll bearers as was noted in Illinois 
(Kofoid 1908). Inasmuch, however, as ten ont of seventeen puises came near to those of ehlorophyll bearers it may be fair to assmme that the two groups are in some way interdependent or that the general conditions favoring one likewise favor the other. The relationships at the other two stations were still less definite and it was not considered worthwhile to transcribe the tables of pulses of Iloina there.

Our records are at variance with the Illinois records in showing more pulses of Ploima to precede pulses of chlorophyll bearers than to follow. The diserepancy is probably dne to the errors ineident to escape of ehlorophyll organisms through the net. But it might be due to a difference in the numerically dominant forms in the two regions or to some similar factor. The problem of difference cannot be solved, apparently, from the 1913 records, but after all there is sufficient likeness to warrant the conclusion that the two groups are elosely inter-related, here as there. The daily record was too short to help in a decision on this matter.

\section{Discussion of Species}

Anuracopsis fissa Gosse.

\begin{tabular}{|c|c|c|c|c|c|}
\hline & Station I & Station II & Station III & Daily & Ifourly \\
\hline verage eggs attacher?.... & 1,786 & 30 & 3,078 & & 985 \\
\hline
\end{tabular}

Identification frequently satisfactory, more often uncertain. Probably some loss through net. Not recorded anywhere during first half year. Appeared at Stations I and II abont mid-Jnly, at Station III in August. Maximnm at Station I in November, at Station 11 in August and at Station $I 11$ in September. Ocenrence frequent at Stations I and III in August, September, October and November, disappearing in December. Occurrenee at Station II rare except in August. Apparently a form favored by warm and quiet water. Larger numbers at Station III suggest a preference for moderate quantities of organie matter in surrounding water.

All stations resemble Illinois in showing a distinct limitation of this form to a four months period after miclsummer. It was recorded in June there and disappeared in early November. A single December record here at Station II indicates the possibility of ocenrence in very small numbers at other times. The pulses came mainly at temperatures above $20^{\circ} \mathrm{C}$, the single exception on November 22 possilly being due to confusion in counting. 


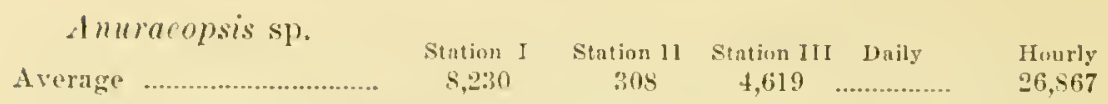

Inentification donbtful. Reeond probahly includes two or threes small forms with indistinet characteristies in the preserved condition. Referred to this gemus as the nearest probability. Ilay include distorted specimens of $A$. fissa. Since the only records of this form ar in . Jnne and July at the three stations, it may be that the whole number shonld be translerred to A. fissit.

A.pplanchna brightuerli Gosse.

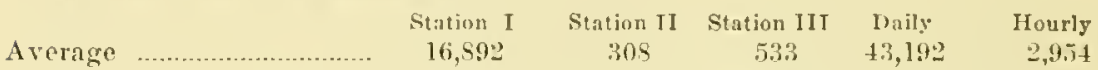

Species determination uncertain. Genus ecrtain. Reeord probably inclndes at least two or three species under this heading, species segregation being too difficult during the comnt. Figgs not connted.

Oecurrence at Station I regular from mid-Mareh to November 1. Maximum, 158,688, on July 5 but almost equalled in April and October. Reeorded only three times at Station II in April, June and July in small numbers. Recorded five times at Station lll from Mareh to November in small numbers and at wide intervals. Distinetly farored by sewage and by temperatures near $20^{\circ} \mathrm{C}$.

The record at Station I shows ten fairly distinet julses, seven of which followed pulses of chlorophyll bearing organisms by from three to seven dass, two of which coincided with such pulses, while one preceded. The eorrelation of these pulses is far the most impressive of any yet observed. The following table, text table 3, slows temperatures and pulses:

TEXT TABLE 3

\begin{tabular}{|c|c|c|c|c|c|}
\hline April ? & is & 122.240 & April 26 & 20 & $\pm 1,600$ \\
\hline May 11 ............... & 21 & $\$ 4,800$ & May 27 & 23 & 51,200 \\
\hline Junie 7 ....... & 25 & 44.9100 & Jult: 5 & 26 & 159,688 \\
\hline Aug: $2 \ldots \ldots$ & 26 & 44,800 & Aug. 15 & 23.5 & 76,500 \\
\hline Sefit $13 \ldots . . . . . . . . . .$. & 25 & 51,200 & Oct 29 & 19 & $10,5,79$ \\
\hline
\end{tabular}

Asplanchnopus sp.

Identifiration doubtful. Recorded thrce times each at Stations I and Il and six times in hourly series at Station III. Not important.

\section{Brachiomes.}

Identifieation of the females of this genus was nearly always satis factory as to genns but the separation of species was frequently diffleult and sometimes impossible. Males were never positively recognized, hence species recorts were of females only. Eggs were easily 
identified when attached but the eonfusion was great when unattaehed. Probably eggs of other genera were often inelnded amongst the free eggs. Eggs of species were not recorded.

Only seven species and one variety were recorded, although there were probably many more. The reference of many individuals to some of these speeies was somewhat arbitraly, but on the whole the eight gronps were fairly definite in the writer's mind and may be properly discussed despite some technieal error in identifying.

Since the eggs were only recorded for the genus as a whole their averages ant the main features of their occurenee may be stated now.

Text Table 4

\begin{tabular}{|c|c|c|c|c|c|}
\hline & Station 1 & Station 1 I & Station III & Daily & Hourly \\
\hline & 255,960 & 16,390 & 28,607 & 409,180 & 122,240 \\
\hline & 26,190 & 2,773 & $4, \pm 43$ & 4,338 & 22,306 \\
\hline 6 & 351,039 & $1+, 780$ & 41,963 & 718,362 & 396,720 \\
\hline 80 & 817 & & 157 & & \\
\hline
\end{tabular}

In view of the mneertainty of identifieation of mnattached Brachionus eggs either male or female, it is hardly worth while to attempt any detailed disenssion of the records for these kinds. The maximmm for both kinds of attached eggs came early in Mareh at Station I. Occirrence of attaehed male eggs was seattered after Mareh, thongh the female eggs were almost constantly present throngh the year. They almost reached the Mareh maximmm twice in September. At Station II there were only three records of male eggs, two eoming in Mareh. Oceurrenee of female eggs was fairly constant from Jme to Oetober inclnsive, infrequent at other times, the maximum eoming in October. At Station III male eggs were recorded seven times, the maximum in March. The female eggs ocemred rather regnlarly from February to Oetober inchsive, exeepting April, when there were none. The maximum came on October 4. Abont the only safe conelusion to be drawn from these inadequate reeords is that male eges a re most mumerons in early springtine at all stations. It is, of eomse, unfortunate that the attaehed eggs were not segregated with thw proper speeies, hut the desirability of segregation was not realized until too late in the eount.

Brachiomus angularis Gosse.

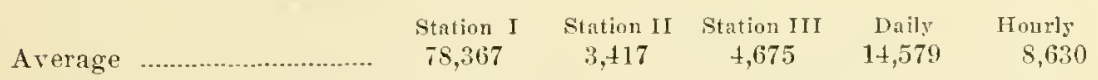

Identifieation usually satisfaetory. Ocemrenee far most conspicnons in Mlay and Jume at Station I, with maximum in mid-Nlay. Miss- 
ing in January, February, aud December, rare in Mareh, April, July, Angust and October. Oecurrence at Station II from April to Novernber inchsive, but seattered and in small numbers with a maximun in September. Limited to same perion at Station III lunt regularly recorded during most of Mlay and Jume with maximum in May, lavored by sewage and by a trmperature near $20^{\circ} \mathrm{C}$. Stagnation seems to be detrimental.

The periods of regular occurrence were too short to give very well marked evidenee of recurpent pulses.

Brachiomus angularis condatus B. and Da.

\begin{tabular}{|c|c|c|}
\hline & Station 1 & Station 11 \\
\hline
\end{tabular}

Identifieation usually satisfactory. Sometimes hapd to clistinguish from type form of $P$. angularis. The separate recold of this variery seems to have been worth white beanse of the tremendous emphasis which it gives to the continuity in occurrence of the two forns. The viring was almost wholly alsent from the collections mutil the type form had passed the spring maximum. As the latter dectined the former increased until it entirely displaced the other. 'This was strihingly true at all thee stations. The variety also disappeared ly Vo. rember at all stations, at which time the type eame in in small nu? ber's for a few weeks. At Station I the maximum canc on June 25 but was almost "cpualled in Septrmber. At both of the other stations the maxima eame in August.

Recurent pulses were very marked in the records for this form as shown by the following table:

\section{TEXT TABLE 5}

$\begin{array}{llr}\text { Station I } & \text { Station I1 } & \text { Station 111 } \\ \text { June } 7 & & \\ \text { June } 25 & \text { July } 12 & \text { July 12 } \\ \text { July } 12 & \text { Aug. } 15 & \text { Aug. 2 } \\ \text { July } 26 & \text { Sept. } 20 & \text { Aug. 31 } \\ \text { Aug. } 20 & \text { Oct. } 11 & \text { Oet. 18 }\end{array}$

Comparison with the tahle of ploiman pulses at Station I shows that lour of the $B$. caudatus pulses correspond exactly white two ot hirs are very close. It is thus evident that the relationship of oceurrence of this organism to that of the ehlorophyll bearers is about as intimate as that of the whole ploiman group. 
The larger numbers at Station I indicate favorable influence of sewage and the distinet limitation to temperatures above $20^{\circ} \mathrm{C}$. and mark B. eaudutus as a summer form. The maxima in late summer may also indicate stagnation as a favorable factor. Kofoid's reference (1908) to the contention of various observers that spinous processes, etc., appear as adaptive respouses to lessened buoyancy of warmer waters is es]ceially interesting in this connection. The condition of our records more strongly supports that view than do the Illinois records. In fact the evidence could hardly be stronger without deliberate manipulation.

Brachionus budapestincusis D.

Average

$$
\begin{aligned}
& \text { Station I Station II Station III Iaily Hourly } \\
& \begin{array}{lllll}
970 & 7,56 \pm & 2,322 & 413 & 9,615
\end{array}
\end{aligned}
$$

Identification doubtful. Recorded six times at Station I, thirteen times at Station II and siven times at Station III. Ocenrence at all stations rather seattered and mainly from July to October. Maximum at Station 11 in Angust. Apparently hindered by sewage but favored by warmth and stagnation. Not a very important form here, though the average at Station I is somewhat higher than it was in Illinois.

Brachionas calyciflorus Pallas. . (B. pala Ehrbg.)

Station I Station II Station III Daily Ifourly

Average .......................... $109,718 \quad 10,528 \quad 32,378 \quad 516 \quad 175,708$

Identification satisfactory. No attempt to distinguish varieties in final records. The above count consists entirely of females exchusive of eggs. The most striking features in the record of the ocenrence of this form are its great abundance in the first four or five months of the year at all stations, its abmpt disappearance at the close of this period and its reappearance in considerable numbers in and after Angust. The three stations vary considerably in these last two points, the break in the record in May being much more abrupt at Station I than at either of the others. Station I also shows only a few very light eatches in the fall while Station III reaches the maximum for the year at that time. Station II has the maximum in February but shows records of considerable numbers through September and October. Station I has the maximum in March. The reasonable inference secms to be that much sewage is favorable to this species in flood water but that it is detrimental in stagnation. Also that temperatures above $20^{\circ} \mathrm{C}$. are rather unfavorable. 
The numbers here were much larger than those noted in Illimois and the vernal maxima came abont a month earlior. Otherwise there is rather close similarity in the records. Recurrent pulses are not distinct, however, at any of our stations here.

Brachionus capsuliftorus P'allas. (R. balieri Ehrbg.)

$\begin{array}{cccccc} & \text { Station I } & \text { Sintion II } & \text { Station III } & \text { Paily } & \text { 1Tourly } \\ \text { Average } & 1,954 & 1.4,415 & 0,582 & 1,45 & 40,468\end{array}$

Identification probable. Oecurence at Station I scattered, in small numbers, from May to December, with a small maximum in October. Oceurrence at Station II almost limited to Angust and Sep)tember, witls a maximum in September. At Station III somewhat similar, except for a slightly larger mumber of earlier recoris of small numbers.

The likeness to Illinois conditions is very marked, espeeially at Station II. Our records indicate that sewage is detrimental whilr stagnation and rather high temperature (near $24^{\circ}$ C.) are beneficial. It seems rather strange that thongh the river showel the largest numbers, the limits of their occurrence were much more sharply defined than at the other stations; only four small eatches being foumd outside of the eleven weeks periou from August i to Oetober 11, as against twiee that number elsewhere. No males were reognized.

Brachiomus patulus Miill. (I3. militaris Ehrbg.)

$\begin{array}{cccccc} & \text { Station I } & \text { Station II } & \text { Station III } & \text { Daily } & \text { Hourly } \\ \text { Average ….......................... } & 120 & 4,804 & 1,6: 31 & 310 & 10,469\end{array}$

Identification eertain. Recorded only once at Station I in July $(6,400)$. Oecurrence at Stations II and III limited to July and Angust and September, except for one eatch on December 6 at Station II. Naximmm on September 6 at both places. Evidently a summer form favored by stagnation but intolerant of sewage. No clata are at hand bearing upon Kofoirl's snggestion (1908) that this specirs probably thrives in warm, shallow water rich in organie matter. Its alsence from sewage does not prove that it would be injured by deeaying regetation, ete.

Israchionus plicatilis Mü]l. (T. mülleri Ehrhg.)

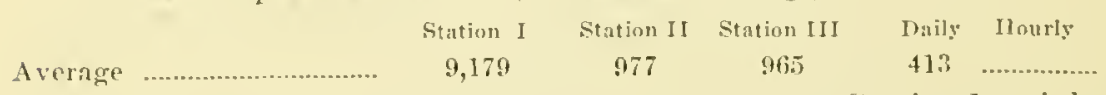

Ictentification usually satisfactory. Oceurrenee at Station I mainly in first three months, thereafter in small numbers at rariable hut usually wille intervals through the year. Maximum (132.240) twiee, 
February 12 and Mareh 5. Numbers always small at other stations, otherwise distributed about the same. Henee this form may be said to be definitely limited to temperatures below $20^{\circ} \mathrm{C}$. Sewage appears to be favorable.

This speeies is not listed by Kofoid for Illinois. Mr. H. K. Harring designates it partieularly as a braekish water form. It is also so listed in Süsurasscrfauna Deulschlands. However, its presenee here is not so prominent as is that of the brackish water diatom, Bacillaria paradoxa. Some other factor than salinity must determine the oeeurrence of sueh forms.

Brachiomes urceus L.

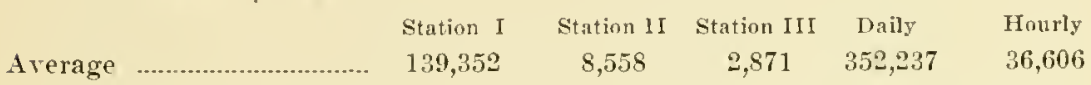

Identifieation usually satisfactory. Some eonfusion with other forms at times. Reeorded in every month of the year at Station I. Missing in March and November at Station II, in April, November and Deeember at Station III. There was a well developed pulse in February at Station I but there were only four eatches from Mareh I to May 14 when a long period of regular appearanee in eonsiderable numbers began, whieh finally ended on October 29. Numbers were then small and absences frequent to the end of the year. Maximum $(899,232)$ reaehed twiee in June. Records seattering at Station II exeept in June, July and August. Maximum (105,792) on August 2. Conditions similar at Station III with smaller numbers. Maximum September 20, 38,400. This form shows a elear preferenee for sewage and for temperatures above $20^{\circ} \mathrm{C}$., but stagnation is apparently detrimental. Recurrent pulses are fairly distinet at Station I as follows :

$\begin{array}{llr}\text { Feb. } 8 & \text { July } 26 & \text { Sept. } 27 \\ \text { Juue } 3 & \text { Aug. } 9 & \text { Oct. } 15 \\ \text { June } 21 & \text { Aug. } 23 & \text { Oct. } 29 \\ \text { July } 12 & \text { Sept. } 9 & \text { Nov. } 15\end{array}$

Of the twelve dates just mentioned, eleven ean be eonneeted definitely with pulses of ehlorophyll bearers, four preeeding by from four to eleven days, four following by three or four days and three exaetly eoineiding.

Brachionus with endoparasites. Average at Station I, 5,363.

Different speeies of Brachionus were found infested with parasites but no speeifie eount was made. These parasites were rather small and their relationships were not determined. In almost all eases they 
ocenpied at least half of the space inside the loriea of the host. None were notied at Stations I1 and III so it is probable that sewage is favorable to the parasites in some way. They were reorded five times at Station I, one in June, thriee in Angust and once in Novembere?

Diurella egg, free.

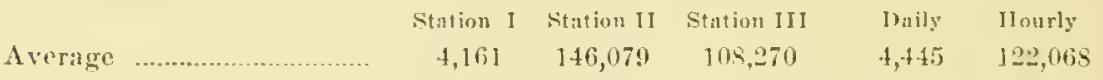

Identification very doubtful. Small eggs attached to filaments of Melosire gromulata were comnted under this heading. They were only' recorded eight times at Station I but they were quite prominent at the other stations, at Station II from Jume to Oetober inclusive, at Station III from May to October inchusive. Inasmuch as no considerable number of Diurclla females were ever foumd, it is probable that these eggs were wongly designated, but nothing is known as to the real identity.

Epiphanes clavulata Ehrbg. (Notommata.)

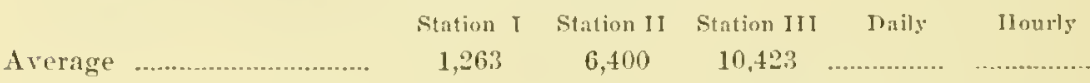

Identifieation meertain. Reeorded five times at Station I, nine times at Station II and seven times at Station II I in August, September and October. Hence it is to be regarded as definitely limited to stagnating waters and temperatures above $20^{\circ} \mathrm{C}$. Sewage nnfavorable. Attached female eggs were also reeorded for this form at Stations II and III.

Filinia brachiata Rous. (Triarthra.)

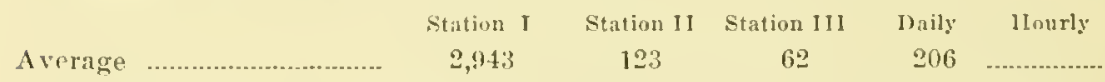

Irlentification eertain. Recorded eleven times at Station I and once at each of the other stations. Oceurrence at Station 1 usually in small numbers at rather wide intervals. Catohes grouped in May and November. Maximm in November. This species was not reported as present in Illinois.

Filinia eggs, attached.

\begin{tabular}{|c|c|c|c|c|c|}
\hline & Etation I & Station II & Station IIl & Daily & IIourly \\
\hline l'emale, average ............... & 79,131 & 554 & $1,00+$ & 12,667 & \\
\hline 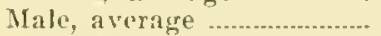 & 24,815 & 431 & 251 & & \\
\hline
\end{tabular}

Identification eertain. Attached female egg appeared in every eateh at Station I from February 12 to April 26, then frequently to 
July 19, being absent the rest of the year except for two small catehes in November. Maximum $(1,481,088)$ in March. Recorded only five times at other stations, mainly in March.

Male eggs were recorded continuously at Station I for a short time in February and Nareh and there were oceasional eatches to June 28. They were recorded once at Station II and twice at Station IIl in small numbers. Both kinds were first reeorded at Station I on February 2.

The maximum egg records of both kinds at Station I preceded the maximum record for females of Filini longiscta by three days and the maximum for female eggs was almost reached again four days after it.

Unattached Filinia eggs were not certainly identified though recorded.

Filinia longiscta Ehrbg.

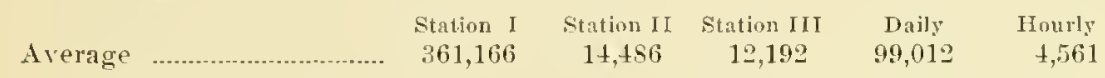

Identification positive. About twice as abundant at Stations II and 11 I as ever noted ly Kofoid in Illinois and about fifty times as many at Station 1. Seasonal limitation earlier and more definite here at all stations. Oceurrence at Station I regular from January 5 to July 19, missing thereafter except for two small catches in December. Maximum on March $8,6,083,040$. Catches of more than 1,000,000 taken seren times in February and Mareh, three in May and one eatch in June and July. An extremely important planktont at this station. At Station II one small catch was made in January but the regular occurrence began February 23 , extending to April 13. Several more catches to July 12, then none till late October, followed by another in December. Naximmm on Nareh \&. At Station III one small eateh came in January, then the regular oceurrence began on February 8, extending with one lapse to July 12. Only two catehes thereafter, one in July and one in Oetober. Maximum on June 28.

There were rather distinet recurrent pulses at Station I culminating as follows:

Jan. 15

Jan. 29.

Feb. 23

May 7

Feb. 12

Mar. 8

Apr. 13

Apr. 26

June 3

July 5

Contrary to Illinois conditions the principal oceurrence of this form was below a temperature of $20^{\circ} \mathrm{C}$. instead of above, and from Mareh to July instead of from May to Oetober, so far as Station I is 
concerned. In view of the enormons mumbers at Station I it may be safe to concluck that the food factor is more potent than temperature and that the smaller Illinois numbers at lower temperatures were only indirectly due to that condition. With abundant food in the sewage the lower temperatures seem quite favorable here. This form may then be rexarded as very dependent npon sewage. The higher temperatures and stagnating waters seem to be deterrent.

Keratclla cochlearis Gosse. (Anuraea.)

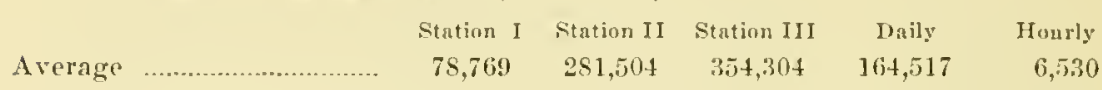

Identifieation usually certain. No attempt to distinguish varieties. Some confusion probably of spineless varieties witl spineless varieties of $K$. quadruta or other species. The numbers were greater at all stations than recorded for Illinois, but the records resemble Illinois records in the fact that the organism was found at some station in every month of the year. Also in the fact that there was a period of regular ocemrence in the first seven months of the year, separated by a period of irregular occurence or absence from a period of regular oecurrence in the last three months. The location of the maximum is distinctly different from the Illinois eondition at all stations. The maximum there was early in Nlay, while our reeords show a maximm at Station I in July and at Stations II and III on November 1, the last two being in remarkably large numbers. The inferenee from our recorls is that sewage is detrimental in large amounts, that stagnation is even more so, and that temperature in moderate limits is less important directly than are other factors. The optimum temperature seems to be slightly below $20^{\circ} \mathrm{C}$. The presence of largest numbers at Station III indieates the probability that a larger amount of organic matter than that in the river may be favorable.

Recurrent pulses are distinguishable at all stations, about half of those at Station I eorresponding elosely with those of chlorophyll boarers.

\begin{tabular}{|c|c|c|c|}
\hline \multicolumn{2}{|c|}{ Station I } & Station 11 & Station III \\
\hline Feb, 12 & June 18 & Mar. 23 & Mar. 23 \\
\hline Mar. 5 & June 28 & A jur. 19 & Apr. 19 \\
\hline Mar. 19 & July 5 & JuIy 12 & May 31 \\
\hline Apr. 2 & Oet. 26 & Nor. 1 & July 12 \\
\hline Apr. 23 & Nor: 1: & & Nov. 1 \\
\hline
\end{tabular}

This was numerically the most important planktont at Stations II and III. 
Keratclla quadrata Miill. (Anuraca aculcata.)

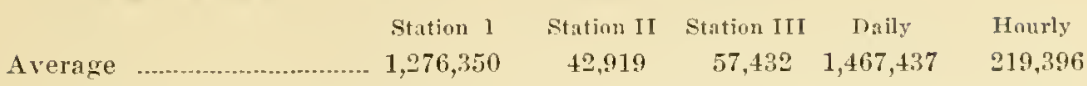

Identification usually eertain. Contrary to Illinois reeords this was mumerieally our most important rotifer, all stations eonsidered. It was one of the most important planktonts. Furtbermore our reeords show it to be a distinctly peremial planktont here, since considerable numbers were found at all stations in every month of the year. At Station I there was only one lapse in the reeord. The increase was umsually uniform from Jamary 5 to the maximum on June 28. followed by a similar decrease to Deember 31. At Station II the oceurrenee resembled that of $K$. cochlcarlis in that there was a deerease in numbers with a few alssenees in the summer months, thus making the records for spring and autumn more prominent. The maximum came on Oetober 18 not far from the $K$. cochlearis maximum. At Station III the reeords for the summer were not materially different from those for spring and fall except that the maximum came on October II in a much larger pulse than at other times.

Not only do our records fail to eorrespond with those of Illinois, they also fail to agree at on three stations. Consider, for example, the maximum in relation to temperature. Station I shows a maximum in a strongly developed pulse at a temperature of $23^{\circ} \mathrm{C}$., Stations II and III at $17^{\circ} \mathrm{C}$. Station I has its largest mumbers in summer, Station II its smallest and Station III much the same as in other seasons. In spite of these differences some definite conclusions are possible. The vastly larger numbers at Station I at all seasons indieate not only a benefieial effect of sewage but the importance of the food faetor. The smaller numbers at all stations in Jamuary and December show that temperatures may get low enough to be injurious, though it is not elear that this may not be due to reduced food supply incident to low temperature. In fact, when one considers that the numbers appearing at Station I at $7^{\circ} \mathrm{C}$. or $9^{\circ} \mathrm{C}$. were as large as those found in the culminations of ordinary pulses at the other stations in any season, it seems that the range of temperatures in ordinary fresh waters has little direet bearing on production. The unusually strong pulses in Oetober at Stations II and III indieate a benefieial effeet dne to relief from Stagnation by the incoming antummal freshet waters from the mountains. 
Recurrent pulses are quite prominent in the reeords for this form, with eulminations as follows:

\begin{tabular}{|c|c|c|c|}
\hline \multicolumn{2}{|c|}{ Stution I } & Station 11 & Station III \\
\hline .Тan. 15 & $\mathbf{J}_{\text {йе } 28}$ & Fels. s & Fob.s \\
\hline dan. 29 & July 12 & Mur. 99 & Mar. 23 \\
\hline liel. 12 & $J_{11} l^{2}=6$ & A pr. 19 & Apr. \\
\hline 1.eh. 23 & Aug. 23 & May 31 & May 17 \\
\hline Mar. 8 & Sept. 13 & July 19 & June 28 \\
\hline Apr. 5 & Oet. s & Aug.::1 & July '26 \\
\hline А pr. 19 & Dore. 3 & Oet. 18 & Oet. 11 \\
\hline May 11 & Deer 14 & Nor, 30 & Dee. 14 \\
\hline June 3 & lhece. :1 & & \\
\hline
\end{tabular}

Kicratclla eggs, attached.

Station I Station II Station III 1)aily Hourly

Average

$263,312 \quad 54,732 \quad 96,442 \quad \mathbf{1 4 0 , 8 1 5} \quad 12,669$

Identifieation certain. No male eggs were recorded and no effort was made to keep the speeies record separate for eggs. The desirability of such separation was overlooked until too late; hence, as might be expected, the egg record shows the same characteristics as the dominant speeies, i.e., $K$. qualvatu at Station $I$, and $K$. cochlearis at the other two stations.

Kicratella egg, free.

Station I Station II Station III Daily IIourly Average _............................ $363,933 \quad 57,631 \quad 100,216 \quad 129,490 \quad 602,201$

Identifieation quite unetrain. 'The designation was probably correct in a large majority of the counts but there is enough uneertainty to invalidate definite conehsions, so they are not offered.

Lecanc luna Mïll. (C'athypna.)

Average

Station I Station II Station III Daily, Hourly

Identifieation uneertain. Recorded only four times at Stations I and II in small numbers, and once at Station III. Probally adventitions. At any rate unimportant.

Notholen striuta Müll.

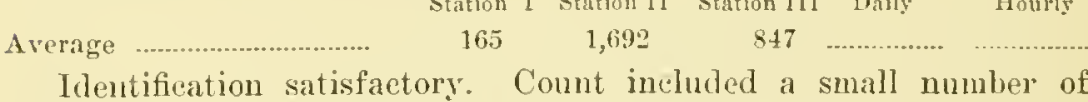
different forms most of which were considered varieties with perhaps one or two other species. Only six catehes at Station I at rather wirle intervals, in very small mmbers and mostly in the first three months. Oecurrence at Station II in every montl except December, seven eatehes in first three months, one eateh in each month thereafter up 
to December. Numbers always small. Maximum, 16,000, April 5. Recorded nine times at Station III, seven times from January 23 to April 19 and twice in November. Numbers always small but considerably larger in November than at other times. It is elear from these records that this form is intolerant of sewage and of summer conditions, probably including temperatures, though the monthly ocenrence at Station II may indicate the influence of a food factor. At any rate the optimum temperature seems to be below $15^{\circ} \mathrm{C}$. The seasonal distribution at our Station III most nearly resembles that noted for Illinois.

\section{Polyarthra trigla Ehrlog. (P. platyptera.) \\ Station I Station II Station III Daily Hourly $\begin{array}{lcccc}\text { Station I } & \text { Station II } & \text { Station III } & \text { Daily } & \text { Hourly } \\ 410,770 & 35,241 & 58,037 & 662,712 & 1,267,469\end{array}$}

Identification certain. Recorded in every month at all stations. Ocenrence at Station I very constant after January 12, only two absences, both in November. Maximum on May 7 , eulminating a gradual increase from first appearance, numbers well sustained after that exeept for a drop in June, another in November and the final decline in December. Continuous recold at Station II except for two misses in June, one in Angust, one in October and three in November. Haximum on September 6 in a well defined pulse. Record at Station IIT began on January 19, after which there was one miss in March, one in June, one in October and three in November. Maximum on September 20 in a minor pulse. The character of the record at Station I suggests the idea that temperatures may vary widely without appreciable influence except as they approach the lower recorded limits. Even here the influence may be through the food supply instead of direct. Stagnation appear's to be slightly favorable. This is next to the most important speeies numerically, of rotifers at Station I.

Recurrent pulses are prominent at all stations as follows:

\begin{tabular}{|c|c|c|c|}
\hline \multicolumn{2}{|c|}{ Station I } & Station II & Station III \\
\hline Jau. 15 & JuIy 30 & Feh. 8 & Feb. S \\
\hline Jan. 29 & Aug. 9 & Nareh 8 & Apr. 26 \\
\hline Feb. 8 & Aug. 20 & March 29 & May :1 \\
\hline Feb. 23 & Sept. 13 & May 10 & July 12 \\
\hline Mar. 8 & Oct. 18 & May 24 & A11g. 2 \\
\hline Apr. 13 & Nox. 1 & Juve 28 & Aug. 31 \\
\hline Apr. 26 & Nov. 19 & Sent. 6 & Sept. \\
\hline May 7 & Nov. 30 & Oct. 18 & O.t. is \\
\hline June 3 & Dec. 14 & Dee. 14 & Dec. 6 \\
\hline Juue 25 & Der. 31 & & \\
\hline
\end{tabular}

July 12

These pulses at Station I are even more distinctly marked than in Illinois, which of conrse might be expected from the rery large 
mumbers distributed over the cutire year. The correspondenee of these pulses with those of ehlorophyll bearer's is yute close, thinteen being within severn days of the same date.

I'olyarlhre trigla eggs, attached.

\begin{tabular}{|c|c|c|c|c|c|}
\hline & Station I & Station 11 & Station III & 1):aily: & II: $: x \in y$ \\
\hline $\begin{array}{l}\text { Female, average ....................... } \\
\text { Jiale averiuge }\end{array}$ & 35.511 & $\begin{array}{r}4: 31 \\
4,100\end{array}$ & tins & 723 & $\begin{array}{r}40,686 \\
8,138\end{array}$ \\
\hline
\end{tabular}

ldentifieation certain. Probathy most eggs berame detachad in manipulations and the records are to that extent unreliable. Certamly there are some very curions features to the recorels as they stand. Female aggs only were recorded at Station III in the regular series and then in small numbers at wide intervals, but the hourly series from the same canal, but a mile away, showed great numbers of both sexes. At Station If the numbers of female eggs were also seant but in the two catches of male eggs one was rather large. At Station I, female eggs appeared irregularly in small numbers from the last of February to the end of Mareh, after which the oceurences were regular and in rather large numbers till May 11 when they abruptly failed. Only a very few catches were found in the interval to midNorember when the oecurrenee beeame regular again for several weeks. The reeords of male eggs eame in November.

Such recorts are quite montisfactory as it is evilent that they do not show the real numbers of eggs prodnced, in view of the large numbers of females recorded at all periods at all stations. Quite probably many of the free eggs counted as Krotolla and Filinia eggs should have been referred to Polyarthra. This was suspeeted early in the count and the eggs were frequently examined for distinctive charaeters in the gromps but none were found that coukl be used acenrately while counting.

Rotifere egrgs, winter, free, unidentified.

These were comnted merely as a matter of routine in trying to give attention to everything found. There is not enough certainty in any observation eonerning then to make comment desirable.

Synchata sp.

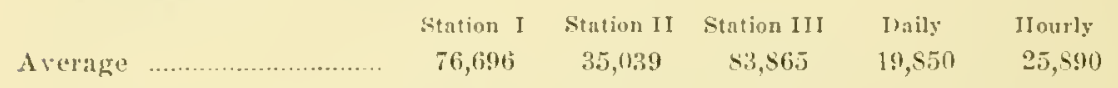

ldentifieation of gemus satisfactory. Judging from living material, three or more speeies were represented in the comnts but they 
could not be accurately distinguished in preserved material. st. tremula., S. stylata and $S$. pectinata were probably most often present. AIthough the assemblage was recorded at Station I in every month of the year, the eatches were few and small during the first three months and in July, August, September and October. The maximum oecurred on June 25 in a strongly developed pulse. The oceurrenee at Station II was somewhat similar except that there were no large numbers till July when there was a fairly strong pulse. The maximum came, however, in the larger November pulse. At Station III the numbers were more evenly distributed from March to December, Angust being the only later month with very small numbers. The November pulse was largest on the whole but the maximum came on Nay 31 in a eateh following a lapse and preeeding two lapses. Such irregular records, in addition to the difficult identification make it necessary to be can. tious as to conclusions. Still it seems elear that sewage is benefieial and that stagnation with high temperature is harmful.

Trichoccra capucina W. \& C.
$\begin{array}{cccccc} & \text { (Rattulus capucimus.) } \\ \text { Station I } & \text { Station II } & \text { Station III } & \text { Daily } & \text { 1Furly } \\ \text { Average } & 246 & 4,777 & 1,004 & 413 & 9,123\end{array}$

Identifieation uneertain. Genus probably correct in all cases. Recorded only four times at Station $I$ in small numbers and at wide intervals; seven times at Station II, onee in fairly large numbers; eight times at Station III, all in small numbers. Unimportant numerically in our plankton. Probably adventitious.

Trichoccra icrnis Gosse. (Rattulus gracilis.)

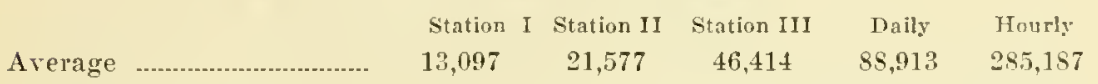

Identification uneertain. May include other species. Not recorderl at Station I till May 27 and not appearing regularly till July 3. Fairly constant through July and August and for a time in September, and Oetober. Maximum in July. Oecurrenee at Station II almost limited to July, August and September with maximum in September. Conditions similar at Station III with a slightly longer period of regular occurrence. Maximum in September. Evidently favored by higher temperatures and quiet waters. Larger numbers at Station III than in river suggest that more organic matter in the water is helpful, though the organism does not do so well in the dilnte sewage of Station I. 
The following l'loima were only reeorded once or twiee, or were only reeognized in living material.

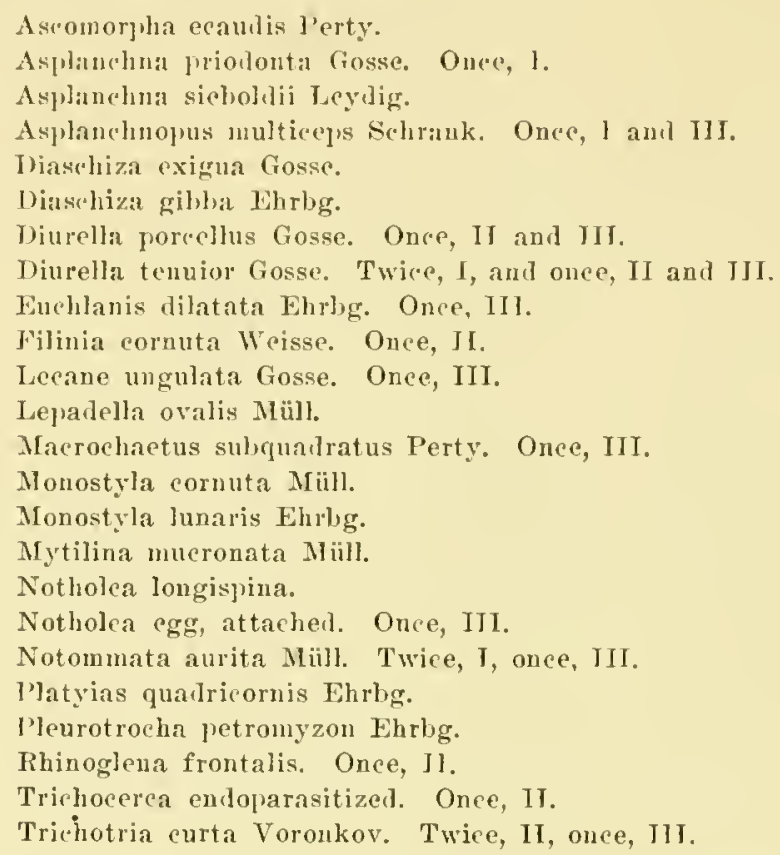

\section{Scirtopoda}

Pedalia mira IIudson was found in very small numbers once or twiee in fresh material from Stoekton Channel but not in regular eatehes for 1913.

\section{GASTROTRICHA}

Chactonotus nodicaudus Voight and another species were each reeorded onee at Station I. They are known to be present in the locality in larger numbers and are, no doubt, strietly adventitions.

\section{ENTOMOSTRACA}

Average

Station I Station II Station III Daily Hourly $560,149 \quad 22,022 \quad 22,551 \quad 1,498,72 \div \quad 83,099$

With the exeeption of three speeimens of Gammarus found at Station III the Crustaeca reeorded eonsisted of Entomostraca. Of this group only the Cladoeera and Copepoda were of any importance in our plankton. Entomostraca were recorled in every month of the year at all stations, but the numbers were small everywhere during the first three months and there were some misses at all stations at 
that period. In addition, Stations II and III showed occasional absenees up to May and June, and in the last two months of the year. The greatest abundance at all stations was in July, Augnst and September with the maximum in Augnst or September at all.

The count of Entomostraea is unsatisfaetory for two reasons: first, specific identifications were too diffieult for the writer under the conditions of work; second, the method of counting permitted too much error. Special trials showed that even distribution of Entomostraca in the counting eell seldom occurs. As the reeords stand, the main error was due in most cases to counting only the same fractional field as was counted for smaller organisms. It was the intention to make a speeial count of Entomostraea later in order to correct this, bnt an examination of the records showed that it was not probable that the limited increase in aeeuracy of count would make any material change in the possible conchsions. For that reason the intention of reeounting was abandoned. So far as can be estimated from several recounts made at random, the varianee in the count by the two different methods is mainly from 10 to 25 per cent.

\begin{tabular}{lcccccc}
\multicolumn{8}{c}{ Cladocera. } \\
& Station I & Station II & Station III & Danly & IIourly \\
Forms recorded ............... & 3 & 4 & 4 & 2 & 2 \\
Individuals per cu. meter.. & 3,836 & 7,385 & 9,197 & 7,432 & 34,752
\end{tabular}

The Cladocera were rarely prominent at any station. There was probably a much larger number of forms present than was reeorded, since names were given only to those with conspicnous characters. The averages were distinetly lower at all stations than they were found to be in Illinois, exeept for one year there of recurrent floods. Sinee 1913 seems to have been an unusually stable year here, there is reason for believing that the Cladocera are naturally fewer here. They were reeorded in every month of the year at some station but the catehes were few and far between and the numbers small at all stations until August. The maximmm eame on Oetober I at Station I and in September at Station II and III, after which the numbers rapidly deelined at all stations. Our records therefore agree with those of Illinois in showing the favorable effect of stable (or even stagnating) water and of high temperatures. We have the further indication that sewage is detrimental since Station I had so much fewer numbers than either of the other stations. The explanation of the deleterious effect of flood waters in Illinois (Kofoid 1908) applies equally well here. The evidence for reeurrent pulses is not convineing here at any station. 


\section{DISCUSSION OF GENERA}

Bosmina longirostris O. W. Mïll.

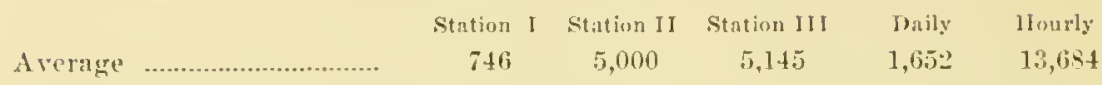

Identifieation probable. This form was rare at Station I, being recorled only eleven thues in small numbers, six times in September and October, the rest scattering. Catches at the other stations were ahmost confined to the same period but there were more of them and the numbers were larger. Clearly favored by warm, stagnating water and rertarded by sewage.

Chydorus sp.

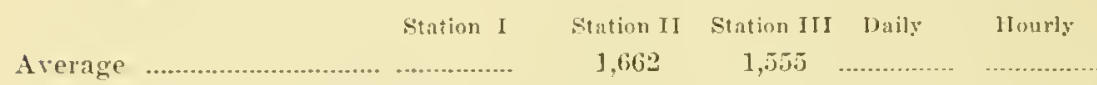

Identification douhtful. Recorded seven times at Station II mainly in August and September, and five times at Station 1 II at irregular intervals. No definite conclusion possible, though the indieation is that sewage is injurious, while warm stagnating water is favorable.

Sidle sp.

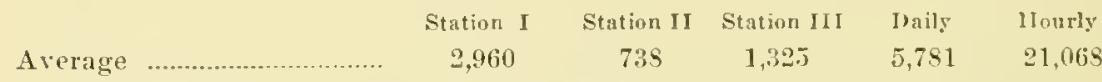

Identifieation doubtful. There was probably eonsiderable confusion with other forms, especially Daphnia. Recorded frepuently at Station I from carly June to late October, larely at other times. Numbers always small execpt on October 1 (105,792). Recorded twice at Station II and seven times at Station III, nearly all in the warm montlis. Scems to be a warm water form farored by sewage and quict waters.

The following other genera of Cladocera were thought to be present :

Alona sp.

Bosmina sp. All three stations.

Dajlunia sp.

\section{Ostracoda}

Ostracola were mainly notable for their absence. Cypris sp. was the only form reegnized and it was rare. It was not recorded from the preserved material. Inasmuch as it has been fomm in abundance in ditehes and temporary ponds about Stockton, it must be regarded as strictly adventitious. 


\section{Copepoda}

$\begin{array}{lcccccc} & & \text { Station I } & \text { Station II } & \text { Station III } & \text { Daily } & \text { Hourly } \\ \text { Forms recorderl .............. } & 4 & 3 & 3 & 4 & 3 \\ \text { Individuals per cu. meter.. } & 556,312 & 14,552 & 14,549 & 1,458,421 & 189,469\end{array}$

Copepoda were recorded in every month of the year at Station I, and they were entirely missing only at Stations II and III in Decenber and November, respectively. Numbers were small at all stations through the first three months and in the last month. At Stations II and III they only reached 100,000 in three catches in September at the former, and one catch at the latter. There was no increase in numbers at either place until May and the dechine was very rapid after September. On the contrary, Station I showed very marked and steady increase in numbers after March and the decline after September was gradual, thongh starting abruptly with the close of the month. The maximum at Station I came in August according to the record but it was so nearly eqalled in September that a recount might show it really to be in that month. However, this does not affect the general conchusion that the warmest months are most favorable, the eulmination coming with approaching stagnation. The record also elearly shows that the dihte sewage of Station I was distinctly favorable to this group.

Specific identifications were not attempted and there was certainly some confusion of forms during the comnt. Some of these errors conld be corrected by a recomnt, hut in the writer's judgment there would not be enough advantage to warrant the great effort involved.

Dr. C. D. Marsh, of the United States Bureau of Plant Industry, very kindly identified a few forms from a very limited amount of material sent to him. He noted the presence of Cyclops americumus Marsh, Cyclops prasinus Fischer, and Cyclops albidus Jurine. No other Copepoda were found in the samples sent to him but the writer is certain that some other forms occurred at times in limited numbers. Since Cyclops completely dominated the other genera in numbers, discussion of seasonal distribution will be deferred till discussion of that group is reached.

\section{Discussion of Genera}

Canthocamptus sp.

Identification fairly certain. Recolded only twice at Station I, thrice at Station II and five times at Station III in small numbers and at wide intervals, but mainly in spring and fall. This genus has been 
foumd in abundance in some of the shallow temporary ponds in Stockton in Felnuary, Narel and April, hence it is to be regarded as adrentitious in the plankton eolleetions.

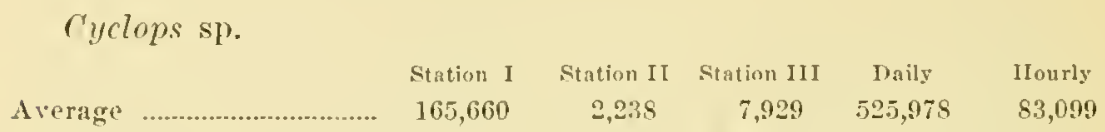

Identifieation of gemus usually eertain. May inelude some other genera when preservation of the individual was poor. As mentioned alove, Dr. Marsh has indieated the presence of three speeies in the first half year. 'These were $C$. amcricanus Marsh, C. prasinus Fiseher, and $C$. albidus Jurine. It is probable that there were few other speeies and that these furnished the prineipal numbers.

The genus was rarely missing at Station I, thongh the numbers were eomparatively small before Nay and in Deeember. Only two catehes were recorded before June 21 at Station II and two after September 13. Conditions were somewhat the same at Station III, though the number of eatches before mid-June was larger. The evidence seems to be eonelusive that the genus is favored by sewage, by stagnation and by high temperature. It does not seem possible that reeounting by any method could ehange the basis for such conelusions.

There is some evidence of recurrent pulses at Station I but a recount wouk be necessary before listing them with full confidence. As it stands, no very elose relationship to the algal pulses ean be shown exeept in two or three eases.

Diaptomus sp.

While this genus does not appear in the reeord, it is so eertain that it was present that definite mention of the faet seems desirable. It may have been sometimes ineluded in the count with Cyelops, but the numbers were never very large and it may have failed to get into the counting field except in one or two cases.

Nauplius spp.

$\begin{array}{cccccc} & \text { Station I } & \text { Stntion II } & \text { Station III } & \text { Daily } & \text { IIourly } \\ \text { Average …...................... } & 392,240 & 11,722 & 5,239 & 962,366 & 106,370\end{array}$

All kinds of larval eopepods were included under this heading. Undonbtedly, nearly all belonged to Cyclops. They showed praetieally the same charaeteristies of distribution at all stations as those atready noted for Cyclops, almost the only difference being that more eatehes were recorded. This might be expeeted since sueh a variety of larval forms was ineluded in the count. 
No copepods other than the forms already noted were recorded from the 1913 collections. Since most of the Entomostraca were quite well preserved, it may be possible to make a critical study of the group at a later period.

\section{MALACOSTRACA}

Three specimens, probably Gammarus sp., were found at Station III in Jannary, 1913. They were taken from very shallow water before the best place for collecting was found and they were evidently adventitious in the plankton.

\section{Glochidia spp.}

\section{MISCELLANEOUS}

Average

$\begin{array}{ccccc}\text { Station I } & \text { Station II } & \text { Station III } & \text { Daily } & \text { Hourly } \\ 256 & 6,415 & \pm 71 & 723 & \ldots \ldots \ldots \ldots \ldots\end{array}$

General identification certain. May include larvae of several species of fresh water clams. Recorded three times at Station I in July and Angust and five times at Station III, mostly in the same period. At Station II the numbers were much larger and the eatches more numerous. Recorded three times in January and February in very small numbers and almost continuonsly in June and July. Sewage evidently detrimental and flood water favorable to oceurrence in the plaukton. Effect of temperature uncertain.

Macrobiotus sp.

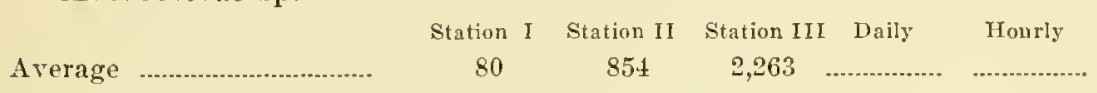

Identification satisfactory. All the Tardigrada found were referred to this genus. It was only recorded twice at Station I, eleven times at Station II and three times at Station III, always in small numbers. Evidently adventitious.

Ncmatoda sp.

Average

$\begin{array}{ccccc}\text { Station I } & \text { Station II } & \text { Station III } & \text { Daily } & \text { Hourly } \\ 212 & 185 & 424 & \ldots \ldots\end{array}$

Identification of the order certain. Nothing definite known as to generic classification. Very many specimens were immature. Recorded six times at Station I in small numbers and at wide intervals, twice at Station II, and five times at Station III, these five being taken in the first three months. These are evidently adventitions forms in the plankton. 
Other groups represented by only one or two forms or seen only in fresh material are as follows:

Chironomus larva. Twice, 11. Oligocliactes. Three times, II. Nais (?) sp.

Oclosoma sp.
P'lanarian.

Statoblast of l'ertinatella. (?) Statoblast of Plumatella. (?) Iydrachnicla sp. Twice, 11.

Simmarizing, it may be worth while to call particular attention to the number of forms present at different stations in different months, and to the proportional differences in numbers of organisms at the three stations by months, as shown by the accompanying text table.

Text Table 6. -Nunuens of linds of Planktonts by Stations and by Montus IN 1913

\begin{tabular}{|c|c|c|c|c|c|c|c|c|c|c|c|c|}
\hline & $\mathrm{J}_{\mathrm{ar}}$ & 1ary & & Feb & uary & & & rech & & & pril & \\
\hline Stations & I & II & 111 & 1 & 11 & 111 & I & II & III & I & II & III \\
\hline Bacteriaceac. & 1 & 0 & 0 & 1 & 0 & 1 & 1 & 0 & 0 & 0 & 0 & \\
\hline Schizoplyycere & 7 & 4 & 3 & 7 & 4 & 3 & 6 & 6 & 6 & 7 & 7 & \\
\hline Chlorophyecae & 7 & 6 & 3 & 9 & 6 & 6 & 8 & S & 8 & 13 & 9 & \\
\hline Bacillariaceac... & 24 & 28 & 18 & 22 & 28 & 28 & 26 & 34 & 35 & 27 & 37 & \\
\hline Conjugatie. & 6 & 3 & 3 & 4 & 4 & 5 & 1 & 6 & 4 & 2 & 6 & \\
\hline Mastigophora & 6 & 5 & 5 & 10 & 6 & 11 & S & 7 & 7 & 7 & 6 & \\
\hline Rhizopodir. & 2 & 1 & 2 & 3 & 2 & 3 & 3 & 2 & 4 & 5 & 5 & \\
\hline Ileliozon.... & 0 & 0 & 0 & 0 & 0 & 0 & 1 & 3 & 1 & 1 & 0 & \\
\hline Ciliata ....... & 13 & 2 & 3 & 17 & 5 & 9 & 15 & 7 & 10 & 16 & 8 & \\
\hline Suctoria & 0 & 0 & 0 & 0 & 0 & 0 & 0 & 0 & 0 & 0 & 1 & \\
\hline Rhizota..... & 0 & 1 & 0 & 0 & 0 & 0 & 0 & 0 & 0 & 0 & 0 & \\
\hline Brlelloida & 3 & 3 & 2 & 3 & 2 & 2 & 3 & 3 & 2 & 2 & 2 & \\
\hline Ploima & 11 & 10 & 9 & 10 & 12 & 10 & 15 & 11 & 12 & 14 & 12 & \\
\hline Cladocera & 1 & 1 & 1 & 0 & 0 & 0 & 0 & 0 & 1 & 0 & 2 & \\
\hline Copepoda.. & 1 & 1 & 1 & 1 & 1 & 2 & 2 & 1 & 1 & 3 & 2 & \\
\hline Miscellaneous ......................... & 1 & 4 & 1 & 2 & 3 & 2 & 0 & 3 & 2 & 1 & 1 & \\
\hline
\end{tabular}

\begin{tabular}{|c|c|c|c|c|c|c|c|c|c|c|c|c|}
\hline & & fay & & & une & & & uly & & & igust & \\
\hline Stations & I & II & III & I & 11 & 111 & I & II & III & I & II & III \\
\hline Bacteriaceac. & 1 & 1 & 0 & 1 & 1 & 1 & 1 & 0 & 1 & 1 & 1 & 1 \\
\hline Schizopliy ceae & 9 & 5 & 6 & 10 & 7 & 10 & 8 & 10 & 11 & 12 & 14 & 14 \\
\hline Chloropliyceae.. & 10 & 8 & 8 & 11 & 8 & 7 & 11 & 9 & 10 & 10 & 10 & 9 \\
\hline Bacillariacene... & 25 & 37 & 31 & 23 & 42 & 34 & 18 & 35 & 29 & 22 & 35 & $3: 3$ \\
\hline Conjugatae..... & 1 & 4 & 2 & 4 & 4 & 5 & 5 & 5 & 5 & 5 & 6 & 6 \\
\hline Mastigophora....... & 10 & 7 & 9 & 9 & 9 & 11 & 10 & 12 & 14 & 15 & 13 & 10 \\
\hline Rhizoporla ........ & 6 & 2 & 2 & 4 & 3 & 3 & 5 & 3 & 4 & 6 & 5 & 7 \\
\hline Heliozo:a............. & 1 & 0 & 2 & 1 & 1 & 2 & 3 & 4 & 3 & 4 & 4 & 3 \\
\hline Cilinta.. & 8 & 4 & 5 & 3 & 3 & 3 & 7 & 2 & 2 & 8 & 5 & 5 \\
\hline Suctoria & 0 & 0 & 0 & 0 & 0 & 0 & 0 & 1 & 1 & 0 & 2 & 2 \\
\hline Rhizota & 0 & 0 & 0 & 0 & 0 & 0 & 0 & 0 & 0 & 1 & 2 & 1 \\
\hline Bdelloida & 2 & 2 & 2 & 2 & 2 & 1 & 3 & 3 & 1 & 3 & 3 & 2 \\
\hline Ploima .. & 16 & 9 & 15 & 16 & 15 & 13 & 16 & 20 & 16 & 15 & 16 & 16 \\
\hline Cladocera & 1 & 1 & 1 & 1 & 0 & 1 & 2 & 1 & 2 & 2 & 3 & 3 \\
\hline Copepoda. & 2 & 1 & 1 & 1 & 1 & 1 & 1 & 1 & 1 & 2 & 2 & 2 \\
\hline Miscellancous... & 1 & 5 & 0 & 1 & 2 & 0 & 1 & 1 & 1 & 1 & 1 & 2 \\
\hline Total & 93 & 56 & $S 4$ & 87 & 98 & 92 & 91 & 107 & 101 & 107 & 122 & 116 \\
\hline
\end{tabular}


Text Table 6. -Numbers of Kinds of l'lanktonts by Stations and by Months IN 1913-Continued

\begin{tabular}{|c|c|c|c|c|c|c|c|c|c|c|c|c|}
\hline \multirow[b]{2}{*}{ Stations } & \multicolumn{3}{|c|}{ September } & \multicolumn{3}{|c|}{ October } & \multicolumn{3}{|c|}{ November } & \multicolumn{3}{|c|}{ December } \\
\hline & 1 & II & III & I & Il & III & I & II & 111 & 1 & I I & III \\
\hline Bacteriaceae. & 1 & 0 & 1 & 1 & 1 & 0 & 1 & 1 & 1 & 1 & 0 & \\
\hline Schizophyceae. & 12 & 12 & 11 & 11 & 10 & 6 & 9 & 12 & 11 & 12 & 5 & \\
\hline Chloropliyeere & 11 & 10 & 11 & 11 & 11 & 11 & 10 & 11 & 10 & 11 & 6 & 7 \\
\hline Bacillariacene... & 25 & $2 S$ & 25 & $2 S$ & 25 & 31 & 26 & 29 & 35 & 32 & 29 & 36 \\
\hline Conjugatae..... & 5 & 6 & 5 & 5 & 5 & 4 & 3 & 4 & 3 & 4 & 5 & \\
\hline Mastigophora & 15 & 12 & 16 & 13 & 9 & 10 & 14 & 10 & 12 & 13 & 8 & \\
\hline Rhizopodia. & 6 & 7 & 6 & 6 & 4 & 5 & 7 & 5 & 6 & 5 & 4 & \\
\hline Heliozon & 3 & 3 & 4 & 5 & 3 & 5 & 3 & 2 & 2 & 1 & 0 & \\
\hline Ciliata. & 5 & 3 & 6 & 12 & 6 & 5 & 15 & 8 & 11 & 20 & 6 & 1 \\
\hline Suctoria & 1 & 1 & 1 & 1 & 2 & 1 & 2 & 2 & 0 & 3 & 3 & \\
\hline Rhizota & 1 & 1 & 1 & 1 & 1 & 2 & 0 & 1 & 1 & 0 & 0 & \\
\hline Bdelloida. & 3 & 3 & 2 & 3 & 3 & 2 & 3 & 3 & 2 & 3 & 3 & \\
\hline Ploima & 13 & 17 & 16 & 16 & 15 & 16 & 11 & 11 & 11 & 8 & 12 & \\
\hline Cladocera & 2 & 3 & 1 & 2 & 2 & 1 & 2 & 1 & 2 & 1 & 2 & \\
\hline Copepoda & 1 & 1 & 2 & 1 & 2 & 1 & 1 & 1 & 0 & 1 & 0 & \\
\hline Miscellancous ......... & 0 & 1 & 0 & 0 & 1 & 1 & 1 & 0 & 0 & 0 & 2 & \\
\hline
\end{tabular}

Total

$\begin{array}{lllllllllllll}104 & 108 & 108 & 116 & 100 & 101 & 108 & 101 & 107 & 115 & 85 & 83\end{array}$

This table shows some points quite well. The number of forms was lowest at all stations in January. There was then stearly increase to May, when flood waters were highest and the number of forms recorded slightly less. Inerease in number of forms began again in .June, becoming greatest at Stations II and III in August and at Station I in October. The numbers were well sustained at the two stations mntil December, when there was a marked decrease. Station I not only showed increase to October, but almost equaled it in December. While it is probable that more acenrate species determination might change the detail of this showing, it is not probable that the general differences would be affected.

One legitinate inference from this table is that Station $\mathrm{I}$ is less subject to seasonal fluctuations than either of the other stations. At present the only reasonable explanation of this fact seems to be that the dilute sewage of Station $I$ is the prime factor, for the superficial resemblances would lead one to expect that Stations I and III would most closely approach each other in character and distribution of populations, rather than Stations II and III. But the reverse is true, and sewage is the only known factor of sufficient moment to account for it. It is true that temperatures rum slightly higher at Station I, but is it not possible that this higher temperature is partly due to the rapid tumover of the great quantities of organic matter.

Aside from the question of temperature there is ample reason for assigning main influence to sewage because of the great food supply, a supply superabundant and hence essentially constant throngh the 
year, with the exeeption of llay and June, the time of the mountain floods. The decrease in number of forms at this time strengthens the view that flool waters dilute the sewage and reduce the food supply, thus redueing reproductive and growth activities. There is also consiclerable loss through washing ont, cren with the rather low waters of 1913. The 1914 collections should certainly throw some additional light on this question.

\section{THE DAILY SERIES}

As noted dsewhere. the daily series was mulertaken in the hope that it wouk give definite information eonerning the problems of reeurent pulses and the incident eomlitions. This hope was partly realized, although the thirty-one day's constituting the series was not enongh, and it is evident that more faithful adherenee to a miform hour of eollection is desirable. Since this last would involve very marked differences in eondition of ticle, it is probable that Stoekton is not a good locality for such a test. It would be much better to try it in a locality free from ticlal influenee. It is also probable that the large amount of traffie past the point at which this series was taken might affect the results. At auy rate, these two factors, at least, might be climinated in some other locality. However mimportant they might later be proven to be, they do make the problem needlessly complex.

Under the eiremstanees it does not seem desirable to disenss individually even the more conspicuous species. Generalizations to be reaehed by such diseussion in this series do not differ materially from those to be obtained from eonsideration of the larger groups. Species records are given in table 4.

Althongh the thirty-one days did not give a series of suffieicut length to be wholly satisfactory, there are some points of deeided interest. These are graphieally indieated in plates 1, 6, and 3 . In plate 1 , showing volumes, there was a prominent pulse apex on July 13, another maximun for the series on July 18 , and another almost as large on July 27. Explanation of this is aftorded in part by plate 6, where it is shown that elnlorophyll bearers and Protozoa and Rotifera all had pulse eulminations near July 13 and July $2 \bar{\tau}$, while the Entomostraea slowed a pulse eulnination maximum for the series on July 22. It is evident that the median position of the volumetrie maximum is due to its dependemee on the entomostracan numerieal 
maximum sinee the bodies of individual Entomostraea are so much larger than those of the other plankitonts. Just why the numerical maximum of Entomostraea shonld fall between pulses of other groups does not so clearly appear. The most obvious explanation is that the abundant food supply furnished by other organisms near July 12 led to abundant reproduction of Entomostraca (mainly Cyclops), which in turn reduced the number of other organisms and led to its own decline. The pulse culmination of other organisms at July 27 would then be due to rapid recovery from the inroads of the Entomostraca.

On acconnt of insuffieiency of reeords, consideration of light relations does not give very satisfying aid toward an explanation of these pulses. Both our records and those of Mr. Higby, the Stockton weather observer, were made at a particular time of day and so fail to show the day as a whole so far as clouds, ete., were concerned. It is also true that such records fail to show the influence of the wind except for a small part of the day. As the reeords stand (table $\mathbf{T}$ ), the daylight conditions appear to have been too nearly uniform through the series to have had any marked influence on plankton pulses.

Reference to the hmar eycle for July, 1913, however, suggests the probability of its having a strong influence in this comnection. It may be noted that the begimning of the marked rise in prodnetion of chlorophyll bearers came on July 10 at the first quarter of the moon, and that the apex of the pulse for these organisms came on July 17, at full moon. The rapid decline thereafter may be casily explained by the unnsual abundance of Entomostraca and other predatory animals, while the smaller pulse enlminating on July 27 might be due to partial recovery from their attacks. The evidence liere that the waxing moon brings rapid increase of chlorophyll bearing organisms is as strong as conld possibly be imagined, sinee the record eovers only a single lunar cycle. It makes one wish that the daily records might have been earried orer several lunar cyeles in order to find the variations whieh might be expected. This particular series certainly confirms in a definite way Professor Kofoid's argument (1908) that pulses of ehloropliyll bearers, and consequently of other planktonts, tend to accompany increases of lunar light.

The important features in the records of this series are concerned most directly with the ehlorophyll bearing organisms, as just diseussed. But, as a matter of interest, brief mention will now be given of the 
typical Protozoa (Mastigophora are inchuded above with chlorophyll bearers) and of the Rotifera. Examination of plate 6 discloses the fact that Protozoa showed pulses at about the same periods as dicl the clulorophyll beares's, slightly preceling the latter at the first and coineirling at the seeond. The evidence which this gives of close assoriation of the two groups is the only important feature. The analysis of the relationship presents some deceded difficulties. In the first place, most of the I'rotoza foum here at this time were of the type whieln depends upon bacteria for food rather than upon green organisms (at least no Protozoa were ever olserved with green organisms in their horlies). The mesenee of green organisms might favor them, howerer, by exeretion of oxygen and ahsolption of earlon dioxide. Aside from these considerations, the only reason for concidence of pulses in the two groups would seem to be in general eonditions favorable to botll.

In the ease of the Rotifera, the abundance of food with which most of them are furnished by an increase in green organisms would seem sufficient to aceount for elose corresponcheres of pulses of the two groups. Unfortmately for the validity of this view, the first rotiferan pulse (pl. 6) eulminates on July 12, five days before the "ulmination of the pulse of ehlorophyll bearers. It is also true that the seond pulse coinciles exactly with that of the grem organisms. If the food relationslipe were the deciding factor, the rotiferan pulse should always follow. It is possible that here again is a case in which the gaseous content of the water forms one of the connecting links for two groups of organisms.

\section{SUMMARY}

Considering the large numbers of faetors which might influenee the loeation of pulses of various organisms or groups of organisms, it is neeessary for the mesent to say that the showing made by this daily series of a single hnar cyele may be to some degree aceidental. Hence no inference ean be regarded as proven. The important inferrnees suggested by these daily reeords may be summarized as follow:s :

1. There was a very distinct increase in numbers of green organisms as the light of the moon inereased.

2. There was in abrupt decrease in green organisms as Entomostraca increased, which was followed by a partial recovery after the entomostracan maximum. 
3. The two pulses of chlorophyll bearers were closely accompanied by similar pulses of Protozoa (exchusive of Mastigophora) and of Rotifera.

4. It is very necessary to have similar series covering several lunar eycles in order to evaluate the various factors of distribution and the bouds of relationship of plankton organisms.

Before leaving the diseussion of this series, the point should be emphasized that daily collections frequently give a very different view of the situation from any that may be obtained at longer intervals. Comparison of plates 3 and 1 (graph Station I and Daily) shows this very clearly. Referring first to plate 1 , it will he seen that although the regular Station I series was taken twice a week the difference is very great. In the Station I regular series the volumetrie maximum came on July 30, but the daily record shows that four eatches (July $13,18,20$, and 27 ) exceeded it, two of them greatly. The semiweekly record shows this maximum on the rise of a pulse while the daily record shows it as on the decline of another. The daily record also shows marked fluctnations in volume of the catehes during this lunar eycle which are not indicated by the other.

If the regular series had been taken only once a week (which is usually the shortest interval used by investigators), the dates would have been July 5, 12, 19, 26, and August 2. Comparing this with the daily reeord we see that it wonld have shown an erroneous picture of conditions since it would have indieated a considerable abrupt rise in volumes to fairly stable, higher levels.

Turning to plates 3 and 6 , we find the same things true. In the case of the Entomostraca the remarkable pulse from July 20 to 23 is entirely missed by even the semiweekly method. While the pulses of the other groups are not entirely missed, they appear much more abrupt in the regular series than they really are.

In eonsequence of these remarkable differenees it is surely clear that only the most general conchusions may be safely drawn from series of catches taken at intervals greater than one day.

\section{TIIE HOURLT SERIES}

This series, covering a period of about twelve hours on August 11, was mondertaken in the hope of finding some indication of the importance of the daily tidal currents in a study of the plankton. It was 
also expreted that some information might be obtained as to diumal influenees of light. The series is too short to be satisfactory (twentyfour hours would be better) and several days should be eovered instead of one.

Despite these dofects, the recorts indicate some points of interest. It happened that on the day selected low tide eame at about 11 A.M. at Stockton, but there was no available way of reeording the tide accurately. There is nothing in the reeord that ean be positively commected with tides.

Still less than in the Daily serries thes there seem to be anything indieated by the species record which is not as well shown by major groups. For that rason the general disenssion only will be given. Reference to table 5 will easily show suel detail as has been reeorded.

Sinee ehlorophyll bearing organisms give, to a large extent, the basis of interpretation of plankton eonditions they may receive first attention. Plate 6 (hourly) shows a preliminary drop in numbers from $T$ A.M. to 8 ..M. a nearly uniform suceession of eatehes to $12 x$. and a constant rise through the remainder of the series to the elose at $6: 45$ P.M. A graph of such very prominent charaeters demands explanation, but the demand eamot be fully satisfied from the present records. During the forenoon perion of nearly uniform numbers the tide was ebbing, the air was hazy with full sunlight, there was little wind and the water was nearly smooth most of the time. In the afternoon perion of rapidly and constantly rising numbers there was flowing tide, hazy air with full sumlight, strong wind, almost a gale at the elose, and very rough water, with strong cross eurrents dne to wind. The water temperature varier from $2 t^{\circ} \mathrm{C}$ at 7 . A. $\mathrm{m}$. to $26^{\circ} \mathrm{C}$ from 11 1.M. to 4 1.M. and to $25^{\circ} \mathrm{C}$ at $6: 45$ P.x. Among the ohservable factors involved, the temperature seemed to be the only one of suffieient constaney to aceount for the increase. Light was the only other faetor that seemed likely to have had a benefieial effect and it was surely very much poorer in the afternoon on account of rough water. In view of sueh adverse conditions as rough water and poorer light it wonld have been reasonable to expeet that there would at least be no inerease in numbers of plankton in the afternoon. As the evidence stands it points distinctly to the conelusion that temperature was the dominant factor in the dinrnal fluetuation of chlorophyll bearers.

If there had been only one or two larger catches in the afternoon or if there had been fluetnation in numbers there might be some 
question as to the sufficieney of the above evidence, but it will be noted that after $12 \mathrm{M}$. there was a steady increase broken by only one fall below the last preceding number and this break occurred at 6 P.M. A more detailed analysis of the chlorophyll bearing group very forcibly emphasizes the reliability of the record covering this point. In plate 11 it will be scen that Sehizophyceae and Bacillariaceae have very pronounerd increase after 12 o'clock, while Chlorophyceae and Conjugatae have moderate increase, somewhat wavering, and that Mastigophora have a strong but erratic rise from greater numbers at 1 P.x. a low minimmm, to 7 P.M., almost equal to the forenoon maximum. It is also clear that all these except the Chlorophyeene show the sharp temporary decline at 6 P.M. Looking up species records in table 5, we find that the 6 P.M. deeline is mainly due to defieiencies in numbers of Nostoe and Cyelotclla. Also that the erratic record of Mastigophora throngh the day is dne principally to Chromulina, Itemidinium and Trachelomonas, all very diffieult to identify or to count. Taken as a whole, the evidence indicates that the records give a fairly dependable idea of the history of the chlorophyll bearers through the twelve-lour period. From this history the tentative conclusion may be drawn that temperature is a major if not the determining factor in daily finctuations of numbers. It may be, however, that wind and waves do not exclude enough sunlight in shallow water to make any great difference and that the greatest influence in this ease was due to sunlight. This last view is supported by the history of the other groups.

In case of the Protozoa, the Rhizopoda (pl. 11, and table 5) and the Heliozoa (table 5) give responses similar to chlorophyll bearers, i.e., an afternoon rise; but their numbers are relatively small, for most of the catches and their afternoon prominenee might easily be due to the stirring of bottom waters by the strong currents caused by eombined wind and tide. This leaves, then, the Ciliata as the only typical protozoan group with a reasonably elear record. Reference to table 5 shows the ciliate assemblage to consist almost entirely of Holophrya, Tinlinidium and two Torticclla and that they all agree in a strong forenoon represcntation with an afternoon decline, well pronounced for three of them. Since temperature would be expeeted to affect these as markedly as it did the ehlorophyll bearers, while light probably would not, we have a valid eonchusion indieated that light is the major factor in the afternoon rise in numbers of chlorophyll bearers. 
The Rotifera (pl. 19) show substantial agreement with the Ciliata, both collectively and individually. Inence we are still further led to doulht the dominance of temperature.

As to Entomostruca (pl. 19) the eatches of Clatocera were too variahle to give any information, and those of Copepoda were also rather indefinite. There was not much differenee between the forenoon and afternoon catches either of Cladocera or of Copepoda or of both together.

As shown by plate 1, the whole plankton volume inereased strongly throngh most of the tweke hours, both aetnally and also relatively to the volume of sediment. No explanation of this faet scems to be available, although the distribution of the chlorophyll bearers may be of suffieient importance.

The foregoing discussion leaves a final impression which is badly muddled. This may truly represent the faets, but it is not satisfying to the mint. A different form of diseussion may help to elear the problems involved. Examination of tables and plates already mentioned discloses the faet that, based on distribution through the twelve hours, there were two fairdy well marked groups of planktonts, consisting on the one hand of the chlorophyll bearers and on the other hand of the more highly motile animal forms. The former showed a steady inerease in numbers as the hours of afternoon passed. The latter showed just as pronomeed a decrease, though less uniform, from the forenoon number's.

Apparently the general factors which could probably be involved are the following: vital, chemieal and physical. While speeifie subdivisions of these make a formidale list, whieh is further complieated by their very general interdependenee, it seems that some are sufficiently dominant to enable tentative discussion, as in the aceompanying list :

$\begin{array}{ll}\quad \text { Vital Factors } & \text { Chemical Factors } \\ \text { Locomotion } & \text { Organie content } \\ \text { Irritalility } & \text { Mineral content } \\ \text { Feerling } & \text { Gaseous content } \\ \text { Respiration } & \\ \text { Excretion } & \\ \text { Reproduction } & \\ \text { Other organisms } & \end{array}$

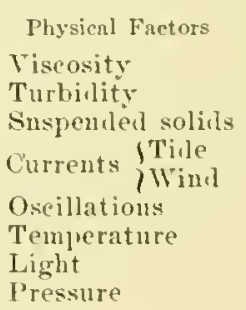

Locomotion, among the vital finctors, is characteristie of the trical animal forms, but its effeetiveness may be inereased or diminished by respiration and exeretion, or other faetors, in the same animal or in 
neighboring organisms of any type. It may be similarly affected by the gaseous eontent of the rater, which in turn is determined to some extent by temperature, light and eurrents in water and air, and so on with an indefinite number of eombinations. It is necessary to limit our present diseussion to those eombinations which are most probably determinative within the twelve-hon period. Continuing the reference to loconotion with this limitation in view, we have to note that the more typically animal organisms may have been less numerous in afternoon catehes because of migration to bottom lavel's of water, the lowest of which the net dirl not reaeh. Sueh a migration might be dne to the influence of several other factors. Rising temperature might induce it directly by discomfort or indirectly by lessened viscosity of water, relatively increasing the influence of gravity, or by redncing the gaseous content, probably not greatly effective, or hy changing the gaseons eontent throngh more oxygen excretion and earbon dioxide absorption by green organisms, or by inerease of disagreeable exeretions from the surface organisms as they became more active under higher temperature.

Locomotion might also be affected by the wind, direetly by discomfort due to surface agitation, indireetly by interference with food taking near the surface through rapid oscillations of surface layers of water. Leeward drive of the wind is not considered because it wonld affeet green organisms as mueh or more than the loeomotor organisms.

Light might affeet locomotion direetly by diseom fort and indireetly by the inerease of stareh mannfacture, in green plants, with the larger amount of oxygen liberation and earbon dioxide consumption, thus shifting the region of the mean gas content to which motile forms are accustomed, to some distance below the surface.

Locomotion might affect non-motile surfaee organisms throngh removal of predatory organisms by migration, thus letting growth and multiplication go on meheckerl. It wonld not be neeessary for an organism to pass a whole life eycle in order to show this effeet. Tndonbtedly there are at any given moment in a plankton population many very young individuals, many just maturing, and many just ready to divide. Unfavorable conditions would arrest or deter developmental processes which would be again aceelerated by farorable eonditions. At a favorable time, then, many new organisms, which liad been restrained during an adverse period, might be liberated and allowed to grow. 
Reproduction as a factor influeneing diumal oseillations of numbers nay not be important, lut, for the reason just stated, it molably is. If, in addition to this, it could be shown that any eonsiderable number of plankton forms aceelerate both growth and fission proeesses with clinmal rise in temperature and that fission may ocen two or more times in twenty-four hon's, the argument in favor of dominanee of temperature throngh the reproductive factor would be eonvincing. 'The writer has examined large numbers of publications without finding definite diseussion of this point. Apparently the only rases in which the number of generations in a twenty-four hour period has been aecurately determined have shown what oceured under special laboratory conditions only, and they do not tell what oecu's with a mixed population under natural eonditions. Eren so, the published records of such studies deal almost entirely with animal* types. Since the inerease of numbers due simply to acceleration of vital proesses is sufficint to aecount for any probable influener of the reproductive factor in this series, it is doubtless best to say that the addition of a distinct generation during the twelve-hour period is improbalile.

It is also true that reproduetion may be influenced by light. Sone organisms may be stimulated to greater reproductive eapacity, some to less. In the green organisms, with which we are now mainly concelned. it may be seen that light, through aceeleration of food manufacture, might eause increase of fission, due to inereased availability of energy producing and building materials. On the other hand, it seens to be prefty well known that in higher algae and phanerogams food manufacture is characteristic of day time, growth and reproduction of night, i.e., the plant does not earry on all its funetions equally well at the same time.

The gaseous content of the water would be mainly eftective, under ordinary eonditions, through its influence on the irritability of the organisms and through its more or less direet eonneetion with their feeding and respiration. A very sliglit differenee in dissolved gases would surely change the responses of some organisms to light and other stimuli, but it is hard to determine the definite eomection of that fact with the conditions now under eonsideration. As Birge and Juday have elearly shown, the physiology of plankton organisms cannot be fully determined by tests under artificial conditions sueli as those of the laboratory, e.g., the capacity of rarious animal forms for meeting anaerobic conditions of the environment is vastly greater in 
natural bodies of water than it is in artificial cultures. In the present instance it seems possible that the decline in numbers of certain zooplanktonts toward midday might be due to negative phototropism caused by supersaturation of water by oxygen liberated during photosyuthesis by plants. But it might be due to negative phototropism due to rising temperature, or to negative phototropism or positive geotropism due to inereasing agitation of the water, or to various other faetors or combinations of factors.

So far as green organisms are coneerned, it may be readily understood that photosymthetic and growth and reproductive processes might all be accelerated by the presence of carbon dioxide with a rising temperature and a considerable amount of sunlight (though less than the maximum because of rough water). It is also true that increase of oxygen formation might inerease the buoyaney of the plant cells so that larger numbers of them would be in the region of water traversed by the net. This is especially probable in the presence of wind beeause any agitation of the shallow (two and one-half meters) water would be an aid to buoyancy.

There is no possibility of segregating tidal from other influences on our present information. So far as the currents, wind and tide, and oscillations of the water are concerned, taken all together, they might induce negative phototropism, or positive geotropism and thigmotropism in the animals. They might also affect the green organisms by aicling buoyancy and by increasing the circulation of the water, thus bringing more carbon dioxide to the absorbing surfaces and rapidly removing oxygen and other waste products from such surfaces.

Perhaps enough has already been said about temperature, but it will do no harm to recall that it affects flotation of organisms through changes in viscosity, that it probably plays an important part in reversal of tropisms under natural conditions, and that any change either aceelerates or retards all of the activities of the organisms.

For this series the influence of light cannot be segregated from that of temperature since both are dependent on the sun's rays. It may be said, however, that light plays more or less part in reversal, nr intensity of reversal, of tropisms of organisms, and that it is of najor importanee in photosynthesis and thus in effect on the gas content of the water.

So far as the other factors listed above are concerned, it is not seen that they conld be of appreciable influence in this period under the conditions of variability recorded for the organisms and for the general factors involved. 
One point of general interest may be noted in plate 1, where it appears from the volumetrie graph that the total rolume recreased gradually to midlay and increased again through the aftermoon, but that the net volume of plankton increased fairly steadily throngliout the twelve hours. This is not what might he expected because the wint and tide of the afternoon should, throretieally, stir the water enough to increase the relative amomint of silt. The mexpeeted silt dimimation might be due to collecting conditions, the stronger combined enrent from wint and ticle in the aftermoon carrying away the silt stirrel up by impact of the clrain cup eylinder upon the bottom.

\section{CONCLUSION}

In eonclusion it may be said that the following points appear distinetly from the present study :

1. San Joarnin waters are eapable of supporting abuudant plankton, and they do so in the vieinity of Stoekton.

2. The plankton of the sewage-laden Stoekton Chamnel is distinet] different from that of the river, the number and volume of its animal forms being especially consplieuous as distinguished from the algal dominants of the latter.

3. Temperature is, within certain limits, the detrmining factor in seasonal distribution. This may be by direct retardation of growth and reproduction in organisms, or by indirect influenee through food supply and gaseous content of water.

4. Water eurrents above a very moderate speed are distinctly inimical to plankton development.

5. The peeuliar sneeession of raing season and dry season has resulted in an autumnal maximum of plankton abont Stockton, a condition directly eontrary to that of remal maxima recorded ly various olservers in other loealities.

6. Collections taken at intervals of one week or more do not furnish a basis for aeeurate determination of plankton distribntion through the year. Daily collections properly taken would probably do so.

7 . There is some evilenee in favor of the idea that increase of lumar light tends to the increase of plankton, espeeially chloroplyyll bearers.

8. There is evidence to show that fluetuations in amount of plankton oecur at various hours of the day. 
9. The abundant ocemrence of Bacillaria paradoxa, generally listed as a typical braekish water form, is notable. This seems to be one case in which marked departure from a typical ehemical environment has not visibly affected structure or behavior.

10. Lastly, it is necessary to emphasize the fact again that whatever fault or error there may be in this report is chargeable absolutely to the writer. In some cases expert advice has not been followed after being asked. On the other hand, there is the teepest obligation to the persons already mentioned for adrice and assistance.

\section{ADDENDUH}

Since writing the disenssion of the series of plankton collections of 1913 the statisties for the collections of 1914 and 1915 have been compiled and examined. Inasmueh as weekly collections only were taken in 1914 and 1915, and sinee two stations only were used in each of these years, the reeords are muel less comprehensire than those for 1913. On this account, and also because the 1914 and 1915 records are essentially similar to those for 1913 , it seems inadvisable to prepare them for publication. The eollections for $191 t$ and 1915 have already been deposited with the Department of Zoology of the University of California and it is the writer's intention to deposit the manuscript records in the same plaee. 
Tabie 1.-ORganisms 1'er CUbic Meter in l'tankton of STOCKTON Cinanel IN 1.13

\begin{tabular}{|c|c|c|c|c|c|c|}
\hline 1913 & $\begin{array}{l}\text { Spirilluun } \\
\text { undula }\end{array}$ & $\begin{array}{l}\text { Anahnena } \\
\text { sp. }\end{array}$ & $\begin{array}{c}\text { Aphanocapsa } \\
\text { sp. }\end{array}$ & $\begin{array}{l}\text { Glococapsa } \\
\text { conglonierata }\end{array}$ & $\begin{array}{c}\text { Glococapsa } \\
\text { Ep. }\end{array}$ & $\begin{array}{l}\text { Gomphosphaera } \\
\text { aponinac }\end{array}$ \\
\hline $1 / 5$ & & ..... & 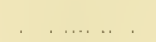 & $\ldots$. & & 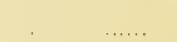 \\
\hline $1 / 8$ & 100 & $\ldots$. & $\ldots$ & $\ldots \ldots$ & $\ldots \ldots \ldots$ & 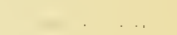 \\
\hline $1 / 12$ & & $\ldots .$. & . . & $\ldots \ldots$ & …........... & \\
\hline $1 / 15$ & 400 & $\ldots \ldots$ & . & $\ldots$. & 다............... & \\
\hline $\begin{array}{l}1 / 19 \\
1 / 22\end{array}$ & $26,+4 S$ & 800 & $\ldots$ & & ……… & \\
\hline $1 / 26$ & ……......... & ....... & . & . & 400 & . \\
\hline $1 / 29$ & $\ldots \ldots$ & $\ldots \ldots$ & & .. & & \\
\hline $2 / 2$ & ............... & $\ldots .$. & $-\infty$ & .. & 400 & \\
\hline $2 / 5$ & .......... & 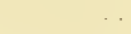 & & ...... & 2,400 & $\therefore$. \\
\hline $2 / 8$ & …..... & . & $\ldots$ & $\ldots .$. & 800 & \\
\hline $2 / 12$ & 800 & .. & .. & . & $\ldots \ldots \ldots$ & 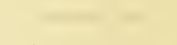 \\
\hline $2 / 19$ & .......... & 800 & - & . & ……...... & \\
\hline $2 / 23$ & ……...... & $\ldots$ & . & 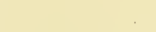 & ……..... & 39,672 \\
\hline $2 / 26$ & $\ldots .$. & .. & $\ldots \ldots$ & .. & .. & 1,600 \\
\hline $3 / 1$ & 1,600 & . . & ....... & .. & & 3,200 \\
\hline $3 / 5$ & $\ldots$. & $\ldots$ & $\ldots .$. & . & …ㄴ............ & 52,896 \\
\hline $\begin{array}{l}3 / 5 \\
3 / 12\end{array}$ & $\ldots \quad \ldots \ldots$ & $\ldots$ & $\cdots$ & 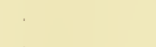 & $\ldots \ldots \quad \ldots \ldots$ & \\
\hline $3 / 15$ & . & $\cdots$ & $\therefore$ & & 52,896 & \\
\hline $3 / 19$ & . ............. & $\ldots$. & .. & . & $\ldots$ & 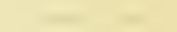 \\
\hline $3 / 23$ & , .......... & ..... & & & ........ & \\
\hline $3 / 26$ & $\ldots, \quad \ldots \ldots$ & & 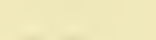 & & & \\
\hline $\begin{array}{r}3 / 29 \\
4 \quad 2\end{array}$ & $\cdots$ & 1,600 & .. & & 1,600 & \\
\hline 45 & …........... & $\ldots \ldots \ldots \ldots \ldots$ & $\ldots \ldots$ & & 52,596 & \\
\hline 4/ 9 & , ….............. & $\ldots \ldots \ldots$ & $-\quad \ldots$ & & ............... & 6,400 \\
\hline$+/ 13$ & ....... & & $\ldots .$. & .. & $\ldots \ldots$ & 3,200 \\
\hline $4 / 16$ & ……........ & 1,600 & $\ldots \ldots$ & ... & ............ & $\ldots . \quad \ldots \ldots \ldots$ \\
\hline $4 / 19$ & $\ldots \ldots$ & $1,(\mathrm{i}) 0$ & $\cdots$ & ... & & $\begin{array}{lll}\ldots . & . . & \ldots .\end{array}$ \\
\hline $4 / 23$ & .............. & ........... & $\ldots, \quad \ldots$ & . & 52,896 & \\
\hline $4 / 26$ & ………... & …, $\ldots \ldots \ldots$ & $\cdot \quad \cdots$ & .. & $79,3+4$ & 3,200 \\
\hline $\begin{array}{l}4 / 30 \\
5 / 3\end{array}$ & ....... & 79344 & $\ldots \ldots$. & $\cdots$ & $\cdots \cdots$ & 3200 \\
\hline $5 / 7$ & 1,600 & 9,600 & .... & $\cdots$ & 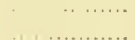 & $\begin{array}{l}3,200 \\
1,600\end{array}$ \\
\hline $5 / 11$ & 1,600 & 52,896 & ..... & $\ldots \ldots$ & & 1,600 \\
\hline $5 / 14$ & ......... & 105,792 & $\ldots-\ldots$ & $\ldots$ & 105,792 & 3,200 \\
\hline $5 / 17$ & & 6,400 & ... & ...... & ....... & \\
\hline $5 / 21$ & . $\quad \ldots .$. & $\mathbf{1 5 8 , 6 8 S}$ & 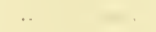 & $\ldots \ldots$ & & 105,792 \\
\hline $5 / 24$ & & 3,200 & . & .. & 105,792 & 3,200 \\
\hline $5 / 27$ & 3,200 & & ……… & $\ldots$ & $211,5 S 4$ & \\
\hline $5 / 31$ & 105,792 & & & & 3,200 & 3,200 \\
\hline 6/ 3 & 3,200 & 6,400 & $1,269,504$ & $\ldots .$. & 105,792 & $\cdots \cdot$ \\
\hline (j) 7 & & 25,600 & 740.544 & . & $105,79^{2}$ & ….... \\
\hline $6 / 11$ & 3,200 & 6,400 & 816,336 & .... & & \\
\hline $6 / 16$ & 3,200 & 6.400 & 317,376 & $\ldots$. & 6,400 & 3,200 \\
\hline $6 / 18$ & 105,792 & 6,400 & 740,544 & $\ldots .$. & 3,200 & ... $\quad .$. \\
\hline $6 / 21$ & & 370,272 & 687,648 & $\ldots \ldots \ldots$. & .. & \\
\hline $6 / 25$ & 3,200 & 32,000 & $1,110,816$ & . & .... .... & 317,376 \\
\hline $6 / 28$ & 3,200 & 370,272 & 687,645 & $x_{1}$ & & \\
\hline $7 / 3$ & 3,200 & ....... & 687,648 & 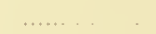 & 1,600 & \\
\hline i) 5 & 105,792 & & 476,064 & & 264,480 & $\cdots$ \\
\hline $7 / 9$ & & $15 S, 6 \varsigma S$ & 687,648 & $3 S, 400$ & 370,272 & . \\
\hline $7 / 12$ & $1 . \quad \ldots \ldots \ldots$ & $1,163,712$ & $1,005,024$ & 899,232 & $581,5.56$ & 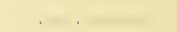 \\
\hline $7 / 16$ & $\ldots \ldots . . . .$. & $\$ 46,336$ & $1,216,60 \mathrm{~s}$ & $15 \mathrm{~S}, \mathrm{GSS}$ & $1,375,296$ & \\
\hline $7 / 19$ & 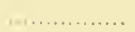 & $5, \$ 1,856$ & $15 \mathrm{~S}, 6 \mathrm{SS}$ & 3,200 & $52 S, 960$ & \\
\hline $7 / 23$ & ……… & 105,792 & $6,+00$ & $\ldots$. & 264,450 & \\
\hline $7 / 26$ & ……… & $211,5 S 4$ & 264,480 & & $1,005,024$ & \\
\hline $7 / 30$ & ............. & 158,658 & 211,584 & 3,200 & 317,376 & \\
\hline
\end{tabular}


Table 1.-Organismes Per Cubic Meter in Plankton of STockton Channel in 1913-(Contimed)

\begin{tabular}{|c|c|c|c|c|c|c|}
\hline 1913 & $\begin{array}{l}\text { Spirillum } \\
\text { undula }\end{array}$ & $\begin{array}{c}\text { Arabaena } \\
\text { sp. }\end{array}$ & $\begin{array}{l}\text { Aphanocapsa } \\
\text { sp. }\end{array}$ & $\begin{array}{l}\text { Gloeocapsa } \\
\text { conglomerata }\end{array}$ & $\begin{array}{c}\text { Glococapsa } \\
\text { sp. }\end{array}$ & $\begin{array}{c}\text { Gomphosphaer } \\
\text { aponinae }\end{array}$ \\
\hline $8 / 2$ & 3,200 & & 3,200 & & 105,792 & $\cdots$ \\
\hline $8 / 6$ & ............... & & & & 264,180 & \\
\hline $8 / 9$ & $\ldots, \quad \ldots \ldots .$. & 3,200 & 12,800 & .... & 528,960 & \\
\hline $\begin{array}{l}S / 13 \\
8 / 15\end{array}$ & 3,200 & 105,792 & 3,200 & & 317,376 & .. \\
\hline $\begin{array}{l}8 / 15 \\
8 / 20\end{array}$ & $\begin{array}{l}3,200 \\
3,200\end{array}$ & $\begin{array}{r}155,6 \mathrm{SS} \\
6.400\end{array}$ & 12,800 & 3,200 & 370,272 & $\cdots$ \\
\hline $\begin{array}{l}8 / 20 \\
8 / 23\end{array}$ & 3,200 & $\begin{array}{r}6,400 \\
211,584\end{array}$ & 211,584 & ... & 423,168 & n.............. \\
\hline $\begin{array}{l}8 / 23 \\
8 / 27\end{array}$ & 105,792 & $211,58 \frac{1}{2}$ & 105,792 & … & 476,064 & \\
\hline$S / 31$ & $100,1$. & 19,200 & ... & $\begin{array}{l}105,792 \\
105,792\end{array}$ & $\begin{array}{l}899,232 \\
370,272\end{array}$ & ..... \\
\hline $9 / 2$ & & 3,300 & ... & 105,792 & 370,272 & 158,688 \\
\hline $9 / 6$ & 3,200 & 12.800 & 105,792 & $\ldots \ldots \ldots$ & 634,752 & ... . . .... \\
\hline $9 / 9$ & . . 11 & 264,480 & 105,792 & $\ldots \ldots \ldots \ldots \ldots$ & 370,272 & …, \\
\hline $9 / 13$ & .. & 264,480 & 105,792 & .... & 370,272 & \\
\hline $\begin{array}{l}9 / 17 \\
9 / 20\end{array}$ & $\cdots$ & 6,400 & & $\ldots \ldots, \ldots \ldots$, & 476,064 & ... \\
\hline $\begin{array}{l}9 / 20 \\
9 / 24\end{array}$ & . .. & 6,400 & 52,896 & ....... & 740,544 & \\
\hline $\begin{array}{l}9 / 24 \\
9 / 27\end{array}$ & $\cdots \cdots$ & 211,584 & 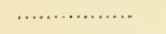 & .............. & 423,168 & $52, \$ 96$ \\
\hline $\begin{array}{r}9 / 27 \\
10 / 1\end{array}$ & 52,896 & $\begin{array}{r}6,400 \\
-200\end{array}$ & .. & $\ldots$ & 687,648 & $\ldots \quad \ldots \ldots$ \\
\hline $\begin{array}{l}10 / 1 \\
10 / 4\end{array}$ & $\begin{array}{c}52,896 \\
\ldots \ldots\end{array}$ & 105,792 & 5.396 & $\cdots$ & 952,128 & \\
\hline $\begin{array}{l}10 / 4 \\
10 / 8\end{array}$ & $\begin{array}{ll}. .1 \\
.\end{array}$ & $\begin{array}{r}6,400 \\
52,896\end{array}$ & $\begin{array}{r}52,596 \\
105,792\end{array}$ & ... & 740,544 & 52,596 \\
\hline $10 / 11$ & 52,896 & 52,596 & $10 \omega, \sqrt{3}$ & $\begin{array}{ll}\ldots \ldots \ldots & \ldots \\
\ldots \ldots \ldots & \ldots\end{array}$ & $\begin{array}{l}523,900 \\
423,168\end{array}$ & $\ldots \ldots, \quad \ldots \ldots$ \\
\hline $10 / 15$ & 52,896 & …...... & 52,896 & $\begin{array}{llll}\cdots & \cdots & \cdots \\
\ldots & \ldots & \cdots\end{array}$ & $15 \mathrm{~S}, 6 \mathrm{~S} 8$ & $\cdots$ \\
\hline $10 / 18$ & $\ldots \ldots \ldots$ & $\ldots \ldots \ldots \ldots$ & $\ldots \ldots \ldots \ldots$ & $\ldots \ldots \ldots$ & 52,896 & 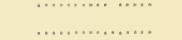 \\
\hline $10 / 22$ & ........... & $, \ldots \ldots, \quad \ldots$ & …............ & $\ldots \quad \ldots \ldots \ldots$ & 52,896 & …........... \\
\hline $\begin{array}{l}10 / 26 \\
10 / 29\end{array}$ & 52,896 & . . . . ......... & ................ & ….......... & 158,688 & ................ \\
\hline $\begin{array}{l}10 / 29 \\
11 / 1\end{array}$ & 105,792 & $\ldots \cdot, \ldots \ldots$ & ……....... & .............. & 264,480 & n........... \\
\hline $\begin{array}{l}11 / 1 \\
11 / 5\end{array}$ & 158,688 & ................ & ................ & .............. & 634,752 & (............... \\
\hline $\begin{array}{l}11 / 5 \\
11 / 8\end{array}$ & 105,792 & $\ldots \cdot \quad \cdot \ldots$ & ............ & $\ldots \ldots \ldots \ldots \ldots, \ldots$ & 123,168 & .............. \\
\hline $\begin{array}{l}11 / 8 \\
11 / 12\end{array}$ & $\begin{array}{r}52,896 \\
2\end{array}$ & $\ldots \ldots, \ldots, \ldots$ & & $\cdots \cdots$ & $264, \pm 50$ & …............. \\
\hline $\begin{array}{l}11 / 12 \\
11 / 15\end{array}$ & 238,032 & $\ldots \ldots \ldots \ldots$ & 105,792 & ............... & 634,752 & (............... \\
\hline $\begin{array}{l}11 / 15 \\
11 / 19\end{array}$ & $15 \mathrm{~S}, 6 \mathrm{SS}$ & & , ................. & ............... & $581, \$ 56$ & ............. \\
\hline $\begin{array}{l}11 / 19 \\
11 / 22\end{array}$ & 52,896 & $\cdot$ & ......... & ................. & 317,376 & ................ \\
\hline $11 / 26$ & 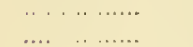 & $\begin{array}{l}\ldots \\
\ldots\end{array}$ & .. & n., & 476,064 & ............... \\
\hline $11 / 30$ & & ... & 52,896 & & 105,792 & $\cdots$ \\
\hline $12 / 3$ & 1,600 & $\ldots \ldots$. & & …............. & 52,896 & \\
\hline $\begin{array}{l}12 / 6 \\
12 / 10\end{array}$ & .. & & 3,200 & $\ldots \ldots \ldots \ldots \ldots$, & & $\ldots$ \\
\hline $\begin{array}{l}10 \\
14\end{array}$ & $26+48$ & 15. 100 & .. & ...... & 19,836 & …............ \\
\hline $12 / 17$ & $\begin{array}{l}20,+48 \\
26,448\end{array}$ & $\begin{array}{l}26,448 \\
26,+48\end{array}$ & & . . & 66,120 & n............... \\
\hline $12 / 20$ & 26,448 & $\begin{array}{r}20,+40 \\
\ldots \ldots \ldots \ldots \ldots\end{array}$ & .. & $\ldots$ & 52,896 & . \\
\hline $12 / 21$ & 400 & 800 & & $\ldots .$. & 13,224 & (......... \\
\hline $12 / 27$ & 400 & 800 & (.......... & . & $\begin{array}{l}39,062 \\
46,254\end{array}$ & ............... \\
\hline $12 / 31$ & 19,836 & ............. & ......... & . $\quad \ldots \ldots \ldots \ldots \ldots$ & 39,672 & ……, \\
\hline 1913 & $\begin{array}{l}\text { Inactis tinctoria } \\
\text { Agardh }\end{array}$ & $\begin{array}{l}\text { Merismopedium } \\
\text { glaucum }\end{array}$ & $\begin{array}{l}\text { Microcystis } \\
\text { sp. }\end{array}$ & $\begin{array}{l}\text { Nostoc } \\
\text { sp. }\end{array}$ & $\begin{array}{l}\text { Oscillatoria } \\
\text { formosa }\end{array}$ & $\begin{array}{l}\text { Oscillatoria } \\
\text { sp. }\end{array}$ \\
\hline $1 / 5$ & $\cdots$ & …… $\ldots$. & ......... & $+\ldots \ldots+\ldots, \ldots$ & 800 & ‥ \\
\hline $\begin{array}{l}1 / 8 \\
1 / 12\end{array}$ & $\ldots$ & $\cdots$ & ......... & .................. & 800 & ……........ \\
\hline $\begin{array}{l}1 / 12 \\
1 / 15\end{array}$ & ...... & (n, $\ldots, \ldots, \ldots, \ldots$ & , $\ldots \ldots, \ldots, \ldots, \ldots$ & …........... & , $\ldots \ldots \ldots \ldots \ldots \ldots$ & n.............. \\
\hline $\begin{array}{l}1 / 15 \\
1 / 19\end{array}$ & . $\ldots \ldots \ldots \ldots \ldots$ & $\ldots \ldots \ldots \ldots \ldots$ & ............... & ............... & 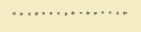 & 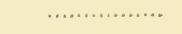 \\
\hline $\begin{array}{l}1 / 19 \\
1 / 22\end{array}$ & & & 800 & 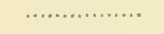 & ......., & (.................. \\
\hline $1 / 36$ & & ... $>$ & $\begin{array}{r}800 \\
\ldots . . . . . . . . .\end{array}$ & ……… & n..., & . \\
\hline $1 / 29$ & & 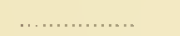 & ................. & 800 & 400 & ......... \\
\hline $2 / 2$ & $\ldots \ldots$ & $\ldots \ldots: \ldots \ldots \ldots$ & $\ldots \ldots \ldots \ldots \ldots \ldots$ & 800 & $\ldots \ldots$ & ................ \\
\hline $\begin{array}{l}2 / 5 \\
2 / 8\end{array}$ & .. & .... & $\cdots$ & 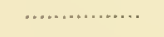 & ............... & (n............... \\
\hline & & & & , n............., & .... & \\
\hline
\end{tabular}




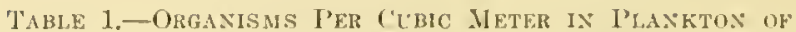
STOCKTON (HANNEL IN 1913-(Continued)

\begin{tabular}{|c|c|c|c|c|c|c|}
\hline 1913 & $\begin{array}{c}\text { Inartis tinetoria } \\
\text { Agardh }\end{array}$ & $\begin{array}{l}\text { Merismopedium } \\
\text { glaveum }\end{array}$ & $\begin{array}{l}\text { Microcystis } \\
\text { sp. }\end{array}$ & $\begin{array}{c}\text { Nostoc } \\
\text { sp. }\end{array}$ & $\begin{array}{l}\text { Oscillatoria } \\
\text { formosa }\end{array}$ & $\begin{array}{c}\text { Oscillatoria } \\
\text { sp. }\end{array}$ \\
\hline 212 & & $\ldots \ldots-\quad-$. & $\begin{array}{lll}\ldots \ldots & \ldots \ldots\end{array}$ & - & 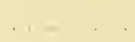 & - \\
\hline $2 / 15$ & ..... & 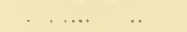 & & & & \\
\hline 219 & ...... & $\ldots$ & . & . & & 800 \\
\hline 2,3 & $\ldots .$. & $\ldots \ldots \ldots$ & . & 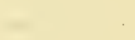 & & . \\
\hline 226 & $\ldots$ & …......... & $\ldots$ & .. & 3,200 & .. \\
\hline 31 & $\begin{array}{llll}\ldots & \ldots & \ldots & \ldots\end{array}$ & ............ & ... $\ldots$ & . & - & .. \\
\hline $3 / 5$ & $\begin{array}{lll}\ldots & \ldots \ldots\end{array}$ & ㄷ............ & $\ldots \ldots$ & 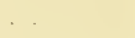 & $\ldots$ & 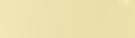 \\
\hline $3 / 8$ & $\ldots \ldots$ & ……… & ... & .. & ... & .. \\
\hline $3 / 12$ & $\ldots \ldots$. & ….............. & ... & 1,600 & 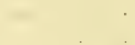 & . \\
\hline $\begin{array}{l}3 / 15 \\
3 / 19\end{array}$ & ……… & $\ldots$. & ..... & 1,800 & $79,3+4$ & . \\
\hline $3 / 23$ & ….............. & ................. & $\ldots$ & & & 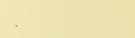 \\
\hline $3 / 26$ & ………... & ....... & $\ldots \ldots$ & .. & 52,896 & .. \\
\hline $3 / 29$ & ....... & .. & & .. & 3,200 & .. \\
\hline $4 / 2$ & ............... & ....... & $\ldots \ldots$ & & 3,200 & \\
\hline+15 & & ........... & & .... & 1,600 & \\
\hline$+/ 9$ & ……..... & ............. & 3,200 & $\ldots$ & 6,400 & .. \\
\hline $4 / 13$ & & & & & & \\
\hline 416 & ..... & $\cdots \cdot$. & 1,600 & & 1,600 & . \\
\hline+19 & ...... & & $\begin{array}{ll}\ldots \ldots & . . \\
\end{array}$ & & $\begin{array}{r}3,200 \\
-0,006\end{array}$ & \\
\hline $\begin{array}{l}123 \\
126\end{array}$ & & & & $\cdots$ & 52,896 & \\
\hline $4 / 30$ & ......... & $\ldots$ & $\ldots$ & & 1,600 & .. \\
\hline $5 / 3$ & ....... & ..... & $\ldots \ldots, \quad \ldots$ & $\cdots$ & .. & \\
\hline $5 / 7$ & ....... & ....... & ….. , , & ...... & $=$ & $=$ \\
\hline 511 & & $\ldots .$. & $\ldots \ldots \ldots, \quad \ldots \ldots$ & $\ldots \ldots$. & . & $\ldots$ \\
\hline $5 / 14$ & ..... & ............. & ……........ & .... & $\ldots$. & $\ldots$ \\
\hline $5 / 17$ & ..... & ..... & & 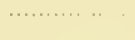 & $\cdot . \cdot$ & .... 11 \\
\hline $\begin{array}{l}21 \\
21\end{array}$ & $\ldots$. & ....... & $\begin{array}{r}10 i, 192 \\
3.200\end{array}$ & ......... & ....... & … 3,200 \\
\hline $5 / 27$ & $\cdots$ & 3,200 & , .......... & & ....... & ……, \\
\hline $5 / 31$ & & $\ldots \ldots \ldots$ & & & ……...... & .......... \\
\hline 6i/ 3 & ..... & $\ldots \ldots,+$. & 3,200 & 6,400 & …… & ........... \\
\hline 6) 7 & ..... & $\ldots \ldots-\ldots$ & $\ldots$ & 6,400 & & \\
\hline 6.11 & $\ldots$ & ...... _. $\quad \ldots$. & $\ldots \ldots+\ldots \ldots$ & ... & ....... & 3.200 \\
\hline $6 / 16$ & & ........... & $\ldots \ldots$ & 6.400 & . & 105,792 \\
\hline $6 / 18$ & ……… & 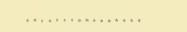 & & 3,200 & & $\ldots$ \\
\hline 6.21 & & & & 6,400 & & $\ldots$ \\
\hline $6 / 25$ & & ..... & & $155,6 \times 5$ & & $\ldots$ \\
\hline $6 / 25$ & ...... & ……… & 846.336 & 317,376 & ....... & \\
\hline 73 & & & $211,5 \mathrm{St}$ & $2,226,336$ & $\ldots$ & 1,600 \\
\hline $7 / 5$ & .... & ………… & 12,800 & 793,440 & & \\
\hline $7 / 9$ & ....... & ............. & 105,792 & 787,6418 & & 105,792 \\
\hline $7 / 12$ & & ………... & 264,480 & 476,064 & & 3.200 \\
\hline $7 / 16$ & $. \quad-\ldots \ldots$ & ……… & 317,376 & 793.440 & .......... & $211,5,4$ \\
\hline $7 / 19$ & $\ldots . \quad \ldots \ldots$ & $\ldots \ldots$ & $26+, 480$ & 740,544 & $\ldots \ldots$ & 370,272 \\
\hline $7 / 23$ & ....... & ……… & 264,480 & 171,489 & ......... & 317.376 \\
\hline $7 / 26$ & ..... & $\ldots$ & 264,480 & 528,960 & & 476,064 \\
\hline $7 / 30$ & . & & 211,584 & 323,776 & $\ldots$ & 317,376 \\
\hline $8 / 2$ & $\ldots$ & 3,200 & 105,792 & 3,200 & $\ldots$ & $476,06-1$ \\
\hline$s / r_{i}$ & & 6,400 & 3,200 & 370,272 & & 476.064 \\
\hline 8/ 9 & & $\ldots$ & $10.5,7923$ & $26-1,4,40$ & & $317,376 \mathrm{f}$ \\
\hline 13 & 793,440 & & $158,68 \mathrm{~S}$ & $1,00.5,02 \cdot 1$ & $\ldots$ & $1,602,6172$ \\
\hline$s / 15$ & & & 6,400 & 476,064 & .............. & 528,960 \\
\hline $8 / 20$ & 211,584 & ............... & 3,200 & $42: 3,168$ & …… … & $1,692,6172$ \\
\hline $8 / 2: 3$ & 211,584 & ……… & 6,400 & 370.272 & ............... & $1,110,516$ \\
\hline $8 / 27$ & $264,4 \leqslant 0$ & & & 581,856 & .............. & $8.16,336$ \\
\hline $8 / 31$ & 211,584 & & & $1,005,024$ & … … & $2,221,632$ \\
\hline $9 / 2$ & $3,226,656$ & ……… & 105.792 & 899.2332 & ............... & $2,062,944$ \\
\hline $9 / 6$ & $6,876,480$ & .............. & $\ldots$ & 899,232 & $\ldots$ & $1,216,608$ \\
\hline
\end{tabular}


Table 1.-Organisms Per Cubic Meter in Plankton of STOCKTON CHANNEL, IN 1913-(Continued)

\begin{tabular}{|c|c|c|c|c|c|c|}
\hline 1913 & $\begin{array}{l}\text { Inactis tinctoria } \\
\text { Agardh }\end{array}$ & $\begin{array}{l}\text { Merismopedium } \\
\text { glaucum }\end{array}$ & $\begin{array}{l}\text { Microcystis } \\
\text { sp. }\end{array}$ & $\begin{array}{l}\text { Nostoc } \\
\text { sp. }\end{array}$ & $\begin{array}{l}\text { Oscillatoria } \\
\text { fornısa }\end{array}$ & $\begin{array}{l}\text { Oscillatoria } \\
\text { sp. }\end{array}$ \\
\hline $9 / 9$ & 5.130912 & & & $264+480$ & & 899,232 \\
\hline 913 & $5,501,184$ & & & 846,336 & & $1,216,608$ \\
\hline $9 / 17$ & $4,231,680$ & & 317,376 & 423,168 & & 105,792 \\
\hline $9 / 20$ & $6,876,480$ & 105,792 & 158,688 & 264,480 & ........ & $1,110,816$ \\
\hline $9 / 24$ & $6,559,104$ & & & 476,064 & & 370,272 \\
\hline $9 / 27$ & $4,337,472$ & 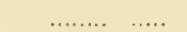 & 52,596 & 52,896 & & 740,544 \\
\hline $10 / 1$ & $2,433,216$ & ……....... & 105,792 & & & 370,272 \\
\hline $10 / 4$ & $2,221,632$ & ............ & 105,792 & 158,685 & . & $105,79^{2}$ \\
\hline $10 / \mathrm{s}$ & $1,428,192$ & & 52,896 & $158,68 \mathrm{~s}$ & & 317,376 \\
\hline $10 / 11$ & $1,163,712$ & 52,896 & 105,792 & 6,400 & & 105,792 \\
\hline $10 / 15$ & $1,216,60 \mathrm{~s}$ & $\ldots$ & 6,400 & & $\ldots .$. & 528,960 \\
\hline $10 / 18$ & 476,064 & & & & & 105,792 \\
\hline $10 / 22$ & $8 \pm 6,336$ & ……1. & 6.400 & …........... & $\ldots \ldots$ & 370,272 \\
\hline $10 / 26$ & 105,792 & & 52,896 & & . & \\
\hline $10 / 29$ & 317,376 & & 6,400 & 6,400 & $\ldots$ & $211,5 \mathrm{~S} 4$ \\
\hline $11 / 1$ & 264,480 & 634,752 & 105,792 & 6,400 & $\ldots .$. & 52,896 \\
\hline $11 / 5$ & & 370,272 & 6,400 & 52,896 & & 52,896 \\
\hline $11 / s$ & 158,688 & $264,4 \mathrm{SO}$ & 52,896 & $\ldots+\ldots$ & ....... & 52,896 \\
\hline $11 / 12$ & 79,344 & $3,358,596$ & & & & 52,596 \\
\hline $11 / 15$ & 158,688 & $1,269,504$ & $52, \mathrm{~s} 96$ & & ...... & \\
\hline $1 / 19$ & 52,896 & 528,960 & & 3,200 & …… & 52,896 \\
\hline $11 / 22$ & 52,896 & 634,752 & & $\ldots \ldots$ & .................. & $15 \mathrm{~S}, 6 \mathrm{SS}$ \\
\hline $11 / 26$ & & 634,752 & & …… … & ………… & \\
\hline $11 / 30$ & ……….... & 105,792 & 1,600 & ............. & $\ldots \ldots$ & \\
\hline $12 / 3$ & & 343,824 & 3,200 & & & 52,896 \\
\hline $12 / 6$ & 1,600 & 211,584 & ......... & 1,600 & ……............. & 79,344 \\
\hline $12 / 10$ & ............... & 92,568 & .......... & ......... & ……........... & 26,148 \\
\hline $12 / 14$ & ……… & 132,240 & .......... & ............ & …….......... & 33,060 \\
\hline $12 / 17$ & ….............. & 238,032 & ........ & $\ldots \ldots \ldots$ & …............ & 33,060 \\
\hline $12 / 20$ & & 105,792 & & . & & 39,672 \\
\hline $12 / 24$ & ....... & 33,060 & 400 & ....... & 800 & 13,224 \\
\hline$/ 27$ & ………..... & 99,180 & & 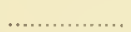 & …… & 52,896 \\
\hline $12 / 31$ & $\cdots$ & 79,344 & & & & 13,224 \\
\hline
\end{tabular}

\begin{tabular}{|c|c|c|c|c|c|c|}
\hline 1913 & $\begin{array}{l}\text { Osciliatoria } \\
\text { tenuis }\end{array}$ & $\begin{array}{l}\text { Phormidium } \\
\text { spp. }\end{array}$ & $\begin{array}{l}\text { Stigonema } \\
\text { sp. }\end{array}$ & $\begin{array}{c}\text { Total } \\
\text { Schizophyceae }\end{array}$ & $\begin{array}{l}\text { Actinastrum } \\
\text { hantzschii }\end{array}$ & $\begin{array}{c}\text { Aetinastrum } \\
\text { hantzschii (large) }\end{array}$ \\
\hline $1 / 5$ & & 13,224 & & 14,024 & & \\
\hline $1 / 8$ & 1,200 & & .................... & 2,000 & ........ & ……… \\
\hline $1 / 12$ & $\cdots .$. & .............. & ………........ & . & ………...... & ........ \\
\hline & …… & & ……… & & ......... & 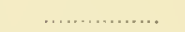 \\
\hline $1 / 19$ & & 400 & & 800 & & \\
\hline $1 / 22$ & 800 & 800 & ……............ & 3,200 & 800 & ..... \\
\hline $1 / 26$ & ........ & 26.848 & ................ & 27.349 & & \\
\hline $1 / 29$ & …..... & 800 & & 2,000 & & \\
\hline $2 / 2$ & ......... & 13,624 & ................. & 14,824 & 400 & … \\
\hline 2) 5 & . & 400 & …ㄴ..ㄴ... & 2,800 & $\ldots$ & ………… \\
\hline $2 / 8$ & ..... & 39,672 & .................... & 40,472 & $\ldots \ldots$ & ……........... \\
\hline 12 & & 26,448 & ㄷ..…… & 26,448 & ............ & ……… \\
\hline 15 & 26,448 & 370.272 & ........ & 396,720 & & ...... \\
\hline 19 & & 92,568 & .................. & 94,168 & 1,600 & ......... \\
\hline 23 & $\ldots \ldots$ & 238,032 & ................... & 277,704 & & \\
\hline 26 & & 238,032 & ……......... & 244,432 & $\ldots$ & $\ldots$ \\
\hline 1 & 3,200 & 79,344 & .................... & $S 5,744$ & ............ & ………… \\
\hline 5 & $\ldots$ & $158,68 \mathrm{~S}$ & .................. & 211,584 & ….............. & ….............. \\
\hline 8 & $\ldots .$. & 318,976 & ……… & 318,976 & ………… & . \\
\hline & ....... & & & & & ㄱ. \\
\hline 15 & & 158,688 & …….......... & 213,184 & & .... \\
\hline 19 & 1,600 & 235,032 & ……........ & 318,976 & $52, \$ 96$ & \\
\hline
\end{tabular}




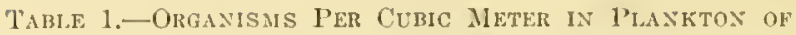
STOCKTON CHaxNeL IX 1913-(Continued)

\begin{tabular}{|c|c|c|c|c|c|c|}
\hline 1913 & $\begin{array}{c}\text { Oscillatoria } \\
\text { tenuis }\end{array}$ & $\begin{array}{l}\text { Phormidium } \\
\text { spp. }\end{array}$ & $\begin{array}{l}\text { Stigonema } \\
\text { sp. }\end{array}$ & $\begin{array}{c}\text { Total } \\
\text { Schizophyceao }\end{array}$ & $\begin{array}{l}\text { Actinastrum } \\
\text { hantzachii }\end{array}$ & $\begin{array}{l}\text { Actinastrum } \\
\text { hintzschii (large) }\end{array}$ \\
\hline $3 / 2: 3$ & 1,600 & $79,3.14$ & & $80,91 \cdot 1$ & 52,896 & \\
\hline $3 / 26 i$ & & $238,03: 2$ & & 290,923 & 1,600 & . \\
\hline $3 / 29$ & & $10,5,7952$ & & 110,592 & & 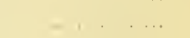 \\
\hline $1 / 2$ & $\ldots \ldots \ldots \ldots$ & 158,688 & ........ & 1033,488 & 3,200 & \\
\hline $4 / 5$ & ............. & 185,136 & $\ldots \ldots \ldots \ldots$ & 239,632 & & .. \\
\hline $4 / 9$ & , ............ & 158,645 & $\ldots \ldots \ldots \ldots$ & 175,685 & 1,600 & 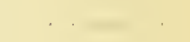 \\
\hline $1 / 13$ & & 6,400 & & 11,200 & & \\
\hline $\begin{array}{l}4 / 16 \\
1 / 19\end{array}$ & $\begin{array}{r}52,896 \\
1,600\end{array}$ & 261,150 & $\cdots$ & 322,176 & $\ldots$ & \\
\hline $\begin{array}{l}1 / 19 \\
4 / 23\end{array}$ & & $\begin{array}{r}158,648 \\
70,3+4\end{array}$ & $\begin{array}{l}. . \\
. .\end{array}$ & $\begin{array}{l}165,088 \\
185,136\end{array}$ & 52,896 & \\
\hline $\begin{array}{l}4 / 23 \\
1 / 26\end{array}$ & .......... & $\begin{array}{r}1,, 3+4 \\
3,200\end{array}$ & & 92,114 & & 3,200 \\
\hline $4 / 30$ & & (3) & & 1,600 & & \\
\hline $5 / 3$ & $18 . \overline{5}, 136$ & & & 267,680 & & 3.200 \\
\hline $5 / 7$ & 1,600 & 1,600 & $\ldots$ & 14,400 & & 3,200 \\
\hline $5 / 11$ & 52,896 & 52,890 & $\ldots$ & $160,28 \mathrm{~S}$ & 3,200 & $\cdots$ \\
\hline $5 / 14$ & 105,792 & $\ldots \ldots \ldots \ldots$ & $\ldots$ & 320,576 & & $\ldots .$. \\
\hline $5 / 17$ & 317,376 & $\ldots \ldots \ldots$ & & 323,776 & ..... & ......... \\
\hline $5 / 21$ & 3,200 & & 6,400 & 379,872 & & ......... \\
\hline $5 / 24$ & 370,272 & & 3,200 & $488,86+1$ & 6,400 & \\
\hline $5 / 27$ & 105,792 & 3,200 & $\ldots \ldots \ldots$ & 323,766 & & \\
\hline $5 / 31$ & $158,6 \mathrm{ss}$ & 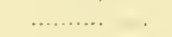 & .......... & 168,288 & 3,200 & 3,200 \\
\hline $6 / 3$ & $\ldots \ldots \ldots$ & ............ & & $1,391,290 \mathrm{i}$ & 105,792 & 3,200 \\
\hline (i) 7 & $\ldots$ & ........ & 6,400 & $S 84,736$ & 3,200 & \\
\hline $6 / 11$ & 3,200 & ...... & $\ldots \ldots \ldots$ & 859,136 & $\ldots \quad \ldots \ldots$ & .... \\
\hline $6 / 16$ & 3,200 & .......... & $\ldots \ldots \ldots$ & 461,568 & & \\
\hline $6 / 18$ & $10 \overline{5}, 792$ & & $\ldots \ldots$. & 559,136 & 105,792 & \\
\hline $6 / 21$ & 3,200 & 158,685 & $\ldots \ldots$ & $1,226,208$ & 3,200 & \\
\hline $6 / 2 i$ & 3,200 & 264,480 & & $1, S S 6,560$ & 3,200 & 3,200 \\
\hline $6 / 28$ & 211,581 & 3,200 & ......... & $2,436,416$ & & .... \\
\hline $7 / 3$ & & . & $\cdots$ & $3,127,16 \mathrm{~s}$ & 105,7992 & .... \\
\hline $7 / 5$ & 12,800 & $\ldots$ & ......... & $1,559,584$ & 3.200 & .... \\
\hline $7 / 9$ & & $\ldots . \quad \ldots \ldots$ & $\ldots \ldots$. & $2,164,240$ & 3,200 & \\
\hline $7 / 12$ & 370,272 & $\ldots$ & .. & $4,763,840$ & 6,400 & 12,500 \\
\hline $7 / 16$ & $\ldots \ldots \ldots$ & …1... $\quad \ldots$ & & $4,919,328$ & ............. & $10 \tilde{5}, 79^{\circ}$ \\
\hline $7 / 19$ & & ..... $\quad . . \quad \cdot$ & …... &, 002 & $\ldots \ldots$ & 19,200 \\
\hline $7 / 23$ & 105,792 & ........... & $\cdots \cdot$ & $1,262,20 \mathrm{~s}$ & & 6,400 \\
\hline $7 / 26$ & & a & ...... & $2,750,602$ & 3,200 & 105,792 \\
\hline $7 / 30$ & & ...... & ........ & $1,543,5,84$ & ........ . & 6,400 \\
\hline 8/ 2 & 3,200 & … $\ldots, \ldots$, & & 703,648 & ...... & 6,400 \\
\hline $8 / 6$ & & & & $1,114,016$ & & 12,800 \\
\hline S/ 9 & 155,688 & & & $1,391,296$ & $\cdots \quad \ldots$ & 19,200 \\
\hline $8 / 13$ & 264,480 & $52 \$, 960$ & &, 632 & $\ldots \ldots \ldots \ldots$ & 264,480 \\
\hline $\mathrm{S} / 15$ & 3,200 & & 105,792 & 376 & & 6,400 \\
\hline $8 / 20$ & 105,792 & 158,688 & 12,800 & 056 & & 158,688 \\
\hline $8 / 23$ & & 211,584 & $\ldots \ldots+\ldots$ & 2,7 & 3,200 & 158,688 \\
\hline $8 / 27$ & & 105,792 & & 2,8 & 3,200 & 370,272 \\
\hline $8 / 31$ & 3,200 & & & $3,936,704$ & …….......... & 158,658 \\
\hline $9 / 2$ & 3,200 & $1,110,816$ & ................. & 8,0 & ․ . …… & 12,800 \\
\hline $9 / 6$ & 211,584 & $1,481,088$ & ....... & $11,435,336$ & ……..... & 3,200 \\
\hline $9 / 9$ & 211,584 & 952,128 & & $\$, 19 S, \& \& 0$ & & 3,200 \\
\hline $9 / 13$ & 3,200 & 528,960 & $\ldots \ldots$ & $8,806,832$ & 3,200 & 6.400 \\
\hline $9 / 17$ & & & & 850 & & 0,400 \\
\hline $9 / 20$ & & 264,480 & & $9,580,576$ & 211,584 & 6.400 \\
\hline $9 / 24$ & 52,896 & $1,163,712$ & & $9,309,696$ & & 105,792 \\
\hline $9 / 27$ & $\ldots \ldots \ldots$ & 158,689 & & $6,036,544$ & 52,896 & 12,800 \\
\hline $0 / 1$ & . & 423,168 & & $0,36 \mathrm{~s}$ & $52,5 ! 16$ & 264,180 \\
\hline 4 & & 105,792 & $=i$ & $3,550,432$ & …..... $\quad \ldots$ & 476,064 \\
\hline 8 & 52,896 & 634,752 & $\ldots \ldots$ & $3,332,448$ & & 158,685 \\
\hline & 6,400 & 58 & & $2,4 \cdot 16,016$ & ...... & 158,688 \\
\hline $0 / 15$ & 476,064 & 105,792 & & $2,545,40 \mathrm{~s}$ & ……… & $158,6 \mathrm{ss}$ \\
\hline
\end{tabular}


Table 1.-Organisms Per Cubic aleter in Plankton of Stockton Channel in 1913-(Continued)

1913
$10 / 18$
$10 / 22$
$10 / 26$
$10 / 29$
$11 / 1$
$11 / 5$
$11 / 5$
$11 / 12$
$11 / 15$
$11 / 19$
$11 / 22$
$11 / 26$
$11 / 30$
$12 / 3$
$12 / 6$
$12 / 10$
$12 / 14$
$12 / 17$
$12 / 20$
$12 / 24$
$12 / 27$
$12 / 31$

$\begin{gathered}\text { Oscillatoria } \\ \text { tenuis }\end{gathered}$
370,272
317,376
52,896
6,400
6,100
$\ldots \ldots \ldots$
52,896
3,200
1,600
79,344
3,200
$\ldots \ldots \ldots$
400
800
13,224
105,792
400
26,448
13,224

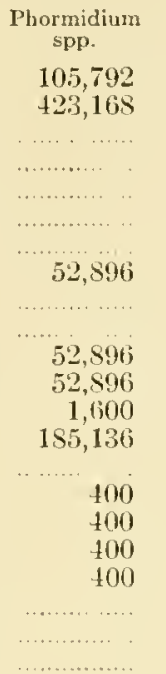

Stigonema
sp.

Total
Schizophyceae
$1,110,816$
$2,016,448$
370,272
$\$ 12,640$
$1,699,072$
912,032
793,440
$4,284,576$
$2,063,144$
$1,008,224$
$1,385,496$
689,245
347,024
641,152
297,328
158,052
260,668
364,060
264,880
89,156
225,608
145,461

Actinastrum
hantzschii

Actinastrum

..............

..............

................

……

(..............

\begin{tabular}{|c|c|}
\hline & $1,385,496$ \\
\hline & 689,245 \\
\hline \multirow{6}{*}{1,600} & 347,024 \\
\hline & $6 \pm 1,152$ \\
\hline & 297,328 \\
\hline & $158,0.52$ \\
\hline & 260,668 \\
\hline & 364,060 \\
\hline \multirow{4}{*}{800} & 264,880 \\
\hline & 89,156 \\
\hline & 225,608 \\
\hline & $1-15,461$ \\
\hline
\end{tabular}
(1) hant zschii (large)

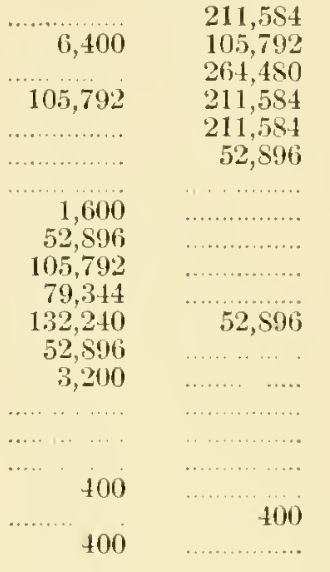

1913

Coelastrun

Pediastrum Pediastrum duplex

Pediastrum simplex

Raphidium polymorphum

Richteriella botryoides

1/ 5

$1 / 8$

$1 / 12$

$1 / 15$

$1 / 19$

$1 / 22$

$1 / 26$

$1 / 29$

2) 2

2) 5

6,612

100

400

1,200

1,200

1,600

4,500

400

$800 \quad 19, \$ 36$

$800 \quad 13,22$

$3,200 \quad 2,400$

$4,800 \quad 5,600$

4,500

39,672

26,445

6,400

6,400

1,600

9,600

9,600

79.344

3,200

9,600

3,200

12,800

3,200

6,400

11,200

92,568

26,448

79,344

3,200

12,800

12,800

$6,+00$

22,400

132,240

9,600

16,000

9,600

6,400
7034

6,400

9,600

1,600

16,000

1,600

3,200

16,000

13,224

1,600

52,890

1,600

79,344

6,400

800
1,600

1,600

52,896

1,600

3,200

3,200

1,600

6,400

4,800

79,344

79.344

132,240

132,240 
Table 1,-Organisms Pfr ('thic Meter in P'lankton of StockTON ("hanNet, in 1913-(Continued)

\begin{tabular}{|c|c|c|c|c|c|c|}
\hline 1913 & $\begin{array}{l}\text { Coclastrum } \\
\text { nicroporum }\end{array}$ & $\begin{array}{l}\text { Pediastrum } \\
\text { boryanmm }\end{array}$ & $\begin{array}{l}\text { Pedinstrum } \\
\text { duplex }\end{array}$ & $\begin{array}{l}\text { Pedinstrum } \\
\text { simplex }\end{array}$ & $\begin{array}{l}\text { Raphidium } \\
\text { polytuorphum }\end{array}$ & $\begin{array}{l}\text { Richteriplla } \\
\text { botryoides }\end{array}$ \\
\hline $1: 30$ & & 6,400 & $(6,400)$ & & $79,3+1$ & \\
\hline 513 & & & 3,200 & & 105,792 & \\
\hline $5 / 7$ & $\cdots$ & $\ldots \ldots$ & 6,100 & & 1,600 & \\
\hline $5 / 11$ & . 1 & & 105,792 & .. & 107,392 & $1,(600)$ \\
\hline $5 / 14$ & & 6,400 & & & $1\left(1,5,99^{2} 2\right.$ & \\
\hline $5 / 17$ & . . ............. & 6,400 & 6,100 & & $105,99^{\circ}$ & - \\
\hline $5 / 21$ & $\begin{array}{llll}. . & \ldots & \ldots\end{array}$ & & 19,200 & 0,400 & 158,685 & \\
\hline $5 / 24$ & 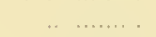 & 6,400 & 6,400 & & 317,376 & 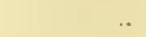 \\
\hline $5 / 27$ & & 3,200 & 12,400 & .. & 264,480 & \\
\hline $5 / 31$ & 261,180 & & 6,400 & & 743,744 & \\
\hline $6 / 3$ & $15 x, 6$ s & 105,792 & 12,4110 &..- & $211,5,4$ & \\
\hline $6 / 7$ & & 3,200 & 32,000 & . & 105,792 & \\
\hline $6 / 11$ & & & $158,6 \times 8$ & $\ldots .$. & 317,376 & \\
\hline $6 / 16$ & & & 25,600 & .. & 528,960 & \\
\hline $6 / 18$ & & 3,200 & 6,400 & - & & \\
\hline $6 / 21$ & 370,272 & & $158,6 \mathrm{SS}$ & $\ldots \ldots$. & 634,752 & \\
\hline $6 / 25$ & ..... & 3,200 & 317,376 & $\ldots \ldots$. & 264,480 & 3,200 \\
\hline $6 / 28$ & $\ldots .$. & 6,400 & 370,272 & ……......... & 3,200 & $\ldots \ldots$ \\
\hline $7 / 3$ & & & 793,440 & & 4,800 & - \\
\hline $7 / 5$ & 6,400 & & 476,064 & 3,200 & & \\
\hline $7 / 9$ & $158,6 S 8$ & 6,400 & $1,005,024$ & ….... & 108,992 & r. \\
\hline $7 / 12$ & 158,688 & & $1,269,504$ & & 3,200 & 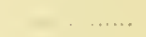 \\
\hline $7 / 16$ & 105,792 & & 793,440 & 12,800 & $264,4<0$ & \\
\hline $7 / 19$ & 105,792 & 12,800 & 740.544 & & 3,200 & \\
\hline $7 / 23$ & 211,584 & & 634,752 & $159,68 \mathrm{~S}$ & 6,400 & \\
\hline $7 / 26$ & 476,064 & 6.100 & 793,440 & 19,200 & $267,6 \times 0$ & \\
\hline $7 / 30$ & 211,584 & & $7+0,544$ & 3,200 & 3,200 & .... \\
\hline $8 / 2$ & 105,792 & 3,200 & 176,064 & 6,400 & 105,792 & \\
\hline $8 / 6$ & 211,584 & 12,800 & 264,180 &.$\quad \ldots$ & 323,776 & ...... . \\
\hline $8 / 9$ & 211,581 & 3,200 & 793,440 & & 3,200 & \\
\hline $8 / 13$ & 105,792 & & $+23,16 \mathrm{~S}$ & 6,400 & 264,450 & \\
\hline $8 / 1.5$ & $211.5 \mathrm{St}$ & ....... & 317,376 & & 3,200 & \\
\hline $8 / 20$ & 423,168 & ..... & $211,5,44$ & & 105,792 & $\cdots$ \\
\hline $8 / 23$ & 634,752 & & $\pm 66,064$ & 3,200 & $211,5 \mathrm{~S} 4$ & \\
\hline $\mathrm{S} / 27$ & 525,960 & 3,200 & 105,792 & .......... & 6,400 & \\
\hline $8 / 31$ & 634,752 & & 105,792 & $\ldots$ & 370,272 & \\
\hline $9 / 2$ & $1,005,024$ & 12,800 & 634,752 & 6,100 & 179,264 & \\
\hline $9 / 6$ & $2,221,632$ & & 634,752 & 211,594 & 211,584 & 105,792 \\
\hline $9 / 9$ & $2,697,696$ & 105,792 & 657,645 & 105,792 & $26+, 480$ & \\
\hline $9 / 13$ & $3,544,032$ & 105,792 & 476,064 & & $264,4 \leq 0$ & $\ldots$ \\
\hline $9 / 17$ & $1,163,712$ & 6.400 & 423,168 & 12,800 & 267,680 & $\ldots$ \\
\hline $9 / 20$ & 793,440 & 6,400 & $740,5+4$ & & 211,584 & ......... \\
\hline $9 / 24$ & $26-1,450$ & 12,800 & $1, \$ 51,360$ & 25,600 & 317,376 & \\
\hline $9 / 27$ & 476,064 & ....... & 793,440 & 6,400 & 317,376 & \\
\hline $10 / 1$ & 423,168 & & 952,128 & 6,400 & 317,376 & \\
\hline $10 / 4$ & 317,376 & $12, \$ 00$ & $1,110,816$ & 19,200 & 370,272 & 52,896 \\
\hline $10 / 8$ & $15 \mathrm{~S}, 6 \mathrm{SS}$ & 105,792 & $1,795,464$ & 6,400 & 376,672 & \\
\hline $10 / 11$ & 211,584 & 12,800 & $2,010,0+4$ & ........... & $171,4 \mathrm{SS}$ & \\
\hline $10 / 15$ & 52,896 & & $1,533,984$ & … … ...... & & \\
\hline $10 / 18$ & & & 176,064 & & $158,68 \mathrm{~S}$ & 52,896 \\
\hline $10 / 22$ & 158,688 & 6,400 & $740,54 t$ & 52,896 & ............... & 105,792 \\
\hline $10 / 26$ & 12,800 & & 793,440 & & & 52,596 \\
\hline $10 / 29$ & 211,581 & 19.200 & $\$ 46,336$ & 12,500 & $26+6,450$ & 52,896 \\
\hline $11 / 1$ & $158,6 \mathrm{SS}$ & 6,400 & 528,960 & 6,400 & 317.376 & 52,596 \\
\hline $11 / 5$ & 52,896 & 12,800 & 952,125 & & 6,400 & \\
\hline $11 / 8$ & & 6,400 & 158,688 & 52,896 & 370,272 & \\
\hline $11 / 12$ & 52,896 & 52,896 & 317,376 & ................. & 572,781 & \\
\hline $11 / 15$ & 264,480 & 52,896 & 6,400 & ........ & 423,168 & \\
\hline $11 / 19$ & 79,344 & 12,500 & $52, \$ 96$ & …...... & 158,658 & \\
\hline $11 / 22$ & 25,800 & 6,400 & 238,032 & & 105,792 & \\
\hline
\end{tabular}


Table 1.-Organisms P'er (Udic Meter in Plankton of Stockton Channel in 1913-(Continued)

\begin{tabular}{|c|c|}
\hline 1913 & $\begin{array}{l}\text { Coelastrum } \\
\text { microporum }\end{array}$ \\
\hline $11 / 26$ & 6,400 \\
\hline $11 / 30$ & 52,896 \\
\hline $12 / 3$ & 79,344 \\
\hline $12 / 6$ & 3,200 \\
\hline $12 / 10$ & 800 \\
\hline $12 / 14$ & $\mathrm{~S} 00$ \\
\hline $12 / 17$ & ..... \\
\hline $12 / 20$ & \\
\hline $12 / 24$ & ... \\
\hline $12 / 27$ & …............. \\
\hline $12 / 31$ & \\
\hline
\end{tabular}

Pediastrum
boryanum
6,400
1,600
3,200
1,600
800
800
1,600
1,600

$\begin{gathered}\text { Pediastrum } \\ \text { duplex }\end{gathered}$
32,000
79,344
52,896
19,200
19,836
33,060
400
13,224
13,224
39,672
33,060

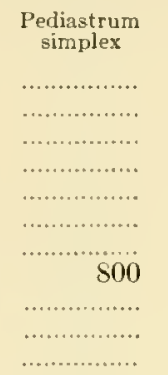

Raphidium

Richteriella polymorphum botryoides

1,600

105,792

54,496

59,908

13,224

53,296

$46,2 \mathrm{S4}$

13,224

119,016

\$5,956

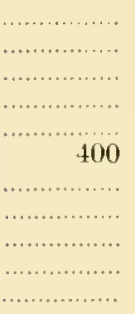

Scenedesmus obliquus

Scenedesmus

Sohroederia

Selenastrum

Stigeoclonium

sp.

Ulothrix

1) 5

6,612

setigera

bibraianum

$\mathrm{sp}$.

1.8

$1 / 12$

$1 / 15$

$1 / 19$

$1 / 22$

$1 / 26$

$1 / 29$

$2 / 2$

2/ $\mathrm{S}$

$2 / 12$

$2 / 15$

$2 / 19$

$2 / 23$

$2 / 26$

$3 / 1$

$3 / 5$

$3 / 8$

$3 / 12$

$3 / 15$

$3 / 19$

$3 / 23$

$3 / 26$

$3 / 29$

4/ 2

$4 / 5$

4.9

$4 / 13$

$4 / 16$

$4 / 19$

$4 / 23$

$4 / 26$

$4 / 30$

$5 / 3$

$5 \longdiv { 7 }$

$5 / 11$

$5 / 14$

$5 / 17$

$5 / 21$

$5 / 24$

$5 / 27$

$5 / 31$

$\ldots \ldots+\ldots+\ldots, \ldots$

400
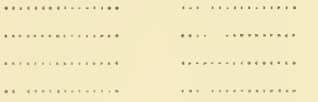

13,224

33,060

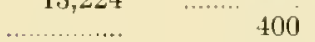

400
400

13,224

800

1,600

52,896

800

52,896

39,672

132,240

3,200

6,400

$1,600 \quad 79,344$

6,400

52,896

132,240

3,200

105,792

3,200

3,200

6,400

105,792

1,600

79,344

6,400

$15 \mathrm{~s}, 688$

52,896

132,240

6,400

52,896

79,344

1, 600

3,200

264,480

211,584

$423,16 \mathrm{~S}$

$1,322,400$

32,240

52,896

52,896

185,136

317,376

19,200

264,480

$1,057,920$

$1,216,608$

$3,38.5,344$

$\begin{array}{ll}\ldots \ldots \ldots \ldots \ldots & 400 \\ \ldots \ldots \ldots \ldots \ldots & 400\end{array}$

400
400

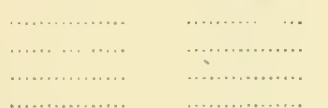

800

52,896

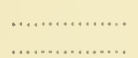

...............

................

n.............

n.............

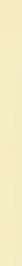

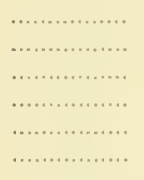
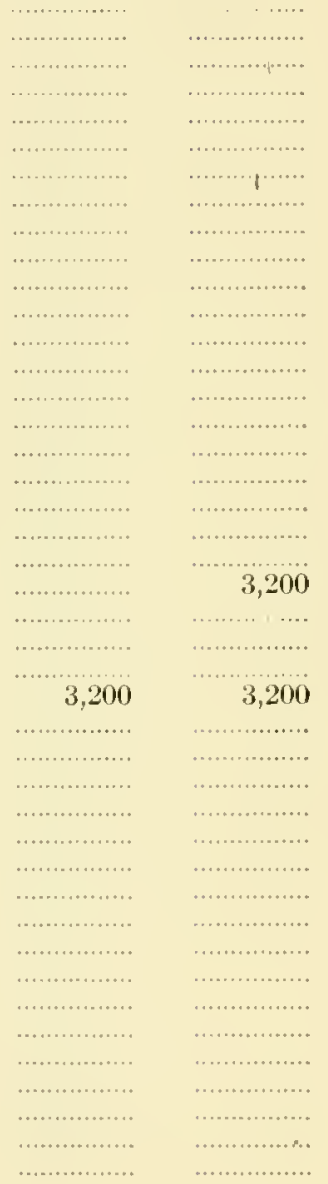

$$
\begin{array}{r}
1,600 \\
1,600 \\
3,200 \\
3,200 \\
105,792 \\
105,792 \\
105,792
\end{array}
$$


Table 1.-Organisms Per ('ubic Meter in 1'hanktos of STOCKTON ('HANNEL IN 1913-(Contimued)

\begin{tabular}{|c|c|c|c|c|c|c|c|c|}
\hline 1913 & $\begin{array}{l}\text { Scunedismus } \\
\text { obliquus }\end{array}$ & $\begin{array}{l}\text { Sernedesmus } \\
\text { quadricauda }\end{array}$ & $\begin{array}{l}\text { Sehroederia } \\
\text { sotigera }\end{array}$ & $\begin{array}{l}\text { Selenastrum } \\
\text { bibraianum }\end{array}$ & Stigeor & nium & $\begin{array}{l}\text { ¿loth } \\
\text { 8p. }\end{array}$ & Irix \\
\hline (i) 7 & $1,957,152$ & $2,697,6996$ & 317,376 & .. & . & 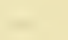 & & . \\
\hline (j) 11 & (i3 31,752 & $1,533: 3,984$ & $158,6 \times 8$ & $\begin{array}{llll}\ldots \ldots & \ldots\end{array}$ & ... & & & \\
\hline (i) $11 \mathrm{i}$ & 423,16 is & 1,110, sifi & 3,200 & .......... & .... & & & \\
\hline $\mathrm{i} / 1 \mathrm{~s}$ & $6: 34,752$ & $1,7-15,660$ & 261,480 & …..... & & & & \\
\hline$\left(j^{\prime 2} / 21\right.$ & 370,272 & $2,9099,280$ & 264,450 & 3,200 & .. & & & \\
\hline $1 ; / 25$ & 899,232 & $2,80,3,158$ & 105,792 & .. & . & & & 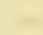 \\
\hline (i) & $1,110,816$ & $2,803,185$ & $10-3,792$ & . ... & & & & \\
\hline $7 / 3$ & 740,544 & $1,163,712$ & $15 S, 6 \mathrm{SS}$ & $\ldots$ & & & & \\
\hline $7 / 5$ & $158,(358$ & 370,272 & & . & & 200 & & \\
\hline $7 / 9$ & 211,584 & 634,752 & & $\ldots \ldots$ & & & & \\
\hline $7 / 12$ & $211,5 \mathrm{St}$ & 176,$00 ; 4$ & & $\ldots \ldots$ & & & & 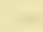 \\
\hline $7 / 16$ & 423,168 & $1,375,2936$ & & & & & & \\
\hline $7 / 10$ & 525,960 & $952,12 x$ & & . & & & & \\
\hline $7 / 23$ & 105,792 & $5 \times 1,850$ & 105,792 & & & & & \\
\hline $7 / 20$ & Gst, 645 & $1,005,024$ & 105,792 & & & & & \\
\hline $7 / 30$ & 317,376 & 634,752 & 3,200 & $\cdot$ & & & & \\
\hline $8 / 2$ & 105,792 & 899,232 & $: 3,200$ & 1 & $\rightarrow$ & & & \\
\hline$S / 6$ & $155,6 \times 5$ & 634,752 & & & & & $\ldots$ & \\
\hline S/ 9 & & 551,856 & & $\quad$. & .. & 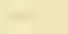 & $\cdots$ & \\
\hline$\therefore 13$ & 370,272 & $1,639,776$ & $264,4,50$ & - & .. & & & \\
\hline \& 15 & 264,450 & $\$ 99,232$ & & & & & & \\
\hline $8 / 20$ & 211,584 & $5 \$ 1,856$ & & & 1 & & & - \\
\hline $8 / 2: 3$ & $423,16 \mathrm{~s}$ & $1,110, \mathrm{~S} 16$ & 3,200 & 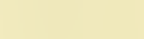 & & & & \\
\hline $8 / 27$ & 528,960 & $1,216,6 \cap \mathrm{s}$ & $\ldots$ & $\ldots$. & 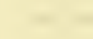 & & 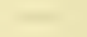 & \\
\hline $\mathrm{S} / 31$ & 123,16 is & 846,336 & & ... & & & & , \\
\hline $9 / 2$ & 581,856 & $1,322,400$ & $\ldots$. & $\cdots$ & & & .. & \\
\hline $9 / 13$ & 176,061 & $1,057,920$ & $-\ldots \ldots$ & $\ldots$ & & .. & - & \\
\hline $9 / 9$ & 528,960 & $1,16: 3,712$ & ... & $\ldots$ & & & & \\
\hline $9 / 13$ & 476,064 & $1,533,5,84$ & $\ldots$ & $\ldots$ & 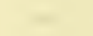 & 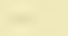 & 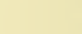 & 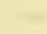 \\
\hline $9 / 17$ & $37(1,272$ & $1,163,712$ & & $\ldots$ & & & & \\
\hline $9 / 20$ & 657,648 & $1,425,192$ & & $\ldots$ & & 1 & & \\
\hline 924 & $26 \cdot 1,4 \mathrm{SO}$ & $1,586,880$ & $52, \$ 96$ & ........ & & & & \\
\hline $9 / 27$ & 528,960 & $1,6399,776$ & 52,596 & $\ldots \ldots \ldots$ & & & & \\
\hline $10 / 1$ & $1,057,920$ & $2,062,944$ & $\ldots$ & ........ & & & 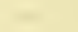 & $\cdots$ \\
\hline $111 / 1$ & 710,514 & $1,533,9,944$ & & $\ldots \ldots$. & & & 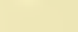 & $\ldots$ \\
\hline 10) $\mathrm{S}$ & $5 \$ 1,856$ & $1,428,192$ & & ... $.-1=$ & & & 1,1 & . \\
\hline $10 / 11$ & $1,057,9220$ & 952,128 & 105,792 & $\ldots . . \quad \ldots$ & & & .. & \\
\hline $10 / 15$ & (is7,6i4s & $1,2699,504$ & 52,896 & …...... & & & & \\
\hline 1015 & $657.64 \mathrm{~s}$ & $1,057,1120$ & & $\therefore .$. & 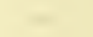 & & & \\
\hline $10^{1 / 2 * 2}$ & 657,648 & $1,365,296$ & 52,596 & . . . & & & & \\
\hline $10 / 26$ & 793,440 & $1,533,05 t$ & & 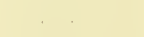 & & & .. & $1+1$ \\
\hline $10 / 29$ & $1, \pm 29,192$ & $1,957,152$ & $261,4 \$ 0$ & & & & & \\
\hline $11 / 1$ & $687,6 \pm 8$ & $2,115,840$ & 105,792 & & & & & \\
\hline $11 / 5$ & $1,005,02 t$ & $3,438,2 \pm 0$ & 0,400 & & & & & \\
\hline 11/ $\mathrm{s}$ & 158,688 & 899,232 & 105,792 & $\ldots \ldots \ldots$ & i & & & \\
\hline $11 / 12$ & 8999,232 & $2,644,800$ & 317,376 & ......... & & & & \\
\hline $11 / 15$ & 176,064 & $1,163,712$ & 317,376 & $\ldots \ldots \ldots \cdot \quad \cdots$ & & & & \\
\hline $11 / 19$ & 185,136 & 846,336 & , n.......... & … & & & & \\
\hline $11 / 22$ & $20(3,928$ & $925,+1.90$ & & $\ldots \ldots$ & & & & \\
\hline $11 / 26$ & $1.5,136$ & 370,272 & $1,(60)$ & $\ldots \ldots$ & & - & & \\
\hline $11 / 30$ & $15 \mathrm{~s}, \mathrm{fiSS}$ & $66 ; 1,200$ & 1,600 & $\ldots \ldots$ & & & & \\
\hline $12 / 3$ & 317,376 & $1 \$ 5,136$ & -.... & w. & 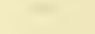 & .. & 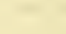 & 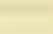 \\
\hline $12 / 6$ & 16,000 & $390,-720$ & $\therefore$ & $\ldots \ldots$ & & . & 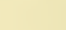 & \\
\hline $12 / 10$ & $19,, 336$ & 112,404 & & $\ldots .$. & & & .. & \\
\hline $12 / 14$ & $99,1 \leq 0$ & $211,5 \times 4$ & 13,224 & .. & & .. & .. & \\
\hline $12 / 17$ & 52,896 & 132,240 & 400 & $\ldots$ & & & $\therefore$ & \\
\hline $12: 20$ & (ifi, 120 & 178,528 & $26,4+4$ & 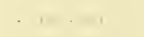 & 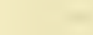 & & .. & . \\
\hline $12 / 24$ & 13,224 & $6 t i .120$ & 13,224 & $\ldots$ & & & $\cdots$ & \\
\hline $12 / 27$ & 20,445 & $99,1 \mathrm{SO}$ & 13,224 & ... & & & $\ldots$ & \\
\hline $12 / 31$ & $19,3,36$ & 132,240 & 19,836 & ....... & $\ldots$ & .. .. & $\ldots$ & \\
\hline
\end{tabular}


Table 1.-Organisms Per (ubic Meter in Plankton of Stockton Channel in 1913-(Continued)

\begin{tabular}{|c|c|c|c|c|c|c|}
\hline 1913 & $\begin{array}{l}\text { Total } \\
\text { Chlorophycese }\end{array}$ & $\begin{array}{c}\text { Asterionella } \\
\text { gracillima }\end{array}$ & $\begin{array}{l}\text { Asterionella } \\
\text { gracillima (large) }\end{array}$ & $\begin{array}{l}\text { Amphiprora } \\
\text { alata }\end{array}$ & $\begin{array}{c}\text { Bacillairia } \\
\text { paradoxa }\end{array}$ & $\begin{array}{l}\text { Cocconeis } \\
\text { pediculus }\end{array}$ \\
\hline $1 / 5$ & 19,836 & 707,484 & & & 6,612 & \\
\hline 1) $\mathrm{s}$ & 1,200 & 257,868 & $\ldots$ & &.$\ldots \ldots$ & $=$ \\
\hline $1 / 12$ & 100 & 525,960 & & & $\ldots$ & $\ldots$. \\
\hline $1 / 15$ & 1,600 & $2,254,692$ & 19,836 & & .. & \\
\hline $1 / 19$ & 2,800 & $4,350,696$ & 100 & 13,294 & & \\
\hline $1 / 22$ & 40,660 & 740,544 & & & 16,281 & \\
\hline $1 / 26$ & 14,024 & 238,032 & & & & \\
\hline $1 / 29$ & 21,036 & $\mathbf{1}, 071, \mathbf{1} 14$ & ................ & ................. & 1,600 & \\
\hline $2 / 2$ & 14,824 & $1,031,472$ & $\ldots \ldots$ & & 6,100 & \\
\hline $2 / 5$ & $32,4.48$ & 985,185 & (n.... & 13,224 & क & \\
\hline $2 / 8$ & 11,200 & $1,044,696$ & & & & \\
\hline $2 / 12$ & 13,600 & 251,256 & ............... & 52,896 & $\ldots$ & \\
\hline $2 / 15$ & 117,792 & $\$ 59,560$ & ................ & 26,418 & . & \\
\hline $2 / 19$ & $2+2,032$ & $1,097,592$ & $\ldots$ & 26,145 & . & \\
\hline $2 / 23$ & 93,368 & 370,272 & & 800 & . & \\
\hline $2 / 26$ & 219,584 & $4,496,616$ & a... & .. & . & 1,600 \\
\hline $3 / 1$ & $98,5+4$ & 528,960 & $\ldots$ & 3,200 & .. & \\
\hline $3 / 5$ & 96,944 & 290.925 & ....... & & .. & \\
\hline $3 / 5$ & 27,200 & 132,240 & ..... & . & . & \\
\hline $3 / 12$ & $6.5,896$ & & & & & \\
\hline $3 / 15$ & 169,040 & 370,272 & . & 1,600 & & \\
\hline $3 / 19$ & 279,250 & 132,240 & .. & 1,600 & . & \\
\hline $3 / 23$ & 224,354 & 185,136 & 6,612 & 1,600 & . & \\
\hline $3 / 26$ & 32,000 & $15 S, 6 S \mathrm{~S}$ & ......... & $\ldots$ & ..... & \\
\hline $3 / 29$ & 19,200 & 581,856 & $\ldots \ldots \ldots \ldots \ldots$ & & .... & \\
\hline $4 / 2$ & 28,800 & 79,344 & . . & & 3,200 & . \\
\hline $4 / 5$ & 196,336 & 105,792 & .- & 1,600 & 3,200 & \\
\hline 4/ 9 & 96,944 & 105,792 & $26, \pm 1 S$ & 1,600 & & \\
\hline $4 / 13$ & 25,600 & 16,000 & 1,600 & 1,600 & 3,200 & \\
\hline $4 / 16$ & 255,632 & 105,792 & ................ & $\ldots \ldots$ & & \\
\hline $4 / 19$ & 133,540 & 26,148 & .............. & .......... & . & \\
\hline $4 / 23$ & 375,072 & 132.240 & ................. & .......... & . & $\ldots$ \\
\hline $4 / 26$ & 290,080 & 132,240 & …............ & ....... & $\ldots$ & \\
\hline $4 / 30$ & 201,136 & $\cdots$. & 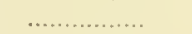 & 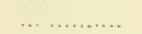 & .... & \\
\hline $5 / 3$ & 113,792 & 1,600 & ........ & i... & ..... & \\
\hline $5 / 7$ & 145,040 & 502,512 & & & .. & \\
\hline $5 / 11$ & 404,720 & 52,596 & 714,096 & 1,600 & ... & \\
\hline $5 / 14$ & 432,765 & 105,792 & 264,180 & ...... & $\ldots .$. & \\
\hline $5 / 17$ & 147,392 & 211,584 & 370,272 & ......... & $\ldots \ldots \ldots$ & \\
\hline $5 / 21$ & 713,248 & 211,584 & 3,200 & & ........ & \\
\hline $5 / 24$ & $1,873,760$ & 12,800 & & 3,200 & & \\
\hline $5 / 2 \vec{\imath}$ & $2,026,0+5$ & $158,6 \$ 8$ & 3,200 & $158,68 \mathrm{~s}$ & .. $\ldots \ldots \ldots \ldots$ & \\
\hline $5 / 31$ & $5,834,560$ & & & 3,200 & & \\
\hline 6) 3 & $5,829,-710$ & 158,688 & 3,200 & $\ldots, \ldots$ & & \\
\hline $6 / 7$ & $5,116,416$ & 105,792 & & . & & \\
\hline $6 / 11$ & $2,503,455$ & 211,584 & 105,792 & & & \\
\hline $6 / 16$ & $1,091,744$ & $423,16 \mathrm{~s}$ & 423.169 & 3,200 & & \\
\hline $6 / 18$ & $2,750,192$ & 528,960 & 476,064 & & & \\
\hline $6 / 21$ & $4,714,14 t$ & 423,168 & 264,180 & & & \\
\hline $6 / 25$ & $4,603,16 \mathrm{~S}$ & 476,064 & $1.5 \mathrm{~s}, 6 \mathrm{SS}$ & 105,792 & & \\
\hline $6 / 28$ & $4,399,968$ & 634,752 & 264,480 & 3,200 & & \\
\hline $7 / 3$ & $2,966,976$ & 105,792 & 3,200 & & & \\
\hline $7 / 5$ & $1,021,024$ & $\ldots \ldots \ldots$ & $\ldots \ldots \ldots \ldots \ldots$ & 3,200 & & ... \\
\hline $7 / 9$ & $2,131,5+0$ & $\ldots \ldots \ldots$ & …........... & & & \\
\hline $7 / 12$ & $2,138,232$ & .......... & .............. & 3,200 & & $\ldots$ \\
\hline $7 / 16$ & $3,080,768$ & ......... , & ................ & , & 12,800 & \\
\hline $7 / 19$ & $2,362,624$ & & …............. & 6,400 & 57,600 & .. $\quad \ldots$ \\
\hline $7 / 23$ & $1,811,264$ & & …, $+\ldots \ldots$ & & & . . . . . \\
\hline $7 / 26$ & $3,470,240$ & & 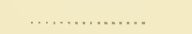 & 3,200 & $211,5 \mathrm{St}$ & .............. \\
\hline $7 / 30$ & $1,920,256$ & $\ldots \ldots$ & ,....... & 3,200 & & \\
\hline
\end{tabular}


Table 1.-Organisms Per Cubic Meter in PJankton of Stockton Channeid in 1913-(Continued)

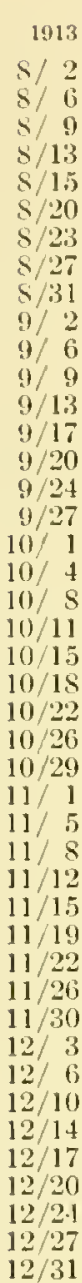

$$
\begin{gathered}
\text { Totnl } \\
\text { Chlorophycene } \\
1,710,872 \\
1,618,880 \\
1,612,480 \\
3,338,918 \\
1,702,272 \\
1,692,672 \\
3,024,672 \\
2,763,392 \\
2,538,988 \\
4,018,296 \\
4,922,528 \\
5,557,280 \\
6,410,016 \\
3,414,944 \\
3,085,784 \\
4,481,664 \\
3,880,6018 \\
5,137,312 \\
4,633,912 \\
4,667,636 \\
4,680,448 \\
3,755,616 \\
2,591,904 \\
3,312,352 \\
3,451,040 \\
5,324,496 \\
4,191,584 \\
5,526,784 \\
1,851,968 \\
5,211,856 \\
2,809,888 \\
1,441,592 \\
1,674,976 \\
866,285 \\
1,009,824 \\
746,944 \\
491,216 \\
213,584 \\
372,272 \\
239,632 \\
331,800 \\
121,016 \\
299,140 \\
2990,928 \\
\end{gathered}
$$

Cyclotella epp.

257,868

] 06,592

$1 / 5$

$1 / 12$

$1 / 15$

$1 / 19$

$1 / 22$

$1 / 20$

317,376

793,440

$1,573,656$

449,616

201,972

257,868

158,688

357,048

$$
3,200
$$$$
\text { alata }
$$

Bacillairi

$$
32000
$$$$
3,200
$$

$(i, 400$

12,800

$10.5,792$

25,600

105, 792

25,600

$(6,4) 0$

3,200

3,200

105,792

$52,8.16$

6,400

$6,4(1)$

52,896

6,400

52,896

52,896

12.800

32,000

6,400

52,896

6,400

6,400

105,792

52,896

12,800

52,896

105, 792

52,896

158,688

$\ldots$.
79,344
3,200

$1,507,536$
$1,401,744$
614,916
199,360
185,136
105,792
85,956
59,508
19,836

1,600

79,344
9,600
1,600
1,600
52,896
390,108
400
$\ldots . . . \ldots . .$.

1.600

52,896

9,600

6,400

1,600

52,896

$396 \pi 2 \quad 10830$

13,224

$26,44 \mathrm{~S}$

13.224

33,060

Corcone is pediculus

$2 / 2$

2/ $\mathrm{S}$

304,152
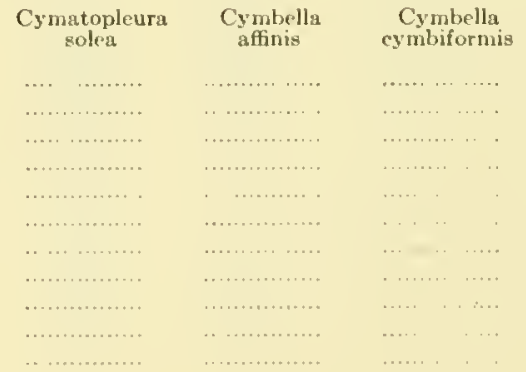

Cymbella

Cymbella sp. 
Table 1.-Organisms Per Cubic Meter in Plankton of Stockton Channel IN 1913-(Continued)

\begin{tabular}{|c|c|c|c|c|c|c|}
\hline 1913 & $\begin{array}{l}\text { Cyclotella } \\
\text { spp. }\end{array}$ & $\begin{array}{c}\text { Cymatopleura } \\
\text { solea }\end{array}$ & $\begin{array}{l}\text { Cymbella } \\
\text { affinis }\end{array}$ & $\begin{array}{c}\text { Cymbella } \\
\text { cymbiformis }\end{array}$ & $\begin{array}{c}\text { Cymbella } \\
\text { parva }\end{array}$ & $\begin{array}{l}\text { Cymbella } \\
\text { sp. }\end{array}$ \\
\hline $2 / 12$ & 740,544 & & & 1,600 & & \\
\hline $2 / 15$ & $1,150,488$ & & & & & 800 \\
\hline $2 / 19$ & $1,401,744$ & ...... & ....... & 1,600 & & \\
\hline $2 / 23$ & 886,008 & & ...... & ............. & ... & \\
\hline $2 / 26$ & $3,570,180$ & ....... & ....... & $\ldots \ldots$ & ... & 3,200 \\
\hline $3 / 1$ & $5,210,256$ & & & & .... & \\
\hline $3 / 5$ & $5,659,872$ & 3,200 & & & & \\
\hline $3 / 8$ & $1,613,32 \mathrm{~s}$ & ........ & 1,600 & 3,200 & $\ldots$. & \\
\hline $3 / 12$ & $2,697,696$ & ................. & ................. & ........... & & \\
\hline $3 / 15$ & $1,110,816$ & .............. & ……........ & ................. & ............... & \\
\hline $3 / 19$ & $2,168,736$ & .................. & ................... & & & \\
\hline $3 / 23$ & $2,724,144$ & ............... & ......... & 3,200 & ... & 1,600 \\
\hline $3 / 26$ & $1,163,712$ & …............. & .......... & ........... & ... & \\
\hline $3 / 29$ & 925,680 & ................ & .......... & ............ & & \\
\hline $4 / 2$ & 925,680 & ................. & & & 3,200 & \\
\hline $1 / 5$ & $2,459,664$ & ................ & ................ & .......... & 1,600 & \\
\hline $4 / 9$ & $6,162,384$ & & .......... & .............. & ... & \\
\hline $4 / 13$ & $3,570,480$ & 3,200 & ........ & ............ & ..... & \\
\hline $4 / 16$ & $9,151,008$ & ................. & & & & \\
\hline $4 / 19$ & $10,684,992$ & ............... & .......... & $\ldots, 3, \ldots$ & .... & \\
\hline $4 / 23$ & $15,172,080$ & …............. & ........... & …..... & ....... & \\
\hline $4 / 26$ & $15,286,944$ & ................... & ........... & ........... & .......... & \\
\hline $1 / 30$ & $18,116,880$ & ……........ & .......... & & . & \\
\hline $5 / 3$ & $20,391,408$ & ……........ & ......... & 3,200 & & \\
\hline $5 / 7$ & $19,597,968$ & ............... & ent & ........... & ..... & \\
\hline $5 / 11$ & $32,610,384$ & .................. & 1,600 & ............ & …............. & \\
\hline $5 / 14$ & $60,248,541$ & …, $\ldots \ldots \ldots$ & $\ldots \ldots \ldots$ & ... & .... & \\
\hline $5 / 17$ & $43,216,032$ & .................. & ........... & .......... & .... & \\
\hline $5 / 21$ & $36,022,176$ & ................... & .......... & ........... & .... & \\
\hline $5 / 24$ & $35,704,800$ & ................ & …....... & n........ & . & \\
\hline $5 / 27$ & $54,482,880$ & ................. & -1 & .......... & ............... & \\
\hline $5 / 31$ & $53,001,792$ & ….............. & 3,200 & ........... & .............. & \\
\hline $6 / 3$ & $57,286,368$ & ...,......... & $\ldots . .$. & $\ldots$ & .... & \\
\hline $6 / 7$ & $60,195,648$ & ….......... & & & $\ldots$ & \\
\hline $6 / 11$ & $59,349,312$ & .................. & 105,792 & 3,200 & & \\
\hline $6 / 16$ & $38,508,288$ & & $\ldots \ldots$ & $\ldots$ & & 3,200 \\
\hline $6 / 18$ & $42,475,488$ & & ... & .......... & ....... & \\
\hline $6 / 21$ & $34,646,880$ & ............... & ............... & ................ & …........... & \\
\hline $6 / 25$ & $36,974,304$ & ............... & ............ & & & \\
\hline $6 / 28$ & $51,362,016$ & .............. & ........... & 6,400 & …............... & \\
\hline $7 / 3$ & $35,175,840$ & ……........... & ………... & ............. & …............ & \\
\hline $7 / 5$ & $14,2 S 1,920$ & $\ldots \ldots \ldots \ldots \ldots \ldots$ & …........... & $\ldots \ldots \ldots \ldots \ldots$ & . ............. & \\
\hline $7 / 9$ & $12,324,768$ & 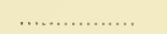 & …........... & & 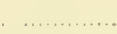 & \\
\hline $7 / 12$ & $16,768,032$ & ,............. & ................ & $\ldots \ldots \ldots$ & $\ldots \ldots \ldots \ldots \ldots \ldots$ & \\
\hline $7 / 16$ & $45,755,010$ & …............ & …............. & ............... & $\ldots$ & \\
\hline $7 / 19$ & $24,279,264$ & & & & & \\
\hline $7 / 23$ & $11,742,912$ & …............ & & 6,400 & $\begin{array}{lll}\ldots . & \ldots \ldots\end{array}$ & \\
\hline $7 / 26$ & $17,349,888$ & .................. & 3,200 & $\ldots \ldots$ & . . ................. & \\
\hline $7 / 30$ & $15,168,800$ & ................ & $\ldots$ & $\ldots$ & . . ......... . & \\
\hline $8 / 2$ & $14,916,672$ & n............. & $\ldots \ldots \ldots, \ldots$ & .......... & .... & \\
\hline$S / 6$ & $9,838,656$ & 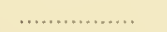 & .......... & $\ldots \ldots$ & $\cdots \cdot$ & \\
\hline $8 / 9$ & $10,790,781$ & $\ldots \ldots \ldots \ldots \ldots \ldots$ & .......... & .......... & $\cdots$ & \\
\hline $8 / 13$ & $14,229,024$ & ... & ............ & ....... & & \\
\hline $8 / 15$ & $6,770,688$ & 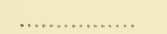 & (n) & . & & \\
\hline $8 / 20$ & $12,113,184$ & …........... & .............. & ... ...... & & \\
\hline $8 / 23$ & $14,440,608$ & …….......... & ........... & ........ & $\ldots$ & \\
\hline $8 / 27$ & $20,047,584$ & …............... & …................. & $\cdots$ & & \\
\hline $8 / 31$ & $21,895,944$ & ….......... & ……...... & ....... & ... & \\
\hline $9 / 2$ & $12,166,080$ & .................. & .................. & ................... & & \\
\hline $9 / 6$ & $12,166,080$ & 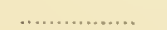 & , $\ldots \ldots \ldots \ldots, \ldots$ & n................ & & \\
\hline
\end{tabular}




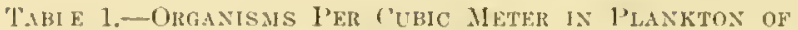
STOCKTON ('HANNEl, I. 1913-(Continued)

1913

() 9

9/1:3

9) 17

() $/ 20$

() $12+\frac{1}{2}$

$9 / 27$

10) 1

10/ 4

$10 / 8$

$10 / 11$

10/15

$10 / 1 \mathrm{~s}$

$10 / 22$

$10 / 26$

$10 / 29$

11/1

$11 / 5$

$11 / 8$

11/12

$11 / 15$

$11 / 19$

$11 / 22$

$11 / 26$

$11 / 30$

$12 / 3$

12 f

$12 / 10$

$12 / 11$

$12 / 17$

$12 / 20$

$12 / 24$

$12 / 27$

$12 / 31$

1913

$1 / 5$

$1 / \mathrm{S}$

$1 / 12$

$1 / 1.5$

$1 / 1 !$

$1 / 22$

126

$1 / 29$

$2 / 2$

2) 5

2/ 8

$2 / 12$

$2 / 15$

$2 / 19$

$2 / 23$

$2 / 26$

$3 / 1$

35

$3 / \mathrm{S}$

$3 / 12$

315

$3 / 19$$$
\text { C }
$$

Cymatoplenra
soles

Cymbella

Cymbelln

Cymbella

Cymbella

12., 160,080

15), 129,256

$1-1,-193,50-1$

$13,060.5,312$

$14,757.354$

$1 ! 1,677,312$

$21,6,57,360$

$12,695,040$

$18,090,432$

$22,851,072$

$20,785,128$

$25,866,144$

28, 246,464

$34,276,608$

$31,853,392$

] $2,5,59,248$

9. 208,904

$7,77.5,712$

11. 240,400

$7,722,816$

$7,061,616$

$7,697,96 \mathrm{~s}$

$6,692,944$

$6,876,180$

$6,955,524$

$4,522,608$

$1,970,376$

$2,281,140$

$2,499,336$

$2,737,36 \mathrm{~s}$

$1,243,128$

$2.576,220$

$1,835,136$

Cymbella

tumida

Diaton

unidentified

\section{Diatoms}

vulgare

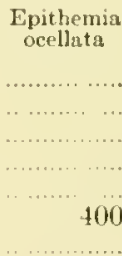

$+00$

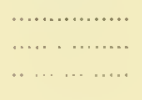

400

100
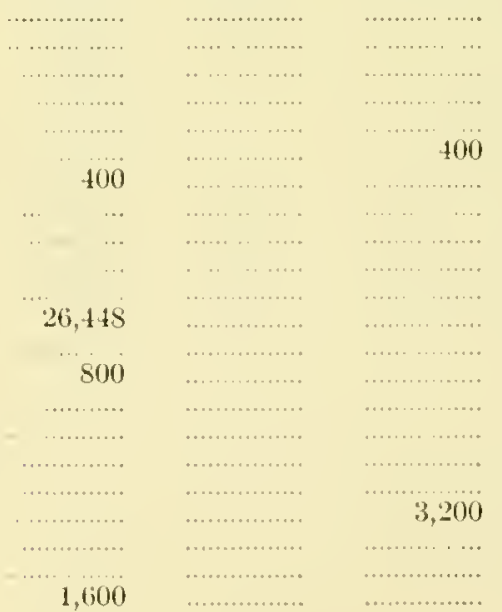
eapucina

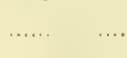

0.100

6. 400

3.200

800

800

$\$ 00$

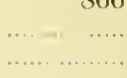

Fragillaria crotonensis

................

800

$\$ 00$

$\$ 00$

$26,+15$

800

\$00

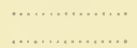

1,600

1,600

$\$ 00$

1,600

3,200

...............

3,200

6,400

1,600 
Table 1.-Organisms Per Cubic Meter in Plankton of STOCKTON ChaNNEL IN 1913-(Continued)

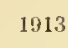

$3 / 23$

$3 / 26$

$3 / 29$

$4 / 2$

$4 / 5$

$4 / 9$

$4 / 13$

$4 / 16$

$4 / 19$

$4 / 23$

$4 / 26$

$4 / 30$

5/ 3

$5 / 7$

$5 / 11$

$5 / 14$

$5 / 17$

$5 / 21$

$5 / 24$

$5 / 27$

$5 / 31$

6/ 3

$6 / 7$

6.11

$6 / 16$

$6 / 18$

$6 / 21$

$6 / 25$

$6 / 28$

7. 3

7/ 5

7/ 9

$\frac{7}{7 / 16}$

$7 / 19$

$7 / 23$

$7 / 26$

$7 / 30$

8/ 2

S/ 6

8/ 9

$8 / 13$

$\mathrm{S} / 15$

$8 / 20$

$8 / 23$

S/27

$8 / 31$

$9 / 2$

$9 / 6$

$9 / 9$

$9 / 13$

$9 / 17$

$9 / 20$

$9 / 24$

$9 / 27$

$10 / 1$

$10 / 4$

$10 / 8$

$10 / 11$

$10 / 15$

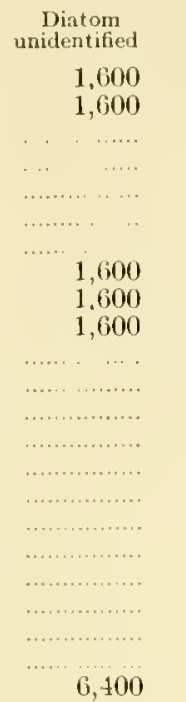

Diatoma

Epithemia

Cymbel
tumida

3,200

.........

3,200

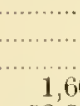

52,890

6,400

25,200
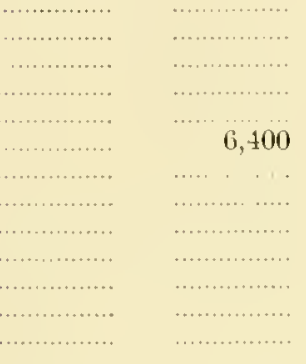

6,400

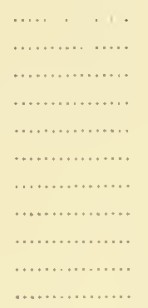

3,200

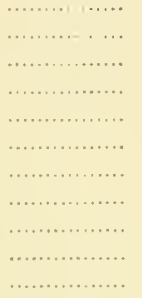

6,400
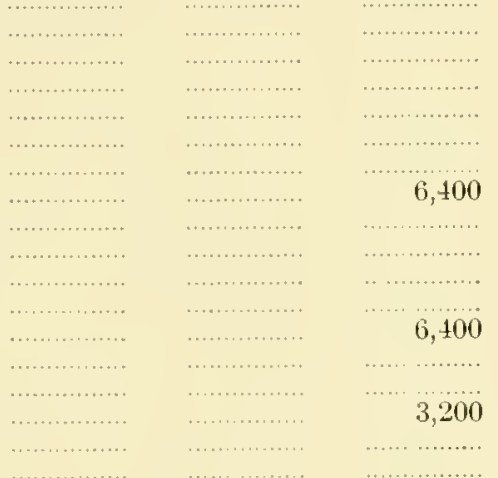

$$
3,200
$$
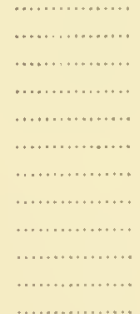

105,792

105,792
6,400

$6, \pm 00$
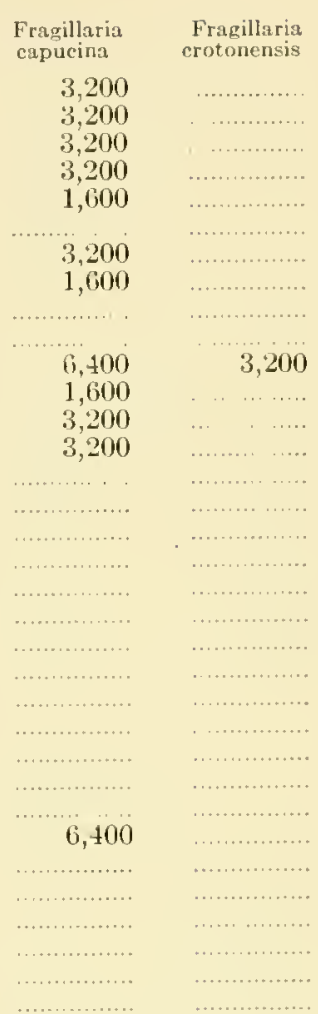

$6, \pm 00$

6,100

3,200

12,800

6,100

3,200

6,400

6,400

6,400

3,200

6,400

6,400 
Table 1.-ORganisMS 1'kR CUBIC Meter IN Plankton of Stocktos ('hasinel IN 1913-(Continued)

1913
$10 / 15$
$10 / 22$
$10 / 26$
$10 / 29$
$11 / 1$
$11 / 5$
$11 / 8$
$11 / 12$
$11 / 15$
$11 / 19$
$11 / 22$
$11 / 26$
$11 / 30$
$12 / 3$
$12 / 6$
$12 / 10$
$12 / 14$
$12 / 17$
$12 / 20$
$12 / 24$
$12 / 27$
$12 / 31$

Cymbella
turuida

Diaton
unidentified

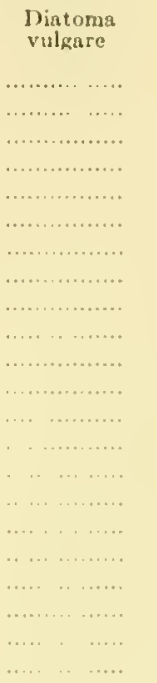

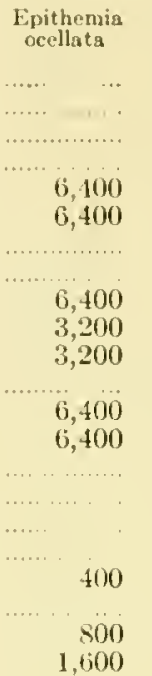

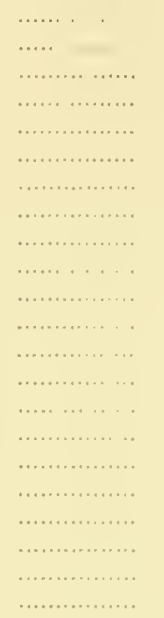

Fragillaria capucina

Frapillaria ..................

$$
6,400
$$

6,400

1,600

1,600

800

1,600

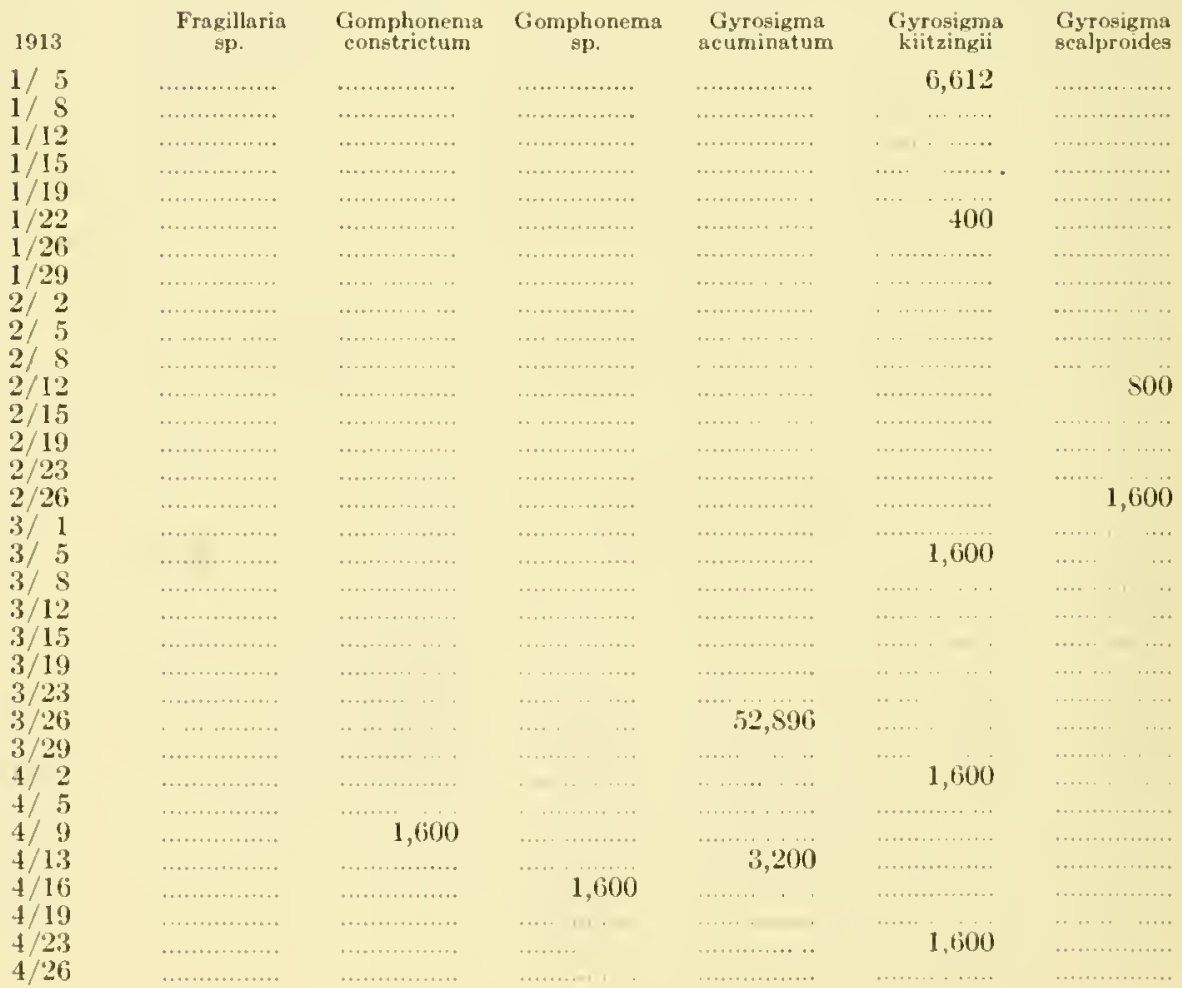


Table 1.-ORganis Stockton ChanNeI 1N 1913-(Contimed)

\begin{tabular}{|c|c|c|c|c|c|c|}
\hline 1913 & $\begin{array}{l}\text { Fragillaria } \\
\text { sp. }\end{array}$ & $\begin{array}{c}\text { Gomphonema } \\
\text { constrictum }\end{array}$ & $\begin{array}{c}\text { Gomphonema } \\
\text { sp. }\end{array}$ & $\begin{array}{l}\text { Gyrosigma } \\
\text { acuminatum }\end{array}$ & $\begin{array}{c}\text { Gyrosigma } \\
\text { kiitzingii }\end{array}$ & $\begin{array}{l}\text { Gyrosigma } \\
\text { sealproides }\end{array}$ \\
\hline $4 / 30$ & .... & ..... & ... & .... & ...... & \\
\hline $5 / 3$ & $\ldots$ & (n.............. & $\cdots \cdot$ & $\ldots \ldots$ & & \\
\hline $5 / 7$ & ............... & ............... & ... & & 1,600 & \\
\hline $5 / 11$ & ............... & , $\ldots \ldots \ldots \ldots, \ldots$ & ........ & $\ldots \ldots \ldots, \ldots$ & 52,896 & (................ \\
\hline $\begin{array}{l}5 / 14 \\
5 / 17\end{array}$ & 6,400 & $\begin{array}{l}\ldots \\
\ldots\end{array}$ & & , & 3,200 & \\
\hline $5 / 21$ & & & & & . & \\
\hline $5 / 24$ & $\ldots$ & ....... & ..... & $\ldots \ldots$ & ............ & 3,200 \\
\hline $5 / 27$ & ... & .. & & & & .. \\
\hline $5 / 31$ & (n............ & (n.............. & …............ & 3,200 & $\ldots \ldots+\ldots \ldots \ldots$ & ............... \\
\hline $6 / 3$ & (................. & ................ & ................. & ….... $\quad \ldots$ & …........ & ... \\
\hline $6 / 7$ & …............ & $\ldots \ldots \ldots \ldots, \cdots$ & 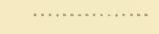 & $\ldots \ldots, \quad \ldots$ & , n....... & ......... \\
\hline $\begin{array}{l}6 / 11 \\
6 / 16\end{array}$ & ............, & ………... & …............ & . & ........... & ................. \\
\hline $6 / 18$ & ………1........ & $\cdots$ & …..... & $\ldots \ldots+\cdots$ & .......... & ; \\
\hline $6 / 21$ & ……………… & ….... & ………… & ……............. & (n............ & …… \\
\hline $6 / 25$ & ................ & n............ & ............... & $\ldots \ldots \ldots \ldots \ldots$ & ......... & 3,200 \\
\hline $6 / 28$ & ................ & ................ & ......... & ....... & .......... & ........ \\
\hline $7 / 3$ & n............... & ............... & n.............. & ................ & 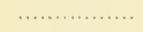 & ................. \\
\hline 7) 5 & n....., & 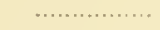 & n............... & ………, & 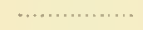 & . \\
\hline $7 / 9$ & …............... & ............... & (............... & …............ & ….......... & n............. \\
\hline $7 / 12$ & . & ………, & ................ & 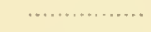 & .......... & $\ldots \ldots$ \\
\hline $7 / 16$ & n............. & …, & $\ldots \ldots \ldots$ & .......... & ........... & , $\ldots \ldots \ldots \ldots \ldots$ \\
\hline $\begin{array}{l}7 / 19 \\
7 / 23\end{array}$ & ………… & 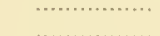 & (n)....... & . & 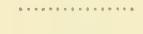 & .................... \\
\hline $7 / 26$ & …….......... & 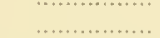 & 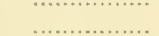 & ………......... & 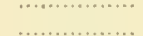 & ............. \\
\hline $7 / 30$ & n............. & ............... & …............. & & (2) & \\
\hline $8 / 2$ & . & ............... & ....... & ................ & 25,600 & \\
\hline $8 / 6$ & ................. & .............. & n........ & …... & 11. & \\
\hline $8 / 9$ & .............. & .............. & $\ldots \ldots$ & ….......... & $\ldots$. & 3,200 \\
\hline $8 / 13$ & ......... & 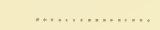 & $\ldots \ldots$ & ........... & $\ldots \ldots, \ldots \ldots \ldots$ & 158,688 \\
\hline $8 / 15$ & $\cdots$ & & $\ldots$ & 6,400 & $\ldots \ldots \quad \ldots \ldots$ & 264,480 \\
\hline $8 / 20$ & ................. & ............... & $\ldots \ldots$ & .......... & & 3,200 \\
\hline $8 / 23$ & & & .. & .......... & 3,200 & 6,400 \\
\hline $8 / 27$ & ................. & ........., & ........ & ....... & & 158,688 \\
\hline $\mathrm{S} / 31$ & & .................. & ......... & ................ & 3,200 & 105,792 \\
\hline $9 / 2$ & 3,200 & .... & ... & & & 158,685 \\
\hline $9 / 6$ & …............. & .... & .. & 6,400 & 105,792 & 12,800 \\
\hline $9 / 9$ & ............... & ...... & .... & ... & 6,400 & . \\
\hline $9 / 13$ & …............ & & .. & $\ldots \ldots$ & 6,400 & 6,400 \\
\hline $9 / 17$ & ….......... & 3,200 & & $\ldots \ldots, \ldots+\ldots$ & ..... & 6,400 \\
\hline $9 / 20$ & ................ & ....... , i & …. & $\ldots \ldots$ & ․ & 105,792 \\
\hline $9 / 24$ & & …. & (........ & .. ....., $\ldots$ & ... & $10.5,792$ \\
\hline $9 / 27$ & ............. & ........ & & & & 52,896 \\
\hline $10 / 1$ & …… & 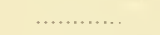 & ... & 52,896 & & \\
\hline $10 / 4$ & …........... & & ... & .............. & 25,600 & \\
\hline $10 / 8$ & ............... & 52,896 & $\ldots$ & ................. & 12,800 & ..... \\
\hline $5 / 11$ & .......... & & 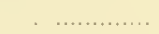 & $\ldots \ldots$ & 6,400 & 6,400 \\
\hline $10 / 15$ & ........ & 52,896 & , .............. & .... & $\ldots \ldots$ & 105,792 \\
\hline $10 / 18$ & …......... & $\ldots \ldots, \quad \ldots$. & ...... & $\ldots$ & $\ldots \ldots$ & 105,792 \\
\hline $1 / 22$ & ............... & $\ldots \ldots \ldots \ldots$ & $\ldots .$. & ....... & 12,800 & $\ldots, \quad, \ldots \ldots, \ldots$ \\
\hline $10 / 26$ & ................ & …..... & & & 12,800 & \\
\hline $10 / 29$ & 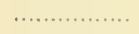 & $\cdots$ & $1, \ldots \ldots \ldots \ldots$ & n........ & n............... & \\
\hline $11 / 1$ & , $\ldots \ldots, \ldots, \ldots, \ldots$ & …. & 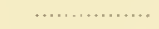 & ........... & n.w. & $\ldots \ldots$ \\
\hline $\begin{array}{l}5 \\
8\end{array}$ & .................. & 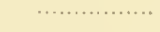 & 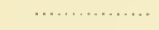 & , n...... & & \\
\hline 12 & & & & & 52,890 & \\
\hline 15 & ………… & …………...... & . & …...... & …................ & \\
\hline 19 & ……, & ................ & 3,200 & ... & $\cdots$ & \\
\hline & n............. & ............... & $\ldots \ldots \ldots \ldots \ldots \ldots$ & ................. & 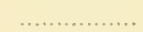 & , $\ldots \ldots \ldots \ldots \ldots$, \\
\hline
\end{tabular}




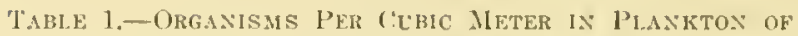
STOCKTON ('HANEL IN 1913-(Continued)

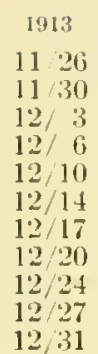

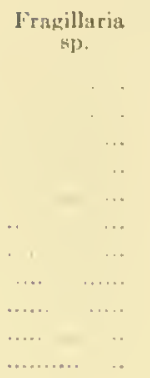

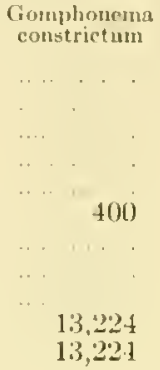

$$
\begin{aligned}
& \text { Gomphonema } \\
& \text { sp. }
\end{aligned}
$$

Gyrosigna
acuninatum

Cyrosigma kiitzingii

1,600

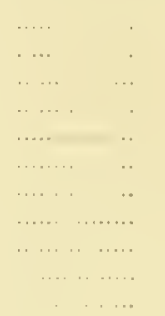

1,600 3,200

G.yrosigma scalproides

1913

$1 / 5$

1/ 8

$1 / 12$

$1 / 15$

$1 / 19$

$1 / 22$

$1 / 29$

$2 / 2$

2) 5

$2 / 5$
$2 / 12$

2/12

$2 / 19$

$2 / 23$

$2 / 26$

$3 / 1$

$3 / 5$

$3 / 8$

$3 / 12$

$3 / 15$

$3 / 19$

$3 / 23$

$3 / 26$

$3 / 29$

$4 / 2$

$4 / 5$
$4 \quad 9$

4/ 13

$4 / 16$

$+19$

$+/ 23$

$4 / 26$

$4 / 30$

$5 / 3$

$5 / 7$

$5 / 11$

$5 / 14$

$5 / 17$

$5 / 21$

$5 / 24$

$5 / 27$

$5 / 31$

6) 3

Melosira \\ granulata}

19,836

26,448

2,400

13,224

$20,4+5$

33,060

$125,6 \mathrm{i} \mathrm{s}$

72,732

204,972

132,240

145,464

304,152

$5+2,184$

119,016

476,064

343,824

132.240

264,480

158,688

793,440

$1,031,472$

793,440

476,064

502,512

502,512

132,240

$6.34,752$

$9.52,128$

572,781

528,960

$2,27,5,528$

$3,702,720$

449,616

449,616

343,824

343,824

$5 \$ 1, \$ 56$

$1,269,504$

$1,163,712$

$1,005,024$

$1,375,296$

317,376

634,752

\begin{tabular}{|c|c|c|}
\hline \multirow{2}{*}{$\begin{array}{c}\text { Melosira } \\
\text { granulata A } \\
\text { (small) }\end{array}$} & $\begin{array}{c}\text { Melosira } \\
\text { varians }\end{array}$ & $\begin{array}{c}\text { Nevicula } \\
\text { affinis }\end{array}$ \\
\hline & 26,448 & $-1,-1,1=1$ \\
\hline$\ldots \quad \ldots$ & - & - \\
\hline$\ldots \ldots, \ldots, \cdot$ & .. & $\cdots$ \\
\hline$\ldots \ldots \ldots \ldots$ & & .. \\
\hline .......... & 2,800 & .. \\
\hline$\ldots$ & 800 & $\ldots$. \\
\hline ……...... & 800 & $\ldots$ \\
\hline …......... & & $\cdots \cdots$ \\
\hline .............. & 400 & .... \\
\hline …, & 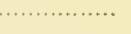 & 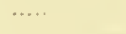 \\
\hline$\ldots \ldots \ldots$ & $\cdots \cdots$ & $\cdots$ \\
\hline ............. & 3,200 & $1,1,0$ \\
\hline .. & 26,748 & \\
\hline …........ & 3,200 & \\
\hline …......... & 3.200 & $\cdots$ \\
\hline …….... & 3,200 & \\
\hline$\cdots \cdots \cdots$ & 6.100 & $\cdots$ \\
\hline ….......... & 79,311 & \\
\hline & 6,400 & \\
\hline 185.136 & 3,200 & \\
\hline 317,376 & 9,600 & ...... \\
\hline $211,58 t$ & 132,240 & \\
\hline . & $1,6,00$ & \\
\hline ... & 52,896 & ... \\
\hline & 6,400 & \\
\hline $316,3,6$ & ... & \\
\hline 238,032 & $1.60 t)$ & $\cdots$ \\
\hline 1,600 & 9,600 & \\
\hline 52,896 & & \\
\hline 1,600 & 3,200 & $\cdots$ \\
\hline & 3,200 & \\
\hline $\begin{array}{l}211,0 \mathrm{t} t \\
15 \mathrm{~S}, 6 \mathrm{~S}\end{array}$ & 6,400 & \\
\hline & 3,200 & \\
\hline 105,792 & 3,200 & ..... \\
\hline 317,376 & ... $\quad$. & n.... \\
\hline 105,792 & .. $\ldots \ldots$ & ........ . \\
\hline $105,79^{\circ}$ & n...... & ......... \\
\hline
\end{tabular}

$1,322,400$ alpestris

Navicula bacillum

52,596

1, 600

52,896

52,896

1,600

1,600

1,600

800

100

$13,22 \cdot 1$

$19,8.36$

13,224

$\$ 00$

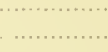

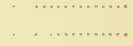

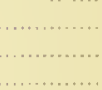

…….....

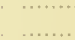

$1,600 \quad 52,896$

$1,600 \quad 52,596$

$1,600 \quad 1,600$

$52,896 \quad 105,792$

105,792

$3,200 \quad 105,792$

3,200

$211,5 \$ 4$

$\begin{array}{ll}3,200 & 158,658 \\ & 105,792\end{array}$ 
Table 1.-Organisis Per Cubic Miter in Plankton of Stockton Channel IN 1913-(Continued)

\begin{tabular}{|c|c|c|c|c|c|c|}
\hline 1913 & $\begin{array}{c}\text { Melosira } \\
\text { granulata }\end{array}$ & $\underset{\text { granulata }}{\text { Melosira }}$ & $\begin{array}{c}\text { Melosira } \\
\text { varians }\end{array}$ & $\begin{array}{l}\text { Navicula } \\
\text { affinis }\end{array}$ & $\begin{array}{l}\text { Navicula } \\
\text { alpestris }\end{array}$ & $\begin{array}{l}\text { Navicula } \\
\text { bacill um }\end{array}$ \\
\hline $6 / 7$ & 528,960 & (smain) & .. & & 3,200 & \\
\hline $6 / 11$ & 370,272 & $\ldots .$. & .. & $\ldots$ & & 211,584 \\
\hline $6 / 16$ & $1,322,400$ & $\ldots$ & $\ldots$ & ..... & $\ldots$ & $26 \cdot 1,450$ \\
\hline $6 / 18$ & $1,375,296$ & $\ldots$ & .. & & & 211,584 \\
\hline $6 / 21$ & 634,752 & ...... & $\ldots$ & ........ & 6,400 & \\
\hline $6 / 25$ & $2,062,944$ & & & & & 3,200 \\
\hline $6 / 28$ & $7,617,024$ & & 6,400 & & $\ldots \ldots \ldots$ & 158,688 \\
\hline $7 / 3$ & $3,067,968$ & ...... & 6,400 & & …...... $\quad \ldots$ & 3,200 \\
\hline $7 / 5$ & $1,005,024$ & ................ & .............. & …............. & $\ldots \ldots \cdot \ldots$ & 3,200 \\
\hline $7 / 9$ & $1,481,088$ & & $\ldots \ldots \ldots$ & & . . $\quad \ldots$ & \\
\hline $7 / 12$ & $2,697,696$ & & .......... & & $\ldots \ldots \ldots$ & 3,200 \\
\hline $7 / 16$ & $1,586,880$ & $\ldots .$. & .............. & ....... & & 105,792 \\
\hline $7 / 19$ & $2,168,736$ & & ........ & & $\ldots \ldots, \ldots$ & …............. \\
\hline $7 / 23$ & $1,428,192$ & ….......... & $\ldots \ldots \ldots \ldots$ & $\ldots \ldots$ & ..... $\quad \ldots$ & ….......... \\
\hline $7 / 26$ & $2,962,176$ & …..... & $\ldots$ & ..... & $\ldots \ldots$ & \\
\hline $7 / 30$ & $2,539,008$ & & & & $\ldots \ldots \ldots$ & \\
\hline $8 / 2$ & $3,914,304$ & $\ldots$. & $\ldots \ldots$ & & $\ldots \ldots \ldots \ldots$ & 3,200 \\
\hline $8 / 6$ & $3,355,344$ & ..... & ........... & & $\ldots \ldots . \quad \ldots$ & 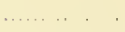 \\
\hline S/ 9 & $4,972,224$ & & & & & \\
\hline $8 / 13$ & $10,314,720$ & ...... & $\ldots \ldots$. & 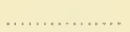 & 3,200 & 105,792 \\
\hline $\mathrm{S} / 15$ & $10,103,136$ & ........ & (n) & $\ldots \ldots \ldots \ldots$ & 3,200 & 3,200 \\
\hline $8 / 20$ & $5,342,496$ & ........ & & & 6,400 & 158.688 \\
\hline $\mathrm{s} / 23$ & $4,760,640$ & ............. & ............. & $\ldots \ldots$ & $\ldots$. & 211,584 \\
\hline $8 / 27$ & $6,083,0.10$ & ........ & & & ......... & 105,792 \\
\hline $8 / 31$ & $8,357,568$ & ...... & & & $\ldots$. & 3,200 \\
\hline $9 / 2$ & $7,828,608$ & $\ldots \ldots$ & ......... & & $\ldots \ldots \ldots \ldots$ & 211,584 \\
\hline $9 / 6$ & $16,556,44 \mathrm{~S}$ & ....... & ........... & & …............. & 158,688 \\
\hline $9 / 9$ & $10,420,512$ & $\ldots$. & & & & 264,480 \\
\hline $9 / 13$ & $5,025,120$ & ....... & ......... & ................. & .............. & 370,272 \\
\hline $9 / 17$ & $5,251,776$ & ....... & ......... & $\ldots$ & ……… & 105,792 \\
\hline $9 / 20$ & $8,410,464$ & ..... & & & & 105,792 \\
\hline $9 / 24$ & $15,604,320$ & ..... & ......... & 52,896 & 105,792 & 105,792 \\
\hline $9 / 27$ & $5,183,808$ & & & & & 264,480 \\
\hline $10 / 1$ & $8,145,984$ & ..... & & & 6,400 & 264,480 \\
\hline $10 / 4$ & $5,236,704$ & & & & & 52,896 \\
\hline $10 / S$ & $S, 040,192$ & ..... & & & 52,896 & 52,896 \\
\hline $10 / 11$ & $5,289,600$ & ........ & 6,400 & & 105,792 & \\
\hline $10 / 1.5$ & $7,828,608$ & & ......... & & 6,400 & 264,480 \\
\hline $10 / 18$ & $4,601,952$ & ....... & ........ & ..... & 52,896 & 158,688 \\
\hline $10 / 22$ & $4,654,848$ & $\ldots \ldots$ & $\ldots \ldots .$. & & & \\
\hline $10 / 26$ & $3,544,032$ & ..... & ....... & & 52,896 & 52,896 \\
\hline $10 / 29$ & $2,750,592$ & & & & 52,896 & 211,584 \\
\hline $11 / 1$ & $2,010,048$ & $\ldots$ & ......... & .. & & \\
\hline $11 / 5$ & $1,798,464$ & $\ldots$ & & & 52,896 & 52,896 \\
\hline $11 / \mathrm{s}$ & $\$ 99.232$ & ....... & ........ & ....... & ........ & 264,480 \\
\hline $11 / 12$ & $1,137,264$ & …….......... & $\ldots \ldots \ldots$ & $\ldots \ldots$ & ........... & 1,600 \\
\hline $11 / 15$ & $1,005,024$ & ….............. & & & ........... & 105,792 \\
\hline $11 / 19$ & 740,544 & ……… & ........... & ........ & .............. & 52,896 \\
\hline $11 / 22$ & 978,576 & .................... & & & & 52,896 \\
\hline $11 / 26$ & $1,137,264$ & ......... & $\cdots$ & & & \\
\hline $11 / 30$ & $1,084,368$ & 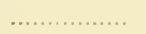 & & .. & 1,600 & 52,896 \\
\hline $12 / 3$ & $1,745,568$ & ............. & 3,200 & ...... & & 1,600 \\
\hline $12 / 6$ & $1,057,920$ & & & & 1,600 & \\
\hline $12 / 10$ & 350,436 & ....... & 2,400 & .... $>$ & & 33,060 \\
\hline $12 / 14$ & 257,868 & …….......... & 400 & & 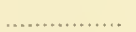 & 400 \\
\hline $12 / 17$ & 337,212 & & & & & 33,060 \\
\hline $12 / 20$ & 370,272 & & 800 & & 400 & 19,836 \\
\hline $12 / 24$ & 271,092 & & $\$ 00$ & ...... & 800 & 39,672 \\
\hline $12 / 27$ & 588,468 & & 26,448 & & 400 & \\
\hline $12 / 31$ & 925,683 & …… & 33,060 & ....... & 13,224 & 46,284 \\
\hline
\end{tabular}


Table 1.-ORganisms P'er Cubic Meter in Plankton of StockTon ChaNel in 1913-(Continued)

\begin{tabular}{|c|c|c|c|c|c|c|}
\hline 1913 & $\begin{array}{l}\text { Navicula } \\
\text { dubia }\end{array}$ & $\begin{array}{c}\text { Navicula } \\
\text { gracilis }\end{array}$ & $\begin{array}{c}\text { Navicula } \\
\text { sp. }\end{array}$ & $\begin{array}{c}\text { Navicula } \\
\text { viridis }\end{array}$ & $\begin{array}{l}\text { Nitzschia } \\
\text { acicularis }\end{array}$ & $\begin{array}{l}\text { Nitzschia } \\
\text { angularis }\end{array}$ \\
\hline $1 / 5$ & & & -. & & & \\
\hline $1 / 8$ & .... & .. ........ & & & 400 & \\
\hline $1 / 12$ & n.......... . & . . . ........... & 400 & & & .. \\
\hline $1 / 15$ & ……..... : & . . . . . . . & 13,224 & $\$ 00$ & $13,22-1$ & \\
\hline $1 / 19$ & $\ldots \ldots \ldots \ldots \ldots \ldots$ & ……........ & 33,060 & & $13,-24$ & \\
\hline $1 / 22$ & ..............., & 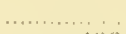 & . & SOO & $\$ 110$ & \\
\hline $1 / 26$ & ................ & 400 & ............... & ......... & 13,24 & . \\
\hline $1 / 29$ & …............ & & & & $26,8 \pm 8$ & \\
\hline $2 / 2$ & ............... & 13,221 & ..... & .... & $19,8: 36$ & \\
\hline $2 / 5$ & ……….... & $13,2,4$ & & $\ldots .$. & $13,2: 24$ & \\
\hline $2 / 8$ & …........... & 800 & $\ldots$ & $\ldots .$. & 27,218 & \\
\hline $2 / 12$ & ............... & 39,672 & n..., & ........ & $26,1+5$ & \\
\hline $2 / 15$ & ............... & 800 & ....... & ....... & $26,-148$ & .... \\
\hline $2 / 19$ & …............. & 39,672 & & & 120,616 & \\
\hline $2 / 23$ & …............. & 39,672 & $\mathrm{~S} 00$ & .... & ......... & \\
\hline $2 / 26$ & ................. & 1,600 & $\ldots \ldots$ & ... & 3,200 & \\
\hline $3 / 1$ & ................. & 1,600 & & & 107,392 & \\
\hline $3 / 5$ & ................ & & 52,896 & ..... & ............ & \\
\hline $3 / 5$ & …............. & 1,600 & 3,200 & $\ldots$ & 3,200 & \\
\hline $3 / 12$ & ……........ & $52,8 ! 6$ & 52,596 & . . ..... & 3,200 & $\ldots$ \\
\hline $3 / 15$ & …............. & $105,79:$ & $\ldots \ldots \ldots \ldots \ldots \ldots$ & n........... & 1.600 & \\
\hline $3 / 19$ & …............ & 1,600 & $\ldots$ & & 79,314 & \\
\hline $3 / 23$ & ................. & $105,79^{\circ} 2$ & & & $1,(100$ & \\
\hline $3 / 26$ & …............. & 105,792 & ......... & & 79,344 & \\
\hline $3 / 29$ & .................. & 52,890 & & & 1,600 & \\
\hline $4 / 2$ & ….......... & 79,314 & & & 79,311 & \\
\hline $4 / 5$ & & & 52,896 & & $\cdots$ & \\
\hline $4 / 9$ & ….......... & 105,702 & 1,600 & & & \\
\hline $4 / 13$ & $\ldots \ldots$ & 1,000 & & & 4,500 & \\
\hline $4 / 16$ & ….......... & 52,896 & 1,600 & & $50,9+4$ & \\
\hline $4 / 19$ & $\ldots \ldots \ldots \ldots \ldots$ & 52,896 & & & 1,600 & \\
\hline $4 / 23$ & ……........ & & & & $211,5 \mathrm{S4}$ & \\
\hline $4 / 26$ & . & 52.896 & 1,600 & $\ldots$ & 185,136 & \\
\hline $4 / 30$ & - ............... & 79,344 & & & $26+.150$ & \\
\hline $5 / 3$ & ................. & . & $\cdots$ & ...... & $79,3+14$ & \\
\hline $5 / 7$ & . . ............. & 1,600 & ........... & ......... & 317,376 & \\
\hline $5 / 11$, & ................ & 52,896 & ... & & 290,928 & \\
\hline $5 / 14$ & ..., .......... & 105,792 & & & 952,128 & \\
\hline $5 / 17$ & ................ & $15 \mathrm{~s}, 6 \mathrm{~S}, \mathrm{~S}$ & 3,200 & & $1,533,95 \div$ & 6,400 \\
\hline $5 / 21$ & ……........ & 3,200 & & & $2,644,800$ & \\
\hline $5 / 24$ & …............. & 261,480 & & 6,400 & $5,2 \$ 9,600$ & \\
\hline $5 / 27$ & $\quad$.............. & & ….... & $\ldots \ldots \ldots \ldots$ & $15,181,152$ & \\
\hline $5 / 31$ & …............ & 317,376 & ........... & $\ldots \ldots \ldots$ & $20,999,712$ & \\
\hline $6 / 3$ & . $\ldots \ldots \ldots \ldots \ldots$ & 264,450 & & & $23,221,314$ & \\
\hline $6 / 7$ & .................. & 3,200 & & & $11,055,261$ & \\
\hline $6 / 11$ & …............ & 3,200 & ... & .... & $11,105,160$ & $\ldots$ \\
\hline $6 / 16$ & …….......... & 105,792 & & & $13,752,960$ & \\
\hline $6 / 18$ & .................. & 211,584 & & & $19,624, \pm 16$ & \\
\hline $6 / 21$ & - $\ldots \ldots \ldots \ldots \ldots$ & 370,272 & .......... & ...... & $14,969,56 \mathrm{~s}$ & 6,400 \\
\hline$\dot{b} / 25$ & ................ & $158,0 \mathrm{SS}$ & $\ldots$ & $\ldots$ & $11,901,600$ & \\
\hline $6 / 25$ & ................ & 211,584 & & & $11,108,160$ & .... \\
\hline $7 / 3$ & ................. & $211,5 \bigcirc 4$ & ..... & ......... & $10,050,240$ & $\ldots \ldots \ldots$ \\
\hline $7 / 5$ & ........ & & & & $4,284,576$ & $\ldots .$. \\
\hline $7 / 9$ & ….............. & 3,200 & & 3,200 & $2,909,280$ & „............ \\
\hline $7 / 12$ & ................. & & & ....... & $4,866,432$ & …….......... \\
\hline $7 / 16$ & ................ & 370,272 & $\ldots$ & ….... $\ldots$ & $5,035,120$ & \\
\hline $7 / 19$ & , & 211,584 & & $\ldots \ldots \ldots \ldots \ldots$ & $4,125,8,89$ & \\
\hline $7 / 23$ & . . .............. & 3,200 & ... & …..... $\quad$. & $2,380,320$ & \\
\hline $7 / 26$ & .............. & 423,168 & & & $(0,952,272$ & \\
\hline $7 / 30$ & ................. & 370,272 & & $\ldots \ldots \ldots, \ldots$ & $3,755,616$ & \\
\hline
\end{tabular}


Table 1.-Organisms Per Cubic Meter in Plankton of Stockton Channel in 1913-(Continued)

\begin{tabular}{|c|c|c|c|c|c|c|}
\hline 1913 & $\begin{array}{l}\text { Navicula } \\
\text { dubia }\end{array}$ & $\begin{array}{c}\text { Navicula } \\
\text { gracilis }\end{array}$ & $\begin{array}{c}\text { Navicula } \\
\text { sp. }\end{array}$ & $\begin{array}{l}\text { Navicula } \\
\text { viridis }\end{array}$ & $\begin{array}{l}\text { Nitzschia } \\
\text { acicularis }\end{array}$ & $\begin{array}{l}\text { Nitzschia } \\
\text { augularis }\end{array}$ \\
\hline$S / 2$ & 6,400 & $26+, 480$ & $\begin{array}{llll} & \ldots & \ldots & \ldots\end{array}$ & .. & $3,385,314$ & \\
\hline $8 / 6$ & & $158,6 \mathrm{SS}$ & & , & $3,702,720$ & \\
\hline $8 / 9$ & 3,200 & 264,450 & ..... & .... & $3,279,5.52$ & \\
\hline $8 / 13$ & & $2,539.00 \mathrm{~s}$ & $\ldots . .$. & ................. & $6,453,312$ & .. \\
\hline$\$ / 15$ & $\ldots$ & $952,12 S$ & ........... & ................ & $1,586,880$ & \\
\hline $8 / 20$ & ........ & $1,269,504$ & .......... & & 634,752 & \\
\hline $8 / 23$ & & $1,110,816$ & ............ & $\ldots \ldots, \ldots \ldots \ldots$ & $1,005,024$ & \\
\hline $8 / 27$ & 3,200 & 793,110 & ...... & .......... & $2,539,00 \mathrm{~s}$ & \\
\hline $\mathrm{S} / 31$ & ............ & $1,322,400$ & ....... & ......... & $4,760,6-10$ & \\
\hline $9 / 2$ & & $1,163,712$ & ... & & $5,236,704$ & ... \\
\hline $9 / 6$ & 3,200 & 846,336 & $\ldots$. & $\ldots . .$. & $3,596,928$ & \\
\hline $9 / 9$ & ......... & $\$ 46,336$ & $\ldots \ldots$ & $\ldots . .$. & $2,115,840$ & \\
\hline $9 / 13$ & $\ldots$. & 476,064 & & & $1,904,256$ & \\
\hline $9 / 17$ & ..... & 370,272 & ................ & ......... & $2,010,048$ & \\
\hline $9 / 20$ & ...... & 846,336 & . ..... & ......... & $2,750,592$ & \\
\hline $9 / 24$ & $\ldots .$. & 899,232 & & $\ldots$. & $3,332,148$ & \\
\hline $9 / 27$ & $\ldots \ldots$. & 476,061 & 52,896 & $\ldots \ldots$ & $2,750,592$ & .. \\
\hline $10 / 1$ & ...... & 525,960 & $\ldots \ldots \ldots \ldots \ldots$ & $\ldots .$. & $3,120,864$ & .. \\
\hline $10 / 4$ & & & & $\ldots$ & $1,533,981$ & \\
\hline $10 / S$ & $\ldots \ldots$ & 52,896 & ............... & $\ldots \ldots$ & $1,745,56 \mathrm{~S}$ & ... \\
\hline $10 / 11$ & $\ldots \ldots$ & 204,180 & n............... & ........ & $1,904,256$ & \\
\hline $10 / 15$ & ....... & $15 \mathrm{~S}, 6 \mathrm{SS}$ & .............. & $\ldots$ & $2,062,944$ & \\
\hline $10 / 18$ & & $158,6 S 8$ & $\ldots \ldots$ & ........ & $2,221,632$ & .. \\
\hline $10 / 22$ & 52,896 & 52,896 & ......... & ........ & $2,062,944$ & \\
\hline $10 / 26$ & ........... & $15 \mathrm{~S}, 6 \mathrm{SS}$ & & & $1,163,712$ & \\
\hline $10 / 29$ & ......... & 105,792 & …........... & $\ldots \ldots$ & $1,745,568$ & .. \\
\hline $11 / 1$ & $\ldots \ldots$ & & ……..... & ......... & $1,322,400$ & \\
\hline $11 / 5$ & ...... & ... & …........... & ............... & $1,005,024$ & \\
\hline $11 / 8$ & & & ................ & .......... & $1,322,400$ & \\
\hline $11 / 12$ & $\ldots .$. & 52,896 & & & $3,173,760$ & \\
\hline $11 / 15$ & 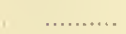 & & .......... & & $1,851,360$ & \\
\hline $11 / 19$ & .......... & 79,344 & ................. & 3,200 & $1,719,120$ & $\ldots$ \\
\hline $11 / 22$ & $\ldots \ldots \ldots$ & 105,792 & -................ & $\ldots \ldots$ & $2,062,941$ & \\
\hline $11 / 26$ & ....... & 79,341 & $\ldots \ldots \ldots$ & & $2,036,496$ & \\
\hline $11 / 30$ & $\ldots .$. & 105,792 & ............ & $\ldots$. & $2,062,944$ & $\ldots$ \\
\hline $12 / 3$ & ....... & & & $\ldots .$. & $1,163,712$ & \\
\hline $12 / 6$ & ... & 105,792 & $\cdots$ & 3,200 & $1,666,224$ & 3,200 \\
\hline $12 / 10$ & & 19.836 & & .......... & $56 \mathrm{~S}, 632$ & \\
\hline $12 / 14$ & .... & 46,281 & n............. & n................ & 416,556 & \\
\hline $12 / 17$ & & 39,672 & ................ & .................. & 310,764 & \\
\hline $12 / 20$ & 800 & 46,284 & .............. & ............... & 138,852 & \\
\hline $12 / 24$ & $\ldots \ldots$ & 46,284 & …............ & ……......... & 119,016 & \\
\hline $12 / 27$ & & 66,120 & ................... & & $145,46 \frac{1}{2}$ & \\
\hline $12 / 31$ & $\ldots \ldots \ldots \ldots$ & 92,568 & .............. & 400 & 79,344 & .................. \\
\hline
\end{tabular}

\begin{tabular}{|c|c|c|c|c|c|c|}
\hline 1913 & $\begin{array}{l}\text { Nitzsehia } \\
\text { sigma }\end{array}$ & $\begin{array}{l}\text { Nitzschia } \\
\text { sigmoidea }\end{array}$ & $\begin{array}{l}\text { Nitzschia } \\
\text { vermicularis }\end{array}$ & $\begin{array}{l}\text { Pleurostauron } \\
\text { parvulum }\end{array}$ & $\begin{array}{c}\text { Stauroneis } \\
\text { phoenicenteron }\end{array}$ & $\begin{array}{c}\text { Stephonodiscus } \\
\text { sp. }\end{array}$ \\
\hline $1 / 5$ & $\ldots . .$. & ….. & & 6,612 & & \\
\hline 1) $\mathrm{s}$ & ....... & & 400 & 800 & $\cdots$ & \\
\hline $1 / 12$ & .... & ..... & & \pm 00 & ...... & \\
\hline $1 / 15$ & .... & …......... & & 26,448 & ..... & \\
\hline $1 / 19$ & & ……............. & 400 & 39,672 & & \\
\hline $1 / 22$ & 19,836 & ......... & $\ldots \ldots$ & $26,+4 S$ & 800 & 400 \\
\hline $1 / 26$ & ................. & ...... & ..... & 26,448 & 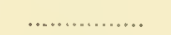 & .. \\
\hline $1 / 29$ & ............... & $\ldots \ldots$ & ................. & $26, \pm 48$ & …........... & ....... \\
\hline $2 / 2$ & ……....... & ……......... & ................. & 400 & & ........ \\
\hline $2 / 5$ & ................ & ................ & ................. & $46,28 t$ & 800 & ................. \\
\hline $2 / 8$ & $\ldots \ldots \ldots \ldots \ldots$ & ……, & .............. & 26,448 & & \\
\hline
\end{tabular}


TABLE 1.-ORgaNisMS PER ('tBic MFTER IN P'LANKTON OF

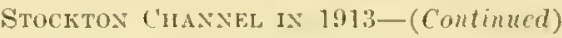

\begin{tabular}{|c|c|c|c|c|c|c|}
\hline 1913 & $\begin{array}{l}\text { Nitzschia } \\
\text { sigma }\end{array}$ & $\begin{array}{l}\text { Nitzochia } \\
\text { sigmoidea }\end{array}$ & $\begin{array}{l}\text { Nitaschia } \\
\text { vermeularis }\end{array}$ & $\begin{array}{l}\text { Pleurostauron } \\
\text { parvulum }\end{array}$ & $\begin{array}{c}\text { Stauroneis } \\
\text { phoenicenteron }\end{array}$ & $\begin{array}{c}\text { Stephonodiseus } \\
\text { sp. }\end{array}$ \\
\hline 212 & & .. & $\ldots$ & & & \\
\hline 215 & $\ldots$ & $\ldots$ & 1,600 & $21 j,+15$ & & \\
\hline 219 & & 3,200 & & 39,672 & & \\
\hline 223 & S & 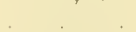 & & 800 & & \\
\hline $2-26$ & & 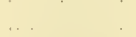 & & 1,600 & & \\
\hline 31 & . & . & 1,6000 & 52.496 & & \\
\hline $3 / 5$ & & $x^{\prime}$ & & 52,594 & & \\
\hline $3 ! 5$ & & 1,600 & 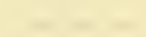 & $79,3+4$ & 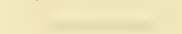 & 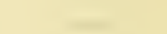 \\
\hline 312 & & & & 79.344 & & \\
\hline 315 & & & $\cdots$ & $10,7,792$ & & \\
\hline 319 & . & . & .. . & 105,792 & & \\
\hline 323 & & & & $13: 2,240$ & & $\ldots$ \\
\hline 326 & & 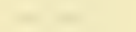 & 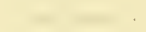 & & 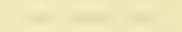 & \\
\hline $3 / 2 !$ & & & & 1.600 & & \\
\hline 42 & .. & & & 1.6000 & & \\
\hline $4 / 5$ & .. & & & 79,344 & & \\
\hline+9 & . & & & & & \\
\hline+13 & & 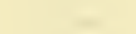 & 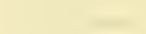 & $1,000)$ & & 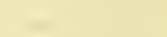 \\
\hline+16 & & & & 158,658 & & \\
\hline 419 & & & & 158 fiss & & \\
\hline+23 & 1,600 & & & 52,896 & & \\
\hline+26 & & & & 79,344 & & \\
\hline 430 & & & & 52.896 & & \\
\hline 53 & & . & & 52.894 & & 3.200 \\
\hline $5 / 7$ & & . & & 79.344 & & \\
\hline $5 \quad 11$ & . & 1.600 & & 1,600 & & \\
\hline 5.11 & & .. & .. & 158, ist & & \\
\hline $5 / 17$ & 6.100 & . & & $211.5 \mathrm{st}$ & 6.400 & \\
\hline $5 / 21$ & & 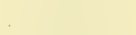 & & 105.792 & & \\
\hline 5,21 & & & & $211,5,34$ & & \\
\hline $5 / 27$ & $(0,400$ & & & & 3.200 & 105.792 \\
\hline $5 / 31$ & & & & & & \\
\hline 63 & & & & 3,200 & & \\
\hline $6 / 7$ & & & & 3,200 & & \\
\hline (j) 11 & & & & 3,200 & & \\
\hline (6) 16 & 6,400 & & & 211,584 & 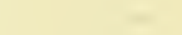 & 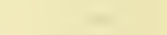 \\
\hline 618 & & & & 3,200 & & \\
\hline $6 / 21$ & $\ldots$ & - & . & & & \\
\hline 6.25 & . & & . & 105,792 & & \\
\hline $6 / 28$ & $\ldots$ & .. & & & & \\
\hline 73 & & 3,200 & ....... & .. & $\ldots$ & 1 \\
\hline 75 & . & .. & . ... . & & & \\
\hline 79 & .. & & .. . & & & \\
\hline 712 & . & & & & & \\
\hline 711 & & & & & & \\
\hline 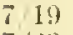 & & & $\ldots .$. & & 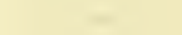 & 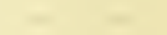 \\
\hline $7 / 23$ & & & & & & \\
\hline 720 & & & & & & \\
\hline $\begin{array}{l}730 \\
8 \quad 2 \\
38\end{array}$ & 6.100 & & & & & \\
\hline 8,$1 ;$ & & & & & & \\
\hline $8 / 9$ & 3,200 & & $\ldots$ & & & - \\
\hline 813 & & & & & & \\
\hline $8 / 15$ & & & & & 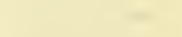 & \\
\hline$S / 20$ & 3200 & & & & & \\
\hline $8 / 23$ & . & & & 3,200 & & \\
\hline $8 / 27$ & 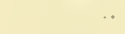 & & & & & \\
\hline $8 / 31$ & & 400 & & & & \\
\hline $\begin{array}{l}9 / 2 \\
9 / 6\end{array}$ & 3,200 & $\ldots$ & & 105.792 & 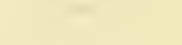 & .. \\
\hline
\end{tabular}


Table 1.-Organisms Per Cubic Meter in Plankton of Stockton Channel IN 1913-(Continued)

\begin{tabular}{|c|c|c|c|c|c|c|}
\hline 1913 & $\begin{array}{l}\text { Nitzschia } \\
\text { sigma }\end{array}$ & $\begin{array}{l}\text { Nitzschia } \\
\text { signroidea }\end{array}$ & $\begin{array}{l}\text { Nitzschia } \\
\text { vermicularis }\end{array}$ & $\begin{array}{l}\text { Pleurostauron } \\
\text { parvulum }\end{array}$ & $\begin{array}{c}\text { Stauroneis } \\
\text { Phoenicenteron }\end{array}$ & $\begin{array}{l}\text { Stephonodiscus } \\
\text { sp. }\end{array}$ \\
\hline $9 / 9$ & & & 6,400 & & & \\
\hline $9 / 13$ & & $\ldots \ldots \ldots, \ldots$ & 6,100 & & & \\
\hline $9 / 17$ & .................. & ...... & .... & & & \\
\hline $9 / 20$ & & & $6, \pm 00$ & & & \\
\hline $9 / 24$ & 105,792 & ..... & $6, \pm 00$ & & & ... $>$ \\
\hline $9 / 27$ & 52,896 & .... & & & & \\
\hline $10 / 1$ & $\ldots$ & . $\ldots \ldots \ldots \ldots$ & ... & 105,792 & $\cdots$ & \\
\hline $10 / 4$ & ................ & . . .............. & … & & ....... & \\
\hline $10 / S$ & ............ & ............. & 19,200 & & $\ldots .$. & ..... \\
\hline $10 / 11$ & 6,400 & .. ... & & 52,896 & & \\
\hline $10 / 15$ & 12,800 & . . . . . . & 12,800 & …' 1 & $\ldots \ldots$ & \\
\hline 10/1S & 52,896 & & 52,896 & & & \\
\hline $10 / 22$ & का & ...... & ..... & 52,596 & ... & \\
\hline $10 / 26$ & & .......... & ......... & 105,792 & ..... & ... \\
\hline $10 / 29$ & & ................. & $\ldots \ldots$. & 52,896 & ... & \\
\hline $11 / 1$ & & $1, \ldots .$. & $\ldots \ldots \ldots$ & & $\ldots . .$. & \\
\hline $11 / 5$ & 12,800 & ..... & $\ldots$ & 52,896 & .......... & $\ldots$ \\
\hline $11 / 8$ & ….......... &.$\quad \ldots$. & $\ldots$ & & …......... & ... \\
\hline $11 / 12$ & …............ & - $\quad \ldots \ldots \ldots$ & & $79,3 \pm 1$ & ................ & \\
\hline $11 / 15$ & 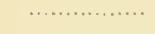 & $\cdots$ & $6, \pm 00$ & & …... & \\
\hline & & $\ldots$ & & 52,896 & ............... & .... \\
\hline $11 / 22$ & 3,200 & $\ldots \ldots$ & 1,600 & & & \\
\hline $11 / 26$ & $\Rightarrow 000$ & . & . & 1,600 & $\cdots$ & .. \\
\hline $11 / 30$ & 3,200 & $\cdot \quad \ldots$. & .. & 105,792 & $\ldots \ldots \ldots, \ldots$ & .... \\
\hline $12 / 3$ & 3,200 & ........... & & 1,600 & ... & \\
\hline $12 / 6$ & & $\cdots$ & 3,200 & & ... & \\
\hline $12 / 10$ & $\mathrm{~S} 00$ & . . ........ & & 33,060 & ...... & \\
\hline $12 / 14$ & 19,836 & ….......... & $\ldots$ & $26, \pm 18$ & .......... & \\
\hline $12 / 17$ & $\$ 00$ & & $\ldots$. & 19,836 & & \\
\hline $12 / 20$ & 39,672 & .............. & $\ldots$ & 33,060 & 400 & \\
\hline $12 / 24$ & 800 &.$\ldots$ & & 100 & & \\
\hline $12 / 27$ & 39,672 & $-\quad . \quad \ldots$. & & 26,448 & 400 & \\
\hline $12 / 31$ & . .. $\quad$, & $1 \quad \ldots$ & 800 & $26,4 \pm 8$ & $\ldots \ldots$ & 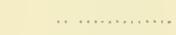 \\
\hline 1913 & $\begin{array}{l}\text { Suricella } \\
\text { sp. }\end{array}$ & $\begin{array}{l}\text { Synedra } \\
\text { radians }\end{array}$ & $\begin{array}{l}\text { Synedra } \\
\text { ulna }\end{array}$ & $\begin{array}{l}\text { Total } \\
\text { Bacillariaceae }\end{array}$ & $\begin{array}{c}\text { Closterium } \\
\text { acerosum }\end{array}$ & $\begin{array}{r}\text { Closterium } \\
\text { rostratum }\end{array}$ \\
\hline $1 / 5$ & ……, n, & ....... & 132,240 & $1,163.712$ & & \\
\hline $1 / 8$ & ............. & ........ & 59,508 & 152,016 & ........ & …............ \\
\hline $1 / 12$ & ............ &.$\quad \ldots$. & 66,120 & $915,6.56$ & ... & \\
\hline $1 / 15$ & & ........... & 135,852 & $3,275,1+0$ & & \\
\hline $1 / 19$ & & ......... & 198,360 & $6,253,140$ & ......... & ... \\
\hline $1 / 22$ & 3,200 & .......... & 211,584 & $2,858,573$ & 400 & $\ldots$ \\
\hline $1 / 26$ & & $\ldots \ldots \ldots \ldots$ & 257,865 & 774,404 & 400 & \\
\hline $1 / 29$ & $\$ 00$ & ............. & 251,256 & $1,761,992$ & $\ldots \ldots \ldots, \quad \ldots \ldots$ & ….......... \\
\hline $2 / 2$ & & ............ & 152,076 & $1,454,82 \mathrm{~S}$ & .............. & \\
\hline $2 / 5$ & 1,600 & 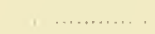 & 310,761 & $1,94 \mathrm{~S}, 32 \mathrm{~S}$ & & .. \\
\hline $2 / S$ & 800 & & 132,240 & $1,668,624$ & 1,600 & ...... \\
\hline $2 / 12$ & & $1, \ldots$ & 370,272 & $1,656,200$ & .... & ..... \\
\hline $2 / 15$ & 800 & $\ldots \ldots$ & 436,092 & $2,837,136$ & $\ldots$ & ...... \\
\hline $2 / 19$ & 4,800 & ................ & 357.048 & $36+1,776$ & $\ldots \ldots \ldots, \quad \ldots$ & ........ \\
\hline $2 / 23$ & 3,200 & ............. & 317,376 & $1,766,792$ & $\ldots \ldots$ & $\ldots \ldots$ \\
\hline $2 / 26$ & 6,400 & .................. & 528,960 & $5,0+9,120$ & ....... & .... \\
\hline $3 / 1$ & & ................ & 581,856 & $6,934,754$ & $\ldots \ldots$ & .... \\
\hline $3 / 5$ & 3,200 & , . ........... & $211,5 S t$ & $6,621,600$ & ...... & $\ldots .$. \\
\hline $3 / 5$ & - & & 235,032 & $2,348,224$ & $\ldots \ldots$ & $\ldots \ldots$ \\
\hline $3 / 12$ & 3.200 & & $155,6 \mathrm{~s}$ & $3,206,60 \mathrm{~S}$ & ........ & \\
\hline $3 / 15$ & & ................ & 370.272 & $2,925,280$ & ................ & ....... \\
\hline $3 / 19$ & 3,200 & ................. & 290,925 & $4,263,892$ & .................. & ........ \\
\hline
\end{tabular}


Table 1.-ORganis as Per Cubic Methe in Plankton of S'TOCKTON (HANNel IN 1913-(Continued)

\begin{tabular}{|c|c|c|c|c|c|c|}
\hline 1913 & $\begin{array}{c}\text { Surirclla } \\
\text { sp. }\end{array}$ & $\begin{array}{c}\text { Synedra } \\
\text { radians }\end{array}$ & $\begin{array}{l}\text { Synerdra } \\
\text { ulua }\end{array}$ & $\begin{array}{c}\text { Total } \\
\text { Bacillariaceac }\end{array}$ & $\begin{array}{l}\text { Closterium } \\
\text { acerosum }\end{array}$ & $\begin{array}{l}\text { Clostcrium } \\
\text { rostratum }\end{array}$ \\
\hline $3 / 26$ & & & $396,-220$ & $2,441,216$ & .. & \\
\hline $3 / 29$ & 12,500 & & 105,792 & 2567,808 & .. & \\
\hline 42 & 3,200 & & $264,4 \leq 0$ & $2,313,424$ & .. & \\
\hline 4 & & & 370,272 & $3,209,808$ & & 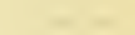 \\
\hline $4 / 9$ & 3,200 & & 185,136 & $7,360,5 \cdot 1-1$ & & \\
\hline+13 & 52,596 & & 79,344 & $4,706,045$ & & \\
\hline $4 / 16$ & & 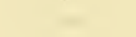 & 396,720 & $11,112,608$ & & .. \\
\hline $4 \quad 19$ & & & $15 \mathrm{~S}, 6 \mathrm{SS}$ & $11,613,872$ & & \\
\hline $4 / 23$ & & & 714,096 & $19,156,352$ & & \\
\hline $4 / 26$ & 3,200 & & 132,240 & $19,654,516$ & & \\
\hline+30 & & & 132,240 & $19,204,448$ & & \\
\hline $5: 3$ & 6,400 & 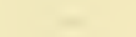 & 581,856 & $21,622,416$ & . & ......... \\
\hline 57 & & & 290,928 & $21,166,352$ & & ….... \\
\hline $5 / 11$ & 1,600 & 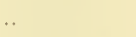 & 132,210 & $34,420,018$ & & ..... \\
\hline $5 / 14$ & 6,400 & $\ldots$ & 657,648 & $63,435,104$ & ..... & $\cdots--\cdots$ \\
\hline $\begin{array}{l}5 \\
5\end{array}$ & 211,584 & & $\begin{array}{r}2,010,048 \\
657,645\end{array}$ & $\begin{array}{l}49,630,352 \\
40,739,520\end{array}$ & ...... & \\
\hline $5^{24}$ & 19,200 & & 423,168 & $43,227,536$ & & ... \\
\hline 527 & 25,600 & & $1,957,152$ & $74,204,992$ & & \\
\hline $5 / 31$ & 3,200 & & $1,110,816$ & $75,971,456$ & ........... & 3,200 \\
\hline 6/ 3 & $\therefore$ & & 846,336 & $82,633,152$ & & \\
\hline $6 / 7$ & 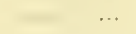 & & $1,375,296$ & $73,250,160$ & & 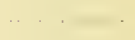 \\
\hline $6 / 11$ & & & $1,110,816$ & $72,552,912$ & $\cdots$ & \\
\hline $6 / 16$ & 6,400 & & 899,232 & $55,939,872$ & ..... & . \\
\hline $\begin{array}{l}6 / 18 \\
6 / 21\end{array}$ & 6,100 & .. & $\begin{array}{r}1,110,516 \\
476,064\end{array}$ & $\begin{array}{l}66,023, \mathrm{~s} 0 \mathrm{~S} \\
51,797,984\end{array}$ & $\ldots \ldots$ & \\
\hline $6 / 25$ & & & $1,692,672$ & $53,755,136$ & & \\
\hline $6 / 23$ & 3,200 & .. & $2,856,384$ & $74,335,080$ & 6,400 & . \\
\hline 5/ 3 & & . & $1,533,954$ & $50,161,408$ & & \\
\hline $7 / 5$ & & .. & 423,168 & $20,001,05 \mathrm{~S}$ & & \\
\hline $7 / 9$ & 6,400 & $\ldots .$. & 476,064 & $17,204,000$ & $\ldots \ldots$ & $\ldots$ \\
\hline $7 / 12$ & & & 423,168 & $24,761,729$ & & \\
\hline $7 / 16$ & 3,200 & $4,496,160$ & 634,792 & $58,002,816$ & $\ldots$ & ........ \\
\hline $7 / 19$ & & 634,752 & 317,376 & $31,501,600$ & & .... \\
\hline $7 / 23$ & 3,200 & 581,556 & 528,960 & $16,675,040$ & & ..... \\
\hline $7 / 26$ & 105,792 & 899,232 & 687,645 & $29,637,760$ & & \\
\hline $7 / 30$ & 6,400 & 423,168 & 528,960 & $23,495,424$ & 6,400 & 3,200 \\
\hline s/ 2 & ........... & 370,272 & $423,16 \mathrm{~S}$ & $23,354,240$ & & \\
\hline $8 / 6$ & & 634,752 & 423,168 & $18,159,32 \mathrm{~S}$ & 6,400 & 105,792 \\
\hline S/ 9 & 105,792 & $1,005,024$ & 529,960 & $20,966,016$ & & $211,58 t$ \\
\hline $8 / 13$ & 6,400 & $2,750,592$ & $2,062,944$ & $39,059,645$ & 3,200 & 423.168 \\
\hline $8 / 15$ & 6,400 & 740,541 & $1,005,024$ & $21,613,56 \mathrm{~S}$ & 6,400 & 19,200 \\
\hline $8 / 20$ & 6,400 & $\$ 46,336$ & $952,12 \mathrm{~S}$ & $21,815,552$ & ........ & 105,792 \\
\hline $\mathrm{S} / 23$ & & 740,541 & $1,375,296$ & $31,965,194$ & .. & 6,400 \\
\hline $8 / 31$ & 12,800 & $2,115,840$ & $1,375,296$ & $39,987,680$ & & 105,792 \\
\hline $9 / 2$ & 6,400 & $1,451,088$ & $1,322,400$ & $29,588,064$ & & 211,584 \\
\hline $9 / 6$ & 12,800 & 634,752 & $2,539,00 \mathrm{~s}$ & $36,761,024$ & 3,200 & 264,480 \\
\hline $9 / 9$ & & 687,648 & $1,057,920$ & $27,590,816$ & ............ & 3,200 \\
\hline $9 / 13$ & $158,6 \mathrm{ss}$ & 740,544 & $1,533,984$ & $25,372,384$ & & 6,400 \\
\hline $9 / 17$ & & 687,648 & $657,6+8$ & $26,731,680$ & ......... & 105,792 \\
\hline $9 / 20$ & & 952,128 & 816,336 & $27,194,944$ & & 105,792 \\
\hline $9 / 24$ & 19,200 & $1,639,776$ & 793,440 & $37,535,264$ & ........... & 52,896 \\
\hline $9 / 27$ & 52,896 & $1,322,400$ & 423,168 & $30,415,200$ & & 6,400 \\
\hline $10 / 1$ & 6,400 & $1,692,672$ & $1,216,608$ & $36,8+1,216$ & 6,400 & $6,-100$ \\
\hline $10 / 4$ & 52,896 & $1,375,296$ & $1,375,296$ & $22,379,712$ & . . ........ & \\
\hline $10 / 8$ & 19,200 & $1,481,088$ & $1,216,608$ & $30,908,765$ & & . \\
\hline $10 / 11$ & 12,800 & $1,692,672$ & $1,375,296$ & $33,574,464$ & ............ & 6,100 \\
\hline $10 / 15$ & 155,688 & $1,269,504$ & $2,803,488$ & $35,802,496$ & & 52,896 \\
\hline $10 / 18$ & 19,200 & $1,005,024$ & $1,322,400$ & $35,512,416$ & 6,400 & \\
\hline $10 / 22$ & $\ldots \ldots \ldots$ & $1,269,50 \cdot 1$ & 846,336 & $37,370,176$ & 6,400 & ..... \\
\hline
\end{tabular}


Table 1.-Organisms Per Cubic Meter in Plankton of Stockton Channel in 1913-(Continued)

\begin{tabular}{|c|c|c|c|c|c|c|}
\hline 1913 & $\begin{array}{c}\text { Surirella } \\
\text { ap. }\end{array}$ & $\begin{array}{c}\text { Synedra } \\
\text { radians }\end{array}$ & $\begin{array}{c}\text { Synedra } \\
\text { ulna }\end{array}$ & $\begin{array}{c}\text { Total } \\
\text { Bacillariaceae }\end{array}$ & $\begin{array}{c}\text { Closterium } \\
\text { acerosum }\end{array}$ & $\begin{array}{l}\text { Closterium } \\
\text { rostratum }\end{array}$ \\
\hline $10 / 26$ & 6,400 & 846,336 & 528,960 & $40,861,312$ & & \\
\hline $10 / 29$ & 12,800 & 793,440 & 793,440 & $38,450.896$ & & 105,792 \\
\hline $11 / 1$ & 105,792 & $7 \cdot 40,544$ & 211,584 & $17,098,208$ & & $\cdots$ \\
\hline $11 / 5$ & 6,400 & 528,960 & 528,960 & $13,467,584$ & .. & \\
\hline $11 / \mathrm{s}$ & 6,400 & 634,752 & 264,480 & $11,233,152$ & & \\
\hline $11 / 12$ & 1,600 & $1,243,056$ & 476,064 & $17,409,184$ & . & 52,896 \\
\hline $11 / 15$ & & $158,68 S$ & 105,792 & $10,962,272$ & ... & \\
\hline $11 / 19$ & 3,200 & 290,928 & 370,272 & $10,547,104$ & . & 6,400 \\
\hline $11 / 22$ & 52,896 & 79,344 & 423,168 & $11,546,480$ & & \\
\hline $11 / 26$ & 3,200 & 132,240 & 211,584 & $10,301,072$ & $\ldots$ & 1,600 \\
\hline $11 / 30$ & 3,200 & 158,688 & 396,720 & $10,874,080$ & .. & 1,600 \\
\hline $12 / 3$ & & 79,344 & 925,680 & $12,398,464$ & & 1,600 \\
\hline $12 / 6$ & 6,400 & 1,600 & 158,688 & $9,041,168$ & & 3.200 \\
\hline $12 / 10$ & & 39,672 & 113,204 & $3,751,992$ & 1,600 & \\
\hline $12 / 14$ & 800 & 52,896 & 191,784 & $3,943,552$ & (2) & \\
\hline $12 / 17$ & 400 & 33,060 & 125,628 & $3,598,928$ & 800 & 400 \\
\hline $12 / 20$ & 4,000 & 52,896 & $370,27^{\circ}$ & $3,976,400$ & ...... & \\
\hline $12 / 24$ & 19,836 & $33,060^{\circ}$ & 138,852 & $2,071,744$ & …. & \\
\hline $12 / 27$ & 46,284 & 46,284 & 621,528 & $4,627,788$ & $\ldots \ldots$ & \\
\hline $12 / 31$ & 26,448 & 26,448 & 509,124 & $3,671,048$ & & \\
\hline
\end{tabular}

1913
$1 / 5$
$1 / 8$
$1 / 12$
$1 / 15$
$1 / 19$
$1 / 22$
$1 / 26$
$1 / 29$
$2 / 2$
$2 / 5$
$2 / 8$
$2 / 12$
$2 / 15$
$2 / 19$
$2 / 23$
$2 / 26$
$3 / 1$
$3 / 5$
$3 / 8$
$3 / 12$
$3 / 15$
$3 / 19$
$3 / 23$
$3 / 26$
$3 / 29$
$4 / 2$
$4 / 5$
$4 / 9$
$4 / 13$
$4 / 16$
$4 / 19$
$4 / 23$
$4 / 26$
$4 / 30$

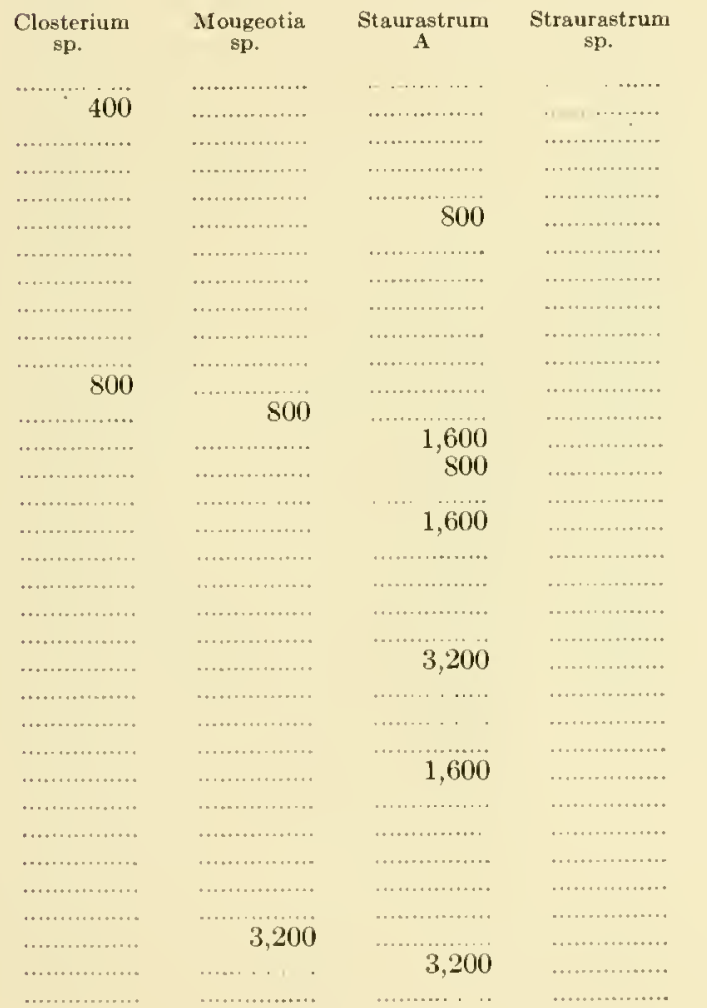

\begin{tabular}{|c|c|}
\hline $\begin{array}{c}\text { Total } \\
\text { Conjugatae }\end{array}$ & $\begin{array}{l}\text { Total } \\
\text { Algae }\end{array}$ \\
\hline & $1,197,572$ \\
\hline 400 & 456,016 \\
\hline 400 & 916,456 \\
\hline & $3,277,140$ \\
\hline 21,036 & $6,283,188$ \\
\hline $\begin{array}{r}21,030 \\
800\end{array}$ & $\begin{array}{r}2,923,465 \\
816476\end{array}$ \\
\hline & $1,785.028$ \\
\hline & $1,484,476$ \\
\hline & $1,963,576$ \\
\hline 1,600 & $1,721,896$ \\
\hline 800 & $1,697,048$ \\
\hline 1,600 & $3,354,048$ \\
\hline 1,600 & $3,979,576$ \\
\hline 800 & $2,138,664$ \\
\hline & $5,513,136$ \\
\hline 600 & $7,021,272$ \\
\hline$\ldots$ & $6,930,128$ \\
\hline & $2,694,400$ \\
\hline & $3,275,504$ \\
\hline & $3.307,504$ \\
\hline 3,200 & $4,551,808$ \\
\hline 3,200 & $4,572,420$ \\
\hline & $\begin{array}{l}2,764 \\
2,697\end{array}$ \\
\hline 1,600 & $2,537,312$ \\
\hline 6,400 & $3,652,176$ \\
\hline & $7,633,176$ \\
\hline & $4,7+2,845$ \\
\hline & $11,720,416$ \\
\hline & $11,912,800$ \\
\hline 3,200 & $19,719,760$ \\
\hline 3,200 & $20,040,240$ \\
\hline & $19,407,18$ \\
\hline
\end{tabular}


'Table 1.-Organisms Phr Cibic Mfeter in Plankton of StocktoN CHANine IN 1913-(Continued)

\begin{tabular}{|c|c|c|c|c|c|c|}
\hline 1913 & $\begin{array}{c}\text { Closteriuın } \\
\text { sp. }\end{array}$ & $\begin{array}{c}\text { Mougeotia } \\
\mathrm{sp} .\end{array}$ & Staurastrum & $\begin{array}{c}\text { Struurastrum } \\
\text { sp. }\end{array}$ & $\begin{array}{l}\text { Total } \\
\text { Conjugatae }\end{array}$ & $\begin{array}{l}\text { Total } \\
\text { Alyae }\end{array}$ \\
\hline $5 / 3$ & & & .. & . & $\cdots$ & 22,003, nss \\
\hline 57 & 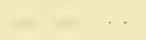 & .. & 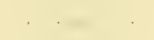 & $\ldots \ldots$ & & $21,327,392$ \\
\hline 511 & ..... & & & & & $31,946,656$ \\
\hline $\begin{array}{ll}5 & 14 \\
5 & 17\end{array}$ & $\ldots . \quad \ldots$ & ... & $=$ & . $\cdots$. & ...... & $15-1,1 \mathrm{~s}, 44 \mathrm{~S}$ \\
\hline $\begin{array}{l}5 / 17 \\
5 / 21\end{array}$ & & . & & & . & $50,101,520$ \\
\hline $\begin{array}{l}5 / 21 \\
5 / 24\end{array}$ & (........... & $\ldots$ & & ........ & & $41,532,640$ \\
\hline $\begin{array}{l}5 / 24 \\
5 / 27\end{array}$ & ....... & & & $\begin{array}{llll}\cdots & \ldots & \ldots & \ldots \\
\ldots & \ldots \ldots & \ldots\end{array}$ & & $\begin{array}{l}-13,0,90,160 \\
76,55 \mathrm{~S}, 011\end{array}$ \\
\hline $5 / 31$ & & & & $\ldots$ & 3,200 & $82,083,296$ \\
\hline $6 / 3$ & & & & & & $89,557,408$ \\
\hline $6 / 7$ & $\ldots \ldots$ & 6,400 & $\ldots$ & 3,300 & 9,600 & $79,290,912$ \\
\hline $6 / 11$ & ........ & $\begin{array}{ll}\ldots \ldots \ldots & \ldots\end{array}$ & & ….......... & & 7 (i) 245,736 \\
\hline $6 / 16$ & .... & . . & 6,100 & .... & 6.400 & $57,502,784$ \\
\hline $\begin{array}{l}6 / 18 \\
6 / 21\end{array}$ & ............. & $\cdots$ & $\ldots$ & 3,200 & 3,200 & $\begin{array}{l}69,735,928 \\
57,741,536\end{array}$ \\
\hline $6 / 25$ & & 105,792 & & & 105,992 & $60,357,056$ \\
\hline $6 / 28$ & & & $10.5,792$ & & 112,192 & $81,289,856$ \\
\hline $7 / 3$ & $-\quad-\ldots \ldots$ & & & & & $56,258,752$ \\
\hline $7 / 5$ & $\ldots .$. & & 3200 & & 6,400 & $22,693,898$ \\
\hline $\begin{array}{l}7 / 9 \\
7 / 12\end{array}$ & & & 6,400 & . & 6,400 & $21,500,080$ \\
\hline $\begin{array}{l}7 / 12 \\
7 / 16\end{array}$ & & 3,200 & & & 3,200 & $31,667,000$ \\
\hline $\begin{array}{l}7 / 16 \\
7 / 19\end{array}$ & & 3,200 & 6,400 & .. & 9,600 & $66,012,512$ \\
\hline $7 / 23$ & & 3,200 & & $\cdots$ & 9,590 & $\begin{array}{l}30,312,220 \\
19,758,102\end{array}$ \\
\hline $7 / 26$ & .. $\quad+1$, & . . ....... & & 3,200 & 6,400 & $35 . \$ 65,002$ \\
\hline $7 / 30$ & . & ........ & & & ......... & $20,959,264$ \\
\hline S/ 2 & $\cdots$ & ......... & & ... & & $25,771,960$ \\
\hline$S / 6$ & & & & & 112,192 & $21,004.416$ \\
\hline $8 / 9$ & & 158,688 & & $158,(258$ & 528,960 & $24,498,752$ \\
\hline $8 / 13$ & $\ldots \ldots \ldots$ & $\$ 46,336$ & & 3,200 & $1,275,904$ & $49,334,132$ \\
\hline S/ 15 & - ............ & $\$ 46,336$ & 3,200 & ............ & 875,136 & $25,866,952$ \\
\hline $8 / 20$ & $\ldots \ldots$ & 476,064 & & & $581,8.56$ & $27,142,336$ \\
\hline $8 / 23$ & .... & 370,272 & & & 634,752 & 29.835 .045 \\
\hline $8 / 27$ & .................. & 264,480 & 3,200 & $\ldots \ldots \ldots$ & 274,080 & $37,911,936$ \\
\hline $8 / 31$ & ..... & 476,064 & & …... & $5 \$ 1,856$ & $47,045,22 \mathrm{~s}$ \\
\hline $9 / 2$ & …........... & $1,745,56 \mathrm{~S}$ & & ...... & $1,967,352$ & $43,650.304$ \\
\hline $9 / 6$ & . ……...... & $1,639,776$ & 105,792 & & $2,013,245$ & $5.5,138,336$ \\
\hline $9 / 9$ & ... & 264,480 & 6,400 & .... & 274.080 & $41,621,056$ \\
\hline $9 / 13$ & $\ldots$ & 158,68s & & .... & $165,08 s$ & $40,754,320$ \\
\hline $9 / 17$ & $\ldots \ldots \ldots \ldots$ & 158,688 & 6,400 & & 270,880 & $36,295.360$ \\
\hline $9 / 20$ & . ........... & & & & 105,792 & $39,967,096$ \\
\hline $9 / 2+$ & ....... & & 211,584 & 52,596 & 317,376 & $51,644,000$ \\
\hline $9 / 27$ & & 52,596 & $52 . \$ 96$ & . & 112,192 & $50,444,544$ \\
\hline $10 / 1$ & $\ldots . \quad \ldots \ldots \ldots$ & …...... & 12,800 & & $1,263,104$ & $47,584,896$ \\
\hline $10 / 4$ & . & & 6,400 & & 6,400 & $30,570,496$ \\
\hline $10 / \&$ & $\ldots$ & 52,896 & $105,79^{2} 2$ & 52,896 & 211,584 & $39,120,434$ \\
\hline $10 / 11$ & & $52.59 t i$ & 6,400 & & 72,096 & 40) \$25, 920 \\
\hline $10 / 15$ & $\ldots$ & 105,792 & 52,596 & & 211,584 & $42,36,5,000$ \\
\hline $10 / 15$ & $\ldots \ldots$ & 52,896 & 52.896 & 52,896 & $165,0 \mathrm{SS}$ & $39,3 \triangleleft 0,224$ \\
\hline $10 / 22$ & & & 12,800 & $\ldots$ & 19,200 & $42,718,176$ \\
\hline $0 / 26$ & $-1-$ & . & 52,896 & .. & 52,896 & $44,785,416$ \\
\hline $10 / 29$ & .. & . & 52,896 & 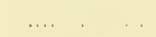 & 156,658 & $44,852,512$ \\
\hline $11 / 1$ & …. $\quad \ldots \ldots$ & $\ldots$ & & .... . & & \\
\hline $11 / 5$ & ....... $\quad \ldots$. & .. & 12,800 & $\cdots$ & 12,400 & $\begin{array}{l}20,024.992 \\
13,931,456\end{array}$ \\
\hline $11 / 3$ & ……...... & $\ldots$ & 1,600 & $\ldots .+-$ & 1,600 & $27,145,245$ \\
\hline & & & & & & $15,993,992$ \\
\hline & ........ & 1,600 & 1,600 & $\ldots .$. & 9,600 & $13,059,416$ \\
\hline $11 / 22$ & & 1,600 & & & 1,600 & $14,611,552$ \\
\hline $11 / 26$ & & 1,600 & -1 & ..... $\quad \ldots .$. & 3,200 & $11,859,805$ \\
\hline
\end{tabular}


Table 1.-Organisms Per Cubic Mleter in Plankton of Stockton Channel in 1913-(Continued)

\begin{tabular}{|c|c|c|c|c|c|c|}
\hline 1913 & $\begin{array}{c}\text { Closterium } \\
\text { sp. }\end{array}$ & $\begin{array}{l}\text { Mougeotia } \\
\text { sp. }\end{array}$ & Staurastrum & $\begin{array}{l}\text { Straurastrum } \\
\text { sp. }\end{array}$ & $\begin{array}{c}\text { Total } \\
\text { Conjugatae }\end{array}$ & $\begin{array}{l}\text { Total } \\
\text { Algae }\end{array}$ \\
\hline $11 / 30$ & & & & & 1,600 & $12,232,52 \mathrm{~S}$ \\
\hline $12 / 3$ & & & 6,400 & & 8,000 & $13,796,160$ \\
\hline $12 / 6$ & $\cdots$ & & (1. & & 3,200 & $9,532,912$ \\
\hline $12 / 10$ & , ......... & ... & & .... & 21,336 & $4,1 \pm 4,964$ \\
\hline $12 / 14$ & & & & & & $4,602,940$ \\
\hline $12 / 17$ & .......... , & $\ldots$ & & ... & 1,200 & $4,230,26 \mathrm{~S}$ \\
\hline $12 / 20$ & & $\ldots \ldots$ & & & $\cdots \cdots$ & $4,599,528$ \\
\hline $12 / 2 \pm$ & & & 400 & & 400 & $2,282,716$ \\
\hline $12 / 27$ & 年 & 400 & & & 100 & $5,1.53,036$ \\
\hline $12 / 31$ & n............. & …........... & ............. & n............. & ........ & $4,127,276$ \\
\hline
\end{tabular}

1913

$1 / 5$

$1 / \mathrm{S}$

$1 / 12$

$1 / 15$

$1 / 19$

$1 / 22$

$1 / 26$

$1 / 29$

$2 / 2$
Total

Chlorophy
bearin

$1,197,572$

456,016

917,256

$4,255,716$

$7,257,952$

$3,02+248$

$1,059,168$

$2,079,556$

$1,513,724$

$2,157,085$

$2,259,656$

$1,0.50,704$

$3,675,424$

$5,512,136$

$2,528,560$

$6,268,050$

$7,113,336$

$7,019,072$

$2,755,296$

$3,322,000$

$3,188,592$

$4,599,504$

$4,686,212$

$3,117,56 \mathrm{~s}$

$3,179,96 \mathrm{~S}$

$2,697,600$

$3,666,576$

$7,647,576$

$4,755,64 \mathrm{~S}$

$12,156,384$

$11,976,896$

$20,939,56 \mathrm{~S}$

$20,254,224$

$19,5 \pm 2,624$

$22,294,816$

$21,378,688$

$35,355,32 \mathrm{~s}$

$64,300,640$

$50,683,376$

$42,053,824$

$+5,854,640$

$77,086,976$

$\$ 3,517,888$

$90,601,15^{\circ}$

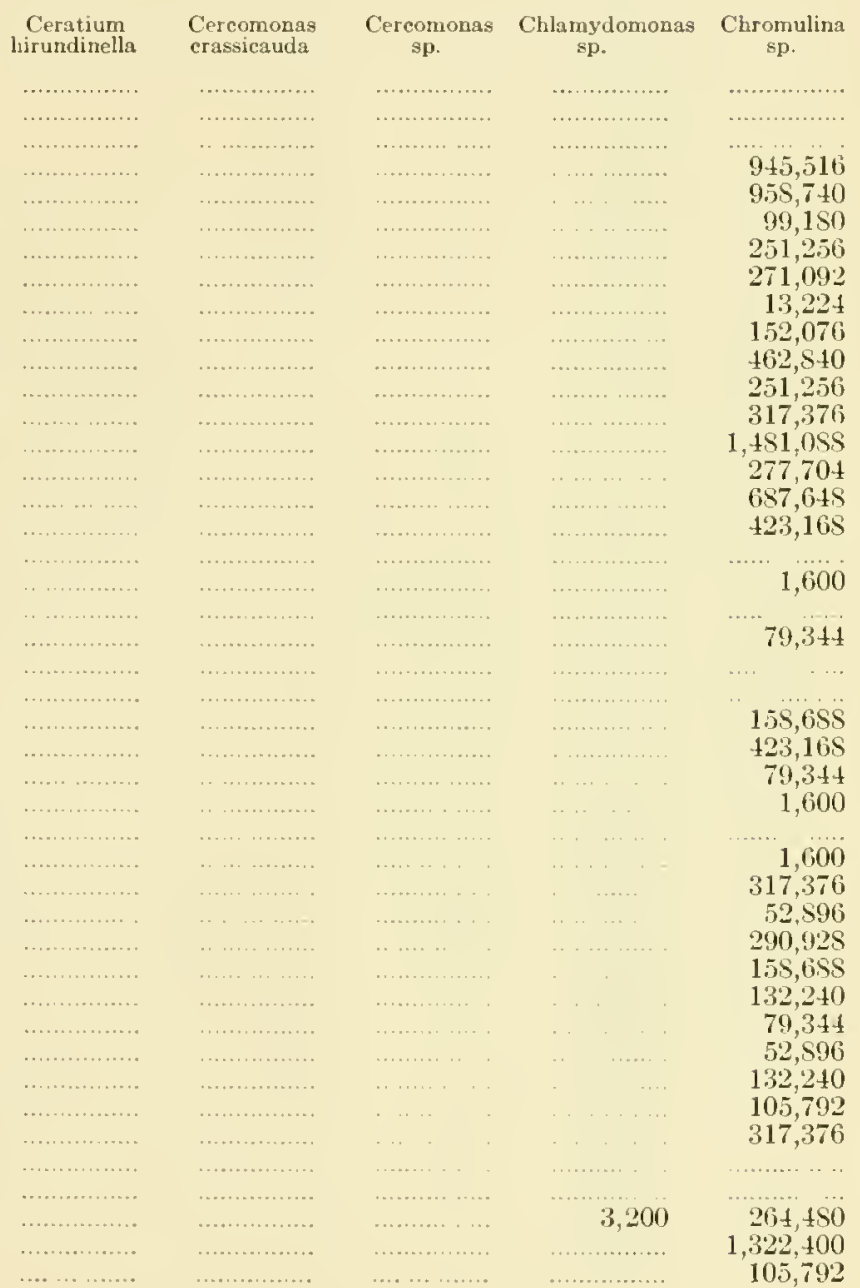




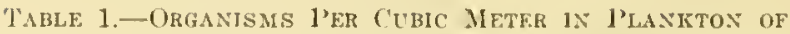
STOCKTON (HANNEL IN 1913-(Continued)

Total Chlorophyn bearing

1913

(6) 7

$6 / 11$

$6 / 16$

$6 / 1 \mathrm{~S}$

6/21

(i) $/ 25$

$6 / 28$

7/ 3

$7 / 5$

$7 / 9$

$7 / 12$

$7 / 16$

$7 / 19$

$7 / 23$

$7 / 26$

$7 / 30$

S/ 2

S/ 6

s/ 9

$\mathrm{S} / 13$

$8 / 15$

$8 / 20$

$8 / 23$

$8 / 27$

S/31

$9 / 2$

9/ 6

$9 / 9$

$9 / 13$

$9 / 17$

$9 / 20$

$9 / 24$

$9 / 27$

$10 / 1$

$10 / 4$

$10 / 8$

$10 / 11$

$10 / 15$

$10 / 18$

$10 / 22$

$10 / 26$

$10 / 29$

$11 / 1$

$11 / 5$

$11 / \mathrm{S}$

$11 / 12$

$11 / 15$

11/19

$11 / 22$

$11 / 26$

$11 / 30$

12/ 3

$12 / 6$

$12 / 10$

$12 / 14$

$12 / 17$

$12 / 20$

$12 / 24$

$12 / 27$

$12 / 31$

$80,295,936$

$77,356,352$

$58,9916,672$

$71,130,624$

$58,441,984$

$61,801,248$

83, 154,016

$59,196,832$

$24,657,440$

$24,516,650$

$37,862,232$

$71,364,605$

$43.853,794$

$23,044,054$

$44,063,852$

$31,213,344$

$30,601,496$

$25,992,640$

$27,411,232$

$56,819,882$

$32,637,640$

$37,612,544$

$38,727,776$

$46,325,600$

$58,364,972$

$58,853,856$

$71,957,264$

$64,266,944$

$62,385,784$

$57,307,872$

$49,541,272$

$59.108,736$

$55,149,632$

$59,909,664$

$37,200,696$

$45,580,140$

$47,708,800$

$46,335,128$

$45,833,536$

$48,536,736$

$49,760,640$

$52,006,272$

$31,041,856$

$25,526,176$

$20,151,680$

$40,772,368$

$23,200,645$

$18,674,392$

$20,426,064$

$14,403,616$

$15,549,728$

$16,574,800$

$11,905,456$

$5,169,854$

$5,796,300$

$5,633,212$

$5,321,200$

$3,422,780$

$6,502,284$

$5,146,724$ hirundinella

Cereomonas

crassicauda

132,240
Cereomonas Chlamydomonas Chromulina

$$
\text { sp. } 8 \mathrm{p} \text {. }
$$

sp.

10i, 792

211,584

899,232

(i.34, 752

370,272

581,856

740,544

$1,428,192$

(i. 34752

$2,456,112$

$4,919,328$

$5,1 \mathrm{~S} 3, \mathrm{~s}(\mathrm{OS}$

$105,792 \quad 6,929,376$

$3,173,760$

$7,299,648$

$3,279,5,52$

$3,967,200$

$3,226,656$

$1,481,058$

$6,347,520$

$4,231,680$

$6,876,480$

$6,770,68 \mathrm{~s}$

3,200

$26+480$

$1,533,984$

370,272

423,168

211,584

$158,68 \mathrm{~S}$

423,168

$5,289,600$

$370,272-5,55+080$

$687,648 \quad 7,722,816$

$105,792 \quad 10,579,200$

$11,531,32 \mathrm{~S}$

$13,224,000$

$17,825,952$

$5,977,248$

$6,559,104$

$9,785,760$

$9,151,008$

$5,342,496$

$4,513,536$

$4,549,056$

$2,539,008$

$5,395,392$

$4,813,536$

$4,231,680$

$6,612,000$

$7,299,64 \mathrm{~S}$

$5,448,285$

$5,977,24 \mathrm{~S}$

$12,906,624$

$6,347,520$

$5,104,464$

$5,210,256$

$2,089,392$

$2,856,384$

$2,221,632$

$1,957,152$

806,664

859,560

932,292

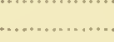

400

621,528

932,292

971,964

641,364 
Table 1-Organisms Per Cubic Mieter in Plankton of Stockton Channel IN 1913-(Continued)

\begin{tabular}{|c|c|c|c|c|c|c|}
\hline 1913 & $\begin{array}{c}\text { Cryptomonas } \\
\text { sp. }\end{array}$ & $\begin{array}{c}\text { Dinobryon } \\
\text { sertularia }\end{array}$ & $\begin{array}{c}\text { Eudorina } \\
\text { elegans }\end{array}$ & $\begin{array}{c}\text { Euglena } \\
\text { deses }\end{array}$ & $\begin{array}{c}\text { Euglena } \\
\text { viridis }\end{array}$ & $\begin{array}{c}\text { Flagellate } \\
\text { unidentified }\end{array}$ \\
\hline $1 / 5$ & & & & & & ..... \\
\hline $1 / 8$ & & ...... & 400 & ..... & …............ & \\
\hline $1 / 12$ & ............ & ………... & 800 & & 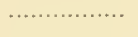 & 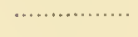 \\
\hline $1 / 15$ & . & ㅅ.............. & 400 & ......... & …............. & \\
\hline $\begin{array}{l}1 / 19 \\
1 / 22\end{array}$ & & ...... & $\begin{array}{r}2,000 \\
800\end{array}$ & ……… & .............. & \\
\hline $\begin{array}{l}1 / 222 \\
1 / 26\end{array}$ & ………… & ................ & $\begin{array}{l}800 \\
800\end{array}$ & …... & ……………. & \\
\hline $1 / 29$ & 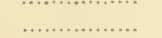 & 400 & 2,400 & ………….. & …………. & \\
\hline $2 / 2$ & ......... & $\ldots \ldots$ & 2,400 & & ………… & \\
\hline $2 / 5$ & ………… & ………… & 1,600 & & .............. & 19,836 \\
\hline $2 / 8$ & ................ & $\ldots \ldots$ & 8,000 & ……........ & ……........ & \\
\hline $2 / 12$ & … & …… & 1,600 & .... & ... & ........... \\
\hline $\begin{array}{l}2 / 15 \\
2 / 19\end{array}$ & .... & 1600 & $\begin{array}{r}1,600 \\
20,800\end{array}$ & & 1,600 & 800 \\
\hline $\begin{array}{l}2 / 19 \\
2 / 23\end{array}$ & ........ & 1,000 & $\begin{array}{r}20,500 \\
6,400\end{array}$ & & 26,448 & \\
\hline $2 / 26$ & ....... & ....... & 9,600 & & 1,600 & 1,600 \\
\hline $3 / 1$ & ………... & ....... & 9,600 & ....... & ... $\ldots . .$. & ....... \\
\hline $3 / 5$ & ....... & $\ldots \ldots$ & 9,600 & ….... & ....... & $\ldots \ldots \ldots$ \\
\hline $3 / 8$ & ..... & ...... & 3,200 & & & \\
\hline $3 / 12$ & …… & & 1,600 & ............. & 1,600 & .......... \\
\hline $3 / 15$ & ...акака. & ................ & 16,000 & .... & & \\
\hline $3 / 19$ & ………........ & ….... & 3,200 & . … & 1,600 & \\
\hline $3 / 23$ & 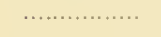 & ....... & 3,200 & ............. & $\ldots \ldots \ldots$ & 52,896 \\
\hline $3 / 26$ & $\ldots \ldots \ldots \ldots \ldots$ & … & 9,600 & ...... & ……..... & \\
\hline $3 / 29$ & ....... & ........ & 57,600 & $\ldots \ldots$ & ……... & \\
\hline $4 / 2$ & ….......... & ........ & 79,344 & ........ & ............... & .......... \\
\hline $4 / 5$ & & ....... & 9,600 & ........ & ........... & ... \\
\hline $4 / 9$ & . . & ...... . & 6,400 & ........ & .........., & …........ \\
\hline $4 / 13$ & .................. & $\ldots$ & 9,600 & & ..... & ......... \\
\hline $4 / 16$ & ............. & …… & 9,600 & ……… & ...... & \\
\hline $4 / 19$ & . & …........... & 3,200 & ............... & $\cdots$ &.. \\
\hline $4 / 23$ & …, & $\cdots \ldots$ & 1,600 & $\ldots \ldots$ & & \\
\hline $\begin{array}{l}4 / 26 \\
4 / 30\end{array}$ & ….... & $\begin{array}{l}\cdots \\
\cdots \\
\cdots\end{array}$ & 3,200 & ..... & 1,600 & \\
\hline $5 / 3$ & ……........... & $\ldots .$. & $\cdots$ & …ㄴ..… & ........... & ………... \\
\hline $5 / 7$ & 단..… & $\ldots \ldots$. & ............. & …… - … & & \\
\hline $5 / 11$ & ………… & $\ldots \ldots$ & …........ & …… & 105,792 & \\
\hline $5 / 14$ & ……… & ……ㄴ.. & ............ & ........... & 3,200 & \\
\hline $5 / 17$ & ..... & .............. & & 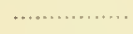 & 105,792 & \\
\hline $5 / 21$ & ..... & & 3,200 & …как.к. & \begin{tabular}{lll|}
. & $\ldots$ & $\ldots$
\end{tabular} & . \\
\hline $5 / 24$ & ... & ....... & $\begin{array}{llll}\ldots \ldots & \ldots\end{array}$ & .... & ........... & 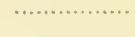 \\
\hline $5 / 27$ & $\cdots$ & $\cdots$ & & $\cdots$ & ........ & ...... $>$ \\
\hline $\begin{array}{l}5 / 31 \\
6 / 3\end{array}$ & 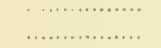 & ………"... & $\begin{array}{l}6,400 \\
6,400\end{array}$ & …..... & .......... & …….......... \\
\hline 6/ 7 & & ….................. & ............ & ㄱ..…… & ………..... & $\ldots$ \\
\hline $6 / 11$ & .................. & ........ & & & ... ........... & ... \\
\hline $6 / 16$ & .......... & ....... . & 6,400 & ....... & 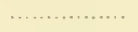 & \\
\hline $6 / 1 S$ & ............. & ............. & 19,200 & ....... $\ldots \ldots$ & ........ & \\
\hline $6 / 21$ & ............. & ......... & 6,400 & & & \\
\hline $6 / 25$ & ............ & ................ & 12,800 & ....... & 158,688 & 3,200 \\
\hline $6 / 28$ & ............... & ………... & 12,800 & ........ & .............. & $\cdots$ \\
\hline $7 / 3$ & ….......... & …как...... & 32,000 & ...... & & \\
\hline $7 / 5$ & ………... & ……......... & & & 3,200 & \\
\hline & ............. & 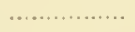 & 19,200 & 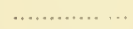 & 211,584 & \\
\hline $7 / 12$ & .............. & ............... & 6,400 & & 793,440 & \\
\hline $7 / 16$ & ..... & .............. & 6,400 & ................... & 158,688 & ... $\quad \ldots$ \\
\hline 19 & ............. & 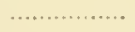 & ............ & ……… & 6,400 & ..... \\
\hline $7 / 23$ & …......... & $\ldots \ldots \ldots \ldots$ & $\ldots \ldots \ldots$ & …......... & 105,792 & ........ \\
\hline $7 / 26$ & ............. & ........... & & …… & 370,272 & \\
\hline 30 & ....... & .............. & 6,400 & ............. & 423,165 & \\
\hline
\end{tabular}


'Table 1.-Organisms Per Cubic Meter in Piankton of Stockton Chandel in 1913-(Contimucd)

1913

$8 / 2$

$\mathrm{S} / 6$

87

$8 / 13$

S. 15

$S / 20$

$\mathrm{S} / 23$

$8 / 27$

$\mathrm{S} / 31$

$9 / 2$

9/ $1 \mathrm{i}$

9/ 9

9/13

917

0) 20

(9) $/ 21$

$9 / 27$

$10 / 1$

$10 / 4$

$10 / 8$

10/11

$10 / 15$

$10 / 18$

$10 / 22$

$10 / 26$

$10 / 29$

11/ 1

11/ 5

$11 / 8$

$11 / 12$

$11 / 15$

$11 / 19$

$1 \mathrm{I} / 22$

$11 / 26$

$11 / 30$

12/ 3

$12 / 6$

$12 / 10$

$12 / 14$

$12 / 17$

$12 / 20$

$12 / 24$

$12 / 27$

$12 / 31$

1913

$1 / 5$

$1 / 8$

$1 / 12$

$1 / 15$

$1 / 19$

$1 / 2 \cdot 2$

$1 / 20$

$1 / 29$

2) 2

2) 5

$2 / \mathrm{S}$
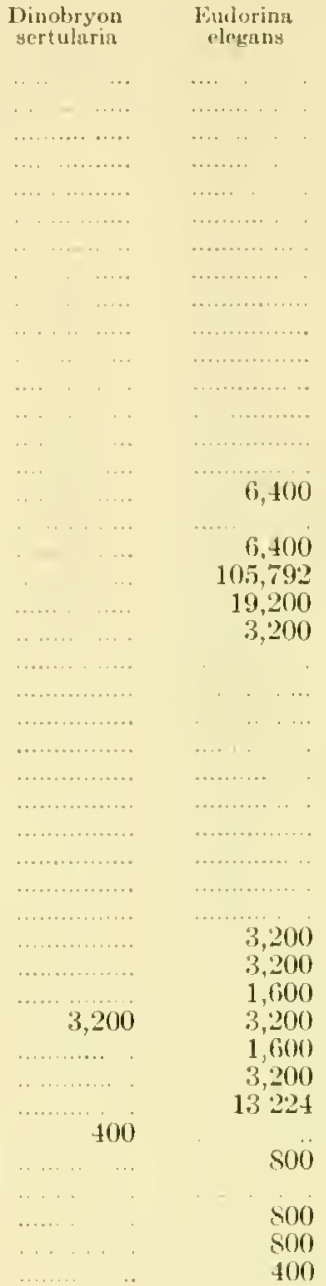

\section{Euglena}

Euglena

ptomo

476,064

158,6388

$10.5,792$

.............

211,584

52,896

.... , .....

264,480

105,792

79,344

185,136

185,136

132,240

52,596

1,600

66,120

400

99.180

26,448

59,508

(if) 120

112,404

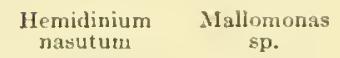

sp.

Pandorina
noorum

3,200

3,200

1,600

3,200

1,600

3,200

$13 \cdot 24$

800

800

800

400

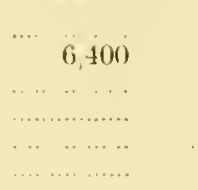

105,792

476,064

261,480

3,200

15x, 6SS

158.68S

10.5.792

158,685

$20.4,480$

105,792

158,685

211,584

$15 \mathrm{~S}, 6 \mathrm{SS}$

52.896

105,792

105,792

52,896

6,400

(j), 400

6,400

3,400

79,344

6, 400

79,344

12,500

3,200

1..............

$\$ 80$

105,792

Flagellate
undentified

$+\cdots$

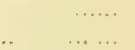

.

‥

.

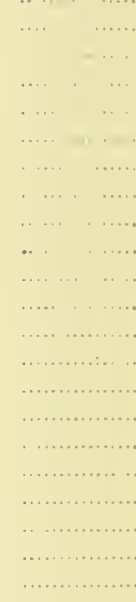

Phacus

Peridinium Peridinium cinctum $r$ sp.

pleuronectes

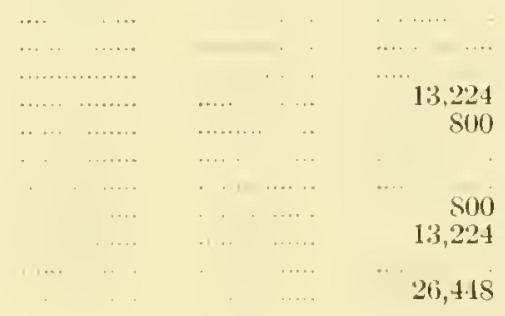


Table 1.-Organisms Per Cubic Mleter in Plankton of Stockton Channel IN 1913-(Continued)

\begin{tabular}{|c|c|c|c|c|c|c|}
\hline 1913 & $\begin{array}{l}\text { Henaidinium } \\
\text { nasutum }\end{array}$ & $\begin{array}{l}\text { Mallomonas } \\
\text { sp. }\end{array}$ & $\begin{array}{l}\text { Pandorina } \\
\text { morum }\end{array}$ & $\begin{array}{l}\text { Peridinium } \\
\text { cinctum }\end{array}$ & $\begin{array}{c}\text { Peridinium } \\
\text { sp. }\end{array}$ & $\begin{array}{l}\text { Phacus } \\
\text { pleuronectes }\end{array}$ \\
\hline $2 / 12$ & & & & & & . \\
\hline $2 / 15$ & ................ & 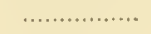 & 1,600 & 800 & ................ & ........ \\
\hline $2 / 19$ & $\ldots \ldots$ & $\ldots$ & 16,000 & .. & $\ldots$ & \\
\hline $2 / 23$ & …............. & …........... & .. & $\ldots \ldots \ldots \ldots$ & $\cdots$ & ..... \\
\hline $2 / 26$ & $\cdots$ & ......... & & $\ldots \ldots, \ldots \ldots$ & .... & .. \\
\hline $\begin{array}{l}3 / 1 \\
3 / 5\end{array}$ & ........ & n..., & 6,700 & ............... & .. & ..... \\
\hline $3 / 5$ & …... & …, & & & $\cdots$ & a... \\
\hline $3 / 12$ & ............... & ... & 3,200 & 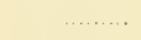 & $\cdots$ & \\
\hline $3 / 15$ & $\ldots \ldots \ldots \ldots \ldots$ & , $\ldots \ldots \ldots \ldots \ldots$ & 6,400 & ... & .... & ... \\
\hline $3 / 19$ & ............... & $\cdots$ & … & . $\ldots \ldots$ & …........... & ..... \\
\hline $3 / 23$ & . .............. & ................ & 3,200 & $\cdot \quad \ldots \ldots$ & ...... & \\
\hline $3 / 26$ & $\ldots \ldots \ldots \ldots$ & …............ & 79,344 & $\ldots$ & …............. & ..... \\
\hline $3 / 29$ & . & ................. & $\begin{array}{llll}\ldots & \ldots & \ldots\end{array}$ & $\ldots$ & ............... & …..... \\
\hline $4 / 2$ & n., $\ldots \ldots \ldots \ldots$ & $\cdots$ & & & & \\
\hline $4 / 5$ & nenton. & ................ & 1,600 & ... & … & \\
\hline $\begin{array}{l}49 \\
+\quad 13\end{array}$ & ................ & (n..... & 6,100 & $\cdots \cdot \quad \cdots \cdots$ & ......... & \\
\hline $\begin{array}{l}4 / 13 \\
4 / 16\end{array}$ & ……, & ………… & 1,600 & … $\quad \ldots+\ldots$, & '....... & \\
\hline $\begin{array}{l}4 / 16 \\
4 / 19\end{array}$ & $\ldots \ldots+\ldots+\cdots, \ldots$ & (n..... & 3,200 & $\ldots \ldots \ldots \ldots$ & ...... & $\cdots$ \\
\hline $\begin{array}{l}4 / 19 \\
4 / 23\end{array}$ & ……, & …......... & 1,600 & $\cdot \quad \ldots \ldots \ldots$, & & 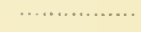 \\
\hline $\begin{array}{l}4 / 23 \\
+/ 26\end{array}$ & $\ldots \ldots \ldots \ldots \ldots$ & …............ & 1,600 & . . . ......... & ................ & , ................ \\
\hline $\begin{array}{l}4 / 26 \\
+/ 30\end{array}$ & $\begin{array}{l}\ldots \ldots \\
\ldots \ldots \ldots \ldots \\
\ldots \ldots\end{array}$ & .............. & 3,200 & ..... & ....... & $\cdots \cdot$ \\
\hline $\begin{array}{l}4 / 30 \\
5 / 3\end{array}$ & $\begin{array}{l}\ldots \ldots \ldots \ldots \ldots \\
\ldots \ldots \ldots \ldots \ldots \ldots\end{array}$ & ......, & ,........., & $\ldots \ldots \ldots$ & ........n. & 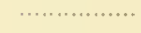 \\
\hline $\begin{array}{l}5 / 3 \\
5 / 7\end{array}$ & …… & $\ldots \ldots \ldots \ldots \ldots, \ldots$ & $\cdots$ & . $\ldots \ldots$ & ........ & .... \\
\hline $5 / 11$ & $\ldots \ldots \ldots \ldots$ & 52,896 & $\ldots .$. & 105,792 & $\cdots$ & \\
\hline $5 / 14$ & $\ldots \ldots \ldots \ldots$ & $\ldots \ldots \ldots$ & $\ldots . .$. & . . . . . & …... & 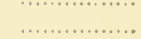 \\
\hline $5 / 17$ & $\ldots \ldots \ldots \ldots \ldots \ldots$ & ................ & & $\ldots$. & .................. & ….............. \\
\hline $5 / 21$ & . & ................ & 6,400 & $\cdots$ & ….......... & ……....... \\
\hline $5 / 24$ & . ............ & ................ & .. $\ldots \ldots \ldots \ldots$ & ........ & ................. & .................. \\
\hline $5 / 27$ & ............... & , $\ldots \ldots \ldots \ldots, \ldots$ & … & $\ldots \ldots$ & ...... & ............... \\
\hline $5 / 31$ & ................ & , $\ldots \ldots \ldots \ldots \ldots$ & $\ldots \ldots \ldots, \quad \ldots$ & (n.... & $\cdots,-0,0$ & .... \\
\hline $6 / 3$ & ................ & ................ & ……...... & $\ldots \ldots \ldots$ & 158,688 & \\
\hline $6 / 7$ & . $\quad$ n.......... & , n......, & & ...... & 211,584 & \\
\hline $6 / 11$ & ............... & 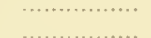 & & $\cdots$ & 158688 & \\
\hline $\begin{array}{l}6 / 16 \\
6 / 18\end{array}$ & & (........... & $\begin{array}{l}0,200 \\
3,200\end{array}$ & 317,376 & $\begin{array}{r}100,000 \\
3,200\end{array}$ & \\
\hline $6 / 21$ & $\ldots \ldots$. & ............... & . & $+\ldots$ & $\ldots$ & ....... \\
\hline $6 / 25$ & …............ & ............... & $\ldots \ldots$ & & ......... & .... \\
\hline $6 / 28$ & .............. & ................. & ... & 105,792 & $\ldots \ldots \ldots, \quad \ldots \ldots$ & $\ldots$. \\
\hline $7 / 3$ & ….......... & …, & .. & 423,168 & $\ldots \ldots, \ldots, \ldots$ & ..... \\
\hline $7 / 5$ & ……........ & 3,200 & ....... $\quad$.. & $1,005,024$ & n......... & ................ \\
\hline$7 \longdiv { 9 }$ & . & ............... & …... & 3,200 & $\cdots$. & .... \\
\hline $7 / 12$ & n..., n, & …........... & $\ldots \ldots$ & $\ldots \ldots \ldots$ & ..... & n..., n..., \\
\hline $7 / 16$ & (n, & '.............. & $\ldots \ldots \ldots, \cdots$ & $\cdots, \quad \cdots$ & .............. & n............ \\
\hline $7 / 19$ & 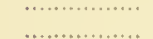 & 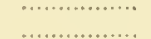 & …..... & $\ldots \ldots \ldots \ldots$ & .................. & 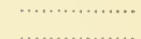 \\
\hline $7 / 26$ & …, & …............... & .......... & 317,376 & $\cdots$ & ...... \\
\hline $7 / 30$ & 52,896 & ................. & ......... & 3,200 & .................. & $\ldots$ \\
\hline $8 / 2$ & 634,752 & …............ & $\cdots$ & .. & $\cdots$ & .... \\
\hline $8 / 6$ & $1,163,712$ & .................. & .............. & ... & …........... & …............. \\
\hline $8 / 9$ & $9.52,128$ & , $\ldots \ldots \ldots \ldots \ldots$ & . & & , n.............. & ......... \\
\hline $8 / 13$ & & 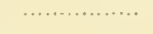 & & 105,792 & ......... & $\cdot \cdot$ \\
\hline $8 / 15$ & $1,745,56 \mathrm{~s}$ & $\ldots \ldots \ldots \ldots \ldots$ & $3,-200$ & $\ldots \ldots$ & . & ............... \\
\hline $8 / 20$ & $2,165,736$ & …....... & ..... & ............ & n..........., & 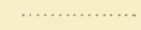 \\
\hline $8 / 23$ & $1,533,954$ & … & & 0 & $\ldots$ & .... \\
\hline $8 / 27$ & $2,380,320$ & ….......... & .. . & 3,200 & ....... & ............... \\
\hline $8 / 31$ & $4,125,888$ & 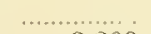 & $\ldots \ldots$ & 158,688 & ...... & ................. \\
\hline $9 / 2$ & $4,178,78 t$ & 3,200 & ................. & 370,272 & n., $, \ldots, \ldots, \ldots$ & .................... \\
\hline $9 / 6$ & $4,866,732$ & …......... & ……........... & 3,200 & ………....... & \\
\hline
\end{tabular}


Table 1.-Organisms Per ('ubic Meter in Plankton of STOCKTON CHANNEL IN 1913-(Continued)

\begin{tabular}{|c|c|}
\hline 1913 & $\begin{array}{l}\text { Iemiclinium } \\
\text { nasutum }\end{array}$ \\
\hline $9 / 9$ & $9,679,968$ \\
\hline $9 / 13$ & $7,617,024$ \\
\hline $9 / 17$ & $2,221,6332$ \\
\hline $9 / 20$ & $2,433,216$ \\
\hline $9 / 24$ & 528,960 \\
\hline $9 / 27$ & $3,8(i 1,408$ \\
\hline $10 / 1$ & 2168736 \\
\hline 10/4 & 528,960 \\
\hline $10 / 8$ & 317,376 \\
\hline $10 / 11$ & $1,451,058$ \\
\hline $10 / 15$ & $26.1,480$ \\
\hline $10 / 1 \mathrm{~s}$ & 211,584 \\
\hline $10 / 22$ & \\
\hline $10 / 26$ & \\
\hline $10 / 29$ & 52,896 \\
\hline $11 / 1$ & \\
\hline $11 / 5$ & ....... \\
\hline $11 / 8$ & $\ldots \ldots$ \\
\hline $11 / 12$ & ………… \\
\hline $11 / 15$ & \\
\hline $11 / 19$ & . \\
\hline & 1,000 \\
\hline
\end{tabular}
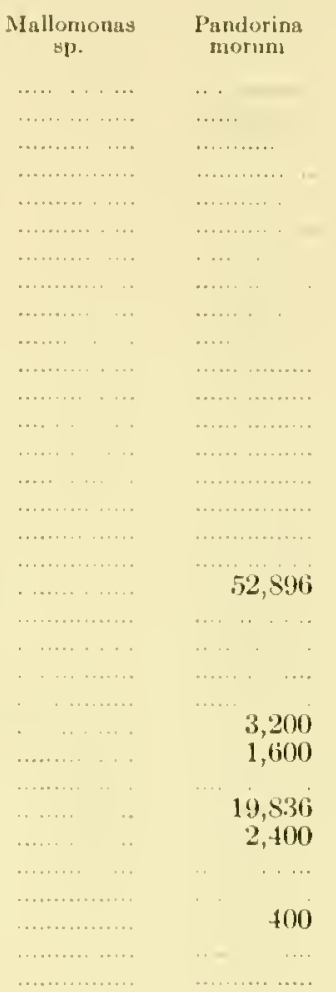

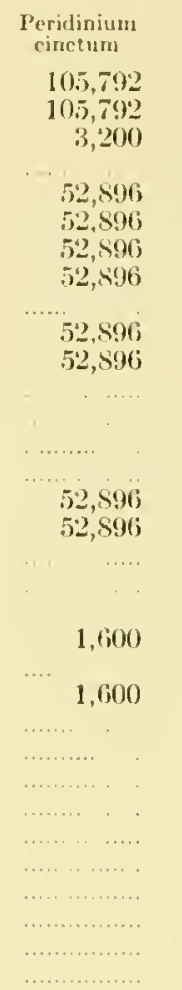

Peridinium sp.

Phneus pleuronectes

$11 / 26$

$11 / 30$

$12 / 3$

$12 / 6$

$12 / 10$

$12 / 14$

$12 / 17$

$12 / 20$

$12 / 24$

$12 / 27$

$12 / 31$

\section{0}
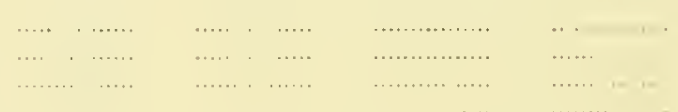

264,480 158,688 $1.58,685$ 105.792 52,596

52896 $47 t, 064$

211,581 52,896 370,272 23,, 032 238,032 52,890 52,896 52,596 26,448 26, 415 13,224

19,830 400

13,224 400

39,672 39,672 52,896 
Table 1.-Organisms Per Cubic Meter in Plankton of Stockton Channel IN 1913-(Continued)

\begin{tabular}{|c|c|c|c|c|c|c|}
\hline 1913 & $\begin{array}{l}\text { Platydorina } \\
\text { caudata }\end{array}$ & $\begin{array}{l}\text { Pleodorina } \\
\text { californica }\end{array}$ & $\begin{array}{l}\text { Pteromonas } \\
\text { sp. }\end{array}$ & $\begin{array}{l}\text { Spondylomorum } \\
\text { quarternarium }\end{array}$ & $\begin{array}{l}\text { Synura } \\
\text { uvelia }\end{array}$ & $\begin{array}{c}\text { Trachelomona } \\
\text { euchlora }\end{array}$ \\
\hline $3 / 23$ & & & & & & 52,896 \\
\hline $3 / 26$ & …, n........ & n... & n............. & ……, & …........... & 52,896 \\
\hline $3 / 29$ & , & ............. & ............... & ...... & ...... & 1,600 \\
\hline $4 / 2$ & …............ & …............. & ……........ & ….............. & ............... & 1,600 \\
\hline $\begin{array}{l}\text { 4) } 5 \\
+9\end{array}$ & ............. & n., & ……....... & .................. & ................ & 1,600 \\
\hline $4 / 13$ & ………, & ……….... & ………… & $\begin{array}{l}\cdots \\
\ldots \ldots\end{array}$ & …... & \\
\hline $4 / 16$ & ........ & $\cdots \cdots$ & .......... & $\ldots$. & ...... & 105,792 \\
\hline 1/19 & ............... & ................. & (.................. & 3,200 & & 1,600 \\
\hline $4 / 23$ & …............ & ….... & (........ & $\cdots \cdots$ & $\ldots$ & 476,064 \\
\hline $\begin{array}{l}4 / 26 \\
4 / 20\end{array}$ & .............., & , n...... & 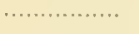 & $\ldots \ldots+\ldots, \cdots$ & ................. & 52,596 \\
\hline $4 / 30$ & …............ & ….... & , $\ldots \ldots \ldots \ldots \ldots$, & $\cdots \cdots$ & ….........., & 1,600 \\
\hline $\begin{array}{l}5 / 3 \\
5 / 7\end{array}$ & ….............. & …............. & ……....... & ……........ & …............ & 105,792 \\
\hline $5 / 11$ & ……......... & ……, & ………, & ………… & ….........., & 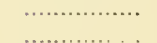 \\
\hline $5 / 14$ & …............. & …............. & ................ & …........... & $\ldots \ldots$ & 3,200 \\
\hline $5 / 17$ & …........... & (......... & …........... & .............. & .............. & ............ \\
\hline $5 / 24$ & ………… & ................ & 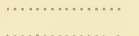 & ...... & ..... & \\
\hline $5 / 27$ & ……............ & ….............. & ………, & …….......... & ............... & 105,030 \\
\hline $5 / 31$ & , n............ & . …......... & n............... & ……, & 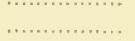 & \\
\hline $6 / 3$ & , $\ldots \ldots \ldots \ldots \ldots$ & ……......... & ……......... & …............ & .......... & 158,685 \\
\hline $6 / 11$ & …, & ……… & ………, & $\begin{array}{l}\ldots . \\
\ldots\end{array}$ & ……1, & 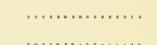 \\
\hline $6 / 16$ & ............... & …............. & ....... & ..... & 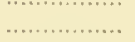 & 3,200 \\
\hline $6 / 18$ & …........... & 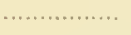 & & & ................. & 158,688 \\
\hline $6 / 21$ & …............. & …............ & 158,685 & $\cdots \cdots$ & n............. & 3,200 \\
\hline $\begin{array}{l}6 / 25 \\
6 / 28\end{array}$ & ……......... & , n.m. & $\cdots$ & (........ & …............. & 3,200 \\
\hline $7 / 3$ & ………… & ………… & ………. & 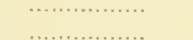 & …........... & , n..., \\
\hline $7 / 5$ & ................ & 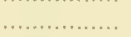 & 158,688 & 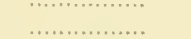 & ………… & ..... \\
\hline $7 / 9$ & ….......... & ……........ & 32,000 & $\ldots \ldots \ldots$ & 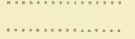 & \\
\hline $\begin{array}{l}7 / 12 \\
7 / 16\end{array}$ & ............., & ……, & $\ldots \ldots \ldots \ldots$ & ….......... & .............. & (........... \\
\hline $7 / 19$ & n..., & 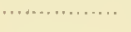 & n..., n., & …., n..., & 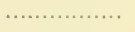 & $\cdots$ \\
\hline $7 / 23$ & ………… & ……… & ....... & …....... & ............ & $\cdots$ \\
\hline $7 / 26$ & n............ & ….......... & 105,792 & ………… & ………... & \\
\hline $\begin{array}{l}7 / 30 \\
8 / 2\end{array}$ & & & , n............. & & & \\
\hline $\begin{array}{l}S / 2 \\
S / 6\end{array}$ & 6,400 & 6,400 & …............ & 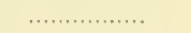 & 3,200 & 3,200 \\
\hline $\begin{array}{l}8 / 6 \\
8 / 9\end{array}$ & $\ldots \ldots \ldots \ldots \ldots$ & $\ldots \ldots \ldots \ldots \ldots$ & & $\cdots$ & 6,100 & 3,200 \\
\hline $\begin{array}{l}8 / 9 \\
8 / 13\end{array}$ & 6,400 & 6,400 & $\begin{array}{r}3,200 \\
50\end{array}$ & & & \\
\hline $8 / 15$ & $\begin{array}{c}0, \mathbf{T} 0 \\
\ldots \ldots \ldots \ldots \ldots \ldots\end{array}$ & $\begin{array}{r}0, \pm 00 \\
\ldots \ldots . .\end{array}$ & 100,692 & $\ldots$ & $\begin{array}{l}3,200 \\
3200\end{array}$ & .. \\
\hline $8 / 20$ & ................ & ............ & $15 S, 688$ & …….... & $\odot, \angle 00$ & \\
\hline $8 / 23$ & (n............. & (n............. & 3,200 & ….......... & 264,480 & ….... \\
\hline $5 / 27$ & n.en, & $\ldots \ldots \ldots \ldots \ldots$ & $\ldots \ldots \ldots$ & ............... & n................ & ... \\
\hline $\begin{array}{l}8 / 31 \\
9 / 2\end{array}$ & 12,800 & n......, & $\cdots \cdot$ & $\cdots$ & & \\
\hline $9 / 6$ & $\begin{array}{r}12,500 \\
\ldots \ldots \ldots \ldots \ldots\end{array}$ & ……… & ............. & .... & $6, \pm 00$ & \\
\hline $9 / 9$ & 6,400 & ............... & (n) & $\ldots, \ldots, \ldots, \ldots$ & 105,792 & \\
\hline $\begin{array}{l}9 / 13 \\
9 / 17\end{array}$ & 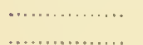 & n.............. & “ & $\cdots \cdots \cdots$ & $\cdots \cdots$ & \\
\hline $9 / 20$ & ……… & ………... & 211.584 & 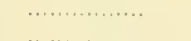 & $\begin{array}{r}3,200 \\
-808\end{array}$ & \\
\hline $9 / 24$ & n............ & ………, & …............. & …........... & 105,058 & \\
\hline $9 / 27$ & …........... & ................ & ….......... & ................ & n.............. & \\
\hline $10 / 4$ & 6,400 & ............... & ............ & …............. & $\cdots$ & $\cdots$ \\
\hline $10 / 8$ & $\ldots \ldots \ldots \ldots \ldots$ & ................. & 52,896 & ............... & 52,896 & ........ \\
\hline $10 / 11$ & n........, & . (............... & $\ldots \ldots, \ldots$ & …............ & 52,896 & .... \\
\hline $10 / 15$ & n............., & n.w. & .. & …...... & & \\
\hline
\end{tabular}


Table 1.-Organisms l'eir Cubic Meter in Plankton of STOCKTON CHANNEL IN 1913-(Continued)
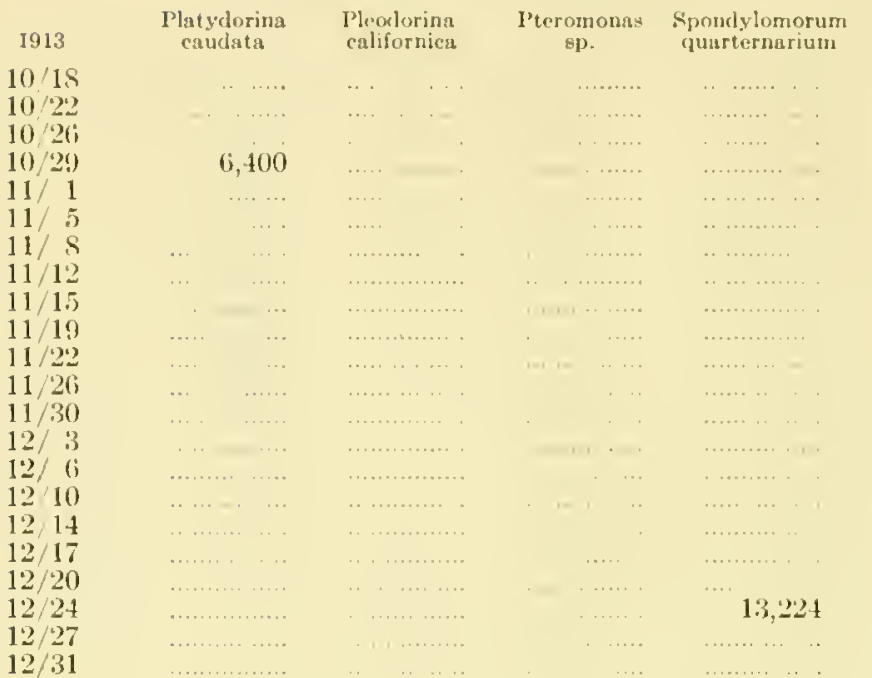

$\underset{\substack{\text { Synura } \\ \text { uvella }}}{\text { and }}$

Trachrlomonas cuchlora

$10 / 1 \mathrm{~S}$

$10 / 22$

1026

$11 / 1$

$11 / 5$

$11 / 8$

$11 / 1.5$

$11 / 19$

$11 / 242$

$11 / 30$

$12 / 3$

126

1214

$12 / 17$

$12 / 20$

$12 / 27$

$12 / 31$

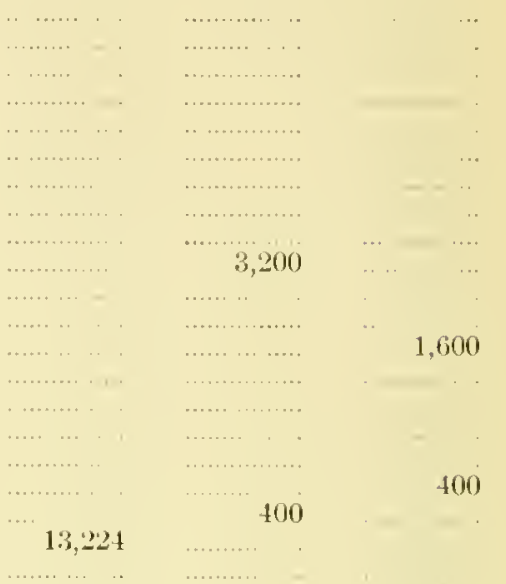

400

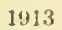

Trachelomonas Trachelomonas

Total olvoeina

Iastigophora

Amoebr

Amoeba radius:

Arcella

$1 / 5$

$1 / 8$

$1 / 12$

$1 / 15$

$1 / 19$

$1 / 22$

$1 / 26$

$1 / 29$

$2 / 2$

$2 / 5$

2) 8

$2 / 12$

$2 / 15$

2/ 19

$2 / 2: 3$

$2 / 26$

$3 / 1$

$3 / 5$

$3 / 8$

$3 / 12$

$3 / 15$

$3 / 19$

$3 / 23$

$3 / 26$

$3 / 29$

4/ 2

4) 5

4 ?

$1 / 13$

$4 / 16$

4/19

4/2:3

$4 / 26$

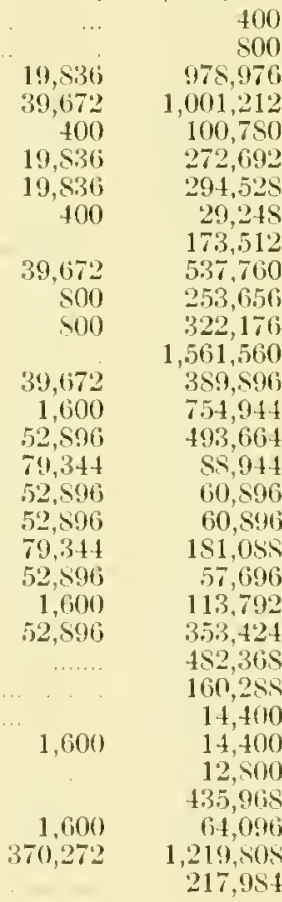

Sol)

400

400

800

217.984
800

1,600

1,600

3,200 
Table 1.-Organisms Per Cubic Meter in Plankton of StOCKTON ChanNed in 1913-(Continued)

\begin{tabular}{|c|c|c|c|c|c|c|}
\hline 1913 & $\begin{array}{l}\text { Trachelomonas } \\
\text { sp. }\end{array}$ & $\begin{array}{l}\text { Trachelomonas } \\
\text { volvocina }\end{array}$ & $\begin{array}{c}\text { Total } \\
\text { MIastigophora }\end{array}$ & $\begin{array}{l}\text { Amoeba } \\
\text { proteus }\end{array}$ & $\begin{array}{l}\text { Amoeba } \\
\text { radiosa }\end{array}$ & $\begin{array}{c}\text { Arcella } \\
\text { vulgaris }\end{array}$ \\
\hline $4 / 30$ & & & 135,440 & & 1,600 & \\
\hline $5 / 3$ & $\ldots$ & 105,792 & 290,928 & 1,600 & 79,314 & \\
\hline $5 / 7$ & & & 52,896 & & 1,600 & \\
\hline $5 / 11$ & & 79,344 & 370,272 & $\ldots \ldots$ & 1,600 & \\
\hline $5 / 14$ & 3,200 & & 112,192 & & & \\
\hline $5 / 17$ & ..... & 264,480 & 581,856 & .......... & & \\
\hline $5 / 21$ & $\ldots .$. & 211,581 & 221,184 & & 3,200 & \\
\hline $5 / 24$ & ..... & 105,792 & 264,480 & & . & ... \\
\hline $5 / 27$ & $\ldots$ & 264,480 & 532,160 & & & ... \\
\hline $5 / 31$ & ..... & 211,584 & $1,540,384$ & & & \\
\hline $6 / 3$ & ..... & 317,376 & $7 \$ 6,914$ & ......... & ... & $\ldots$ \\
\hline $6 / 7$ & ..... & 687,648 & $1,005,024$ & & & \\
\hline $6 / 11$ & $\ldots$ & 793.440 & $1,110,816$ & & 3,200 & \\
\hline $6 / 16$ & $\ldots$ & 423,168 & $1,497,0 \mathrm{~S} 8$ & & & \\
\hline $6 / 18$ & $\ldots$ & 264,480 & $1,503,48 \mathrm{~s}$ & ......... & & \\
\hline $6 / 21$ & $\ldots$. & 158,688 & 700,448 & & & \\
\hline $6 / 25$ & ..... & 687,648 & $1, \pm 47,392$ & & & \\
\hline $6 / 28$ & $\ldots$ & $1,005,024$ & $1,867,360$ & & & $\ldots$ \\
\hline 7/ 3 & ..... & $1,057,920$ & $2,941,280$ & & & \\
\hline $7 / 5$ & ..... & 264,480 & $2,069,314$ & 6,100 & & ....... \\
\hline $7 / 9$ & ..... & 264,480 & $3,016,576$ & & & \\
\hline $7 / 12$ & $1 \quad \ldots$ & 476,064 & $6,195,232$ & & & 3,200 \\
\hline $7 / 16$ & ..... & ..... . . ..... & $5,352,096$ & $\ldots \ldots$ & .......... & \\
\hline $7 / 19$ & $\ldots$ & ....... & $7,041,56 \mathrm{~S}$ & ……… & …...... & \\
\hline $7 / 23$ & & 3,200 & $3,285,952$ & . & (1). & $\ldots . .$. \\
\hline $7 / 26$ & ....... & 105,792 & $8,198,8 \$ 0$ & ... & $\ldots$ & \\
\hline $7 / 30$ & ....... & & $4,244,480$ & & & \\
\hline $8 / 2$ & $\ldots \ldots$ & 105,792 & $4,832,736$ & $\ldots \ldots$. & & \\
\hline $8 / 6$ & ...... & 105,792 & $4,988,221$ & …ㄴ..1.... & 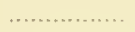 & \\
\hline s/ 9 & $\ldots$ & 211,584 & $2,912,480$ & & & \\
\hline $8 / 13$ & $\ldots$ & $1,057,920$ & $8,485,750$ & 158,688 & & \\
\hline $8 / 15$ & $\ldots$ & 793,440 & $6,780,2 \mathrm{sS}$ & 105,792 & & \\
\hline $8 / 20$ & $\ldots$. & $1.110,816$ & $10,473,40 \mathrm{~s}$ & & & \\
\hline $8 / 23$ & $\ldots$ & 158,688 & $8,892,928$ & & & \\
\hline $8 / 27$ & $\ldots$ & 317,376 & $8,519,456$ & & $\ldots$. & \\
\hline $8 / 31$ & $\ldots$ & 740,544 & $11,319,744$ & ......... & $\ldots$. & \\
\hline $9 / 2$ & $\ldots$ & 528,960 & $15,203,552$ & & & \\
\hline $9 / 6$ & & 634,752 & $16,824,128$ & $\ldots \ldots$ & 3,200 & 6,400 \\
\hline $9 / 9$ & ....... & 657,648 & $22,645,888$ & & & \\
\hline $9 / 13$ & ...... & 476,064 & $21,634,464$ & ....... & & \\
\hline $9 / 17$ & & 793,440 & $21,012,512$ & & 158,688 & \\
\hline $9 / 20$ & $\ldots \ldots$ & 264,480 & $9,574,176$ & ...... & 211,584 & \\
\hline $9 / 24$ & ............ & 317,376 & $7,464,736$ & & & \\
\hline $9 / 27$ & ....... & 317,376 & $14,705,0 \mathrm{~s} s$ & & & \\
\hline $10 / 1$ & ..... & $423,16 \mathrm{~S}$ & $12,377,661$ & ... & 52,896 & \\
\hline $10 / 4$ & $\ldots$ & 370,272 & $6,630,200$ & & & \\
\hline $10 / \mathrm{S}$ & ...... & 952,128 & $6,459,712$ & & & \\
\hline $10 / 11$ & $\ldots \ldots \ldots$ & 581,856 & $6,935,776$ & & 52,896 & \\
\hline $10 / 15$ & …............ & $1,057,920$ & $4,020,024$ & ......... & ......... & \\
\hline $10 / 18$ & & 846,336 & $6,453,312$ & & & \\
\hline $10 / 22$ & 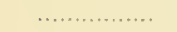 & 793,440 & $5,818,560$ & & 211.584 & \\
\hline $10 / 26$ & ……… & 740,544 & $5,025,120$ & & 476,064 & \\
\hline $10 / 29$ & 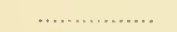 & 476,064 & $7,259,552$ & 6,400 & 370,272 & \\
\hline $11 / 1$ & ....... & 211,584 & $8,052,992$ & r & 264,480 & \\
\hline $11 / 5$ & ……… & & $5,606,976$ & & & 6,400 \\
\hline $11 / \mathrm{s}$ & & 158,688 & $6,373,120$ & & ......... & \\
\hline $1 / 12$ & …… & 502,512 & $13,86.5,152$ & & & \\
\hline $1 / 15$ & …ㄴ..…, & 476,064 & $7,365,344$ & & …......... & \\
\hline $11 / 19$ & ……......... & 158,688 & $5,667,872$ & & ................. & $\ldots$. \\
\hline $11 / 22$ & ……… & 158,688 & $5,814,512$ & 3,200 & & \\
\hline
\end{tabular}


'Table 1.-Organism Per Cublc Meter in Plankton of STOCKTON CIANNEL IN 1913-(Continued)

1913
$11 / 26$
$11 / 30$
$12 / 3$
$12 / 6$
$12 / 10$
$12 / 14$
$12 / 17$
$12 / 20$
$12 / 24$
$12 / 27$
$12 / 31$

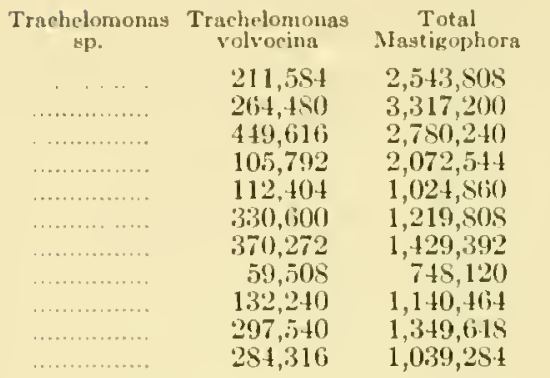

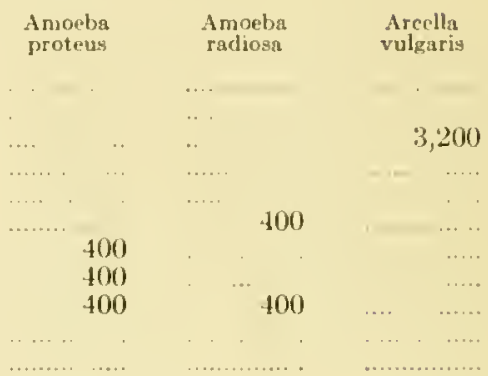
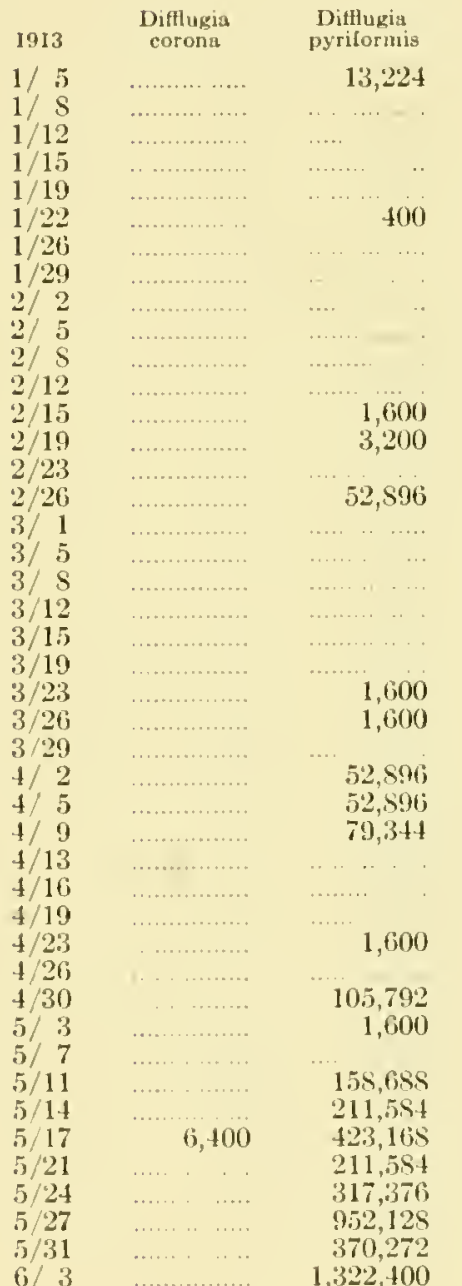

Hyalodiscus $\mathrm{sp}$.

Hyalosphenis cuneats

Hyalosphenia

Microgromia

socialis

1) 5

1/12

$1 / 15$

$1 / 19$

$1 / 22$

$1 / 26$

$1 / 29$

2) 2

$2 / \mathrm{S}$

2/12

2/15

2/19

$2 / 23$

$2 / 26$

3) 1

$3 / 5$

3) $\mathrm{s}$

$3 / 12$

$3 / 15$

$3 / 19$

$3 / 23$

$3 / 26$

$3 / 29$

$4 / 2$

4) 5

4/ 9

$4 / 13$

$4 / 16$

$4 / 19$

$4 / 23$

$+26$

$4 / 30$

$5 / 3$

5/ 7

$5 / 11$

$5 / 14$

$5 / 17$

$5 / 21$

$5 / 24$

$5 / 27$

5)/31

6) 3 pyrilorm

cuneat
papilio

$\ldots \ldots$
$\ldots \ldots \ldots$
$\ldots \ldots$
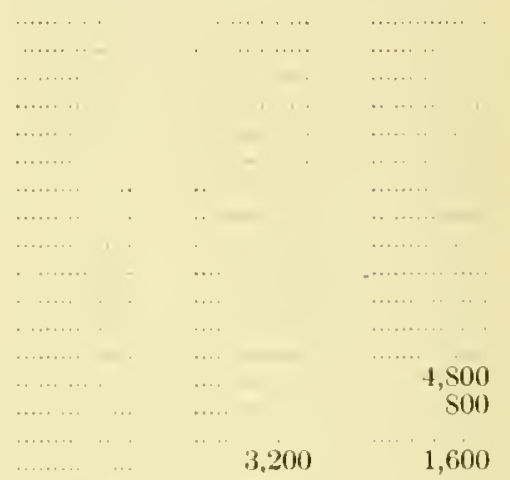

3.200

1,600

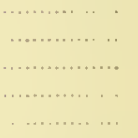

1,600

1,600

1,600

1,600

79,344

185,130

1,600

1,600

3,200

105,792

105,792 
Table 1. Organisms Per Cubic Meter in Plankton of Stockton ChanNel IN $1913-$-(Continued)

\begin{tabular}{|c|c|c|c|c|c|c|}
\hline 1913 & $\begin{array}{l}\text { Difflugia } \\
\text { corona }\end{array}$ & $\begin{array}{l}\text { Difflugia } \\
\text { pyriformis }\end{array}$ & $\begin{array}{c}\text { Hyalodiscus } \\
\text { sp. }\end{array}$ & $\begin{array}{l}\text { Hyalosphenia } \\
\text { euneata }\end{array}$ & $\begin{array}{l}\text { Hyalosphenia } \\
\text { papilio }\end{array}$ & $\begin{array}{l}\text { Microgromia } \\
\text { Bocialis }\end{array}$ \\
\hline $\begin{array}{l}6 / 7 \\
6 / 11\end{array}$ & & $\begin{array}{l}740,544 \\
155,658\end{array}$ & $\ldots \ldots \ldots$ & ….... & $\begin{array}{r}3,200 \\
\ldots\end{array}$ & $\begin{array}{l}3,200 \\
3,200\end{array}$ \\
\hline $6 / 16$ & & 423,168 & & & & \\
\hline $6 / 18$ & & 158,685 & 대. & ..... & $\ldots \ldots$ & 3,200 \\
\hline $6 / 21$ & & 19,200 & ........ & $\ldots .$. & $\ldots \ldots$ & 3,200 \\
\hline $6 / 25$ & $\ldots$ & $5 \$ 1, \$ 56$ & ……........ &.... & $1, \quad+\ldots \ldots$ & .. \\
\hline $6 / 28$ & $\ldots, \ldots, \ldots$ & 581,856 & ……........ & $\ldots$ & $\ldots \cdot \quad \ldots$ & .. \\
\hline $7 / 3$ & $. \quad \quad .$. & 105,792 & …........... & $\ldots$ & $\cdots \quad \ldots$ & . \\
\hline $7 / 5$ & $\ldots$ & 211,584 & & $\cdots$ & ... & $\cdots \cdots$ \\
\hline $7 / 9$ & ….... $\quad$.. & 264,480 & $\ldots \ldots$ & $\cdots$ & $\cdots$ & $\cdots \cdots$ \\
\hline $\begin{array}{l}7 / 12 \\
7 / 16\end{array}$ & 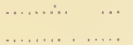 & $\ldots+\ldots$ & & : & $\cdots$ & 3,200 \\
\hline $7 / 19$ & …..... . & 3,200 & $\ldots \ldots$ & $\ldots$ & $\ldots$ & \\
\hline $7 / 23$ & ... ......... & & & ... . & ...... & 105,792 \\
\hline $7 / 26$ & $\ldots \ldots \ldots \ldots$ & $26+, 4 \mathrm{SO}$ & $\ldots \ldots$ & $\ldots \ldots \ldots$ & $\ldots . .$. & 3,200 \\
\hline $\begin{array}{l}7 / 30 \\
8 / 2\end{array}$ & . & & …. …… & $\begin{array}{lll}\cdots & \cdots \\
\cdots & \cdots & \ldots \\
\ldots\end{array}$ & & . . \\
\hline $8 / 6$ & ............. & & $\ldots \ldots \quad \ldots \ldots$ & $\ldots \ldots \ldots$ & …......... & . \\
\hline S/ 9 & $\ldots \ldots \ldots \ldots$ & 3,200 & …........... & $\ldots \ldots \ldots$ & $\cdot$ & .... \\
\hline $\begin{array}{l}\mathrm{S} / 13 \\
\mathrm{~S} / 15\end{array}$ & & & ......... & $\cdots$ & $\ldots$ & 105,792 \\
\hline $\mathrm{S} / 20$ & & 3,200 & & $\ldots$ & $\ldots$ & \\
\hline $8 / 23$ & 6,400 & 3,200 & ... $\quad \ldots \ldots \ldots$ & $\ldots$ & $\cdots$ & \\
\hline $8 / 27$ & $\ldots \ldots \ldots$ & & $\ldots \ldots \ldots \ldots$ & $\ldots$ & $\ldots .$. & 3,200 \\
\hline $8 / 31$ & $\ldots \ldots, \quad \ldots$ & …..... $\quad \ldots$ & ………... & . & $\cdots, \quad \cdots \cdot$ & $\ldots$ \\
\hline $9 / 2$ & . $\ldots, \cdots$ & $\ldots \ldots, \quad \cdots$ & $\ldots \ldots, \ldots \ldots$ & n..... & $\begin{array}{l}\ldots \ldots \\
\ldots \ldots\end{array}$ & ......... \\
\hline $\begin{array}{l}9 / 6 \\
9 / 9\end{array}$ & $\ldots, \quad \ldots$ & 6,400 & 3,200 & $\ldots$ & $\ldots \ldots$ & $\ldots \ldots$ \\
\hline $9 / 13$ & & & 3,200 & & ..... & \\
\hline $9 / 17$ & ...... $\quad \ldots \ldots$ & $\ldots$ & & & & 105,792 \\
\hline $\begin{array}{l}9 / 20 \\
9 / 24\end{array}$ & ...... & $\ldots \ldots \ldots$ & 158,685 & $\cdots \cdots$ & & 52,896 \\
\hline $\begin{array}{l}9 / 24 \\
9 / 27\end{array}$ & ........... & ......... & 105,792 & $\cdots \cdot$ & ........ & 52,896 \\
\hline $\begin{array}{l}9 / 27 \\
10 / 1\end{array}$ & ㄱ... & & $52, \$ 96$ & $\cdots \cdot$ & $\cdots .$. & \\
\hline $\begin{array}{l}10 / 1 \\
10 / 4\end{array}$ & ……1. & & $\ldots+\ldots \ldots$ & $\cdots \cdots$ & $\ldots . .$. & $\begin{array}{l}211,0 \mathrm{~s} \\
264,4 \mathrm{~S} 0\end{array}$ \\
\hline $10 / \mathrm{s}$ & ………… & 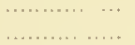 & $\ldots$ & $\ldots \ldots .$. & $\ldots \ldots$. & 211,584 \\
\hline $10 / 11$ & . ........... & & … & 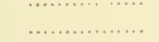 & …..... & 264,480 \\
\hline $10 / 15$ & 1. …..... & 105,792 & $\ldots, \ldots \ldots \ldots$ & …............ & ............... & 52,896 \\
\hline $10 / 15$ & $\ldots . \quad \ldots \ldots$ & $\ldots$ & & $\ldots \ldots$ & $\ldots \ldots \ldots .$. & \\
\hline $10 / 22$ & $\ldots \ldots \ldots$ & & 634,752 & ……........ & $\ldots \ldots$. & 211,584 \\
\hline $10 / 26$ & $\cdots \cdot$ & $\ldots \ldots \ldots \ldots \ldots$ & 370,272 & ......... & …........... & \\
\hline $10 / 29$ & $\ldots$. & $\ldots \ldots$ & 52,896 & …….......... & ….... & 211,584 \\
\hline 11/ 1 & …............. & ....... & ……...... & $\cdots$ & ............. & $\begin{array}{r}52,896 \\
105,709\end{array}$ \\
\hline $11 / 5$ & …........ & $\ldots \ldots$. & ............. & ............. & ........ & 105,792 \\
\hline $11 / 8$ & 3,200 & $\begin{array}{l}\ldots \ldots . \\
\ldots \ldots\end{array}$ & & …........... & $\ldots \ldots$. & ". \\
\hline $\begin{array}{l}11 / 12 \\
11 / 15\end{array}$ & $\ldots$ & & $\begin{array}{r}132,240 \\
158,688\end{array}$ & $\cdots \cdots$ & $\ldots$ & 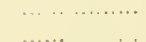 \\
\hline $\begin{array}{l}11 / 15 \\
11 / 19\end{array}$ & & 3,200 & 1,600 & $\ldots .$. & .... & 1,600 \\
\hline $\begin{array}{l}11 / 19 \\
11 / 22\end{array}$ & . & . & $\ldots \ldots$ & ……............ & 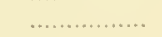 & 1,000 \\
\hline $11 / 26$ & $\ldots+\ldots$ & . . & ………… & …다... & ……....... & $\ldots$ \\
\hline $11 / 30$ & $\ldots .$. & $\ldots \ldots$ & ................. & …... & …какак... & $\ldots \ldots$ \\
\hline $12 / 3$ & & ...... & & & ................ & \\
\hline $12 / 6$ & & & 1,600 & ...... & $\ldots \ldots$. & $\ldots \ldots$ \\
\hline $12 / 10$ & $\ldots+\ldots$ & 800 & $\ldots \ldots \ldots$ & 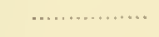 & $\ldots \ldots \ldots \ldots \ldots$ & ......... \\
\hline $12 / 14$ & $\ldots . \quad \ldots$ & ..... …... & $\ldots \ldots \ldots \ldots$ & ……........ & ………..... & .......... \\
\hline $12 / 17$ & $\ldots . . \quad \ldots$ & $\ldots \ldots \ldots \ldots \ldots$ & .............. & ........ & ………… & ........ \\
\hline $12 / 20$ & $\ldots+\cdots, \ldots$ & 400 & $\cdots . .$. & ........ & ………. & ............ \\
\hline $\begin{array}{l}12 / 24 \\
12 / 27\end{array}$ & $\ldots \ldots$ & 400 & ㄱ...… & ………… & ……….............. & $\ldots$ \\
\hline $12 / 31$ & ………… & ......... & … ……. & .................. & ……….......... & …………... \\
\hline
\end{tabular}


Table 1.-Organisms l'er ('Thic Metek in Planktoñ of Stockton Chandel in 1913-(Comtinued)

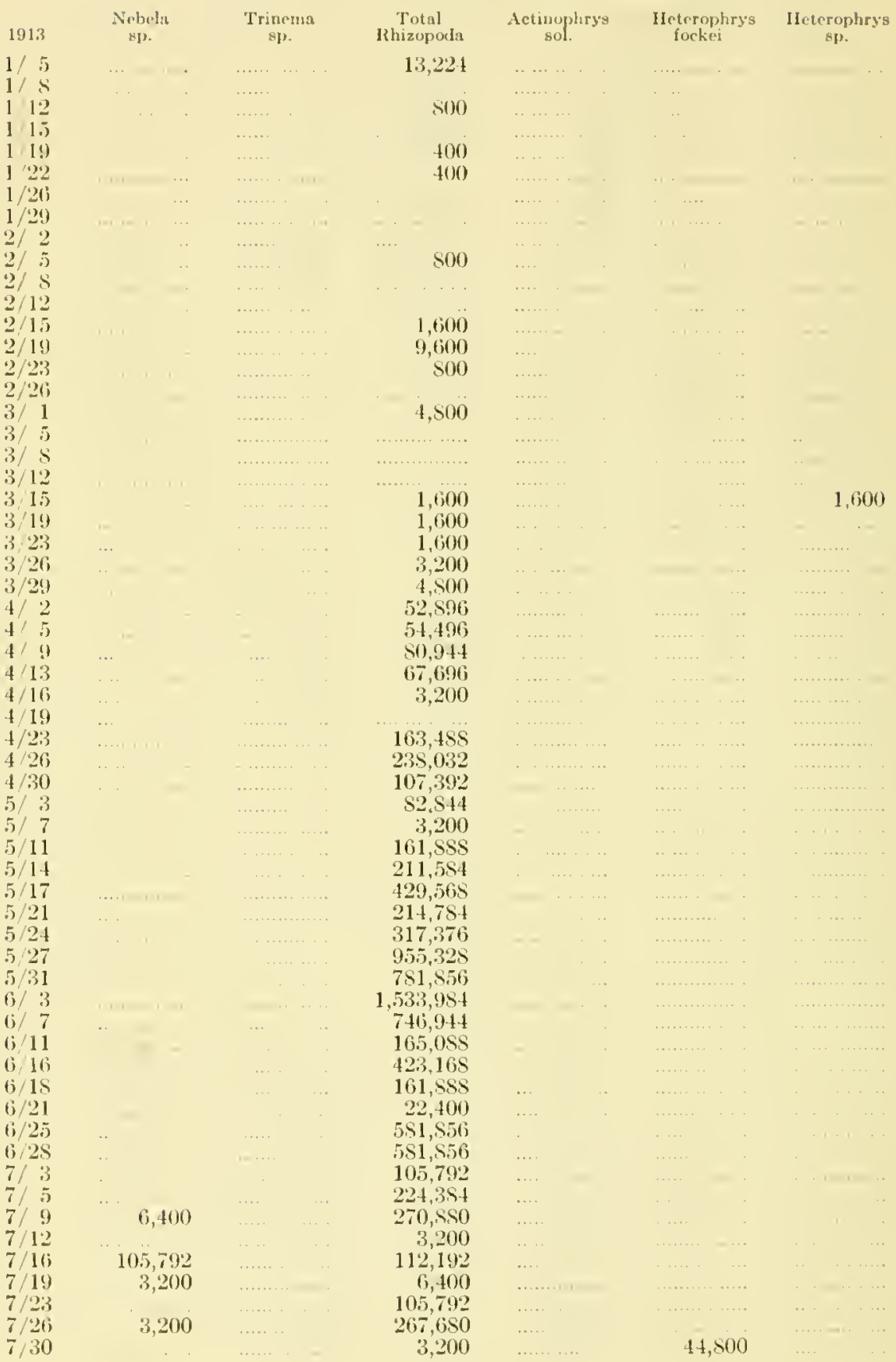


Table 1.-Organisms Per (ubic Meter in Plankton of Stockton Channel in 1913-(Continued)

\begin{tabular}{|c|c|c|c|c|c|c|}
\hline 1913 & $\begin{array}{l}\text { Nebela } \\
\text { sp. }\end{array}$ & $\begin{array}{l}\text { Trinema } \\
\text { sp. }\end{array}$ & $\begin{array}{c}\text { Total } \\
\text { Rhizopora }\end{array}$ & $\begin{array}{c}\text { Actinophrys } \\
\text { sol. }\end{array}$ & $\begin{array}{l}\text { Heterophrys } \\
\text { fockei }\end{array}$ & $\begin{array}{c}\text { Heterophrys } \\
\text { sp. }\end{array}$ \\
\hline $8 / 2$ & & & & & 525,960 & \\
\hline $8 / 6$ & & & & & 105,792 & …... \\
\hline 8/ 9 & 105,792 & & 108,092 & & 317,376 & \\
\hline $8 / 13$ & 105,792 & & 846,326 & & 105,792 & \\
\hline $8 / 15$ & $\ldots \ldots, \quad \ldots$ & & 317,376 & $\ldots$ & $211,58 t$ & $211,58 t$ \\
\hline $8 / 20$ & ......... & $158,6 \mathrm{SS}$ & 101,858 & & 2000 & ... \\
\hline $8 / 23$ & ........ & $\ldots$ & 168,258 & $\cdots \cdot$ & 3,200 & .. \\
\hline $8 / 27$ & $\ldots$ & 1. & 112,192 & $\ldots \ldots \quad \cdots \ldots$ & 3,200 & .... \\
\hline$S / 31$ & . & .... & 201,480 & $\ldots \ldots$ & & $\ldots$ \\
\hline $9 / 2$ & . & & 3,200 & $\ldots, \ldots \ldots \ldots$ & - & $\ldots \ldots$ \\
\hline $9 / 6$ & $\ldots \ldots \ldots \ldots$ & & 9,600 & $\ldots \ldots \ldots \ldots \ldots$ & …....... & $\ldots$. \\
\hline $9 / 9$ & .............. & 105,792 & 115,392 & $\ldots \ldots+\ldots \ldots$ & $\ldots \ldots \ldots \ldots$ & .... + +10 \\
\hline $9 / 13$ & …...... & & 3,200 & ..... & .. & ...... \\
\hline $9 / 17$ & ........... & 3,200 & 267,080 & $\cdots \cdots+, \ldots+\cdots$ & ") & .... \\
\hline $9 / 20$ & & & 323,168 & ........ & $211,55 t$ & ....... \\
\hline $9 / 24$ & .............. & & $158,68 \mathrm{~s}$ & $\ldots \ldots$ & 211,581 & \\
\hline $9 / 27$ & . . . . & 105,792 & $158,68 \mathrm{~s}$ & $\ldots \ldots$ & & .... \\
\hline $10 / 1$ & . . . . & & 264,180 & . & 158,658 & ... \\
\hline $10 / 4$ & $\cdots$ & & 264,480 & , & $264,4 \leq 0$ & ........ \\
\hline $10 / 8$ & ,........ & & 211,581 & $\ldots \ldots \quad \ldots .$. & $15 \mathrm{~s}, 6 \mathrm{sS}$ & $\ldots \ldots$ \\
\hline $10 / 11$ & .......... & & 370,272 & $\ldots \ldots$ & 6,400 & $\ldots \ldots$. \\
\hline $10 / 15$ & .......... & $10.5,792$ & 370,272 & $\ldots, \quad \ldots$ & 52,896 & .... \\
\hline $10 / 18$ & ..... & .. . & & & $52, \$ 96$ & \\
\hline $10 / 22$ & ......... & ... . & $1,163,712$ & 105,792 & 105,792 & .. . \\
\hline $10 / 26$ & $\ldots$ & & $581,8.56$ & $581, \$ 56$ & $.1,1$ & \\
\hline $10 / 29$ & & & 855,524 & 52,896 & . & $. \quad .$. \\
\hline $11 / 1$ &.$\quad \ldots \ldots$ & 211,584 & 351,856 & $\cdot \quad \cdot \ldots \cdot$ & $1, \ldots \ldots$. & .......... \\
\hline $11 / 5$ & . $\quad \ldots \ldots \ldots$ & $211,5 \mathrm{St}$ & 323,776 & . . & & ......... \\
\hline $11 / s$ & ..... & '... & … & & .. & . \\
\hline $11 / 12$ & .... & 1,600 & 137,040 & & & \\
\hline $11 / 15$ & $\ldots \ldots$. & .. . & $15 \mathrm{~S}, 6 \mathrm{SS}$ & . & . & ... \\
\hline $11 / 19$ & $\ldots . \quad \ldots$. & $\ldots$ & $6,+100$ & $1+1,1$ & & \\
\hline $11 / 22$ & $\ldots \ldots$ & $\cdots$ & 3,200 & & $\cdots$ & n........., \\
\hline $11 / 26$ & . & . . & 11 & & 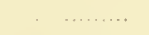 & …, $\ldots \ldots$ \\
\hline $11 / 30$ & $\ldots$ & $\ldots$. & & 1,600 & . & $\ldots$ \\
\hline $12 / 3$ & $\ldots$. & ...... & 3,200 & ...... + 1 1 & ....... & . \\
\hline $12 / 6$ & $\ldots$ & $\ldots$ & 1,600 & n...... & ........ & .... \\
\hline $12 / 10$ & $\ldots \ldots \ldots, \ldots$ & .... & 800 & ......... , & $\ldots \ldots \ldots$ & \\
\hline $12 / 14$ & …........ & $\ldots$. & 400 & ......... & $\ldots \quad \ldots \ldots$ & . \\
\hline $12 / 17$ & …..... & ...... & 400 & n.......... & .. $\quad \ldots .$. & . \\
\hline $12 / 20$ & $\ldots \ldots, \ldots \ldots$ & $\ldots$ & 400 & . ...... & $\ldots \ldots$ & \\
\hline $12 / 24$ & $\ldots \ldots \ldots \quad \ldots$. & $\ldots$. & 1,200 & ......... & $\ldots$. & .... \\
\hline $12 / 27$ & …........ & $\ldots$ & 100 & . ........ & .... & $\ldots \ldots$ \\
\hline $12 / 31$ & & $\cdots$ & $\cdots$ & & 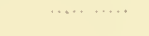 & ….... \\
\hline 1913 & $\begin{array}{l}\text { Nuclearia } \\
\text { simplex }\end{array}$ & $\begin{array}{l}\text { Pinaciophora } \\
\text { fluviatilis }\end{array}$ & $\begin{array}{c}\text { Raphidiophrys } \\
\text { elegans }\end{array}$ & $\begin{array}{c}\text { Total } \\
\text { Heliozoa }\end{array}$ & $\begin{array}{c}\text { Askenasia } \\
\text { elegans }\end{array}$ & $\begin{array}{l}\text { Bursaria } \\
\text { sp. }\end{array}$ \\
\hline $1 / 5$ & $\ldots \quad \ldots \ldots$ & . & & $\ldots \ldots$ & $\ldots \ldots \ldots, \ldots \ldots$ & $\ldots \ldots \ldots \ldots$ \\
\hline $1 / 5$ & $\cdot 1, \ldots$. & . & . & $\cdot \ldots \cdot \cdot \cdot$ & . .............. & ......... \\
\hline $1 / 12$ & $\ldots$ & $\cdots \cdot$ & $\cdots \cdot$ & & ....... & 400 \\
\hline $1 / 15$ & $\cdots$ & $\cdots$ & ....... & $\ldots$ & ............ & ........ \\
\hline $1 \quad 19$ & $\ldots \ldots$ & ' & & ... & 列 & …… \\
\hline $1 / 22$ & $\ldots \ldots$ & . . & & $\ldots$ & .... & $\ldots \ldots \ldots \ldots$ \\
\hline $1 / 26$ & ... & . & ............ & & $\ldots$ & 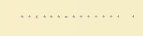 \\
\hline $\begin{array}{l}1 / 29 \\
2 / 2\end{array}$ & $\cdots \cdots \cdots$ & & .... & & $\$ 00$ & \\
\hline $2 / 5$ & $\ldots$ & .. & & ....... & 800 & $\cdots$ \\
\hline $2 / S$ & ..... $\quad \ldots$. & . .. & ........... & n........ & 1,600 & \\
\hline
\end{tabular}


Table 1.-Organisms Per ('ubic Meter in Plankton of Stockton Chandet, in 1913-(Continued)

\begin{tabular}{|c|c|c|c|c|c|c|}
\hline 1913 & $\begin{array}{l}\text { Nuclearia } \\
\text { simplex }\end{array}$ & $\begin{array}{l}\text { Pinaciophora } \\
\text { fluviatilis }\end{array}$ & $\begin{array}{c}\text { Raphidiophrys } \\
\text { elegans }\end{array}$ & $\begin{array}{c}\text { Total } \\
\text { lleliozora }\end{array}$ & $\begin{array}{l}\text { Askenasia } \\
\text { clegans }\end{array}$ & $\begin{array}{c}\text { Bursaria } \\
\text { sp. }\end{array}$ \\
\hline \multicolumn{7}{|l|}{$2 / 12$} \\
\hline 215 & $x^{2}$ & ... & 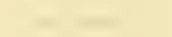 & 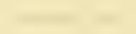 & 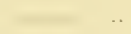 & 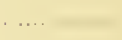 \\
\hline $\begin{array}{ll}2 & 19 \\
2 & 2\end{array}$ & & . & & & & \\
\hline $2 / 26$ & .. &.. & & & & \\
\hline $3 / 1$ & . & $\ddot{.}$ & & & $\cdots$ & $\ldots$ \\
\hline $3 / 5$ & (....... & , & 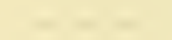 & whe $\quad \ldots$ & $.1, \ldots+\ldots$ & .....,,$\ldots$ \\
\hline $3 / 8$ & .. & & & ...... & & \\
\hline $3 / 12$ & . -- & - & & & 1,600 & \\
\hline $3 / 15$ & …. & 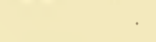 & & 1,600 & $\ldots \ldots \ldots$. & \\
\hline $3 / 19$ & 1,600 & & & & & 1,600 \\
\hline $3 / 23$ & $\cdots$ & . & 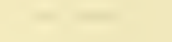 & 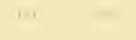 & . . . & 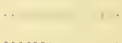 \\
\hline $\begin{array}{l}3 / 26 \\
3 / 29\end{array}$ & 3,200 & $\cdots \cdots$ & $\cdots$ & & $\begin{array}{l}\cdots \\
\cdots\end{array}$ & …... \\
\hline $4 / 2$ & W, & $\ldots \quad \ldots$ & $\cdots$ & & $\begin{array}{lll}\cdots & & \\
\cdots & \ldots\end{array} \ldots \ldots$ & …........ \\
\hline 45 & & $\cdots$ & & & … …… & \\
\hline $\begin{array}{l}4 / 9 \\
4 / 13\end{array}$ & $\begin{array}{r}1,600 \\
-0,000\end{array}$ & $\cdots \cdot$ & 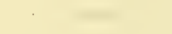 & 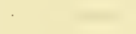 & . . .... & …..... \\
\hline $\begin{array}{l}4 / 13 \\
4 / 16\end{array}$ & 52,896 & $\cdots \cdots$ & $\ldots .$. & & ....... & $\cdots$ \\
\hline $\begin{array}{l}4 / 16 \\
4 / 19\end{array}$ & 1,600 & $\begin{array}{l}\ldots . . \\
\ldots \ldots\end{array}$ & $\ldots$. & & $\cdots .$. & \\
\hline $4 / 23$ & 79,344 & & & & & \\
\hline $4 / 26$ & 52,896 & $\ldots \ldots$ & 52,896 & 52,896 & $\cdots$ & \\
\hline $4 / 30$ & . & $\ldots$ & 132,240 & 132,240 & 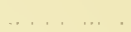 & 3,200 \\
\hline $5 / 3$ & .... & ..... $\quad \ldots \ldots \ldots$ & & & & \\
\hline $5 / 7$ & $\ldots \ldots, \quad \ldots \ldots$ & $\ldots \ldots, \quad \ldots \ldots$ & 211,584 & 211,584 & ..... & \\
\hline $5 / 11$ & $\ldots+\cdots, \quad \ldots$ & $\ldots \ldots \ldots$ & $158,6,88$ & $1.58,688$ & $\ldots \ldots$ & \\
\hline $5 / 14$ & $\ldots \ldots \ldots$ & $\ldots \ldots \ldots \ldots$ & 3,200 & 3,200 & $\ldots$ & \\
\hline $5 / 17$ & ….. $\quad \cdots$ & $\cdots$ & & & & \\
\hline $5 / 21$ & & ...... & $1,216,608$ & $1,216,60 \mathrm{~S}$ & . & \\
\hline $5 / 24$ & ….......... & ...... &.$\quad \quad \ldots$. & $\ldots \ldots$ & ...... & \\
\hline $\begin{array}{l}5 / 27 \\
5 / 31\end{array}$ & ……" & $\cdots$ & … & 3500 & $\cdots$ & \\
\hline $\begin{array}{l}5 / 31 \\
6 / 3\end{array}$ & & $\cdots$ & 0,200 & 0,200 & $\cdots \cdot$. & \\
\hline $6 / 7$ & …........... & $\ldots \ldots \ldots \ldots$ & 740,541 & 740,544 & $\ldots \ldots$ & \\
\hline $6 / 11$ & … ….... & …........... & $1,005,024$ & $1,005,024$ & $\ldots$ & \\
\hline $6 / 16$ & …. & $\ldots \ldots$ & $1,322,400$ & $1,322,400$ & & \\
\hline $6 / 18$ & . & $\ldots .$. & 158,688 & 158,688 & ........ & .......... \\
\hline $6 / 21$ & ......... & & 264,480 & 264,480 & & \\
\hline $6 / 25$ & ……… & $\ldots$. & $1, \$ 51,360$ & $1, \$ 51,360$ & $\ldots \ldots \ldots$ & \\
\hline $6 / 28$ & ……… & $\ldots$ & 740,544 & 740,544 & …......... & ...... \\
\hline 7/ 3 & & $\ldots \ldots$. & 793,440 & 793,440 & $\ldots \ldots \ldots \ldots \ldots$ & \\
\hline 7/ 5 & 6,400 & ....... & 526,960 & 528,960 & $\ldots \ldots, \quad \ldots$ & \\
\hline 7/ 9 & ........... & & $\$ 46,336$ & 846,336 & ......... & \\
\hline $7 / 12$ & & $\ldots$ & 158,688 & 158,688 & $\ldots \ldots, \quad \ldots \quad \ldots$ & \\
\hline $7 / 16$ & 3,200 & ....... & 528,960 & 525,960 & ………… & \\
\hline $7 / 19$ & ......... & ...... & 370,272 & 370,272 & & \\
\hline $7 / 23$ & $\ldots . .-1$ & $\ldots$ & 317,376 & 317,376 & $\ldots$. & \\
\hline $7 / 26$ & ....... & $\ldots$. & 370,272 & 370,272 & ...... & \\
\hline $7 / 30$ & & $\ldots \ldots$ & 370,272 & 415,072 & $\ldots$. & \\
\hline $8 / 2$ & $\ldots \ldots$ & .. & $1,269,504$ & $1,798,464$ & . & \\
\hline $8 / 6$ & & & 264,480 & 370,272 & .. & .. \\
\hline \&/ 9 & & .... & 423.168 & 740,544 & $\ldots$ & $\ldots$ \\
\hline$s / 13$ & 155,688 & & $1,745,568$ & $1, \$ 51,360$ & . & . \\
\hline$\$ / 15$ & & $\ldots$ & 528.960 & 952,128 & $\ldots$ & \\
\hline $8 / 20$ & ..... & ..... & 317,376 & 317,376 & . & \\
\hline $8 / 23$ & & & $1,5 \$ 6,8<0$ & $1,590,0 \mathrm{s0}$ & $\ldots i$ & \\
\hline $8 / 27$ & 3,200 & $\ldots \ldots \ldots$ & 105,792 & 108,992 & ..... & . \\
\hline$\$ / 31$ & & ........... & $687,64 \mathrm{~S}$ & 6857,648 & $\begin{array}{lll}\text {. } & \cdots\end{array}$ & ........ . \\
\hline $9 / 2$ & 3,200 & $\begin{array}{llll}\ldots & \ldots & \ldots\end{array}$ & $211,5 \& 4$ & 211,584 & .. & \\
\hline & & & 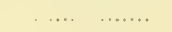 & .... & & \\
\hline
\end{tabular}


Table 1.-Organisms Per Cubic Meter in Plankton of Stockton Channel 1N 1913-(Continued)

\begin{tabular}{|c|c|c|c|c|c|c|}
\hline 1913 & $\begin{array}{l}\text { Nuclearia } \\
\text { simplex }\end{array}$ & $\begin{array}{l}\text { Pinaciophora } \\
\text { Aluviatilis }\end{array}$ & $\begin{array}{c}\text { Raphidiophrys } \\
\text { elegans }\end{array}$ & $\begin{array}{c}\text { Total } \\
\text { Heliozoa }\end{array}$ & $\begin{array}{c}\text { Askenasia } \\
\text { elegans }\end{array}$ & $\begin{array}{l}\text { Bursaria } \\
\text { sp. }\end{array}$ \\
\hline $\begin{array}{l}9 / 9 \\
9 / 13\end{array}$ & & & 3200 & ? & & $\cdots$ \\
\hline $\begin{array}{l}9 / 13 \\
9 / 17\end{array}$ & & $\begin{array}{l}\cdots \\
\ldots \ldots\end{array}$ & $\begin{array}{r}3,200 \\
\ldots \ldots \ldots\end{array}$ & 3,200 & $\cdots \cdots$ & $\begin{array}{ll}\cdots & \cdots \\
\cdots & \cdots\end{array}$ \\
\hline $9 / 20$ & $\cdots$ & & $\begin{array}{l}\cdots \ldots \ldots \\
\ldots \ldots \ldots \ldots \ldots+\cdots\end{array}$ & 211,584 & .. . . ........ & \\
\hline $9 / 24$ & .. & 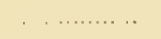 & .............. & 211,554 & $\ldots \ldots \ldots \ldots \ldots$ & \\
\hline $9 / 27$ & &.$\quad \ldots \ldots \ldots$ & . $\ldots . .$. & 211,584 & $\ldots$. & 105,792 \\
\hline $10 / 1$ & ....... & .. $\ldots . ., \ldots$ & & $\begin{array}{r}52,596 \\
26,480\end{array}$ & $\ldots \ldots \quad \ldots \ldots \ldots$ & $\cdots$ \\
\hline $\begin{array}{ll}10 / 4 \\
10 / S\end{array}$ & ... & . . . . & 1.,$\ldots$ & $\begin{array}{l}20 t,+80 \\
158,685\end{array}$ & $\ldots \ldots \ldots$ & $\begin{array}{l}\ldots \ldots \ldots \\
\ldots \ldots \ldots \ldots\end{array}$ \\
\hline $10 / 11$ & 52,596 & 423,168 & . . ......... & 129,568 & ….......... & ................. \\
\hline $10 / 15$ & 105,792 & 52,896 & ............... & 105,792 & …........... & 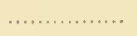 \\
\hline $10 / 18$ & & 176,064 & $\ldots \ldots \ldots$ & 528,960 & ................ & ….... \\
\hline $10 / 22$ & 105,792 & 370,272 & & 581,856 & n............. & .............. \\
\hline $10 / 26$ & 105,792 & 317,376 & $211,58 t$ & $1,110,816$ & .............. & .. ............ \\
\hline $10 / 29$ & ….... $\quad \ldots$. & 370,272 & $\cdots$ & 423,168 & $\ldots \ldots, \ldots \ldots$ & $\ldots \ldots \ldots \ldots$ \\
\hline $11 / 1$ & $\ldots \ldots \ldots \ldots$ & 476,064 & & 476,064 &.$\quad \ldots \ldots \ldots \ldots$ & $\ldots \ldots \ldots \ldots$ \\
\hline $11 / 5$ & ….......... & 105,792 & $4,549,056$ & $4,654,8+8$ & ............ & $\ldots \ldots \ldots \ldots$ \\
\hline $11 / \mathrm{s}$ & …............ & & $1,428,192$ & $1,425,192$ & $\ldots \ldots \ldots \ldots$ & .......... \\
\hline $11 / 12$ & ............... & $79,34 t$ & $3,702,720$ & $3,782,064$ & $\ldots \ldots \ldots \ldots$ & .. $\ldots \ldots$ \\
\hline $11 / 15$ & $\cdots$ & 52,896 & $1,715,568$ & $1,798,464$ & , $\ldots \ldots \ldots \ldots$ & \\
\hline $11 / 19$ & .... & $\cdots$ & $\$ 19,888$ & $\$ 19,858$ & .. $\ldots \ldots \ldots \ldots$ & $\ldots \ldots \ldots$ \\
\hline $11 / 22$ & $-\ldots$. & & 1,600 & 1,000 & ....... & , n...... \\
\hline $11 / 26$ & $\ldots$. & 52,896 & 1,600 & 54,496 & n............. & ........ \\
\hline $11 / 30$ & $\cdots$ & ..... & 396,720 & 395,320 & 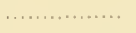 & ................ \\
\hline $12 / 3$ & ........ & $\ldots \ldots \cdot$, & 1,600 & 1.600 & …........... & .......... \\
\hline $12 / 6$ & ...... & ,........... & 52,896 & 52,896 & ............... & ....... \\
\hline $12 / 10$ & ....... & ................ & ............... & & $\ldots \ldots \ldots \ldots \ldots$ & , n........ \\
\hline $12 / 11$ & w.... & , $\ldots \ldots \ldots+\ldots$ & $\ldots \ldots, \ldots \ldots$ & & $\cdots$ & …... \\
\hline $12 / 17$ & … & ……, & $\ldots \ldots \ldots$ & . & . ......... & ....... \\
\hline $12 / 20$ & $\ldots \ldots$ & ……, & $\ldots \quad \ldots \ldots$ & - & $\cdot \quad \ldots \ldots$ & ........ \\
\hline $12 / 24$ & $\ldots \ldots$ & …......... & $\quad 400$ & .. & $\ldots \ldots$ & …. \\
\hline $\begin{array}{l}12 / 27 \\
12 / 31\end{array}$ & ........ & ………, & 400 & 100 & $\ldots \ldots \ldots \ldots$ & $\cdots$ \\
\hline 1 & & , n., & $\cdots$ & & …. & \\
\hline 1913 & $\begin{array}{l}\text { Chilodon } \\
\text { sp. }\end{array}$ & $\begin{array}{c}\text { Ciliate } \\
\text { unidentified }\end{array}$ & $\begin{array}{l}\text { Coleps } \\
\text { hirtus }\end{array}$ & $\begin{array}{l}\text { Colpoda } \\
\text { sp. }\end{array}$ & $\begin{array}{l}\text { Cyclidium } \\
\text { sp. }\end{array}$ & $\begin{array}{l}\text { Didinjum } \\
\text { nasutum }\end{array}$ \\
\hline $1 / 5$ &,,$+ \quad \ldots \ldots \ldots$ & $\ldots \ldots \ldots \ldots \ldots \ldots$ & $\therefore$ & . . .... & $1+\ldots \ldots$. & $\cdots$ \\
\hline $1 / 8$ & $-\quad \ldots \ldots$ & ................ & $\cdots, \ldots$ & $\cdots$ & $\ldots \ldots$. & $\ldots \ldots$ \\
\hline $1 / 12$ & .. $\quad \ldots \ldots \ldots$ & .............. & $\begin{array}{ll}. . & \ldots .\end{array}$ & $\cdots$ & $\cdots \cdot$ & $\cdots$ \\
\hline $1 / 15$ & $\cdot \quad \cdot \quad \ldots \ldots \ldots$ & ........... & .... & $\ldots$. & $\cdots$ & 100 \\
\hline $1 / 19$ & , $\quad$. & 96118 & $\cdots \cdot$ & ... 100 & $\ldots+\ldots \ldots$ & ........ \\
\hline $1 / 22$ & ..... & 26,448 & $\ldots \ldots$ & 100 & ............ & 59806 \\
\hline $1 / 26$ & $\ldots$ & $\begin{array}{l}46,284 \\
52,896\end{array}$ & $\begin{array}{l}\ldots \ldots \\
\ldots \ldots\end{array}$ & & … & $\begin{array}{r}52,856 \\
400\end{array}$ \\
\hline $\begin{array}{l}1 / 29 \\
2 / 2\end{array}$ & ..... & $\begin{array}{r}52,896 \\
800\end{array}$ & …..... & $\begin{array}{ll}\cdots & \cdots \\
\ldots \ldots & \ldots\end{array}$ & $\ldots \ldots$ & \\
\hline $\begin{array}{l}2 / 2 \\
2 / 5\end{array}$ & …............ & $\begin{array}{r}500 \\
33,060\end{array}$ & $\ldots \ldots \ldots \ldots$ & $\ldots \ldots$ & $\begin{array}{l}\cdots \\
\cdots \\
\ldots\end{array}$ & $\cdots$ \\
\hline $2 / 8$ & ... & 3,200 & $\ldots \ldots$ & $\ldots \ldots \quad \ldots \ldots$ & $\ldots . \quad \ldots$ & 4,800 \\
\hline $2 / 12$ & ................ & 52,896 & .. & $\ldots \ldots \ldots \ldots$ & $\ldots \quad \quad \ldots \ldots$ & 1,600 \\
\hline $2 / 15$ & n........... & 66,120 & ............ & $\ldots \ldots \ldots, \quad \ldots \ldots$ & $\ldots \ldots, \quad \ldots \ldots$ & 39,672 \\
\hline $2 / 19$ & $\cdots$ & $\begin{array}{r}1,600 \\
26,+48\end{array}$ & 800 & …...... & $\cdots \cdot$ & 3000 \\
\hline $2 / 23$ & $\cdots$ & $\begin{array}{r}26,448 \\
105,792\end{array}$ & & .............. & ....... & 3,200 \\
\hline $\begin{array}{l}2 / 26 \\
3 / 1\end{array}$ & …. & $\begin{array}{r}105,792 \\
1,600\end{array}$ & $\cdots$ & ... & n.... & 1,600 \\
\hline $\begin{array}{l}3 / 1 \\
3 / 5\end{array}$ & ..................... & $\begin{array}{r}1,600 \\
52,896\end{array}$ & & .................. & $\ldots \ldots, \ldots \ldots$ & 3,200 \\
\hline $\begin{array}{l}3 / 5 \\
3 / 8\end{array}$ & ............... & $\begin{array}{l}52,896 \\
79,344\end{array}$ & , $\quad \ldots \ldots \ldots$ & …......... & $\ldots \ldots,+\cdots$ & $\ldots \cdot, \quad \ldots$ \\
\hline $\begin{array}{l}3 / 8 \\
3 / 12\end{array}$ & .............. & $\begin{array}{r}79,344 \\
\ldots \ldots \ldots\end{array}$ & & ........... & $\begin{array}{llll}\cdots & \cdots & \cdots & \cdots\end{array}$ & $\ldots, \quad \ldots \ldots \ldots$ \\
\hline $3 / 15$ & $\ldots \ldots \ldots \ldots$ & ....... & $-1 . \ldots \ldots \ldots$ & …… & ……, & \\
\hline $3 / 19$ & 1,600 & 52,896 & ............... & ….......... & n.............. & ….... \\
\hline
\end{tabular}




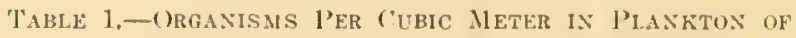
STUCKTos ("1ANAEL IN 1913-(Continued)

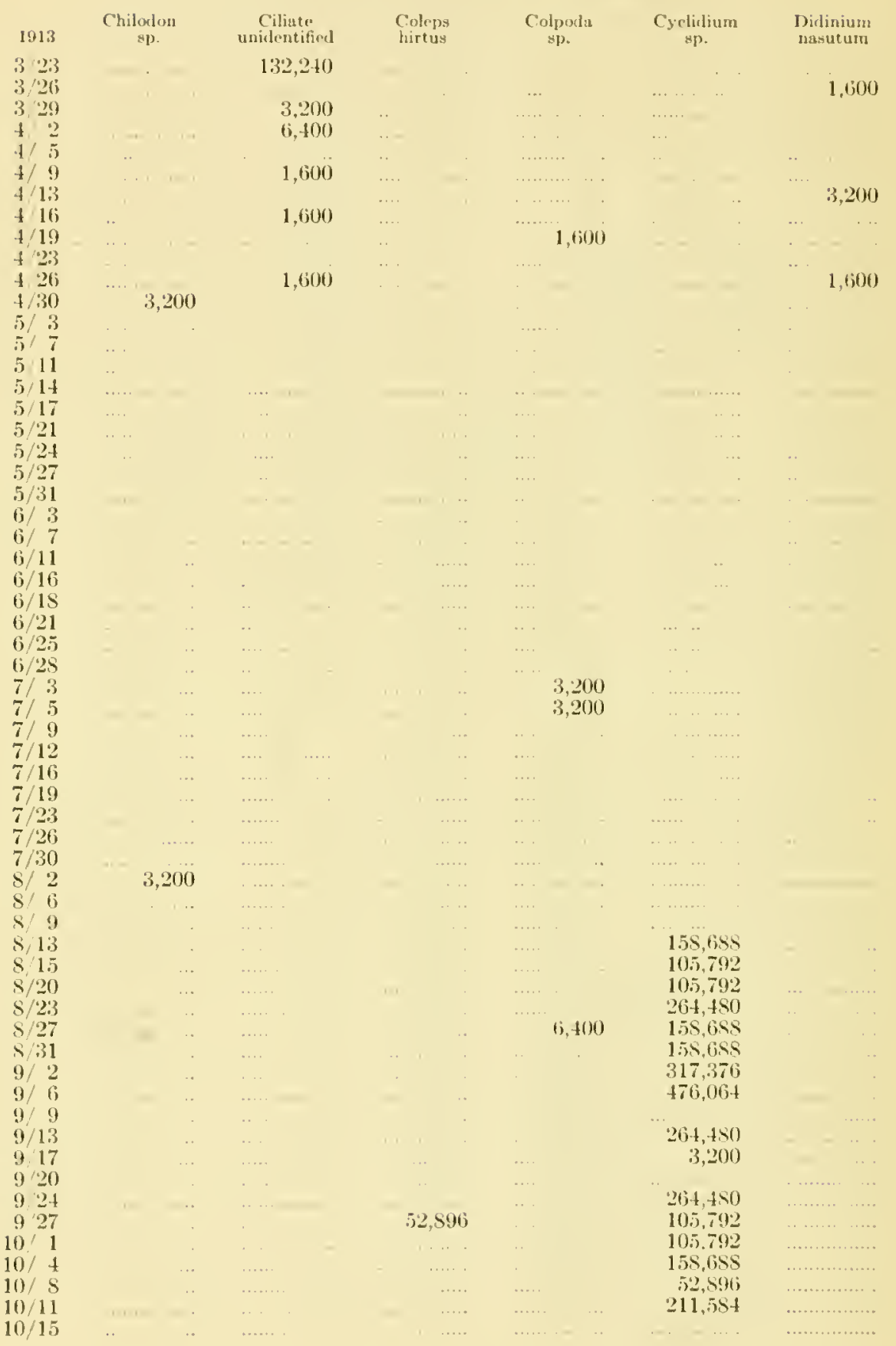


Table 1.-Organisus Per ('ubic Mgter in Plankton of Stockton Channel in 1913-(Continued)

\begin{tabular}{|c|c|c|c|c|c|c|}
\hline 1913 & $\begin{array}{c}\text { Chilodon } \\
\text { sp. }\end{array}$ & $\begin{array}{c}\text { Ciliate } \\
\text { unidentified }\end{array}$ & $\begin{array}{l}\text { Coleps } \\
\text { hirtus }\end{array}$ & $\begin{array}{l}\text { Colpoda } \\
\text { sp. }\end{array}$ & $\begin{array}{c}\text { Cyclidium } \\
\text { sp. }\end{array}$ & $\begin{array}{l}\text { Didinium } \\
\text { nasutum }\end{array}$ \\
\hline $10 / 18$ & $1,1,1,$. & . & .... & $\ldots \ldots$ & 158,688 & \\
\hline $10 / 22$ & ... & & $\ldots$. & $\ldots \ldots$ & $\cdots$ & \\
\hline $10 / 26$ & .... & & & & & \\
\hline $10 / 29$ & .. & & 264,480 & & & \\
\hline $11 / 1$ & ....... & & 105,792 & .... & & \\
\hline $11 / 5$ & ......... & .... & $\ldots$. & .... & & \\
\hline $\begin{array}{l}11 / \mathrm{S} \\
11 / 12\end{array}$ & & $\cdots \cdot$ & if 600 & . . & & 32000 \\
\hline $\begin{array}{l}11 / 12 \\
11 / 15\end{array}$ & & & $\ldots$ & & & $\begin{array}{l}32,000 \\
19,200\end{array}$ \\
\hline $11 / 19$ & $\ldots$ & $\ldots \quad \ldots$ & , n...... & & & 1,600 \\
\hline $11 / 22$ & & 1 & ......... . & & & \\
\hline $11 / 26$ & & & ......... & & & \\
\hline $11 / 30$ & & .... & $\ldots \ldots$. & & & \\
\hline $12 / 3$ & & ..... & (....... & & & \\
\hline $12 / 6$ & 22,400 & $\ldots$ & & 1 & & 3,200 \\
\hline $12 / 10$ & $\cdots \cdots$ & $\ldots \ldots, \quad \ldots \ldots$ & 100918 & & & \\
\hline $12 / 1 \pm$ & …........ & .............. & 132,240 & .. & 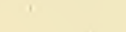 & \\
\hline $12 / 16$ & n...... & . $\ldots \ldots \ldots, \ldots$ & 119,010 & ... & $\ldots$. & $\cdots$ \\
\hline $12 / 20$ & $\cdots$ & & 66,120 & $\cdots+1+x$ & & $1 \ldots \ldots$ \\
\hline $\begin{array}{l}12 / 24 \\
12 / 27\end{array}$ & $\ldots+\ldots$, & . . & $19,8.36$ & $\cdots$ & & .. \\
\hline $\begin{array}{l}12 / 27 \\
12 / 31\end{array}$ & . & an & 400 & & & \\
\hline & $\cdots$ & ..... & & & & \\
\hline
\end{tabular}

\begin{tabular}{|c|c|c|c|c|c|c|}
\hline 1913 & $\begin{array}{c}\text { Enchely's } \\
\text { sp. }\end{array}$ & $\begin{array}{c}\text { Euplotes } \\
\text { harpa }\end{array}$ & $\begin{array}{c}\text { Euplotes } \\
\text { patella }\end{array}$ & $\begin{array}{c}\text { Frontonia } \\
\text { sp. }\end{array}$ & $\begin{array}{l}\text { Halteria } \\
\text { grandinella }\end{array}$ & $\begin{array}{c}\text { Hastatella } \\
\text { radians }\end{array}$ \\
\hline $1 / 5$ & & & & & & . \\
\hline $1 / \mathrm{s}$ & $\ldots$ & $\ldots$. & & & $\cdots$ & \\
\hline $1 / 12$ & & & & & & \\
\hline $\begin{array}{l}1 / 15 \\
1 / 19\end{array}$ & & 1,600 & & & & \\
\hline $\begin{array}{l}1 / 19 \\
1 / 22\end{array}$ & & $\begin{array}{l}13,224 \\
11,200\end{array}$ & & & & \\
\hline $\begin{array}{l}1 / 22 \\
1 / 26\end{array}$ & & $\begin{array}{l}11,200 \\
19,836\end{array}$ & & & 52,896 & \\
\hline $1 / 29$ & & 33,060 & & & 46,284 & \\
\hline $2 / 2$ & .. & 13,224 & & & 800 & \\
\hline $2 / 5$ & .. & 26,448 & & & 800 & 1,600 \\
\hline $2 / 8$ & & 16,000 & 800 & & 4,500 & \\
\hline $2 / 12$ & $\cdots$ & 39,672 & & & 1,600 & \\
\hline $2 / 15$ & & 158,685 & 52,896 & & 4,800 & 52,896 \\
\hline $2 / 19$ & & 115,464 & 52,896 & & 1,600 & 1,600 \\
\hline $2 / 23$ & 1,600 & 132,240 & 66,120 & & 3,200 & 1,600 \\
\hline $2 / 26$ & & 132,240 & 105,792 & & 3,200 & 3,200 \\
\hline $3 / 1$ & & 317,376 & 52,896 & & 105,792 & 12,800 \\
\hline $3 / 5$ & & 6,400 & & & 52,896 & \\
\hline $3 / 8$ & & 158,658 & 3,200 & & 3,200 & \\
\hline $3 / 12$ & & 79,344 & 1,600 & 158,688 & & \\
\hline $3 / 15$ & & 158,688 & 12,800 & & 3,200 & \\
\hline $3 / 19$ & & 370,272 & & & & \\
\hline $3 / 23$ & & 264,480 & 9,600 & & 9,600 & \\
\hline $3 / 26$ & & 79,344 & & & & \\
\hline $3 / 29$ & & 35,200 & & & & - \\
\hline $4 / 2$ & & 70,400 & 3,200 & & & \\
\hline $4 / 5$ & & 211,584 & 9,600 & & 105,792 & \\
\hline $4 / 9$ & & 132,240 & & & & 6,400 \\
\hline $4 / 13$ & & 25,600 & & . & & 9,600 \\
\hline $4 / 16$ & $\ldots$ & & & & & 9,600 \\
\hline $4 / 19$ & $\ldots$ & 6,400 & & .. & & 105,792 \\
\hline $4 / 23$ & . & & & & & 1,600 \\
\hline $4 / 26$ & & 1,600 & & & & \\
\hline
\end{tabular}


Table 1.-Organisms Per Cuhic Mitrk in Plankton of Stockton Channel IN 1913-(Continued)

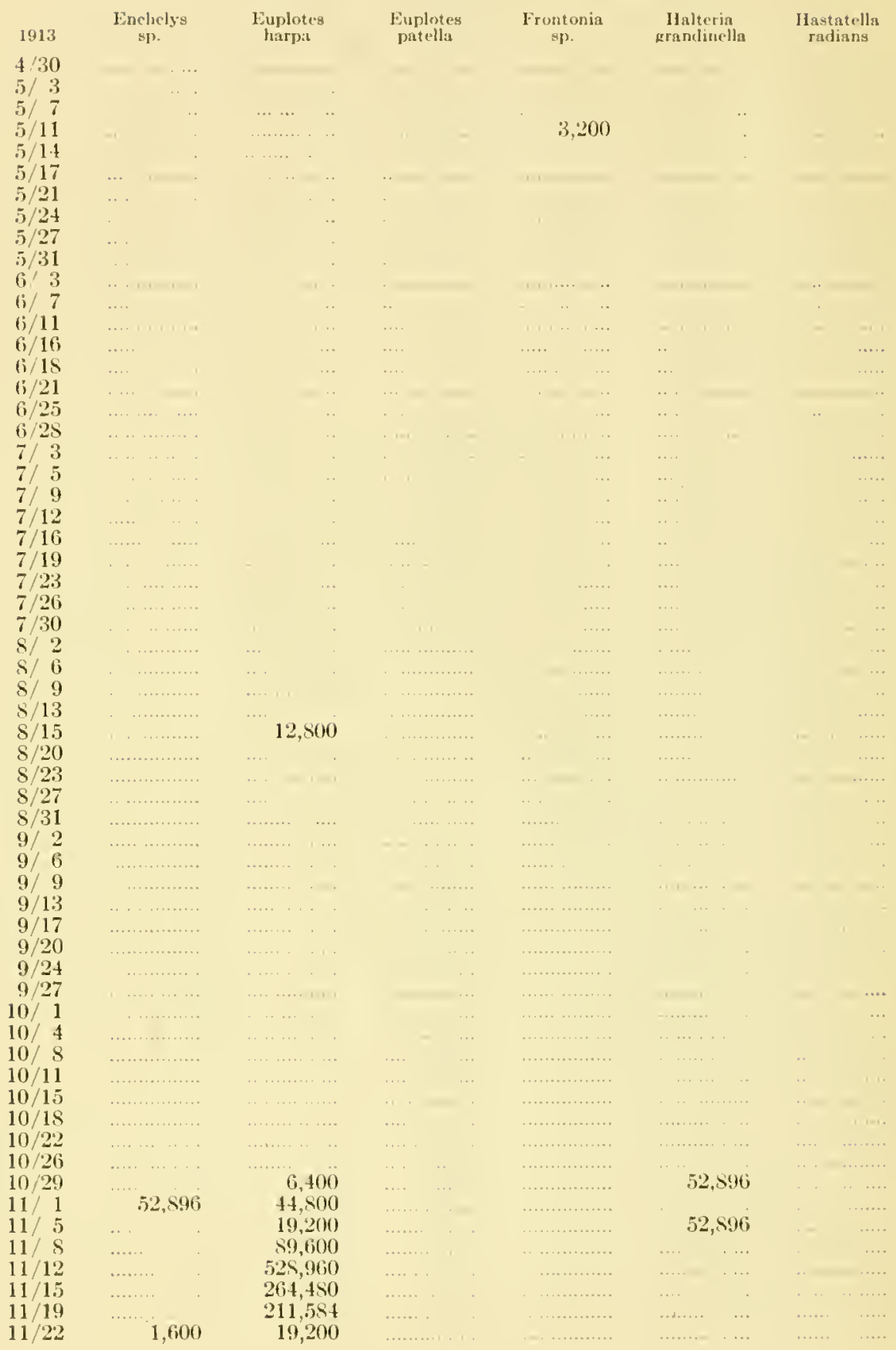


Table 1.-Organisms Fer Cubic Meter in Plankton of Stockton Channel in 1913-(Continued)

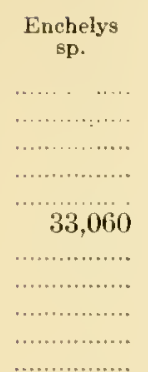
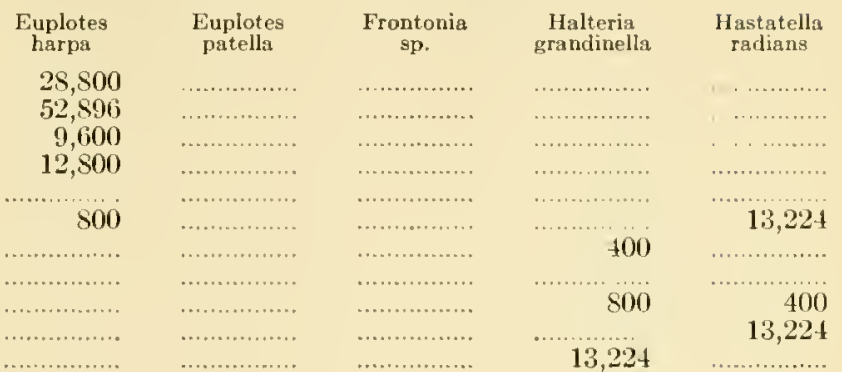

Holophrya

sp.

Loxophyllum

$\mathrm{sp}$.

Paramecium

Paramecium

Paramecium

Pleuronema

$1 / 5$

$1 / 8$

$1 / 12$

$1 / 15$

$1 / 19$

$1 / 22$

$1 / 26$

$1 / 29$

2/ 2

2) 5

2/ 8

$2 / 12$

$2 / 15$

$2 / 19$

$2 / 23$

$2 / 26$

$3 / 1$

$3 / 5$

$3 / 8$

$3 / 12$

$3 / 15$

$3 / 19$

$3 / 23$

$3 / 26$

$3 / 29$

1/ 2

4/5

4/ 9

$4 / 13$

$4 / 16$

$4 / 19$

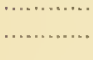

……......

.............

…….......

…………

…..........

39,672

…........

3,200
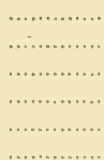

..................
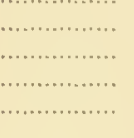

bursaria

caudatum

sp.
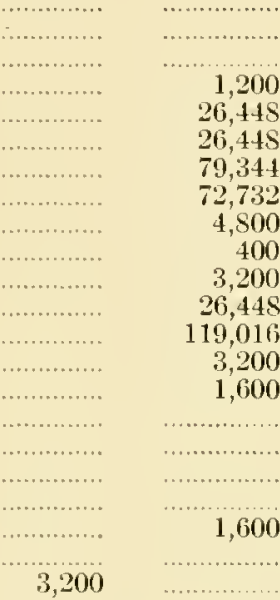

26,448

$26,44 \mathrm{~S}$

79,344

72,732

4,800

400

3,200

26,448

119,016

3,200

1,600

1,600

52,896

581,856

9,600

238,032

105,792

132,240

158,68s

290,928

$211,58+$

3,200

185,136

79,344

211,584

105,792

211,584

105,792

$132,2.10$

79,344

105,792

$1,005,02+$

105,792

264,480
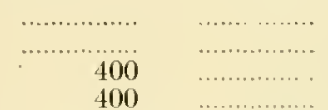

400

400

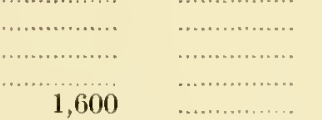

9,600

6,400

3,200

3,200
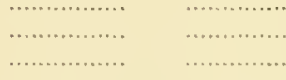

1,600

3,200

3,200

3,200

6,400 
'TABde 1.-ORganisMS l'ER ('UBIC METER IN PlaAkToN OF STOCKTON ('HANNEL IN $1913-$ (Continucd)

\begin{tabular}{|c|c|c|c|c|c|c|}
\hline 1913 & $\begin{array}{l}\text { Holophrya } \\
\text { sp. }\end{array}$ & $\begin{array}{c}\text { Loxophyllum } \\
\text { sp. }\end{array}$ & $\begin{array}{l}\text { Paramecium } \\
\text { aurelia }\end{array}$ & $\begin{array}{c}\text { Paramecium } \\
\text { bursaria }\end{array}$ & $\begin{array}{l}\text { Paramecium } \\
\text { caudatum }\end{array}$ & $\begin{array}{c}\text { I'leuronema } \\
\text { sp. }\end{array}$ \\
\hline $6 / 7$ & & - & $=$ & -. & $\rightarrow \quad \ldots$ & .. \\
\hline $6 / 11$ & 15s.tiss & . & & . & 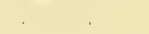 & .. \\
\hline $6 / 16$ & $: 3,200$ & . & & 11 & ....... & .. \\
\hline $6 / 18$ & 3,200 & . & . & . & ....... & .. \\
\hline (i) $/ 21$ & 3,200 &... & .. & , & . . . & . \\
\hline $6 / 25$ & 3,200 & . & .. . 1, & - & ...... $\quad$. & .... \\
\hline 0.25 & $15 \mathrm{~s}$, iss & $\ldots$ & .. . & - .. & $\ldots$ & .... \\
\hline $7 / 3$ & 3,200 & $\ldots$ & $\ldots \ldots$ & $\ldots \ldots, \quad \ldots$ & .., & 3.200 \\
\hline $7 / 5$ & $155,6 \mathrm{SS}$ & . & .. & ......... & $\ldots . \quad \ldots$ & ........ . \\
\hline 7) 9 & 211,584 & $\ldots \quad \quad \ldots$ & .. . & . . ....... & $\ldots$. & .... $\quad$.. \\
\hline $7 / 12$ & 3,200 & $\ldots$ & .. & ................ & ...... $\quad$.. & ....... \\
\hline $7 / 16$ & 6,400 & .. & $\therefore \ldots$ & ……, n... & $\ldots \ldots, \cdots$ & ............ \\
\hline $7 / 19$ & …. +1, & n............... & $\ldots \ldots+, \quad, \ldots$ & $\ldots \ldots \ldots \ldots \ldots$ & n........ & $\ldots$ \\
\hline $7 / 23$ & & ............... & $\begin{array}{lll}\ldots . & . & \ldots\end{array}$ & …........... & $\ldots \ldots \ldots \ldots$ & .. \\
\hline $7 / 26$ & 211,584 & ................ & $\ldots \ldots,+\ldots$. & ................ & $\ldots \ldots \ldots$ & ........ \\
\hline $7 / 30$ & 105,792 & ............... & $\ldots \ldots, \quad$, & ……, & …... $\quad$.. & ....... \\
\hline $8 / 2$ & 105,792 & .............. & $\ldots \ldots$. & …........... & ...... & ........ \\
\hline S/ 6 & 105,792 & .............. & ..... & n............ & $\ldots \ldots \ldots$ & . \\
\hline $5 / 9$ & 740.544 & ............... & $\ldots \ldots \ldots \quad \ldots$ & ................ & ........ & \\
\hline$S / 13$ & 0331,752 & ............... & $\ldots \ldots \ldots, \ldots$ & . $\ldots \ldots \ldots \ldots \ldots$ & ......... & ......... \\
\hline $\mathrm{S} / 15$ & 317,376 & .............. & $\ldots \ldots \ldots \ldots$ & ……........ & $\ldots \ldots \ldots$ & $\ldots \ldots$ \\
\hline $8 / 20$ & 105,792 & …........... & ................ & . . ............ & …..... & \\
\hline $\mathrm{S} / 23$ & $15 \mathrm{~s}, \mathrm{fiss}$ & ................. & ................. & . . .............. & ............ & \\
\hline $5 / 27$ & 105,792 & .............. & .............. & ................ & ............ & \\
\hline$S / 31$ & 3,200 & ............... & ................ & ….......... & …........... & ... \\
\hline $9 / 2$ & 3,200 & .................. & ................. & ................ & ................. & \\
\hline $9 / 6$ & 317,376 & …........... & …............ & ................ & ............... & \\
\hline $9 / 9$ & $211,5,94$ & & .............. & …........... & n............... & \\
\hline $9 / 13$ & a... & .......... & ................. & ..... & ................ & \\
\hline $9 / 17$ & 3,200 & ……...... & ….......... & …........... & .............. & \\
\hline $9 / 20$ & 370,272 & ............... & ................ & ................ & …............ & \\
\hline $9 / 24$ & 158,088 & n.............. & , .............. & ............... & ................ & \\
\hline $9 / 27$ & 211,584 & ….......... & & ................ & ............... & \\
\hline $10 / 1$ & $211,5,4$ & n............ & ….......... & ................ & …............ & \\
\hline $10 / 4$ & 52,896 & ............... & & …............ & ............... & \\
\hline $10 / \mathrm{s}$ & $423,16 \mathrm{~S}$ & & 6,400 & $\cdots$ & ............... & \\
\hline $10 / 11$ & $10.5,792$ & .............. & $\ldots .$. & ................ & .............. & \\
\hline $10 / 15$ & 105,792 & …............ & ................ & ................ & …… & \\
\hline $10 / 1 \mathrm{~S}$ & 105,792 & …............. & .......... & ................. & …............ & \\
\hline $10 / 22$ & 370,272 & ................ & ................ & …, & …........... & \\
\hline $10 / 26$ & 52,896 & ................ & ................. & . ............... & ….......... & \\
\hline $10 / 29$ & & & & & …............ & \\
\hline $11 / 1$ & 52,596 & ................ & 51,200 & $26 \div, 450$ & .............. & \\
\hline $11 / 5$ & 52.896 & ................... & 70,400 & & …............... & \\
\hline $11 / 8$ & 52,896 & ……..... & 96,000 & 57,600 & .............. & 6,400 \\
\hline $11 / 12$ & 52,596 & ............... & & 581,856 & ................ & 132,240 \\
\hline $11 / 15$ & & ................ & 25,600 & & ............... & 6,400 \\
\hline $11 / 19$ & 105,792 & ......... & 79,344 & 1,600 & ................ & 79,344 \\
\hline $11 / 22$ & 79,344 & ............... & 6,400 & ......... $\quad \ldots$ & ................ & 79,344 \\
\hline $11 / 26$ & & .................. & 3,200 & & ................ & 105,792 \\
\hline $11 / 30$ & $2: 35,(132$ & & $3,20()$ & & 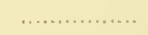 & \\
\hline $12 / 3$ & 79,344 & $\ldots \ldots \ldots \ldots$ & 19,200 & 6,400 & ............... & 79,344 \\
\hline $12 / 6$ & 1,600 & & & 6,400 & & 3,200 \\
\hline $12 / 10$ & $\cdots$ & $\cdots$ & 13,224 & 13,224 & 4,000 & 26,445 \\
\hline $12 / 14$ & & $S 00$ & 10,400 & 800 & & 39,672 \\
\hline $12 / 17$ & 13,224 & $\ldots \ldots \ldots$ & 145,464 & .. & 9,600 & \\
\hline $12 / 20$ & $72,7: 32$ & & 105,792 & 19,836 & 13.224 & 400 \\
\hline $12 / 24$ & 13,224 & $\ldots \ldots \ldots$ & 16,000 & 3,200 & 4, 800 & .. \\
\hline $12 / 27$ & 59,508 & $\ldots \ldots \ldots$ & 72,732 & 13,224 & 5,600 & ............ \\
\hline $12 / 31$ & 39,672 & ….... & 33,060 & 19,836 & …........... & ...... \\
\hline
\end{tabular}


Table 1.-Organisms Per Cubic M1eter in Plankton of Stockton Channel IN 1913-(Continued)

\begin{tabular}{|c|c|c|c|c|c|c|}
\hline 1913 & $\begin{array}{l}\text { Prorodon } \\
\text { sp. }\end{array}$ & $\begin{array}{l}\text { Stentor } \\
\text { coeruleus }\end{array}$ & $\begin{array}{l}\text { Stentor } \\
\text { niger }\end{array}$ & $\begin{array}{l}\text { Tintinnidium } \\
\text { fluviatile }\end{array}$ & $\begin{array}{l}\text { Trachelius } \\
\text { ovum }\end{array}$ & $\begin{array}{l}\text { Trichodina } \\
\text { pediculus }\end{array}$ \\
\hline $1 / 5$ & & 800 & 6,612 & & & \\
\hline $1 / 8$ & ......... & 400 & 1,200 & $\ldots \ldots$ & $\ldots$ & \\
\hline $1 / 12$ & & 1,200 & 2,000 & ………… & $\ldots$ & $\therefore$ \\
\hline $1 / 15$ & ...... & 33,060 & 26,448 & .............. & $\ldots$ & 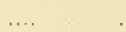 \\
\hline $1 / 19$ & .............. & 52,896 & 39,672 & $\ldots$ & . & \\
\hline $1 / 22$ & & 72,732 & 112,404 & …............. & 800 & .... \\
\hline $1 / 26$ & ................ & 132,240 & 515,736 & ................. & ... $>2>0$ & \\
\hline $1 / 29$ & … & 26,448 & 158,688 & …….......... & 400 & ....... \\
\hline $2 / 2$ & & & 33,060 & & $\ldots$ & \\
\hline $2 / 5$ & ....... & 400 & 39,672 & ................. & ...... & ........... \\
\hline $2 / 8$ & & & 11,200 & ................ & $\ldots .$. & \\
\hline $2 / 12$ & 52,896 & 1,600 & 66,120 & …………. & $\cdots$ & \\
\hline $2 / 15$ & 105,792 & 8,000 & 39,672 & ................. & & \\
\hline $2 / 19$ & 800 & 800 & 52,896 & ................... & 1,600 & 3,200 \\
\hline $2 / 23$ & 66,120 & 1,600 & 105,792 & ................ & $\ldots$ & 1,600 \\
\hline $2 / 26$ & 3,200 & & 67,200 & …........ & & 6,400 \\
\hline $3 / 1$ & 105,792 & 12,800 & $158,68 \mathrm{~S}$ & ……........ & $\ldots \ldots \ldots$ & 9,600 \\
\hline $3 / 5$ & & & 185,136 & ……….... & $\ldots \ldots$ & \\
\hline $3 / 8$ & 3,200 & & 158,688 & ............... & ……....... & 1,600 \\
\hline $3 / 12$ & & 105,792 & 608,304 & ……….... & ……... & \\
\hline $3 / 15$ & 16,000 & $\ldots$. & 35,200 & …............. & $\ldots . .$. & \\
\hline $3 / 19$ & 6,400 & & 211,584 & $\ldots \ldots \ldots \ldots \ldots$ & ......... & 3,200 \\
\hline $3 / 23$ & 3,200 & 6,400 & 238,032 & ……….... & …… & का \\
\hline $3 / 26$ & & & 132,240 & …............. & & \\
\hline $3 / 29$ & 1,600 & & 79,344 & …............ & ……........ & 3,200 \\
\hline $4 / 2$ & & 6,400 & 22,400 & & .............. & \\
\hline $4 / 5$ & 6,400 & 6,400 & 28,800 & ….......... & ……........... & $\cdots$ \\
\hline $4 / 9$ & & 9,600 & & & & \\
\hline $4 / 13$ & 6,400 & & 6,400 & & & \\
\hline $4 / 16$ & .......... & & 105,792 & $\ldots .$. & 3,200 & \\
\hline $4 / 19$ & .............. & & 41,600 & & ........... & $\cdots \cdot$ \\
\hline $4 / 23$ & ........... & 6,400 & 54,400 & $\ldots \ldots$ & ………... & \\
\hline $4 / 26$ & & 3,200 & 211,584 & ................. & ................... & $\ldots$ \\
\hline $4 / 30$ & 3,200 & & 19,200 & & & \\
\hline $5 / 3$ & & 6,400 & 105,792 & …................ & .......... & \\
\hline $5 / 7$ & & $\ldots$ & 25,600 & ……… & ……… & ……....... \\
\hline $5 / 11$ & & & 105,792 & $\ldots \ldots$ & ........ & \\
\hline $5 / 14$ & .. & $\ldots$ & & ……......... & ................... & .............. \\
\hline $5 / 17$ & & $\ldots$ & 211,584 & & .......... & ……........ \\
\hline $5 / 21$ & & ..... & & & $\ldots \ldots$ & .. \\
\hline $5 / 24$ & .......... & ........ & 6,400 & $\ldots \ldots \ldots \ldots$ & ……ка... & ... \\
\hline $5 / 27$ & . . . & ... & & ........... & ........ & ……........ \\
\hline $5 / 31$ & .............. & ... $\ldots \ldots$ & & $\cdots$. & ...... & ... \\
\hline $6 / 3$ & . & & .... & $\ldots \ldots$ & $\ldots \ldots$ & ........ \\
\hline $6 / 7$ & .............. & ..... & .. . . & $\begin{array}{ll}\ldots . . . & \ldots\end{array}$ & ......... & ..... \\
\hline $\begin{array}{l}6 / 11 \\
6 / 16\end{array}$ & ……. & & & $\cdots$ & ......... & ……........... \\
\hline $6 / 15$ & ............. & & & ………… & . & ………… \\
\hline $6 / 21$ & ........... & ..... & ........ & ………... & ................... & …… \\
\hline $6 / 25$ & ........ & - & ………… & ……...... & ................ & ………..... \\
\hline $6 / 28$ & & ..... & ........ & ...... & …....... & ……........ \\
\hline $7 / 3$ & ………...... & ….... & ………...... & ……….... & .............. & …1........ \\
\hline $7 / 5$ & & & & & ................. & ............... \\
\hline $7 / 9$ & 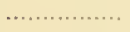 & ......, & 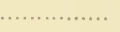 & 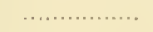 & ................. & …........... \\
\hline $7 / 12$ & … & …........ & ........ & …....... & …а....... & ㄷ.......... \\
\hline $7 / 16$ & …............ & 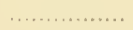 & … & ….......... & ................ & …........... \\
\hline $7 / 19$ & ............. & & & 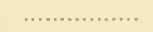 & .............. & ................. \\
\hline $7 / 23$ & …… & …ㄴ..… & ………........ & ……........... & ............... & \\
\hline $7 / 26$ & & 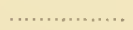 & & & & 6,400 \\
\hline $7 / 30$ & ................ & ………… & & 105,792 & ...... & \\
\hline
\end{tabular}


Table 1.-Organisms Per (ubic Meter in Plankton of Stockton Ciansel in 1913-(Continucd)

\begin{tabular}{|c|c|c|c|c|c|c|}
\hline 1913 & $\begin{array}{c}\text { Prorolon } \\
\text { sp. }\end{array}$ & $\begin{array}{l}\text { Stentor } \\
\text { coeruleus }\end{array}$ & $\begin{array}{l}\text { Stentor } \\
\text { viger }\end{array}$ & $\begin{array}{l}\text { Tintinnidium } \\
\text { fluviatile }\end{array}$ & $\begin{array}{l}\text { Trachelius } \\
\text { ovum }\end{array}$ & $\begin{array}{l}\text { Trichorlina } \\
\text { pediculus }\end{array}$ \\
\hline $8 / 2$ & & & & & . & . \\
\hline 56 & $\ldots$ & ... & .... & 3,200 & $.=1=1 \quad 1$. & 1 \\
\hline S/ 9 & .. $+-1-\ldots$ & ........... & ... in & .. & $\ldots \ldots \ldots$ & . \\
\hline $8 / 13$ & & & & 6,400 & 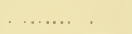 & . \\
\hline $8 / 15$ & & & $\ldots \ldots$. & 317,376 & .......... & 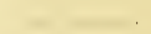 \\
\hline$S / 20$ & 3,200 & .......... & $\ldots \ldots \quad \ldots \ldots$ & 3,200 & . $\quad \ldots \ldots \ldots \ldots$ & .. \\
\hline $8 / 23$ & ..... & ........ & $\ldots \ldots \quad \ldots$ & 12,800 &....- & . \\
\hline $8 / 27$ & $\ldots \ldots$ & ...... & ................ & 3,200 & $\ldots \ldots \ldots$ & .. \\
\hline $8 / 31$ & $\ldots \ldots \ldots$ & ............... & ........... & 12,800 & . $\quad \ldots \quad \ldots \ldots \ldots$ & $\ldots$ \\
\hline $9 / 2$ & ............... & ............... & . . ............ & 6,400 &,$\ldots$ & . \\
\hline $9 / 6$ & $\ldots \ldots \ldots \ldots+\ldots$ & ….......... & ............... & & $\ldots \ldots \ldots \ldots$ & . \\
\hline $9 / 9$ & ................. & . . ............. & $\ldots \ldots, \ldots$ & 264,480 & $-\quad \ldots . . .1$. & .. \\
\hline $9 / 13$ & ............... & ............... & $\ldots \ldots \ldots \ldots$ & 25,600 & $\ldots \ldots$ & . \\
\hline $9 / 17$ & ................ & ................ & $\ldots \ldots \ldots$ & 211,594 & ........ & $1, \quad$. \\
\hline $9 / 20$ & …............ & ..... & $\ldots$ & & .. $\quad \ldots$. & \\
\hline $9 / 2+$ & ................... & $\ldots$. & . ........ & 6,400 & . .... & \\
\hline $9 / 27$ & ............... & .... & ..... & $158,6 \mathrm{SS}$ & .... & \\
\hline $10 / 1$ & . .............. & ................ & $\ldots \ldots . \ldots$ & 211,584 & . . & 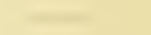 \\
\hline $10 / 4$ & ............. & ............... &.$\quad \ldots$ & 12,800 & $1 \quad$. & \\
\hline $10 / 8$ & 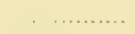 & .... & $\ldots \ldots \ldots$ & 6,400 & . & \\
\hline $10 / 11$ & & & $\ldots \ldots$ & $158,6 \mathrm{sS}$ & - & \\
\hline $10 / 15$ & 52,896 & 6,100 & . & & & \\
\hline $10 / 1 \mathrm{~S}$ & & $\ldots$. & & 6.100 & 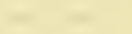 & $1,+1$. \\
\hline $10 / 22$ & 52,896 & .......... & $, \quad 1, \quad \ldots$ & 105,792 & & . \\
\hline $10 / 26$ & & $\ldots \ldots$ & .. $\quad \ldots$ & 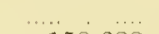 & 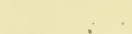 & 1 \\
\hline $10 / 29$ & 6,400 & …........... &.$\quad 1 \quad 25$ & 158,688 & $--\quad \ldots$ & \\
\hline $11 / 1$ & & ............... & 6,400 & ...... . . & $-\quad \ldots$ & \\
\hline $11 / 5$ & 6,400 & ................ & $, \quad, \quad \ldots$ & ….. & $\ldots$ & . \\
\hline $11 / \mathrm{S}$ & 12,800 & .............. & ... +101, & ...... , , & . & \\
\hline $11 / 12$ & $\ldots \ldots$ & ............... & 9,600 & …...... & . & 16,000 \\
\hline $11 / 15$ & & .. & & ... . & . & \\
\hline $11 / 19$ & 52,890 & & 6,400 & & & 9,600 \\
\hline $11 / 22$ & 6,400 & & 3,200 & ..... & ...... & 3,200 \\
\hline $11 / 26$ & 12,800 & 6,100 & & ........ & ....... & $\ldots$ \\
\hline $11 / 30$ & 3,200 & & 22,400 & & $\ldots \ldots$. & ... \\
\hline $12 / 3$ & $132,2+0$ & 19,200 & 19,200 & & ...... & .. . . \\
\hline $12 / 6$ & 9,600 & 3,200 & 16,000 & 3,200 & $\ldots$ & $\ldots \ldots$ \\
\hline $12 / 10$ & $\ldots$ & 2,400 & 800 & 800 & , & ... \\
\hline 12,14 & & $\$ 00$ & 39,672 & $\ldots$. & . & 800 \\
\hline $12 / 17$ & 1,600 & 32,672 & 79,344 & $\ldots$ & - & . \\
\hline $12 / 20$ & 33,060 & 165,300 & 158,6ss & . & & \\
\hline $12 / 24$ & & 2,400 & 7,200 & & & 800 \\
\hline $12 / 27$ & .. & 46,254 & 400 & 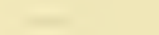 & & .. . \\
\hline $12 / 31$ & . & 66,120 & 39,672 & & .. & 1 \\
\hline 1913 & $\begin{array}{l}\text { Vorticella } \\
\text { longifilum }\end{array}$ & $\begin{array}{l}\text { Vorticella } \\
\text { sp. }\end{array}$ & $\begin{array}{l}\text { Total } \\
\text { Cilista }\end{array}$ & $\begin{array}{c}\text { Acineta } \\
\text { sp. }\end{array}$ & $\begin{array}{l}\text { Podophry"a } \\
\text { sp. }\end{array}$ & $\begin{array}{c}\text { Sphacrophry: } \\
\text { sp. }\end{array}$ \\
\hline $1 / 5$ & . & .......... & 7,412 & ..... & . & \\
\hline $1 / 8$ & & ............... & $1,(300$ & ......... & .. & •. \\
\hline $1 / 12$ & .. & ............... & 1,000 & $\ldots$ & $\begin{array}{ll}\ldots & \ldots\end{array}$ & $\ldots$ \\
\hline $1 / 15$ & . & ................ & 63,108 & . ........ &,$\quad \ldots$ & $\ldots$. \\
\hline $1 / 19$ & 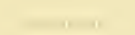 & .................. & $132,0.40$ & 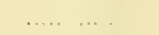 & $\ldots \ldots \ldots \ldots$ & $\ldots$ \\
\hline $1 / 22$ & $\ldots \ldots, \quad \ldots$ & ............... & 250,5332 & $\cdots$ & $\ldots \ldots \ldots \ldots$ & $\ldots$ \\
\hline $1 / 26$ & $\ldots \quad \ldots$ & .............. & 899,632 & $\ldots \ldots$. & .............. & .... \\
\hline $1 / 29$ & ..... & ............ & 391,308 & $\ldots \ldots \ldots$ & $\ldots \ldots \ldots$ & . \\
\hline $2 / 2$ & & . $\quad \ldots \ldots \ldots \ldots$ & 53,484 & $\ldots \ldots$ & .. $\quad .$. & $\ldots$ \\
\hline $2 / 5$ & &,$\ldots$ & $10: 3,180$ & ... & .... & .. $\quad-$ \\
\hline $2 / 8$ & .. ........ & ............. & $85,27: 2$ & . ... & ........ & $\ldots$ \\
\hline $2 / 12$ & $\ldots \ldots$ & ............... & 284,104 & & . ... & ....... \\
\hline
\end{tabular}


Table 1.-Organisms Per Cubic Meter in Plankton of STOCKTON Channel in 1913-(Continued)

\begin{tabular}{|c|c|c|c|c|c|c|}
\hline 1913 & $\begin{array}{l}\text { Vorticella } \\
\text { longifilum }\end{array}$ & $\begin{array}{c}\text { Vorticella } \\
\text { sp. }\end{array}$ & $\begin{array}{c}\text { Total } \\
\text { Ciliata }\end{array}$ & $\begin{array}{c}\text { Acineta } \\
\text { sp. }\end{array}$ & $\begin{array}{c}\text { Podophrya } \\
\text { sp. }\end{array}$ & $\begin{array}{c}\text { Sphaerophrya } \\
\text { sp. }\end{array}$ \\
\hline $2 / 15$ & 1,600 & $\ldots . . . \quad \cdots \cdots \cdots$ & 649,152 & & $\cdots$ & \\
\hline $2 / 19$ & ............... & ................ & 272,856 & .... & $\cdots$ & ... \\
\hline $2 / 23$ & & .......... & 411,920 & & ...... & ,................ \\
\hline $2 / 26$ & $\ldots .$. & ................ & 454,720 & & N...... & \\
\hline $3 / 1$ & & $\cdots$ & $780,54.4$ & & & $\ldots \ldots$ \\
\hline $3 / 5$ & 3,200 & .. & 302,128 & & $\cdots$ & . $\ldots \ldots \ldots$ \\
\hline $3 / 8$ & $\ldots .$. & ... & 460,816 & & & \\
\hline $3 / 12$ & & & $1,538,782$ & & , w... & \\
\hline $3 / 15$ & 3,200 & .. & 245,288 & ......... & $\cdots \cdot$ & $\cdots$ \\
\hline $3 / 19$ & , $\ldots \ldots \ldots \ldots \ldots$ & & $\mathrm{S} 93,584$ & & $\cdots \cdot$ & \\
\hline $3 / 23$ & 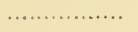 & 3,200 & 778,944 & ........ & n..... & , ....... \\
\hline $3 / 26$ & .... & $\ldots \ldots \ldots \ldots \ldots$ & 315,424 & $\ldots \ldots \ldots \ldots \ldots \ldots$ & . $\ldots \ldots \ldots \ldots \ldots \ldots$ & , n....... \\
\hline $3 / 29$ & $\ldots \ldots$ & .............. & 281,232 & ........ & (n..., & ... . \\
\hline $4 / 2$ & ..... & …........... & 399,728 & $\cdots \cdots$ & w... & . \\
\hline $4 / 5$ & .... & ........... & 370,176 & ... & $\cdots$ & \\
\hline $4 / 9$ & & 1600 & 364,624 & & & \\
\hline $\begin{array}{l}4 / 13 \\
4 / 16\end{array}$ & 79,344 & 1,600 & $\begin{array}{r}70,4115 \\
387,272\end{array}$ & & - & \\
\hline $4 / 19$ & 105,792 & & 340,525 & ..... & $\ldots$ & \\
\hline $4 / 23$ & 1,600 & 1,600 & 278,784 & & .... & ..... \\
\hline $4 / 26$ & $\ldots \ldots \ldots$ & 79,314 & $\$ 11,120$ & ........ & $\therefore \ldots$ & …..... \\
\hline $4 / 30$ & & 528,960 & 766,144 & $\ldots$ & ..... & ............ \\
\hline $5 / 3$ & 1,600 & 687,648 & 910,132 & .... & ...... & ,........ \\
\hline $5 / 7$ & & 396,720 & $5.54,560$ & $\ldots$. & $\cdots \cdots$ & \\
\hline $5 / 11$ & 1,600 & 396,720 & 586,656 & $\cdots$ & ..... & $\cdots \ldots$ \\
\hline $5 / 14$ & ..... & $1,533,984$ & $1,639,776$ & & ..... & .. \\
\hline $5 / 17$ & & $1,692,672$ & $2,915,680$ & & $\cdots$ & \\
\hline $5 / 21$ & 3,200 & 740,514 & 849,536 & $\ldots$ & $\cdots \cdots$ & ... \\
\hline $5 / 21$ & & $1, \pm 28,192$ & $1,699,072$ & & .. & ... \\
\hline $5 / 27$ & 6,400 & $1,163,712$ & $1,170,112$ & $\ldots \ldots$ & .... & $\cdots$ \\
\hline $5 / 31$ & & $1,322,400$ & $1,322,100$ & $\ldots$ & .... & \\
\hline $6 / 3$ & $\ldots$ & $1,428,192$ & $1,428,192$ & $\ldots$ & .............. & , $\ldots \ldots$. \\
\hline $6 / 7$ & n.............. & $2,433,216$ & $2,433,216$ & $\cdots$ & ...... & \\
\hline $6 / 11$ & & $1,745,568$ & $1,904,256$ & .... & (................ & …. \\
\hline $6 / 16$ & $\ldots$ & $1,795,464$ & $1,801,604$ & & .................. & $\ldots \ldots$ \\
\hline $6 / 18$ & $\ldots$. & $2,591,904$ & $2,595,104$ & $\therefore$ & $\cdots$ & .... \\
\hline $6 / 21$ & & $3,596,928$ & $3,600,12 \mathrm{~S}$ & .... & .................. & ........ \\
\hline $6 / 25$ & 12,800 & $1,851,360$ & $1,873,360$ & .... & n............. & ......... \\
\hline $6 / 28$ & $\ldots \ldots \ldots \ldots \ldots$ & $2,062,944$ & $2,221,632$ & & ..... & ...... \\
\hline $7 / 3$ & .......... & $1,692,672$ & $1,702,272$ & & ................. & $\ldots$. \\
\hline $7 / 5$ & …........... & $2,644,800$ & $2,800,688$ & & ................. & ........ \\
\hline $7 / 9$ & .................. & 476,064 & $687,6 \pm 18$ & $\ldots$ & ..... & ...... \\
\hline $7 / 12$ & ........ & $740,5 \pm 4$ & 743,714 & & ................ & ....... \\
\hline $7 / 16$ & $\ldots .$. & $1,110,816$ & $1,116,216$ & & ................. & ................ \\
\hline $7 / 19$ & & $1,057,920$ & $1,057,920$ & ... & $\cdots$ & ........ \\
\hline $7 / 23$ & $\ldots$. & 476,064 & 476,064 & $\cdots$ & .................. & ............. \\
\hline $7 / 26$ & & $1,269,504$ & $1,487,488$ & .... & …............ & n.......... \\
\hline $7 / 30$ & 6,400 & 899,232 & $1,117,216$ & $\ldots$ & $\ldots \ldots$. & ....... \\
\hline $8 / 2$ & ….............. & $1,639,776$ & $1,748,768$ & & $\ldots \ldots$ & $\ldots$. \\
\hline$S / 6$ & ............... & 634,752 & 713,741 & ............... & , & ……..... \\
\hline S/ 9 & ................. & 687,648 & $1,428,192$ & ... & ............... & ......... \\
\hline $8 / 13$ & ................ & $2,168,736$ & $2,968,576$ & $\ldots$. & ……........ & ........ \\
\hline $8 / 15$ & & $1,375,296$ & $2,128,640$ & ..... & ................ & 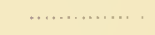 \\
\hline $8 / 20$ & ... . . & $1,586,880$ & $1,804,864$ & & . . . . . . . . . . & n.......... \\
\hline $8 / 23$ & .. ............ & 793,410 & $1,229,405$ & & .. ............. & $\ldots \ldots, \ldots, \ldots$ \\
\hline $8 / 27$ & & $7 \pm 0,541$ & $1,014,624$ & 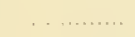 & ............... & ............. \\
\hline $8 / 31$ & & $1,851,360$ & $2,028,045$ & $\ldots \ldots$ & .................. & .............. \\
\hline $9 / 2$ & & 899,232 & $1,216,208$ & 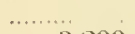 & …........... & ............... \\
\hline $9 / 6$ & ..... & 899,232 & $1,692,672$ & 3,200 & ............... & ............... \\
\hline $9 / 9$ & ....... & 634,752 & $1,110,816$ & n...... & n............ & ….... \\
\hline
\end{tabular}


TABle 1.-ORganisMS 1'ER ('UBIC METER IN PLANKTON OF Stocktox ('HanNel 1. 1913-(Continued)

\begin{tabular}{|c|c|c|c|c|c|c|}
\hline 1913 & $\begin{array}{l}\text { Vorticelia } \\
\text { longifilum }\end{array}$ & $\begin{array}{l}\text { Vorticella } \\
\text { sp. }\end{array}$ & $\begin{array}{c}\text { Totul } \\
\text { Ciliatu }\end{array}$ & $\begin{array}{c}\text { A cineta } \\
\text { sp. }\end{array}$ & $\begin{array}{c}\text { Porloplirya } \\
\text { sp. }\end{array}$ & $\begin{array}{c}\text { Spliaerophrya } \\
\text { sp. }\end{array}$ \\
\hline 913 & . & 952,128 & $1,212,20 \mathrm{~s}$ & 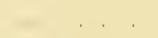 & . & $. \quad, \quad \ldots$. \\
\hline (1) 17 & 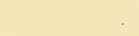 & $1,00,5,0 \times 21$ & $1,222,00 \mathrm{~s}$ & . & . & . \\
\hline 920 & & 123,168 & 793,440 & & .. & $\cdots$ \\
\hline 92.1 & 52,896 & 581,856 & 1,$06 ; 1,3200$ & & $\ldots \ldots$ & .. \\
\hline 927 & 52,896 & 317,376 & $79.3,4 \cdot 10$ & . & 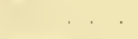 & .. \\
\hline 101 & .. & $1,322,400$ & $1,851,360$ & $\cdots$ & $\ldots \ldots$ & $\ldots .$. \\
\hline 104 & & 657.618 & $912,0,32$ & . & $\ldots$ & . . \\
\hline $10 / S$ & 6,400 & 528,960 & $1,021,224$ & .. & $\cdots$ & .. . \\
\hline $10 / 11$ & . . & 529,960 & $1,00.5,024$ & & & .. \\
\hline 10,15 & $-1-5$. & 657.6 .18 & 852,736 & . & 6,400 & .. \\
\hline 10.18 & & $+23,168$ & $694,0.1 \mathrm{~S}$ & 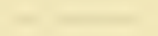 & .. & . \\
\hline $10 / 22$ & $\therefore 2,896$ & $1,692,672$ & $2,274,798$ & . . & .. & .. \\
\hline $10 / 26$ & 211,584 & 634,752 & 899,242 & $\ldots$. & $-\ldots$ & . $\ldots$ \\
\hline $10 / 29$ & 105,792 & $1,4 \mathrm{~S} 1,0 \mathrm{SS}$ & $2,(195,7+4$ & $\ldots \quad \ldots \ldots$ & .. & $\cdots$ \\
\hline $11 / 1$ & $\ldots$ & 317,376 & 895,840 & .. . & ..... & .......... \\
\hline $11 / 5$ & $\ldots$ & $1 . \overline{8}, 688$ & $360,-150$ & $\ldots \ldots$ & $\ldots$ & $\ldots . \quad$. \\
\hline $11 / 8$ & & & 318,296 & ... & & .......... \\
\hline $11 / 12$ & $\ldots$ & 290,928 & 1, (itti, Oso & . . & .. & ........... \\
\hline $11 / 15$ & & & 315,650 & 6,400 & . & $\cdots \cdots$ \\
\hline $11 / 19$ & 79,344 & 211,584 & Si39,0SS & . & & 52,596 \\
\hline $11 / 22$ & 9,600 & 211,554 & 419,562 & 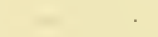 & 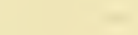 & ........ \\
\hline $11 / 26$ & 6,400 & 79,344 & 242.736 & . & & . \\
\hline $11 / 30$ & 158,688 & 79,344 & $5.59,360$ & & & ... \\
\hline $12 / 3$ & 52,896 & 52,596 & 470,320 & & & 3,200 \\
\hline $12 / 6$ & 22,400 & 105,792 & 209,792 & $\ldots$. & 3,200 & \\
\hline $12 / 10$ & $39,6-2$ & 13,244 & 113,792 & $\$ 00$ & $\$ 00$ & 800 \\
\hline $12 / 14$ & $125,62 \mathrm{~S}$ & 72,732 & 470,618 & . ... & & .......... \\
\hline $12 / 17$ & 13,224 & 26,419 & 447,092 & . & 800 & $\ldots \ldots$ \\
\hline 1220 & 46,284 & 39,672 & $721,10 \mathrm{~S}$ & . . & & $\ldots \ldots$ \\
\hline $12 / 24$ & 52,896 & 19,836 & 141,392 & $\ldots . \quad \ldots$ & $\$ 00$ & $\ldots$. \\
\hline $12 / 27$ & 52,896 & 33,060 & 297,328 & $\ldots \ldots \quad \ldots \ldots$ & ....... & $\ldots, \quad \ldots$. \\
\hline $12 / 31$ & $\$ 5,956$ & 52,896 & $350, \pm 36$ & $\ldots \ldots \cdot, \quad \ldots$, & ( $\ldots \ldots \ldots \ldots \ldots$ & $\begin{array}{lll}\ldots & \ldots & \ldots\end{array}$ \\
\hline 1913 & $\begin{array}{c}\text { Total } \\
\text { Suctoria }\end{array}$ & $\begin{array}{c}\text { Total Protozoa } \\
\text { without } \\
\text { Mastigophora }\end{array}$ & $\begin{array}{c}\text { Total Protozoa } \\
\text { with } \\
\text { Mastigophora }\end{array}$ & $\begin{array}{l}\text { Collotheca } \\
\text { egg, attached }\end{array}$ & $\begin{array}{c}\text { Collotheca } \\
\text { pelagica }\end{array}$ & $\begin{array}{c}\text { Total } \\
\text { Rhizota }\end{array}$ \\
\hline $1 / 5$ & - & 20,636 & 20,636 & n...,,$\ldots$ & . & . . \\
\hline $1 / 8$ & & 1,600 & 2,000 & n..... & .... $\quad$. & 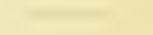 \\
\hline $1 / 12$ & $\cdots$ & 4.800 & 5,600 & $\cdots$ & $\cdots$ & \\
\hline $\begin{array}{l:l}1 & 15 \\
1 & 19\end{array}$ & $\cdots$ & $\begin{array}{r}63,108 \\
132,410\end{array}$ & $\begin{array}{l}1,012,054 \\
1,133,652\end{array}$ & $\begin{array}{l}\ldots \ldots \\
\ldots \\
\ldots\end{array}$ & . & .. \\
\hline $1 / 22$ & $\ldots$ & 251,232 & 352,012 & $\ldots, \quad, \quad$ & . & .. \\
\hline $1 / 26$ & $\ldots$ & $\$ 99,632$ & $1,172,324$ & $\ldots \ldots \ldots \ldots$ & 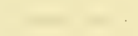 & . \\
\hline $1 / 29$ & ....... & 391,308 & 6 S5, 336 & $\ldots \ldots \ldots \ldots$ & $\cdots$ & . \\
\hline $2 / 2$ & ...... & 53,484 & 82,732 & n........... & .. & \\
\hline $2 / 5$ & $\ldots \ldots \ldots$ & 103,980 & 277,492 & $\ldots . \quad-\ldots \ldots$ & $\cdots$ & . \\
\hline $3 / 8$ & ...... & 85,272 & 623,032 & $\ldots \ldots, \quad \ldots \ldots$ & $\ldots$ & $\ldots$ \\
\hline $2 / 12$ & .... & 234,104 & 537,760 & $\cdots \cdots$ & $\cdot \cdot$ & . \\
\hline $2 \quad 15$ & $\ldots \ldots$ & 650,752 & 972,928 & 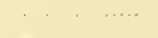 & .. & . . \\
\hline 219 & $\ldots \ldots$ & 252,456 & $1,814,016$ & $\cdots$ & $\cdots$ & \\
\hline $2 / 3$ & .. & 412,720 & $\$ 02,616$ & $\ldots \ldots$ & .. & \\
\hline $\begin{array}{l}206 \\
3 / 1\end{array}$ & … & $\begin{array}{l}184,720 \\
755,314\end{array}$ & $\begin{array}{l}1,239,664 \\
1,279,008\end{array}$ & . & $\cdots$ & \\
\hline $3 \quad 5$ & $\ldots \ldots$ & $\begin{array}{l}15,314 \\
302,125\end{array}$ & $\begin{array}{r}1,279,008 \\
391,072\end{array}$ & $\ldots$ & . & $-\quad .$. \\
\hline $3 / 8$ & $. \quad, \ldots \ldots \ldots \ldots$ & 460,516 & 521,712 & $\ldots \ldots$ & & \\
\hline 312 & ............ & $1,538,782$ & $1,599,678$ & ... & 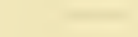 & $\ldots$ \\
\hline $3 / 15$ & $\ldots$ & $251,4 S S$ & 432,576 & ... & & . \\
\hline $3 / 19$ & . $\quad$......... & $895,1,4$ & 952,880 & $\ldots . \quad \ldots$ & $\cdots$ & 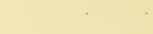 \\
\hline $3 / 23$ & ......... & 750,544 & $\$ 94,336$ & ... & $\ldots+\quad 1=$ & .... \\
\hline
\end{tabular}


Table 1.-Organisms Per Cubic Meter in Plankton of Stochton Channel in 1913-(Continued)

\begin{tabular}{|c|c|c|c|c|c|c|}
\hline 1913 & $\begin{array}{l}\text { Total } \\
\text { Suctoria }\end{array}$ & $\begin{array}{l}\text { Total Protozoa } \\
\text { without } \\
\text { Mastigophora }\end{array}$ & $\begin{array}{c}\text { Total Protozoa } \\
\text { with } \\
\text { Mastigophora }\end{array}$ & $\begin{array}{l}\text { Collotheca } \\
\text { egg, attached }\end{array}$ & $\begin{array}{l}\text { Collotheca } \\
\text { pelagica }\end{array}$ & $\begin{array}{c}\text { Tota! } \\
\text { Rhizota }\end{array}$ \\
\hline $3 / 26$ & & 384,624 & 702,048 & . & & \\
\hline $3 / 29$ & & $2 \$ 6,032$ & 768,400 & . & & \\
\hline $4 / 2$ & & 452,624 & 612,912 & & & \\
\hline $4 / 5$ & ........ & 424,672 & 439,072 & & & \\
\hline $4 / 9$ & & 445,568 & $459,96 \mathrm{~S}$ & & & \\
\hline $4 / 13$ & ............. & 138,104 & 150,904 & .. & & \\
\hline $4 / \mathbf{1 6}$ & & 390,472 & $\$ 26,410$ & $\ldots$ & & \\
\hline $4 / 19$ & & 340,528 & 104,624 & & & \\
\hline $4 / 23$ & & 442,272 & $1,662,080$ & & & \\
\hline$+/ 26$ & .... & $702,04 \mathrm{~S}$ & 920,032 & ...... & & \\
\hline$\pm / 30$ & …........... & $1,005,776$ & $1,141,216$ & $\ldots .$. & $\ldots$ & \\
\hline $5 / 3$ & & 993,276 & $1,284,204$ & & & \\
\hline $5 / 7$ & & 769,344 & 822,240 & & & \\
\hline $\begin{array}{l}5 / 11 \\
5 / 14\end{array}$ & & $\begin{array}{r}907,232 \\
1,854,560\end{array}$ & $\begin{array}{l}1,277,504 \\
1,966,752\end{array}$ & & $\ldots$ & \\
\hline $5 / 17$ & & $3,345,248$ & $3,927,104$ & & & \\
\hline $5 / 21$ & ... & $2,280,928$ & $2,502,112$ & & & \\
\hline $5 / 24$ & & $2,016,448$ & $2,250,928$ & & & \\
\hline $5 / 27$ & & $2,125,440$ & $2,657,600$ & $\ldots$. & . & \\
\hline $5 / 31$ & $\ldots$ & $2.107,456$ & $3,647,840$ & $\cdots \cdot$ & $\ldots$ & \\
\hline $6 / 3$ & 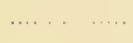 & $2,962,176$ & $3,709,120$ & & $\cdots$ & - \\
\hline $6 / 7$ & &, 714 & 4,92 & $\cdots$ & $\cdots$ & \\
\hline $\begin{array}{l}6 / 11 \\
6 / 16\end{array}$ & & $\begin{array}{l}3,07+368 \\
3,5+7,172\end{array}$ & $\begin{array}{l}4,185,184 \\
5044,260\end{array}$ & $\cdots$ & $\cdots$ & \\
\hline $6 / 18$ & & $2,915,680$ & 4,4 & ...... & ...... & \\
\hline $6 / 21$ & …......... & $3,887,008$ & $4,587,456$ & .......... & $\ldots$ & \\
\hline $6 / 25$ & & $4,306,576$ & $5,753,968$ & & & \\
\hline $6 / 28$ & & $3,544,032$ & $5,411,392$ & ..... & & \\
\hline I/ 3 & ………...... & $2,601,50 \cdot 4$ & $5,5+2,784$ & ......... & ... & \\
\hline $7 / 5$ & ...... & $3,560,032$ & $5,629,376$ & ..... & & \\
\hline 7/ 9 & ....... & $1,504,864$ & $4,821,440$ & ..... & & \\
\hline $7 / 12$ & .......... & 905,632 & $7,100,864$ & ......... & .. & \\
\hline $7 / 16$ & $\ldots \ldots$ & $1,757,368$ & - $7,109,464$ & .......... & .. & \\
\hline $7 / 19$ & $\ldots$ & $1,434,592$ & $8,476,160$ & $\ldots$ & & \\
\hline$\tau / 23$ & ........ & 899,232 & $4,1 S 5,184$ & & . & \\
\hline $7 / 26$ & & $2,125,440$ & $10,324,320$ & ..... & .. & \\
\hline $7 / 30$ & ..... & $1,535,485$ & 5,7 & & & \\
\hline $8 / 2$ & & $3,547,232$ & $\begin{array}{l}8,379,968 \\
6,109+0\end{array}$ & $\because$ & ………..... & \\
\hline $\begin{array}{l}8 / 6 \\
8 / 9\end{array}$ & $\cdots$ & $\begin{array}{l}016 \\
728\end{array}$ & $\begin{array}{l}6,102,240 \\
5,190,208\end{array}$ & & ………… & $\ldots$ \\
\hline $8 / 13$ & .......... & 262 & $14,152,012$ & & & \\
\hline $8 / 15$ & & $3,395,144$ & $10,178,432$ & $\ldots$ & 6,400 & 6,400 \\
\hline $8 / 20$ & & $2,284,12 \mathrm{~S}$ & $12,757,536$ & & & \\
\hline $8 / 23$ & ....... & 776 & $11,850,704$ & . & 6,400 & 6,400 \\
\hline $8 / 27$ & & $1,235,808$ & $9,755,26 t$ & ..... & …. & \\
\hline $8 / 31$ & & $2,980,176$ & $14,299,920$ & & & \\
\hline $9 / 2$ & & $1,430,992$ & $16,634,54 t$ & 12,800 & 6,400 & 19,200 \\
\hline $9 / 6$ & 3,200 & $1,705,472$ & $18,529,600$ & ....... & ...... & \\
\hline $9 / 9$ & & $1,226,208$ & $23,872,096$ & $\ldots \ldots$ & & \\
\hline $9 / 13$ & & $1,248,608$ & $22,883,072$ & ....... & . & \\
\hline $9 / 17$ & & $1,289,688$ & $22,502,200$ & ........ & ........... & \\
\hline $9 / 20$ & $\ldots$ & $1,328,192$ & $10,902,368$ & ................... & …........ & \\
\hline $9 / 24$ & & $1,434,592$ & $8,899,328$ & ……........... & .................... & ..... \\
\hline $9 / 27$ & & $1,163,712$ & $15,86 \mathrm{~s}, 800$ & ....... & ......... & \\
\hline $10 / 1$ & ........, & $2,168,736$ & $14,546,400$ & ….. & ........ & ............ \\
\hline 4 & & $1,440,992$ & $8,071,192$ & ......... & & \\
\hline$/ 8$ & & $1,394,496$ & $7,854,20 \mathrm{~s}$ & & 6,400 & 6,400 \\
\hline $10 / 11$ & & $1,804,864$ & $8,740,640$ & & & \\
\hline $0 / 15$ & 6,400 & $1,335,200$ & $5,355,224$ & ........ & 105,792 & 105,792 \\
\hline
\end{tabular}


Table 1.-Organisms Phr Cunic Meter in l'Lankton of Stockton Crannel in 1913-(Continued)

1913
$10 / 18$
$10 / 22$
$10 / 26$
$10 / 29$
$11 / 1$
$11 / 5$
$11 / 8$
$11 / 12$
$11 / 15$
$11 / 19$
$11 / 22$
$11 / 26$
$11 / 30$
$12 / 3$
$12 / 6$
$12 / 10$
$12 / 14$
$12 / 17$
$12 / 20$
$12 / 24$
$12 / 27$
$12 / 31$

Total
Suctoria

Total Protozoa
without
Mastigophora
$1,223,008$
$4,020,096$
$2,591,914$
$3,377,436$
$1,753,750$
$5,339,104$
$1,746,458$
$5,565,184$
$2,279,232$
$1,715,272$
424,672
297,232
957,680
478,320
267,485
116,992
471,018
449,192
721,508
143,392
298,128
350,436

Total Protozoa
with
Mastigophora
$7,676,320$
$9,838,656$
$7,617,0 ; 34$
$10,636,988$
$9,806,752$
$10,946,080$
$8,119,6018$
$19,430,336$
$9,641,576$
$7,386,144$
$6,239,184$
$2,841,040$
$4,274,850$
$3,258,560$
$2,340,032$
$1,1+1,852$
$1,690,826$
$1,875,584$
$1,469,628$
$1,253,856$
$1,647,776$
$1,389,720$

1913

$1 / 5$

$1 / \mathrm{S}$

$1 / 12$

$1 / 15$

$1 / 19$

$1 / 22$

$1 / 26$

$1 / 29$

$2 / 2$

$2 / 5$

$2 / 8$

$2 / 12$

$2 / 15$

$2 / 19$

$2 / 23$

$2 / 26$

$3 / 1$

$3 / 5$

$3 / 8$

$3 / 12$

$3 / 15$

$3 / 19$

$3 / 23$

$3 / 26$

$3 / 29$

4/ 2

$4 / 5$

$+9$

$4 / 13$

$4 / 16$

$4 / 19$

$4 / 23$

$4 / 26$

Rotifer exg.

$8,000 \quad 185,136$

$39,672 \quad 1,309,176$

$39,672 \quad 1,243,056$

$8,000 \quad 1,282,728$

$25,600 \quad 1,335,624$

$11,200 \quad 1,203,384$

$25,600 \quad 1,626,552$

21,000

11,200

$1,401,744$

357,048

674,424

3,200

$1,057,920$

$1,745,568$

$1,639,776$

766,992

$3,200 \quad 2,512,560$

$1,269,504$

3,200

$71+, 096$

793,440

343,524

6,400

525,960

79,344

290,925

317,376

132,240

185,136

10.5,792

$79,3 \cdot 1 \cdot 1$

3.200
Collotheca Totol pelagiea Rhizota
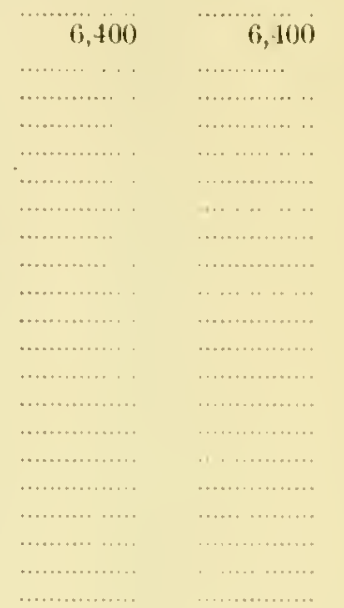

12,800

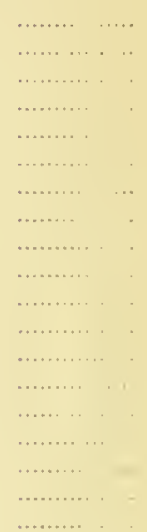

Total

Rotifer egg,

unidentified

115,604

$231,420)$

178,524

451,616

$727,90 \mathrm{~s}$

193,136
26,418

46,284

3,200

800

66,120

3,200

1,600

1,600

3,200

6,400

52,896

1,600

105,792

6,400

3,200

1,600

1,600

52,896

3,200

132,240

3,200

$1,(500$

1,600

1,600
$1,37.5,496$

$1,329,012$

$1,293,92 \mathrm{~S}$

$1,361,024$

$1,284,728$

$1,864,536$

$1,425,744$

369,848

676,024

$1,064,320$

$1,75.5,168$

$1,692,672$

768,592

$2,681,552$

$1,275,904$

720,496

798,240

343,824

585,256

82, 544

290,925

449,616

$13.5,440$

186,736

105.792

80,944

1,600
1,600 
Table 1.-Organisms Per Cubic Meter in Plankton of Stockton Channel in 1913-(Continued)

\begin{tabular}{|c|c|c|c|c|c|c|}
\hline 1913 & $\underset{\text { Reptunia }}{\text { Rotaia }}$ & $\begin{array}{c}\text { Rotaria } \\
\text { rotatoria }\end{array}$ & $\begin{array}{c}\text { Rotifer egg, } \\
\text { winter }\end{array}$ & $\begin{array}{l}\text { Rotifer egg. } \\
\text { unidentified }\end{array}$ & $\begin{array}{c}\text { Rotifer } \\
\text { unidentified }\end{array}$ & $\begin{array}{c}\text { Total } \\
\text { Bdelloida }\end{array}$ \\
\hline $4 / 30$ & & 79,344 & & & 79,344 & $158,6 \mathrm{SS}$ \\
\hline $5 / 3$ & & 79,344 & $\ldots$ & & 158,688 & 238,032 \\
\hline $5 / 7$ & $\ldots \ldots \ldots, \ldots$ & 105,792 & $\ldots \ldots \ldots$ & & 1,600 & 107,392 \\
\hline $5 / 11$ & & 1,600 & $\ldots \ldots \ldots \ldots \ldots$ & & & 1,600 \\
\hline $5 / 14$ & $\ldots$. & 6,400 & & 6,400 & 6,400 & 12,800 \\
\hline $5 / 17$ & & 370,272 & 6,400 & & 211,584 & 581,856 \\
\hline $5 / 21$ & & 3,200 & & & 264,480 & 267,680 \\
\hline $5 / 24$ & & 25,600 & & $\ldots$. & 264,480 & 290,080 \\
\hline $5 / 27$ & & 6,400 & $\cdots$ & & & 6,400 \\
\hline $5 / 31$ & & 6,400 & ..... & & 6,400 & 12,800 \\
\hline $6 / 3$ & & 6,400 & $\ldots .$. & $\ldots$. & 3,200 & 9,600 \\
\hline $6 / 7$ & ... & $\ldots \ldots$ & $\ldots$ & & 6,400 & 6,400 \\
\hline $6 / 11$ & & $\ldots \ldots \ldots$ & .......... & ...... & 3,200 & 3,200 \\
\hline $6 / 16$ & & & $\ldots \ldots$ & & 12,800 & 12,800 \\
\hline $6 / 18$ & & 19,200 & $\ldots$ & & 3,200 & 22,400 \\
\hline $6 / 21$ & ..... & 19,200 & & & 6,400 & 25,600 \\
\hline $6 / 25$ & & $158,6 \mathrm{SS}$ & & 3,200 & 6,400 & 165,088 \\
\hline $6 / 28$ & & 423,168 & .. & & . & 423,168 \\
\hline $7 / 3$ & 6,400 & 158,688 & & $\ldots$ & & 165,088 \\
\hline $7 / 5$ & & 19,200 & $\ldots$ & $\ldots \ldots \quad \ldots \ldots$ & $15 S, 68 \mathrm{~s}$ & 177,888 \\
\hline $7 / 9$ & & 6,400 & ... & $\ldots \ldots$ & 3,200 & 9,600 \\
\hline $7 / 12$ & & 211,584 & .... . & ... & 3,200 & $214,7 \mathrm{~s} 4$ \\
\hline $7 / 16$ & & 19,200 & ..... & ...... & 19,200 & $3 S, 400$ \\
\hline $7 / 19$ & $\ldots$. & & & $\ldots \ldots$ & $158,68 s$ & 158,688 \\
\hline $7 / 23$ & ..... & 317,376 & $\ldots \ldots$ & $\ldots \ldots$ & & 317,376 \\
\hline $7 / 26$ & & 12,800 & & $\ldots$ & 26,500 & 38,400 \\
\hline $7 / 30$ & 6,400 & 6,400 & & . & 3,200 & 16,000 \\
\hline $8 / 2$ & 6,400 & 32,000 & 19,200 & & 3,200 & 41,600 \\
\hline $8 / 6$ & 6,400 & 32,000 & 3,200 & & 211,584 & 249,984 \\
\hline $8 / 9$ & 6,400 & 370,272 & 264,480 & & & 376,672 \\
\hline $8 / 13$ & & 105,792 & & & 317,376 & 105,792 \\
\hline $8 / 15$ & 57,600 & 153,600 & ....... & .. & 317,376 & 528,576 \\
\hline $8 / 20$ & 25,600 & 237,184 & ……............. & ..... & 158,688 & 262,784 \\
\hline $8 / 23$ & 12,800 & 16,000 & ...... & & 6,400 & 35,200 \\
\hline $8 / 27$ & 32,000 & 105,792 & $\ldots \ldots$ & & $\mathbf{1 5 8 , 6 8 s}$ & 296,480 \\
\hline $8 / 31$ & $\ldots \ldots$ & $\ldots \ldots \ldots$ & ……… & ……........ & 105,792 & 105,792 \\
\hline $9 / 2$ & & & & & 3,200 & 3,200 \\
\hline $9 / 6$ & .... & 6,400 & & & 105,792 & 112,192 \\
\hline $9 / 9$ & $\ldots$. & & 3,200 & & 3,200 & 3,200 \\
\hline $9 / 13$ & & 12,500 & $\cdots$ & & 105,792 & 118,592 \\
\hline $\begin{array}{l}9 / 17 \\
9 / 20\end{array}$ & 12,800 & 211.581 & $\ldots \ldots$ & & 6.400 & $930-4$ \\
\hline $9 / 24$ & 12,800 & 6,400 & ...... & & 6,400 & $\begin{array}{r}230,784 \\
19,200\end{array}$ \\
\hline $9 / 27$ & . & & $\ldots .$. & & & \\
\hline $10 / 1$ & & 52,896 & ........... & ......... & $\ldots \quad \ldots \ldots$ & 52,896 \\
\hline $10 / 4$ & 25,600 & 6,400 & & & & 32,000 \\
\hline $10 / 8$ & 6,400 & 12,800 & 6,400 & & 211,584 & 230,794 \\
\hline $10 / 11$ & 6,400 & & & ….... & 105,792 & 112,192 \\
\hline $10 / 15$ & 158,688 & 65,696 & & & 211,584 & 435,968 \\
\hline $10 / 18$ & 38,400 & 19,200 & ....... & & & 57,600 \\
\hline $10 / 22$ & 12,800 & 105,792 & & 단..…… & 264,480 & 389,472 \\
\hline $10 / 26$ & 19,200 & 19,200 & 6,400 & 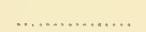 & 52,896 & 91,296 \\
\hline $10 / 29$ & 19,200 & 25,600 & ${ }^{\circ} \ldots \ldots$ & & 211,584 & 256,384 \\
\hline $11 / 1$ & 76,800 & 211,584 & … ….... & ………....... & 105,792 & 394,176 \\
\hline $11 / 5$ & $158,68 \mathrm{~s}$ & 158,688 & ㄷ..… & ...…… & ........... & 317,376 \\
\hline $11 / 8$ & 105,792 & 105,792 & 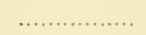 & ………...... & .................. & 211,584 \\
\hline $11 / 12$ & 105,792 & 79,344 & & 다......... & ………… & 186,136 \\
\hline $11 / 15$ & 6,400 & 105,792 & 6,400 & ………… & & 112,192 \\
\hline $11 / 19$ & 19,200 & 317,376 & 3,200 & 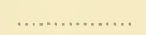 & 52,896 & 489,472 \\
\hline $11 / 22$ & 12,800 & 132,240 & 6,400 & ………… & 52,596 & 207,936 \\
\hline
\end{tabular}


Table 1.-Organisms Per Cubic Meter in Plankton of Stockion Channed in 1913-(Continued)

$\begin{array}{rr}1913 & \begin{array}{c}\text { Rotaria } \\ \text { neptunia }\end{array} \\ 11 / 26 & 52,896 \\ 11 / 30 & 16,000 \\ 12 / 3 & 52,596 \\ 12 / 6 & 41,600 \\ 12 / 10 & 19,826 \\ 12 / 14 & 33,060 \\ 12 / 17 & 33,060 \\ 12 / 20 & 52,896 \\ 12 / 24 & 4,800 \\ 12 / 27 & 13,224 \\ 12 / 31 & 52,896\end{array}$

$\begin{array}{rr}\begin{array}{r}\text { Rotiria } \\ \text { rotatoria }\end{array} & \begin{array}{r}\text { Rotifer rgg, } \\ \text { winter }\end{array} \\ 51,200 & 9,600 \\ 79,341 & 52,896 \\ 79,371.1 & \\ 155,136 & 1,600 \\ 19,836 & \ldots \ldots . \\ 800 & 400 \\ 1,600 & 400 \\ 13,22.1 & 100 \\ 26,418 & 800 \\ 39,672 & 1,600\end{array}$

Rotifer egg,
unidentificd$$
\text { . }
$$

\begin{tabular}{l}
$\ldots \ldots \ldots$ \\
$\ldots \ldots$ \\
$\ldots \ldots$ \\
$\ldots \ldots$ \\
$\ldots \ldots \ldots$ \\
$\ldots \ldots$ \\
$\ldots \ldots$ \\
$\ldots \ldots \ldots$ \\
$\ldots \ldots \ldots$ \\
$\ldots \ldots \ldots$ \\
$\ldots \ldots \ldots$ \\
\hline
\end{tabular}

Rotifer
uniclentified

Total

$\begin{array}{rrr} & & 104,096 \\ & 1,600 & 96,914 \\ & & 132,210 \\ & 226,736 \\ \ldots & 39,672 \\ & \ldots & 33,860 \\ \ldots & & 34,660 \\ \ldots & 66,120 \\ \ldots & 4,800 \\ & & 39,672 \\ & 400 & 92,968\end{array}$

Anuraeopsis

Anuraeopsis

Anuraeopsis

sp.

Asplanchna

Asplanchnopus

sp.

Brachionus

$1 / 5$

$1 / 8$

$1 / 12$

$1 / 15$

$1 / 19$

$1 / 22$

$1 / 26$

$1 / 29$

$2 / 2$

$2 / 5$

2/ 5

$2 / 12$

$2 / 15$

$2 / 19$

$2 / 23$

$2 / 26$

$3 / 1$

$3 / 5$

$3 / 8$

$3 / 12$

$3 / 15$

$3 / 19$

$3 / 23$

$3 / 26$

$3 / 29$

$4 / 2$

$4 / 5$

4/ 9

$4 / 13$

$4 / 16$

$4 / 19$

$4 / 23$

$4 / 26$

$4 / 30$

$5 / 3$

$5 / 7$

$5 / 11$

$5 / 11$

$5 / 17$

$5 / 21$

$5 / 24$

$5 / 27$

$5 / 31$

$6 / 3$ fissa

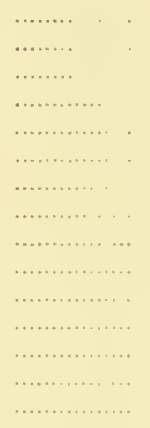

\section{..}

$$
\text { .. }
$$
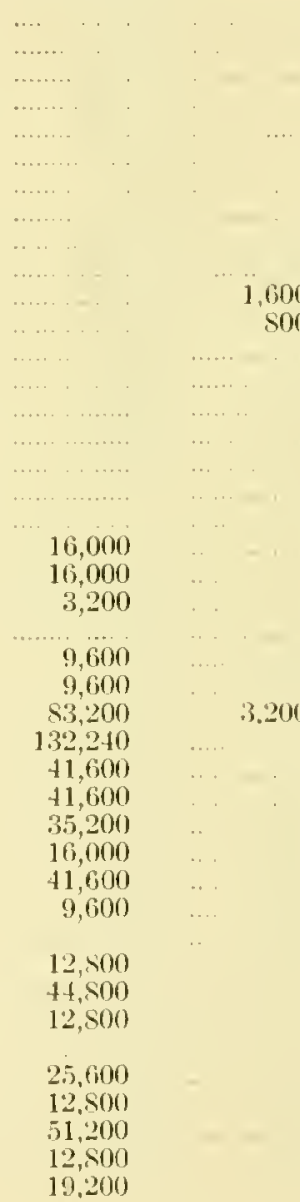

6,400

3,200

1,600

6.400

3,200

12,800

132,240

18.5, 136

$26,4,40$

978,576

$1,425,192$

$1,0.77 .920$

370,272

$423,16 \mathrm{~S}$

17!),201)

is 1 .sist

$47(3,064$ 
table 1.-Organisms Per Cubic Meter in Plankton of Stockton Channel in 1913-(Continued)

\begin{tabular}{|c|c|c|c|c|c|c|}
\hline 1913 & $\begin{array}{l}\text { Anuraeopsis } \\
\text { egg, attached }\end{array}$ & $\begin{array}{l}\text { Anuraeopsis } \\
\text { fissa }\end{array}$ & $\begin{array}{l}\text { Anuraeopsis } \\
\text { sp. }\end{array}$ & $\begin{array}{l}\text { Asplanehna } \\
\text { brightwellii }\end{array}$ & $\begin{array}{l}\text { Asplanchnopus } \\
\text { sp. }\end{array}$ & $\begin{array}{c}\text { Brachionus } \\
\text { angularis }\end{array}$ \\
\hline $6 / 7$ & & 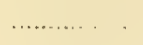 & & 44,800 & & 158,685 \\
\hline $\begin{array}{l}6 / 11 \\
6 / 16\end{array}$ & ....... & …......... & ……......... & 32,000 & & 370,272 \\
\hline $\begin{array}{l}6 / 16 \\
6 / 18\end{array}$ & .... & ………... & …… & 19,200 & ...... & 264,450 \\
\hline $\begin{array}{l}6 / 18 \\
6 / 21\end{array}$ & ... & & 6.100 & $\begin{array}{l}6,400 \\
6,+00\end{array}$ & & 19,200 \\
\hline $\begin{array}{l}6 / 21 \\
6 / 25\end{array}$ & & & $\begin{array}{l}0,400 \\
\ldots \ldots \\
\ldots\end{array}$ & $\begin{array}{r}6,-100 \\
51,200\end{array}$ & & $3 \cdot 3 \cap 0$ \\
\hline $6 / 2 S$ & $\ldots \ldots$ & & $\ldots$ & $\begin{array}{l}51,200 \\
38,400\end{array}$ & & 3,200 \\
\hline $7 / 3$ & ....... & ………... & ………..... & 83,200 & & 12,800 \\
\hline $7 / 5$ & & ....... & ……............ & 158,688 & $\ldots$ & 3,200 \\
\hline $7 / 9$ & $\ldots \ldots$. & ……….... & ………....... & 19,200 & & \\
\hline $7 / 12$ & ........ & ………… & 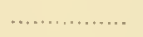 & 41,800 & & 158,688 \\
\hline $7 / 16$ & ....... & ….......... & ….......... & 12,800 & .... & \\
\hline $7 / 19$ & 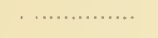 & & $\ldots$ & 6,400 & & \\
\hline $\begin{array}{l}7 / 23 \\
7 / 26\end{array}$ & $\ldots \ldots$ & 6,400 & & 3,200 & & \\
\hline $\begin{array}{l}7 / 26 \\
7 / 30\end{array}$ & ...... & …...... & $\ldots$ & $\begin{array}{l}19,200 \\
25,600\end{array}$ & & \\
\hline $8 / 2$ & $\ldots . .$. & $\ldots \ldots$ & $\ldots$ & $\begin{array}{r}2 ., 600 \\
+4,500\end{array}$ & …... & \\
\hline $8 / 6$ & & & & & & \\
\hline S/ 9 & & 6,400 & & & & 3,200 \\
\hline 8,13 & 6,400 & $3 S, 400$ & & 38,400 & ....... & \\
\hline $8 / 15$ & . . & 6,400 & ...... & 76 & $\ldots \ldots$ & $\cdots$ \\
\hline $8 / 20$ & , .............. & 12,800 & & 25,600 & $\ldots$ & \\
\hline $8 / 23$ & ……....... & 3,200 & & 25,600 & & \\
\hline $\begin{array}{l}8 / 27 \\
8 / 31\end{array}$ & ㄱ…… & 19,200 & $\ldots$ & 32,000 & & \\
\hline $9 / 2$ & …......... & $\begin{array}{r}19,200 \\
6,400\end{array}$ & ....... & $\begin{array}{r}6,400 \\
12,800\end{array}$ & & \\
\hline $9 / 6$ & ...... & & & & & \\
\hline $9 / 9$ & ....... & & & 6,400 & & \\
\hline $9 / 13$ & .......... & 3,200 & ..... & 51,200 & & \\
\hline $9 / 17$ & 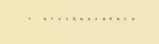 & 6,400 & & 3,200 & & \\
\hline $\begin{array}{l}9 / 20 \\
9 / 24\end{array}$ & 6,400 & & & & & 52,896 \\
\hline $\begin{array}{l}9 / 24 \\
9 / 27\end{array}$ & & 105,792 & & & & 105,792 \\
\hline $10 / 1$ & 52,596 & 52,896 & & $\ldots . . .$. & ….... & $\begin{array}{l}370,272 \\
317,376\end{array}$ \\
\hline $0 / 4$ & & 6,400 & & & & (3) \\
\hline $10 / 8$ & 6,400 & 19,200 & & & & 52,596 \\
\hline $10 / 11$ & & & & $6,+400$ & & \\
\hline $10 / 15$ & & 12,500 & ....... & 19,200 & & \\
\hline $10 / 18$ & & 105,792 & ......... & 6,400 & …........... & \\
\hline $10 / 22$ & 6,400 & 12,800 & $\ldots \ldots \ldots \ldots \ldots$ & 57,600 & ..... & $\cdots$ \\
\hline $0 / 26$ & & 6,400 & & 12,5 & & \\
\hline $10 / 29$ & 6,100 & 108,800 & $\ldots .$. & 105,792 & & \\
\hline $\begin{array}{l}11 / 1 \\
11 / 5\end{array}$ & 6,400 & 158,688 & & 6,400 & & \\
\hline 8 & .... & $\ldots+\cdots$ & & $\ldots . .$. & $\begin{array}{l}\cdots . \\
\ldots . .\end{array}$ & 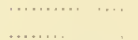 \\
\hline $1 / 12$ & $\ldots$ & & & ................ & ..... & 3,200 \\
\hline 5 & & 12.300 & & & & 19,200 \\
\hline $1 / 19$ & $+1,600$ & 54,400 & & & & 22,400 \\
\hline $1 / 22$ & 52,896 & $158,68 \mathrm{~S}$ & $\ldots$ & .... & & $79,3+4$ \\
\hline $1 / 26$ & $\ldots .$. & 132,240 & & & & 16,000 \\
\hline $1 / 30$ & ..... & 6.400 & & $\ldots$ & ............ & 3,200 \\
\hline $2 / 3$ & ...... & 3,200 & $\ldots$ & ........ & ........ & 3,200 \\
\hline & ...... & $\cdot . .$. & $\ldots$ & $\ldots .$. & …....... & …n., \\
\hline & & ....... & & & $\ldots \ldots$ & …...... \\
\hline $2 / 17$ & ...... & $\ldots \ldots \ldots$ & & & ........ & \\
\hline & ‥1…… & $\begin{array}{lll}\cdots & \ldots \\
\ldots \ldots \ldots \ldots \ldots \ldots & \ldots\end{array}$ & 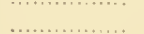 & $\cdots$ & $\cdots$ & 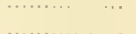 \\
\hline & & …........... & ………... & & & $\ldots \ldots$ \\
\hline 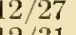 & $\ldots$ & ............. & & $\ldots$ & . & \\
\hline 81 & & & & & & \\
\hline
\end{tabular}


'Pable 1.-Organisms Phr Curic Migter in Plankton of Stockton Channei, in 1913-(Continued)

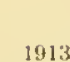

$1 / 5$

$1 / 8$

$1 / 12$

$1 / 15$

$1 / 19$

$1 / 2 \cdot 2$

$1 / 26$

$1 / 29$

2/ 2

2/ 5

8

$2 / 12$

$2 / 15$

$2 / 19$

$2 / 23$

$2 / 26$

$3 / 1$

$3 / 5$

3.8

$3 / 12$

$3 / 15$

$3 / 19$

$3 / 2: 3$

$3 / 26$

$3 / 29$

1/ 2

4/ 5

1/ 9

$4 / 13$

$4 / 16$

$+19$

$4 / 23$

$4 / 26$

$4 / 30$

$5 / 3$

57

$5 / 11$

$5 / 14$

5

$5 / 21$

$5 / 27$

$5 / 31$

6/ 3

6/ 7

$6 / 11$

6/ 16

$6 / 18$

$6 / 21$

$6 / 25$

$6 / 28$

$7 / 3$

$7 / 5$
Brachionus ntugularis caudutus
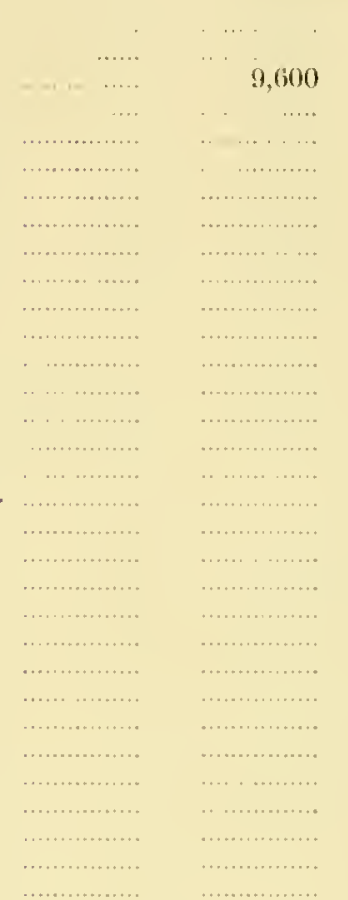

12,800

12,800

12,800

25,600

211,564

581,856

952,128

370,272

317,376

899,232

$1,110,816$

$2,591,904$

$1,269,50-1$

(iS7,64S

476,069

$1,163,712$

$1,375,296$

793,410

793,440

317,376

$1,481,0 \mathrm{SS}$
Brachionus
ealyciflorus

6, 612

$39,6-2$

10,000

13,224

13,224

$\mathrm{S} 00$

19,836

$59,50 \mathrm{~S}$

33,060

52,596

171,912

$221, \mathrm{SOS}$

9,600

66,120

211,554

396,720

317,376

$1,295,952$

$1,110,816$

$3,914,304$

132,240

264,480

449,616

343,824

264,450

714,096

317,376

16,000

19,200

79,344

38,400

44,800

57,600

25,600

105,792

$18.5,136$

79,344

140,800

102,400

44,800

6,100

Brachionus

13rachionus ga, at tached female.

Brachionus , attached .. ... ... .... 400

400
2.100

1,200

800

4,800

19,836

1,600

33,060

S.5,956

$79,3+4$

$224,80 \mathrm{~S}$

39,672

304,152

528,960

290,925

$1,375,296$

714,096

$60 \mathrm{~S}, 304$

92,800

105,792

132,210

317,376

290,928

155,136

3,200

12,800

52,896

9,600

12.800

9,600

61, 600

$\begin{array}{rr}6,100 & 502,511 \\ & 502,512\end{array}$

238,032

12,800

370,272

42:3, 168

211,584

317,376

$423,16 \mathrm{~S}$

211,581

899,232

476,064

2S\$,000

952,128

370,272

793,440

846,336

$6,400 \quad 528,960$
158,689

$158,68 \mathrm{~s}$

3,200

528,960

$\$ 46,336$

476,064

6,400

6. 100
8,400

5, 200

39,672

79,341

52,896

$10.5,792$

6,400

16,000

12,800

317,376

79,344

48,000

32,000

32,000

200,928

........ , . .

.........

52,896

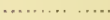

.................

6,400

44,800

3,200

147,200

12,800

$317,3,6$
476,064 
Table 1.-Organisms Per Cubic Meter in Plankton of Stocktox Channel in 1913-(Continued)

\begin{tabular}{|c|c|c|c|c|c|c|}
\hline 1913 & $\begin{array}{l}\text { Brachionus } \\
\text { angularis } \\
\text { caudatus }\end{array}$ & $\begin{array}{c}\text { Brachionus } \\
\text { budapestenensis }\end{array}$ & $\begin{array}{l}\text { Brachionus } \\
\text { calyciflorus }\end{array}$ & $\begin{array}{l}\text { Brachionus } \\
\text { capsuliflorus }\end{array}$ & $\begin{array}{l}\text { Brachionus } \\
\text { egg, attached } \\
\text { female }\end{array}$ & $\begin{array}{l}\text { Brachionus } \\
\text { egg, attached } \\
\text { male }\end{array}$ \\
\hline $7 / 30$ & 423,168 & & & 6,400 & 12,800 & \\
\hline $8 / 2$ & 211,584 & & .. & & $2,644,480$ & \\
\hline $8 / 6$ & 105,792 & 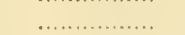 & $\ldots$ & $\ldots$ & 3,200 & .. \\
\hline S/ 9 & 105,792 & …............. & $\ldots \ldots, \ldots$ & in...... & $158,68 \mathrm{~S}$ & 105,792 \\
\hline $8 / 13$ & $1,269,504$ & & $\begin{array}{llll}\ldots & \ldots & \end{array}$ & & 317,376 & \\
\hline $8 / 15$ & $1,428,192$ & & & 6,400 & 687,648 & 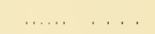 \\
\hline $8 / 20$ & $1,692,672$ & ............. & $\ldots \ldots \ldots$ & 6,400 & 952,128 & n...... \\
\hline $8 / 23$ & $\mathrm{~S} 99,232$ & & $\ldots \ldots \ldots$ & $\ldots \ldots$ & 740,544 & ......... \\
\hline $8 / 27$ & 952,128 & .... & ............ & ...... & 476,064 & ................ \\
\hline $8 / 31$ & 317,376 & $\cdots$ & ................ & & 105,792 & \\
\hline $9 / 2$ & 476,064 & ....... & .................. & 6,400 & $15 \mathrm{~S}, 68 \mathrm{~S}$ & \\
\hline $9 / 6$ & $\$ 76,064$ & ..... & ........ & $\ldots$ & 317,376 & 105,792 \\
\hline $9 / 9$ & $2,433,216$ & ...... & $\ldots$ & 3,200 & $1,269,504$ & 19,200 \\
\hline $9 / 13$ & $2,062,944$ & . & & 3,200 & 476,064 & $\ldots \ldots \ldots$ \\
\hline $9 / 17$ & 657,648 & ................ & 6,400 & & 370,272 & .. \\
\hline $9 / 20$ & 19,200 & & $\ldots$ & & 6,400 & ....... \\
\hline $9 / 24$ & 264,480 & $\ldots$. & 12,800 & .. & 105,792 & .......... \\
\hline $9 / 27$ & 740,544 & $\ldots$ & $\ldots \ldots$ & ... & $1,005,024$ & \\
\hline $10 / 1$ & $5 S 1,856$ & 19,200 & & 12,500 & 370,272 & .............. \\
\hline $10 / 4$ & $5 \mathrm{S1}, 856$ & 6,400 & 6,400 & 6,400 & 423,168 & \\
\hline $10 / 8$ & 793,440 & .... & & 32,000 & 634,752 & 52,896 \\
\hline $10 / 11$ & 423,168 & $52, \mathrm{~S} 96$ & 6,400 & 6.400 & $158,68 \mathrm{~S}$ & \\
\hline $10 / 15$ & 264,480 & $\ldots \ldots$ & . . & 6,400 & 158,688 & 19,200 \\
\hline $10 / 18$ & 158,688 & 6,400 & & 32,000 & 52,896 & \\
\hline $10 / 22$ & 370,272 & ................ & 6,400 & $\ldots$ & 211,584 & 211,581 \\
\hline $10 / 26$ & 19,200 & & $\ldots$ & ( & & $\ldots$ \\
\hline $10 / 29$ & 25,600 & 6,400 & & $6, \pm 00$ & 6,400 & $\ldots$ \\
\hline 11/ 1 & & $\ldots \quad \ldots \ldots \ldots$ & & 6,400 & & $\ldots$ \\
\hline 11) 5 & 6,400 & n............. & 6,400 & $\cdots \cdot$ & $\cdots$ & .. \\
\hline $\begin{array}{l}11 / 8 \\
11 / 12\end{array}$ & …1, & …, & $\begin{array}{l}\cdots, 200 \\
\cdots\end{array}$ & & 9,600 & 9,600 \\
\hline $11 / 15$ & $\ldots \ldots \ldots \ldots \ldots$ & $\ldots \ldots \ldots \ldots \ldots$ & 6,400 & $\ldots \ldots$ & 12,800 & 12,800 \\
\hline $11 / 19$ & .............. & …, $\ldots \ldots+\ldots$ & 3,200 & & 19,200 & ............... \\
\hline $11 / 22$ & .................. & ................. & 3,200 & ........... & 105,792 & . .............. \\
\hline $11 / 26$ & ................... & ….............. & 9,600 & .......... & 79,344 & ................ \\
\hline $11 / 30$ & & .................. & $\ldots \ldots$ & .................. & 16,000 & \\
\hline $12 / 3$ & $\ldots$ & ........ & & $\ldots \ldots$. & 9,600 & $\ldots$ \\
\hline $12 / 6$ & ......... & …… & ......... & ........... & $\cdots$, & (n........ \\
\hline $12 / 10$ & $\cdots$ & $\ldots$. & …...... & ....... & 1,600 & $\cdots$ \\
\hline $12 / 14$ & & ..... & & $\cdots$ & $\mathrm{S} 00$ & ........... \\
\hline $12 / 17$ & $\ldots$ & .. & ... & (....... & $\ldots \ldots$ & …...... \\
\hline $12 / 20$ & $\cdots$ & ..... & 800 & . . . . . & …... & (n., \\
\hline $\begin{array}{l}12 / 24 \\
12 / 27\end{array}$ & .... & 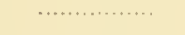 & .......... & . & 1,600 & 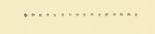 \\
\hline $12 / 31$ & .. & . & 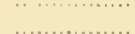 & & & \\
\hline 1913 & $\begin{array}{l}\text { Brachionus } \\
\text { egg, free } \\
\text { feniale }\end{array}$ & $\begin{array}{l}\text { Bracbionus } \\
\text { egg, free } \\
\text { nale }\end{array}$ & $\begin{array}{c}\text { Brachionus } \\
\text { male }\end{array}$ & $\begin{array}{c}\text { Brachionus } \\
\text { plicatilis }\end{array}$ & $\begin{array}{c}\text { Brachionus } \\
\text { urceus }\end{array}$ & $\begin{array}{c}\text { Brachionus } \\
\text { with } \\
\text { endoparasites }\end{array}$ \\
\hline $1 / 5$ & 13,224 & $., 1, \ldots . . . \ldots$ & $1 \ldots$ & 1,600 & 6,612 & \\
\hline 1/ 8 & 33,060 & ................ & ................. & 2,000 & 400 & ........ \\
\hline $1 / 12$ & 6,400 & ............... & & 5,200 & 800 & \\
\hline $1 / 15$ & 26,448 & n..........., & , & 13,224 & 400 & ........... \\
\hline $1 / 19$ & 13,224 & .................. & ...... & 26,448 & & ............... \\
\hline $1 / 22$ & 400 & & & 4,800 & 1,600 & \\
\hline $1 / 26$ & & ......... & & 26,448 & 400 & ......... \\
\hline $1 / 29$ & 19,836 & ............... & & 52,896 & 17,600 & $\cdots$ \\
\hline $2 / 2$ & 13,224 & .............. & & 92,568 & 59,505 & ......... \\
\hline $2 / 5$ & 92,568 & ................. & ............... & 99,180 & 52,896 & \\
\hline
\end{tabular}


Thale 1. - Organisis 1'er Cubic Mieter in Piankton of Stockton Chaxdel 1N 1913-(Continued)

\begin{tabular}{|c|c|c|c|c|c|c|}
\hline 1913 & $\begin{array}{l}\text { Brachionus } \\
\text { cgR, free } \\
\text { female }\end{array}$ & $\begin{array}{l}\text { J3rachionus } \\
\text { exg. free } \\
\text { male }\end{array}$ & $\begin{array}{l}\text { 3rachionus } \\
\text { male }\end{array}$ & $\begin{array}{l}\text { Irrachionus } \\
\text { plicatilis }\end{array}$ & $\begin{array}{c}\text { Brachionus } \\
\text { urceus }\end{array}$ & $\begin{array}{l}\text { Brachionus } \\
\text { with } \\
\text { endoparasites }\end{array}$ \\
\hline $2 / 8$ & 119,016 & & & $79,34.1$ & 52,896 & \\
\hline $2 / 12$ & 39,672 & . & 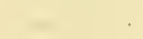 & 132,240 & $10,5,792$ & w \\
\hline $2 / 15$ & - & & & $1,(100)$ & 3,200 & .. \\
\hline $2 / 19$ & $92,56,5$ & 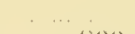 & .. & 3,200 & $1=1,+2$. & .. $+1+1=$ \\
\hline $2 / 23$ & $171,9) 12$ & 80() & & 17,600 & 800 & $\ldots \quad \ldots$ \\
\hline $2 / 26$ & 105,792 & $1,(30) 0$ & $1 \ldots$ & 16,000 & 79,344 & .... \\
\hline $3 / 1$ & 52,896 & & $\ldots$ & 25,600 & & . . \\
\hline $3 / 5$ & $211,5 \mathrm{S4}$ & 79,344 & & $1: 32,240$ & 6,100 & ... \\
\hline $3 / 8$ & $\begin{array}{r}52,896 \\
176,064\end{array}$ & $1(j 0)$ & 1,600 & $\begin{array}{l}12,400 \\
35,100\end{array}$ & $1=-\ldots \ldots$ & . \\
\hline $3 / 15$ & $+60,004$ & 1,1007 & 6,400 & 19,200 & & $\cdots$ \\
\hline $3 / 19$ & 159, (ise & 1.6000 & $\ldots . \quad, \quad$. & 12,800 & & ..... \\
\hline $3 / 23$ & 185,136 & $\therefore \rightarrow$ & & $(i, 400$ & & .. \\
\hline $3 / 26$ & 264,450 & . & .. & 22,400 & 3.200 & $\ldots$ \\
\hline $3 / 29$ & 211,581 & 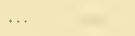 & . $\quad$. & 25,600 & 3,200 & . \\
\hline $4 / 2$ & 132,210 & ... & . & 9,600 & & . \\
\hline $4 / 5$ & 52,896 & ... & .. & 19,200 & & . \\
\hline $\begin{array}{l}4 / 9 \\
4 / 13\end{array}$ & 1,600 & $\ldots$ & $x$ & 3.200 & 3,200 & .. \\
\hline $4 / 16$ & & $\ldots$ & 11 & & 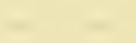 & . \\
\hline $4 / 19$ & 1,600 & $\ldots$. & & & & . \\
\hline $4 / 23$ & 3,200 & .... & . . ........... & & . & $\ldots \ldots$ \\
\hline $4 / 26$ & 1,6000 & $\ldots$ & ................ & 3,200 & ... , in , $\rightarrow$ & $---\ldots$. \\
\hline $4 / 30$ & 1,600 & ... & . $\ldots \ldots \ldots \ldots$ & .. & .... & $\ldots$ \\
\hline $\begin{array}{l}5 / 3 \\
5 / 7\end{array}$ & $\cdots$ & $\ldots$ & ……, & 1,600 & 3,200 & $\ldots$ \\
\hline 5) 11 & $12: 3,169$ & .... & ................... & $\ldots \ldots$ & & .. \\
\hline $5 / 14$ & 423,168 & ...... & ........ & $\ldots$. & 25,600 & \\
\hline $5 / 17$ & 1,$00 ;, 024$ & ........... & .............. & .... & 32,000 & \\
\hline $5 / 21$ & 211,584 & ........... & $\ldots \ldots \ldots \ldots$ & $\ldots$ & $15 \mathrm{~S}, 6 \mathrm{SS}$ & $1, \ldots \ldots$ \\
\hline $5 / 24$ & 211,584 & .......... & & & 128,000 & \\
\hline $5 / 27$ & 211,594 & $. \quad \ldots .$. & ..... & 12,800 & 423,165 & , \\
\hline $5 / 31$ & 317,376 & $\ldots \ldots$ & & . & 370,272 & \\
\hline 6/ 3 & 158,688 & $\ldots \ldots$ & $211,5 \mathrm{st}$ & . & 899,232 & \\
\hline $6 / 7$ & 211,581 & $\ldots \ldots$, & 3,200 & 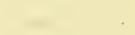 & 740,514 & 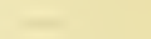 \\
\hline$f i / 11$ & 317,376 & $\ldots \ldots$ & .. & & 505,600 & \\
\hline $6 / 16$ & 370,272 & $\ldots \ldots$ & .. & 1 & 423,168 & - \\
\hline $6 / 18$ & 317,376 & ...... & - & & $6.57,645$ & \\
\hline $6 / 21$ & 317,376 & . & & 3,200 & 899,232 & \\
\hline $6 / 25$ & 581,856 & . & & & 581,856 & 525,960 \\
\hline $6 / 25$ & 657,648 & .. & . & 6,400 & 128,000 & \\
\hline $7 / 3$ & 201,480 & & .. & & 51,200 & \\
\hline $7 / 5$ & $1,00,5,024$ & - & .. & $(j, 400$ & 44,800 & \\
\hline $7 / 9$ & $\$ 99,232$ & $\ldots$ & $\ldots$ & & 11,900 & \\
\hline $7 / 12$ & $1,005,024$ & ... & $\ldots$ & & 528,960 & \\
\hline $7 / 16$ & 370,272 & . . 1 & . & & $52 \times, 960$ & \\
\hline $7 / 19$ & 264,180 & .... & & & 370,272 & .. \\
\hline $7 / 23$ & 740,544 & .. & & 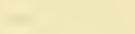 & $(i, 400$ & .. \\
\hline $7 / 26$ & 470,064 & . & & & 423,168 & \\
\hline $7 / 30$ & $423,16 \mathrm{~s}$ & - & & & 105,792 & 12,800 \\
\hline $8 / 2$ & $423,16 \mathrm{~S}$ & , & - & & 370.272 & 3,200 \\
\hline $8 / 6$ & 631,752 & & & & 264,450 & 6,100 \\
\hline $8 / 9$ & $1,163,712$ & , & & 6,400 & 793,440 & . \\
\hline $8 / 13$ & $1,110,816$ & , & $10.5,792$ & & 793.440 & \\
\hline $8 / 15$ & 899,232 & ........... & 1. & .. & $264,4>0$ & $1, \ldots$ \\
\hline $8 / 20$ & $2,486,112$ & 1. . .......... & .. & $\ldots$ & 470,064 & $\ldots$ \\
\hline$S / 2: 3$ & $(i 3 \cdot 1,752$ & & 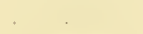 & $\ldots$ & 581,856 & \\
\hline $8 / 27$ & $1,005,024$ & $11 \quad \ldots$ & $\begin{array}{ll}\ldots . & . .\end{array}$ & $\ldots+, 1$, & 370,272 & , .. \\
\hline $8 / 31$ & 687,648 & . $\quad \ldots$. & .... . & & 105,792 & $\ldots$ \\
\hline
\end{tabular}


Table 1.-Organisms Per Cubic Mieter in Plankton of Stockton Channel in 1913-(Continued)

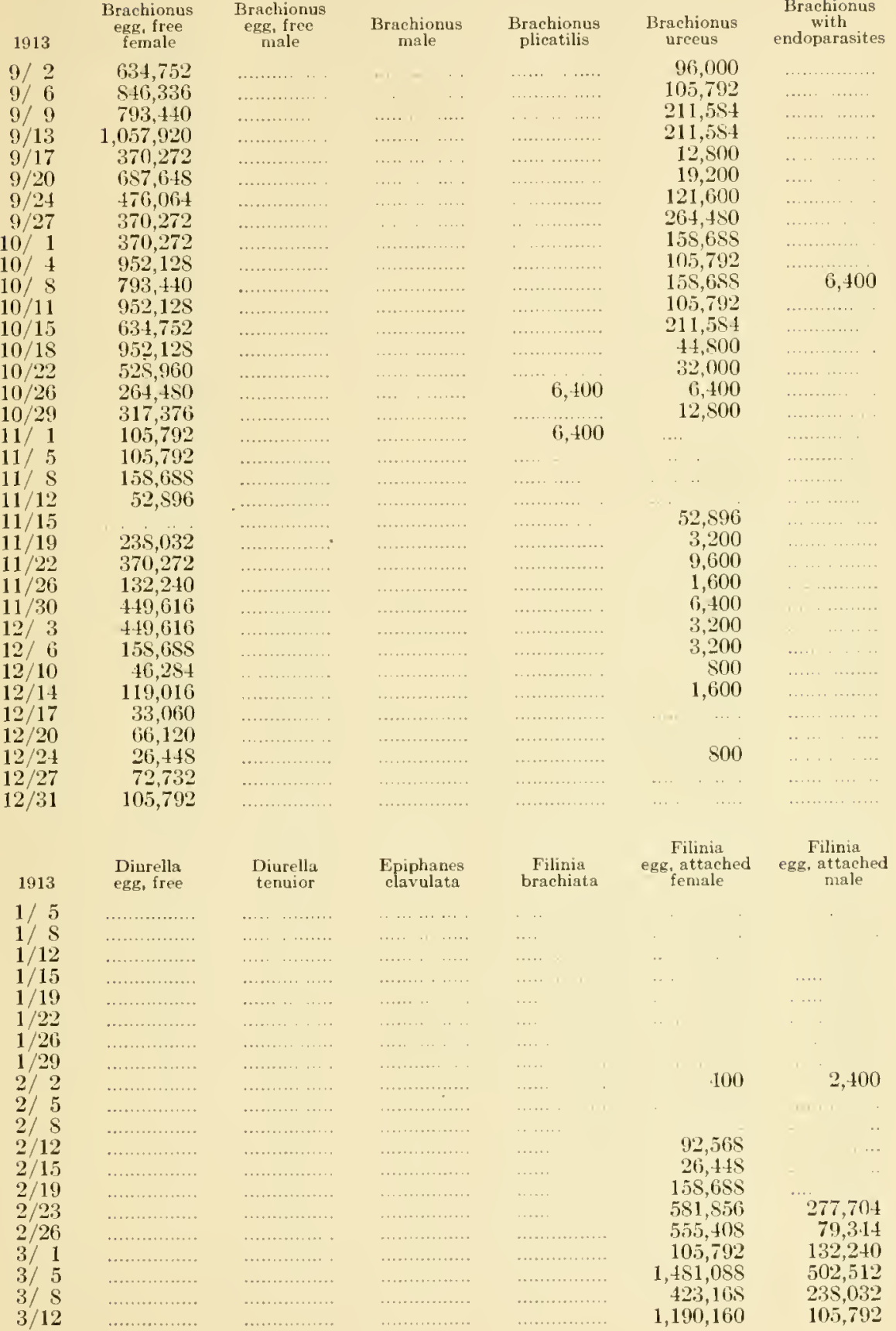


Tahle 1.-Orgaxisms Per ('vric Meter ix Planktox of STOCKто: (IIANAEl, IS 1913-(Contimurd)

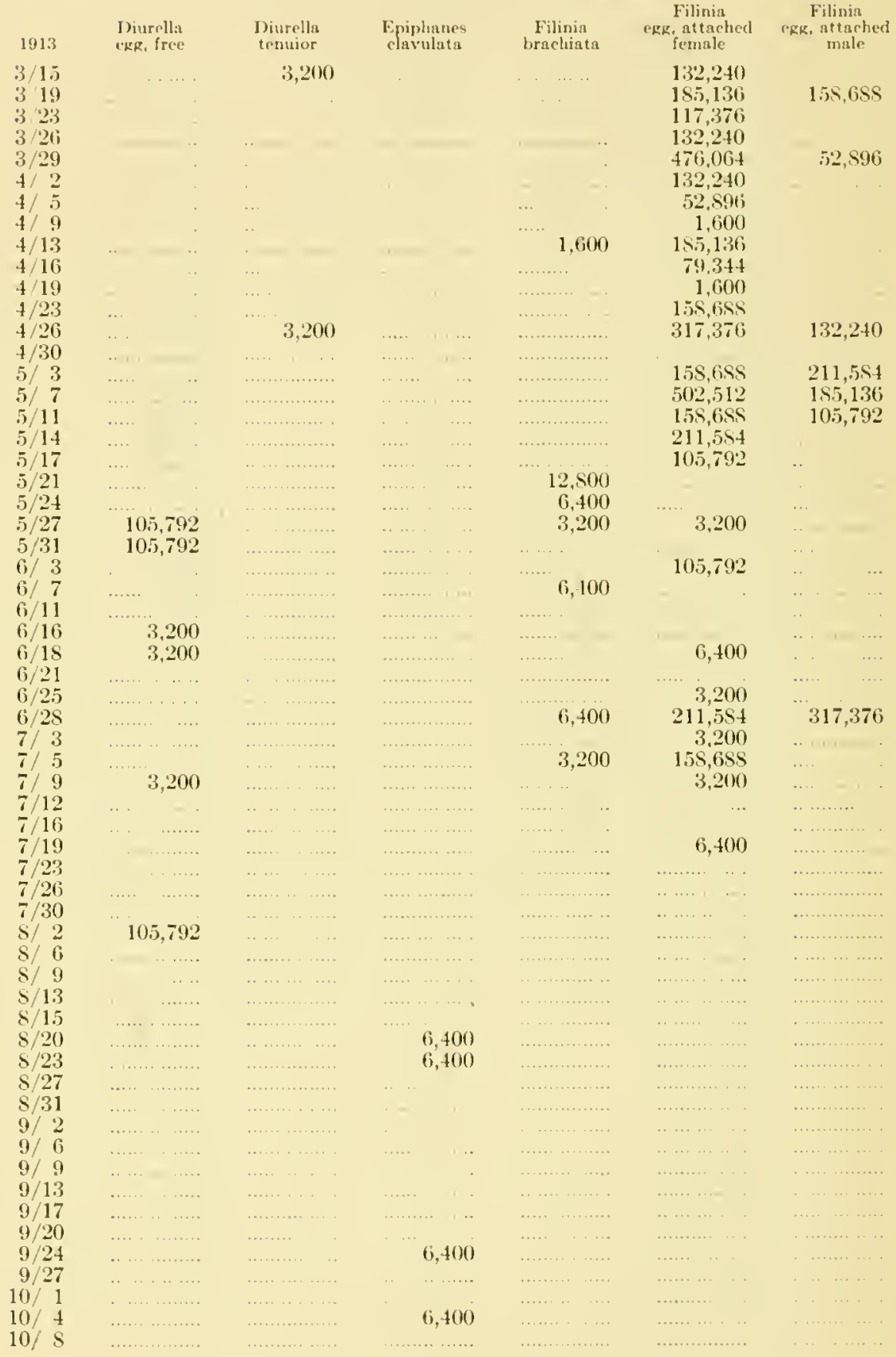


Table 1.-Organisms Per Cubic Meter in Plankton of Stockton ChanNel in 1913-(Continued)

\begin{tabular}{|c|c|}
\hline 1913 & $\begin{array}{l}\text { Diurella } \\
\text { egg, free }\end{array}$ \\
\hline $10 / 11$ & \\
\hline $10 / 15$ & 52,596 \\
\hline $10 / 18$ & 52,896 \\
\hline $10 / 22$ & \\
\hline $10 / 26$ & \\
\hline $10 / 29$ & \\
\hline $11 / 1$ & \\
\hline 11/ 5 & \\
\hline $\begin{array}{l}11 / 8 \\
11 / 12\end{array}$ & \\
\hline $11 / 15$ & \\
\hline $11 / 19$ & \\
\hline $11 / 222$ & \\
\hline $11 / 26$ & \\
\hline $11 / 30$ & \\
\hline $12 / 3$ & \\
\hline $12 / 6$ & \\
\hline $12 / 10$ & \\
\hline $12 / 14$ & \\
\hline $12 / 17$ & .. \\
\hline $12 / 20$ & \\
\hline $12 / 24$ & \\
\hline $\begin{array}{l}12 / 27 \\
12 / 31\end{array}$ & \\
\hline
\end{tabular}

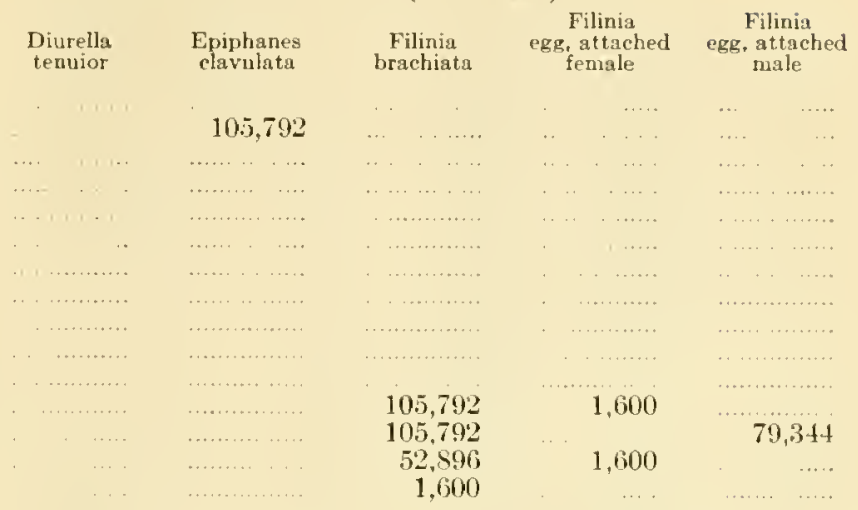

\begin{tabular}{|c|c|c|c|c|c|}
\hline $\begin{array}{c}\text { Filinia } \\
\text { egg, free }\end{array}$ & $\begin{array}{c}\text { Filinia } \\
\text { longiseta }\end{array}$ & $\begin{array}{l}\text { Keratella } \\
\text { cochlearis }\end{array}$ & $\begin{array}{l}\text { Keratella } \\
\text { egg, attached }\end{array}$ & $\begin{array}{l}\text { Keratella } \\
\text { egg, free }\end{array}$ & $\begin{array}{l}\text { Keratella } \\
\text { male }\end{array}$ \\
\hline & 72,732 & & & 72,732 & \\
\hline & 20,800 & & 400 & 79,344 & \\
\hline & 5,600 & 400 & 6.000 & 25,200 & \\
\hline & 26,448 & 13,224 & 26.448 & 99,180 & \\
\hline & 2,400 & 400 & 26,445 & 46,294 & \\
\hline & 1,600 & 33,060 & 19,836 & 39.672 & \\
\hline & 800 & & 72,732 & 138,852 & \\
\hline & 46,284 & 800 & 112,404 & 125,628 & \\
\hline & 4,800 & 13,224 & 33,060 & 171,912 & \\
\hline & 13,600 & 800 & 39,672 & $145,+64$ & \\
\hline & 66,120 & 800 & 171,912 & 343,824 & \\
\hline & 304,152 & 52,896 & 436,392 & 899,232 & \\
\hline & 19,200 & 9,600 & 3,200 & 800 & \\
\hline & 383,496 & 14,400 & 6,400 & 132,240 & \\
\hline $10,5,792$ & $2,062,944$ & 39,672 & 52,896 & 198,360 & \\
\hline 132,240 & $1,401,7+4$ & 79,344 & 79,344 & 449616 & \\
\hline 238,032 & 555,408 & 79,344 & 9,600 & & \\
\hline $.904,256$ & $3,702,720$ & 158,688 & 1,600 & 79.344 & \\
\hline 793,440 & $6,083,040$ & 105,792 & 158,688 & 1,600 & \\
\hline 899,232 & $5,025,120$ & 105,792 & 1,600 & & \\
\hline 290,928 & $1,110,816$ & $2 S, 800$ & 1,600 & 1,600 & \\
\hline 449,616 & $1,586,850$ & $343, \$ 24$ & 290,928 & 1,600 & . \\
\hline 211,584 & 978,576 & 211,584 & 211,584 & 79,344 & \\
\hline 52,896 & 608,304 & 238,032 & 423,168 & 396,720 & \\
\hline 52,896 & 608,304 & 158,658 & $555,40 \mathrm{~s}$ & 740,544 & \\
\hline$\ldots \quad \ldots$ & 238,032 & 370,272 & 132,240 & $2,059,392$ & \\
\hline & 238,032 & 132,240 & $1,454,640$ & 872,784 & \\
\hline & 132,240 & $23 \times, 032$ & 608,304 & $2,115,840$ & \\
\hline$\ldots$. & $+76,064$ & 48,000 & 502,512 & $2,115,840$ & \\
\hline 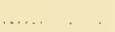 & 185,136 & 6,400 & 264,480 & $2,062,044$ & \\
\hline & $264,4 \$ 0$ & 211,584 & 925,680 & $1,295,952$ & \\
\hline & 290,928 & 290,928 & $423,16 \mathrm{~s}$ & $1,005,024$ & \\
\hline
\end{tabular}


'lable 1.-Organisms l'er Cubic Meter is Plankton of Stockton Chandel in 1913-(Continued)

\begin{tabular}{|c|c|c|c|c|c|c|}
\hline 1913 & $\begin{array}{l}\text { Filinia } \\
\text { egge, free }\end{array}$ & $\begin{array}{l}\text { Filinia } \\
\text { longiseta }\end{array}$ & $\begin{array}{l}\text { Keratella } \\
\text { cochlearis }\end{array}$ & $\begin{array}{l}\text { Kirratella } \\
\text { ekg. attuched }\end{array}$ & $\begin{array}{l}\text { Ficratellla } \\
\text { equ. frow. }\end{array}$ & $\begin{array}{l}\text { Keratella } \\
\text { male }\end{array}$ \\
\hline+20 & (i) 15,304 & $5 \$ 1, \$ 56$ & $21], 561$ & 423,168 & $1,9: 30, \pi(1) 1$ & \\
\hline $4: 30$ & & $2(i, 1,1 \times()$ & & $47(0,0), 4$ & $1,53: 9,9 \times 1$ & \\
\hline 5) 3 & S1!nstis & 370.272 & 1,600 & 5012,512 & $1,243,05, i$ & \\
\hline $5 / 7$ & SI!MBNS & $1,1330,704$ & 105,792 & $1,\left(1005,\left(10^{\circ} \cdot 1\right.\right.$ & $2,0336,-196$ & \\
\hline $5 / 11$ & $5(1) 2,512$ & $(125,125$ & 52,596 & \$1!, & $7(13,+10$ & \\
\hline 5) 1.1 & $105,-192$ & $1,639,7-66$ & & 370,272 & $470,06.1$ & \\
\hline 517 & 211,584 & $1,0.57,1,20$ & 3,200 & 3,200 & 317,376 & \\
\hline $5 / 21$ & 561,560 & IXN, ITS & $\ldots \ldots$ & 15ล,6אל & 476.0044 & \\
\hline $5 / 21$ & 370,272 & 6.100 & & & $476,06.1$ & \\
\hline $5-7$ & -1 & 15S, fis & 6,400 & $105.79^{\circ 2}$ & $211,5 \mathrm{~K}$ & 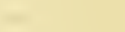 \\
\hline $5 / 31$ & .. & $25,6(0)$ & & 3,200 & 476,$01 ; 4$ & \\
\hline $6 / 3$ & 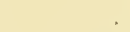 & $211,5 \times 1$ & 3,200 & $(33.1,752$ & $1,322,1000$ & \\
\hline 67 & & 51,2000 & 6,400 & 105,792 & 370,272 & \\
\hline 611 & & $(i, 400)$ & 3,200 & 105,792 & 3,2000 & \\
\hline $6 / 16$ & $10,5,79)^{2}$ & 35.400 & 19,200 & 15S.GSE & 204.150 & 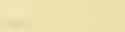 \\
\hline 618 & 3,200 & 51,200 & 154,6 ibs & $+76,064$ & $52 x, 910$ & \\
\hline $6 / 21$ & 155,658 & 211,554 & 6,400 & 211.58 & $1,5 \times 6,850$ & \\
\hline 6.25 & 3,2001 & 423,165 & $211,5,54$ & $1,533,6,6 \mathrm{St}$ & $1,533,944$ & 15 S.6S \\
\hline $6 / 25$ & 105,792 & $1,110,516$ & 317,376 & $1,957,152$ & $1,4 \leqslant 1,0 \leqslant x$ & \\
\hline $7 \quad 3$ & $1.5,6,648$ & 261,450 & 214,480 & $317.37 t$ & 3.200 & 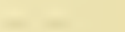 \\
\hline $7 / 5$ & 370,272 & $1,375,296$ & $703,4 \cdot 10$ & 211,551 & 476,0 (i) & \\
\hline $7 / 9$ & 476,0164 & 12,400 & 211,594 & 3,200 & 211,554 & \\
\hline $7 / 12$ & 370.272 & 105,7912 & 423,168 & 3,200 & 687,645 & \\
\hline 716 & & 25,600 & 12,800 & 105,792 & & \\
\hline $7: 19$ & 105,792 & 6.400 & 32,000 & $211.5 \mathrm{S4}$ & $105,79.2$ & \\
\hline $7 / 23$ & 105,792 & $=$ & $38,-100$ & 211,554 & & \\
\hline $7 / 26$ & 211,544 & & 6.400 & 264,450 & & 3,200 \\
\hline $5 / 30$ & $1.51,685$ & $\ldots$ & 12,800 & $105,7 ! 12$ & $3,20(1)$ & \\
\hline S/ 2 & & & & 15, & 105.792 & \\
\hline $8 / 6$ & 3.200 & . & ; & 3,200 & & \\
\hline $8 \quad 9$ & 264,480 & & ... & 105,792 & $26.1,4 \times 0$ & \\
\hline$S / 13$ & $42 \%, 168$ & & & 105,792 & 3,200 & \\
\hline $8 / 15$ & 370,272 & .. & & 3,200 & 3,200 & \\
\hline$\$ 20$ & 476,064 & . & & & 3,200 & \\
\hline $8 / 23$ & 158, (jos & & & 317,376 & .. & \\
\hline 827 & $158,6 \mathrm{TS}$ & & & 3.200 & & \\
\hline $8 / 31$ & 264,180 & . & & 3,200 & & \\
\hline $9 / 2$ & 105,792 & .. & 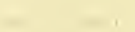 & 12,090 & $\ldots$ & .. \\
\hline $51 / 6$ & 3,200 & . & & $105,7\left(y^{2}\right)$ & 3,200 & \\
\hline 99 & 3,200 & & & $3,2(30)$ & & \\
\hline (9) 13 & 3,200 & & & 423,165 & ..... & \\
\hline $9 / 17$ & 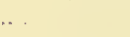 & & 6,400 & 3,200 & $\ldots$ & \\
\hline !) $/ 20$ & & 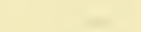 & & 12,800 & ...... & .. \\
\hline 924 & 52.596 & .. & & 52,596 & ...... & \\
\hline 9127 & 52,596 & & & 370.272 & $\ldots$ & \\
\hline $10 / 1$ & 52,696 &.. & 6,400 & 634,752 & . & \\
\hline $10 / 4$ & 105,792 & & ... & 793.440 & & \\
\hline $10 / \mathrm{s}$ & .. & . & 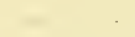 & $1,798,161$ & 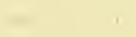 & . \\
\hline $10 / 11$ & & & & $1,216.60 \mathrm{~s}$ & & ... \\
\hline 1015 & 211.554 & & 52,896 & $1,216,60 \mathrm{~S}$ & & \\
\hline $10 \quad 15$ & 52,896 & & 1 iss,6ss & 423,145 & & \\
\hline $10 \div 22$ & 52,696 & .. & 264,450 & 634.752 & 370,272 & \\
\hline $10 / 26$ & & & 528,960 & $123,16 \mathrm{~S}$ & $158,68 \mathrm{~S}$ & 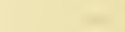 \\
\hline $10 / 29$ & $158,6 \mathrm{NS}$ & $\cdots$ & 423,165 & $476,040$. & 158, (tosi & \\
\hline $11 / 1$ & $311,5 \mathrm{~S} 4$ & ", & 105,792 & 6.400 & $1(15,79) 2$ & \\
\hline $11 / 5$ & 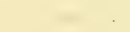 & & 211,584 & 6,400 & & \\
\hline $11 \mathrm{~s}$ & & & 89.600 & 25.600 & & \\
\hline 1112 & & . & 132,210 & $52, \mathrm{~N} 996$ & 79,314 & \\
\hline 1115 & $10,5,792$ & & 51,200 & 12,500 & i, 561,5 & \\
\hline 11,19 & 132,240 & & 52,896 & $2 \times, 800$ & 714,096 & \\
\hline
\end{tabular}


Table 1.-Organisms Per Cubic Meter in Plankton of StockTon ChanNel IN 1913-(Continued)

1913
$11 / 22$
$11 / 26$
$11 / 30$
$12 / 3$
$12 / 6$
$12 / 10$
1214
$12 / 17$
$12 / 20$
$12 / 24$
$12 / 27$
$12 / 31$

\section{3}

$1 / 5$

$1 / 8$

$1 / 12$

$1 / 15$

$1 / 19$

$1 / 22$

$1 / 26$

$1 / 29$

$2 / 2$

$2 /$

$2 / 12$

215

2/19

$2 / 23$

$2 / 26$

$3 / 1$

$3 / 5$

$3 / 8$

$3 / 12$

$3 / 15$

$3 / 19$

$3 / 23$

$3 / 26$

$3 / 29$

$4 / 2$

$+5$

4/ 9

$+/ 13$

$1 / 16$

$\pm / 19$

$4 / 23$

$4 / 26$

$+/ 30$

$5 / 3$

$5 / 7$

$5 / 11$

$5 / 14$

$5 / 17$

$5 / 21$

$5 / 24$

$5 / 27$

$5 / 31$

$6 / 3$

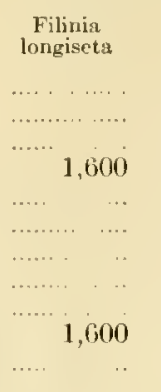

Keratella
cochlearis
48,000
51,200
52,890
57,600
3,200
1,600
800
1,600
1,600

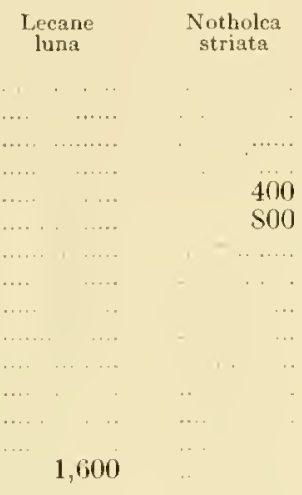

1,600

41,600

925,680

317,376

343,824

952,128

740,544

$1,0 \mathrm{~S} 4,36 \mathrm{~s}$

$2,1+2.288$

$3,385,344$

$4,205,232$

$3,041,520$

925,680

$1,719,120$

$4,205,232$

$2,195,181$

$2,459,664$

$2,010,048$

$1,613,32 \mathrm{~S}$

$3,067,968$

$5,104,464$

$2.909,280$

$1,005,024$

$1,322,400$

317,376

740,544

846,336

$1,533,981$

Keratella
egg, attached
22,400
$2,, 800$
19,200
52,896
52,896
6,400
72,732
4,000
46,284
13,224
26,448
66,120

Keratella egg, free

423,168

79,344

105,792

52,896

52,896

46,284

1,600

19,836

$19, \$ 36$

39,672

79,344

Notommata Polyarthra aurita

trigla

Polyarthra trigla egg. attaclied

6,400

400

1,200

39,672

800

19,836

60,120

1,600

19,836

105,792

39,672

4,800

11.400

105.792

28,800

70,344

370,272

$581, \$ 56$

158,688

238,032

$132,2 \cdot 10$

25,600

79,314

105,792

$15 \mathrm{~S}, 6 \mathrm{SS}$

396,720

$1,110,816$

$1,560,432$

766,992

$1,772,016$

370,272

$2,641,800$

$2,062,911$

$1,216,608$

$3,147,312$

$2,724,144$

528,960

264,480

57,600

38,400

19,200

19,200

105,792 female

Tieratella

male
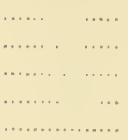

(n)............$$
\text { . .... }
$$

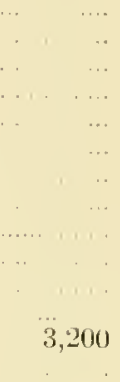

$$
\begin{aligned}
& 3,200 \\
& 52,896 \\
& 1,600
\end{aligned}
$$




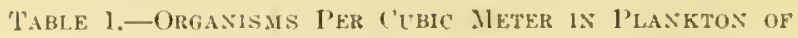
STоскто: ("IANNEL Is 1913-(Continued)

\begin{tabular}{|c|c|c|c|c|c|c|}
\hline 1913 & $\begin{array}{l}\text { Keratella } \\
\text { quadrata }\end{array}$ & $\begin{array}{l}\text { Leeane } \\
\text { lunn }\end{array}$ & $\begin{array}{l}\text { Notholea } \\
\text { striata }\end{array}$ & $\begin{array}{l}\text { Notomuata } \\
\text { aurita }\end{array}$ & $\begin{array}{l}\text { Polyarthrs } \\
\text { trigla }\end{array}$ & $\begin{array}{l}\text { Polyorthra tritala } \\
\text { cke. attached } \\
\text { female }\end{array}$ \\
\hline 6 7 & 816,330 & & & & $6,400)$ & \\
\hline (i) 11 & $52+960$ & & & .. & 19,200 & \\
\hline (i) 16 & 317.376 & 6,400 & & 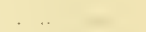 & 51,200 & 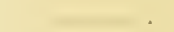 \\
\hline (i) is & 740,544 & & & . & 317,376 & \\
\hline bi/21 & $1.795,464$ & . & & .. & 476,064 & \\
\hline 1325 & $6,030,141$ & & & . & $1,005,021$ & \\
\hline 628 & $7,035,16 \mathrm{~s}$ & & $\ldots \therefore$ & & $6897,64.5$ & \\
\hline $7: 3$ & $1,798,464$ & . & 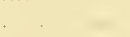 & .. & 19,200 & 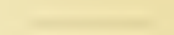 \\
\hline $7 / 5$ & $1,163,712$ & & . & 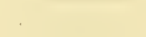 & 158,658 & \\
\hline $7 ! 9$ & 264,480 & & & .. & $\$ 99,232$ & 3,200 \\
\hline $7 / 12$ & $1,322,100$ & & & . & $1,692,672$ & 3,200 \\
\hline 716 & 052,128 & $\cdots$ & & & 687,645 & \\
\hline $7 / 19$ & 846,336 & .. & . & , & 158,658 & 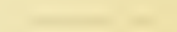 \\
\hline $7 / 23$ & $1,692,672$ & & & & 134,400 & 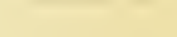 \\
\hline $7 / 26$ & $2,062,944$ & & & & 634,752 & \\
\hline 730 & $2,010,018$ & & & $\ldots \ldots$ & 952,125 & \\
\hline$\therefore / 2$ & $1,110,816$ & $\ldots$ & & .. & 793,440 & 3,200 \\
\hline $8 / 6$ & $689,6.18$ & $\ldots \ldots$ & 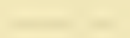 & 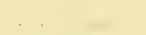 & 657,645 & \\
\hline S 9 & 740,544 & & & & $2,327,124$ & \\
\hline 8 13 & 899,232 & ... & & & 952,128 & \\
\hline 815 & 423,168 & $\cdots$ & & & $1,057,920$ & \\
\hline$S: 00$ & $1,163,712$ & & & & $1,904,250$ & \\
\hline 823 & $1,904,256$ & 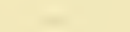 & $(i, 400$ & & $1,428,192$ & \\
\hline 827 & 528,960 & & & & 952,128 & 12,800 \\
\hline $8 / 31$ & 581,856 & .. & & & $5 \$ 1,556$ & \\
\hline 92 & 158,688 & $=1$ & & & 952,125 & 3,200 \\
\hline $9 / 6$ & 317,376 & & & & $264,4 \$ 0$ & \\
\hline $9 / 9$ & 899,232 & $\ldots$ & . & & 846,336 & 105,792 \\
\hline ) 13 & $1,957,152$ & & & & $1,057,920$ & 105,792 \\
\hline $\begin{array}{ll}9 & 17\end{array}$ & $1,005,024$ & & & & 264,450 & \\
\hline $9 / 20$ & 89,600 & & & & 899,232 & \\
\hline $9 / 24$ & $8+6,336$ & & & & 581,856 & 52,896 \\
\hline 927 & $1,322,400$ & $\ldots .$. & & & 740,544 & 52,596 \\
\hline 10) 1 & $1,533,984$ & 列 & .. & & 476,064 & \\
\hline $10 / 4$ & $2,062,911$ & & & & $5 S 1,856$ & \\
\hline $10 / 8$ & $5,395,392$ & $\ldots$ & & 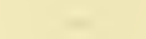 & 634,752 & 52,590 \\
\hline 10)/11 & $4,866,432$ & & .. & & 634,752 & 105,792 \\
\hline 1015 & $3,914,304$ & & & & 634,752 & - \\
\hline $101 \mathrm{~s}$ & $2,010,048$ & & & & 740,544 & \\
\hline $10 / 22$ & $2,697,696$ & & & & 423,165 & \\
\hline $10 / 26$ & 952,128 & & & & 44,800 & . \\
\hline $10 \quad 29$ & $1,269,504$ & 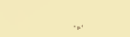 & & & 32,000 & \\
\hline $11 / 1$ & 581,656 & & & & 158.698 & \\
\hline $11 / 5$ & 64,000 & & & & & \\
\hline $\begin{array}{lll}11 & 8 \\
11 & 12\end{array}$ & 19,200 & & & & 52.896 & \\
\hline $\begin{array}{l}11 / 12 \\
11\end{array}$ & 12.500 & & & & $(3,400$ & 19.200 \\
\hline $11 / 19$ & 25,600 & & & & 476,064 & $201,4 \times 0$ \\
\hline 112.2 & 12,500 & & & & 158,658 & 19,200 \\
\hline $11 / 26$ & 25,600 & - & & & $1 \times 5.136$ & 108,900 \\
\hline $11 / 30$ & 38,400 & & & & 528,960 & 132,240 \\
\hline $12 / 3$ & $79,3.44$ & & & & $264,4 \leq 0$ & 28,500 \\
\hline 126 & 35,200 & & & & 449.616 & 52,1996 \\
\hline 1210 & 33,060 & & & & 46,254 & 1,600 \\
\hline 1214 & 132,240 & & & & 495,900 & 64,120 \\
\hline 12.17 & 33,060 & & 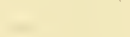 & & $(16,120$ & $13,22.4$ \\
\hline $12 \div 0$ & 92.56 is & & & & 66.120 & 13,2221 \\
\hline $12 / 24$ & 46,284 & & - & & 5,600 & \\
\hline $12 / 27$ & 85,956 & 400 & & & 46,254 & $\Delta()()$ \\
\hline $12 / 31$ & 125,628 & & & & 132,240 & 1,600 \\
\hline
\end{tabular}


Table 1.-Organisms Per Cubic Meter in Plankton of STOckToN (hanNel in 1913-(Contimued)

\begin{tabular}{|c|c|c|c|c|c|c|}
\hline 1913 & $\begin{array}{l}\text { Polyarthra } \\
\text { trigla egg. } \\
\text { attached male }\end{array}$ & $\begin{array}{c}\text { Synchaeta } \\
\text { sp. }\end{array}$ & $\begin{array}{c}\text { Trichocerca } \\
\text { capucina }\end{array}$ & $\begin{array}{c}\text { Trichocerca } \\
\text { iernis }\end{array}$ & $\begin{array}{c}\text { Total } \\
\text { Ploinia }\end{array}$ & $\begin{array}{l}\text { Total Ploima } \\
\text { without eggs }\end{array}$ \\
\hline $1 / 5$ & & & I & ..... & 199,960 & 114,004 \\
\hline $1 / 8$ & & $\cdots$ & - & $\ldots .$. & 265,644 & $15.5,440$ \\
\hline $1 / 12$ & & ......... & .. & & 142,514 & 102,544 \\
\hline $1 / 15$ & ... & $\ldots \ldots, \quad \ldots$ & $\ldots \ldots$ & ........ & $+19,944$ & $258,26.8$ \\
\hline $1 / 19$ & & & $\ldots .$. & ....... $\quad \ldots$ & 221,984 & 130,028 \\
\hline $1 / 22$ & & 800 & $\ldots \ldots$. & ............... & 148,640 & 83,932 \\
\hline $1 / 26$ & $\ldots$ & & $\ldots \ldots$ & ............... & 530,960 & 301,540 \\
\hline $1 / 29$ & & $\mathrm{~S} 00$ & $\ldots$ & ................. & 827,464 & 567,996 \\
\hline $2 / 2$ & & .. & 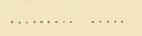 & $\ldots \ldots$ & 696,848 & 403,120 \\
\hline $2 / 5$ & $\ldots$ & ... & $\ldots$ & ........ & $\mathrm{S} 07,840$ & 364,836 \\
\hline $2 / 8$ & & & .... & $\ldots . .$. & $1,667,024$ & $900,0: 32$ \\
\hline $2 / 12$ & & $\ldots$ & . & $\ldots .$. & $3,733,661$ & $1,985,200$ \\
\hline $2 / 15$ & & & . & & $96,8 \pm 8$ & 60,000 \\
\hline $2 / 19$ & & & & ............ & 990,528 & 560,960 \\
\hline $2 / 23$ & & 1,600 & . . . & & $4,3 \$ 6,320$ & $2,692,8 \pm 8$ \\
\hline $2 / 26$ & 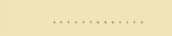 & 3,200 & $\ldots$ & & $4,05 \mathrm{~s}, \mathrm{896}$ & $2,107,392$ \\
\hline $3 / 1$ & $\ldots$ & 3.200 & ....... & . & $1,924,960$ & $1,052,672$ \\
\hline $3 / 5$ & & 6,100 & $\ldots$ & $\ldots$ & $11,674,672$ & $5,722,272$ \\
\hline $3 / 8$ & & & .. & 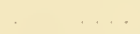 & $11,317,818$ & $8,8.56,5,44$ \\
\hline $3 / 12$ & $\cdots$ & 6,400 & $\ldots$ & & $13,336,096$ & $9,577,280$ \\
\hline $3 / 15$ & & 6,400 & $\therefore$ & - & $2,468,480$ & $1,8 \cap 8,112$ \\
\hline $3 / 19$ & & & $\ldots$ & & $4,6,63,600$ & $3,311,55^{2}$ \\
\hline $3 / 23$ & & & $\ldots$ & . & $3,587,984$ & $2,618,720$ \\
\hline $3 / 26$ & & 9,600 & .. & $\ldots \ldots$ & $4,062,44 \mathrm{~s}$ & $2,390,672$ \\
\hline $3 / 29$ & & 16,000 & & $\ldots \ldots$ & $5,717,172$ & $2,525,552$ \\
\hline $4 / 2$ & & 6,400 & & ..... & $7,860,608$ & $4,598,432$ \\
\hline $4 / 5$ & & 3,200 & & $\ldots$. & $7,887,712$ & $5,398,400$ \\
\hline 49 & & 52.896 & & ... & $7,612,976$ & $4,726,944$ \\
\hline $4 / 13$ & & & 1 & . & $6,18^{2}, 992$ & $3,075,776$ \\
\hline $4 / 16$ & & & . & $\ldots \ldots$ & $5,263,056$ & $2,801,792$ \\
\hline $4 / 19$ & & & .. & $\ldots$. & $9,316,752$ & $6,526,912$ \\
\hline $4 / 23$ & & $\because$ & & $\ldots \ldots$ & $5,025,776$ & $3,211,312$ \\
\hline $4 / 26$ & & 1,600 & & ..... & $9,573,136$ & $6,017,904$ \\
\hline $4 / 30$ & & 3.200 & & & $8,009,55^{2}$ & $4,508,062$ \\
\hline $5 / 3$ & & 6,400 & & & $6,757,440$ & $3,504,336$ \\
\hline $5 / 7$ & & 52,896 & & & $13,93^{\prime}, 448$ & $8,775,0,5$, \\
\hline $5 / 11$ & & 1,600 & 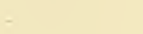 & & $13,163,00 \mathrm{~s}$ & $9,936,352$ \\
\hline $5 / 14$ & & & ' & $\ldots$ & $8,664,960$ & $6,701,405$ \\
\hline $5 / 17$ & & 44,800 & - & ....... & $5,911,168$ & $3,845,024$ \\
\hline $5 / 21$ & & 317,376 & 1 & & $5,143,968$ & $3,504,192$ \\
\hline $5 / 24$ & (............. & 70.400 & & & $2,5.56,12 \mathrm{~S}$ & $1,180,832$ \\
\hline $5 / 27$ & & \pm 4.800 & & 12,800 & $2,786,620$ & $1,786,492$ \\
\hline $5 / 31$ & 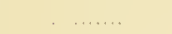 & 12,800 & & & $3,194,464$ & $2,186,240$ \\
\hline $6 / 3$ & & 317,376 & & & $7,483,936$ & $1,359,172$ \\
\hline $6 / 7$ & & 32,000 & 6,400 & & $1,018,208$ & $2,854,496$ \\
\hline $6 / 11$ & $\cdots$ & & $r^{2}$ & & $2,5,50,672$ & $1,842,304$ \\
\hline $6 / 16$ & $\ldots \cdot$ & 3,200 & & & $3,464,960$ & $1, \pm 66,400$ \\
\hline $6 / 18$ & & 211,584 & & & $4,797,336$ & $3,0,5,064$ \\
\hline $6 / 21$ & & 317,376 & & & $7,916,704$ & $4,835,936$ \\
\hline $6 / 25$ & $\ldots$ & $2,641,800$ & 6,400 & & $18,537,504$ & $13,717,568$ \\
\hline $6 / 28$ & $\ldots .$. & $1,745,56 \mathrm{~S}$ & 6,400 & & $17,6+17,6 \mathrm{SO} 0$ & $12,3.58,0,80$ \\
\hline $7 / 3$ & & 32,000 & .. & 6,400 & $4,125,504$ & $3,219,872$ \\
\hline $7 / 5$ & & 528,960 & .. & 19,200 & $7,111,068$ & $4,731,648$ \\
\hline $7 / 9$ & & 12,800 & . & 211,584 & $5,127,720$ & $2,8 \pm 3,592$ \\
\hline $7 / 12$ & & 3,200 & & 317,376 & $8,578,0,56$ & $5,979,752$ \\
\hline $7 / 16$ & & 0,400 & & 6,400 & 4.348 .576 & $3,026,176$ \\
\hline $7 / 19$ & & & & 6,400 & $3,390,04 \mathrm{~s}$ & $2,219,936$ \\
\hline $7 / 23$ & & 6,100 & & & $3,428,256$ & $2,20 \mathrm{~S}, 14 \mathrm{~S}$ \\
\hline $7 / 26$ & & & & 12,800 & $5,972,352$ & $4,649,952$ \\
\hline $7 / 30$ & & .... & - & 19,200 & $4,255,784$ & $3,552,136$ \\
\hline s/ 2 & …, & . & & 19,200 & $3,639,032$ & $2,683,704$ \\
\hline
\end{tabular}


'Table 1.-Organisms 1'for ('vibic Meter in l'lanktod of STockToN ('HANNEL IN 1913 -(Continued)

\begin{tabular}{|c|c|c|c|c|c|c|}
\hline 1913 & $\begin{array}{l}\text { Polyarthra } \\
\text { trigla cke. } \\
\text { attached nale }\end{array}$ & $\begin{array}{c}\text { Syncluseta } \\
\text { sp. }\end{array}$ & $\begin{array}{l}\text { Trichocerca } \\
\text { cupucina }\end{array}$ & $\begin{array}{c}\text { Triehocerca } \\
\text { ierais }\end{array}$ & $\begin{array}{l}\text { Total } \\
\text { l'loina }\end{array}$ & $\begin{array}{l}\text { Total Ploima } \\
\text { without egess }\end{array}$ \\
\hline $8 / 6$ & . & & & 158,688 & $2,5,51, \mathrm{~s}(0,5$ & $1,9017,1.56$ \\
\hline i) & .. & 12,500 & .. & $10.5,792$ & $(j, 02 \geq 9,196 j$ & $3,966,252$ \\
\hline$\times 13$ & .. & & ...... & 19,200 & $13,0,12,8-15$ & $4,116,0996$ \\
\hline $8 / 15$ & .. & & ..... & $105,79)^{2}$ & $5,3332,701$ & $3,369,152$ \\
\hline$\times / 20$ & $\ldots$ & (1) & ....... & & 0,$20 ;, 40 \mathrm{~s}$ & $5,257,904$ \\
\hline 823 & . & $(\mathrm{j}, 100$ & $\ldots .$. & 3,200 & $(i, 716,096$ & $4,50,4.736$ \\
\hline$\times 27$ & 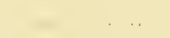 & . & $\ldots \ldots$ & & $4,-191,291 ;$ & $2,4: 35,5,520$ \\
\hline $5 / 31$ & & 6.100 & - $\quad \ldots$. & 12,500 & $2,6356,100$ & $1,625,2,50$ \\
\hline 912 & . & & $\ldots$ & $0, \pm 00$ & $2,(j ; 30,112$ & $1,714,180$ \\
\hline $11 / 6$ & & $(j, 400$ & ... & . ..... & $2,5,51,80 \mathrm{~s}$ & $1,170,112$ \\
\hline !) & & .. & $\cdots$. & & $(j, 547,501\}$ & $4,403,16.9$ \\
\hline !) $1: 3$ & 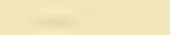 & . & $\ldots$ & $6,100)$ & $7,+19,7.14$ & $5,3.53,600$ \\
\hline 9) 17 & & . & $\ldots$ & & $2,736,096$ & $1.992,352$ \\
\hline $9 / 20$ & & .. & $\ldots$ & & $1,786,976$ & $1,0 \times 0,129$ \\
\hline 9) 24 & & - & $\ldots$. & 19,200 & $2, \$ 12,200$ & $2,06.5,256$ \\
\hline (1) 27 & & & $\ldots$ & 52,896 & $5,342,4 ! 96$ & $3,-191,136$ \\
\hline 10 1 & & $52,8,96$ & . & 6,100 & $4,699,618$ & $3,215,560$ \\
\hline $10 / 1$ & & $\ldots \ldots$ & & $105,79^{4}$ & $5,744,86 \mathrm{is}$ & $3,470,340$ \\
\hline $10 / 8$ & . & .. & 6.400 & 6,400 & $10,114,110$ & $7,105,568$ \\
\hline 1011 & & & $\ldots$ & 12,800 & $8,515,2.56$ & $6,115,(1) 40$ \\
\hline 1015 & $\ldots$. & 19,200 & $\ldots$ & 52,596 & $7,585,0302$ & $5,317,200$ \\
\hline $10 / 8$ & $\ldots$ & $15 s, 688$ & . & . & $4,9560,0132$ & $3,17+944$ \\
\hline 10122 & ... & 105,792 & & & $5,980,266$ & $3,963,818$ \\
\hline $10 / 26$ & & $(3,-10)$ & & & $2,436,221$ & $1,5,59,5 \mathrm{~s}$ \\
\hline $10 / 29$ & & 44,500 & $\ldots \quad \ldots$ & 52,596 & $3,209,776$ & $2,0 \times 6,160$ \\
\hline $11 / 1$ & .. & & ......... & $\ldots \ldots$ & $1,460,192$ & $1,021,221$ \\
\hline $11 / 5$ & .. & & $\ldots \ldots \ldots$ & $\ldots$ & 400,576 & $2 \times 5,3 \times 4$ \\
\hline $11 / 8$ & 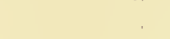 & 6,100 & . ....... & & 352,351 & 165,096 \\
\hline 11.12 & .. & 105,792 & $\cdots$ & 3,200 & 451,96 & 247,632 \\
\hline $11 / 15$ & .. & 105,792 & ................ & $\ldots \ldots \ldots$ & $1,018,136$ & 272,858 \\
\hline 1119 & . & 52,896 & n............. & ........... & $2,242,896$ & 802,818 \\
\hline $11 / 22$ & & 132,240 & ........ & 的 & $1,972,960$ & $-14,7.52$ \\
\hline $11 / 26$ & 25,800 & 12,800 & ................... & $\ldots$ & $95.5,600$ & 496,672 \\
\hline $11 / 30$ & $(j, 400$ & 79,314 & $\ldots \ldots \ldots \ldots \ldots$ & .......... & $1,618,3336 j$ & $75: 3,296$ \\
\hline 123 & $\ldots \ldots$ & 79,344 & .......... & & $1,121,872$ & 475,168 \\
\hline $12 / 6$ & $\ldots \ldots \ldots$ & $.52,896$ & .................. & ... & $853,08 \mathrm{~s}$ & 535,712 \\
\hline $12 / 10$ & & 33,060 & n............. & ......... & $171,0 \mathrm{Sis}$ & 114,804 \\
\hline 1214 & 100 & 92,565 & ......... & & $1,048,6 ! 6$ & $72: 3,508$ \\
\hline $12 / 17$ & ........ & 39,672 & $\ldots \ldots$ & $\ldots$ & 192,736 & 140,852 \\
\hline $12 / 20$ & …......... & 79,341 & .............. & ........... & 384,696 & 239,232 \\
\hline $12 / 24$ & ............... & $39,6-2$ & $\ldots \ldots \ldots \ldots \ldots$ & ....... & 155,864 & 94,756 \\
\hline $12 / 27$ & .................. & 33,060 & $\ldots \ldots \ldots \ldots$ & ........ & 306,952 & 167,300 \\
\hline $12 / 31$ & ................... & 79,344 & ............... & $\ldots, \quad, \cdots$ & $599^{\prime}, 86 \mathrm{~s}^{\prime}$ & 340,012 \\
\hline 1913 & $\begin{array}{c}\text { Total } \\
\text { Rotifera }\end{array}$ & $\begin{array}{c}\text { Bosmina } \\
\text { longirostris }\end{array}$ & $\begin{array}{l}\text { Bosmina } \\
\text { sp. }\end{array}$ & $\begin{array}{l}\text { Sida } \\
\text { sp. }\end{array}$ & $\begin{array}{l}\text { Total } \\
\text { Cladocera }\end{array}$ & $\begin{array}{c}\text { Canthocamptus } \\
\text { sp. }\end{array}$ \\
\hline $1 / 5$ & 315,564 & & ....... & $\ldots$ & & $\cdot \quad \cdots \quad \cdots \cdots$ \\
\hline $1 / 8$ & 500,064 & & n............. & $\ldots \ldots$ & & $\ldots$ \\
\hline $1 / 12$ & 321,065 & & …........... & 400 & 400 & $\begin{array}{lll}\ldots & \ldots & \ldots\end{array}$ \\
\hline $1 / 15$ & 871,560 & (........ & …............ & .......... & .......... & $\ldots$ \\
\hline $1 / 19$ & 949,892 & $\ldots \ldots \ldots$ & …........ & …........... & , $\ldots \ldots \ldots \ldots$ & $\cdots \quad-$ \\
\hline $1 / 22$ & $3+1,776$ & ... & ............... & …....... & …........., & $1, \quad \ldots$ \\
\hline $1 / 26$ & $1,906,156$ & ...... & ….......... & $\ldots \ldots \ldots \ldots \ldots$ & $\ldots \ldots \ldots$ & \\
\hline $1 / 20$ & $2,156,476$ & …............. & $\ldots \ldots \ldots \ldots$ & …............. & .......... & $=$ \\
\hline $2 / 2$ & $1,990,776$ & .. & $\ldots \ldots \ldots \ldots \ldots$ & .......... $\ldots$ & 800 & .. \\
\hline $2 / 5$ & $2,168,564$ & 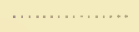 & $\ldots \ldots \quad \ldots \ldots$ & (................. & . $\ldots \ldots$ & $\cdot \cdot$ \\
\hline $2 / 8$ & $2,951,752$ & ......... & $\ldots \ldots \ldots \ldots$ & .............. & . $\quad \ldots, \ldots$ & $\cdots$ \\
\hline $2 / 12$ & $5,6 \cdot 15,200$ & & .............. & ................ & . $\quad \cdots$ & 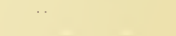 \\
\hline $2 / 15$ & $1,525,692$ & $\ldots \ldots, \ldots \ldots \ldots$ & , $\ldots \ldots \ldots \ldots \ldots, \ldots$ & , $\ldots \ldots \ldots \ldots \ldots$ & b $\cdots$ & $\cdot=$ \\
\hline 219 & $1,300,476$ & ………… & 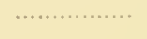 & ....., $\ldots \ldots \ldots$ & $\begin{array}{lll}\ldots & \ldots \ldots\end{array}$ & $\cdot \cdot$ \\
\hline $2 / 23$ & $5,062,3-1+1$ & …, $\ldots \ldots \ldots \ldots$ & 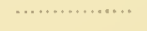 & ............ & $\ldots+\cdots$ & .................. \\
\hline
\end{tabular}


Table 1.-Organisas Per Cubic Mrter in Plankton of Stockton Chaynel in 1913-(Continued)

\begin{tabular}{|c|c|c|c|c|c|c|}
\hline 1913 & $\begin{array}{c}\text { Tolal } \\
\text { Rotifera }\end{array}$ & $\begin{array}{l}\text { Bosmina } \\
\text { longirostris }\end{array}$ & $\begin{array}{c}\text { Bosmina } \\
\text { sp. }\end{array}$ & $\begin{array}{l}\text { Sidla } \\
\text { sp. }\end{array}$ & $\begin{array}{l}\text { Total } \\
\text { Cladocera }\end{array}$ & $\begin{array}{c}\text { Canthocamptus } \\
\text { sp. }\end{array}$ \\
\hline $2 / 26$ & $5,123,216$ & .. . & ... & $\ldots \cdot$ & .. & ...... \\
\hline $3 / 1$ & $3,650,128$ &.. & $\cdots$ & $\cdots \cdots$ & .. & .... \\
\hline $3 / 5$ & $13,367,314$ & ... & .... & 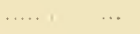 & ... & ....... \\
\hline $3 / 5$ & $12,086,440$ & $\ldots$ & $\ldots \ldots \ldots$ & ....... . & ..... & ...... \\
\hline $3 / 12$ & $16,017,648$ & .... & $\begin{array}{llll} & . . & \ldots & \ldots\end{array}$ & $\cdots+\cdots$ & 3900 & \\
\hline $3 / 15$ & $\begin{array}{l}3,744,384 \\
5,39+096\end{array}$ & $\cdots \cdot$ & & ....... & 3,200 & \\
\hline $\begin{array}{l}3 / 19 \\
3 / 23\end{array}$ & $\begin{array}{l}5,394,096 \\
4,396,224\end{array}$ & $\begin{array}{l}\ldots \\
\ldots \ldots\end{array}$ & & $\cdots$ & & 3,200 \\
\hline $3 / 26$ & $4,406,272$ & $\ldots$ & $\ldots \ldots$ & ........ & ..... . & $\ldots \ldots$ \\
\hline $3 / 29$ & $6,305,728$ & $\ldots \ldots$ & $\ldots$ & .. & $\ldots+\ldots+\ldots$ & ....... \\
\hline $1 / 2$ & $7,943,152$ & ....... & $\ldots \ldots \ldots$ & , n..... $\quad \ldots$ & ................ & $\cdots$ \\
\hline $4 / 5$ & $S, 178,640$ & $\ldots$ & .......... & ……. & ............... & 3,200 \\
\hline $1 / 9$ & \$,062,592 & $\ldots$ & ......... & , $\ldots \ldots \ldots \ldots, \ldots$ & , $\ldots \ldots \ldots$ & \\
\hline $4 / 13$ & $6,318,432$ &.. & …...... & $\ldots \ldots \ldots$ & ................ & ....... \\
\hline+16 & $5,449,792$ & $\cdots$ & ..... & …..., $\ldots$, & $\ldots \ldots$ & $\ldots \ldots$ \\
\hline 419 & $9,422,5+4$ & $\ldots$ & . $\cdots$ & - $\cdots \cdots+\cdots$ & ........ & . \\
\hline $4 / 23$ & $5,106,-20$ & $\ldots$ & $\ldots \ldots+\ldots$ & $\ldots \ldots \ldots, \ldots$ & ........ & $\ldots \ldots \ldots$ \\
\hline $4 / 26$ & $9,577,936$ & $\ldots$ & ............... & n..... $\quad \cdots$ & ........ & ............... \\
\hline $4 / 30$ & $8,168,240$ & .. & … $\quad \ldots$ & n............. & ....... & …...... \\
\hline $5 / 3$ & $6,995,472$ & . & $\ldots \ldots \ldots \ldots$ & …........ & ….... & $\ldots \ldots \ldots, \ldots$ \\
\hline $5 / 7$ & $14,039,840$ & . & …...... & $\ldots \ldots \ldots \ldots$ & . . ......... & .............. \\
\hline $5 / 11$ & $13,164,608$ & 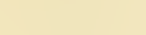 & . $\quad \ldots \ldots \ldots$ & .... & $\ldots \ldots$ & $\ldots \ldots \ldots \ldots$ \\
\hline $.5 / 14$ & $8,677,760$ & .. & & & & \\
\hline $5 / 17$ & $6,493,024$ & $1 .$. & 3,200 & $\ldots \ldots$ & 3,200 & \\
\hline $5 / 21$ & $5,411,618$ & $\cdots$ & 6400 & . & 6.400 & \\
\hline $5 / 21$ & $\begin{array}{l}2,8+6,205 \\
2-703,00\end{array}$ & $\begin{array}{l}\cdots \\
\ldots\end{array}$ & .. & & & . \\
\hline $\begin{array}{l}5.27 \\
5 / 31\end{array}$ & $\begin{array}{l}2,993,020 \\
3,207,264\end{array}$ & . & $\ldots$ & & & \\
\hline 6. 3 & 7.493 .536 & ..... & $\ldots \ldots$ & 6,100 & 6,100 & .. \\
\hline $6 / 7$ & $1,024,008$ & . & $\ldots \ldots \ldots$ & 6,400 & 6,400 & $\ldots$ \\
\hline $6 / 11$ & $2,559,872$ & $\ldots \ldots$ & $\ldots \ldots \ldots$ & 6,400 & 6,400 & \\
\hline $6 / 16$ & $3,477,760$ & .. & ...... & $\ldots \ldots$ & $\ldots$ & ............. \\
\hline $6 / 18$ & $4,819,730$ & . & $\ldots \ldots$ & $\ldots$ & & \\
\hline 621 & $7,942,304$ & ..... & , n...... & 6,400 & 6,100 & \\
\hline $6 / 25$ & $18,702,592$ & ...... & $\ldots \ldots$. & 6,400 & $f, 400$ & \\
\hline $6 / 28$ & $18,070,648$ & $\ldots$ & $\ldots \quad, \ldots \ldots$ & $+x$ & & 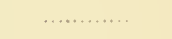 \\
\hline $7 / 3$ & $4,290,592$ & ...... & … & & & \\
\hline $7 / 5$ & $7,289,856$ & . & $\ldots$ & 6,400 & 6,400 & \\
\hline $7 / 9$ & $5,137,320$ & .... & ... & & & \\
\hline $7 / 12$ & $8,792,840$ & $\ldots .$. & $\ldots+\cdots$ & 6,100 & 6,400 & \\
\hline $\begin{array}{l}7 / 16 \\
-19\end{array}$ & $\begin{array}{l}4,386,976 \\
3,548,736\end{array}$ & $\ldots$ & & 12,500 & 12,500 & \\
\hline $\begin{array}{l}7 \quad 19 \\
7 / 23\end{array}$ & $\begin{array}{l}3,548,736 \\
3,745,632\end{array}$ & .. & ........ & & & \\
\hline $7 / 26$ & $6,010,7.52$ & & & 6,400 & 6,400 & \\
\hline $7 / 30$ & $4,271,784$ & 6,400 & 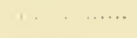 & & 6,400 & \\
\hline $8 / 2$ & $3,6 \mathrm{SO}, 632$ & 6,400 & $\cdots$ & 6,400 & 12,800 & \\
\hline $8 / 6$ & $2,801,792$ & ..... & $\ldots .$. & & & \\
\hline $8 / 9$ & $6,405,868$ & ….... & $\ldots$ & 6,400 & 6,400 & \\
\hline $8 / 13$ & $6,185,040$ & ........ & $\ldots$ & . $\quad \cdots$ & $1+\ldots$ & \\
\hline $8 / 15$ & $5,867,680$ & 3200 & .. & 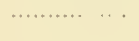 & 3.200 & \\
\hline $8 / 20$ & $9,467,192$ & 3,200 & $\begin{array}{c}\ldots \\
\cdots\end{array} \quad \ldots \ldots$ & 19.200 & $\begin{array}{r}3,200 \\
19,200\end{array}$ & 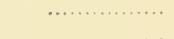 \\
\hline $8 / 23$ & $6,757,696$ & $\cdots$ & $\ldots$ & $\begin{array}{r}19,200 \\
6,400\end{array}$ & 6,400 & , $\ldots \ldots+\ldots \ldots \ldots$ \\
\hline $8 / 27$ & $4,787,776$ & $\cdots$ & $\ldots \ldots$ & $\begin{array}{l}0,400 \\
6,400\end{array}$ & 6.100 & n............. \\
\hline$S / 31$ & $2,792,192$ & $\begin{array}{l}\cdots \\
\ldots \ldots\end{array}$ & $\ldots \ldots$ & $\begin{array}{r}6,100 \\
25,600\end{array}$ & 25.600 & $\ldots \ldots \ldots \ldots \ldots$ \\
\hline $9 / 2$ & $2,652,512$ & & $\ldots$ & & & \\
\hline $9 / 6$ & $\begin{array}{l}2,644,000 \\
6,600,704\end{array}$ & 6,400 & & 6,400 & 12,800 & \\
\hline $\begin{array}{l}9 / 9 \\
9 / 13\end{array}$ & $\begin{array}{l}6,600,704 \\
7,635,336\end{array}$ & $\ldots \ldots$ & ............. & & & \\
\hline 17 & $\begin{array}{l}7,635,336 \\
2,736,096\end{array}$ & 6,400 & …........... & 12,800 & 19,200 & \\
\hline 120 & $2,017,760$ & c 100 & …........... & & & \\
\hline 124 & $2,831,400$ & 6,100 & …........ & 12,800 & 19,200 & \\
\hline
\end{tabular}


Table 1,-Organisms Per Cubic Meter ta Planktos of Stockтos (Hassel, Is 1913-(Continued)

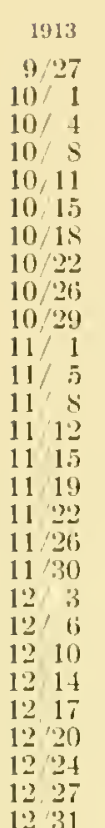

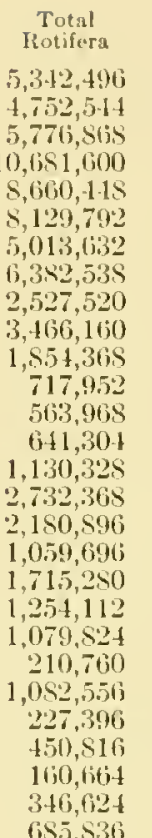

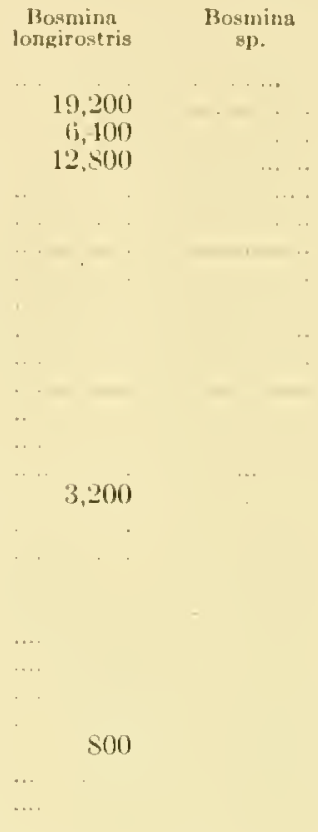

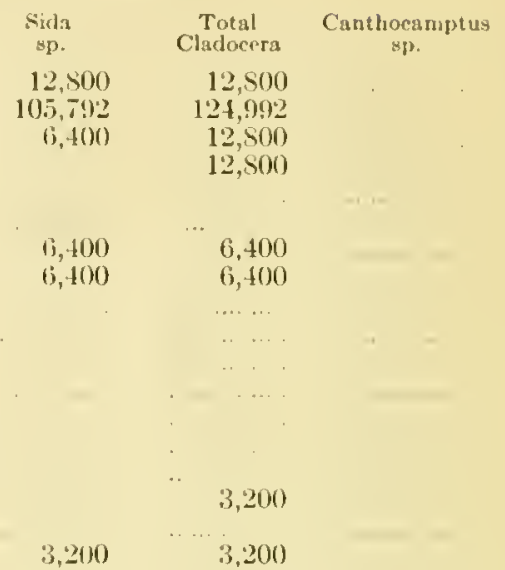

1913

Cycloys sp.

Diaptomus

6,612

$1 /$

112

$1 / 15$

1,19

122

126

1.29

22

$2: 5$

$2 / 8$

212

215

2. 19

$2 \div 3$

2

$3 / 1$

$3 / 5$

$3 / 5$

312

3,15

319

$3 / 23$

3.20

$3 / 29$

$+2$

15

19

$11: 3$
800

2,400

2,000

1,600

1,600

2,400

1,600

1,600

1,600

1,600

3.200

3,200

6. 400

3,200

9,600

19,200

9.600

3,200

1.) $\mathrm{S00}$

12,800

9,600 sp.

Nauplius

sp.

800

$1,600)$

2,400

1,2001

800

2,400

$8(1) 0$

2.400

1,600

12,800

12,800

$1(i, 0)(0)$

3,200

9) 4000

1,600

12,500
9,600

32,000

105,792
Total

Copepoda

7,412

$1,600)$

3.200

3,600

2,000

$1,(i 0)$

2,400

4,500

2.400

4,000

3,200

$1,600)$

3,200

3,200

12,8000

16,000

25,600

3.), 200

$9, \mathrm{in}) 0$

16,000

57,600

120,192
125,192
Total

Entomostraca

7,412

1,600

3,600

3,600

2,000

1,600

2,400

5,600

2,400

4,000

3,200

1,600

3,200

3,200

16,000

16,000

25,600

$35,2(1)(1$

9,600

16,000

57.600

120,192

$12 \times, 192$

Glochidia ....
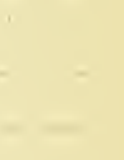
Table 1.-Organisms Per Cubic iteter in Plankton of STOCETON ChanNel IN 1913-(Continued)

\begin{tabular}{|c|c|c|c|c|c|c|}
\hline 1913 & $\begin{array}{c}\text { Cyclops } \\
\text { sp. }\end{array}$ & $\begin{array}{l}\text { Diaptomus } \\
\text { sp. }\end{array}$ & $\begin{array}{l}\text { Nauplius } \\
\text { sp. }\end{array}$ & $\begin{array}{c}\text { Total } \\
\text { Copepoda }\end{array}$ & $\begin{array}{c}\text { Total } \\
\text { Entomostraca }\end{array}$ & Glochidia \\
\hline $4^{\prime} / 6$ & 6,400 & 12,800 & 25,600 & 44,800 & 44,800 & \\
\hline $4 / 19$ & 38,400 & 52,896 & 79,311 & 170,640 & 170,610 & \\
\hline $4 / 23$ & 22,100 & 6,400 & 132,240 & 161,040 & 161,040 & .. \\
\hline $4 / 26$ & 41,600 & 22,400 & 155,136 & 249,136 & 249,136 & \\
\hline $4 / 30$ & 35,400 & 44,800 & 79,314 & 162,544 & 162,544 & \\
\hline $5 / 3$ & 80,000 & 6,400 & 132,240 & 218,640 & 218,640 & .. \\
\hline $5 / 7$ & 73,600 & s & 165,136 & 258,736 & $25 S, 736$ & \\
\hline $5 / 11$ & 51,200 & & 423,169 & 474,368 & 474,368 & \\
\hline $5 / 11$ & 57,600 & & $1,005,024$ & $1,062,624$ & $1,062,624$ & .. \\
\hline $5 / 17$ & $211,5 \$ 4$ & & 264,450 & 475,964 & 479,164 & \\
\hline $5 / 21$ & 57,600 & & 634,752 & 692,352 & 692,352 & . \\
\hline $5 / 21$ & 219,600 & & $1,163,712$ & $1,413,312$ & $1,419,712$ & .. \\
\hline $5 / 27$ & 192,000 & & 952,128 & $1,144,128$ & $1,144,128$ & \\
\hline $5 / 31$ & 160,800 & & $\mathrm{~S} 99,232$ & $1,360,032$ & $1,360.032$ & \\
\hline $6 / 3$ & 317,376 & & 899,232 & $1,216,608$ & $1,223,009$ & \\
\hline $6 / 7$ & 147,200 & & 872,781 & $1,019,984$ & $1,026,354$ & \\
\hline $6 / 11$ & 264,480 & & $1,375,296$ & $1,639,776$ & $1,646,176$ & \\
\hline $6 / 16$ & 115,200 & & 211,584 & 326,754 & 326,784 & \\
\hline $6 / 1 S$ & 179,200 & & 317,376 & 496,576 & 496,576 & \\
\hline $6 / 21$ & 76.800 & & $\$ 46,336$ & 923,136 & 929,536 & \\
\hline 6/25 & 317.376 & & 528,960 & 846,436 & 852,836 & \\
\hline $6 / 28$ & 264,480 & & 476,064 & 740.541 & 740,514 & \\
\hline I/ 3 & 179,200 & .. & 423,168 & 602,368 & 602,368 & \\
\hline $7 / 5$ & 268,800 & & $1,057.920$ & $1,326,720$ & $1,333,120$ & \\
\hline $7 / 9$ & 370.272 & & $1,163,712$ & $1,533,9 S 1$ & $1,533,9 \mathrm{S4}$ & \\
\hline $7 / 12$ & 740,544 & & $\$ 46,336$ & $1,5 \varsigma 6,880$ & $1,593,280$ & \\
\hline $7 / 16$ & 454,400 & & 793,410 & $1,247,840$ & $1,247,840$ & \\
\hline $7 / 19$ & $6 \varsigma 7,648$ & & 740,544 & $1,42 S, 192$ & $1,440,992$ & - 6,400 \\
\hline $7 / 23$ & 264,480 & & $1,110,816$ & $1,375,296$ & $1,375,296$ & …. $\quad \ldots . .$. \\
\hline$T / 26$ & 261,480 & & 687,648 & 952,128 & 958,528 & \\
\hline $7 / 30$ & 317,376 & & 740,544 & $1,057,920$ & $1,064,320$ & 3,200 \\
\hline$S / 2$ & $581,8.56$ & & $1,322,400$ & $1,904,256$ & $1,917,0.56$ & \\
\hline $8 / 6$ & 264,480 & & $1,269,504$ & $1,533,981$ & $1,533,981$ & \\
\hline 8/ 9 & 317,376 & 25,600 & $1,005,024$ & $1,348,000$ & $1,354,400$ & \\
\hline $8 / 13$ & $1,005,024$ & & $1,692,672$ & $2,697,696$ & $2,697,696$ & \\
\hline $8 / 15$ & $\pm 76,064$ & & $1,110,816$ & $1,586,880$ & $1,586,880$ & \\
\hline $8 / 20$ & $7.10,541$ & & $\$+6,336$ & $1,586,880$ & $1,590,080$ & 3,200 \\
\hline $8 / 23$ & 476,064 & & $\$ 46,336$ & $1,322,400$ & $1,341,600$ & \\
\hline $8 / 27$ & 631,752 & & $1,216,60 \mathrm{~S}$ & $1,851,360$ & $1,857,760$ & \\
\hline $\mathrm{S} / 31$ & 317,376 & & 793,440 & $1,110.816$ & $1,117,216$ & \\
\hline $9 / 2$ & 793,440 & & $1,586,880$ & $2,380,320$ & $2,405,920$ & \\
\hline $9 / 6$ & 264,480 & & $1,269,504$ & $1,533,984$ & $1,533,984$ & \\
\hline $9 / 9$ & $5 \$ 1,856$ & & $1,322,400$ & $1,904,256$ & $1,917,056$ & \\
\hline $9 / 13$ & 476,064 & & $1,005,024$ & $1,481,0 \mathrm{SS}$ & $1,4 \$ 1,088$ & \\
\hline $9 / 17$ & 370,272 & & $1,110,816$ & $1,181,088$ & $1,500,285$ & \\
\hline $9 / 20$ & 370,272 & & 370,272 & 740,544 & 740,544 & \\
\hline $9 / 24$ & 224,000 & & 952,128 & $1,176,128$ & $1,195,328$ & \\
\hline $9 / 27$ & 317,376 & & $6 S 7,64 \mathrm{~S}$ & $1,005,024$ & $1,017,824$ & \\
\hline $10 / 1$ & 211,584 & & $26 \cdot 1,480$ & 476,064 & $601,0.56$ & $\ldots$ \\
\hline $10 / 4$ & 211,584 & & 211,584 & 423,168 & 435,968 & \\
\hline $10 / 8$ & 134,400 & & 525,960 & 663,360 & 676,160 & \\
\hline $10 / 11$ & $158,68 \mathrm{~S}$ & & 105,792 & 264,480 & 261,480 & \\
\hline $10 / 15$ & 121,600 & & 264,480 & 386,080 & 386,080 & \\
\hline $10 / 18$ & 64,000 & & 158,688 & 222,658 & $229,0 \mathrm{SS}$ & \\
\hline $10 / 22$ & 38,400 & & 105,792 & 141,192 & 150,592 & \\
\hline $10 / 26$ & $158,6 \mathrm{SS}$ & ........ & 105,792 & 261,180 & 264,480 & \\
\hline $10 / 29$ & 76,800 & & 158,689 & 235,458 & 235,485 & \\
\hline $11 / 1$ & 29,600 & & $211,5.94$ & 211.584 & 211,554 & \\
\hline $11 / 5$ & 400 & & 6,100 & 6,400 & 6,400 & \\
\hline $11 / 8$ & & .............. & 12,800 & 12,800 & $12, \mathrm{~S} 00$ & \\
\hline $11 / 12$ & 3,200 & ................ & 19,200 & 22,100 & 22,400 & \\
\hline
\end{tabular}


Table 1.-Organisms Ier Cubic Meter in Plankton of Stockton Cilasere IN 1913-(Continued)

$\begin{array}{cc}1913 & \begin{array}{c}\text { Cyclops } \\ 8 p .\end{array} \\ 11 / 15 & 12,800 \\ 11,19 & 28,400 \\ 11 / 22 & 158,655 \\ 11,26 & 57,600 \\ 11 / 30 & 22,400 \\ 12 / 3 & 79,344 \\ 12 / 6 & 22,100 \\ 12 / 10 & 52,596 \\ 12 / 11 & 26,145 \\ 12 / 17 & 3,200 \\ 12 / 20 & 46,284 \\ 12 / 24 & 4,000 \\ 12 / 27 & 1,600 \\ 12 / 31 & 4,800\end{array}$

\begin{tabular}{c}
$\begin{array}{c}\text { Diaptomus } \\
\text { sp. }\end{array}$ \\
$\ldots \ldots \ldots$ \\
\hline \\
\end{tabular}

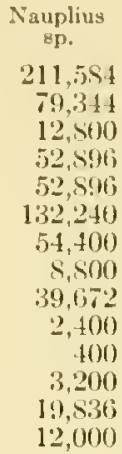

\begin{tabular}{|c|c|}
\hline $\begin{array}{c}\text { Total } \\
\text { Copepoda }\end{array}$ & $\begin{array}{c}\text { Total } \\
\text { Entomostraca }\end{array}$ \\
\hline 224,354 & $224,3 \mathrm{St}$ \\
\hline 105,144 & 111,311 \\
\hline $171,4 \times 8$ & $171,48 \mathrm{G}$ \\
\hline 110,496 & 113,4906 \\
\hline 75,296 & $7.5,290$ \\
\hline 211,584 & $211,5,1$ \\
\hline 76,800 & $76,800)$ \\
\hline 61,696 & 61,1596 \\
\hline$(66,120$ & 66,120 \\
\hline 5,600 & 5,600 \\
\hline 46,684 & 47,484 \\
\hline 7,200 & 7,200 \\
\hline 21,436 & 21,436 \\
\hline $16 . \$ 00$ & 16,500 \\
\hline
\end{tabular}

Glochidia

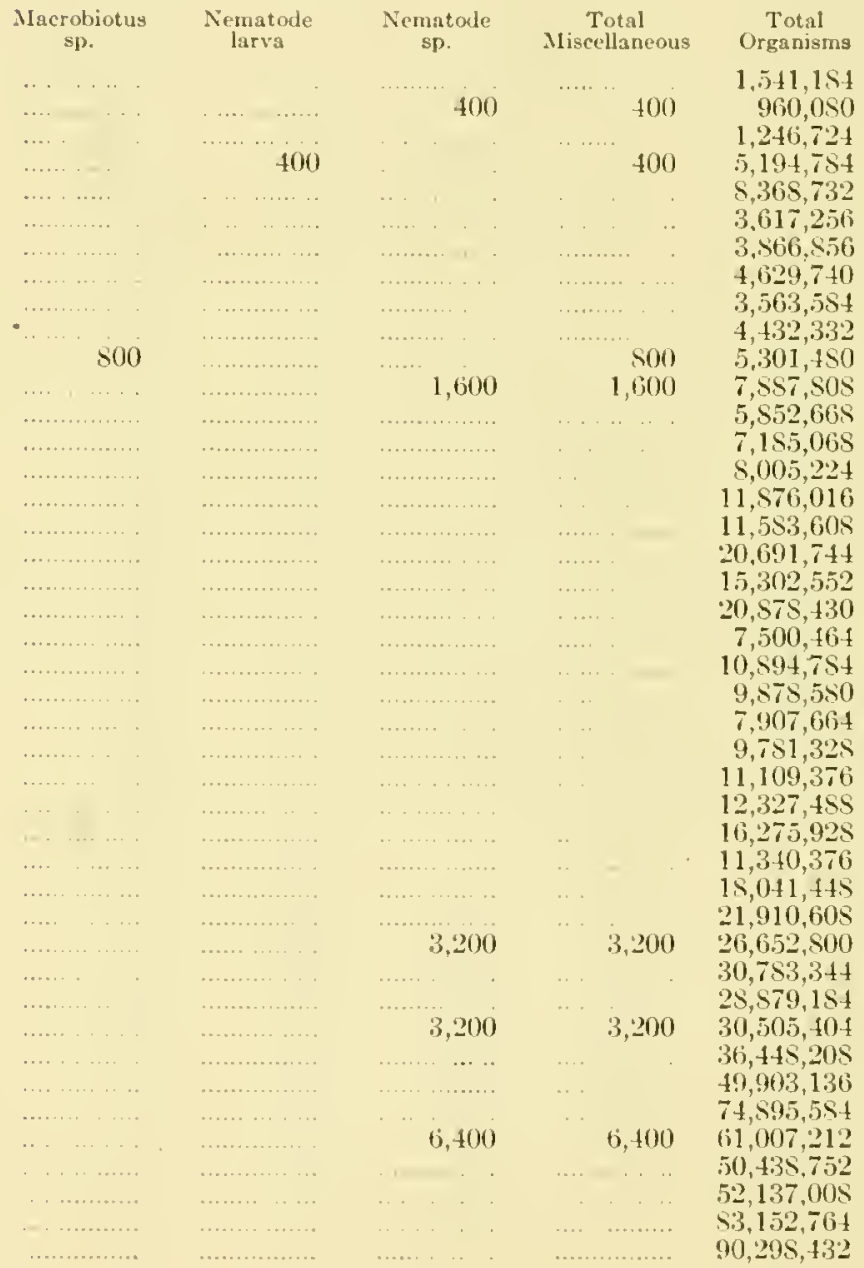


Table 1.-Organisms Per Cubic Meter in Plankton of Stockton ChanNel iN 1913-(Continued)

\begin{tabular}{|c|c|c|c|c|c|}
\hline 1913 & $\begin{array}{l}\text { Maerobiotus } \\
\text { sp. }\end{array}$ & $\begin{array}{l}\text { Nematode } \\
\text { larva }\end{array}$ & $\begin{array}{l}\text { Nematode } \\
\text { sp. }\end{array}$ & $\begin{array}{c}\text { Total } \\
\text { Miscellaneous }\end{array}$ & $\begin{array}{c}\text { Total } \\
\text { Organisms }\end{array}$ \\
\hline $6 / 3$ & & & & . & $102,283,072$ \\
\hline $6 / 7$ & & & & & $89,267,642$ \\
\hline $6 / 11$ & & & & .. & $84,639,96 \mathrm{~S}$ \\
\hline $6 / 16$ & . $\ldots$. & & & & $66,351,588$ \\
\hline $6 / 18$ & & & $\ldots . .$. & & $79,474,405$ \\
\hline $6 / 21$ & 3,200 & & & & $71,200,832$ \\
\hline $6 / 25$ & & .. & ... & 3,200 & $\$ 5,669,652$ \\
\hline $6 / 28$ & & . & & . $\quad$. & $105,512,440$ \\
\hline $\begin{array}{l}7 / 3 \\
7 / 5\end{array}$ & $\begin{array}{l}. . \\
\ldots\end{array}$ & .. & & & $66,694,496$ \\
\hline $\begin{array}{l}7 \text { ) } 5 \\
7 / \\
9\end{array}$ & $\begin{array}{l}\cdots \\
\ldots .\end{array}$ & $\begin{array}{l}. . \\
. .\end{array}$ & & . & 240 \\
\hline $7 / 19$ & $\begin{array}{l}\cdots \cdot \\
\cdots\end{array}$ & & . & 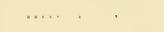 & 92,824 \\
\hline $\begin{array}{l}7 / 12 \\
7 / 16\end{array}$ & $\cdots$ & & ........... & & $48,253,984$ \\
\hline $7 / 16$ & & & & & $78,756,792$ \\
\hline $\begin{array}{r}-1.23 \\
7 / 23\end{array}$ & & $\cdots$ & & 6,400 & $50,284,514$ \\
\hline $\begin{array}{l}7 / 23 \\
7 / 26\end{array}$ & & & & & $\begin{array}{l}4,211 \\
6,602\end{array}$ \\
\hline $7 / 30$ & .. & & & 3,200 & $\begin{array}{l}\text { Ds, } 125,002 \\
35,085,136\end{array}$ \\
\hline $8 / 2$ & ..... & & & & $39,749,616$ \\
\hline$S / 6$ & $\cdots$ & $\ldots$ & & $\ldots \ldots$ & $31,44^{2}, 432$ \\
\hline $\begin{array}{l}8 / 9 \\
8 / 13\end{array}$ & $\ldots$ & …... & & ......... & 9,228 \\
\hline $\begin{array}{l}8 / 13 \\
8 / 15\end{array}$ & & ....... & & & 480 \\
\hline 15 & & & 列 & & 44 \\
\hline $\begin{array}{l}20 \\
23\end{array}$ & & & & 3,200 & 44 \\
\hline 6 & & & $\cdots$ & …... & \\
\hline $8 / 31$ & & $\cdots$ & &. & $\begin{array}{l}54,312,130 \\
65,254,556\end{array}$ \\
\hline $9 / 2$ & & .... & & & 3,280 \\
\hline $9 / 6$ & ............ & $\ldots .$. & ……… & & 5,920 \\
\hline $9 / 9$ & …какак. & & .... . . . . & $\ldots$ &, 912 \\
\hline $9 / 13$ & ...... & & $\cdots$ & $\cdots$ & 72,7 \\
\hline $9 / 17$ & 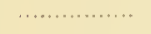 & .... & & . & 62 \\
\hline 20 & ............... & & ....... & & 53,8 \\
\hline $\begin{array}{l}9 / 24 \\
9 / 27\end{array}$ & $\cdots$ & & $\cdots$ & & 56 \\
\hline $\begin{array}{l}9 / 27 \\
0 / 1\end{array}$ & & & & . & 64 \\
\hline$/ \begin{array}{l}1 \\
4\end{array}$ & $\cdots$ & & & & 96 \\
\hline 5 & & & & & 24 \\
\hline$/ 11$ & $\ldots, \quad \ldots \ldots \ldots$ & & & .. & 96 \\
\hline & & & $\cdots$ & $\cdots \cdot$ & 096 \\
\hline & $\ldots \quad \ldots \ldots$ & $\ldots$ & ..... & & 64 \\
\hline 2 & & & & ... & 62 \\
\hline 6 & $\ldots$ & & $\ldots .$. & & 150 \\
\hline 9 & $\ldots \ldots \ldots$ & $\ldots$ & & & 48 \\
\hline 1 & $\cdots$ & & 6,400 & 6,400 & 35 \\
\hline 5 & $\ldots$ & & $\ldots \ldots$ & ...... & \\
\hline & $\ldots \ldots$ & & ...... & & 7,832 \\
\hline & ...... & & $\ldots .$. & & 288 \\
\hline 5 & & & & & 80 \\
\hline 1 & & 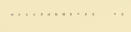 & & & 272 \\
\hline 1 & & & ..... & & 120 \\
\hline $11 / 26$ & & & & ... & 40 \\
\hline 30 & & & .. & & 984 \\
\hline $12 / 3$ & ... ......... & 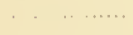 & $\cdots$ & & 416 \\
\hline $12 / 6$ & .............. & & ..... & . & 13,3 \\
\hline $12 / 10$ & . $\ldots \ldots \ldots \ldots$ & ....... & $\cdots$ & & 302 \\
\hline $12 /$ & …..... & & $\ldots$ & . ...... & 442 \\
\hline & $\ldots \ldots, \quad \ldots, \ldots$ & & ........ & …... & 48 \\
\hline & $\ldots \ldots \ldots$ & & ….... & ........ & 456 \\
\hline & ....... & & ................ & ........ & $3,734,436$ \\
\hline 10 & 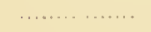 & & & & $7,168,872$ \\
\hline 12 & 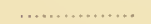 & ....... & ......... & ... & $6,219,632$ \\
\hline
\end{tabular}




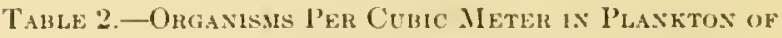
SAN JoAQUTA RIVER 1913

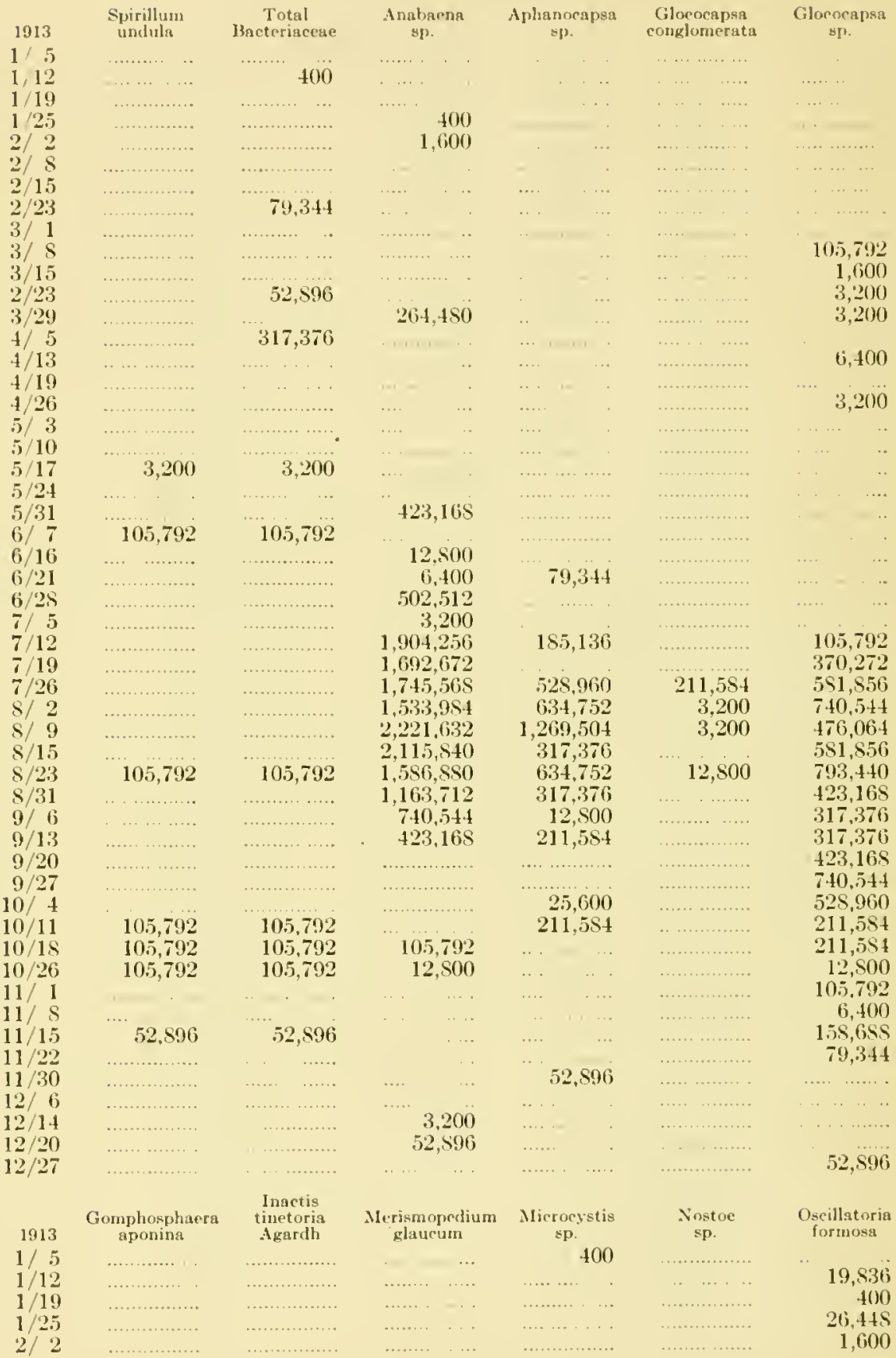


Table 2.-Organisus Per Cubic Mleter in Plankton of San Joaquin River in 1913-(Continued)

1913

$2 / 8$

$2 / 15$

$2 / 23$

3) 1

$3 / \mathrm{s}$

$3 / 15$

$3 / 23$

$3 / 29$

$4 / 5$

$4 / 13$

$4 / 19$

$4 / 26$

$5 / 3$

$5 / 10$

$5 / 17$

$5 / 24$

$5 / 31$

$6 / 7$

$6 / 16$

$6 / 21$

$6 / 28$

$7 / 5$

$7 / 12$

$7 / 19$

$7 / 26$

S/ 2

S/ 9

$8 / 15$

$8 / 23$

$\mathrm{S} / 31$

$9 / 6$

9/13

$9 / 20$

$9 / 27$

$10 / 4$

$10 / 11$

$10 / 1 \mathrm{~s}$

$10 / 20$

$11 / 1$

$11 / 8$

$11 / 15$

11/22

$11 / 30$

$12 / 6$

$12 / 14$

$12 / 20$

$12 / 27$

1913

$1 / 5$

$1 / 12$

$1 / 19$

$1 / 25$

2/ 2

$2 / 8$

$2 / 15$

$2 / 23$

$3 / 1$

$3 / \mathrm{s}$
Inactis

Gomphosphaera

aponina

1,600

tinetoria

Merismopedium

glaucum Microcystis

Nostoc

Oscillatoria

ormosa

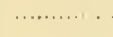

...........

3,200

52,896

............

3,200

........

...........

(.)......

.........

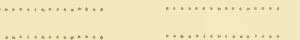

3,200

105,792

3,200

3,200

$\begin{array}{cr}. & 211,584 \\ \ldots & 634,752\end{array}$

$1,692,672$

$2,115,8 \pm 0$

$1,269,504$

211,584

25,600

$, 115,840$

$, 327,421$

$6.34,752$

105,792

52,, 96

105,792

$105,79^{\circ}$

105,792

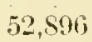

1,600

\section{2,896}

290,928

476,064

105,792

$158,68 \mathrm{~S}$

211,554

3,200

105,792

....... ..

$740,5 \pm 4$

317,376

105,792

317,376

211.534

105,792

6,100

6., 400

1,600

1,600

$\ldots \ldots \ldots \ldots$
$\ldots \ldots \ldots \ldots \ldots$
$\ldots \ldots \ldots \ldots \ldots$
$\ldots \ldots \ldots \ldots \ldots$
$\ldots \ldots \ldots \ldots \ldots$
52,896
3,200

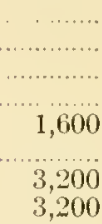

3,200

105,792

423,165

$211,5 \mathrm{St}$

423,165

525,960

52,896

3,200

$158,6 \mathrm{SS}$

$5 \$ 3,456$

$3,50 \mathrm{~S}, 512$

551,856

952,128

$793, \pm \pm 0$

$1,114,016$

$4,178,784$

$5+1,760$

317,376

$7 \pm 0,5 \pm 1$

710,514

317,376

529,960

12,800

12,800

12,800

15S,6SS

79,344

211,584

52,896

1,600

6,100

(), 100

6,100

25,600

12,800

105,792

105,792

6,100

1,600

1,600

1,600

1,600

Oscillatoria

sp.

Osciliatoria

tenuis

Phormidium

spp.

Stigonema

sp.

Schizophy

Actinastrum

hantzschii

800

20,236

400

$27,2+8$

3,200

3,200

52,896

52,896

1.600

105,992

52,896 
Tamle 2,-Organisms Per Cubic Meter in plankton of San Joagun RIVEJ IN 1913-(Conlinued)

\begin{tabular}{|c|c|c|}
\hline 1913 & $\begin{array}{l}\text { Oseillatoria } \\
\text { sp. }\end{array}$ & $\begin{array}{c}\text { Oscillatoria } \\
\text { temuis }\end{array}$ \\
\hline $3 / 15$ & & .. \\
\hline $3^{/ 2}=3$ & 52,596 & . \\
\hline $3 / 29$ & 1,600 & ... \\
\hline $4 / 5$ & & . \\
\hline $\begin{array}{l}4 / 13 \\
4 / 19\end{array}$ & & . \\
\hline$+1 / 26$ & 1,000 & $\ldots$ \\
\hline $5 / 3$ & .. 1 & .. \\
\hline $5 / 10$ & .. & .. \\
\hline $5 / 17$ & $1,1=1$. & .. \\
\hline $\begin{array}{l}\text { 5) } 2 \cdot 1 \\
5 / 31\end{array}$ & , $\quad \cdots, \ldots$ & 105,792 \\
\hline $6 / 7$ & 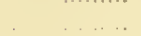 & (10), \\
\hline $6 / 16 \mathrm{i}$ & 38,400 & . \\
\hline 6.21 & ..- & ........ \\
\hline $6 / 25$ & $\ldots . . \quad .$. & $\ldots$. \\
\hline $7 / 5$ & ..... & $\ldots \ldots$ \\
\hline 712 & …. & ... \\
\hline $7 / 19$ & 3,200 & .. \\
\hline 726 & 3,200 & .. \\
\hline$S / 2$ & 793,440 & \\
\hline S/ 9 & 105,792 & 3,200 \\
\hline $8 / 15$ & $10.5,792$ & $\ldots \ldots \ldots$ \\
\hline S 23 & 105,792 & . \\
\hline $8 / 31$ & $211,5 \mathrm{~S} 4$ & .. \\
\hline 96 & $105,79^{\circ}$ & . . . \\
\hline 913 & $\ldots \quad \ldots \ldots$ & -...... \\
\hline $9 / 20$ & $\ldots \ldots \ldots \ldots \ldots$ & n........ \\
\hline $9 / 27$ & $\ldots \ldots, \quad \ldots$ & \\
\hline $10 / 4$ & …........... & 12,500 \\
\hline $10 / 11$ & ........... & $\ldots$ \\
\hline $10 / 18$ & $\cdot \quad \ldots, \ldots \ldots \ldots$ & ....... \\
\hline $10 / 26 j$ & & n....... \\
\hline $11 / 1$ & $211,58 t$ & …… , \\
\hline 118 & . . , , o & $\ldots \ldots \ldots \ldots$ \\
\hline $\begin{array}{l}11 / 15 \\
11 / 22\end{array}$ & 3,200 & $\ldots \ldots \ldots \ldots \ldots$, \\
\hline $11 / 30$ & . & 3,200 \\
\hline $12 / 6$ & ................ & $\ldots \ldots . \quad \ldots$ \\
\hline $12 / 14$ & n............. & ................ \\
\hline $12 / 20$ & 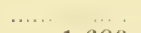 & ………, \\
\hline $12 / 27$ & 1,600 & …..... \\
\hline
\end{tabular}

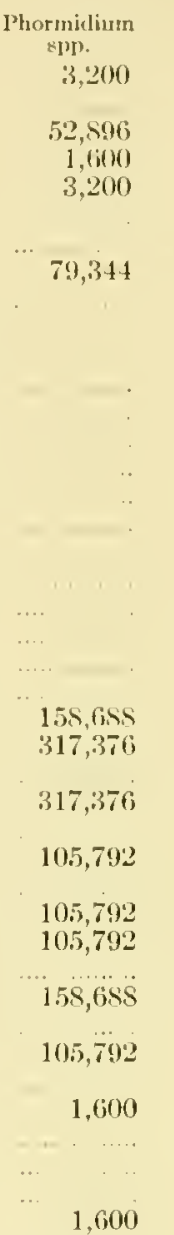

Coelastrum microporum

Pediastrun

$$
\text { Stig }
$$

Stigonem

3

$423,16.5$

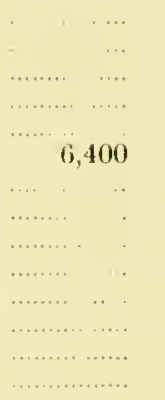

Pediastrum

$$
\begin{array}{r}
1,200 \\
800
\end{array}
$$$$
800
$$

$26,41 \mathrm{~S}$

$19, \mathrm{~S} 36$

21,000

51,200

41,600

79,344

48,000

132,240

1S. $5,1: 36$

41,600

$2 \AA, 800$

105,792

35,200$$
\text { (n) }
$$

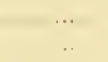

$15,6,656$

$42: 3,16 \mathrm{iS}$

$6 \times 7,648$

35,400

105), 792

211,564

52,696

79,344

$15 \mathrm{~S}, 6 \mathrm{SS}$

3. 200

6,100

6,400

$+$

12,800

12,800
duplex

Total Schizophyceae i) 9,294 56,096 ; 325,376 6it.096; 52,896 15. 136

840,336 $370,27^{\circ} 2$ 952,6148

$1,110 \times 16$ 615,560 323,776 081,776 267,650 $3,151,512$ (j, 512,80S $3,864,608$ $4,529,536$ $4,624,352$ $4,462,464$ $8,211,6,50$ $4,773,440$ $3,609,725$ $4,165,2 \times 5$ $3,821,312$

$3,596,920$

$2,179.840$

647,552 753,344 144,192 825,440 12,500 275,680 S4, 144 59,296 57,696

Pediastrum simplex

400

400

2,400

400

16,000

60,500

16,000

10.5, 792

19,200

19,200

155,136

54,400

3,200

12,800

19,200 4, 500 $\$, 000$

1,600

3,200 54,496

Artinnstrum hantzachii

3,200

5) $2,40(4)$

396,720

3,200

12,800

$10.5,79^{\circ} 2$

6,400

3,200

79,344

3,200

$15 \overline{5}, 130$

$15 \mathrm{~s}, \mathrm{iks}$

(j, 400

19,200

$211,5 \mathrm{St}$

317.876

105,792

25,600

105,792

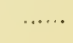

52,896

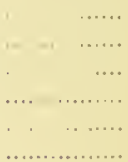

Raphidium polymorphum 400

3,200

1,600

1,600

3,200

1,600

i, 6000

9,600

1,600

105,792

1,600

3,200 
Table 2.-Organisas Per Cubic Meter in Plankton of SAn Joaquin River in 1913-(Contimued)

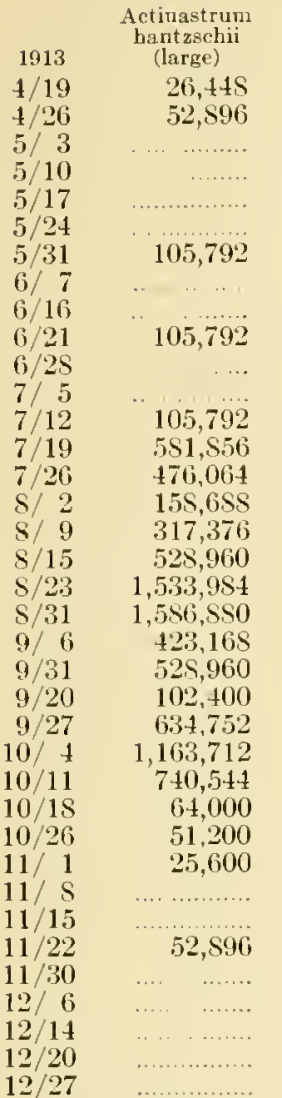

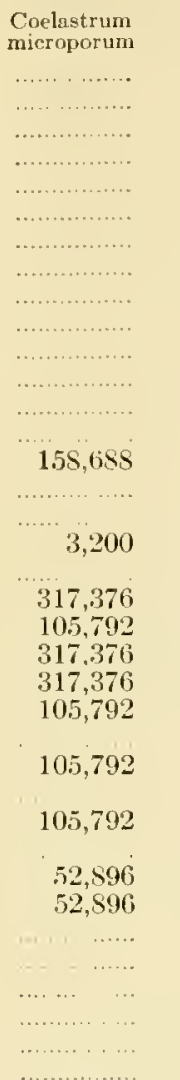

Richteriella botryoides

$1 / 5$

$1 / 12$

$1 / 19$

$1 / 25$

2/ 2

$2 / 8$

$2 / 15$

$2 / 23$

$3 / 1$

$3 / 8$

$3 / 15$

$3 / 23$

$3 / 29$

$4 / 5$

$4 / 13$

$4 / 19$

$4 / 26$

$5 / 3$

$5 / 10$

$5 / 17$

Scenedesmus obliquus

$\$ 00$
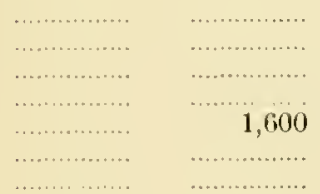

1,600

1,600

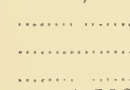

1,600
1,600

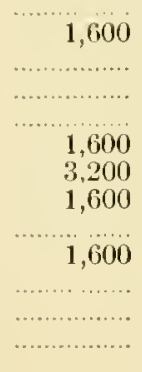

$$
\begin{array}{r}
\text { Pediastrum } \\
\text { boryanum } \\
79,344 \\
105,792 \\
6,400 \\
12,500 \\
\ldots \ldots . . \\
3,200 \\
9,600 \\
1,600 \\
3,200 \\
25,600 \\
6,400 \\
25,600 \\
155,688 \\
3,200 \\
158,688 \\
12,800 \\
25,600 \\
211,584 \\
105,792 \\
76,800 \\
51,200 \\
25,600 \\
12,800 \\
25,600 \\
155,658 \\
19,200 \\
6,400 \\
9,600 \\
6,400 \\
6 . . \\
6,400
\end{array}
$$

Scenedesmus quadricauda

$$
\begin{aligned}
& 400 \\
& 400
\end{aligned}
$$

400

400

105,792

\begin{tabular}{|c|c|}
\hline ...... & , ............... \\
\hline n.............. & ................ \\
\hline …........... & …............. \\
\hline n........ & ................ \\
\hline (., & \\
\hline ……, & …...... \\
\hline .............. & $\cdots$ \\
\hline 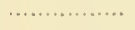 & , \\
\hline 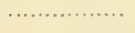 & (................ \\
\hline …........... & …............ \\
\hline , $\ldots \ldots \ldots \ldots \ldots$ & ............... \\
\hline$\cdots \cdots$ & .......... \\
\hline 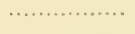 & …..........., \\
\hline n.............. & … \\
\hline$\ldots \ldots \ldots$ & $\ldots \ldots \ldots \ldots \ldots$ \\
\hline ................... & 3,200 \\
\hline ................ & ................ \\
\hline
\end{tabular}

52,896

1, 600

12,800

3,200

52,896

132,240

211,584

105,792

79,311

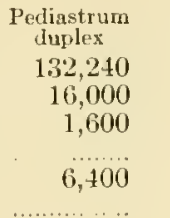

$$
\begin{aligned}
& \text { 6, } 100 \\
& 32.000 \\
& 132,240 \\
& 158,68 \mathrm{~s} \\
& 661,200 \\
& 1,322,400
\end{aligned}
$$

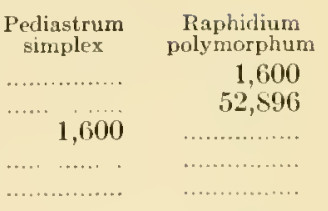

105,792

3,200

Schroederia setigers

Stigeoclonium

sp.

Total

211,584

211,584

634,752

528,960

25,600

$211,5 \mathrm{St}$

12,500

52,896

105,792

1,600

setiger

2,800

1,600

29,648

21,036

145,792

164,896

64,000

201,136

73,600

210,736

427,968

233,040

762,096

121,792

177,792

240,232

321,328

9,600

3,200

22,100 


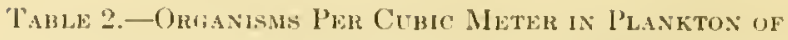
SAN JodQuin RIVER IN 1913-(Continued)

1913
$5 / 24$
$5 / 21$
$6 / 3$
$6 / 16$
$6 / 21$
$6 / 25$
$7 / 5$
$7 / 12$
$7 / 19$
$7 / 26$
$8 / 2$
$8 / 9$
$8 / 15$
$8 / 23$
$8 / 31$
$9 / 6$
$9 / 13$
$9 / 20$
$9 / 27$
$10 / 4$
$10 / 11$
$10 / 18$
$10 / 26$
$11 / 1 / 2$
$11 / 8$
$11 / 15$
$11 / 22$
$11 / 30$
$12 / 6$
$12 / 14$
$12 / 20$
$12 / 27$

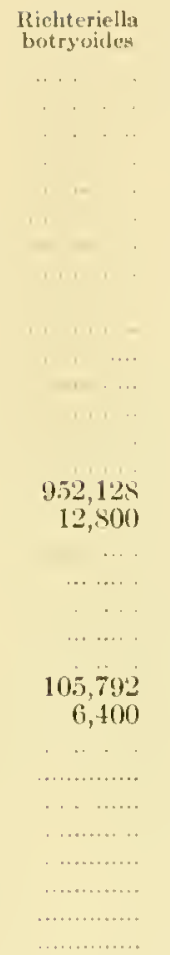

Asterionella gracillima

1913

$1 / 5$

112

$1 / 19$

$1 / 25$

$2 / 2$

2/ 8

$2 / 15$

$2 / 23$

$3 / 1$

$3 / 8$

$3 / 15$

$3 / 23$

$3 / 29$

45

$4 / 13$

$4 / 19$

$4 / 26$

$5 / 3$

$5 / 10$

$5 / 17$

$5 / 24$

5.31

6) 7

(i) 16

6/2I

4,535,832

$945, \overline{16}$

\$, 453,196

932,292

$9,28: 3,248$

(), 915,000

$1,904,256$

$2,353,572$

$819, \mathrm{~S}$ S

$2,274,52 \mathrm{~s}$

$1,005,024$

$1,930,704$

$2,512.56(0)$

$52.896 ;$

555,408

657, 10 IS

449,116

290,928

$2,803,4.58$

158, is

211.58 .1

$1,42 \times, 192$

$1,216,60 \mathrm{~s}$

$3,173,760$

$4,549,050$
Sce

$$
\begin{array}{r}
3,200 \\
105,7 ! 12 \\
211,561 \\
3,200 \\
\ldots . \\
3,200 \\
3,200 \\
15,658 \\
3,200 \\
6,400
\end{array}
$$

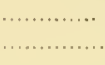$$
\text { cenedesmus }
$$

$105,-792$

105,792

105,792

4'2: $16 \mathrm{~s}$

317,376

211,584

$10 ;, 792$

211,584

6., 100

$10.5,792$

52,896

3,200

1,600

1,600

Asterionella Asterjonell

gracilima
(large)

$$
\text { .... .... }
$$$$
\text { … }
$$

1,600

52,596

105,792

16,000

105,792

79,344

$2,161,730$

123.113

$3,067,96 \mathrm{~s}$

$2,909,280$

$-4,4.3,261$
Sechedesmus

quadricuudu

$105,-7$

12,500

3,200

3,200

3,200

1,600

211,594

317,376

$+76,06-1$

105,792

$155.6 \mathrm{SS}$

581,850

$1,057,920$

952,125

528,960

$1,057,920$

423,168

846,330

$952,12.5$

952,128

$1,057,920$

$5 S 1,8.56$

$158,68 \mathrm{~S}$

$15 \mathrm{~s}, 6 \mathrm{~S}, \mathrm{~S}$

52,806

$10.5,792$

..........

52,596

Amphiprora alata

$10.5,792$
Schroederia stigeoclonium$$
\text { An. }
$$

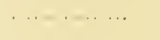

...............

...........

n..............

.................

................

..............

. . . . ......

… $\ldots \ldots \ldots$

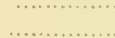

.............

$10.5,792$

$10 \overline{7}, 792$

1,600

$\ldots \ldots$
$\ldots \ldots \ldots$
6,400

................
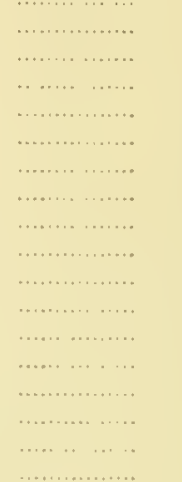

.... ...

........

$\begin{array}{rr}\begin{array}{c}\text { Bacillaria } \\ \text { paradoxa }\end{array} & \begin{array}{r}\text { Coceoneis } \\ \text { pediculus }\end{array} \\ 39,672 & \ldots \ldots \ldots \ldots \ldots \\ 1,200 & 400 \\ 6,400 & \ldots \ldots \ldots \ldots . . . \\ 9,600 & \ldots \ldots \ldots \ldots \ldots \\ 8,000 & \ldots \ldots \ldots \ldots \ldots . . .\end{array}$

12,800

19,200

9,600

6,400

2.5 .600

9,600

$6,+00$

$5 \times 1,856$

$1,600 \quad 41,600$

264,450

185,136

211,584

105,792

I!), 200

39,400

12.800

19,200
I'total

Chlorophycese

$$
3,200
$$

$52,9,9(30$

$22,3,38.1$

If, 0000

$14.5,992$

277,270

$16,5,258$

()9 9,528

2, $160,(0+1)$

$3,034,272$

$2,997,376$

1, 154,265

$4,527,540$

$8,251,7-6$

$5,539,551$

$5,420,992$

$4,05 \mathrm{~S}, 196$

$4,371,480$

$6,285,960$

$7,212,048$

$7,774,016$

$2,397,224$

$2,625,51 \mathrm{~S}$

$1,8 \$ 9,760$

713,245

67\%, 556

$2+9,232$

194.736

19,200

56,096 ;

20,400

110,792

Cyclotella spp.

Gst, 64s

$1,031,472$

$1,533.944$

51.5 .736

$740.5 \cdot 14$

$1,29.5 .952$

$1,216,60 \mathrm{~s}$

$2,136,496$

$10,9,5,572$

6. $0.30,14.1$

$3,967,200$

$3,3.5,596$

$2,115,510$

$\$ 19,888$

714,096

$1,428,192$

706,992

S $40,3.36$

470,0 i.

3.200

$1,209,50.1$

$1,110,816$

$2.539,0(0)$

$2,8,36,3,84$

$1,745,569$

608,301 
Table 2.-Organisms Per Cubic Meter in Plankton of San Joaquin River in 1913-(Continued)

\begin{tabular}{|c|c|c|c|c|c|c|}
\hline 1913 & $\begin{array}{l}\text { Asterionella } \\
\text { gracillima }\end{array}$ & $\begin{array}{c}\text { Asterionella } \\
\text { gracillinia } \\
\text { (large) }\end{array}$ & $\begin{array}{l}\text { Amphiprora } \\
\text { alata }\end{array}$ & $\begin{array}{l}\text { Bacillaria } \\
\text { paradoxa }\end{array}$ & $\begin{array}{l}\text { Cocconeis } \\
\text { pediculus }\end{array}$ & $\begin{array}{l}\text { Cyclotella } \\
\text { spp. }\end{array}$ \\
\hline $6 / 28$ & $4,866,432$ & $2,962,176$ & & 79,344 & & 396,720 \\
\hline I) 5 & 608,304 & 52,596 & ….............. & 396,720 & 1,600 & 423,168 \\
\hline $7 / 12$ & & 79,344 & …................ & $1,248,848$ & & $1,269,504$ \\
\hline $7 / 19$ & & & & $8,569,152$ & …................ & $5,130,912$ \\
\hline $7 / 26$ & & & $\ldots \ldots$. & $3,702,720$ & & $10,050.240$ \\
\hline $8 / 2$ & & & & $21,528,672$ & …............. & $10,261,824$ \\
\hline 8/ 9 & & 3,200 & ......... & $15,392,736$ & ………..... & $3,596,928$ \\
\hline $8 / 15$ & ....... & & & $4,760,640$ & & $3,332,448$ \\
\hline$s / 23$ & & 3,200 & & $2,062,944$ & …............. & $9,045,216$ \\
\hline $8 / 31$ & ......... & ....... & 105,792 & $4,972,224$ & & $14,176,128$ \\
\hline $9 / 6$ & & …...... & ............. & 846,336 & 12,800 & $14,176,12 \mathrm{~s}$ \\
\hline $9 / 13$ & & …....... & ................. & $4,453,264$ & $\ldots \ldots \ldots$ & $14,493,504$ \\
\hline $9 / 20$ & ……......... & …............. & ................ & $3,067,968$ & ................... & $15,868,800$ \\
\hline $9 / 27$ & …….......... & ................... & $\ldots \ldots \ldots \ldots \ldots$ & $1,692,672$ & …............ & $11,954,496$ \\
\hline $10 / 4$ & ....... & , , . . . . & ......... & $1,481,088$ & ........... & $17,753,116$ \\
\hline $10 / 11$ & ....... & ................ & .................. & 528,960 & ……........... & $49,300,272$ \\
\hline $10 / 18$ & ....... & ................... & ………..... & 317,376 & ……....... & $42,750,016$ \\
\hline $10 / 26$ & & & ....... & 76,800 & ......... & $31,218,700$ \\
\hline $11 / 1$ & 52,896 & & ......... & 158,688 & ..... & $8,569,152$ \\
\hline $11 / 8$ & 6,400 & 12,800 & . ................ & 105,792 & & $3,702,720$ \\
\hline $11 / 15$ & 105,792 & 12,800 & $\ldots \ldots$ & 19,200 & & $3,279,552$ \\
\hline $11 / 22$ & 1,600 & 211,584 & $\ldots \ldots$ & 290,928 & 1,600 & $1,533,984$ \\
\hline $11 / 30$ & 9,600 & 52,896 & ..................... & $1,322,400$ & & $1,246,056$ \\
\hline $12 / 6$ & $4,443,264$ & & & $2,909,2 \mathrm{~S} 0$ & 3,200 & 795,040 \\
\hline $12 / 14$ & 449,616 & 290,925 & & $2,195,154$ & & $\mathbf{1}, 216,608$ \\
\hline $12 / 20$ & 476,064 & $79,3+4$ & 1,600 & 555,408 & 1,600 & $1,904,256$ \\
\hline $12 / 27$ & 79,344 & & & $1,216,608$ & 1,600 & $1,190,160$ \\
\hline 1913 & $\begin{array}{c}\text { Cymatopleura } \\
\text { solea }\end{array}$ & $\begin{array}{l}\text { Cymbella } \\
\text { affinis }\end{array}$ & $\begin{array}{c}\text { Cymbella } \\
\text { cymbiformis }\end{array}$ & $\begin{array}{c}\text { Cymbella } \\
\text { sp. }\end{array}$ & $\begin{array}{c}\text { Cymbella } \\
\text { tumida }\end{array}$ & $\begin{array}{l}\text { Diatom } \\
\text { unidentified }\end{array}$ \\
\hline $1 / 5$ & & & 800 & & & \\
\hline $1 / 12$ & ...... & …............ & 400 & 400 & $\ldots \ldots \ldots \ldots \ldots$ & \\
\hline $1 / 19$ & & & & & ......... & 400 \\
\hline $1 / 25$ & 400 & ...... & $800^{\circ}$ & 26,443 & & \\
\hline $\begin{array}{l}2 / 2 \\
3 / 8\end{array}$ & 1,600 & N...... & 6,400 & 79,344 & & 1,600 \\
\hline $2 / 15$ & 6,400 & $\cdots$ & 6,400 & $\begin{array}{l}3,200 \\
6,400\end{array}$ & 3,200 & $\begin{array}{l}6,400 \\
3,200\end{array}$ \\
\hline $2 / 23$ & 3,200 & .......... & 3,200 & 52,896 & & 1,600 \\
\hline $3 / 1$ & 3,200 & & 3,200 & 1,600 & 6,400 & 1,600 \\
\hline $3 / 5$ & & 1,600 & & . & ......... & \\
\hline $3 / 15$ & & 3,200 & 6,400 & .. & & \\
\hline $3 / 23$ & 3,200 & 1,600 & 3,200 & $\ldots \ldots$ & 3.200 & 1600 \\
\hline $3 / 29$ & & 79,344 & 9,600 & ….. & 3,200 & 1,600 \\
\hline 4) 5 & 6,400 & 158.685 & 3,200 & & 79,344 & \\
\hline $4 / 13$ & 3,200 & 79,344 & & & & 52,596 \\
\hline $4 / 19$ & 19,200 & 79,344 & 12,800 & $\cdots$ & & 1,600 \\
\hline $4 / 26$ & 12,800 & 105,792 & & ........ & & \\
\hline $5 / 3$ & 12,800 & 185,136 & 3,200 & & 185,136 & 211,554 \\
\hline $5 / 10$ & 132,240 & 238,032 & 19,200 & ........ & 79,344 & 105,792 \\
\hline $5 / 17$ & 44,800 & 211,584 & 12,800 & ............... & 261,480 & 3,200 \\
\hline $5 / 24$ & 32,000 & 211,584 & 12,500 & & 76,800 & 317,376 \\
\hline $5 / 31$ & 76,800 & 899,232 & 12,500 & ………........ & 12,800 & \\
\hline 6) 7 & 51,200 & 528,960 & 25,600 & 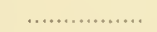 & 64,000 & 317,376 \\
\hline $6 / 16$ & 19,200 & 211,584 & 158,688 & & 32,000 & 6,400 \\
\hline $6 / 21$ & 19,200 & 105,792 & 16,000 & 3,200 & 6,400 & - \\
\hline $6 / 28$ & 12,800 & 79,344 & 3,200 & $\ldots \ldots \ldots$ & 3,200 & \\
\hline $\begin{array}{r}5 \\
12\end{array}$ & & 6,400 & & ...... . & 3,200 & \\
\hline $\begin{array}{l}7 / 12 \\
7 / 19\end{array}$ & 9,600 & & 3,200 & & $\begin{array}{l}6,400 \\
3,200\end{array}$ & \\
\hline$/ 2$ & 12,800 & & & & 6,400 & 3,200 \\
\hline
\end{tabular}


Tabie 2.-Organisus Pen Cíbic Meteis in l'Lankton of San Joaquin Raver in 1913-(Continued)

\begin{tabular}{|c|c|c|c|c|c|c|}
\hline 1913 & $\begin{array}{l}\text { Cynatopleura } \\
\text { soles }\end{array}$ & $\underset{\text { aftinis }}{\text { Cymbclls }}$ & $\begin{array}{c}\text { Cymbella } \\
\text { cymbiformis }\end{array}$ & $\begin{array}{c}\text { Cymbella } \\
\text { sp. }\end{array}$ & $\underset{\text { Cymbella }}{\text { Cymbela }}$ & $\begin{array}{l}\text { Dintom } \\
\text { unidentified }\end{array}$ \\
\hline $8 / 2$ & & 3,200 & & & & $\ldots \ldots$ \\
\hline $8 / ?$ & & 3,200 & 6,400 & & $(i, 400$ & \\
\hline 815 & 6,400 & ..... & 6,400 & $\ldots .$. & 19,200 & -- \\
\hline $8 / 23$ & & & & $\ldots .$. & & . \\
\hline $8 / 31$ & 12,800 & & ........... & ㄷ............ & 211,584 & \\
\hline $9 / 6$ & & 105,792 & & ............... & …........ & ......... \\
\hline 913 & 12,800 & …… & 25,600 & …........ & . $\ldots \ldots \ldots \ldots$ & ........ \\
\hline $9 / 20$ & 12,800 & ...1....... .. & & $\ldots \ldots \ldots$ & …….... & $\begin{array}{lll}* & \ldots & \ldots\end{array}$ \\
\hline $\begin{array}{l}9 / 27 \\
10 / 4\end{array}$ & 12,800 & $211.5 \mathrm{St}$ & 12,800 & ……… & 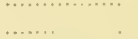 & . . .............. \\
\hline $10 / 11$ & $\begin{array}{ll}\cdots & \ldots \\
& \ldots\end{array}$ & 211,584 & 12,800 & ……...... & $12, \$ 00$ & . .......... . \\
\hline $10 / 18$ & .. & 105,792 & & $\ldots .$. & 25,600 & \\
\hline $10 / 26$ & & $\ldots$ & 12,800 & & & $\cdots$ \\
\hline $11 / 1$ & $(i, 400$ & & 6,400 & 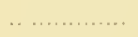 & 6,400 & $\ldots .$. \\
\hline $11 / 8$ & 12,800 & $\ldots . .$. & 6,400 & $\ldots .$. & 19,200 & $\cdots$ \\
\hline $11 / 15$ & & $\ldots \ldots$ & f. 500 & & 52,596 & \\
\hline $\begin{array}{l}11 / 22 \\
11 / 30\end{array}$ & $\begin{array}{l}1,600 \\
3.200\end{array}$ & $\cdots \cdots$ & 6,400 & & 3,200 & \\
\hline $\begin{array}{l}11 / 30 \\
12 / 6\end{array}$ & 3,200 & $\begin{array}{l}\ldots \ldots \\
\ldots \ldots\end{array} \quad \cdots \cdots$ & & & 32,000 & \\
\hline $12 / 14$ & & 1,600 & 3,200 & . & & 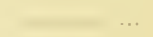 \\
\hline $12 / 20$ & 9,600 & & 3,200 & & 3,200 & \\
\hline $12 / 27$ & & 1,600 & . . & $\ldots .$. & .... & . $\quad \ldots$ \\
\hline 1913 & $\begin{array}{c}\text { Epithemia } \\
\text { ocellata }\end{array}$ & $\begin{array}{c}\text { Eunotia } \\
\text { sp. }\end{array}$ & $\begin{array}{l}\text { Fragillaria } \\
\text { capucina }\end{array}$ & $\begin{array}{l}\text { Fragillaria } \\
\text { crotonensis }\end{array}$ & $\begin{array}{c}\text { Fragillaris } \\
\text { sp. }\end{array}$ & $\begin{array}{l}\text { Gomphonema } \\
\text { constrictum }\end{array}$ \\
\hline $1 / 5$ & & 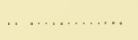 & ...... & 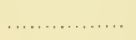 & ..... . & $\ldots \ldots \ldots \ldots$ \\
\hline $1 / 12$ & .......... & …............ & 400 & ....... & ............. & ..... \\
\hline $1 / 19$ & …..ака. & 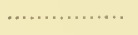 & 2,400 & . . . . . . . & $\cdots$ & \\
\hline $\begin{array}{l}1 / 25 \\
? \quad 2\end{array}$ & ........ & ….............. & 39,672 & 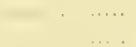 & $\cdots$ & 400 \\
\hline $2 / 2$ & & ㄱ...…... & & .. & ........ & - \\
\hline $\begin{array}{l}2 / 8 \\
2 / 15\end{array}$ & & 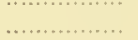 & $\begin{array}{r}6,400 \\
12,800\end{array}$ & $\ldots$ & & \\
\hline $2 / 23$ & & & 12,800 & . & & $\ldots$ \\
\hline $3 / 1$ & 12,800 & ․․……....... & 12,800 & & & .. $\quad \ldots$ \\
\hline $3 / 8$ & & $\ldots$ & 16,000 & & & .. \\
\hline $3 / 15$ & 3,200 & & 28,800 & & & .. \\
\hline $3 / 23$ & 3,200 & ……........ & 132,240 & 1,600 & & . \\
\hline $3 / 29$ & 3,200 & 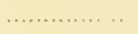 & 35,200 & 6,400 & & \\
\hline $4 / 5$ & 6,400 & …… & 22,400 & 1,600 & & 52,896 \\
\hline $4 / 13$ & 3,200 & .............. & 79,344 & & 1,600 & $\ldots$ \\
\hline $4 / 19$ & 3,200 & …кака. & 105,792 & & - & $\Rightarrow 808$ \\
\hline $4 / 26$ & & ...... & 158,688 & 52,596 & $158.6 \times 5$ & 52,596 \\
\hline $\begin{array}{l}5 / 3 \\
5 / 10\end{array}$ & $\begin{array}{l}3,200 \\
6,400\end{array}$ & ㄱ.. & 158,609 & 52,896 & 105,792 & 79.344 \\
\hline $\begin{array}{l}5 / 10 \\
5 / 17\end{array}$ & 105.792 & 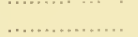 & $\begin{array}{l}79,344 \\
19,200\end{array}$ & & & 3,200 \\
\hline $\begin{array}{l}5 / 17 \\
5 / 24\end{array}$ & 6,400 & ......... & 19,200 & & & 1 1) $8,6 \mathrm{~S}$ \\
\hline $5 / 31$ & 423,168 & & 12,800 & & & 317,376 \\
\hline (i) 7 & 51,200 & 105,792 & 51,200 & & 528,960 & 317,376 \\
\hline $6 / 16$ & 12,500 & . . & 19,200 & $\ldots$ & 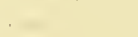 & 15.,6sS \\
\hline $6 / 21$ & 1.600 & ..... & 22,400 & .. & & 1,600 \\
\hline $6 / 28$ & 11,200 & $\ldots$ & 79,344 & & & 1,1600 \\
\hline $7 / 5$ & 3,200 & & 6,400 & & 6,400 & \\
\hline $7 / 12$ & 1,600 & .... & & & 1,600 & \\
\hline $7 / 19$ & 6,400 & & 6.100 & 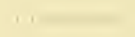 & & \\
\hline $7 / 26$ & 3,200 & ......... & 6,400 & & & 3000 \\
\hline $8 / 2$ & 6,400 & ........... & 6,400 & - & & 3,200 \\
\hline $8 / 9$ & 12,800 & ........ & 6,400 &.$\cdot$ & 3,200 & .. \\
\hline $8 / 15$ & 6,400 & .......... & 6,400 & & 6,400 & .. \\
\hline $\begin{array}{l}S / 23 \\
\$ / 31\end{array}$ & 12,800 & $\begin{array}{l}\ldots \ldots \ldots \\
\ldots \ldots \ldots \ldots\end{array}$ & 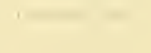 & .. & 105,792 & $-\ldots$ \\
\hline
\end{tabular}


Table 2.-Organisms Per Cubic Meter in Plankton of San Joaquin liver in 1913-(Continued)

Epithemia
ocellata

25,600

Eunotia
sp.

Fragillari

capucina

105,792

105,792

12,800

12,800

$10 / 18$

$10 / 26$

$11 / 1$

$11 / 15$

$11 / 22$

$11 / 30$

$12 / 14$

$12 / 20$

$12 / 27$

1913

$1 / 5$

$1 / 12$

$1 / 19$

$1 / 25$

$2 / 2$

$2 / 8$

$2 / 23$

3/ 1

$3 / \mathrm{S}$

$3 / 15$

$3 / 23$

$3 / 29$

$4 / 5$

$4 / 13$

$4 / 19$

$4 / 26$

$5 / 3$

$5 / 10$

$5 / 17$

$5 / 24$

$5 / 31$

$6 / 7$

$6 / 16$

$6 / 21$

$6 / 28$

$7 / 5$

$7 / 12$

$7 / 19$

$7 / 26$

S/ 2

S/15

$8 / 23$

$8 / 31$

$9 / 6$

$9 / 13$

$9 / 20$

$9 / 27$

9,600

1,600

6,400

Gomphonema sp.

kiitzingii

2,000

1,200

13,224

6,400

52,896

6,400

6,400

3,200

3,200

79,344

79,344

$132,2 \pm 0$

79,344

25,600

79,344

3,200

105,792

105,792

158,688

$+, 500$

1,600

$158,6 \mathrm{ss}$

79,344

211,584

3,200

158,688

83,200

38,400

211,584

12,800

12,800

132,240

105,792

19,200

264,480

264,480

264,450

317,376

105,792

370,272

423,168

423,168

423,168

317,376

105,792

105,792

25,600

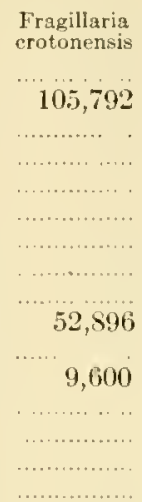

Eragillaria sp.

Gomphonems constrictum

1,600

\begin{tabular}{|c|c|c|}
\hline $\begin{array}{l}\text { Gyrosigma } \\
\text { sealproides }\end{array}$ & $\begin{array}{c}\text { Mastngloia } \\
\text { braunii }\end{array}$ & $\begin{array}{l}\text { Melosira } \\
\text { granulata }\end{array}$ \\
\hline & & 26,445 \\
\hline & 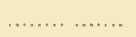 & 19,836 \\
\hline & & 30,060 \\
\hline 13,224 & $\ldots \ldots$. & $85,9.56$ \\
\hline 1,600 & & 608,304 \\
\hline 1,600 & ……........ & 502,512 \\
\hline & & 634,752 \\
\hline & & $1,428,192$ \\
\hline & & 343,824 \\
\hline $52, \$ 96$ & & $925,6 \mathrm{SO}$ \\
\hline & & $3,435,240$ \\
\hline & 6,400 & $1,877,808$ \\
\hline & 3,200 & $1,533,984$ \\
\hline 52,896 & & 396,720 \\
\hline 3,200 & & $3,508,512$ \\
\hline 1600 & & $\begin{array}{r}7,696,368 \\
656,502\end{array}$ \\
\hline & & 1243056 \\
\hline 52,896 & & $1,586,880$ \\
\hline 105,792 & & $3,491,136$ \\
\hline 3,200 & & $2,274,528$ \\
\hline & & $4,566,432$ \\
\hline & .... & $4,6.54,848$ \\
\hline & ..... & $3,279,552$ \\
\hline & & $\$, 198,8,80$ \\
\hline 3,200 & $\ldots$ & $19,016,112$ \\
\hline & $\ldots$. & $11,372,640$ \\
\hline & & $19,994,68 \mathrm{~S}$ \\
\hline & & $27,294,336$ \\
\hline 12,800 & & $26,871,168$ \\
\hline 476,064 & & $65,273,66 \pm$ \\
\hline 846,336 & . . & $61,465,152$ \\
\hline ... & $\cdots .$. & $74,636,256$ \\
\hline & ........ & $169,478,784$ \\
\hline ........ & ………… & $141,443,904$ \\
\hline & ………....... & $180,057,984$ \\
\hline & ....... & $101,242,944$ \\
\hline & .................... & $98,809,728$ \\
\hline & & $55,6 \pm 6,592$ \\
\hline
\end{tabular}


Thale 2.-Organisms Per Cunic Meteik in P'lankton of SAN JoAquin Raver IN 1913-(Continuad)
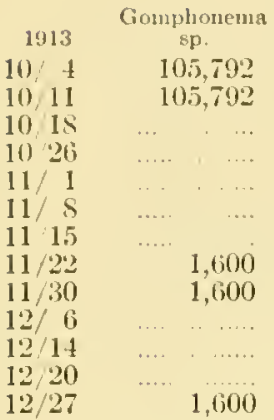

S/ 2

8/ 9

S 15

$8 / 23$

$8 / 31$

$9 / 6$

$9 / 13$

$9 / 20$

$9 / 27$

$10 / 1$

$10 / 11$

$10 / 18$

$10 / 26$

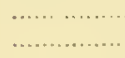

…………

..................

……………

……….......

…….......

.................

$5,368,944$

1,600

$1,243,056$

290,928

238,032

52,896

185,136

211,584

634,752

\begin{tabular}{|c|c|}
\hline $\begin{array}{l}\text { Gyrosikma } \\
\text { acuminatum }\end{array}$ & Gyrosigma \\
\hline & 105,792 \\
\hline 423,168 & $\begin{array}{l}10.5,792 \\
211,551\end{array}$ \\
\hline & 12,800 \\
\hline 12,800 & 105,792 \\
\hline 6,400 & 52,890 \\
\hline & $\begin{array}{l}6,400 \\
1,600\end{array}$ \\
\hline & $\begin{array}{r}1,600 \\
79,344\end{array}$ \\
\hline & 3,200 \\
\hline & 1,600 \\
\hline
\end{tabular}

\begin{tabular}{|c|}
\hline $\begin{array}{l}\text { Gyrosigma } \\
\text { salproides }\end{array}$ \\
\hline$\ldots \ldots, \ldots$ \\
\hline$\cdots \cdots, \quad \cdots$ \\
\hline$\cdots \cdot$ \\
\hline $\begin{array}{l}\ldots \ldots \\
\ldots \ldots\end{array} \quad \ldots$ \\
\hline .. $\quad .$. \\
\hline$\cdots \quad \ldots$ \\
\hline$\cdots$ \\
\hline$\cdots, \quad \cdots$ \\
\hline 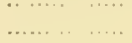 \\
\hline$\ldots \quad \ldots .$. \\
\hline \\
\hline
\end{tabular}

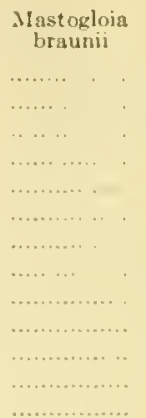

Melosira granulata

$45.91+9,928$

$73,852,8(i)$

$25,505,920$

$12,45,3,15$

$12,007,392$

4,175, 7St

$1,4 \times 1,0 \mathrm{~s}$,

$3,0.11,520$

$1.1,176,12 \mathrm{~S}$

$2,142,2 \times 5$

608, 30.1

8.16,336

661,200

\begin{tabular}{|c|c|}
\hline $\begin{array}{l}\text { Melosira } \\
\text { varians }\end{array}$ & $\begin{array}{c}\text { Navicula } \\
\text { affuis }\end{array}$ \\
\hline 52,896 & \\
\hline 4,800 & \\
\hline 39,672 & 19,836 \\
\hline 79,344 & \\
\hline 79,344 & - \\
\hline 44,800 & ..... \\
\hline 185,136 & \\
\hline 105,792 & \\
\hline 158,658 & \\
\hline 105,792 & \\
\hline 449,616 & 1,600 \\
\hline 264,480 & 1,600 \\
\hline 290,928 & 105,792 \\
\hline 343,824 & 6,400 \\
\hline 185,136 & 1,600 \\
\hline 528,960 & \\
\hline 581,556 & 3,200 \\
\hline 502.512 & 52,896 \\
\hline 634,752 & 52,896 \\
\hline $1,163,712$ & \\
\hline 634,752 & \\
\hline$, 216,60 \mathrm{~s}$ & \\
\hline 793,440 & \\
\hline 317,376 & \\
\hline 238,032 & 3,200 \\
\hline 449,616 & 79,344 \\
\hline
\end{tabular}

- iavicula

Navicula alpestris bacillum

132,240

238,032

105,792

158 , 188

158,658

155,685

12,500

105,792

211,584

105,792

105,792

211,584
.... .

$$
\begin{array}{ll}
\cdots & \\
\cdots & \cdots \\
\cdots & \ldots
\end{array}
$$

a..............

$26+4,40$

70,31 105,792 $52, \$ 96$ 52,896

$$
1,600
$$

79,314

79,344

79,344

185,136

3,200

264,480

$\$ 99,232$

317,376

317,376

3,200

3,200

52,896

52,896

3,200

3.200

264,450

317,376

12,500

$105,-79^{\circ}$

$211,58.1$

\section{. . .}

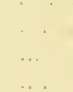

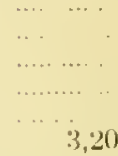

3,200

3,200

235,032
185,136

185,136

343,524

793,440

634,752

$1,005,024$

$1,322,400$

581,856

211,584

79,344

79,344

52,896

105,792

105,792

105,792

3,200

158,685

3,200

105,792

$211,58 t$

317,370

$740,5+1$

211,584

105,792

105,792

211,584

211,55

317,376 
Table 2,-Organis.is Per Cubic Meter in Plankton of San Joaquix River in 1913-(Continued)

1913
$11 / 1$
$11 / 8$
$11 / 15$
$11 / 22$
$11 / 30$
$12 / 6$
$12 / 14$
$12 / 20$
$12 / 27$

Melosira

\begin{tabular}{|c|c|}
\hline $\begin{array}{c}\text { granulata } \\
\text { (small) }\end{array}$ & $\begin{array}{l}\text { Melosira } \\
\text { varians }\end{array}$ \\
\hline & $211,5 \mathrm{~S} 4$ \\
\hline n........., & 105,792 \\
\hline$\ldots$ & 12,800 \\
\hline . $\quad$ a & 19,200 \\
\hline$\cdots$ & 52,890 \\
\hline$\ldots \ldots \ldots, \ldots$ & 70,344 \\
\hline & 52,896 \\
\hline & 12,800 \\
\hline 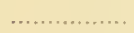 & 423,168 \\
\hline
\end{tabular}

Navicula dubia

$1 / 5$

1/12

$1 / 19$

$1 / 25$

2/ 2

$2 / 15$

$2 / 23$

$3 / 1$

$3 / 8$

$3 / 15$

$3 / 23$

$3 / 29$

$4 / 5$

$4 / 13$

$4 / 19$

$4 / 26$

$5 / 3$

$5 / 10$

$5 / 17$

$5 / 24$

$5 / 31$

6/ 7

6/16

$6 / 21$

$6 / 25$

7.5

$7 / 12$

$7 / 19$

$7 / 26$

S/ 2

S/ 9

$8 / 15$

$8 / 23$

$8 / 31$

9/ 6

$9 / 13$

$9 / 20$

$9 / 27$

10/4

$10 / 11$

$10 / 18$

10/26

11/ 1

11/ 8

$11 / 15$

$11 / 22$

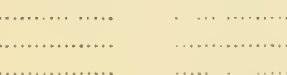

72,732

$15 \mathrm{~s}, 6 \mathrm{sS}$

185,136

105,792

105,792

132,240

1,600

$423,16 \mathrm{~S}$

343,524

264,450

423,165

317,376

793,440

$581,8.56$

290,928

661.200

$1,745,568$

$1,5 \mathrm{S6}, 8 \mathrm{80}$

$1,110,816$

$1,216,60 \mathrm{~s}$

634,752

132240

185,136

264,480

525,960

$423,16 \mathrm{~s}$

846,336

793,440

$1,639,776$

$2,7.50,592$

$3,649,824$

$3,596,928$

2,614, 500

$1,795,464$

$1,269,504$

$8 \pm 6,336$

$7.10,544$

$1,481,088$

$423,16 \mathrm{~S}$

$105,792 \quad 423,168$

52,896

211,584

2506

1S.5, 136

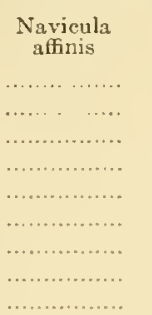

Navieula pestris

$15 \mathrm{~S}, 6 \mathrm{SS}$

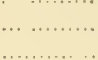

3.200

1,600

6,400

3,200

Navicula

52,896

Navicula

didyma

$52, \$ 96$

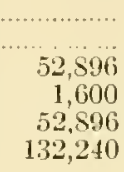

Navicula

sp.

SO0

\begin{tabular}{|c|c|c|}
\hline $\begin{array}{l}\text { Navieula } \\
\text { viridis }\end{array}$ & $\begin{array}{l}\text { Nitzschia } \\
\text { aejularis }\end{array}$ & $\begin{array}{l}\text { Nitzschia } \\
\text { angularis }\end{array}$ \\
\hline 100 & 39,672 & \\
\hline 800 & 39,672 & \\
\hline 13,224 & 19,836 & \\
\hline 1,200 & 59,508 & 400 \\
\hline 3,200 & 185,136 & $\$, 000$ \\
\hline 3,200 & 52,896 & 6,400 \\
\hline & 105,792 & 3,200 \\
\hline 1,600 & 52,896 & 6,400 \\
\hline 6,400 & 52,896 & 3,200 \\
\hline 3,200 & 133,840 & 6,400 \\
\hline 6,400 & 105,792 & 9,600 \\
\hline 6,400 & 1,600 & 3,200 \\
\hline 6,400 & 264,480 & 3,200 \\
\hline 19,200 & 132,240 & 132,240 \\
\hline
\end{tabular}

79,344

3,200

105,792

79,344

211,584

32,000

25,600

64,000

19,200

9,600

12,800

3,200

740,544

423,168

476,064

$158,68 \mathrm{~S}$

317,376

370,272

846,336

$1,0.57,920$

634,752

317,376

317,376

846,336

634,752

528,960

$+23,16 \mathrm{~S}$

$\begin{array}{rr}12,800 & 264,490 \\ 6,400 & 105,792\end{array}$

$6,400 \quad 370,272$

52,896
105,792

12,800 


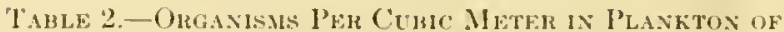
SAN JOAQUIN RIVER IN 1913-(Continued)

1913
$11 / 30$
$12 / 6$
$12 / 1$
$12 / 20$
$12 / 27$

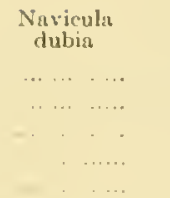

\section{Silaschia}

sigina

1913

$1 / 12$

$1 / 19$

$1 / 25$

$2 / 2$

$2 /$ is

$2 / 15$

$2 / 23$

$3 / 1$

$3 / 8$

$3 / 15$

$3 / 23$

$3 / 29$

4) 5

$4 / 13$

4/19

$4 / 26$

$5 / 3$

$5 / 10$

$5 / 17$

$5 / 24$

$5 / 31$

6/ 7

$6 / 10$

6/21

$6 / 28$

$7 / 5$

$7 / 12$

$7 / 19$

$7 / 26$

S/ 2

S/ 9

$8 / 15$

$\mathrm{S} / 23$

$8 / 31$

$9 / 6$

$9 / 13$

$9 / 20$

$9 / 27$

$10 / 4$

$10 / 11$

$10 / 18$

$10 / 26$

$11 / 1$

$11 / \mathrm{S}$

$11 / 1.5$

$11 / 23$

$11 / 30$

12/ 6

$12 / 14$

$12 / 20$

$12 / 27$

..............

……............

1,600

6. +100

3,200

52,596

$211,5 \mathrm{st}$

3,200

317,376

317,376

6,400

3,200

3,200

.................

6,100
10.

105,792

105,792

$211,5 \mathrm{S4}$

10.5, 792

105,792

10.5, 792

105,792

105, 792

317,376

12,800

3,200

3,200

1,600

$3,200)$

3,200

3,200

Navicula
Rrncilis
$+76,064$
396,720
$132,2.10$
165,136
264,150

Navicula
sp.

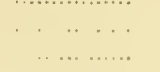

(i), 100

Nitzschia

sicmoiden

- ... 3,200

1 , (iv)

5. 2,896

1,600

3,200

$79,3+4$

3,200

79,314

Nitzschia sp.

79,311

$23,4,36$

52,896

9,600
5,800

12,800

(i, 100

105,792

105,792

12,800

3,200

6. 100

6,400

......

1, 600

52,896

52,896

$15 \mathrm{~S}, 6 \mathrm{SS}$

" 343,824

52,596

108,992

423,168

\$99.232

317,376

214,754

52,896

52,890

1,600

$18.5,136$

158,085

3,200

370,272

476,064

370,272

$2,539,008$

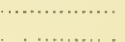

............

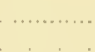

12,500

1,600

\begin{tabular}{|c|c|}
\hline $\begin{array}{l}\text { Navieula } \\
\text { viridis }\end{array}$ & $\begin{array}{l}\text { Nitzsohia } \\
\text { acicularis }\end{array}$ \\
\hline 3,200 & 52,596 \\
\hline , & $79,3.14$ \\
\hline & 1.58, lisis \\
\hline 3,200 & $52,5 ! 16$ \\
\hline
\end{tabular}

Nitzschia

angularis

Sitzschia

Pleurostiuron parvulum

$4100 \quad 235,032$

145,464

$235,0: 32$

522,349

$+, 800) \quad 396,720$

$4 \vec{a} 6064$

$12,800 \quad 423,16 \mathrm{~S}$

$235,0: 3$

$26+, 480$

1,600

3,200

9,600

6,400

502,512

317,376

$+76,061$

581,556

343,824

502,512

132,240

661,200

$4+9,616$

132,240

687,648

793,440

$1,216,60 \mathrm{~S}$

793,410

211,584

79,314

1,600

$3,200 \quad 1,000$

132,240

3,200

6. $400 \quad 26+480$

$6,400 \quad 105,792$

$6,100 \quad 105,792$

$10.5,792$

25,600

4:3, $16 \mathrm{~s}$

317,376

211,584

105,792

12,800

12,800

51,200

12,800

6., 400

6,400
Rhopaloxtia gibls:2

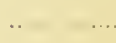

, . . . .

… $\quad \ldots$

+... $\quad \ldots$

(

….

(

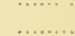

.................

............

…

…….......

3,200
$105,-792$

317,376

211.584

317,376

105,792

12,800

52,896

2,896

52,890

158,058

132,240

52.596

$235,0.32$

15. (j)

$211,55 \cdot 1$ 
Table 2.-Organisms Per Cubic Meter in Plankton of Sax Joaquin River in 1913-(Continued)

\begin{tabular}{|c|c|c|c|c|c|c|}
\hline 1913 & $\begin{array}{c}\text { Stauroneis } \\
\text { phoenicenteron }\end{array}$ & $\begin{array}{l}\text { Surirella } \\
\text { sp. }\end{array}$ & $\begin{array}{l}\text { Synedra } \\
\text { radians }\end{array}$ & $\begin{array}{l}\text { Synedra } \\
\text { ulna }\end{array}$ & $\begin{array}{c}\text { Tabellaria } \\
\text { sp. }\end{array}$ & $\begin{array}{c}\text { Total } \\
\text { Broillariacene }\end{array}$ \\
\hline $1 / 5$ & & $\$ 00$ & & $125,6 \mathrm{~S}$ & 400 & $5,809,536$ \\
\hline $1 / 12$ & 400 & 400 & n............. & 59,508 & $\ldots$ & $2,251,76 \mathrm{~s}$ \\
\hline $1 / 19$ & & 34,260 & …........... & 469,452 & ... & $10,974,996$ \\
\hline $1 / 25$ & 400 & $73,10 \mathrm{~S}$ & ….............. & 178,524 & & $2,663,576$ \\
\hline $2 / 2$ & $\ldots$ & 120,192 & ............... & 290,925 & & $11,996,845$ \\
\hline $2 / 8$ & & 83,200 & ................. & 264,480 & & $12,933,536$ \\
\hline $2 / 15$ & 3,200 & 118,100 & & 235,032 & & $5,016,736$ \\
\hline $2 / 23$ & & 67,200 & & 264,480 & .. & $6,856,748$ \\
\hline $3 / 1$ & . & 264,480 & $\cdots$ & 185,136 & .. & $13,325,744$ \\
\hline $3 / 8$ & ....... & 211,581 & & 370,272 & ... & $11,019,120$ \\
\hline $3 / 15$ & $\ldots \ldots$. & 264,480 & $\ldots$ & $.5 \$ 1,856$ & . & $10,801,04$, \\
\hline $3 / 23$ & $\ldots \ldots$ & 211,581 & $\ldots \ldots \ldots$ & $290,92 \mathrm{~S}$ & & $9,134,064$ \\
\hline $3 / 29$ & & 264,480 & . & 370,272 & $\ldots$ & $14,11.5,040$ \\
\hline $4 / 5$ & & 555,408 & & 661,200 & & $5,260,60 \mathrm{~S}$ \\
\hline $4 / 13$ & & 185,136 & $\ldots$ & $657,6+8$ & & $8,892,3: 36$ \\
\hline $4 / 19$ & & 555,408 & & 502,512 & & $14,298,67^{2} 2$ \\
\hline $4 / 26$ & & 211,584 & & 211,584 & & $11,305,218$ \\
\hline $5 / 3$ & 3,200 & $1,0 \mathrm{~S} 4,36 \mathrm{~s}$ & & 502,512 & & $7,678,57^{\circ}$ \\
\hline $5 / 10$ & 3,200 & 978,576 & ...... & $\$ 19,885$ & .. & $10,505,40 \mathrm{~S}$ \\
\hline $5 / 17$ & 211,584 & $1,798,464$ & ........ & 899,232 & & $16,196,2 \mathrm{SS}$ \\
\hline $5 / 24$ & $.12,500$ & 631,752 & & 740,544 & & $11,764,92 \mathrm{~s}$ \\
\hline $5 / 31$ & ............ & 793,440 & .. & 687,645 & .. & $21,702,976$ \\
\hline $6 / 7$ & & $1,428,192$ & ............ & 687,618 & & $22,407,344$ \\
\hline $6 / 1 ;$ & & 793,441 & ................ & 423,168 & & $16,107,296$ \\
\hline $6 / 21$ & & 290,925 & & 211,584 & & $19,785,264$ \\
\hline $6 / 28$ & 6,400 & 528,960 & .. & 290,928 & 6,400 & $29,834,352$ \\
\hline $7 / 5$ & 3,200 & $158,68 \mathrm{~s}$ & (............ & 79,344 & की & $11,174,332$ \\
\hline $7 / 12$ & $\ldots \ldots$ & 581,856 & ... & $158,6 \mathrm{SS}$ & & $25,030,060$ \\
\hline $7 / 19$ & & $423,16 \mathrm{~s}$ & 476,064 & 105,792 & 3,200 & $43,575,008$ \\
\hline $7 / 26$ & 3,200 & $9.52,128$ & 370,272 & 211,584 & & $44,644,352$ \\
\hline $8 / 2$ & 3,200 & $2,539,008$ & 370,272 & 317,376 & 3,200 & $102,741,536$ \\
\hline$S / 9$ & & $4,707,744$ & 105,792 & 317,376 & & $90,369,66+$ \\
\hline $8 / 15$ & 12,800 & $1,715,365$ & 370,272 & 105,792 & & $90,117,192$ \\
\hline $8 / 23$ & .. & $2,010,048$ & 476,064 & 211,584 & & $193,317,650$ \\
\hline $8 / 31$ & 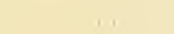 & $2,327,124$ & $1,0.57,920$ & $4,866,132$ & & $178,086,636$ \\
\hline $9 / 6$ & & $1,269,504$ & $1,057,9 \geq 0$ & $2,750,592$ & & $211,605,800$ \\
\hline $9 / 13$ & & $1,481,088$ & 211,554 & $6,463,312$ & & $132,958,752$ \\
\hline $9 / 20$ & 12,800 & $8 \pm 6,336$ & 317,376 & $1,904,256$ & & $123,920,832$ \\
\hline $9 / 27$ & $\ldots$ & $1,163,712$ & 317.376 & $1,269,50 t$ & & $74,461,376$ \\
\hline $0 / 4$ & & 925,128 & 423,168 & $2,433,216$ & & $72,648,572$ \\
\hline $0 / 11$ & & $1,269,504$ & 634,752 & $2,327,124$ & & $132,110,672$ \\
\hline $0 / 18$ & & 634,752 & $10 \div, 792$ & $8+6,336$ & & $71,950,564$ \\
\hline $0 / 26$ & 12,800 & $1,163,712$ & 317,376 & 631,752 & & $47,266,700$ \\
\hline 1 & & 423,168 & 423,168 & 476,064 & & $22,980,76 \mathrm{~s}$ \\
\hline $1 / 8$ & 6,400 & 952,128 & $52,8,96$ & $15,5,68 \mathrm{~S}$ & ...... & $10,20.5,536$ \\
\hline $1 / 15$ & $\ldots \ldots$ & 83,200 & 52,896 & 105,792 & & $5,766,976$ \\
\hline $1 / 22$ & $\ldots \ldots$ & $423,16 \mathrm{~s}$ & 185,136 & 158,688 & & $6,451,616$ \\
\hline $1 / 30$ & & 317,376 & 1,600 & $1.58,688$ & & $18,0.58,240$ \\
\hline $12 / 6$ & & 185,136 & & 317,376 & & $11,466,384$ \\
\hline $12 / 14$ & 3,200 & 235,032 & 132,240 & 185.136 & $\ldots$ & $6,252,552$ \\
\hline $12 / 20$ & & 264,480 & 52,896 & 132,240 & & $4,521,440$ \\
\hline $12 / 27$ & & 528,960 & 1,6000 & 264,480 & & $5,190,960$ \\
\hline 1913 & $\begin{array}{l}\text { Algae } \\
\text { unidentified }\end{array}$ & $\begin{array}{l}\text { Closterium } \\
\text { acerosum }\end{array}$ & $\begin{array}{l}\text { Closterium } \\
\text { acuminatum }\end{array}$ & $\begin{array}{l}\text { Closterium } \\
\text { rostratum }\end{array}$ & $\begin{array}{l}\text { Mougeotia } \\
\text { sp. }\end{array}$ & $\begin{array}{l}\text { Spirogyra } \\
\text { protecta }\end{array}$ \\
\hline $1 / 5$ & ... & $-\ldots \ldots$ & & & 800 & \\
\hline $1 / 12$ & & ........ & 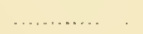 & $\ldots$ & & 2,800 \\
\hline $1 / 19$ & $\because \ldots$ & & & & 400 & \\
\hline $1 / 25$ & & 1,600 & $\ldots \ldots$ & …... & ............ & $\ldots$. \\
\hline $2 / 2$ & . & 1,600 & …............ & ..... & $\ldots$. & \\
\hline
\end{tabular}


Table 2-Organisus Peir Cunic Meter in Plaskton of SAN Joaquin Riven is 1913-(Cortinued)

\begin{tabular}{|c|c|c|c|c|c|c|}
\hline 1913 & $\begin{array}{c}\text { Algar } \\
\text { unidentifed }\end{array}$ & $\begin{array}{l}\text { Closterium } \\
\text { acerosum }\end{array}$ & $\begin{array}{l}\text { Closterium } \\
\text { ucuminatum }\end{array}$ & $\begin{array}{l}\text { Closterium } \\
\text { rostrutum }\end{array}$ & $\begin{array}{c}\text { Mougeotia } \\
\text { sp. }\end{array}$ & $\begin{array}{l}\text { Spirogyra } \\
\text { protecta }\end{array}$ \\
\hline $2 / 8$ & & 3,200 & & & & \\
\hline 215 & & 6,400 & & & $\cdots$ & \\
\hline $2 / 23$ & 1,600 & $\ldots . .$. & $\ldots \ldots$. & . & $\ldots$. & 3,200 \\
\hline $3 / 1$ & & & $\ldots \ldots \ldots$ & $\ldots \ldots . \quad \ldots \ldots \ldots$ & 1,600 & \\
\hline $\begin{array}{l}3 / 8 \\
3 / 15\end{array}$ & ..... & 3,200 & $\ldots \ldots$ & $\ldots$ & $\ldots$ & \\
\hline $\begin{array}{l}3 / 19 \\
3 / 23\end{array}$ & & & $\ldots$ & 1,600 & & 3,200 \\
\hline $3 / 29$ & & & & & & \\
\hline+15 & .... & 6.400 & $\ldots \quad+$. & $\ldots$ & 3,200 & 235,032 \\
\hline$\$ 13$ & & & & $\cdots$ & & ..... \\
\hline $.1 / 19$ & ..... & 3,200 & 1. & $\therefore$ & & \\
\hline$+/ 26$ & ........ & & $\ldots \ldots$ & $\ldots .$. & & \\
\hline 5) 3 & & & $\ldots .$. & $\ldots$ & 3,200 & \\
\hline $5 / 10$ & $\ldots$ & 3,200 & $n \quad \ldots \ldots$ & $\ldots \ldots=$ & . & \\
\hline $5 / 17$ & & & …............ & .... & …............. & 6,400 \\
\hline $5 / 21$ & & 6,400 & ..... & ....... & 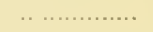 & 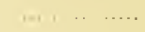 \\
\hline $5 / 31$ & ……...... & 12,800 & ……....... & $\ldots \ldots \ldots \ldots$ & ................ & \\
\hline 6/ 7 & ..... & $\ldots \ldots$ & …........... & 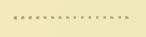 & ....... & ......... \\
\hline (j/ 16 & $\cdots \cdots$ & & …........... & ….............. & $\ldots \ldots \ldots \ldots$ & $\cdots \cdots$ \\
\hline $\begin{array}{l}6 / 21 \\
6 / 25\end{array}$ & $\ldots \ldots$. & $\begin{array}{r}3,200 \\
12,800\end{array}$ & $\cdots 3,200$ & $\ldots \ldots$ & - ........ & ….... \\
\hline $7 / 5$ & $\ldots \ldots$ & 3,200 & & & 3,200 & \\
\hline$\pi / 12$ & ..... & & 6,400 & $\ldots .$. & 555,408 & \\
\hline $7 / 19$ & ...... & 6,400 & $\cdots$ & $\ldots \ldots \ldots$ & 370,272 & \\
\hline $7 / 26$ & ...... & 12,800 & & & 476,064 & \\
\hline S/ 2 & & 25,600 & 12,800 & $\ldots . .$. & 370,272 & \\
\hline $8 / 9$ & ......... & 38,400 & & & 581,856 & \\
\hline $8 / 15$ & ..... & & $\cdots$ & 3,200 & $2,591,904$ & \\
\hline $8 / 23$ & & 19,200 & ...... & & $2,3 \wedge 0,320$ & \\
\hline $8 / 31$ & .... & 12.800 & ........ & 211,584 & $4,347,472$ & 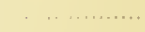 \\
\hline $9 / 6$ & ..... & 64,000 & ….... & ….... & 211,584 & .. \\
\hline $9 / 13$ & & $3 \$, 400$ & $\cdots$ & & 952,128 & \\
\hline $9 / 20$ & ....... & 12,800 & …......... & 105,792 & 317,376 & \\
\hline $9 / 27$ & & 25,600 & & & & \\
\hline $10 / 4$ & $\cdots \cdots$ & & ..... & 105,792 & & \\
\hline $10 / 11$ & & 25,600 & & .................. & 317,376 & \\
\hline $10 / 18$ & 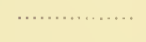 & & ㄷ.......... & $\ldots \ldots \ldots \ldots$ & ... & '. \\
\hline $\begin{array}{l}10 / 26 \\
11 / 1\end{array}$ & ............ & 6,400 & $\ldots \ldots \ldots \ldots \ldots$ & . & $\begin{array}{l}\ldots . . \\
\ldots \ldots\end{array}$ & \\
\hline $11 / 8$ & ................ & & ............ & $\ldots . .$. & & .. . \\
\hline $11 / \mathrm{T}$ & …...... & & & $\ldots$. & 15S,6SS & \\
\hline $11 / 22$ & $\cdots$ & 3,200 & & & 1,600 & \\
\hline 11,30 & $\ldots$. & 3,200 & & 1,600 & & \\
\hline $12 / 6$ & .. & 3,200 & & .... & .. & \\
\hline 1211 & ..... & 3,200 & $=$ & 300 & $\cdots \cdots$ & \\
\hline $12 / 20$ & $\ldots$ & & & 3,200 & 1,600 & 79.344 \\
\hline $12 / 28$ & . & 1,600 & & , n..... & & (3,0, 17 \\
\hline 1913 & $\begin{array}{c}\text { Spiragyra } \\
\text { sp. }\end{array}$ & $\underset{A}{\text { Staurastrum }}$ & $\begin{array}{l}\text { Staurastrum } \\
\text { sp. }\end{array}$ & $\begin{array}{c}\text { Total } \\
\text { Conjugatae }\end{array}$ & $\begin{array}{l}\text { Total } \\
\text { Chlorophyll } \\
\text { bearing }\end{array}$ & $\begin{array}{l}\text { Total } \\
\text { Algine }\end{array}$ \\
\hline $1 / 5$ & 800 & & & 1,600 & $5,814,336$ & $5.913,936$ \\
\hline $1 / 12$ & & & & $1, \$ 00$ & $2,278,20+\frac{1}{4}$ & $2,275,804$ \\
\hline $1 / 13$ & 1,200 & & . & 3,200 & $13,272,3-18$ & $11,005,244$ \\
\hline $1 / 25$ & $19,836 \mathrm{j}$ & & & 21,436 & $3,660,576$ & 2.733 .296 \\
\hline 2/ 2 & $\ldots \ldots$ & & & 1,600 & 13.769 .920 & $12,0+7,440$ \\
\hline $2 / 8$ & & & 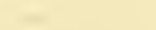 & 23,036 & $16,125,644$ & $13,124,668$ \\
\hline $2 / 1 i$ & $\cdots$ & 6,400 & 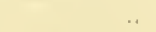 & 12,800 & $8,114,160$ & $5,146,432$ \\
\hline 223 & . & 3,200 & - & 8,000 & $9,711,+336$ & $7,196,124$ \\
\hline $3 / 1$ & . & & & 1,600 & $14,171,618$ & $13,400,944$ \\
\hline $3 / 8$ & $\ldots \ldots$ & 6,100 & . & 9,600 & $11,55,5,5,1$ & $11,348,448$ \\
\hline
\end{tabular}


Table 2.-Organisms Per Cubic Mieter in Plankton of San Joaquin River in 1913-(Continued)

\begin{tabular}{|c|c|c|c|c|c|c|}
\hline 1913 & $\begin{array}{l}\text { Spirogyra } \\
\text { sp. }\end{array}$ & Staurastrum & $\begin{array}{c}\text { Staurastrum } \\
\text { sp. }\end{array}$ & $\begin{array}{c}\text { Total } \\
\text { Conjugatae }\end{array}$ & $\begin{array}{l}\text { Total } \\
\text { Chlorophyll } \\
\text { bearing }\end{array}$ & $\begin{array}{l}\text { Total } \\
\text { Algae }\end{array}$ \\
\hline $3 / 15$ & 1,600 & & & 3,200 & $11,562,384$ & $11,291,504$ \\
\hline $3 / 23$ & 3,200 & & & 11,200 & $10,227,840$ & $9,487,290$ \\
\hline $3 / 29$ & & 3,200 & & 6,400 & $16,907,984$ & $15,208,872$ \\
\hline $4 / 5$ & 3,200 & 1,600 & & 252,432 & $5,806,320$ & $5,957,008$ \\
\hline $4 / 13$ & & & & & $9,506,8+8$ & $9,134,224$ \\
\hline $4 / 19$ & & & & 3,200 & $14,702,392$ & $14,595,000$ \\
\hline $4 / 26$ & & & 1,600 & & $11,812,464$ & $11,634,576$ \\
\hline $5 / 3$ & & & & 6,400 & $8,145,788$ & $7,879,70 \mathrm{~S}$ \\
\hline $5 / 10$ & & & - & 3,200 & $10,720,192$ & $10,508,608$ \\
\hline $5 / 17$ & ........... & $\ldots$ & & 6,400 & $17,202,816$ & $17,074,624$ \\
\hline $5 / 24$ & & & 3,200 & 9,600 & $12,260,192$ & $12,149,000$ \\
\hline $5 / 31$ & & & & 12,800 & $24,202,408$ & $23,197,384$ \\
\hline $6 / 7$ & & & & & $24,771,432$ & $23,8+8,336$ \\
\hline $6 / 16$ & 6,400 & & ...... & 12,800 & $17,315,816$ & $16,754,656$ \\
\hline $6 / 21$ & , & & & 6,400 & $20,548,016$ & $20,261,432$ \\
\hline $6 / 28$ & & 1,600 & & 17,600 & $31,173,494$ & $31,110,998$ \\
\hline $7 / 5$ & ... & 52,896 & 1,600 & 60,896 & $15,355,292$ & $14,671,196$ \\
\hline $7 / 12$ & . & 105,792 & & 667,600 & $30,992,964$ & $29,847,700$ \\
\hline $7 / 19$ & & 12,800 & 3,200 & 392,672 & $58,626,280$ & $52,6+1,128$ \\
\hline $7 / 26$ & $\ldots \ldots$ & 158,688 & 3,200 & 653,952 & $60,00+, 896$ & $52,222,754$ \\
\hline $8 / 2$ & & 6,400 & $423,16 \mathrm{~s}$ & 838,240 & $114,102,658$ & $111,+19,488$ \\
\hline $8 / 9$ & & 476,064 & $105,79^{2}$ & $1,205,292$ & $100,712,962$ & $97,659,996$ \\
\hline $8 / 15$ & & $211,5.84$ & 317,376 & 532,160 & $101,975,404$ & $99,939,656$ \\
\hline $8 / 23$ & ... & 423,169 & $423,16 \mathrm{~S}$ & 865,536 & $214,321,570$ & $210,785,83.4$ \\
\hline $8 / 31$ & & 317,376 & & $5,206,608$ & $196,911,420$ & $193,606,268$ \\
\hline $9 / 6$ & 12,800 & $211,5 \mathrm{St}$ & 317,376 & $817,34 t$ & $226,118,120$ & $221,453,861$ \\
\hline $9 / 13$ & & 740,544 & 10. & $1,836,864$ & $148,511,000$ & $143,032,200$ \\
\hline $9 / 20$ & & $1,057,920$ & 105,792 & $1,599,680$ & 137,1 & $133,713,30 t$ \\
\hline $9 / 27$ & .. & $740,5+t$ & & 766,144 & $90,015,440$ & $85,113,40 \mathrm{~S}$ \\
\hline $10 / 4$ & & $211,5 \mathrm{St}$ & 105 & $423,06 \mathrm{~s}$ & 744 & $82,463,528$ \\
\hline $10 / 11$ & & $211,5.54$ & 105,792 & 660,350 & $1+7,1$ & $1+1,2$ \\
\hline $10 / 18$ & & 105,792 & & 105,792 & 1,960 & $75,340,016$ \\
\hline $10 / 26$ & & ............ & ..... & & $58,621,362$ & $50,145,202$ \\
\hline $11 / 1$ & & & & 6,400 & $29,859,645$ & $25,702,368$ \\
\hline $11 / 8$ & & & & & 9,524 & $10,931,58 t$ \\
\hline $11 / 15$ & & & & 62,688 & 84 & $6,836,096$ \\
\hline $11 / 22$ & $\cdots$ & 1,600 & & 6,400 & 008 & 1.392 \\
\hline $11 / 30$ & & 1,600 & & 9,600 & 8,336 & $18,321,872$ \\
\hline $12 / 6$ & & & & 3,200 & 16,7 & $11,490,384$ \\
\hline $12 / 1 t$ & …........ & 1,600 & & 4,800 & $9,313,272$ & $6,316,648$ \\
\hline $12 / 20$ & & $\ldots$ & & 5,200 & $7,212,112$ & $4,901,536$ \\
\hline $12 / 27$ & & & & $\mathrm{~S} 0,944$ & $6,237,032$ & $5,440,392$ \\
\hline 1913 & $\begin{array}{c}\text { Ceratium } \\
\text { hirundinella }\end{array}$ & $\begin{array}{l}\text { Cereomonas } \\
\text { crassicauda }\end{array}$ & $\begin{array}{c}\text { Chlamydomonas } \\
\text { sp. }\end{array}$ & $\begin{array}{l}\text { Chromulina } \\
\text { sp. }\end{array}$ & $\begin{array}{l}\text { Dinobryon } \\
\text { sertularia }\end{array}$ & $\begin{array}{l}\text { Eudorina } \\
\text { elegans }\end{array}$ \\
\hline $1 / 5$ & $\ldots \ldots \ldots \ldots$ & .... & $\ldots \ldots$ & 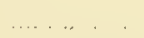 & & 400 \\
\hline $1 / 12$ & & $\ldots$ & ....... & & & 2,800 \\
\hline $1 / 19$ & .. & ..... & …….... & $2,228,24 t$ & & 2,000 \\
\hline $1 / 25$ & ..... & & & 826,500 & & 800 \\
\hline $2 / 2$ & & & & $1,428,192$ & & 30,800 \\
\hline $2 / 8$ & 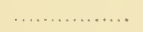 & & & $2,962,176$ & & 22,400 \\
\hline $2 / 15$ & & & & $2,856,384$ & & 19,200 \\
\hline $2 / 23$ & & & & $2,300,976$ & & 158,688 \\
\hline $3 / 1$ & & & & 740,544 & & 22.400 \\
\hline $3 / 8$ & ............ & ... & & 52,896 & & 28,800 \\
\hline $3 / 15$ & $\ldots . \quad \ldots$ & .. & & 52,896 & 1,600 & \\
\hline $3 / 23$ & …............. & ........ & & 290,928 & & 158,685 \\
\hline $\begin{array}{l}3 / 29 \\
4 / 5\end{array}$ & & & & $\begin{array}{l}978,576 \\
105,792\end{array}$ & 3,200 & $\begin{array}{r}502,512 \\
6,400\end{array}$ \\
\hline $4 / 13$ & & & & $15 \mathrm{~S}, 6 \mathrm{~s}$ & & 25,600 \\
\hline
\end{tabular}


Table 2.-Omcianishe Per Cubic Mhtele in Plankton of san Joagrin lRiver in 1913-(Contimued)

\begin{tabular}{|c|c|c|c|c|c|c|}
\hline 1913 & $\begin{array}{l}\text { Ceratiun } \\
\text { hirundinella }\end{array}$ & $\begin{array}{l}\text { Cereomonas } \\
\text { crassicauda }\end{array}$ & $\begin{array}{c}\text { Chamyelomonas } \\
\text { sp. }\end{array}$ & $\begin{array}{l}\text { Chromulina } \\
\text { sp. }\end{array}$ & $\begin{array}{l}\text { Dinobryon } \\
\text { sertuliria }\end{array}$ & $\begin{array}{l}\text { Eudorina } \\
\text { elegans }\end{array}$ \\
\hline+19 & …. . & . & & & & 3,200 \\
\hline 426 & . . . . . & . & ........ & 52,496 & & $1(i,() \times)$ \\
\hline 5) 3 & 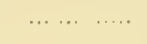 & & .. & . . & & \\
\hline $\begin{array}{ll}5 & 10 \\
5 & 17\end{array}$ & .... & .. & $\ldots \ldots \ldots$ & $3 \cdot 200$ & $\begin{array}{l}15 \mathrm{~s}, 0 \mathrm{~s} \\
10 \mathrm{~s}\end{array}$ & 6.200 \\
\hline $5 / 24$ & $\ldots$ & & 105,792 & 5,200 & 12,800 & $\begin{array}{l}0,-400 \\
3,200\end{array}$ \\
\hline $5 / 31$ & & $\ldots \ldots$ & $1 \ldots \ldots$ & .. & & \\
\hline b/ 7 & 12,400 & ..... &.$\quad \ldots$ & 105,792 & 12,800 & 51,200 \\
\hline $6 / 16$ & 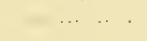 & ...... & ...... & $2(i \cdot 1,4 \leqslant 0$ & 155,655 & 25,6000 \\
\hline $6 / 21$ & $\ldots$ & n....... & $\ldots .$. & 158,685 & 3,200 & $(i 1,000$ \\
\hline $6 / 28$ & ........ & …... & -. & $\cdots$ & .............. & 3.200 \\
\hline $7 / 5$ & $1.6 \mathrm{i} 00$ & ...... & $\cdots$ & $5.5 .5,40 \mathrm{~S}$ & , ..... & 105,792 \\
\hline $7 / 12$ & $1,(1) 00$ & .. & . & $555,40 \mathrm{~S}$ & n............. & 502,512 \\
\hline $\begin{array}{l}7 / 19 \\
7 \\
26\end{array}$ & & 3,300 & . & $5,818,560$ & (n............ & 41,500 \\
\hline $\begin{array}{l}7 / 26 \\
8 / 2\end{array}$ & & 3,200 & & $6,823,551$ & & 317,376 \\
\hline & $(i, 400$ & $\ldots \ldots$ & $\begin{array}{r}3,200 \\
\quad \ldots\end{array}$ & $2,010,048$ & ........ & 105,792 \\
\hline $\begin{array}{ll}8 & 9 \\
8 & 15\end{array}$ & & … & $\cdot \quad \ldots$ & $1,057,920$ & ... & $1,481,088$ \\
\hline $\begin{array}{l}815 \\
8 \quad 23\end{array}$ & & ......... & & $1,481,0 \leq 8$ & & 6,400 \\
\hline & {$[2,800$} & $\ldots \ldots$ & $\begin{array}{r}3,200 \\
317,376\end{array}$ & $3,067,968$ & ... .. & 19,200 \\
\hline $\begin{array}{l}8 / 31 \\
9 / 6\end{array}$ & & & 317,376 & $2,641,800$ & ..... & \\
\hline $9 / 13$ & 25,600 & & $-1-$ & $3,80,5,512$ & & $211,5.5$ \\
\hline $9 / 20$ & & 105,792 & & $4,2+1,680$ & $\ldots$ & $38,-400$ \\
\hline 927 & . 1. & $\ldots \ldots$ & 105,792 & $\begin{array}{l}2,611,800 \\
+317+72\end{array}$ & & 38,400 \\
\hline $10 / 4$ & & $\ldots \ldots$ & (10, & $\begin{array}{l}4,346,462 \\
7,058,064\end{array}$ & & $\begin{array}{l}12,800 \\
7-6000\end{array}$ \\
\hline 1011 & $\cdots$ & $\ldots \ldots$ & -1. & $5,153,808$ & & $\begin{array}{l}25,600 \\
25,600(0)\end{array}$ \\
\hline $101 \mathrm{~s}$ & $\ldots$ & $\ldots . \quad \ldots \ldots$ & . & $7,722,816$ & & 21,1000 \\
\hline $10 / 26$ & . & $, \ldots, \ldots \ldots$ & ... . & $8,251,776$ & & 105,792 \\
\hline $11 / 1$ & ...... $\quad \ldots$ & $\ldots \ldots$ & ... & $3,91+, 301$ & 6,400 & 105,792 \\
\hline $11 / S$ & $\ldots \ldots \ldots \ldots$ & $\ldots \ldots$ & , n.............. & $2,962,176$ & 105,792 & 52,896 \\
\hline $11 / 15$ & …............ & $, 1,1, \ldots \ldots$ & n............... & $3,914,304$ & .......... & 52,596 \\
\hline $11 / 22$ & $\ldots \ldots \ldots$ & .............. & .............. & $6,717,792$ & 132,240 & 3,200 \\
\hline $11 / 30$ & . $\ldots \ldots . .$. & …............. & n.............. & $4,231,680$ & & 52,896 \\
\hline $12 / 6$ & … $\ldots \ldots \ldots \ldots$ & $\ldots \ldots \ldots \ldots \ldots$ & n.............. & $5,1 \mathrm{~s} 3,80 \mathrm{~S}$ & 1,600 & 12,800 \\
\hline $12 / 14$ & . & ............... & $\ldots \ldots \ldots+\ldots, \ldots$ & $2,958,62 \pm$ & ......... & 3,200 \\
\hline $12 / 20$ & 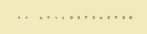 & & n............. & $2,112,288$ & ............... & 3,200 \\
\hline $12 / 27$ & ....... & ............... & n............. & 793,440 & & \\
\hline 1913 & $\begin{array}{l}\text { Euglena } \\
\text { viridis }\end{array}$ & $\begin{array}{l}\text { Flagellate } \\
\text { unidentified }\end{array}$ & $\begin{array}{l}\text { Henidinium } \\
\text { nasutum }\end{array}$ & $\begin{array}{l}\text { Pandorina } \\
\text { morum }\end{array}$ & $\begin{array}{l}\text { Peridinium } \\
\text { cinctum }\end{array}$ & $\begin{array}{l}\text { Phacus } \\
\text { pleuronectes }\end{array}$ \\
\hline $1 / 5$ & . . . n . & $\ldots .$. & (.......... & $\ldots \ldots \ldots$ & $\ldots \ldots \ldots+\ldots, \ldots$ & \\
\hline $1 / 12$ & ................ & n.............. & ............... & ... & ............... & .... \\
\hline $1 / 19$ & n........... & n............ & ............. & 400 & .............. & $\ldots \ldots, \ldots$ \\
\hline $1 / 25$ & ............... & . $\ldots \ldots \ldots \ldots \ldots$ & ................ & 800 & ............... & $\therefore$ \\
\hline $2 / 2$ & 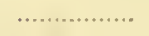 & …............ & …........... & 4,500 & , .......... & $\ldots . \quad \ldots \ldots$ \\
\hline $2 / 8$ & ............... & …............. & …............ & 3,200 & ................ & $\ldots$. \\
\hline $2 / 15$ & ……........ & …........ & $\ldots \ldots \ldots$ & 12,800 & $\ldots$ & $\ldots \ldots \ldots$ \\
\hline $2 / 23$ & n......., & 1,600 & . & 19,200 & $\cdots$ & .......... \\
\hline $3 / 1$ & ................ & 3,200 & n............ & 3,200 & ................ & ................ \\
\hline $3 / 8$ & …............. & …............. & …, & 1,600 & ............... & ......... \\
\hline $3 / 15$ & 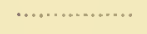 & 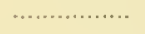 & …........... & 3.200 & …........... & ......... \\
\hline $3 / 23$ & .... ............ & ,............... & ……........ & 79,344 & n......, & .............. \\
\hline $3 / 29$ & …........... & …............. & .......... & 79,344 & n.............. & …... \\
\hline $4 / 5$ & ................ & , & ........... & $3:$ & n........ & \\
\hline $\begin{array}{l}4 / 13 \\
4 / 19\end{array}$ & ……, & ……… & (......... & $\begin{array}{l}3,200 \\
1,600\end{array}$ & (......... & 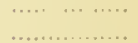 \\
\hline $1 / 26 i$ & ..., & 3,200 & ............... & ............... & & ..... \\
\hline $5 / 3$ & $\ldots$ & 1,600 & ............. & ............... & ……....... & $\ldots \ldots \ldots \ldots$ \\
\hline $5 / 10$ & n............. & $3 \cdot 300$ & (n.......... & $\ldots \ldots \ldots \ldots$ & n.w. & …............. \\
\hline $5 / 17$ & & 3,200 & , n......... & $\cdots$ & (n.............., & .............. \\
\hline
\end{tabular}


Table 2.-Organisus Per Cubic Meter in Plankton of san Joaquin River in 1913-(Continued)

\begin{tabular}{|c|c|c|c|c|c|c|}
\hline 1913 & $\begin{array}{l}\text { Euglena } \\
\text { viridis }\end{array}$ & $\begin{array}{l}\text { Flagellate } \\
\text { unidentified }\end{array}$ & $\begin{array}{l}\text { Hemidinium } \\
\text { nasutum }\end{array}$ & $\begin{array}{l}\text { Pandorina } \\
\text { morum }\end{array}$ & $\begin{array}{l}\text { Peridinium } \\
\text { cinctum }\end{array}$ & $\begin{array}{l}\text { Phacus } \\
\text { pleuronectes }\end{array}$ \\
\hline $5 / 24$ & ..... & $\cdots$ & an...... & 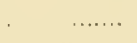 & & $\begin{array}{llll}\ldots & \ldots & \ldots\end{array}$ \\
\hline $5 / 31$ & & ...... & . & & n.............. & $\ldots$. \\
\hline (i) 7 & 211,581 & ....... & .............. & 105,792 & $\ldots \ldots \ldots \ldots$ & ...... \\
\hline $6 / 16$ & 3,200 & .. ... & n............. & 6,400 & $\ldots, \ldots, \ldots, \cdots$ & $\ldots \ldots \ldots \ldots, \ldots$ \\
\hline $6 / 21$ & n........... & , n............ & n..., & 1,600 & …........... & ……, \\
\hline $6 / 28$ & ..... & ...... & ................ & $\ldots .$. & & $\cdots+\cdots$ \\
\hline $\begin{array}{l}7 / 5 \\
7 / 12\end{array}$ & 1,600 & ....... & & 79,344 & $\begin{array}{c}52,890 \\
\ldots \ldots \ldots \ldots\end{array}$ & $\cdots$ \\
\hline $\begin{array}{l}7 / 12 \\
7 / 19\end{array}$ & 1,000 & …. & ……….... & 105,792 & & $\cdots \cdot \cdot$ \\
\hline $7 / 20$ & 105,792 & $\ldots$ & $\ldots \ldots \ldots \ldots \ldots+\ldots$ & 3,200 & 3,200 & …...... \\
\hline $8 / 2$ & 3,200 & w...... & & 6,400 & $\ldots \ldots \ldots, \ldots \ldots$ & $\cdots \cdot$ \\
\hline $\mathrm{S} / 9$ & 3,200 & $\ldots$ & 105,792 & $10.5,792$ & .... & .... \\
\hline $8 / 15$ & 3,200 & $\ldots \ldots$ & 211,584 & $\ldots \ldots$ & 3,200 & n..., \\
\hline $8 / 23$ & 6,400 & ....... & 105,792 & $\ldots \ldots, \quad \ldots \ldots$ & ................. & ................ \\
\hline $\begin{array}{l}8 / 31 \\
9 / 6\end{array}$ & $\cdots$ & $\cdots$ & . . $\quad \ldots, \ldots$ & 12,800 & (n.... & an. \\
\hline $9 / 13$ & & $\cdots$ & 211,584 & & & $\ldots$ \\
\hline $9 / 20$ & & $\ldots \ldots$ & 105,792 & 105,792 & . & (....... \\
\hline $9 / 27$ & & & & . & & $\ldots \ldots$ \\
\hline $\begin{array}{l}10 / 4 \\
10 / 11\end{array}$ & 105,792 & $\cdots \cdots$ & 211,584 & 1,1 & 105,792 & ......... \\
\hline $\begin{array}{l}10 / 11 \\
10 / 18\end{array}$ & 105,792 & $\ldots$ & $\begin{array}{l}211,054 \\
528,960\end{array}$ & $\begin{array}{ll}\ldots & \cdots \\
\ldots & \ldots\end{array}$ & $\cdot \quad \cdots$ & ….......... \\
\hline $10 / 26$ & ….... & ........ & & $\cdots \cdot \cdot$ & …… & $\ldots \ldots \ldots \ldots$ \\
\hline $11 / 1$ & ................ & $\ldots \ldots$ & n............ & 6,400 & 52,896 & $\cdots$ \\
\hline $11 / 8$ & w...... & ..... & , & & & 52,896 \\
\hline $\begin{array}{l}11 / 15 \\
11 / 22\end{array}$ & ........ & $\cdots$ & ……….. & 6,400 & 52,396 & \\
\hline $\begin{array}{l}11 / 22 \\
11 / 30\end{array}$ & & $\begin{array}{l}\cdots \cdots \\
\cdots \cdots\end{array}$ & ………… & 52,896 & $\ldots \ldots+\quad, \ldots \ldots$ & 1,600 \\
\hline $12 / 6$ & & $\begin{array}{l}\cdots \cdots \\
\ldots \cdots\end{array}$ & …, & 52,896 & n............... & $\ldots \ldots \ldots \ldots$ \\
\hline $12 / 14$ & & (n........ & 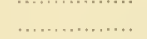 & 3,200 & ………. & n............ \\
\hline $12 / 20$ & 52,596 & ....... & ................ & 6,400 & …, & ………… \\
\hline $12 / 27$ & , ............ & … & $\ldots \ldots \ldots \ldots \ldots+\ldots$ & 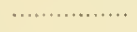 & ............... & ……....... \\
\hline 1913 & $\begin{array}{l}\text { Platydorina } \\
\text { caudata }\end{array}$ & $\begin{array}{l}\text { Pleodorina } \\
\text { californica }\end{array}$ & $\begin{array}{l}\text { Pleodorina } \\
\text { illinoisensis }\end{array}$ & $\begin{array}{c}\text { Pteromonas } \\
\text { sp. }\end{array}$ & $\begin{array}{c}\text { Trachelomonas } \\
\text { enchlora }\end{array}$ & $\begin{array}{c}\text { Trachelomonas } \\
\text { volgensis }\end{array}$ \\
\hline $1 / 5$ & $\ldots \ldots . \quad \ldots$ & , $\quad \ldots \ldots+\ldots$ & 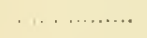 & $\cdots, \quad \cdots \cdots$ & n............ & $\ldots \ldots, \ldots \ldots$ \\
\hline $1 / 12$ & $\ldots, \quad \ldots$ & . $\quad$............ & ................ & . .. $\ldots \ldots \ldots$ & ……........ & ............... \\
\hline $1 / 19$ & '................. & .... $\ldots \ldots \ldots$ & n..., & ................. & 66.120 & 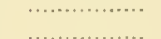 \\
\hline $\begin{array}{l}1 / 20 \\
2 / 2\end{array}$ & ………… & (n..... & ………, & & $00,1-1$ & ……....... \\
\hline $2 / 8$ & ................. & ......... & ................ & ......... & 1,600 & ................. \\
\hline $2 / 15$ & ................ & ................ & …............. & n....... & & ….... \\
\hline $2 / 23$ & ….............. & …........... & ................... & ….... & 52,896 & 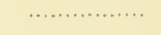 \\
\hline $\begin{array}{l}3 / 1 \\
3 / 5\end{array}$ & ……… & ………... & (............... & $\cdots \cdots$ & & n..., \\
\hline $3 / 15$ & ……….... & 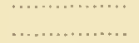 & … & .......... & $\begin{array}{r}132,240 \\
79,341\end{array}$ & ………… \\
\hline $3 / 23$ & .................. & ................... & .................. & ............. & 79,344 & ……1, \\
\hline $3 / 29$ & …........... & ................ & …............. & ................ & 132,240 & …........... \\
\hline $4 / 5$ & …......... & ......... & . & ................. & 52,896 & ….......... \\
\hline $4 / 13$ & 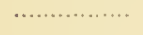 & ............... & , n..., & (.......... & 79,344 & ….............. \\
\hline $4 / 19$ & ................... & ......, & $\ldots \ldots+\cdots, \ldots$ & n.............. & 52,896 & 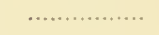 \\
\hline $4 / 26$ & …............. & ………... & n.............. & ........... & & ................ \\
\hline $5 / 3$ & ................. & ............... & ................ & ............ & 132,240 & n......, \\
\hline $5 / 10$ & …........ & ........ & ................. & n............. & 52,896 & ................. \\
\hline $\begin{array}{l}5 / 17 \\
5 / 24\end{array}$ & $\ldots$ & .................... & ……....... & ................ & ..... 3 390 & …............... \\
\hline 531 & 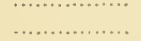 & …..................... & ………… & …...... & 0,200 & …............ \\
\hline $6 / 7$ & ….............. & …........... & …............. & ............... & 211,584 & ................ \\
\hline $6 / 16$ & , & 3200 & ……, & ............... & , $\ldots \ldots \ldots \ldots \ldots$ & $\ldots \ldots \ldots \ldots \ldots$ \\
\hline $6 / 21$ & $\cdots$ & 3,200 & ..... & & , n............ & n..., \\
\hline
\end{tabular}


Table 2.-Organisms Per Cubic Mrater in plankton of SAN Josugun RIVAR 1x 1913-(Cotinued)

\begin{tabular}{|c|c|c|c|c|c|c|}
\hline 1913 & $\begin{array}{l}\text { Platydorina } \\
\text { caudata }\end{array}$ & $\begin{array}{l}\text { Pleodorina } \\
\text { californica }\end{array}$ & $\begin{array}{l}\text { Pleodorinu } \\
\text { illinoisensis }\end{array}$ & $\begin{array}{c}\text { Pteromonas } \\
\text { sp. }\end{array}$ & $\begin{array}{c}\text { Trachedonomas } \\
\text { euchlora }\end{array}$ & $\begin{array}{c}\text { Trachelomonas } \\
\text { volgensis }\end{array}$ \\
\hline ii $/ 28$ & ...... & & $\ldots \ldots \ldots \ldots$ & ..... & …....... . & $\ldots$ \\
\hline $7 / 5$ & ................ & & .......... & .... & $\ldots, \cdots \cdot \cdot, \cdot$ & .. \\
\hline$\frac{7}{7 / 19}$ & ……....... & $\begin{array}{r}3,200 \\
12,500\end{array}$ & $\ldots \ldots \ldots \ldots$ & $\therefore$. & …...... & $\begin{array}{llll}\cdots & \cdots & \cdots & \cdots\end{array}$ \\
\hline$\frac{1}{7 / 30}$ & 6,400 & 158,689 & ............. & $158,68 S$ & . & ${ }^{\prime} \ldots \ldots, \ldots \ldots, \ldots$ \\
\hline $8 / 2$ & 19,200 & $158,6 \mathrm{~s}$ & & , $\quad \ldots \ldots \ldots$ & ....., , , & $\ldots \ldots \ldots$ \\
\hline S/ 9 & $3 \mathrm{~S}, 400$ & 105,792 & 6,100 &...$\quad \ldots \ldots$ & n......... & 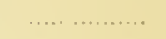 \\
\hline $8 / 15$ & 12,800 & 158,658 & $\ldots, \ldots \ldots \ldots$ & . $\quad \ldots \ldots \ldots \ldots$ & ........ & $\ldots \ldots \ldots \ldots$ \\
\hline $8 / 23$ & 12,500 & 105,792 & .............. & …........... & .............. & $\ldots \ldots \ldots \ldots$ \\
\hline $5 / 31$ & 12,800 & 211,584 & $\ldots \ldots \ldots$ & .. .......... & $\ldots \ldots \ldots \ldots$ & \\
\hline $9 / 6$ & & 89,600 & $\ldots \ldots \ldots \ldots$ & . . .......... & …............. & $10.5,792$ \\
\hline $9 / 13$ & 64,000 & 51,200 & $\ldots \ldots \ldots \ldots \ldots$ & $\ldots \ldots \ldots \ldots \ldots$ & …............. & \\
\hline $9 / 20$ & $\ldots \ldots$ & 12,800 & .. $\ldots \ldots \ldots \ldots$ & $\ldots \ldots, \ldots$ & $\ldots \ldots \ldots \ldots$ & 105,792 \\
\hline $9 / 27$ & 12,800 & & . . ........ & ......... & …... & \\
\hline $10 / 4$ & & 12,500 & $\ldots \ldots$ & $10=-00$ & $\ldots \ldots \ldots$ & 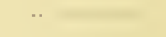 \\
\hline $\begin{array}{l}10 / 11 \\
10 / 18\end{array}$ & . $\ldots \ldots+\ldots, \ldots$ & .. & …… & $10 i 3,62$ & . . . & 105,792 \\
\hline $10 / 26$ & & 12,800 & …...... & $\cdot \quad, \quad \ldots$ & … & \\
\hline $11 / 1$ & 6,400 & 6,400 & $\ldots$ & $\ldots, \quad \ldots$ & $\ldots \ldots, \quad \ldots \ldots$ & \\
\hline $11 / 8$ & (n... & $\begin{array}{l}\ldots \\
\cdots \\
\ldots\end{array}$ & $\begin{array}{r}6,400 \\
\ldots \ldots \ldots\end{array}$ & , & $\ldots \ldots \ldots, \ldots$ & . \\
\hline $11 / 22$ & n $\quad \ldots . .$. & $\ldots \ldots \ldots$ & $\ldots \ldots \ldots$ & . & 1,600 & 1,600 \\
\hline $11 / 30$ & $\cdots$ & ............ & ,.............. & & $.-1-$ & 105,792 \\
\hline $12 / 6$ & $\ldots$. & n....... & , & $\cdots$ &,$\quad .$. & \\
\hline $12 / 14$ & . & $\ldots \ldots \ldots \ldots \ldots$ & $\ldots \ldots \ldots$ & $\cdots$ & . & $\cdots$ \\
\hline $12 / 20$ & & 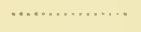 & $\cdots \quad \ldots, \ldots$ & … & · & $\ldots$. \\
\hline $12 / 26$ & 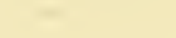 & …........... & $\ldots \ldots \ldots, \ldots$, & 1,600 & $\cdots \cdots$ & $\cdots \cdots$ \\
\hline 1913 & $\begin{array}{c}\text { Trachelomonas } \\
\text { volvocina }\end{array}$ & $\begin{array}{l}\text { Iolvox } \\
\text { aureus }\end{array}$ & $\begin{array}{c}\text { Total } \\
\text { Mastigophora }\end{array}$ & $\begin{array}{l}\text { Amocba } \\
\text { pruteus }\end{array}$ & $\begin{array}{l}\text { Amoeba } \\
\text { radiosa }\end{array}$ & $\begin{array}{l}\text { Arcella } \\
\text { vulgaris }\end{array}$ \\
\hline $1 / 5$ & $\ldots \ldots$ & $\ldots \ldots \ldots \ldots$ & 400 & ... . & . . & $. \quad+\quad, \ldots$ \\
\hline $1 / 12$ & & ....... & 2,800 & .. & ...... . . & $\ldots \ldots \ldots$ \\
\hline $1 / 19$ & 33,060 & ................... & $2,264,104$ & & ....... & $\ldots . \quad \ldots$. \\
\hline $1 / 25$ & 33,060 & .............. & 927,280 & .. & $\ldots \ldots$ & $\ldots \ldots \ldots, \quad \ldots \ldots$ \\
\hline$\because / 2$ & 79,344 & & $1,622,480$ & ... . . & ............... & $\ldots \ldots \ldots$ \\
\hline $2 / 8$ & 1,600 & ............... & $3,000.976$ & . . & $\ldots \ldots \ldots$ & $-\ldots \ldots \ldots$ \\
\hline $2 / 15$ & 79,344 & $\ldots \ldots, \ldots \ldots \ldots$ & $3,025,528$ & ......... & . . . .......... & $, \quad, \quad,$. \\
\hline $2 / 23$ & 52,896 & ............... & $2,592,656$ & . $\ldots \ldots$ & ............. & $\ldots, \quad \ldots \ldots$ \\
\hline $3 / 1$ & 1,600 & …........... & $770,9+4$ & $.1 \ldots . .$. & $\ldots \ldots$ & $\ldots \quad, \ldots$ \\
\hline $3 / 8$ & & ......... & 217,136 & & $\ldots \ldots \ldots \ldots$ & .. $\quad-$. \\
\hline $3 / 15$ & 132.240 & . . ........... & $270,8,60$ & & $\ldots \ldots$ & . .. \\
\hline $3 / 23$ & 185,136 & $\ldots \ldots \ldots$ & 793,440 & & . & $\cdot \quad \ldots$ \\
\hline 3.29 & 1,600 & . & $1,699,072$ & 3.200 & . $\quad \ldots . .$. & . 1 . \\
\hline$t^{\prime} 5$ & & $\ldots \ldots$ & 160,6 SS & 3.200 & & \\
\hline+13 & 105,792 & $\ldots \ldots$ & 372,624 & . & : & 1.600 \\
\hline $1 / 19$ & $52,5(36$ & .... & 107,392 & - & & \\
\hline $4 / 26$ & 105,792 & ... & 177, SSS & 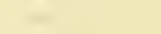 & 52,596 & 3,200 \\
\hline $5: 3$ & (1) & . $\quad \ldots$ & 266,050 & & . & $\ldots$ \\
\hline $5 / 10$ & 1,600 & $\ldots \ldots$ & 211,584 & - & &.$\quad \cdot$. \\
\hline 517 & 105,792 & . ... & 131,392 & - & 3,200 & ........... \\
\hline $5 / 24$ & & $\ldots$ & 112,192 & . & . &.$\quad \ldots \quad \ldots$ \\
\hline $5 / 31$ & 317,376 & & $1,005,024$ & 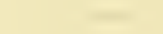 & ...... & 10 \\
\hline $6 / 7$ & 317,376 & ... & $1,028,858$ & & .. .. & 12,500 \\
\hline 616 & $10.5,792$ & 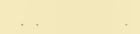 & 564,160 & & ... & . . \\
\hline $6 / 21$ & $: 2,896$ & & $2 \times 3,5 \times 1$ & $-1-$ & $\ldots \ldots$ & ... \\
\hline $6 / 25$ & 52,896 & & 62,496 & & $\ldots$ & 3,200 \\
\hline $7 / 5$ & & & 714.096 & 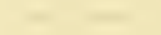 & . .. & $\ldots$ \\
\hline $7 / 12$ & 1,600 & & $1,145,26.1$ & & . & $\ldots \quad \ldots$ \\
\hline $7 / 19$ & $3,200)$ & & $5,9 S 5,152$ & - & - & ............ \\
\hline $7 / 26$ & $211,35 t$ & 25,600 & $7 \mathrm{~s} 07,712$ & $\ldots \quad \ldots$ & & $\cdots \cdots \cdots$ \\
\hline
\end{tabular}


Table 2.-Organisis Per Cubic Meter in Plankton of San Joaquin River in 1913-(Continued)

\begin{tabular}{|c|c|c|c|c|c|c|}
\hline 1913 & $\begin{array}{c}\text { Trachelomonas } \\
\text { volvocina }\end{array}$ & $\begin{array}{l}\text { Volvox } \\
\text { aureus }\end{array}$ & $\begin{array}{c}\text { Total } \\
\text { Mastigophora }\end{array}$ & $\begin{array}{l}\text { Amoeba } \\
\text { proteus }\end{array}$ & $\begin{array}{l}\text { Amoeba } \\
\text { radiosa }\end{array}$ & $\begin{array}{l}\text { Arcella } \\
\text { vulgaris }\end{array}$ \\
\hline $8 / 2$ & , . & 12,800 & $2,696,000$ & & & \\
\hline $8 / 9$ & & 6,400 & $3,029,366$ & & & .......... \\
\hline $5 / 15$ & $158,6 \mathrm{~s}$ & & $2,035,748$ & 3,200 & & \\
\hline $\mathrm{S} / 23$ & 264,480 & 6,400 & $3,644,92 \mathrm{~s}$ & 528,960 & & \\
\hline $8 / 31$ & 423,168 & …....... & $3,622,528$ & & & .... \\
\hline $9 / 6$ & 317,376 & & $4,664,256$ & 211,594 & & \\
\hline $9 / 13$ & 740,544 & 12,800 & $5,491,600$ & $\cdots$. & & \\
\hline $9 / 20$ & 317,376 & ........... & $3,436,544$ & $\cdots \cdots$ & $211,5 \mathrm{st}$ & \\
\hline $9 / 27$ & 423,165 & & $4,902,032$ & .... & . & \\
\hline $10 / 4$ & 528,960 & .............. & $7,761,216$ & & .. & \\
\hline $10 / 11$ & 423,165 & $\ldots \ldots$ & $5,959,952$ & $\ldots \ldots$ & 105,792 & \\
\hline $10 / 18$ & 317,376 & $\cdots$ & $8,780,736$ & .. & & \\
\hline $10 / 26$ & $211,5 \mathrm{S4}$ & $\ldots .$. & $8,581,952$ & & 12.800 & \\
\hline $11 / 1$ & 158,688 & ….............. & $4,157,2 \varsigma 0$ & . & 52,896 & \\
\hline $11 / 8$ & 211,584 & $\ldots \ldots$ & $3,43 \mathrm{~S}, 240$ & .. & & \\
\hline $11 / 15$ & 105,792 & ….... & $4,281,184$ & & 158,688 & $-\quad$ \\
\hline $11 / 22$ & 158,688 & $\ldots \ldots$ & $7,096,616$ & 3,200 & .............. & $-\quad-$ \\
\hline $11 / 30$ & 52,896 & $\ldots \ldots$ & $4,446,464$ & $\ldots$. & n......... & $\begin{array}{ll}. & \ldots\end{array}$ \\
\hline $12 / 6$ & 79,344 & $\ldots$ & $5,277,552$ & $\cdots$ & ..... & .. \\
\hline $12 / 14$ & 1,600 & ......... & $2,996,624$ & ......... & & . . - \\
\hline $12 / 20$ & 52,896 & ......... & $2,310,576$ & n............. & 1,600 & $\ldots \ldots \ldots$ \\
\hline $12 / 27$ & $1,+00$ & 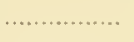 & 796,640 & (n) & ,....... & ......... \\
\hline 1913 & $\begin{array}{l}\text { Cyphoderia } \\
\text { ampulla }\end{array}$ & $\begin{array}{l}\text { Difflugia } \\
\text { corona }\end{array}$ & $\begin{array}{l}\text { Difflugia } \\
\text { pyriformis }\end{array}$ & $\begin{array}{c}\text { Hyalodiscus } \\
\text { sp. }\end{array}$ & $\begin{array}{l}\text { Microg-usuia } \\
\text { socialis }\end{array}$ & $\begin{array}{c}\text { Total } \\
\text { Rhizopoda }\end{array}$ \\
\hline $1 / 5$ & $\ldots \ldots \ldots$ & $\cdots \cdots$ & $\ldots \ldots \ldots, \ldots$, & $\cdots \cdots$ & $\ldots \ldots \ldots+\ldots$ & . . $\ldots \ldots \ldots, \quad, \cdots$ \\
\hline $1 / 12$ & .............. & ... & …….... & $\ldots \ldots \ldots$ & ................ & $\ldots \ldots \ldots \ldots$ \\
\hline $1 / 19$ & ......... & . & ton & $\ldots$ & . & 100 \\
\hline $1 / 25$ & . ........... & ................ & 400 & .. & …......... & 400 \\
\hline $2 / 2$ & (n............ & n., & 1,600 & ........ & …............. & 1,600 \\
\hline $2 / 8$ & ................. & ................. & 1,600 & $\cdots$ & …........... & 1,600 \\
\hline $2 / 15$ & . . ............ & $\ldots \ldots \ldots, \ldots$ & 12,800 & & & 12,800 \\
\hline $2 / 23$ & ……, & ................ & 19,200 & $\ldots+\ldots$ & 79,341 & 98,544 \\
\hline $3 / 1$ & ….......... & $\ldots \ldots \ldots$ & 3,200 & & $\ldots$ & 4,800 \\
\hline $\begin{array}{l}3 / 8 \\
3 / 15\end{array}$ & …, & $\cdots$ & 9,600 & & $\cdots$ & 12,800 \\
\hline $\begin{array}{l}3 / 15 \\
3 / 23\end{array}$ & ……........ & …...... & … $\quad \ldots$ & .. & n..., & … i \\
\hline $\begin{array}{l}3 / 23 \\
3 / 29\end{array}$ & 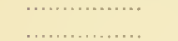 & ... & .. & & ….......... & 1.600 \\
\hline $\begin{array}{l}3 / 29 \\
4 \quad 5\end{array}$ & & & & & . & 3,200 \\
\hline $\begin{array}{l}4 / 5 \\
4 / 13\end{array}$ & & $\cdots$ & 6,400 & ........ & ,.................. & 16,000 \\
\hline $\begin{array}{l}4 / 13 \\
4 / 19\end{array}$ & 52,896 & & 6,400 & $\cdots$ & $\ldots \ldots+\ldots$ & 8,000 \\
\hline $\begin{array}{l}4 / 19 \\
+/ 26\end{array}$ & $\begin{array}{r}02,090 \\
\ldots . . .\end{array}$ & & 79,344 & & n......... & $132.2+0$ \\
\hline $\begin{array}{l}4 / 26 \\
5 / 3\end{array}$ & $\begin{array}{cc}\ldots & \cdot \\
\ldots \ldots \ldots & \cdots \\
\ldots \ldots\end{array}$ & ........... & 32,000 & ......... & …n..., & \$\$, 096 \\
\hline $5 / 10$ & $\begin{array}{l}\ldots \ldots \ldots \\
\ldots \ldots \ldots \\
\ldots \ldots \ldots\end{array}$ & (n........ & ........... & 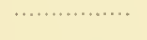 & $\ldots \ldots \ldots \ldots, \ldots$ & , n....... \\
\hline $5 / 17$ & ............. & ........... & 19,200 & $\begin{array}{l}\cdots \\
\cdots\end{array}$ & .. & 22,400 \\
\hline $5 / 24$ & .............. & ............ & 6,400 & ... & ........... & 6,400 \\
\hline $5 / 31$ & & ... & 634,752 & ......... & ............... & 634,752 \\
\hline $6 / 7$ & 12,500 & …........... & 793,440 & … & ....... & 104,944 \\
\hline $6 / 1 ;$ & .......... & …............ & 158,685 & …............ & & $1.58,6 \mathrm{SS}$ \\
\hline $1 / 21$ & .......... & .............. & $211,5 \mathrm{S4}$ & $\ldots \ldots \ldots$ & ….......... & 211,584 \\
\hline $6 / 28$ & .......... & .... & 185,136 & 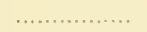 & $\ldots \ldots$ & 189,936 \\
\hline $7 / 5$ & & $\ldots \ldots \ldots$ & $15 \mathrm{~S}, 6.5 \mathrm{~S}$ & 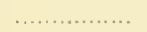 & $\cdots$ & 158,685 \\
\hline $7 / 12$ & 3,200 & $\ldots$. & 132,240 & 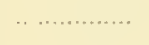 & 1,600 & 146,640 \\
\hline $7 / 26$ & $\begin{array}{lll}. . & \cdots & \ldots \\
\ldots & \ldots & \ldots\end{array}$ & & 12,800 & & $1586 \mathrm{SS}$ & $\begin{array}{r}3,200 \\
171,458\end{array}$ \\
\hline $8 / 2$ & $\begin{array}{llll}\cdots & \cdots & \ldots & \ldots \\
\cdot & \ldots & \ldots\end{array}$ & $\cdots$ & 6,400 & & $15 \mathrm{~S}, 6 \mathrm{SS}$ & 168,258 \\
\hline $8 / 9$ & $\ldots \ldots \ldots \ldots$ & & & & & 3,200 \\
\hline $8 / 15$ & …........... & 6,400 & 19,200 & 3,200 & 105,792 & 131,392 \\
\hline $\begin{array}{l}8 / 23 \\
S / 31\end{array}$ & …......... & & 1 & & 155,658 & $1,189,312$ \\
\hline $\mathrm{S} / 31$ & .............. & 12,800 & 105,792 & 317,376 & $211,5 \mathrm{S1}$ & 647,552 \\
\hline
\end{tabular}


Tamle 2.-Organisms l'en Cubic Meter in P'lanktox of SAN JoAQtun Rrvir in 1913-(Continued)

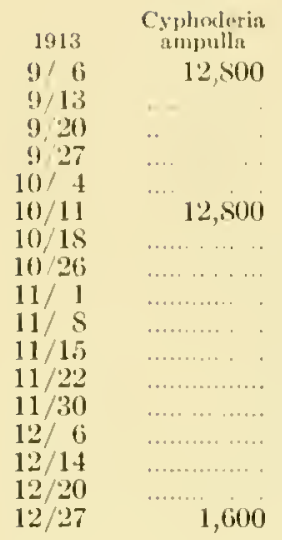

1913

$1 / 5$

$1 / 19$

$1 / 25$

2/ 2

$2 / 15$

$2 / 23$

$3 / 1$

$3 / 8$

$3 / 15$

$3 / 23$

$3 / 29$

$4 / 5$

$4 / 13$

$4 / 19$

$4 / 26$

$5 / 3$

$5 / 10$

$5 / 17$

$5 / 24$

$5 / 31$

6/ 7

$6 / 16$

$6 / 21$

6i/28

$7 / 5$

$7 / 12$

$7 / 19$

$7 / 26$

$8 / 2$

$8 / 9$

$8 / 15$

$8 / 23$

S/31

$9 / 6$

9/13

$9 / 20$

$9 / 27$

Actinophrys

… ............
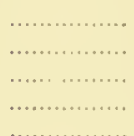

…..............
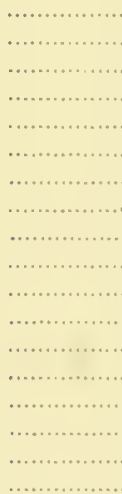

12,800
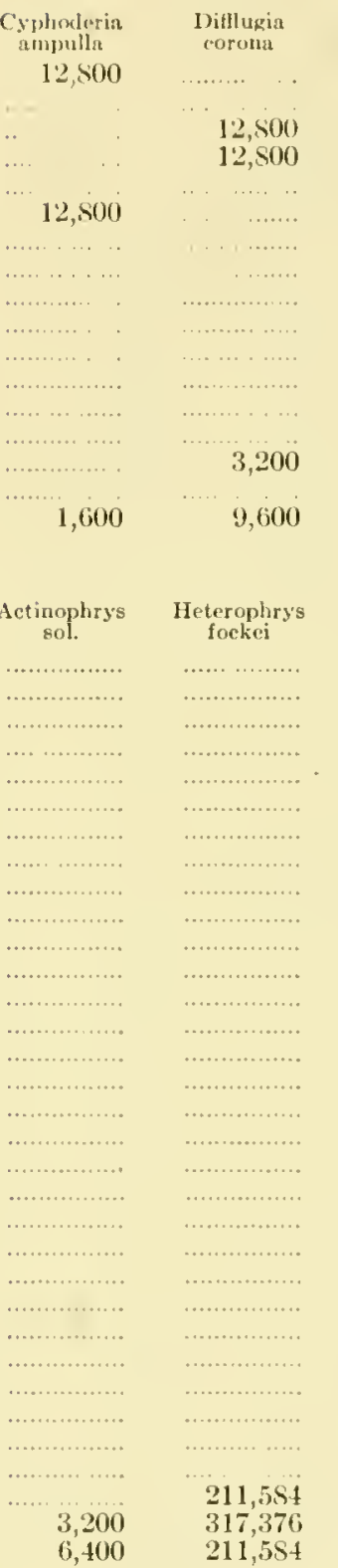

211,581

Heterophrys
fockei

Heterophrys fockei
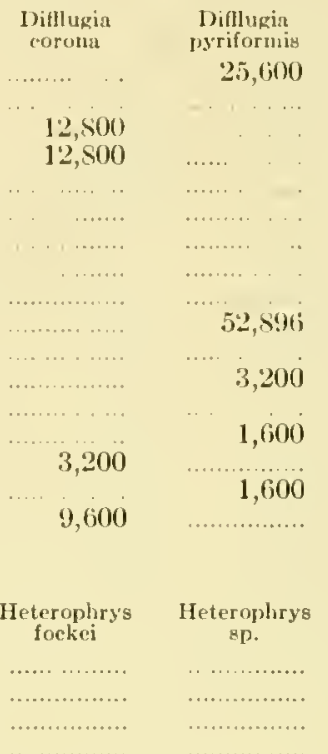

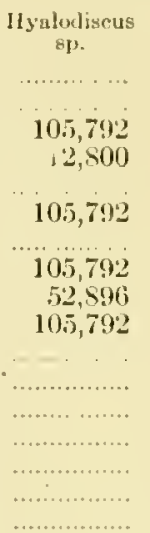

Microgromia socialis 317,376 211,584

$10.5,792$ S.16,336 $10,5,792$ 211,584 211,581 52,896

$\ldots \ldots \ldots \ldots$
$\ldots \ldots \ldots$
$\ldots \ldots \ldots \ldots$
$\ldots \ldots \ldots \ldots$
$\ldots \ldots \ldots \ldots$
$\ldots \ldots \ldots \ldots$
$\ldots \ldots \ldots \ldots$
$\ldots \ldots \ldots \ldots$
$\ldots \ldots$

Total Rhizopoda 567,360 211,584 330,176 131,392 846,336 330,176 $211,5 \mathrm{~S} .1$ 330,176 $15,6,68$ $211,5 \times 4$ $1.58,6$ S 6,400 1,600 3,200 3,200 11,200

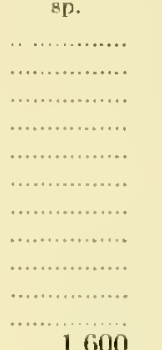
simplex

Pinaciophora fluviatilis

Raphidiophrys elegans
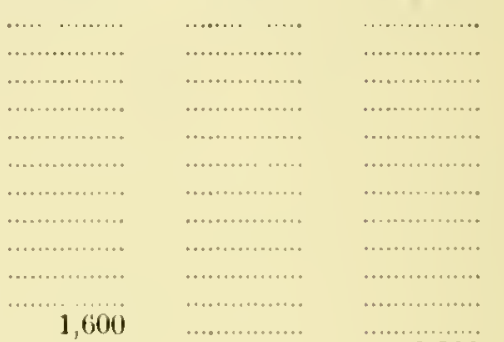

3,200
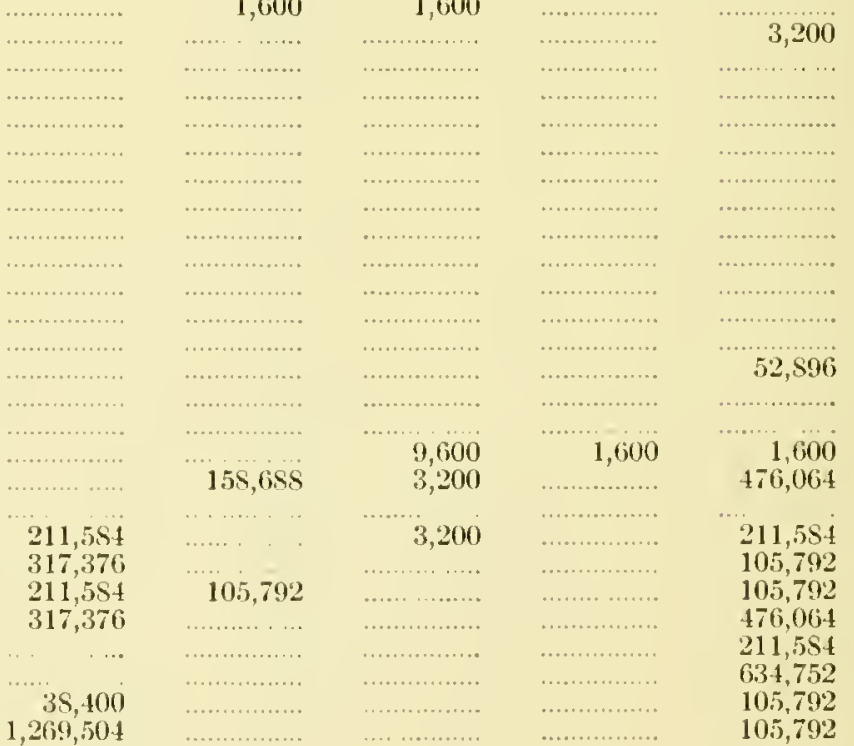
$1,269,504$ $10,792 \quad 1,4 \mathrm{S1}, 0 \mathrm{sS}$ 
Table 2.-Organisms Per Cubic Meter in Plankton of San Joaquin River in 1913--(Continued)

1913
$10 / 4$
$10 / 11$
$10 / 18$
$10 / 26$
$11 / 1$
$11 / 8$
$11 / 15$
$11 / 22$
$11 / 30$
$12 / 6$
$12 / 14$
$12 / 20$
$12 / 27$

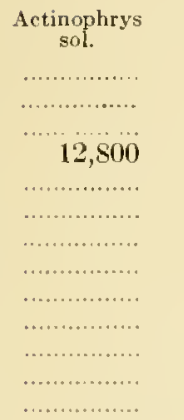

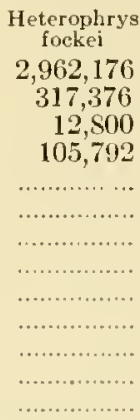

Total
Heliozoa

1913

$1 / 12$

$1 / 19$

$1 / 25$

$2 / 2$

$2 / 8$

$2 / 15$

$2 / 23$

$3 / 1$

$3 / 8$

$3 / 15$

$3 / 23$

$3 / 29$

$4 / 5$

$4 / 13$

$4 / 19$

$4 / 26$

$5 / 3$

$5 / 10$

$5 / 17$

$5 / 24$

$5 / 3$ ?

6) 7

$6 / 16$

$6 / 21$

$6 / 28$

$7 / 5$

$7 / 12$

$7 / 19$

$7 / 26$

S/ 2

S/ 9

$\mathrm{S} / 15$

$8 / 23$

$8 / 31$

$9 / 6$

$9 / 13$

$9 / 20$

$9 / 27$

$10 / 4$

$10 / 11$

$10 / 18$

$10 / 26$
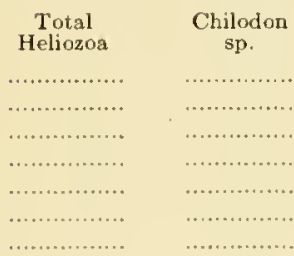

...............

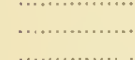

1600

3,200
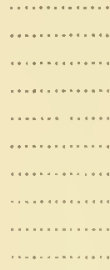

52,896

3,200

476,064

423,168

$426,36 \mathrm{~s}$

429,568

317,376

$211,58 t$

634,752

144,192

$1,385,096$

$1,586,880$

$2,962,176$

$1,586,880$

435,968

105,792
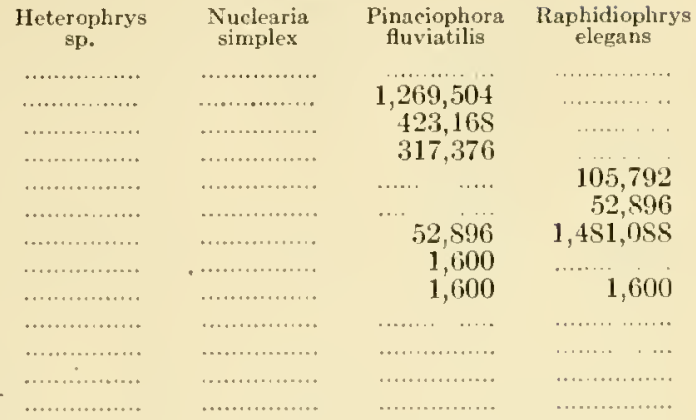

\begin{tabular}{|c|c|}
\hline $\begin{array}{c}\text { Ciliate } \\
\text { unidentifie }\end{array}$ & $\begin{array}{l}\text { Coleps } \\
\text { hirtus }\end{array}$ \\
\hline
\end{tabular}

Cyelidium sp.

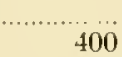

400

1,600

6,400

1,600

6,400

79,344

1,600

1,600

185,136

105,792
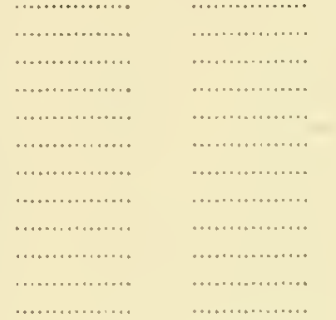

3,200

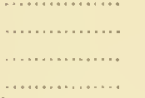

\section{...............}
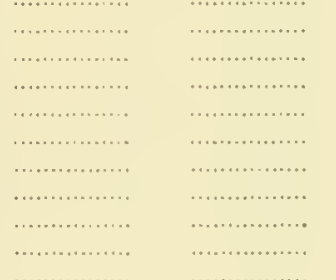

Epistylis sp.

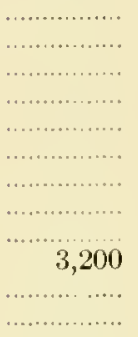

3,200

12,800

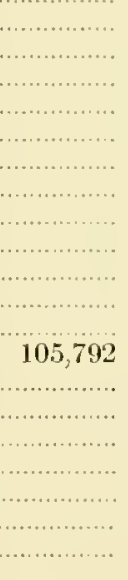

\section{.}

105,792

3,200

105,792

105,792

105,792

105,792 
Table 2.-Organjsms l'er Cribic Meter in Planh́ton of Sax Joaquix River ix 1913-(Continued)

1913
$11 / 1$
$11 / 8$
$11 / 15$
$11 / 22$
$11 / 30$
$12 / 6$
$12 / 11$
$12 / 20$
$12 / 27$

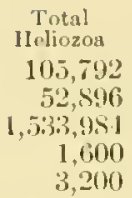

$3 / 29$

$4 / 5$

413

$4 / 19$

$4 / 26$

$5 / 3$

$5 / 10$

$5 / 17$

$5 / 21$

5) $/ 3$ ]

6) 7

6 $/ 10$

6 21

$6 / 25$

$7 / 5$

$7 / 12$

$7 / 19$

$7 / 20$

S/2

(j) ?

$8 / 15$

S/23

$8 / 31$

9) 6

() $/ 13$

$9 / 20$

9/27

$10 / 4$

$10 / 11$

] $0 / 1 \mathrm{~S}$

11) 26

$11 / 1$

11/ 8

1115

$11 / 22$

..........

400

6, 400

12,500

3,200

3,200

3,200

Holophry: sp.

Paramecium aurelia

Parameriu bursaria

Prorndon sp.

3,200

16,000

3.200

....
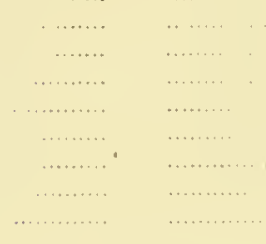

12,800

$52,5 ! 0$

105,792

$105,79^{\circ}$ 
Table 2.-Organisis Per Cubic Meter in Plankton of SAN JoAqUiN RIVER in 1913-(Continucd)

\begin{tabular}{|c|c|c|c|c|c|c|}
\hline 1913 & $\begin{array}{c}\text { Euplotes } \\
\text { harpa }\end{array}$ & $\begin{array}{c}\text { Euplotes } \\
\text { patella }\end{array}$ & $\begin{array}{l}\text { Holophrya } \\
\text { sp. }\end{array}$ & $\begin{array}{l}\text { Paramecium } \\
\text { 2urelia }\end{array}$ & $\begin{array}{l}\text { Paramecium } \\
\text { bursaria }\end{array}$ & $\begin{array}{l}\text { Prorodon } \\
\text { sp. }\end{array}$ \\
\hline $11 / 30$ & & & & & $\cdots$ & \\
\hline $12 / 6$ & 52,896 & ....... & 1,600 & & . & .. \\
\hline $\begin{array}{l}12 / 14 \\
12 / 00\end{array}$ & 3,200 & .................... & 1,600 & 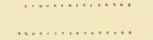 & .... ……… & ..... \\
\hline $12 / 27$ & $\ldots \ldots$ & .................... & ...... & .................... & …............ & \\
\hline 1913 & $\begin{array}{l}\text { Stentor } \\
\text { coeruleus }\end{array}$ & $\begin{array}{l}\text { Stentor } \\
\text { niger }\end{array}$ & $\begin{array}{l}\text { Tintinnidium } \\
\text { fluviatile }\end{array}$ & $\begin{array}{l}\text { Vorticella } \\
\text { longifilum }\end{array}$ & $\begin{array}{l}\text { Yorticella } \\
\text { sp. }\end{array}$ & $\begin{array}{l}\text { Total } \\
\text { Ciliata }\end{array}$ \\
\hline $1 / 5$ & .... & $\ldots \ldots$ & ……...... & $\cdots$ & & 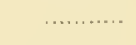 \\
\hline $\begin{array}{l}1 / 12 \\
1 / 19\end{array}$ & $\ldots \ldots$. & ........ & 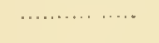 & & …….... & 800 \\
\hline $\begin{array}{l}1 / 19 \\
1 / 25\end{array}$ & & $x^{2}+2$ & & ……… & $\cdots$ & 800 \\
\hline $\begin{array}{l}1 / 25 \\
2 / 2\end{array}$ & & 1,600 & $\cdots$. & ............ & .............. & 4,800 \\
\hline $2 / 8$ & & & & ……........ & $\ldots \ldots$ & 297,328 \\
\hline $2 / 15$ & & & .... & ........ & & 9,000 \\
\hline $2 / 23$ & ……...... & $\begin{array}{l}3,200 \\
3200\end{array}$ & & ……….... & ............. & 162,640 \\
\hline $3 / 1$ & ……… & $\begin{array}{l}3,200 \\
3,200\end{array}$ & $\cdots$ & ……....... & $\cdots$ & 148,340 \\
\hline $\begin{array}{l}3 / 8 \\
3 / 1.5\end{array}$ & & 3,200 & & ...... & & $\begin{array}{l}5,58,708 \\
110,592\end{array}$ \\
\hline $3 / 23$ & & 3,200 & & 6,400 & & 529,712 \\
\hline $3 / 29$ & & $\cdots \cdots$ & & 3,200 & & $+29,565$ \\
\hline $4 / 5$ & 3,200 & $\ldots \ldots$ & .... & 3,200 & 3,200 & 303,728 \\
\hline $4 / 13$ & & & & & 79,344 & $213,1 S 4$ \\
\hline $\begin{array}{l}4 / 19 \\
+/ 90\end{array}$ & $\cdots$ & & & $\ldots$. & & $\begin{array}{r}379,972 \\
210,394\end{array}$ \\
\hline $\begin{array}{l}4 / 26 \\
5 / 3\end{array}$ & . & 6,400 & & $\ldots$ & 132,240 & 249,232 \\
\hline $\begin{array}{l}5 / 3 \\
5 / 10\end{array}$ & & 6,400 & & $\cdots$ & & 6,400 \\
\hline $5 / 17$ & $\ldots \ldots, \quad \ldots$. & & & ... & $15 \varsigma, 6 \varsigma 8$ & 373,472 \\
\hline $5 / 24$ & ..... & 3,200 & .... & .. & 264,480 & 532,160 \\
\hline $5 / 31$ & .. & ….. & & & 793,440 & 806,240 \\
\hline $6 / 7$ & ............ & ...... & ........ & & 793,440 & $1,017,824$ \\
\hline $6 / 16$ & 1 1... . . . . & …........... & +2 & ... & 158,688 & 267,680 \\
\hline $\begin{array}{l}6 / 21 \\
6 / 29\end{array}$ & …… & …..... & ... & ...... & 105,792 & 105,792 \\
\hline $\begin{array}{l}6 / 29 \\
7 / 5\end{array}$ & $\begin{array}{ll}\cdots \\
\ldots\end{array}$ & ㄱ․․…" & $\cdots$ & $\cdots$ & $\begin{array}{r}3,200 \\
211,584\end{array}$ & $\begin{array}{r}1,800 \\
211,584\end{array}$ \\
\hline $7 / 12$ & . . . . . & ………… & $\cdots$ & ......... & 211,584 & 211,584 \\
\hline $7 / 19$ & ... ........... & $\ldots \ldots \ldots \ldots \ldots$ & 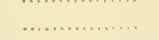 & $\ldots \ldots \ldots, \ldots$ & $1,057,920$ & $1,269,504$ \\
\hline $7 / 26$ & . . ............ & ....... & & & $52 S, 960$ & 546,336 \\
\hline$S / 2$ & …... & &, 200 & .... & $1,057,920$ & $1,219,80 \mathrm{~s}$ \\
\hline $\begin{array}{l}8 / 9 \\
8 / 15\end{array}$ & ..... & & $\ldots \ldots$ & … & 816,336 & $1,451.0 \mathrm{SS}$ \\
\hline $\begin{array}{l}8 / 15 \\
8 / 23\end{array}$ & $\cdots$ & & ........ & & $793,4+40$ & $1,057,920$ \\
\hline $\begin{array}{l}8 / 2.3 \\
8 / 31\end{array}$ & & ..... & ..... & .. & 370,272 & 383,072 \\
\hline $\begin{array}{l}5 / 31 \\
9 / 6\end{array}$ & & $\cdots$ & $\cdots$ & & $\begin{array}{r}1,692,672 \\
317376\end{array}$ & $2,115,840$ \\
\hline $9 / 13$ & ................. & ...... & …...... & $\cdots$ & 952,128 & $\begin{array}{r}31,360 \\
1,163,712\end{array}$ \\
\hline $9 / 20$ & ……… & ............... & ........... & . & $+23,16 \mathrm{~s}$ & $1,163,712$ \\
\hline $9 / 27$ & ..... & ..... & …............ & & 846,336 & 952,128 \\
\hline $\begin{array}{l}10 / 4 \\
10 / 11\end{array}$ & …ака.... & ........ & .... & $10.5,792$ & 528,960 & 846,336 \\
\hline $10 / 11$ & ..... & ...... & & $\ldots+\ldots$ & $+423,168$ & 634,752 \\
\hline $10 / 18$ & .. & ......... & 105,792 & & 528,960 & 634,752 \\
\hline $\begin{array}{l}10 / 26 \\
11 / 1\end{array}$ & 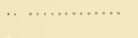 & ……… & $80 \mathrm{c}$ & 12,500 & 317,376 & $3+2,976$ \\
\hline $11 / 1$ & .............. & …… & 52,896 & $\ldots .$. & 423,168 & $5.54,560$ \\
\hline $11 / \mathrm{S}$ & ……… & …. & .......... & . ......., & $\begin{array}{l}52,896 \\
5 ?, 806\end{array}$ & $\begin{array}{l}330,176 \\
457,168\end{array}$ \\
\hline $11 / 15$ & ….......... & …. & 3,200 & & 52,890 & $\begin{array}{l}4.7,168 \\
121,792\end{array}$ \\
\hline $\begin{array}{l}11 / 22 \\
11 / 30\end{array}$ & & & 3,200 & $\ldots \ldots .$. & 1,600 & 1.600 \\
\hline $12 / 6$ & 3,200 & 1,600 & & ....... & 1,600 & 60,896 \\
\hline $12 / 14$ & . ........ & & 6,400 & & & 9,600 \\
\hline $12 / 20$ & & & & 3,200 & 132,240 & 137,040 \\
\hline $12 / 27$ & ..... & 3,200 & 3,200 & $\ldots$ & ......... & 6,400 \\
\hline
\end{tabular}


Table 2.-Organisms P'er Cubla: Mhter in P'LANkToN of SAN JOAQUIN RIVER IN 1913-(Continued)

\begin{tabular}{|c|c|c|c|c|c|c|}
\hline 1913 & $\begin{array}{l}\text { Acineta } \\
\text { sp. }\end{array}$ & $\begin{array}{l}\text { Podophryat } \\
\text { sp. }\end{array}$ & $\begin{array}{c}\text { Sphaerophrya } \\
\text { sp. }\end{array}$ & $\begin{array}{l}\text { Totul } \\
\text { Suctoria }\end{array}$ & $\begin{array}{l}\text { Total P'rotozoa } \\
\text { without } \\
\text { Mastigophora }\end{array}$ & $\begin{array}{l}\text { Total Protozos } \\
\text { with } \\
\text { Mastigophora }\end{array}$ \\
\hline $1 / 5$ & & & ............ & . ............. & & 400 \\
\hline 112 & & & ……..... & & & 2,800 \\
\hline $1 / 19$ & ................ & …….......... & …....... .. & & 800 & $2,261,00 \cdot 1$ \\
\hline $1 / 2.5$ & ……...... & ……........ & ……….... & 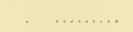 & 1,200 & $328,+450$ \\
\hline 22 & & & & & 6,400 & $1,62,5,580$ \\
\hline $2 / s$ & $\ldots \ldots$ & ..................... & .............. & ............ & 298,924 & $3,2999.901$ \\
\hline $2 / 15$ & ........... & …........... & $\ldots \ldots \ldots$ & ............ & 22,400 & $3,050,028$ \\
\hline $2 / 23$ & …......... & ...... & ........ & ........... & $2(31,181$ & $2, \times 53, \leqslant 10$ \\
\hline $3 / 1$ & …........... & & …........ & ............. & $153,0.10$ & 923,984 \\
\hline $3 / 5$ & & & .. . . . . . & . $\quad \ldots$. & $571,50 \mathrm{~s}$ & $7856+1$ \\
\hline $3 / 15$ & …….......... & ….............. & .............. & .......... & 110,592 & $3 \times 1,172$ \\
\hline $3 / 2: 3$ & & & $\ldots \ldots$ & ......... & 532,912 & $1,326,352$ \\
\hline $3 / 29$ & ....... & ....... & $\ldots$ & $\ldots$. & $435,96 \mathrm{~s}$ & $2,135,040$ \\
\hline $4 / 5$ & ....... & .... & $\ldots$ & $\ldots$ & 319,725 & 486,416 \\
\hline $4 / 13$ & & & $\ldots$ & ... & 221,184 & $593, \mathrm{~s} 0 \mathrm{~s}$ \\
\hline $4 / 19$ & & ..... & .... & & 512,112 & $(319,504$ \\
\hline $4 / 26$ & 3,200 & $\ldots$. & $\ldots$. & 3,200 & $30 \overline{7}, 650$ & $465,56 \mathrm{~S}$ \\
\hline $5 / 3$ & $\ldots$. & $\ldots .$. & $\cdots$ & & 249,232 & 515,312 \\
\hline $5 / 10$ & ...... & .... & & & 6,400 & $217,9 \mathrm{~S} \cdot 1$ \\
\hline $5 / 17$ & & $\ldots$. & $\ldots$. & & 395,872 & 527,264 \\
\hline $5 / 24$ & & ..... & .. & & 5338,560 & $6.51,752$ \\
\hline $5 / 31$ & & & . & & $1,440,992$ & $2,441,016$ \\
\hline 6/ 7 & $\ldots$ & ...... & . & & $1,123,765$ & $2,151,6506$ \\
\hline $6 / 10$ & ...... & & $\ldots$ & & 426,368 & 990,528 \\
\hline $6 / 21$ & $\ldots \ldots$ & & $\ldots$ & & 370,272 & 6033,556 \\
\hline $6 / 25$ & ...... & & ..... & & 194,736 & 257,232 \\
\hline $7 / 5$ & & $\ldots \ldots$ & & & 370,272 & $1,054,365$ \\
\hline $7 / 12$ & 6,400 & & . & 6,400 & 367,824 & $1,513,085$ \\
\hline $7 / 19$ & & $\ldots$ & & $=$ & $1,907,456$ & $7,592,608$ \\
\hline $7 / 26$ & & & & & $1,017,524$ & $8,525,5336$ \\
\hline $8 / 2$ & ... & $\ldots \ldots$ & & & $1,811,20 ; 4$ & $4,507,264$ \\
\hline s/ 9 & & $\ldots$. & 19,200 & 19,200 & $1,929,856$ & $4,959,222$ \\
\hline $8 / 15$ & 105,792 & & & 105,792 & $1,724,672$ & $3,760,420$ \\
\hline $8 / 23$ & ................ & $\cdots$ & ........ & & $1,889,760$ & $5,5334,648$ \\
\hline $8 / 31$ & ……........ & & ....... & & $2,974,976$ & $6,597,50.1$ \\
\hline $9 / 6$ & $\ldots \ldots$ & & & . & $1,519,488$ & $6,183,744$ \\
\hline $9 / 13$ & ……......... & & & & $1,519,4.55$ & $7,011,085$ \\
\hline $9 / 20$ & $\ldots \ldots$. & & 25,600 & 25,600 & $2,907,584$ & $6,344,128$ \\
\hline $9 / 27$ & & & 12,800 & 12,800 & $2,683,200$ & $7,5,4,5,232$ \\
\hline $10 / 4$ & 105,792 & $\ldots$ & 38,400 & 144,192 & $4,799,040$ & $12,560,256$ \\
\hline 1011 & & .... & & & $2,551,805$ & $8,511,760$ \\
\hline $10 / 1 \mathrm{~s}$ & & & 25,600 & $2 \overline{5}, 600$ & $1,307,904$ & $10,(0,5,6.10$ \\
\hline $10 / 2 t j$ & $10.5,792$ & & & 105,792 & $1,214,912$ & $9,7966,564$ \\
\hline $11 / 1$ & $\ldots$ & ........... & & & $\$ 19,040$ & $4,976,320$ \\
\hline $11 / 8$ & ...... & & & & 594,650 & $4,0,32,896$ \\
\hline $11 / 15$ & $\ldots$ & ... & & & $2,179,840$ & $6.401,021$ \\
\hline $11 / 22$ & $\ldots$ & & 3,200 & 3,200 & 132,902 & $7,202,608$ \\
\hline $11 / 30$ & - & 3,200 & 3,200 & 6,400 & 11,200 & $4,457,6664$ \\
\hline $12 / 6$ & & 3,200 & 1,600 & 4.500 & 67,296 & $5,344,845$ \\
\hline $12 / 14$ & 3,200 & & & 3,200 & 16,000 & $3,012,624$ \\
\hline $12 / 20$ & & & & & 140,240 & $2,450,816$ \\
\hline $12 / 27$ & & 1,600 & & 1,600 & 10,200 & $\$ 15, \$ 10$ \\
\hline 1913 & $\begin{array}{l}\text { Collotheca } \\
\text { egg, attached }\end{array}$ & $\begin{array}{l}\text { Collothera } \\
\text { pelagiea }\end{array}$ & $\begin{array}{l}\text { Collotirea } \\
\text { sp. }\end{array}$ & $\begin{array}{c}\text { Total } \\
\text { Rhizota }\end{array}$ & $\begin{array}{c}\text { Rotaria } \\
\text { neptunia }\end{array}$ & $\begin{array}{l}\text { Rotaria } \\
\text { rotatoria }\end{array}$ \\
\hline $1 / 5$ & & .. & $\ldots$ & 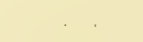 & .. & 2,000 \\
\hline $1 / 12$ & & & & & & 4.400 \\
\hline $1 / 19$ & ...... & & & & 400 & 52,896 \\
\hline $1 / 25$ & & .. & .. & 400 & 2,400 & 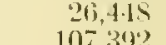 \\
\hline $2 / 2$ & ... . & & .... & . . & ......... & 107,392 \\
\hline
\end{tabular}


Table 2.-Orfanisms Per Cubic Meter in Plankton of San Joaquin River in 1913-(Continued)

\begin{tabular}{|c|c|c|c|c|c|c|}
\hline 1913 & $\begin{array}{l}\text { Collotheca } \\
\text { egg, attached }\end{array}$ & $\begin{array}{c}\text { Collotheca } \\
\text { pelagica. }\end{array}$ & $\begin{array}{c}\text { Collotheca } \\
\text { sp. }\end{array}$ & $\begin{array}{c}\text { Total } \\
\text { Rhizota }\end{array}$ & $\begin{array}{l}\text { Rotaria } \\
\text { neptunia }\end{array}$ & $\begin{array}{c}\text { Rotaria } \\
\text { rotatoria }\end{array}$ \\
\hline $2 / 8$ & & & ........... & $\ldots \quad \ldots$ & F- $=0$ & 57,600 \\
\hline $2 / 5$ & ......... & & .... & ... & & 12,800 \\
\hline $2 / 23$ & ............ & & ........ & $\ldots+\ldots \ldots$ & & 79,344 \\
\hline $3 / 1$ & .......... & .................. & …........... & …........... & .......... & 32,000 \\
\hline $3 / 8$ & .......... & ..... & …......... & . $\ldots \ldots \ldots \ldots \ldots$ & ........... & 80,000 \\
\hline $3 / 15$ & .... & $\cdots$ & ....... & $\ldots$ & & 79,344 \\
\hline $3 / 23$ & …….. & & .. & $\cdots$ & 3,200 & 185,136 \\
\hline $3 / 29$ & …......... & $\ldots \ldots$ & $\ldots \ldots$ & …............. & . & 22,400 \\
\hline $4 / 5$ & & & $\cdots$ & .......... & & 9,600 \\
\hline $4 / 1.3$ & . $\ldots \ldots$ & . $\quad \ldots \ldots+\ldots \ldots$ & ............... & . . . & $\cdots$ & .... \\
\hline $5 / 19$ & . $\quad \ldots+\ldots \ldots \ldots, \ldots$ & ...... & n..... & $\ldots \ldots \ldots \ldots$ & $\cdots \cdot \cdot \cdot$ & \\
\hline $4 / 26$ & . . . . . . & ...... & w....... & . .......... & .. & .... \\
\hline $\begin{array}{l}5 / 3 \\
5 / 10\end{array}$ & $\ldots \ldots$ & . $1+\ldots+\ldots+\cdots$ & (n.......... & (n........ & $\cdots$ & \\
\hline $5 / 17$ &,$\ldots \ldots$ & …............ & ................. & ........... & $\ldots, \ldots$ & 6,400 \\
\hline $5 / 24$ & & & & $\ldots \ldots \ldots$ & $\ldots$ & 6,400 \\
\hline $5 / 31$ & … & ................. & , & …....... & ....... & .. $\quad .$. \\
\hline $\begin{array}{l}6 / 7 \\
6 / 16\end{array}$ & $\begin{array}{l}\ldots \ldots \ldots \\
\ldots \ldots \ldots \ldots\end{array}$ & $\begin{array}{l}\ldots \ldots \\
\ldots \ldots \\
\ldots \ldots \ldots \ldots\end{array}$ & ……… & ... $\ldots$ & & .. \\
\hline $6 / 21$ & . $\quad \ldots \ldots \ldots \ldots$ &,$\ldots \ldots \ldots$ & .............. & .......... & & \\
\hline $6 / 2 S$ & $\ldots \ldots \ldots$ & $\ldots . \quad \ldots \ldots$ & ................ & ..... 1 . & $\ldots$ & 3,200 \\
\hline $7 / 5$ & …......, , &.$\ldots \ldots$ & ......... & .... . & & ..... \\
\hline $\begin{array}{l}7 / 12 \\
7 / 19\end{array}$ & … & .... & , n............ & $\ldots$. & 3,200 & ,.......... \\
\hline $7 / 26$ & ${ }^{\cdot} \cdot \ldots \cdot$ & … & $\cdots$ & $\ldots \ldots$ & & 6,400 \\
\hline $8 / 2$ & & & & & 6,400 & 12,800 \\
\hline 8/ 9 & & & 6,400 & & & \\
\hline $8 / 15$ & 83,200 & 158,688 & 6,400 & 248,298 & 12,800 & 19,200 \\
\hline $8 / 23$ & 83,200 & 317,376 & .......... & 400,576 & & 6,400 \\
\hline $8 / 31$ & & & $\ldots \ldots \ldots$ & 12,800 & $\cdots \cdots$ & 12,500 \\
\hline $\begin{array}{l}9 / 6 \\
9 / 13\end{array}$ & & & & & & \\
\hline $\begin{array}{l}9 / 13 \\
9 / 20\end{array}$ & 12,800 & 38,400 & 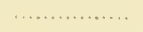 & 51,200 & & \\
\hline $\begin{array}{l}9 / 20 \\
9 / 27\end{array}$ & & 51,200 & $\ldots \ldots$ & 51,200 & 12,800 & \\
\hline $9 / 27$ & 12,800 & 38,400 & & 51,200 & & \\
\hline $10 / 4$ & 128,300 & $1+0,800$ & $\cdots$ & 268,500 & 25,600 & 25,600 \\
\hline $10 / 11$ & $7 \&, 800$ & 115,200 & $\ldots$ & 192,000 & 25,600 & $x^{2}$ \\
\hline $10 / 18$ & 211,584 & 51,200 & & 262,784 & 12,800 & 105,792 \\
\hline $10 / 26$ & 105,792 & $211,5 \times 4$ & ....... & 317,376 & & 12,800 \\
\hline $11 / 1$ & . & 12,800 & & 12,800 & 6,400 & 12,800 \\
\hline $11 / \mathrm{S}$ & & 6,400 & & 6,400 & & 6,400 \\
\hline $11 / 15$ & 25,600 & 25,600 & 1. & 51,200 & 6,400 & - \\
\hline $11 / 22$ & 3,200 & 3,200 & & 6,400 & & \\
\hline $11 / 30$ & & & & & & \\
\hline $12 / 6$ & .... & & $\ldots \ldots$ & .... & 3,200 & 6,400 \\
\hline $12 / 14$ & $\ldots$. & & $\ldots \ldots$ & .... & . & $6,-100$ \\
\hline $12 / 20$ & $\ldots$ & & $\ldots \ldots \ldots$ & .. & $\ldots$ & 6,400 \\
\hline $12 / 27$ & & 1 & ....... & & & . \\
\hline 1913 & $\begin{array}{c}\text { Rotifer egg, } \\
\text { winter }\end{array}$ & $\begin{array}{l}\text { Rotifer egg, } \\
\text { unidentified }\end{array}$ & $\begin{array}{c}\text { Rotifer } \\
\text { unidentified }\end{array}$ & $\begin{array}{l}\text { Total } \\
\text { Bdelloida }\end{array}$ & $\begin{array}{c}\text { Anurenopsis } \\
\text { fissa }\end{array}$ & $\begin{array}{c}\text { Anureaopsis } \\
\text { sp. }\end{array}$ \\
\hline $1 / 5$ & $\ldots, \quad \ldots \ldots \ldots$ & ........ & 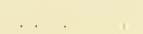 & 2,000 & & \\
\hline $1 / 12$ & $\ldots \quad \ldots \ldots$ & $\ldots \ldots, \ldots \ldots$ & & 4,400 & ..... & \\
\hline $1 / 19$ &.$\quad \ldots \ldots$ & $\ldots \ldots \ldots$ & 800 & $.54,096$ & $\ldots$. & \\
\hline $1 / 25$ & $\ldots . \quad \ldots$ & $\ldots . \quad \ldots$ & 6,000 & 34,848 & & \\
\hline $2 / 2$ & $\ldots \ldots, \ldots$ & $\ldots \ldots \ldots$ & fi, 400 & 113,792 & & \\
\hline $2 / 8$ & & 1,600 & 19,200 & 76.800 & & \\
\hline $2 / 15$ & & $\ldots \ldots \ldots \ldots$ & 3,200 & 16,000 & & \\
\hline $2 / 23$ & 3,200 & $\ldots \ldots \ldots \ldots$ & 12,800 & $92,1+4$ & $\cdots$ & \\
\hline $3 / 1$ & $\ldots \ldots, \quad \ldots$ & & 1,600 & 33,600 & . $\ldots \ldots, \quad \ldots$ & $\ldots \ldots$. \\
\hline $3 / 8$ & ….......... & .. $\quad \ldots \ldots \ldots$ & 52,896 & 132,240 & ....... & $\ldots \ldots$. \\
\hline
\end{tabular}




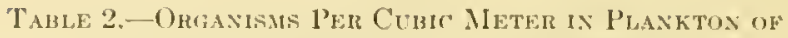
SAN Joaglion RIVER IN 1913-(Continuen)

\begin{tabular}{|c|c|c|c|c|c|}
\hline $\begin{array}{l}\text { Rotifer ckg, } \\
\text { winter }\end{array}$ & $\begin{array}{l}\text { Rotifer roge } \\
\text { unidentifiecl }\end{array}$ & $\begin{array}{c}\text { Rotifer } \\
\text { unidentified }\end{array}$ & $\begin{array}{l}\text { Total } \\
\text { Bdelloida }\end{array}$ & $\underset{\text { fissa }}{\text { Anureassis }}$ & $\begin{array}{c}\text { Anuresopsis } \\
\text { sy. }\end{array}$ \\
\hline & & 9,6000 & 88,911 & & \\
\hline & 16,0000 & & $1 \times 5,33310$ & & \\
\hline & & 3,200 & 25,600 & . & \\
\hline - & & $(6,400$ & 16,000 & & \\
\hline & & 3,200 & 3,200 & & \\
\hline . & 1,600 & 6,400 & 6,400 & 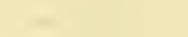 & \\
\hline & 1,600 & & & . & \\
\hline 1,600 & $\ddot{.}$ & 22,400 & 22,400 & & \\
\hline & & & $(i, 400$ & & \\
\hline 12,500 & 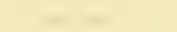 & & 6,100 & & 3,200 \\
\hline & & 12,800 & $12, \$ 00$ & & \\
\hline & $\therefore$ & 12,500 & 12,800 & .. & \\
\hline$\cdots$ & - . & 3,200 & 3,200 & . & -1. \\
\hline & & & 3,200 & & \\
\hline & $\ldots$ & 3,200 & 3,200 & $\ldots$ & $(0,100)$ \\
\hline & & 1.600 & 4,800 & & $6,-100$ \\
\hline & & & & 38,400 & . \\
\hline & & & 6,400 & & \\
\hline 105,792 & & 158,1655 & 174,658 & $\begin{array}{r}6,400 \\
105,7 y 2\end{array}$ & . \\
\hline 3,200 & & 32,000 & 64,000 & $12,6(00)$ & ... . \\
\hline & & 12800 & 19,200 & $10.5,792$ & $\ldots$ \\
\hline 105,792 & $\ldots$ & $211,58 t$ & 224,384 & $10,5,792$ & .... \\
\hline . & 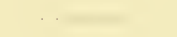 & & & $12, \triangleleft 00$ & . \\
\hline$\ldots \quad \ldots$ & & 25.600 & 25,600 & & \\
\hline .. & -1 & $\begin{array}{l}211,551 \\
105792\end{array}$ & $\begin{array}{l}224,381 \\
105,79^{\circ 2}\end{array}$ & 25,600 & \\
\hline & $\cdots$ & 105,792 & $\begin{array}{l}105,792 \\
156,992\end{array}$ & 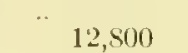 & \\
\hline 25,600 & $\ldots$ & 38,400 & $6+, 000$ & $1-, 000$ & . \\
\hline 38.400 & $\ldots \ldots \ldots$ & 211,584 & 330,176 & & - \\
\hline & & & 12,800 & & \\
\hline$(i, 400$ & & & 19,200 & 6,400 & \\
\hline 52,896 & & 12,800 & 19,200 & & s \\
\hline & . & 6,400 & 12,800 & & 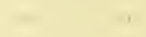 \\
\hline 1,600 & …........ & & $\ldots$ & 3,200 & 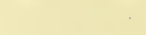 \\
\hline 3,200 & $\ldots$ & & 9,600 & & $-1=$ \\
\hline 3,200 & $\ldots$ & $\therefore$ & 6,400 & & \\
\hline 1,600 & & & 6,400 & 1,600 & $\ldots$ \\
\hline$\ldots$ & .......... & 3,200 & 3,200 & & $\ldots$. \\
\hline $\begin{array}{l}\text { Asplanchna } \\
\text { brightwellii }\end{array}$ & $\begin{array}{c}\text { Asplanchnopus } \\
\text { sp. }\end{array}$ & $\begin{array}{l}\text { Brachionus } \\
\text { angularis }\end{array}$ & $\begin{array}{l}\text { Brachionus } \\
\text { ankularis } \\
\text { caudatus }\end{array}$ & $\begin{array}{c}\text { Brachionus } \\
\text { budapestenensis }\end{array}$ & $\begin{array}{l}\text { Brachionus } \\
\text { calyciflorus }\end{array}$ \\
\hline & & & & $\cdots$ & 800 \\
\hline & & & 400 & & 1,200 \\
\hline & . & $\cdots$ & 400 & $\ldots$ & 1.200 \\
\hline & & 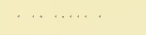 & $\cdots$ & $\ldots .$. & 4,000 \\
\hline & 1,600 & ..... & $\ldots \ldots$ & ….... & 1,600 \\
\hline & .... & - & & .......... & 44,800 \\
\hline & $\ldots \ldots$ & & & & 132,240 \\
\hline .... & 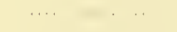 & $\cdots \cdots$ & 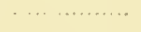 & $\ldots \ldots \ldots$ & +1.600 \\
\hline …. & & & ........ & $\ldots \ldots$ & 1,400 \\
\hline & . & $\ldots$ & & ….... & 3,200 \\
\hline .. & $\ldots$ & & ..... & & 19,200 \\
\hline & & $\begin{array}{l}13,+60 \\
9,600\end{array}$ & & $19,0+4$ & 16,000 \\
\hline 6 & & & & & 16,000 \\
\hline
\end{tabular}


Table 2.-Organisms Per Cubic Meter in Plankton of San Joaquin River in 1913-(Continued)

\begin{tabular}{|c|c|c|c|c|c|c|}
\hline & Asplanchna & Asplanchnopus & Brachionus & $\begin{array}{c}\text { I3rachionus } \\
\text { aogularis }\end{array}$ & Brachionus & Brachionus \\
\hline 1913 & brightwellii & & angularis & & & calyciflorus \\
\hline $4 / 19$ & & & 6,400 & & & 1,600 \\
\hline $4 / 26$ & ........ & …. & & ............... & . $\ldots \ldots \ldots$ & 6,400 \\
\hline $5 / 3$ & n............. & n. & 3,200 & $\cdots \ldots$. & $\ldots . \quad \ldots \ldots \ldots$ & \\
\hline $5 / 10$ & ................ & $\ldots$ & .......... & , . . . . . . . . . & $\ldots \ldots \ldots \ldots, \ldots$ & 6,400 \\
\hline $5 / 17$ & $\cdots$ & $\cdots$ & & ........ & $\ldots \ldots \ldots$ & \\
\hline $\begin{array}{l}5 / 24 \\
5 / 31\end{array}$ & …..., & $\cdots$ & 3,200 & … & n.............. & \\
\hline $\begin{array}{l}5 / 31 \\
6 / 7\end{array}$ & ...... & ... & & ..... & $\begin{array}{ll}\cdots \\
\cdots\end{array}$ & \\
\hline $6 / 16$ & ....... & & & 6.400 & & \\
\hline $6 / 21$ & & .. & 6,400 & 22,400 & $\ldots$ & \\
\hline $6 / 28$ & 6,400 & …..., & 3,200 & 35,200 & 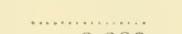 & \\
\hline $7 / 5$ & & & 3,200 & 105,792 & 3,200 & \\
\hline $7 / 12$ & 3,200 & 3,200 & $\ldots \ldots \ldots$ & 714,096 & 1,600 & \\
\hline $7 / 19$ & $\ldots$ & $\ldots$ & ........... & 83,200 & 19,200 & 6,400 \\
\hline $7 / 26$ & & $\cdots$ & .. & & & \\
\hline $8 / 2$ & $\ldots \ldots$ & ............. & $\ldots$ & 211,594 & 105,792 & .... \\
\hline $8 / 9$ & $\cdots$ & .............. & (......... . & 105,792 & 19,200 & 19,200 \\
\hline $8 / 15$ & . $\ldots$ & 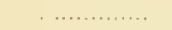 & & $1,005,024$ & 12,800 & 19,200 \\
\hline $8 / 23$ & $\ldots$ & $\ldots \ldots \ldots \ldots \ldots$ & 19.200 & 12,800 & 105,792 & \\
\hline $8 / 31$ & .......... & ....., n....... & 38,400 & 317,376 & $\ldots \ldots, \ldots$ & 25,600 \\
\hline $9 / 6$ & ... ...... & $\cdots$. & & 25,600 & $\ldots .$. & \\
\hline $9 / 13$ & ......... & ............... & & 38,400 & $\ldots \ldots \ldots, \quad \ldots$ & 12,800 \\
\hline $9 / 20$ & . . ......... & .................. & 12,800 & 317,376 & $\ldots \ldots \ldots$ & 12,800 \\
\hline $9 / 27$ & .. ...... & ................ & & 51,200 & 12,800 & 25,600 \\
\hline $10 / 4$ & ...... & $\ldots \ldots \ldots \ldots$ & & 38.400 & 12,800 & 38,400 \\
\hline $10 / 11$ & $\ldots . .$. & ................ & & $211,5 \mathrm{S4}$ & 12,800 & 12,800 \\
\hline $10 / 18$ & $\ldots .$. & ................ & .......... & $6 \pm, 000$ & $\ldots \ldots \ldots$ & 25,600 \\
\hline $10 / 26$ & $\ldots \ldots$ & & & & & 25,600 \\
\hline $11 / 1$ & . $\quad \ldots . . . .$. & , ............... & 6,400 & 25,600 & ................ & 6,400 \\
\hline $11 / 8$ & ......... & $\ldots \ldots \ldots \ldots \ldots$ & 52,896 & ... & $\ldots$ & $1=1, \ldots \ldots \ldots$ \\
\hline $11 / 15$ & ......... & $\therefore \ldots \ldots$ & & ............ & 6,400 & $\ldots$ \\
\hline $11 / 22$ & . ......... & ................ & 3,200 & $\ldots$ & $\ldots \ldots$. & \\
\hline $11 / 30$ & . .......... & $\ldots \ldots \ldots \ldots$ & 3,200 & ........ & 1,600 & \\
\hline $12 / 6$ & . .. ... & $.1 . .$. & & & , ................ & \\
\hline $12 / 14$ & . $\quad \ldots \ldots .$. & ............... & .............. & & …........... & 1,600 \\
\hline $12 / 20$ & ......... & ................. & ............... & $\ldots \ldots$ & ,................ & \\
\hline $2 / 27$ & 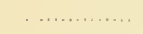 & .......... & ............... & ............. & ................. & $\ldots$. \\
\hline 1913 & $\begin{array}{l}\text { Brachionus } \\
\text { capsuliflorus }\end{array}$ & $\begin{array}{l}\text { Brachionus } \\
\text { egg, attached } \\
\text { fentale }\end{array}$ & $\begin{array}{l}\text { Brachionus } \\
\text { egg, attached } \\
\text { male }\end{array}$ & $\begin{array}{c}\text { Brachionus } \\
\text { egg, free } \\
\text { female }\end{array}$ & $\begin{array}{l}\text { Brachionus } \\
\text { patulus }\end{array}$ & $\begin{array}{c}\text { Brachionus } \\
\text { plicatilis }\end{array}$ \\
\hline $1 / 5$ & ............. & …........ & $\ldots$ & 800 & $\cdots$ & 1. \\
\hline $1 / 12$ & …........... & $\ldots \ldots \ldots \ldots \ldots$ & $\ldots .$. & 4,000 & $\ldots$ & 400 \\
\hline $1 / 19$ & ….......... & .......... & .............. & 400 & $\ldots \ldots$ & \\
\hline $1 / 25$ & ............ & 400 & & 800 & & 800 \\
\hline $2 / 2$ & ............ & & & 1,600 & ....... & 1,600 \\
\hline $2 / 8$ & ............. & 19,200 & & 3,200 & .............. & 3200 \\
\hline $2 / 15$ & $\ldots$. & & 105,792 & 79,344 & ................ & \\
\hline $2 / 23$ & .............. & 41,600 & 6,400 & 6,400 & $\cdots$ & \\
\hline $3 / 1$ & ............ & $\ldots \ldots \ldots \ldots$ & $\ldots \ldots$ & 3,200 & ......... & 3,200 \\
\hline $3 / 8$ & $\cdots$ & & & 6,400 & & 3,200 \\
\hline $3 / 15$ & & 16,000 & .... & 52,896 & & 3,200 \\
\hline $3 / 23$ & 3,200 & 12.800 & & 52,896 & ........... & 6,400 \\
\hline $3 / 29$ & ..... & 6,400 & & 3,200 & ............... & 3,200 \\
\hline $4 / 5$ & 3,200 & & & 3,200 & & \\
\hline $4 / 13$ & $\ldots \ldots, \ldots$ & 52,896 & ..... & $\ldots+$. & ................ & 3,200 \\
\hline $4 / 19$ & & & & & & \\
\hline $4 / 26$ & ….... & 3,200 & 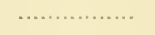 & 3,200 & ............... & 3,200 \\
\hline $\begin{array}{ll}5 & 3 \\
5 & 10\end{array}$ & n..., & ............ & n............. & .. ............ & $\ldots \ldots \ldots \ldots \ldots$ & \\
\hline $5 / 17$ & ......... & $\cdots$ & $\begin{array}{l}\cdots \\
\ldots\end{array}$ & -... & ..... & \\
\hline & & & & & & \\
\hline
\end{tabular}


Table 2.-Orranisms l'em Cubic Meter in Planktos of SAN Johqun liven Ix 1913-(romlinuced) Mrosulit .................
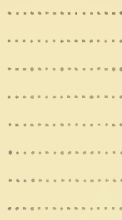

12,800

211,551

25,600

25,600

317,376

34,400

12,800

64,000

$12, \$ 00$

12,800

6,400
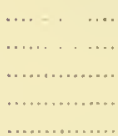

3,200 urceus

1,300 100

3,200

3, 200

6, 400

$2 / 23$

3) 1

$3 / 8$

$3 / 15$

323

$3 / 29$

$1 ;$

$+/ 13$

$4 / 19$

$+26$

$5 / 3$

$5 / 10$

$5 / 17$

$5 / 21$

$5 / 31$

6) 7

(i) 16

$6 / 21$

1,600

3,200

3,200

6,400

38,400

32,000
Brachionus

Brachionus

g, attachuce
male

female

Brachionus

coge. irece

Brachionus patulus

Brachionus plicatilis

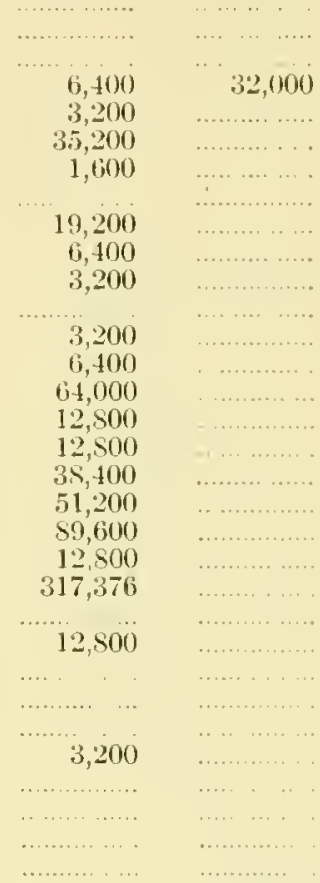

, . . .

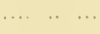

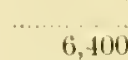

79,3-14

52,496

$105,79^{2}$

19,200

$2.5,600$

25,600

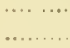

(j, 400

$(i, 400$

(j) 100

25,600

6, 100

105,792

12,800

25,600

12,800

25,600

3s, 400

25, 600

$52,896^{\circ}$

6,400

52,596

1,600

3,200

1,600

Diurella
exg, free

Epiphanes
egg, attached gentale
fentach

Filinia

Filinis female

egr. free

..................
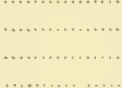

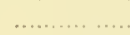

clavilata
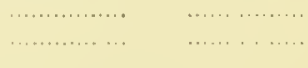

3,200

9,600

19,200

9,600

3,200 2,400 105.792 $23 \times, 032$

3.200

9,600

6,400
1,600

$: 3,200$

$1, \mathrm{i} 00$ 
Table 2 -Organisus Per Cubic Meter in Plankton of San Joaquin River in 1913-(Continued)

\begin{tabular}{|c|c|c|c|c|c|c|}
\hline 1913 & $\begin{array}{l}\text { Brachionus } \\
\text { urceus }\end{array}$ & $\begin{array}{l}\text { Diurella } \\
\text { egg. free }\end{array}$ & $\begin{array}{l}\text { Epiphanes } \\
\text { clavulata }\end{array}$ & $\begin{array}{l}\text { Epiphanes } \\
\text { egg, attaehed } \\
\text { female }\end{array}$ & $\begin{array}{l}\text { Filinia } \\
\text { egg. attached } \\
\text { female }\end{array}$ & $\begin{array}{l}\text { Filinia } \\
\text { egg, free }\end{array}$ \\
\hline $6 / 28$ & 25,600 & 79,344 & & & 9,600 & 1,600 \\
\hline $7 / 5$ & & $158,68 \mathrm{~S}$ & & & ............ & 1,600 \\
\hline $7 / 12$ & 3,200 & $1,031,472$ & & & 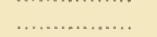 & 235,032 \\
\hline $7 / 19$ & 35,400 & $\pm 76,064$ & ...... & ................. & ……........ & \\
\hline $7 / 26$ & 12,800 & 317,376 & & & ………....... & 3,200 \\
\hline $8 / 2$ & 105,792 & 423,165 & ...... & ........ & & $52 S, 960$ \\
\hline $8 / 9$ & 51,200 & 158,688 & & & ........... & 3,200 \\
\hline $8 / 15$ & 6,400 & 525,960 & 12,500 & 6,400 & ………...... & $158,68 \mathrm{~s}$ \\
\hline $8 / 23$ & & $1,110,816$ & 64,000 & 12,800 & & 158,688 \\
\hline $8 / 31$ & 38,400 & 317,376 & 76,800 & & & 525,960 \\
\hline $9 / 6$ & & & 12,500 & 12,800 & & \\
\hline $9 / 13$ & 12,800 & 952,128 & 64,000 & 25,600 & & 105,792 \\
\hline $9 / 20$ & 12,800 & & 38,400 & & & 105,792 \\
\hline $9 / 27$ & & 528,960 & 38,400 & & ... & 211,581 \\
\hline $10 / 4$ & $\ldots . .$. & 846,336 & 12,800 & .............. & ........ & 105,792 \\
\hline $10 / 11$ & & 525,960 & & & & 105,792 \\
\hline $10 / 15$ & 12,800 & 105,792 & 12,500 & …......... . & …............... & $\ldots \ldots$ \\
\hline $10 / 26$ & 12,800 & 25,600 & & $\ldots \ldots$ & …........... & .............. \\
\hline $11 / 1$ & ….................. & …........... & …............. & …............ & …...... & 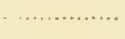 \\
\hline $11 / 8$ & …............ & $\ldots \ldots \ldots$ & …............ & ............... & …...... & ........ \\
\hline $11 / 15$ & .................. & .............. & …............... & …............. & …........... & ...... \\
\hline $\begin{array}{l}11 / 22 \\
11 / 30\end{array}$ & ……….... & ……......... & ….............. & …........... & ………... & ......... \\
\hline $12 / 6$ & $\cdots \cdots$ & ……….... & n...... & (n......... & & \\
\hline $12 / 14$ & 3,200 & ................. & 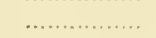 & …................ & ……......... & 1,600 \\
\hline $12 / 20$ & …n... $\quad \ldots$ & ............ & 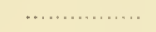 & ....... & & \\
\hline $12 / 27$ & ........ & ….............. & ……......... & ……........... & …… & $\ldots \ldots \ldots \ldots$ \\
\hline 1913 & $\begin{array}{c}\text { Filinia } \\
\text { longiseta }\end{array}$ & $\begin{array}{l}\text { Keratella } \\
\text { cochlearis }\end{array}$ & $\begin{array}{l}\text { Keratella } \\
\text { egg, attached }\end{array}$ & $\begin{array}{l}\text { Keratella } \\
\text { egg, free }\end{array}$ & $\begin{array}{l}\text { Keratella } \\
\text { quadrata }\end{array}$ & $\begin{array}{l}\text { Lecane } \\
\text { luna }\end{array}$ \\
\hline $1 / 5$ & -5 & 400 & & 1,200 & 1,200 & \\
\hline $1 / 12$ & & 1,200 & 800 & 2,400 & 1,200 & \\
\hline $1 / 19$ & 400 & & 1,200 & 19,836 & 1,600 & \\
\hline $1 / 25$ & ......... & 1,200 & & 33,060 & 1,200 & \\
\hline $2 / 2$ & ........ & 3,200 & 1,600 & 17,600 & 20,800 & \\
\hline $2 / 8$ & & 6,400 & 16,000 & 132,240 & 22,400 & \\
\hline $2 / 15$ & & 12,800 & 6,400 & 132,240 & 6,400 & 3,200 \\
\hline $2 / 23$ & 79,344 & 99,200 & 25,600 & 6,400 & 6,400 & \\
\hline $3 / 1$ & 57,600 & 32,000 & 12,800 & $x_{-1}$ & & \\
\hline $3 / \mathrm{s}$ & $290,92 \mathrm{~s}$ & 238,032 & $15 \mathrm{~S}, 6 \mathrm{SS}$ & & 19,200 & \\
\hline $3 / 15$ & 44,800 & 211,584 & 52,896 & & 9,600 & \\
\hline $3 / 23$ & 38,100 & $55.5,10.9$ & $211,58 t$ & 1,600 & 79,344 & \\
\hline $3 / 29$ & 28,800 & 264,480 & 79,344 & 132,240 & 158,688 & \\
\hline $4 / 5$ & 3,200 & $26+4.80$ & 1,600 & 79,344 & 19,200 & \\
\hline $4 / 13$ & 3,200 & 105,792 & 1,600 & $79,3 \pm 4$ & $2 S, 800$ & \\
\hline $4 / 19$ & $\ldots$ & 793,440 & 1,600 & 185,136 & 105,792 & \\
\hline $4 / 26$ & & 132,240 & 1,600 & 3,200 & $\begin{array}{r}41,600 \\
\end{array}$ & \\
\hline $5 / 3$ & 1,600 & $6, \pm 00$ & & 1,600 & 79,344 & \\
\hline $5 / 10$ & 6,400 & & & 3,200 & 44,800 & \\
\hline $5 / 17$ & $\ldots . . . . .$. & 38,400 &... & 105,792 & 3,200 & \\
\hline $5 / 24$ & & & & 3,200 & 12,800 & \\
\hline $5 / 31$ & 12,800 & 12,800 & & 105,792 & 38,400 & \\
\hline $6 / 7$ & & 38,400 & & 105,792 & & 12,800 \\
\hline $6 / 16$ & & 32,000 & 6,400 & 3,200 & $158,68 \mathrm{~S}$ & \\
\hline $6 / 21$ & 6,400 & 211,584 & 9,600 & $158,6 \mathrm{ss}$ & 9,600 & \\
\hline $6 / 25$ & 57,600 & 235,032 & 79,344 & 1,600 & & \\
\hline $7 / 5$ & 3,200 & $555, \pm 08$ & . . & 185,136 & 12,800 & 6,400 \\
\hline $7 / 12$ & 9,600 & $1,798,464$ & & 423,168 & 3,200 & $\ldots$ \\
\hline T/19 & 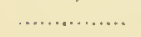 & 634,752 & & 211,584 & 57,600 & \\
\hline $7 / 26$ & ............ & 25,600 & 6,400 & $\ldots \ldots \quad \ldots$ & 12,800 & \\
\hline
\end{tabular}


T'able: 2.-Organisas Pbir Cunic Meter in PLankTon of SAN JoaquiN RIVkr IN 1913-(Continucd)

$\begin{array}{rrr}1913 \\ 8 & 2 \\ 5 & 9 \\ 8 & 15 \\ 8 & 23 \\ 8 & 31 \\ 9 & 6 \\ 9 & 13 \\ 9 & 20 \\ 9 & 27 \\ 10 & 4 \\ 10 / 11 & 11 \\ 10 & 15 \\ 10 & 26 \\ 11 / 1 / 1 & 1 \\ 11 / 2 & 8 \\ 11 / 15 \\ 11 / 22 \\ 11 & 30 \\ 12 & 6 \\ 12 / 14 & 14 \\ 12 & 20 \\ 12 & 27\end{array}$

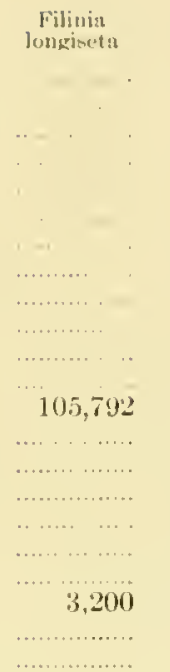

Keratellas
cochlearis
155,685

211,584
38,4100
25,600
12,800
$1,269,504$
$2,115,840$
$2,486,112$
546,336
46,064
449,616
211,544
12,800
3,200
6,400

Tieratella

Kieratella

$3 \mathrm{~S}, 4(1)$

5,600

$1 / 5$

$1 / 12$

$1 / 19$

$1 / 25$

2/ 2

2/ 8

$2 / 15$

$2 / 2: 3$

$3 / 1$

$3 / \mathrm{S}$

$3 / 15$

$3 / 2: 3$

$3 / 29$

1/ 5

$4 / 13$

$4 / 19$

$4 / 26$

$5 / 3$

$5 / 10$

$5 / 17$

$5 / 24$

$5 / 31$

$6 / 7$

$6 / 16$

$6 / 21$

(i) 28

$7 / 5$

$7 / 12$

$7 / 19$

$7 / 26$

8/ 2

8/ 9

815

$8 / 23$

$8 / 31$
Notholea

striata

\section{trigla}

Polyarthra

800

2,400

400

1,200

1,600

3,200

3,200

3,200

3,200

16,000

1,600

…...

12,800

$$
\text { 2,000 }
$$

12,800

57,600

19,200

6,400

12,500

105,792

3,200

12,500

16,000

6, 400

$(\mathrm{i}, 400$

79,314

$6,+400$

S6, 100

158,689

12,800

25,600
105,792

3,200)

(i. 100

79,344

19,200

32,000

6,400

$(i, 40)$

3,200

105.792

12,500

$$
\begin{aligned}
& \text { lieratclla } \\
& \text { egg. attuched }
\end{aligned}
$$

exg, froe

3,200

qualrata

12,400

12,500

$3 \mathrm{~S}, 400$

$12, \infty 00$

6. 4,000

25,000

12,800

12,800

$211,5 \times 4$

$12 \times, 000$

52), 960

25,600

317,376

793,110

528,960

12,500

15.5, 136

52.896

6,400

$6,-100$

(i, 100

3,200

$211,5 \times 4$

211,581

317,376

$6,-100$

52,5116

1,600

3,200

1,600

52,896

Polyarthra Polyarthra

trigla egg, trigla egr,
tached female at tached male

trached nale

Syncho
sp.

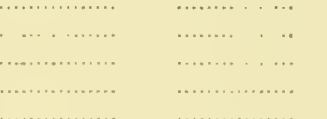

25,600

51,200

52,596

(j. 100

52.596

3,300

$25,6(90$

3,200

6., 100

$$
400
$$

400

3,200

Lecanc

$12,80)$
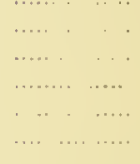

.

................

Trichocerca capueina
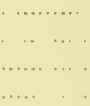

9,600

3,200

3,200

3,200

19,200

16,000

3,200

9.600

9,600

32,700
16,1900
32,240
25,600
6,400
6,100
6,400
$(i, 400$
12,800
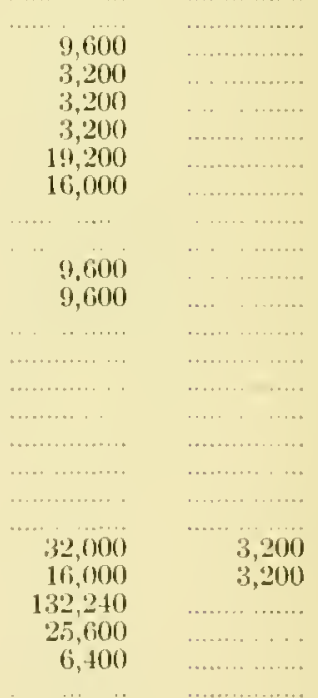
Table 2.-Organisus 1'er Cubic Meter in Plankton of SAN Joaquin River IN 1913-(Continued)

\begin{tabular}{|c|c|c|c|c|c|c|}
\hline 1913 & $\begin{array}{l}\text { Notholea } \\
\text { striata }\end{array}$ & $\begin{array}{l}\text { Polyarthra } \\
\text { trigla }\end{array}$ & $\begin{array}{c}\text { Polyarthra } \\
\text { trigla egg. } \\
\text { attached female }\end{array}$ & $\begin{array}{l}\text { Polyarthra } \\
\text { trigla egg. } \\
\text { attached male }\end{array}$ & $\begin{array}{c}\text { Synchaeta } \\
\text { sp. }\end{array}$ & $\begin{array}{l}\text { Trichocerea } \\
\text { capucina }\end{array}$ \\
\hline $9 / 6$ & & 317,376 & & & & \\
\hline $\begin{array}{l}9 / 13 \\
9 / 20\end{array}$ & & 51,200 & & & $\ldots \ldots \ldots \ldots$ & \\
\hline $9 / 20$ & 12,800 & 35,400 & & & & $12, \$ 00$ \\
\hline $\begin{array}{r}9 / 27 \\
10 / 4\end{array}$ & & 12,800 & 12,800 & & 12,800 & ... \\
\hline $\begin{array}{l}10 / 4 \\
10 / 11\end{array}$ & ........ & 25,600 & ... &.. & & 12,800 \\
\hline $10 / 18$ & 12,800 & 76,500 & $\ldots \ldots$ & 211,584 & 115,200 & 211,581 \\
\hline $10 / 26$ & $\ldots \ldots \ldots \ldots$ & 25,600 & & & 320,000 & \\
\hline $11 / 1$ & $\ldots \ldots \ldots$. & & …........... & . ............... & 264,480 & \\
\hline $11 / \mathrm{s}$ & .......... & …............. & …………... & ……..... & 317,376 & \\
\hline $11 / 15$ & & & …......... & …............ & 51,200 & \\
\hline $11 / 22$ & 3,200 & 52,896 & 다.......... & ……….... & 52,896 & \\
\hline $11 / 30$ & .......... & 25,600 & & & 22,400 & \\
\hline $12 / 6$ & & 41,600 & & & $79,3+4$ & \\
\hline $12 / 14$ & .......... & 105,792 & 3,200 & & $79,3+4$ & \\
\hline $12 / 20$ & ................... & 52,896 & $\ldots \ldots \ldots$ & 1,600 & 105,792 & \\
\hline $12 / 27$ & ........... & 3,200 & ............... & & 79.314 & 1,600 \\
\hline 1913 & $\begin{array}{l}\text { Trichocerca } \\
\text { iernis }\end{array}$ & $\begin{array}{l}\text { Trichotria } \\
\text { curta }\end{array}$ & $\begin{array}{l}\text { Total } \\
\text { Ploima }\end{array}$ & $\begin{array}{c}\text { Total } \\
\text { Rotifera }\end{array}$ & $\begin{array}{c}\text { Bosmina } \\
\text { longirostris }\end{array}$ & $\begin{array}{l}\text { Bosmina } \\
\text { sp. }\end{array}$ \\
\hline $1 / 5$ & & & 5,200 & 7.200 & & \\
\hline $1 / 12$ & $\ldots \ldots$. & & 15,600 & 20,000 & $\ldots$. & \\
\hline $1 / 19$ & .............. & ㄱ..…… & 27,436 & 81,532 & & \\
\hline $1 / 25$ & ………....... & ………… & 45,060 & 80,308 & 800 & \\
\hline $2 / 2$ & 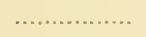 & $\ldots \ldots$ & 73,600 & 197,392 & & \\
\hline $2 / 8$ & …………... & ........... & 308,240 & 385,040 & & \\
\hline $2 / 15$ & ….............. & ……........ & 516,816 & 532,816 & ......... & \\
\hline $2 / 23$ & …........... & …................. & 380,114 & 172,258 & ........ & .. \\
\hline $3 / 1$ & ....... & …............. & 165,000 & 201,600 & & \\
\hline $3 / 8$ & .......... & .......... & 93 & $\begin{array}{r}1,070,528 \\
896006\end{array}$ & …... & $\ldots$ \\
\hline $3 / 15$ & …….......... & …, & $\begin{array}{r}737,152 \\
1,022,432\end{array}$ & $\begin{array}{r}826,096 \\
1,210,768\end{array}$ & ...... & $\cdots$ \\
\hline $\begin{array}{l}3 / 23 \\
3 / 29\end{array}$ & ………..... & $\ldots \ldots$. & $\begin{array}{r}1,022,432 \\
733,952\end{array}$ & 76 & & \\
\hline $4 / 5$ & ……… & ………… & 403,024 & 419,021 & …...... & 6,400 \\
\hline $4 / 13$ & ….............. & …................ & 286,032 & 287,232 & $\ldots \ldots \ldots$ & 3,200 \\
\hline $4 / 19$ & ․․․․…… & … & $1,106,768$ & $1,113,168$ & ....... & \\
\hline $4 / 26$ & 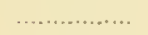 & ……….... & $293,18 t$ & $293,1 \$ 1$ & & 1,600 \\
\hline $5 / 3$ & ….............. & …................ & 100,144 & 100,144 & 3,200 & \\
\hline $5 / 10$ & ………....... & ………… & 14 & 169,600 & . . ...... & in. \\
\hline $5 / 17$ & $\ldots \ldots \ldots \ldots \ldots \ldots$ & ……….... & 150,592 & 156,992 & .......... & \\
\hline $5 / 24$ & & $\ldots$ & 200,888 & 206,689 & ……… . . & \\
\hline $5 / 31$ & …......... & 다........ & 182,592 & 19 & ......... & \\
\hline $6 / 7$ & 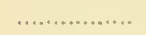 & ……… & $20 S, 192$ & 220,992 & ....... & \\
\hline $6 / 16$ & ………… & ….......... & $277,0 \mathrm{~s} S$ & $27 \pi, 0 \mathrm{~s} s$ & ......... & \\
\hline $6 / 21$ & ………… & ……… & 464,672 & 467,872 & ..........: & \\
\hline $6 / 28$ & & & 687,1 & 69 & 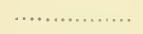 & \\
\hline $7 / 5$ & 12,800 & 3,200 & $1,002,450$ & $1.005,024$ & & \\
\hline $7 / 12$ & 79,344 & $\ldots \ldots \ldots$ & $3,573,554$ & $3,578,3 \mathrm{S4}$ & 3,200 & \\
\hline $7 / 19$ & 12,800 & $\ldots \ldots \ldots$ & $1,297,728$ & $1,297.728$ & 6,400 & \\
\hline $7 / 26$ & 105,792 & & $560,76 \mathrm{~S}$ & 567,168 & & \\
\hline $8 / 2$ & 38,400 & & $1,213,216$ & $1,387,904$ & 6,100 & $\ldots \ldots \ldots$ \\
\hline $8 / 9$ & 19,200 & 6,400 & 579,968 & $579,96 \mathrm{~S}$ & & \\
\hline$S / 15$ & 44,800 & ......... & $1,378,112$ & $1,690,400$ & $38, \pm 00$ & \\
\hline $8 / 23$ & 158,688 & …...... & 782,052 & $1,201,82 \mathrm{~S}$ & & \\
\hline $8 / 31$ & 105,792 & ………..... & $1,573,312$ & 1.810 .496 & 12,800 & \\
\hline $9 / 6$ & & & $1,067,328$ & $1,067,328$ & & \\
\hline $9 / 13$ & 76,800 & 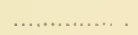 & $1,441,920$ & $1,518,720$ & 76,900 & ......... \\
\hline $9 / 20$ & 211,581 & .... & 903,552 & $1,179,136$ & 51,200 & \\
\hline $9 / 27$ & 128,000 & & 685,184 & 842,176 & 25,600 & \\
\hline $10 / 4$ & 64,000 & $\ldots$. & 794,368 & $1,220,160$ & 12,800 & \\
\hline
\end{tabular}


Table 2,-Orcanisms l'er Cubic Meter in Plankton of SAN JoAQUIN RIVHR IN 1913-(Continued)

\begin{tabular}{|c|c|c|c|c|c|c|}
\hline 1913 & $\begin{array}{l}\text { Trichocerea } \\
\text { iernis }\end{array}$ & $\begin{array}{l}\text { Trichotria } \\
\text { curta }\end{array}$ & $\begin{array}{l}\text { Total } \\
\text { Ploima }\end{array}$ & $\begin{array}{l}\text { Total } \\
\text { Rotifera }\end{array}$ & $\begin{array}{l}\text { Bosmina } \\
\text { longirostris }\end{array}$ & $\begin{array}{c}\text { Зовміแa } \\
\text { вр. }\end{array}$ \\
\hline $10 / 11$ & $6+, 000$ & . $\quad .$. & $6: 37,376$ & 8993,376 & .. $\quad \ldots$ & $1 \ldots$ \\
\hline $101 \%$ & . . & .. & $2,830,016$ & $3,122,976$ & & $x^{2}$ \\
\hline 1026 & .... & ........ & $3,185,792$ & $3,515,9(3,5$ & & $-\ldots$ \\
\hline 11.1 &,$\ldots$ & n............. & $3,949,312$ & $3,9 \leq 1,312$ & 6,400 & \\
\hline $11 / 8$ & $\ldots$. & $\ldots$ & $2,168,736$ & $2,191,336$ & & \\
\hline 1115 & $\ldots, \quad \ldots$ & …........... & 565.66 .1 & 629,6044 & $6,-100$ & \\
\hline $11 / 22$ & . $\quad . \quad \ldots$ & …........... & 811,040 & $\$ 17,410$ & ........... & \\
\hline $11 / 30$ & $\ldots \ldots \ldots \ldots$ & $\ldots \ldots$ & 427,572 & 427,572 & & \\
\hline $12 / 6$ & $\ldots \ldots \ldots$ & ……....... & $15 \cdot 1,54 t$ & 164,141 & 3,200 & \\
\hline $12 / 14$ & ............. & …......... & 239,536 & 245,936 & $\ldots \ldots \ldots, \ldots$ & \\
\hline $12 / 20$ & .......... & $\ldots$ & 159,440 & $16.5,5+0$ & & ... \\
\hline $12 / 27$ & ............... & ... & 08,544 & 101,744 & 6,400 & \\
\hline 1913 & $\begin{array}{c}\text { Chyverus } \\
\text { sp. }\end{array}$ & $\begin{array}{l}\text { Sirla } \\
\text { sp. }\end{array}$ & $\begin{array}{c}\text { Total } \\
\text { Cladocera }\end{array}$ & $\begin{array}{l}\text { Canthocamptus } \\
\text { sp. }\end{array}$ & $\begin{array}{l}\text { Cyclops } \\
\text { sp. }\end{array}$ & $\begin{array}{l}\text { Nauplius } \\
\text { sp. }\end{array}$ \\
\hline $1 / 5$ & ............... & , .......... & $\ldots \ldots \ldots \ldots$ & $\ldots \ldots \ldots$ & & \\
\hline $1 / 12$ & . & $\ldots$ & $\ldots \ldots$ & $\ldots . \ldots$. & & 400 \\
\hline $1 / 19$ & n............ & …............ & 100 & .............. & 400 & 800 \\
\hline $1 / 25$ & ............... & $\cdots$ & 1,200 & ......... & SO0 & 2,800 \\
\hline $2 / 2$ & …........... & …........... & $\ldots, \quad \ldots$ & n............. & . ....... & 9,600 \\
\hline $2 / 8$ & n............... & , $\ldots \ldots \ldots \ldots, \ldots$ & $\cdots \cdots$ & ........ & ................. & 3,200 \\
\hline $2 / 15$ & 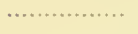 & . $\ldots \ldots \ldots+\ldots, \ldots$ & $\cdots$ & …..... & $\ldots \ldots \ldots \ldots$ & . . \\
\hline $2 / 23$ & ……, & , & $\ldots \ldots, \quad, \ldots$ & $\ldots \ldots$ & ………, & 3,200 \\
\hline $3 / 1$ & ….........., & , $\ldots \ldots \ldots \ldots \ldots$ & $\ldots$ & ........... & ............... & \\
\hline $\begin{array}{l}3 / 8 \\
3 / 15\end{array}$ & ............. & ........ & …... $\quad \ldots$ & n..... & $\ldots \ldots \ldots \ldots$ & \\
\hline $\begin{array}{l}3 / 23 \\
3 / 23\end{array}$ & 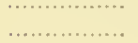 & ………, & ${ }^{\cdots} \cdots, \quad \cdots$ & ……, & , & \\
\hline $3 / 29$ & ................... & & & & ….............. & 1,600 \\
\hline $4 / 5$ & n.............. & ...... & 6,400 & ... & …............ & 1,600 \\
\hline $4 / 13$ & .............. & .............. & 3,200 & ... & (........... & $\ldots$ \\
\hline $4 / 19$ & , & (........... & $100 \Omega$ & & ............. & 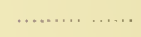 \\
\hline$+1 / 26$ & & n.............. & 1,600 & 3,200 & ......... & $\ldots$ \\
\hline $5 / 3$ & ................. & , $\ldots \ldots \ldots \ldots \ldots$ & 3.200 & .. & ......., & 3,200 \\
\hline $5 / 10$ & …............ & 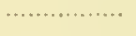 & $\quad \cdots \cdots$ & $\ldots \ldots \ldots \ldots \ldots$ & (........... & \\
\hline $5 / 17$ & ................. & 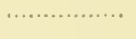 & $\ldots \ldots, \quad \cdots$ & $\ldots+\cdots, \quad \cdots$ & .............., & \\
\hline $\begin{array}{l}5 / 2 t \\
5 / 31\end{array}$ & , & , n......... & $\ldots \ldots \ldots, \quad \cdots$ & $\ldots \ldots \ldots \ldots \ldots$ & ................. & 12,800 \\
\hline $\begin{array}{l}5 / 31 \\
6 / 7\end{array}$ & ……… & $\cdots$ & $\quad \cdots$ & N....... & …..... & 25,600 \\
\hline $6 / 16$ & (n) & $\ldots \ldots \ldots+\ldots$ & $\begin{array}{ll}\cdots & \cdots \\
\cdots & \cdots\end{array}$ & & 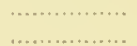 & $\cdot-$ \\
\hline $6 / 21$ & …........... & ........... & $\ldots \ldots \ldots$ & n.............. & ................... & 3,200 \\
\hline $6 / 25$ & ................... & ................. & ….... & 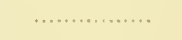 & 3,200 & \\
\hline 7/ 5 & 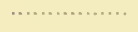 & ......... & & ............ & & 3,200 \\
\hline $7 / 12$ & ……....... & ……, & 3,200 & & 3,200 & 6,400 \\
\hline $\begin{array}{l}7 / 19 \\
7 / 26\end{array}$ & $\ldots \ldots \ldots+\cdots, \ldots$ & $\cdots$ & 6,400 & …. & 12,800 & 6,400 \\
\hline $8 / 2$ & …… & ….......... & 6,400 & .... & ${ }^{\cdots} 19,200$ & 6,400 \\
\hline $8 / 9$ & & ................ & & & 6.400 & 6,400 \\
\hline$\$ / 15$ & $6, \pm 00$ & 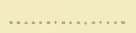 & 44,800 & & 6.400 & 6,400 \\
\hline $8 / 23$ & 12,800 & $\ldots \ldots \ldots$ & 12,800 & 6,400 & 6,400 & 6,400 \\
\hline $8 / 31$ & & 25,600 & $3 S, 400$ & $\ldots, \quad, \ldots$ & 12,800 & 12,800 \\
\hline $9 / 6$ & … & & & $\cdots, \quad \cdots$ & & $211,5 \mathrm{~S} 4$ \\
\hline $9 / 13$ & 12,800 & 12,800 & 102,400 & …........... & 25,600 & 105,792 \\
\hline $9 / 20$ & 12,800 & -.... & 51,200 & n............ & ............... & 105,792 \\
\hline $9 / 27$ & 25,600 & $\ldots \ldots$ & 51,200 & ............ & $\ldots . \ldots \ldots$ & · \\
\hline $10 / 4$ & & $\ldots \ldots+\ldots$ & 12,800 & …........... & ..... $\quad \ldots$. & \\
\hline $10 / 11$ & & $\ldots \ldots \ldots \ldots \ldots$ & & .............. & 12,800 & 25,600 \\
\hline $10 / 18$ & 12,800 & …........... & 12,800 & & $\ldots+\cdots$ & $3 \$ .100$ \\
\hline $10 / 26$ & $1 . \quad \ldots$ & ….......... & $=1$ & 12,800 & $\begin{array}{llll}\ldots & \ldots & \ldots\end{array}$ & $\cdot \cdots$ \\
\hline $11 / 1$ & ............. & ….......... & 6,400 & $\ldots \quad \ldots$ & …............ & .............. \\
\hline $11 / 15$ & $\ldots$ & & 6,100 & 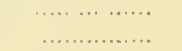 & $\begin{array}{l}\ldots \ldots \ldots \ldots \\
\ldots \ldots \ldots \ldots \ldots\end{array}$ & $\begin{array}{l}\ldots \ldots, \ldots \ldots \\
\ldots \ldots, \ldots \ldots\end{array}$ \\
\hline
\end{tabular}


Table 2.-Organisms Per Cubic Meter in Plankton of San Joaquin River in 1913-(Coutimued)

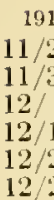

$11 / 22$

$11 / 30$

$12 / 6$

$2 / 14$

$12 / 27$

1913

$1 / 5$

$1 / 12$

$1 / 19$

$1 / 25$

$2 / 2$

2/ 8

$2 / 15$

$2 / 23$

$3 / 1$

$3 / \mathrm{S}$

$3 / 15$

$3 / 23$

$3 / 29$

$4 / 5$

$4 / 13$

$4 / 19$

$4 / 26$

5/ 3

$5 / 10$

$5 / 17$

$5 / 24$

$5 / 31$

$6 / 7$

$6 / 16$

$6 / 21$

$6 / 28$

$7 / 5$

$7 / 12$

$7 / 19$

$7 / 26$

$8 / 2$

S/ 9

$8 / 15$

$\mathrm{S} / 23$

$8 / 31$

$9 / 6$

$9 / 13$

$9 / 20$

$9 / 27$

$10 / 4$

$10 / 11$

$10 / 18$

$10 / 26$

11/ 1

$11 / 8$

$11 / 15$

$11 / 22$

$11 / 30$

$12 / 6$

$12 / 14$

$12 / 20$

$12 / 27$

$\begin{array}{r}\begin{array}{c}\text { Total } \\ \text { Cladocera }\end{array} \\ \hdashline \ldots \ldots \ldots \\ 6,400 \\ 6,400 \\ \hline\end{array}$

Copepo

\section{0}

1,200

3,600

9,600

3,200

3,200

3,200

1,600

4,800

3,200

3,200

12.800

25,600

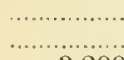

3,200

3,200

3,200

9,600

19,200

25,600

12,800

12,800

19,200

25,600

211,584

131,792

115,592

38,400

38,400

12,800

$$
\begin{array}{r}
12,800 \\
3,200 \\
6,400
\end{array}
$$

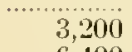

$$
\begin{gathered}
\text { Sida } \\
\text { sp. }
\end{gathered}
$$

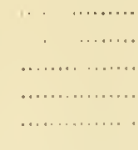

Total

Entomostraca

400

1,600

5,200

9,600 .

3,200

3,200

3,200

1,600

11,200

3,200

4,800

6,400

12,800

25,600

3,200

3,200

3,200

12,800

25,600

32,000

12,800

57,600

32,000

64,000

211,584

233,792

169,792

51,200

12,500

35,400

51,200

12,800

6,400

6,400

3,200

6,400

6,400

6,400 ironomu

larva

105,792
Canthocamptus

Cyclops

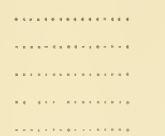

Glochidia

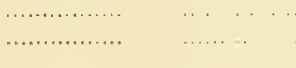

400

3,200

3,200

12,500

12,800

6,400

6,400

16,000

28,800

32,000

105,792

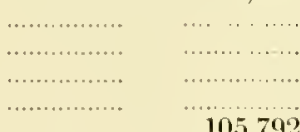

105,792
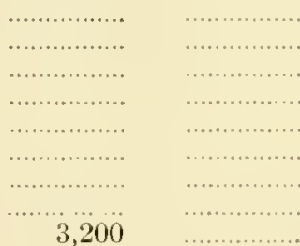

$$
\begin{aligned}
& \text { sp. } \\
& \text { splops }
\end{aligned}
$$

6,400

Insect
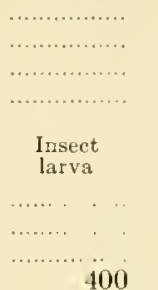

Nacrobiotus sp.

400

2,400

3,200

3,200

3,200

6,400

3,200

3,200

3,200

6,400

6,400

6,400

auplius
sp.

0,100
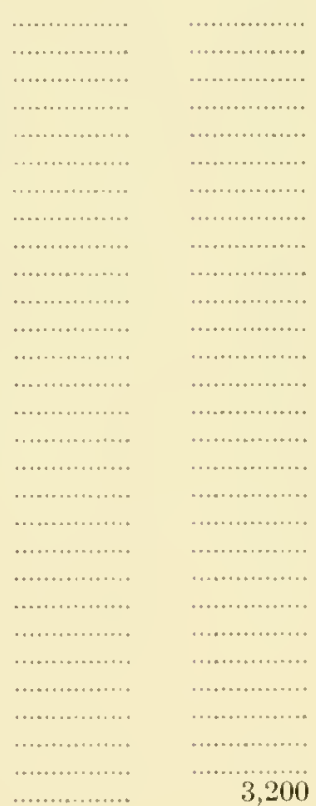

3,200 
Table 2, Organisha Per Cubic . Meter in Plankton of SAN Joagein RIVER IN 1913-(Concluded)

\begin{tabular}{|c|c|c|c|c|c|}
\hline 1913 & $\begin{array}{l}\text { Nenatoda } \\
\text { sp. }\end{array}$ & $\begin{array}{c}\text { Oligochaete } \\
\text { sp. }\end{array}$ & $\begin{array}{l}\text { Water } \\
\text { mite }\end{array}$ & $\begin{array}{c}\text { Total } \\
\text { Miscollanrous }\end{array}$ & $\begin{array}{c}\text { Total } \\
\text { Organisms }\end{array}$ \\
\hline $1 / \pi$ & & & & & $5,5 \geq 1,536$ \\
\hline $1 / 12$ & - & & ..... & 100 & $2,299,40.1$ \\
\hline 119 & $\ldots \ldots$ & 400 & & 400 & $13,3,56,6,80$ \\
\hline $1 / 25$ & $\ldots$ & 1,200 & .. & 4,100 & $3,751,651$ \\
\hline $2 / 2$ & & & & & $13,9 \times 3,312$ \\
\hline $2 ! 5$ & 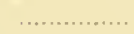 & 3,200 & ..... & $3,20)$ & $16,816,012$ \\
\hline $2 / 15$ & ..... & ................ & .... & 3,200 & $8,672,5 \%$ \\
\hline $2 / 23: 3$ & $\ldots$ & $\ldots \ldots \ldots \ldots$ & ... & 3,200 & $10,5030,(1.52$ \\
\hline $3 / 1$ & & & & 3,200 & $14,529,72 \mathrm{~s}$ \\
\hline $3 / s$ & ...... & .... & ..... & 3,200 & $13,20 \cdot 1,0=0$ \\
\hline $3 / 15$ & & $\ldots \ldots$ & ..... & 3,200 & $12,502,272$ \\
\hline $3 / 23$ & 3,200 & $\ldots \ldots$ & $\ldots .$. & 3,200 & $12,027,610 \mathrm{i}$ \\
\hline $3 / 29$ & ........... & $\ldots$ & $\ldots$ & . & $15,115,10 t$ \\
\hline $4 / 5$ & $\ldots \ldots$ & .... & ... & 6,400 & $6.850,018$ \\
\hline $4 / 13$ & $\ldots \ldots$ & ..... & ... & 3,200 & $10,023,664$ \\
\hline $4 / 19$ & ....... & $\ldots$ & & 3,200 & $16,330,872$ \\
\hline $4 / 26$ & ....... & $\ldots \ldots$ & .... & 3,200 & $12,421,325$ \\
\hline $5 / 3$ & ................ & $\ldots \ldots$ & $\ldots$ & 6,400 & $8,507,964$ \\
\hline $5 / 10$ & & $\ldots$ & & & $10,596,192$ \\
\hline $5 / 17$ & 6,400 & $\ldots$ & 12,800 & 25,600 & $17,754,480$ \\
\hline $5 / 21$ & $\ldots \ldots \ldots \ldots$ & ...... & $\ldots$. & 12,800 & $13,031,040$ \\
\hline $5 /: 31$ & $\ldots . .$. & ........ & ....... & 12,500 & $25,576,192$ \\
\hline b/ 7 & $\ldots$. & & & & $26,220,951$ \\
\hline $6 / 16$ & ... & $\cdots \cdots$ & & 12,800 & $18,035,072$ \\
\hline $6 / 21$ & $\ldots$ & ...... & & 6,400 & $21,395,760$ \\
\hline $6 / 28$ & ..... & & 3,200 & 9,600 & 32071,398 \\
\hline $7 / 5$ & ....... & ..... & …............ & 16,000 & $16,750,4+4$ \\
\hline $7 / 12$ & ......... & $\ldots \ldots$ & ................ & 25,500 & $34,380,762$ \\
\hline $7 / 19$ & ......... & & ................ & 32,000 & $61,859,06 t$ \\
\hline $7 / 26$ & ........ & …. & & & $61,5 \mathrm{S9}, \mathrm{SSS}$ \\
\hline $8 / 2$ & ......... & $\ldots$ & ....... & 105,792 & $117,439.6 \pm 8$ \\
\hline $8 / 9$ & & & & (1) & $103,235,586$ \\
\hline $8 / 15$ & ... & ......... & ........... & $\ldots \ldots, \ldots, \ldots$, & $105,445,076$ \\
\hline $82: 3$ & ......... & ......... & ........... & ............. & $217,550,950$ \\
\hline $8 / 31$ & ....... & .. & …....... & & $201,760,892$ \\
\hline $9 / 6$ & ..... & & & 105,792 & $299,022,312$ \\
\hline $9 / 13$ & $\ldots$ & & ....... & 12,800 & $151,795,800$ \\
\hline 920 & & & .... & & $1 \pm 1,406,360$ \\
\hline $11 / 27$ & & & & & $93,592,016$ \\
\hline $10 / 4$ & & & & & $96,256,744$ \\
\hline $10 / 11$ & , . . . . & & 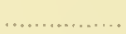 & . & $150,-41,918$ \\
\hline $10 / 18$ & ......... & .............. & …............ & & $\mathrm{S}, 9,902, \mathrm{~S} 32$ \\
\hline $10 / 26$ & $\cdots \cdot$ & & & $105,799^{\circ}$ & $63,576,626$ \\
\hline $11 / 1$ & ....... & ........ & ..... & $\ldots \ldots$ & $3 t, 666,100$ \\
\hline $11 / \mathrm{s}$ & & ................. & ................... & $\ldots \ldots$ & $17,1.5 \%, S 16$ \\
\hline $11 / 15$ & & & & ................ & $13.933,184$ \\
\hline $11 / 22$ & ... & ....... & .......... & ................ & $14,814,640$ \\
\hline $11 / 30$ & ........... & ......... & ............... & ... ............ & $23,213,80 \mathrm{~s}$ \\
\hline $12 / 6$ & ……….... & & & & $17,005,776$ \\
\hline $12 / 14$ & ……........ & ............... & ................ & 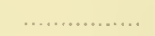 & $9,575,20 \mathrm{~S}$ \\
\hline $12 / 20$ & …............ & n............. & ................ & & $7,518,192$ \\
\hline $12 / 27$ & & & & 6,400 & $6,370,770$ \\
\hline
\end{tabular}


Table 3.-Organisms Per Cubic Meter in Plankton of SNitth's Caval IN 1913

\begin{tabular}{|c|c|c|c|c|c|c|}
\hline 1913 & $\begin{array}{l}\text { Spirillum } \\
\text { undula }\end{array}$ & $\begin{array}{c}\text { Total } \\
\text { Bacteriaceae }\end{array}$ & $\begin{array}{c}\text { Anabaena } \\
\text { sp. }\end{array}$ & $\begin{array}{c}\text { Aphanoeapsa } \\
\text { sp. }\end{array}$ & $\begin{array}{c}\text { Coelosphaerium } \\
\text { kützingianum }\end{array}$ & $\begin{array}{c}\text { Gloeocapsa } \\
\text { conglomerata }\end{array}$ \\
\hline $1 / 11$ & $\ldots \ldots \ldots$ & (n..... & …........... & ............... & ... $\quad \ldots \ldots \ldots$ & 20 \\
\hline ] $/ 19$ & $\cdots$ & & ....... & ..... & $\ldots$ & \\
\hline $1 / 25$ & & & & & .. & \\
\hline $2 / 2$ & 1,600 & 1,600 & n.............. & 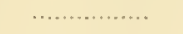 & n............ & ....... \\
\hline $2 / 8$ & ........ & n........ & .............. & $\cdots \cdots$ & ..... & .. \\
\hline $\begin{array}{l}2 / 10 \\
2 / 23\end{array}$ & $\cdots \cdot$ & (n). & ……, & ………? & $\begin{array}{l}\cdots \\
\cdots \cdots\end{array}$ & \\
\hline $3 / 1$ & …............. & (........ & 1,600 & $\ldots \ldots$ & (n...... & ..... \\
\hline $3 / 8$ & n....... & . & $\ldots \ldots \ldots$ & (n....... & $\ldots$. & .. \\
\hline $3 / 15$ & …............ & ….............. & ….... & . . $\ldots \ldots \ldots$ & ........ & ... \\
\hline $3 / 23$ & 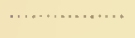 & ……….... & 1,600 & ................ & ..... & $\ldots$ \\
\hline $\begin{array}{r}3 / 29 \\
+\quad 5\end{array}$ & 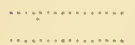 & ...... & n..., n & (........ & .. & .. \\
\hline $\begin{array}{l}\text { 1/5 } \\
4 / 13\end{array}$ & ……, & ………, & 3200 & n... n......... & ............... & $\ldots$ \\
\hline $\begin{array}{l}4 / 10 \\
4 / 19\end{array}$ & …............ & ............ & ........ & $\ldots \ldots$ & n., & ...... \\
\hline $4 / 26$ & & .......... & 3,200 & …....... & ……............. & ……............ \\
\hline $5 / 3$ & ................ & …............ & 6,100 & $\ldots \ldots, \ldots \ldots \ldots$ & & $\ldots$ \\
\hline $5 / 10$ & ............... & ............... & 3,200 & $\ldots$ & 3,200 & \\
\hline $5 / 17$ & …........... & ............... & 16,000 & ..... & ... & \\
\hline $5 / 21$ & , & …............. & $\ldots$ & $\ldots$ & ....... & .. \\
\hline $5 / 31$ & ........ & .............. & 1,600 & & & \\
\hline 6) 7 & n................ & , ................. & 3,200 & 105,792 & ............... & \\
\hline $6 / 16$ & 600 & & 9,600 & 3,200 & ...... & \\
\hline $6 / 21$ & 1,600 & 1,600 & $2 S, 800$ & $79,3+1$ & ..... & \\
\hline $6 / 28$ & $\ldots \ldots \ldots \ldots, \ldots$ & $\ldots \cdots, \ldots$ & 476,061 & $18.5,136$ & n............. & …, n..., \\
\hline $\begin{array}{l}7 / 5 \\
7 / 12\end{array}$ & i. 600 & , 600 & 3,200 & 52,596 & ..... & \\
\hline$\frac{7}{7 / 19}$ & $\begin{array}{r}1,000 \\
\ldots . . . \ldots \ldots\end{array}$ & 1,600 & $2,036,196$ & 261,180 & ..... & 155,136 \\
\hline $7 / 26$ & . & … & $\begin{array}{r}4,001,922 \\
+125 \mathrm{SSS}\end{array}$ & $\begin{array}{l}105,792 \\
26+180\end{array}$ & …..... & 105702 \\
\hline $8 / 2$ & …............ & ............. & 793,440 & $423,16 \mathrm{~s}$ & & 6,400 \\
\hline $8 / 9$ & n............ & ............... & $2,697,696$ & $1,163,712$ & $\ldots .$. & $158,6 \mathrm{SS}$ \\
\hline $8 / 23$ & 3.200 & 3,200 & 586.580 & 156 & 3.200 & \\
\hline$S / 31$ & & 0,200 & $1,481,088$ & $\begin{array}{r}100,000 \\
. \quad \ldots \ldots \ldots\end{array}$ & $\begin{array}{r}0,-200 \\
\ldots \ldots \ldots \ldots \ldots\end{array}$ & 105,792 \\
\hline $9 / 6$ & 105,792 & 105,792 & $2,539,00 \mathrm{~S}$ & & .............. & $\ldots \ldots \ldots$ \\
\hline $9 / 13$ & „............. & ................ & 1692,672 & 211,584 & .............. & \\
\hline $9 / 20$ & ................ & $\ldots \ldots . . . \ldots \ldots$ & & 528,960 & .................. & \\
\hline $9 / 27$ & ................. & ........... & 12,800 & 12,800 & ….............. & \\
\hline $10 / 4$ & ................ & …..... & 12,800 & 12,800 & ........... & \\
\hline $10 / 11$ & $\cdots$ & $\cdots$ & & $211,5 \mathrm{~S} 4$ & ... & $\ldots$ \\
\hline $10 / 18$ & ................. & ..................... & 12,800 & $\ldots \ldots$ & …........... & \\
\hline $10 / 26$ & & …........... & & 6,400 & & \\
\hline $\begin{array}{l}11 / 1 \\
11 / 8\end{array}$ & $\ldots$ & (n....... & 52,896 & ............... & 105,792 & \\
\hline $11 / 15$ & 1,600 & 1,600 & $\therefore \ldots \ldots \ldots, \ldots$ & ........... & ….............. & \\
\hline $11 / 22$ & ................ & 1,000 & …..... & ................ & ................. & \\
\hline $11 / 30$ & ................ & ……...... & …............... & ……....... & n..., & ... \\
\hline $12 / 6$ & & & & 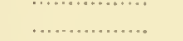 & ……....... & \\
\hline $12 / 11$ & 1,600 & 1,600 & 132,240 & …......... & .... & ……...... \\
\hline 120 & & $\ldots \ldots \ldots \ldots$ & ............. & …......... & ............... & .......... \\
\hline 87 & 然 & $\cdots$ & ...... & …, & n.w. & …..... \\
\hline 1913 & $\begin{array}{c}\text { Gloeocapsa } \\
\text { sp. }\end{array}$ & $\begin{array}{l}\text { Gomphosphaera } \\
\text { aponina }\end{array}$ & $\begin{array}{l}\text { Inactis } \\
\text { tinctoria } \\
\text { Agardh }\end{array}$ & $\begin{array}{l}\text { Merismopedium } \\
\text { glaucum }\end{array}$ & $\begin{array}{l}\text { Microcystis } \\
\text { sp. }\end{array}$ & $\begin{array}{l}\text { Nostoc } \\
\text { sp. }\end{array}$ \\
\hline $\begin{array}{l}1 / 11 \\
1 / 19\end{array}$ & , $\ldots \ldots+\ldots$ & ,................ & …..... & $\ldots \ldots \ldots \ldots$ & $\ldots \ldots$ & \\
\hline $\begin{array}{l}1 / 19 \\
1 / 25\end{array}$ & . & 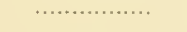 & n............. & $\ldots \ldots+\cdots$ & 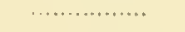 & n.......... \\
\hline $\begin{array}{r}1 / 25 \\
2 / 2\end{array}$ & $\ldots \ldots \ldots \ldots, \ldots$ & , $\ldots \ldots \ldots \ldots \ldots \ldots$ & , n............... & , $\ldots \ldots \ldots \ldots \ldots$ & . & .......... \\
\hline $\begin{array}{l}2 / 2 \\
2 / 8\end{array}$ & & & ....... & ,........ & ......... & ... \\
\hline $2 / 15$ & ............... & 3,200 & (n... & ....... & ......... & . \\
\hline
\end{tabular}




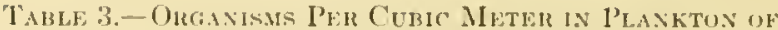
Sultui Canalo in 1913-(Coulimued)

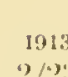

$2 / 2: 3$

$3 / 1$

$3 / 15$

$3 / 2.3$

3. 29

$+15$

$-1.13$

$4 / 19$

$4 / 26$

$5 / 3$

510

$5 / 17$

5.24

531

(i) 7

(i) 16

$6 \cdot 21$

(i) $/ 28$

$7 / 5$

$7 / 12$

$7 / 19$

$7 / 26$

$8 / 2$

S/ 9

$\mathrm{S} / 15$

$8 / 23$

$\$ / 31$

$9 / 6$

9,13

9.20

9 27

11) 4

10 11

$10 / 18$

$10 / 26$

11/ 1

$11 \mathrm{~S}$

$11 / 15$

$11 / 22$

$11 / 30$

12/ 6

$12 / 14$

$12 / 20$

$12 / 27$

1913

1/11

$1 / 19$

$1 / 2.5$

2 ! 2

$2 / 8$

2/15

$2 / 23$

3 1 1

$3 / \mathrm{S}$

$3 / 15$

$3 / 23$

$3 / 29$
Inact is
tinctoria

tinctoria
Agardh

Glococapsa

sp.

$\begin{array}{rr}\ldots . & 3,200 \\ 1,60) & 1,600 \\ 1,600 & 3,200 \\ 79,344 & \ldots \ldots \\ 52,596 & \ldots \ldots \\ \ldots & \ldots \ldots \\ 1,600\end{array}$

1,600

$52 \mathrm{sat}$

1,600

1,600

1,600

1,600

1,600

$1,6,00$

1,600

290,928

211.584

$8+6,3306$

$476,06-1$

$1,269,504$

317,376

581,856

317,376

423,16 is

$1,0.57,9^{\circ} \geq 0$

952,135

$740,5 \cdot 11$

$7+1,5+4$

317,376

(i) 400

52,896

$158,6 \mathrm{SS}$

105,792

52,596

52.896

79,344

1. 600

133,840

()scillatoria

400

Oscillatoria

$76, \times 00$

317,376

6. 400

52,546

3,200

105,793

$1,16: 3,712$

$6,(1) 30,144$

$-, 931,400$

$9.52,12 \mathrm{~s}$

$1,566,8<0$

$11,31 !, 74.1$

423,168

528,960

317,376

52,896

52,896

132,240

52,896

10.5. 792

12, 800

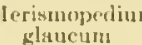

Microcystis

sp.

Nosto

Bj).

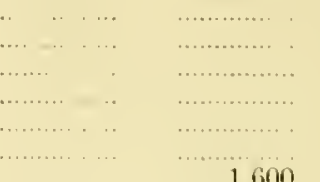

1.600

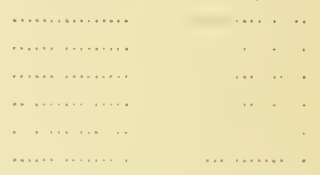

3,200

IDS, tiss

$264,+80$

211,554

370,272

$211,58 t$

$211,5 \mathrm{St}$

32,000

12,500

12,200

$6+, 000$

12,500

25,600

317,376

$211,58 t$

25,600

6,400

6,400

52,596

12,800

$16,000)$

$6, \pm 00$

30) 1,381

$2,062,914$

591,856

1,110,816;

6) $6,6 \pm 5$

$1,216,608$

$1,322,400$

$6,576,480$

$3,491,136$

$7+0,54 t$

$1,0.57,920$

$2,6 \pm 4,500$

$63+, 752$

$317,37 \mathrm{~A}$

317.376

6.400

12,800

12,800

…

Stigonema

sp.

Total schizophycese

$+100$

\begin{tabular}{|c|c|}
\hline $\begin{array}{c}\text { Oscillntoria } \\
\text { tenuis }\end{array}$ & $\begin{array}{c}\text { Phormidium } \\
\text { spp. }\end{array}$ \\
\hline$\cdot$ & \\
\hline 400 & $\begin{array}{r}3.200 \\
66,120\end{array}$ \\
\hline & 1,600 \\
\hline 1.600 & 3,200 \\
\hline $7 !, 3 \pm t$ & 52,896 \\
\hline . . & 185,136 \\
\hline . & 1,600 \\
\hline 52,896 & 52,496 \\
\hline & $\begin{array}{r}79,3+1 \\
317,376\end{array}$ \\
\hline
\end{tabular}

3,200

$6(3,520)$

$1.1 i() 0$

7,000

135,440

185,336

4,300

1.600

110,592

$150,2 \mathrm{SS}$

470.064 
Table 3.-Organisms Per Cuble Meter in Plankton of Suitu's Canal in 1913-(Continued)

\begin{tabular}{|c|c|c|c|c|c|c|}
\hline 1913 & $\begin{array}{c}\text { Oscillatoria } \\
\text { formosa }\end{array}$ & $\begin{array}{l}\text { Oscillatoria } \\
\text { sp. }\end{array}$ & $\begin{array}{c}\text { Oscillatoria } \\
\text { tenuis }\end{array}$ & $\begin{array}{c}\text { Phormidium } \\
\text { spp. }\end{array}$ & $\begin{array}{l}\text { Stigonema } \\
\text { sp. }\end{array}$ & $\begin{array}{c}\text { Total } \\
\text { Schizophyceae }\end{array}$ \\
\hline $4 / 5$ & 3,200 & $\ldots \ldots$ & 3,200 & 79,344 & & 250,832 \\
\hline $1 / 13$ & & & 1,600 & 132.240 & & $1+0,210$ \\
\hline $4 / 19$ & & ......... & 1,600 & 105,792 & & $110,59^{\circ}$ \\
\hline $1 / 26$ & & & & & & $163,48 \mathrm{~s}$ \\
\hline $5 / 3$ & & .................. & 3,200 & 3,200 & & (is, 696 \\
\hline $5 / 10$ & .......... & .............. & ............. & 1,600 & & 9,600 \\
\hline $5 / 17$ & & & .................. & 52,896 & 16,000 & 84.896 \\
\hline $5 / 21$ & & ... & ............ & ....... & & 1,600 \\
\hline $5 / 31$ & & & (......... & & & 3,200 \\
\hline $6 / 7$ & 6.100 & & & & & 123,392 \\
\hline $6 / 16$ & 9,600 & 3,200 & ... & 79,344 & & 120,914 \\
\hline $6 / 21$ & 9600 & $\ldots \ldots$ & & 1,600 & 1,600 & 132,144 \\
\hline $6 / 28$ & & & & 1,600 & 1,600 & 758,800 \\
\hline $7 / 5$ & & & 1,600 & $\ldots \ldots \ldots$ & 1,600 & $2,130,210$ \\
\hline $7 / 12$ & 1,600 & 1,600 & 3,200 & $\ldots \ldots \ldots$ & 52,896 & $3,735,568$ \\
\hline $7 / 19$ & 3,200 & 317,376 & $\cdots$ & $\ldots$ & 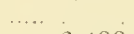 & $6,562,301$ \\
\hline $7 / 26$ & & 370,272 & & & 6.400 & $6,7,80,294$ \\
\hline $8 / 2$ & & 317,376 & & .......... & & $2,651,200$ \\
\hline $8 / 9$ & 6,100 & 697,618 & & $\ldots$ & 158.685 & $7,623,424$ \\
\hline $8 / 15$ & ..... & & & & & 323,726 \\
\hline $8 / 23$ & …... & 211,584 & 3,200 & \pm 76.064 & . & $11,252,352$ \\
\hline $\mathrm{S} / 31$ & & 317,376 & $\ldots \ldots \ldots$ & $1,798,464$ & . & $13,554,174$ \\
\hline $9 / 6$ & & & $\ldots \ldots$. & & & $11,662,720$ \\
\hline $9 / 13$ & .. & 105,792 & $\ldots$. & & & $5,218.716$ \\
\hline $9 / 20$ & & & . & 317,376 & $211,5 \mathrm{St}$ & $6,571,904$ \\
\hline $9 / 27$ & .. & 105,792 & & 528,960 & $\ldots-\ldots$ & $13,3 \times 0,992$ \\
\hline $10 / 4$ & & . & $\ldots \ldots$ & $\ldots$. & $\ldots \ldots$ & $1,824,061$ \\
\hline $10 / 11$ & .. & ...... & .......... & $\ldots$ & $\ldots \ldots \ldots$ & $1,599,680$ \\
\hline $10 / 18$ & & . $\ldots \ldots \ldots$ & ............ & $\ldots \ldots \quad, \ldots$ & .......... & 355,776 \\
\hline $10 / 26$ & & . & ......... & $\ldots \ldots . \quad .$. & . $\quad \ldots \ldots .$. & 25,600 \\
\hline $11 / 1$ & & & . & $\ldots \ldots \quad \ldots \ldots$ & .... & 230.781 \\
\hline $11 / S$ & 6.400 & & & $\ldots \ldots$ & & 283,680 \\
\hline $1 / 15$ & 3,200 & 1,600 & & $\ldots$ & & $295,72.5$ \\
\hline $11 / 22$ & ( & ... & 3,200 & 52,596 & 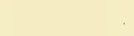 & 174,658 \\
\hline $11 / 30$ & $\cdot \quad .$. & & ..... & 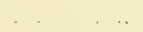 & & $159,68 \mathrm{~S}$ \\
\hline $12 / 6$ & $\ldots \ldots \ldots$ & 52,896 & $\ldots$ & $\ldots$ & & $132,2-10$ \\
\hline $12 / 11$ & .... & 1,600 & 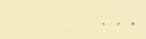 & & $\cdots$ & 135,110 \\
\hline $12 / 20$ & 9,600 & & ...... & ..... & .. & 9,600 \\
\hline $12 / 27$ & .... & 52,896 & $\ldots . .$. & . ... & . & 52,896 \\
\hline 1913 & $\begin{array}{l}\text { Actinastrum } \\
\text { hantzschii }\end{array}$ & $\begin{array}{c}\text { Actinastrum } \\
\text { hantzschii } \\
\text { (large) }\end{array}$ & $\begin{array}{l}\text { Coelastrum } \\
\text { microporum }\end{array}$ & $\begin{array}{l}\text { Crucigenia } \\
\text { lauterbornii }\end{array}$ & $\begin{array}{l}\text { Pediastrum } \\
\text { boryanum }\end{array}$ & $\begin{array}{l}\text { Pediastrum } \\
\text { duplex }\end{array}$ \\
\hline $1 / 11$ & & $\cdots$ & & .. & 400 & 400 \\
\hline $1 / 19$ & ....... . & ..... & ...... & ...... & 6,400 & \\
\hline $1 / 25$ & ....... & & . & & 6,400 & 7,200 \\
\hline $2 / 2$ & $\ldots \ldots$ & . & $\ldots \ldots \ldots$ & & 19,200 & $79,3 \pm 4$ \\
\hline $2 / 8$ & & & & & 32000 & 9,600 \\
\hline $2 / 15$ & & & & & 51,200 & 79,344 \\
\hline $2 / 23$ & 3,200 & & . & . & $3 \AA, 400$ & 132,240 \\
\hline $3 / 1$ & 1,600 & - & $\ldots \ldots$ & & $10.5,792$ & 9,600 \\
\hline $3 / 8$ & 1,600 & 1. & . ....... & & 158,698 & 6,400 \\
\hline $3 / 15$ & 105,792 & - & $\ldots \ldots$ & $\ldots \ldots \ldots$ & 79,344 & 79,344 \\
\hline $3 / 23$ & 9,600 & $\ldots .$. & $\ldots$. & & 159685 & 132.240 \\
\hline $3 / 29$ & 158,688 & $\ldots$ & & & 132,210 & 132,240 \\
\hline $4 / 5$ & 3,200 & $1, \quad \ldots \ldots$ & $\ldots \ldots$ & & 158,685 & $158,68 \mathrm{~S}$ \\
\hline $4 / 13$ & 52,896 & & . ............ & & 12,800 & 105,792 \\
\hline $4 / 19$ & 1.600 & & & & $10.5,792$ & 22.400 \\
\hline $4 / 26$ & 105,792 & 26,448 & $\ldots \ldots \ldots \ldots$ & $\ldots \ldots \ldots \ldots$ & 79,344 & 105,792 \\
\hline $5 / 3$ & & 9,600 & & & 132,240 & 79.344 \\
\hline $5 / 10$ & 6,400 & ................. & ................. & ..... & 22.400 & $12,>00$ \\
\hline
\end{tabular}


Table 3.-Organisms Per Cubic Meter in l'lankton of Sintu's CaNal, in 1913-(Continued)

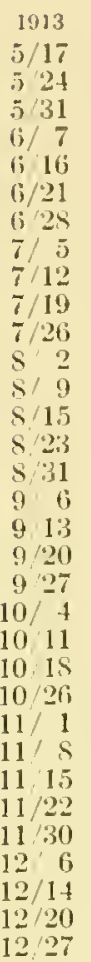

$4 / 19$

426

5) 3

5) 10

.5 $/ 17$

i) $/ 24$

5) $/ 31$

6) 7

(i) 16

6.21 Actinastrum

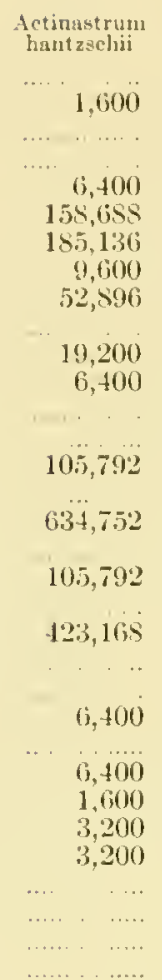

hantzschii
(large)

……….......

….............

1,600

3,200

1,600

$79,3 \cdot 14$

79,344

$52 \kappa, 960$

423,168

264,480

317,376

793,440

$3,067,96 \mathrm{~s}$

211,584

211,584

211,584

952,125

$1,451,059$

$1,481,058$

317,376

$26+450$

105,792

52,896

$79,3+4$

6,400

3,200

Pediastrun

simplex

$$
\begin{array}{r}
\ldots \ldots \ldots \\
3,200 \\
1,600 \\
6,400 \\
3,200 \\
3,200 \\
52,896 \\
1,600 \\
1,600 \\
\ldots \\
52,896 \\
1,600 \\
3,200
\end{array}
$$

Raphidium polymorphum

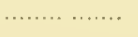

1,600 132,240

1,600

1,600

1,600

54,496

79,344

$3: 200$ botryoides

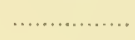

.................

1,600
Scenedesmus obliquus

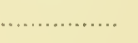

…….......
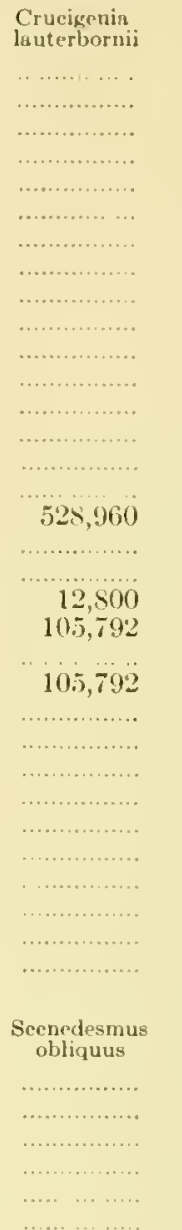

Pedinstrum boryanum

$9,(600$

9,600

52,896

19,200

9,600

79.341

158,685

19,200

211,55 !

19,200

158,685

105,792

10:5, 792

$211,5 \mathrm{~S} 4$

$10.5,79^{2}$

211,584

51,200

211,584

317,376

19,200

211,584

(i. 100

52,896

9,600

6,400

3,200

3,200

Scenedesmus quadricauda

400

400

400
1,600

3,200

105,792

$70,3+4$

6,400

132,240

9,600

132,240

290,928

105,792

158,685

132,240

105,792

6,400

3,200

105,792

1,600

3,200

52), 996

3,200

6,400

132,240

3,200 9,600
Pediastrum duplex

12,800

1,600

6,400

25,600

105,792

22,400

211,584

396,720

925, 680

$1,551,360$

$1,451,085$

$1,692,672$

$1,375,296$

$5 \$ 1,856$

$2,221,632$

$1,163,712$

$2,4333,216$

$3,596,928$

4.241,680

$2,962,176$

$4,559,056$

$4,770,640$

$2,539,008$

$1,639,776$

$1,533,954$

634,752

132,240

185, 136

105,792

52,896

52,596

9,600

52,596

Schroederia setigera

\section{................}

1,600

1,600 
Table 3.-Organisms Per Cubic Meter in Plankton of Suith's Canal in 1913-(Continued)

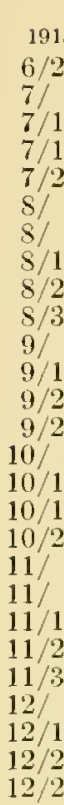

1913

$1 / 11$

$1 / 19$

$1 / 25$

$2 / 2$

$2 / 8$

$2 / 15$

$2 / 23$

$3 / 1$

$3 / 8$

$3 / 15$

$3 / 23$

$3 / 29$

$4 / 5$

$4 / 13$

$4 / 19$

$4 / 26$

$5 / 3$

$5 / 10$

$5 / 17$

$5 / 24$

$5 / 31$

$6 / 7$

$6 / 16$

$6 / 21$

$6 / 28$

$7 / 5$

$7 / 12$

$7 / 19$

$7 / 26$

8/ 2 Pediastrur
simplex
1,600

52,896

32,000

6,400

105,792

105,792

105,792

$15 \$, 688$

105,792

528,960

12,800

211,584

25,600

12,800

211,584

12,800

6,400

(... 3,200

1, 600

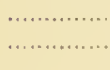

1,600

Total

Chlorophyceae

1,200

9,600

14,000

100,114

48,000

237,936

257,981

129,792

302,128

280,480

358,861

795.040

431,168

174,685

316,528

479,264

359,472

125,744

27,200

19,200

$11,5,592$

180,240

116,992

$211.5 \mathrm{S4}$

746,944

597,556

$1,64 \pm, 576$

$2,593,408$

$2,577,408$

$2,548,508$

$\begin{gathered}\text { Raphidium } \\ \text { polymorphum }\end{gathered}$
$\begin{gathered}1,600 \\ 1,600 \\ 3,200 \\ 3,200 \\ 3,200 \\ 3,200\end{gathered}$

370,272

317,376

211,584

224,384

211,584

105,792

$52,89 \ddot{6}$

211,584

132,240

1,600

79,344

1,600

132,210

Asterionella

gracillima

773,604

$6,083,040$

$3,153,924$

$5,183,508$

$9,997,344$

$2,062,944$

$2,641,800$

$1,666,224$

$1,481,088$

$1.295,952$

$1,137,264$

$3,702,720$

$211,5 \mathrm{~S} 4$

793,440

343,524

581,856

$2,9,800$

$3,623,376$

608.304

185,136

105,792

S19,8S8

2,353,872

$3,067,96 \mathrm{~s}$

899,232

238,032
Richteriella
botryoides

..............

…….........

..............

.

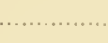

105,792

952,128

25,600

317,376

….........

, n............

(n).....

……......

n............

..........

……....

Asterionella

bracillima
(large)

1,600

1,600

................

…......

26,148

79,341

158,688

$132,2+0$

52,896

105,792

502512

$1,031,472$

$2,803,488$

$3,120,864$

502,512

1,600

$$
\begin{array}{r}
\text { cenedesmus } \\
\text { obliquus } \\
3,200 \\
3,200 \\
3,200 \\
105,792 \\
3,200 \\
158,688 \\
12,800 \\
423,168 \\
211,581 \\
105,792 \\
423,169 \\
105,792 \\
433,168 \\
211,581 \\
317,376 \\
211,584 \\
158,688 \\
105,792 \\
3,200 \\
1,600 \\
\ldots \ldots \ldots \ldots \ldots \\
3,200 \\
1,600
\end{array}
$$

Amphiprora alata

$$
\begin{array}{rr}
\ldots \ldots \ldots & \ldots \\
\ldots \ldots \ldots & . \\
\ldots \ldots \ldots & \ldots \\
1,600 &
\end{array}
$$

132,240

3,200

1,600

238.032

1,600

52,896

$\because, 200$

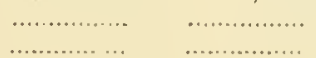

Scenedesmus quadricauda

264,450

10.5, 792

290,928

15s,68s

317,376

476,064

370,272

899,232

528,960

$8 \div 6,336$

$1,163,712$

$52 \mathrm{~S}, 960$

846,336

$1,269,504$

$2,115,6+4$

$1,692,672$

$8 \pm 6,336$

$1,110,816$

1,216,608

$8.16,336$

687,648

290,928

158,688

6,400

3,200

1, 600

52,896

Amphora coffaeformis

Bacillaria paradosa

2,000

4,800

4,500

6,400

3,200

3,200

25,600

6,400

132,210

$15 \mathrm{~S}, 6 \mathrm{~S} \mathrm{~S}$

105,792

$132,2+0$

185,136

41,600

9,600

12,800

3,200

16,000

12800

6,400

38,400

12.800

$1,428,192$

$1,904,256$

$5,183,80 \mathrm{~S}$

$4,760,6 \pm 0$ 


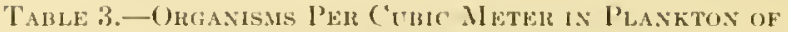
SMITH's CANat iN 1913-(Contimued)

\begin{tabular}{|c|c|c|c|c|c|c|}
\hline 1913 & $\begin{array}{c}\text { Total } \\
\text { Chlorophyreas }\end{array}$ & $\begin{array}{l}\text { Asterionella } \\
\text { gracillima }\end{array}$ & $\begin{array}{l}\text { Asteriomellat } \\
\text { gracillimait } \\
\text { (large) }\end{array}$ & $\begin{array}{l}\text { Anphiprora } \\
\text { alata }\end{array}$ & $\begin{array}{l}\text { Amphora } \\
\text { eoffaeformis }\end{array}$ & $\begin{array}{l}\text { Bacillaria } \\
\text { puradoxa }\end{array}$ \\
\hline $8 / 9$ & $2,194,3336$ & & & & 12,800 & $14,4(13,50) 1$ \\
\hline $5 / 15$ & $2,165,736$ & & ....... & 211,584 & $\ldots \ldots$ & 3,200 \\
\hline 823 & $1,562,256$ & 3,200 & ................ & ............... & ....................... & $2,062,0+1$ \\
\hline s 31 & $6,042,9444$ & & & …....... & ....... & $1,0 \pi 7,920$ \\
\hline 966 & $7,606,924$ & & .............. & & …............. & 423,165 \\
\hline $9 / 13$ & $6,068,518$ & ............ & ............. & 105,792 & .................... & 1795464 \\
\hline $9 / 20$ & $6,674,876$ & & & $\ldots \ldots$ & .......... & $13,2 \cdot 11,72\}$ \\
\hline $9 / 27$ & $6,292,426$ & & ........ & $\ldots \ldots \ldots$ & .................... & $2,221,6322$ \\
\hline $10 / 4$ & $9,222,112$ & & ..................... & & & $2,327,424$ \\
\hline $10 / 11$ & $9,133,712$ & .... & ............. .. & 105,792 & ........... & 740,544 \\
\hline $10 / 1$ s & $4,337,472$ & & & 105,792 & ...………..... & $423,16 \mathrm{~s}$ \\
\hline $10 / 26$ & $3,466,640$ & $52, \$ 96$ & & ............... & .................. & $211,5 \mathrm{~S} 1$ \\
\hline $11 / 1$ & $3,355,245$ & & $(i, 400$ & ...... & ....... & 105,792 \\
\hline $11 / \mathrm{s}$ & $1,811,264$ & 6,400 & 52,896 & ....... & & 102,400 \\
\hline $11 / 15$ & $1,112,416$ & 22,400 & 158,688 & ........ & ................... & $25, S(00$ \\
\hline $11 / 22$ & 579,408 & 79344 & 155,136 & …….......... & ................... & 370,272 \\
\hline $11 / 30$ & 364,624 & 1,600 & 1,600 & & & 290,92א \\
\hline $12 / 6$ & 67,296 & $5,316,048$ & & 1,600 & & $1,613,328$ \\
\hline $12 / 14$ & 59,296 & $1,877,808$ & 634,752 & $\ldots \ldots \ldots$ & 1,600 & 740,514 \\
\hline $12 / 20$ & 12,500 & 238,032 & ............... & .................. & ........ & 502,512 \\
\hline $12 / 27$ & 242,832 & 158,688 & ….......... & ............. & …..... & $26 \div, 450$ \\
\hline 1913 & $\begin{array}{l}\text { Cocconeis } \\
\text { pediculus }\end{array}$ & $\begin{array}{l}\text { Coeeoneis } \\
\text { sp. }\end{array}$ & $\begin{array}{l}\text { Cyclotella } \\
\text { spp. }\end{array}$ & $\begin{array}{c}\text { Cymatopleura } \\
\text { solea }\end{array}$ & $\begin{array}{l}\text { Cymbelliz } \\
\text { affinis }\end{array}$ & $\begin{array}{c}\text { Cymbella } \\
\text { cymbiformis }\end{array}$ \\
\hline $1 / 11$ & .......... & ............. & 146,264 & - & $\ldots \ldots \ldots$ & \\
\hline $1 / 19$ & & 1......... & $1,560,432$ & $\ldots \ldots$ & ........ & \\
\hline $1 / 25$ & .................. & .................. & 958,740 & & ...................... & 1,600 \\
\hline $2 / 2$ & & & $1,137,264$ & 1,600 & .......... & \\
\hline $2 / 8$ & ......... & ......... & $1,481,088$ & $\ldots \ldots$ & .................. & \\
\hline $2 / 15$ & .......... & ............ & $1,798,464$ & ……........... & .................... & 22,400 \\
\hline $2 / 23$ & & & $6,506,20 \mathrm{~S}$ & & & \\
\hline $3 / 1$ & 1,600 & 1,600 & $16,794,450$ & 6,400 & 12,800 & 52,896 \\
\hline $3 / 8$ & & & $6,109,488$ & 6,400 & & \\
\hline $3 / 15$ & . . . & ....... & $4,839,094$ & 3,200 & .... & 6,400 \\
\hline $3 / 23$ & & $\ldots \ldots$ & $3,491,136$ & 3,200 & & \\
\hline $3 / 29$ & 1,600 & & $4,496,160$ & 9,600 & 52,896 & 9,600 \\
\hline $4 / 5$ & $\cdots$ & & $1,322,400$ & 3,200 & 1,600 & 6,400 \\
\hline $4 / 13$ & & 52,896 & $1,745,56 \mathrm{~s}$ & 12,800 & 3,200 & \\
\hline $4 / 19$ & & ........... & $3,358,596$ & 6,400 & & 3,200 \\
\hline $4 / 26$ & $\ldots$ & ……........... & $2,062,944$ & ............ & 105,792 & \\
\hline $5 / 3$ & & ........ & $3,782,064$ & & 1,600 & \\
\hline $5 / 10$ & 1,600 & …............. & $1,533,994$ & & 52,896 & \\
\hline $5 / 17$ & ....... & ………….... & $2,245,080$ & 3,200 & 1,600 & 3,200 \\
\hline $5 / 24$ & ….............. & ........... & 899,232 & $\cdots$ & 3,200 & 3,200 \\
\hline $5 / 31$ & ………..., & ……….... & $5,51,850$ & ........ & & ....... \\
\hline (i) 7 & ……….... & ....... & S19,SSS & & 3,200 & \\
\hline (i) 16 & …............ & … & $1,295,952$ & 3,200 & 3,200 & \\
\hline $6 / 21$ & ………….... & ……….... & $1,560,432$ & & 1,600 & 3,200 \\
\hline $6 / 28$ & ……… & 대. & $3,619,824$ & 3,200 & 1,600 & \\
\hline $7 / 5$ & ................ & .................. & $3,226,656$ & $\ldots \quad \ldots$ & 1,600 & \\
\hline $7 / 12$ & …...... & & $5,316,045$ & ........... & 3,200 & \\
\hline $7 / 19$ & ......... & ......... & $7,405,440$ & & ......... & \\
\hline $7 / 26$ & ........... & 다. & $8,410,464$ & 19,200 & .......... & 6,400 \\
\hline $8 / 2$ & ………...... & ................... & $10,367,616$ & & & \\
\hline$S / 9$ & 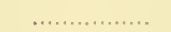 & ………….... & $6,823,584$ & 3,200 & ……............ & 6,400 \\
\hline $8 / 15$ & & & $7,669,920)$ & 6,400 & ........... & \\
\hline $8 / 23$ & 3,200 & ........ & $13,59-1,272$ & 25,600 & .................. & \\
\hline $8 / 31$ & 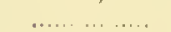 & ................ & $14,281,920$ & & (1) & 12,800 \\
\hline $9 / 6$ & ........ & .......... & $12,906,624$ & 25,600 & ………..... & 25,600 \\
\hline
\end{tabular}


Table 3.-Organisms Per Cubic Meter in Plankton of Smith's Canal in 1913-(Continued)
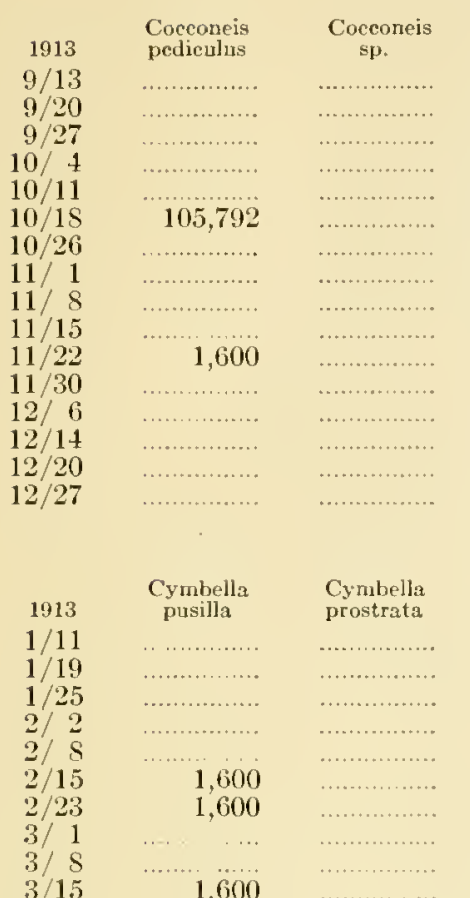

$3 / 15$

$3 / 23$

$3 / 29$

$+5$

$4 / 13$

$4 / 19$

$4 / 26$

$5 / 3$

$5 / 10$

$5 / 17$

$5 / 24$

$5 / 31$

$6 / 7$

$6 / 16$

$6 / 21$

$6 / 28$

$7 / 5$

$7 / 12$

$7 / 19$

$7 / 26$

S/ 2

8/ 9

$\mathrm{S} / 15$

$8 / 23$

$8 / 31$

$9 / 6$

$9 / 13$

$9 / 20$

$9 / 27$

$10 / 4$

$10 / 11$

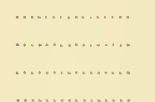

3,200

3,200

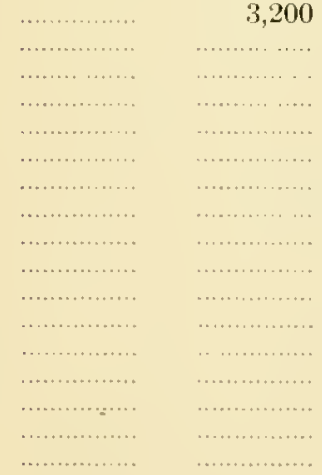

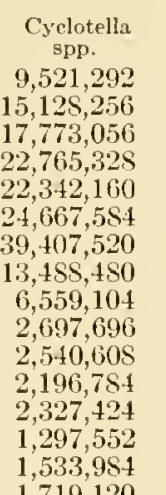

$1,719,120$

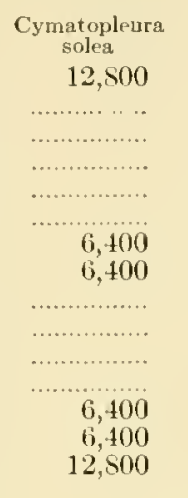
Cymbella affinis ………........
105,792

Cymbella

12,800

$\begin{array}{rr}52,596 & 6.400 \\ 6,400 & 12,800 \\ \ldots . . & 3,200 \\ 1,600 & 12,800 \\ 1,600 & 3,200 \\ 52,890 & \ldots . \\ 52,896 & 6,400 \\ 5 . & \ldots \ldots\end{array}$

$\begin{gathered}\text { Cymbella } \\ \text { sp. } \\ 800\end{gathered}$
$\ldots \ldots \ldots \ldots$
1,600
1,600
3,200

$\underset{\text { tumida }}{\text { Cymbella }}$

.................

……......

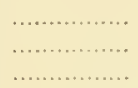

3,200

6,400

3,200

Diatom unidentified

Epithemia ocellata

\section{.................}

3,200

79,344

3.200

52,896

3,200

3,200

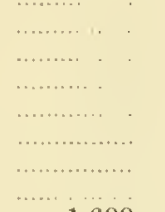

1,600

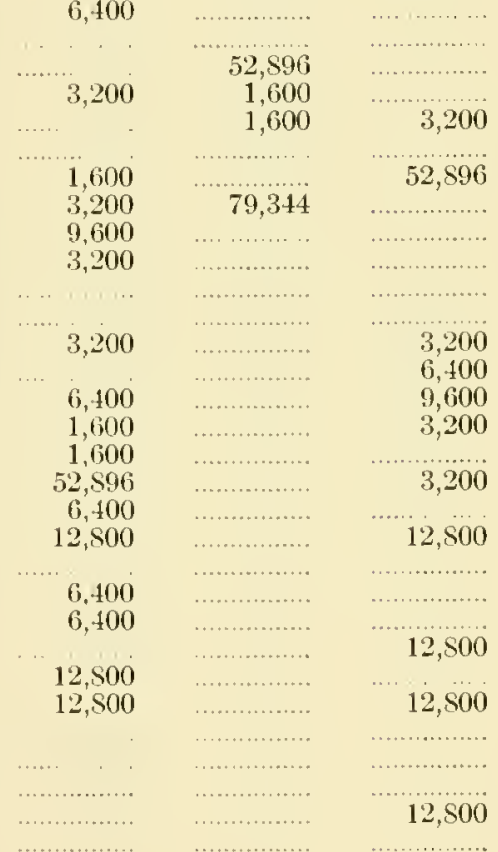


Table 3.-Organisma Prer Cuhic Metrin in Plankton of Sumtu's Canal in 1913-(Continued)

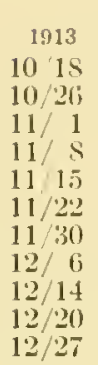

1913

$1 / 11$

$1 / 19$

$1 / 25$

$2 / 2$

$2 / 8$

$2 / 15$

$2 / 23$

$3 / 1$

$3 / 8$

$3 / 15$

$3 / 23$

$3 / 29$

$4 / 5$

$4 / 13$

$4 / 19$

$\pm / 26$

$5 / 3$

$5 / 10$

$5 / 17$

$5 / 24$

$5 / 31$

(j) 7

$6 / 16$

$6 / 21$

$6 / 25$

$7 / 5$

$7 / 12$

$7 / 19$

$7 / 26$

S/ 2

S/ 9

$\mathrm{S} / 15$

$8 / 2.3$

$8 / 31$

$9 / 6$

$9 / 13$

9) $/ 20$

$9 / 27$

10/ 4

$10 / 11$

$10 / 15$

$10 / 26$

$11 / 1$

$11 / 9$

$11 / 15$

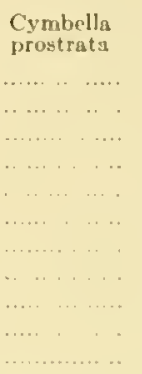

Cymbella

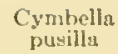


Table 3.-Organisms Per Cubic Meter in Plankton of Smith's Canal in 1913-(Continued)

\begin{tabular}{|c|c|c|c|c|c|c|}
\hline 1913 & $\begin{array}{l}\text { Eunotia } \\
\text { flexuosa }\end{array}$ & $\begin{array}{c}\text { Eunotia } \\
\text { sp. }\end{array}$ & $\begin{array}{c}\text { Fragillarja } \\
\text { capueina }\end{array}$ & $\begin{array}{l}\text { Fragillaria } \\
\text { crotonensis }\end{array}$ & $\begin{array}{c}\text { Fragillaria } \\
\text { sp. }\end{array}$ & $\begin{array}{c}\text { Gomphonema } \\
\text { constrictum }\end{array}$ \\
\hline $11 / 22$ & & … & 6,400 & 3,200 & & \\
\hline $11 / 30$ & & & & & & 1,600 \\
\hline $12 / 6$ & & .. & 3,200 & .... & 1,600 & \\
\hline $12 / 14$ & 1,600 & (........ & …. & ………... & ................. & ... \\
\hline $12 / 20$ & 6,400 & & & .... & n.............. & $\cdots$ \\
\hline $12 / 27$ & $\ldots$ & 1,600 & 3,200 & .... & ..... & \\
\hline 1913 & $\begin{array}{l}\text { Gomphonema } \\
\text { olivaceum }\end{array}$ & $\begin{array}{l}\text { Gomphonema } \\
\text { sp. }\end{array}$ & $\begin{array}{l}\text { Gomphonema } \\
\text { subclavatum }\end{array}$ & $\begin{array}{c}\text { Gyrosirma } \\
\text { acuminatum }\end{array}$ & $\begin{array}{c}\text { Gyrosigma } \\
\text { kitzingii }\end{array}$ & $\begin{array}{l}\text { Gyrosigua } \\
\text { scalproides }\end{array}$ \\
\hline $1 / 11$ & & ..... & .. & n..., n..., & 400 & \\
\hline $1 / 19$ & ........ & ........ & $\ldots . .$. & $\ldots$ & 3,200 & \\
\hline $1 / 25$ & …........... & ............. & ..... & …............ & 800 & . \\
\hline $2 / 2$ & $\ldots .$. & $\ldots \ldots$ & $\ldots \ldots$ & ............... & 6,400 & \\
\hline $2 / 8$ & $\ldots \ldots$ & $\ldots$. & $\ldots$ & $\ldots$ & 6,400 & \\
\hline $2 / 15$ & .... & $\cdots$ & $\ldots \ldots$ & & 105,792 & \\
\hline $2 / 23$ & …...., & … & & 3,200 & 3,200 & \\
\hline $3 / 1$ & ......... & ... & $\ldots .$. & 52,896 & 105,792 & \\
\hline $\begin{array}{l}3 / 8 \\
3 / 15\end{array}$ & …. & .. & $\cdots$ & .......... & & 1600 \\
\hline $\begin{array}{l}3 / 10 \\
3 / 23\end{array}$ & (n...... & & & ........... & $\begin{array}{l}3,200 \\
3,200\end{array}$ & 132,240 \\
\hline $3 / 29$ & ..... & & & 1,600 & 132,240 & 1,600 \\
\hline $4 / 5$ & ....... & 1,600 & & n............ & 79,311 & $\ldots . \quad \ldots$ \\
\hline $4 / 13$ & .............. & ….. & $\cdots$ & n...... & 9,600 & …... \\
\hline $4 / 19$ & , ................. & ....... & ........ & ........... & 79,344 & 1,600 \\
\hline $4 / 26$ & ...... & .... & & $\ldots+\ldots+1$ & 6,400 & 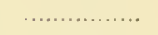 \\
\hline $5 / 3$ & ................. & $\ldots$. & & ...... & 3,200 & \\
\hline $5 / 10$ & ............... & ..... & $\cdots$. & …..... & 3,200 & \\
\hline $5 / 17$ & & 1,600 & $\ldots$ & ......... & 1,600 & 1,600 \\
\hline $\begin{array}{l}5 / 21 \\
5 / 31\end{array}$ & . ..., n...... & $\ldots, \quad \cdots$ & . ... & (....... & 12,800 & 3,200 \\
\hline $6 / 7$ & 1,600 & $\cdots$ & $\cdots$ & ......... & 12,800 & 52,896 \\
\hline $6 / 16$ & 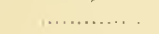 & ......... & & & 12,800 & \\
\hline $6 / 21$ & …, & …, $\ldots \ldots \ldots \ldots$ & $\cdots \cdot . \cdot$ & , ........ & 9,600 & 1,600 \\
\hline $6 / 28$ & ….......... & ............... & .............. & & 12,800 & 1,600 \\
\hline $7 / 5$ & … & & & 1,600 & 3,200 & .. \\
\hline $7 / 12$ & …............. & …..... & ...... & ............... & 105,792 & ... \\
\hline $7 / 1,9$ & ......... & ....... & $\cdots$ & .......... & 32,000 & \\
\hline $7 / 26$ & 1.. & & & $\ldots$ & 476,064 & 6,400 \\
\hline$S / 2$ & .. & ....... & ... & ....... & $15 \mathrm{~S}, 6 \mathrm{~S} 8$ & 317,376 \\
\hline $8 / 9$ & $, \quad, \ldots \ldots \ldots \ldots$ & ................ & ............... & .... & 211,584 & $1,481,085$ \\
\hline $8 / 15$ & & & & 211,584 & 105,792 & $1,00.5,024$ \\
\hline $8 / 23$ & 3,200 & ........ & . $\ldots \ldots \ldots \ldots \ldots$ & 105,792 & 370,272 & $2,697,696$ \\
\hline $8 / 31$ & ......... & $\ldots . \ldots \ldots$ & $\ldots \ldots \ldots \ldots \ldots$ & 211,581 & 317,376 & $1,586,8 \mathrm{SO}$ \\
\hline $9 / 6$ & & $\ldots \ldots \quad \quad \ldots \ldots \ldots$ & ..... & 105,792 & 423,168 & 740,544 \\
\hline $9 / 13$ & $1,1, \quad \ldots \ldots \ldots$ & $\ldots \ldots, \quad \ldots \ldots \ldots$ & .. & & 211,581 & 317,376 \\
\hline $9 / 20$ & $\ldots \ldots \ldots \ldots \ldots$ & ........ & $\ldots \ldots$ & 317,376 & 105,792 & 317,376 \\
\hline $9 / 27$ & 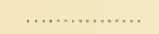 & 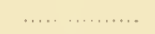 & & & 12,800 & $211,5 \mathrm{St}$ \\
\hline $10 / 4$ & . . ........... & ........ & 12,800 & & 105,792 & 317,376 \\
\hline $10 / 11$ & $\ldots \ldots \ldots \ldots \ldots \ldots$ & ........ & 105,792 & $\ldots \ldots \ldots \cdot \ldots$ & 38,400 & 211,584 \\
\hline $10 / 18$ & ..... & .. & 105,792 & & & 105,792 \\
\hline $10 / 26$ & …, & ........ & . & 105,792 & 12,800 & 423,168 \\
\hline $11 / 1$ & & ........ & & $\ldots \ldots \ldots \ldots$ & & 6,400 \\
\hline $11 / 8$ & … & ......... & $\ldots \quad, \ldots \ldots$ & ................ & 105,792 & $15 \mathrm{~S}, 6 \mathrm{SS}$ \\
\hline $11 / 15$ & . .............. & ......... &.$\quad \ldots \ldots \ldots$ & ................ & 6,400 & 79,344 \\
\hline $11 / 22$ & . .............. & $\ldots \ldots$ & $\ldots$ & 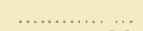 & 52,896 & 132,240 \\
\hline $11 / 30$ & $\cdots$ & $\cdots \cdot$ & $\ldots$ & 9,600 & 6,400 & 3,200 \\
\hline $12 / 6$ & & & & ........... & 52,896 & 52,836 \\
\hline $12 / 14$ & ....... & 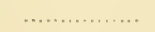 & ............... & & 52,890 & \\
\hline $12 / 20$ & & ............... & ............... & 3,200 & 6,400 & 52,896 \\
\hline $12 / 27$ & ........ & ....... & . & .......... & 3,200 & 105,792 \\
\hline
\end{tabular}




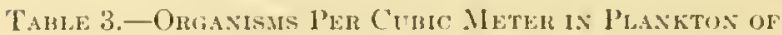
SuItit's CaNal is 1913-(Continued)

\begin{tabular}{|c|c|c|c|c|c|c|}
\hline 1913 & $\begin{array}{c}\text { Melosira } \\
\text { granulata }\end{array}$ & $\begin{array}{l}\text { Melosira } \\
\text { granulata } \\
\text { (smiall) }\end{array}$ & $\begin{array}{l}\text { M+losira } \\
\text { varinns }\end{array}$ & $\begin{array}{l}\text { Naricula } \\
\text { affinis }\end{array}$ & $\begin{array}{l}\text { Navicula } \\
\text { alpestris }\end{array}$ & $\begin{array}{l}\text { Navicula } \\
\text { bucillum }\end{array}$ \\
\hline 1,11 & & & 4,800 & & & $\ldots \ldots$ \\
\hline 119 & 1,600 & ......... & 211,581 & 1,600 & $\ldots \ldots \ldots \ldots$ & $\ldots \ldots \ldots$ \\
\hline 1,25 & 119,016 & ............... & $19,8: 36$ & & $\ldots \ldots \ldots \ldots \ldots$ &.$\ldots \ldots$ \\
\hline$\because 2$ & 143,616 & .............. & 9,600 & 1,600 & $\ldots \ldots \ldots \ldots$ & $\ldots \ldots \ldots$ \\
\hline 2,8 & 952,125 & & $25,(j 00$ & . . . & $\ldots \ldots \ldots \ldots$ & $\ldots \ldots, \ldots$ \\
\hline 215 & 599,232 & ..... & $264,4,50$ & & ........ & $\ldots . \quad \cdot$ \\
\hline $2 / 23$ & $1,560,432$ & & $(1,1000)$ & & & $\ldots \ldots, \quad \ldots \ldots$ \\
\hline $3 / 1$ & 6s7, 645 & $\ldots \ldots \ldots, \ldots$ & 2014,480 & 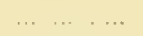 & 1,600 & $\ldots \ldots \quad \ldots \ldots$ \\
\hline $3 / s$ & $1,0 \leq 4,36$ is & .... & $10.5,792$ & &.,$\quad=\quad .$. & ….... \\
\hline $3 / 15$ & $4,152,336$ & & $1 \$ 5,136$ & 6,100 & 105,792 & $\ldots \ldots \ldots$ \\
\hline $3 / 23$ & $1,877,808$ & $6,321,072$ & 423,168 & $10.5,792$ & 105,792 & \\
\hline $3 / 29$ & $2,353,872$ & $9,045,216$ & 396,720 & 1,600 & 132,240 & 185,136 \\
\hline $4 / 5$ & 872,784 & 1332,240 & $105,79.2$ & & 1,600 & ........ \\
\hline 413 & $5,104,164$ & 740,514 & $15 \mathrm{~S}, 6 \mathrm{SS}$ & 185,130 & 79,344 & .. . \\
\hline $4 / 19$ & $5,765,664$ & 634,752 & 9,300 & 1,400 & -9.314 & \\
\hline $4 / 26$ & $9,203,901$ & $581,8.56$ & 235,0732 & 79,341 & 3,200 & $79,34.1$ \\
\hline 5/ 3 & $1,560,+32$ & $211,5 \mathrm{~s} 4$ & 70,344 & $\ldots \ldots \ldots \ldots \ldots$ & .............. & 105,792 \\
\hline $5 / 10$ & $2,010,045$ & 158,688 & $10.5,792$ & .............. & & 52,596 \\
\hline $5 / 17$ & $3,649,824$ & $105,-792$ & 79,344 & $\ldots \ldots$ & 1,600 & 132,240 \\
\hline $5 / 24$ & $3,279,552$ & & 19,200 & .............. & 52,896 & 3,200 \\
\hline $5 / 31$ & $1,454,640$ & 1,600 & 3,200 & $\ldots$ & & 3,200 \\
\hline 6) 7 & $5,07 \$, 016$ & $\ldots \ldots \ldots$ & 6,400 & & 1,600 & 52,896 \\
\hline $6 / 16$ & $6,426,564$ & $\ldots \ldots \ldots \ldots$ & 79,344 & $\cdots$ & 1,600 & 52,896 \\
\hline $6 / 21$ & $8,119,536$ & ................. & 132,210 & - & & 52,596 \\
\hline $6 / 25$ & $14,652,192$ & …............ & 6,400 & $\cdot$ & 3,200 & 1,600 \\
\hline$T / 5$ & $9,891,552$ & ................... & 155,136 & & & 52.596 \\
\hline $7 / 12$ & $16,503,552$ & ................ & 155,685 & $\ldots \ldots \ldots$ & 1,600 & \\
\hline $7 / 19$ & $13,647,168$ & , .............. & & ........... & $\ldots \ldots \ldots$ & $10.5,792$ \\
\hline $7 / 26$ & $24,137,952$ & ................. & 12,800 & & & 3,200 \\
\hline $8 / 2$ & $34,170,816$ & $\ldots .$. & $(i, 400$ & . & 3,200 & 105,792 \\
\hline$S / 9$ & $64,321,536$ & 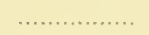 & 158,688 & $\ldots \ldots$ & 3,200 & $211,3 \$ 4$ \\
\hline $8 / 15$ & $86,643,648$ & ...... & 211,584 & .. & & 3,200 \\
\hline $8 / 23$ & $84,845,184$ & & 105,792 & & 105,792 & \\
\hline $\mathrm{S} / 31$ & SS,971,072 & & & & & \\
\hline $9 / 6$ & $193, \$ 10,944$ & & 25,600 & & 211,584 & 105,792 \\
\hline $9 / 13$ & $75,439,744$ & ................. & & $\ldots \ldots \ldots$ & .............. & $211, i \leqslant 1$ \\
\hline $9 / 20$ & $127,912,576$ & & 317,376 & & $\ldots \ldots \ldots \ldots$ & $10 ;, 792$ \\
\hline $9 / 27$ & $72,265,984$ & $\ldots$ & & $\ldots \ldots$ & & $211,5 \mathrm{~S} 4$ \\
\hline $10 / 4$ & $53,214,576$ & n............ & 105,792 & & $105,-792$ & \\
\hline $10 / 11$ & $60,521,224$ & .............. & 12,800 & .. & 211.554 & 105,792 \\
\hline $10 / 15$ & $27,515,965$ & ..... & 105,792 & $\ldots \ldots \ldots$ & & 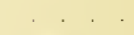 \\
\hline $10 / 26$ & $22,057,632$ & ............ & 6,400 & ..... & 105,792 & $\ldots \ldots \ldots$ \\
\hline $11 / 1$ & $15,445,632$ & ............. & 6,400 & $\ldots \ldots \ldots$ & 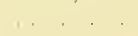 & 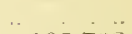 \\
\hline $11 / \mathrm{S}$ & $6,612,000$ & .................. & 19,200 & …... & & 105,792 \\
\hline $11 / 15$ & $2,697,696$ & ................. & 3,200 &.$\quad$. & & 1,600 \\
\hline $11 / 22$ & $2,115,840$ & ................... & 52,896 & $\ldots \ldots \ldots$ & 52,896 & $\ldots$ \\
\hline $11 / 30$ & $3,914,304$ & ............... & 6,400 & . & 3,200 & \\
\hline $12 / 6$ & $2,327,424$ & ............ & 73,341 & ........... & 52,896 & 1,600 \\
\hline $12 / 14$ & $1,507,536$ & ............. & $52, \times 96$ & & $\ldots$ & 79,344 \\
\hline $12 / 20$ & 661,200 & ............. & 25,600 & & 1,600 & \\
\hline $12 / 27$ & $1,110,816$ & …............ & 155,136 & ................. & & 52,896 \\
\hline 1913 & $\begin{array}{l}\text { Navicula } \\
\text { didytua }\end{array}$ & $\begin{array}{l}\text { Navicula } \\
\text { dubia }\end{array}$ & $\begin{array}{l}\text { Navicula } \\
\text { gracilis }\end{array}$ & $\begin{array}{l}\text { Ninvicula } \\
\text { sp. }\end{array}$ & $\begin{array}{l}\text { Navicula } \\
\text { viridis }\end{array}$ & $\begin{array}{l}\text { Nitzschia } \\
\text { acicularis }\end{array}$ \\
\hline $1 / 11$ & .. $\ldots \ldots \ldots$ & ........... & . & & & \\
\hline $1 / 19$ & . ............. & $\ldots \ldots \ldots \ldots$ & & $52, \$ 96$ & .. & $80,9 \cdot 1 \cdot 1$ \\
\hline $1 / 25$ & 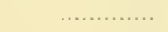 & . & 500 & $\ldots$ & … . . & 59,505 \\
\hline $2 / 2$ & & $\ldots \ldots \ldots \ldots \ldots$ & 15s,fisis & 1,600 & 4,800 & 155,136 \\
\hline $2 / 8$ & 3,200 & ……........ & 158,658 & 1,600 & $\ldots \ldots \ldots \ldots$ & 158,685 \\
\hline
\end{tabular}


Table 3.-Organismis Per Cubic Meter in Plankton of Surth's Canal in 1913-(Continued)

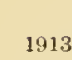

$2 / 15$

$3 / 1$

$3 / 8$

$3 / 15$

$3 / 23$

$3 / 29$

$4 / 5$

$4 / 13$

$4 / 19$

$4 / 26$

$5 / 3$

$5 / 10$

$5 / 17$

$5 / 24$

$5 / 31$

6) 7

$6 / 16$

$6 / 21$

$6 / 28$

$7 / 5$

$7 / 12$

- 19

$7 / 26$

S/2

$8 / 9$

$\mathrm{s} / 15$

$8 / 23$

$8 / 31$

$9 / 6$

$9 / 13$

$9 / 20$

9/27

$10 / 4$

10/I I

$10 / 1 \mathrm{~s}$

$10 / 26$

11/ 1

11/ $\mathrm{S}$

$11 / 15$

$11 / 22$

$11 / 30$

12/6

$12 / 14$

$12 / 20$

$12 / 27$

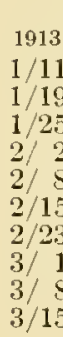

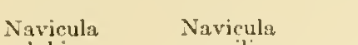

\begin{tabular}{|c|c|c|}
\hline $\begin{array}{l}\text { Navicula } \\
\text { didyma }\end{array}$ & $\begin{array}{l}\text { Navicula } \\
\text { dubia }\end{array}$ & $\begin{array}{l}\text { Navicula } \\
\text { gracilis }\end{array}$ \\
\hline 3,200 & .. & 264,480 \\
\hline$\cdots \cdots$ & $\cdots$ & 6,400 \\
\hline & ..... & 290,928 \\
\hline 1,600 & …............ & 185,136 \\
\hline & & 290,928 \\
\hline 3,200 & & 290,928 \\
\hline 1,600 & $\cdots$ & 476,064 \\
\hline$\ldots$. & ............... & 581,856 \\
\hline$\cdots$ & $\ldots \ldots \ldots \ldots \ldots$ & 155,136 \\
\hline & & 238,032 \\
\hline 1,600 & $\ldots \ldots \ldots \ldots+\ldots, \ldots$ & 608,304 \\
\hline .. . . & , & 105,792 \\
\hline & & 132,240 \\
\hline .. . & $\cdots$, & 155,658 \\
\hline$\ldots$ & · & 211,584 \\
\hline ........ & $\ldots \ldots \ldots \ldots$ & 317,376 \\
\hline$\cdots \cdot$ & $\cdots$ & 370,272 \\
\hline …" & $\cdot$ & 79,344 \\
\hline & .......... & 185,136 \\
\hline 52,896 & & 1,600 \\
\hline ..., & ...... & 634,752 \\
\hline $\begin{array}{c}. . \\
. .\end{array}$ & . ............ & 100,892 \\
\hline$\cdots$ & & $1,795,461$ \\
\hline$\cdots$ & 6400 & $\begin{array}{r}740,541 \\
200\end{array}$ \\
\hline$\cdots$ & 0,400 & $\begin{array}{r}2,062,914 \\
+9-60950\end{array}$ \\
\hline ........ & & $3,385,341$ \\
\hline ....... & 105,792 & $2,644,800$ \\
\hline ..... & $\cdots$ & $1,904,256$ \\
\hline$\ldots \ldots \ldots \ldots$ & $\ldots \ldots$ & 423,165 \\
\hline$\ldots \ldots \ldots, \quad \ldots \ldots$ & ......... & $2,327,424$ \\
\hline$\cdots$ & $\ldots \ldots, \quad, \ldots$ & $1,375,296$ \\
\hline ..... & …n... $\quad \ldots$ & 952,128 \\
\hline ... & $\ldots \ldots, \quad \ldots \ldots$ & $1,163,712$ \\
\hline & & 740,544 \\
\hline$\ldots$. & 52,896 & 317,376 \\
\hline & 105,792 & 52,896 \\
\hline 52,596 & $\ldots \ldots \ldots$ & 158,688 \\
\hline$\ldots \ldots$ & ............... & 52,596 \\
\hline & n............. & 155,136 \\
\hline 3,200 & n..., & 158,688 \\
\hline & 600 & 370,272 \\
\hline & 1,000 & 185,136 \\
\hline & & 317,376 \\
\hline
\end{tabular}
angularis sigma

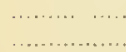

9,600

6,400

3,200

3,200

Nitzschia sigmoidea

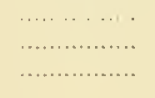

……....
Nitzschia

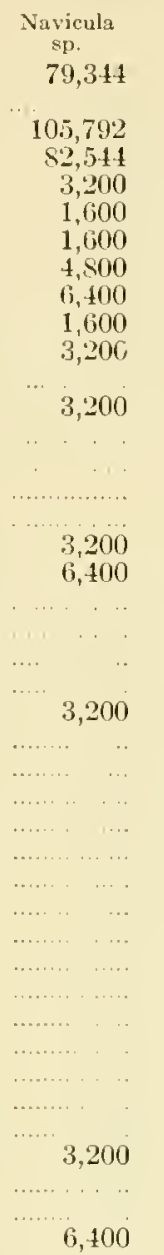

Navicula

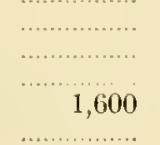

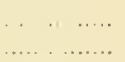

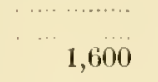

1,600
$\ldots \ldots \ldots \ldots$
9,600
79,344

Nitzschia
vermicularis
1,600
$3 . .200$
52,896
105,792
9,600
3,200
1,600
6,400

12, 800

3,200

1,600

3,200

1,600

6,400

3,200

3,200

1,600

3,200

3,200

3,200

3,200

(.............

3,200

12,500

12,800

$6, \pm 00$

6,400

.. .

12,800

12,800

25,600

...........

\section{6.}

6,400

9,600

52,896

3,200

3,200

Nitzschia

acicularis

132,240

73,341

$15 \mathrm{~S}, 6 \mathrm{SS}$

79,344

105,792

211,584

343,824

238,032

264,480

264,450

476,064

52,896

105,792

211,584

1. 5,136

132,240

211,584

816,336

661,200

$1,005,024$

819,585

608,304

793,110

687,648

793,440

634,752

158,688

423,168

$3,067,968$

3,365,341

$1,269,501$

528,960

$1,481,088$

528,960

211,584

211,581

105,792

$158,68 \mathrm{~S}$

317,376

502,512

211,584

290,925

502,512

132,240

79,344

132,240

Piunularia

acrosphaeria

Pleurostauron

parvulum

39,672

317,376

72,732

264,480

211,584

$15 \mathrm{~S}, 6 \mathrm{~s}$

211,584

740,544

290,928

$476,06 \pm$ 
Table 3-Organishe P'er Cubic Meter ix Plankton of Simtu's Caxal ix 1913-(Continued)

1913
$3 / 23$
$3 / 29$
$4 / 5$
$4 / 13$
$1 / 19$
$4 / 26$
$5 / 3$
$5 / 10$
$5 / 17$
$5 / 24$
$5 / 31$
$6 / 7$
$6 / 16$
$6 / 21$
$6 / 25$
$7 / 5$
$7 / 12$
$7 / 19$
$7 / 26$
$8 / 2$
$8 / 9$
$8 / 15$
$8 / 23$
$8 / 31$
$9 / 6$
$9 / 13$
$9 / 20$
$9 / 27$
$10 / 4$
$10 / 11$
$10 / 15$
$10 / 26$
$11 / 1$
$11 / 8$
$11 / 15$
$11 / 22$
$11 / 30$
$12 / 6$
$12 / 14$
$12 / 20$
$12 / 27$

$2 / 27$

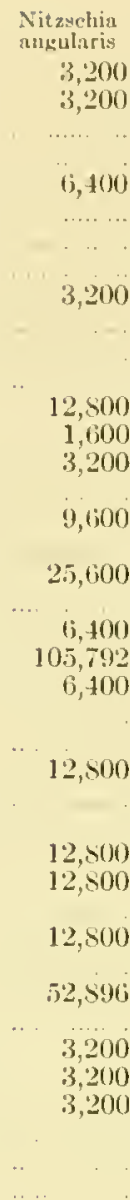

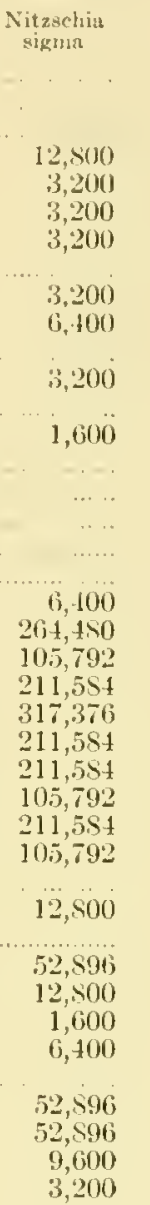

\begin{tabular}{|c|c|}
\hline $\begin{array}{l}\text { Nit aschia } \\
\text { sigmoidea }\end{array}$ & $\begin{array}{l}\text { Nitzschia } \\
\text { vermiculisis }\end{array}$ \\
\hline 3,200 & \\
\hline 52,896 & \\
\hline 52,596 & 3,200 \\
\hline & 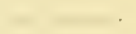 \\
\hline ………… & . \\
\hline 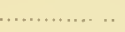 & .... \\
\hline ...... & 3,200 \\
\hline & 6,400 \\
\hline$\ldots \ldots \ldots$ & ....... \\
\hline (........ & $\cdots$ \\
\hline 6,400 & 3,200 \\
\hline$\ldots$ & 1,600 \\
\hline$\ldots \ldots$ & 6,400 \\
\hline 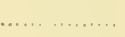 & 79,341 \\
\hline 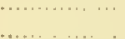 & $\cdots \quad \cdot$ \\
\hline ............ & 3,200 \\
\hline ......... & 105,792 \\
\hline & $15 S, 6.58$ \\
\hline$\cdots$ & $10-792$ \\
\hline$\ldots \ldots$ & ] 05,792 \\
\hline $\begin{array}{ll}\cdots & \cdots \\
\cdots, & \ldots\end{array}$ & $211,5 \mathrm{~S} 4$ \\
\hline$\ldots \ldots$ & 38,400 \\
\hline ..... & 12.500 \\
\hline$\ldots$ & 12,500 \\
\hline & 6,400 \\
\hline ..... & $\cdot \cdot$ \\
\hline & $6,400)$ \\
\hline 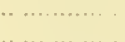 & . $\quad .$. \\
\hline$\ldots$ & . \\
\hline & 6,400 \\
\hline
\end{tabular}

Pinnularia

Pleurostruron parvolum

370,272

423,165

343,524

$5 \mathrm{~S} 1, \mathrm{5} 6$

211,554

132,240

211,584

211,554

132,240

1,600

158,658

1,600

52,896

52,896

158,658

J) 5,685

3,200

$158,6 \mathrm{~s}$

105,792

155,658

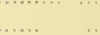

105,792

105,792

$105,79^{2}$

$10,5,792$
$6,400 \quad 52,896$

52,896

$211,5 \mathrm{St}$

52,596

1,600

105,792

132.240

52,896

52.596

185,136

\begin{tabular}{|c|c|c|}
\hline 1913 & $\begin{array}{c}\text { Stauroneis } \\
\text { phoencenteron }\end{array}$ & $\begin{array}{l}\text { Surirella } \\
\text { sp. }\end{array}$ \\
\hline $1 / 11$ & & 400 \\
\hline $1 / 1$ & & 17.600 \\
\hline 1,25 & & 5,600 \\
\hline $2 / 2$ & & 65,600 \\
\hline $2 / 8$ & .. & 19,200 \\
\hline $2 / 15$ & $\ldots$ & 114,544 \\
\hline $2 / 23$ & & 94,496 \\
\hline $3 / 1$ & $\cdots$ & 132,240 \\
\hline $3 / 5$ & .. & 48,000 \\
\hline $3 / 15$ & & 158,658 \\
\hline 12 & & ],32,240 \\
\hline $3 / 29$ & ....... & 185,136 \\
\hline $4 / 5$ & & 132,240 \\
\hline & 3,200 & 185,136 \\
\hline 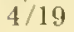 & & 79,344 \\
\hline
\end{tabular}

Synedra
radians

$\begin{array}{cc}\begin{array}{c}\text { Symedra } \\ \text { ulna }\end{array} & \begin{array}{c}\text { Total } \\ \text { Barillariaceae }\end{array} \\ 26,448 & 995,989 \\ 449,616 & 8,850,154 \\ 469,152 & 1,582,641 \\ 343,824 & 7,547,616 \\ 235,032 & 13,286,048 \\ 343,824 & 6,526,064 \\ 396,720 & 11,554,384 \\ 502,512 & 21,603,120 \\ 290,928 & 10,066,896 \\ 793,440 & 12,653,248 \\ 238,032 & 15,174,656 \\ 476,064 & 23,028,112 \\ 370,272 & 5,009,024 \\ 52,, 960 & 10,329,424 \\ 123,168 & 11,761,264\end{array}$
acerosum

3,200 3,200

1,600 3,200

6,400

3,200 
Table 3.-Organisms Per Cubic Meter in Plankton of Suith's Canal in 1913--(Continued)

\begin{tabular}{|c|c|c|c|c|c|c|}
\hline 1913 & $\begin{array}{c}\text { Struroneis } \\
\text { phoenicenteron }\end{array}$ & $\begin{array}{l}\text { Surirella } \\
\text { sp. }\end{array}$ & $\begin{array}{l}\text { Synedra } \\
\text { radians }\end{array}$ & $\begin{array}{l}\text { Synedra } \\
\text { ulna }\end{array}$ & $\begin{array}{c}\text { Total } \\
\text { Bacillariacese }\end{array}$ & $\begin{array}{l}\text { Closterium } \\
\text { acerosum }\end{array}$ \\
\hline $4 / 26$ & $\ldots \ldots$ & 54,400 & & 185,136 & $14,915,72 \mathrm{~S}$ & 6,400 \\
\hline $5 / 3$ & & 35,200 & & 6,400 & $6,323,232$ & \\
\hline $5 / 10$ & & 105,792 & .............. & 317,376 & $8,531,408$ & $\ldots$ \\
\hline $5 / 17$ & . . & 158,688 & & 185,136 & $8,256,480$ & ........ \\
\hline $5 / 24$ & $\ldots$ & 60,500 & & 105,792 & $5,198,76 \mathrm{~s}$ & ..... \\
\hline $5 / 31$ & & & & 1,600 & $2,285,728$ & \\
\hline $6 / 7$ & 1,600 & 132,240 & $\cdots$ & 132,240 & $5,722,096$ & \\
\hline $6 / 16$ & 3,200 & 79,314 & $\ldots$ & 238,032 & $14,880,432$ & \\
\hline $6 / 21$ & $\ldots$ & $211,5 S 4$ & & 235,032 & $17,599,021$ & 3,200 \\
\hline $6 / 28$ & .. & 105,792 & .... & $1,190,160$ & $22,537,552$ & \\
\hline $7 / 5$ & .. & 132,240 & 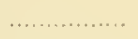 & 343,824 & $15,092,112$ & \\
\hline $7 / 12$ & .. & 449,616 & & 343,824 & $26,131,376$ & 6,400 \\
\hline 719 & . & 211,584 & 105,792 & 158,685 & $24,500,12 \mathrm{~s}$ & \\
\hline $7 / 26$ & . & $1,425,192$ & 793,440 & 267,650 & $\$ 3,673,600$ & 12,800 \\
\hline $8 / 2$ & .. & 687,615 & 261,180 & 211,584 & $53,816,832$ & 6,400 \\
\hline $8 / 9$ & & $4,125,888$ & 158,688 & & $95,438,685$ & $37, \pm 00$ \\
\hline $\mathrm{S} / 15$ & 3,200 & $1,556,880$ & $476,06 \pm$ & 370,272 & $119,512,496$ & \\
\hline $8 / 23$ & .. & $2,274,523$ & $1,057,920$ & 158,688 & $113,258,240$ & 12,800 \\
\hline $8 / 31$ & $\ldots$ & $1,163,712$ & 528,960 & $4,125,888$ & $118,406,815$ & $3 \varsigma, 400$ \\
\hline $9 / 6$ & .. & 634,752 & 423,168 & $3,805,512$ & $220,996,096$ & 76,500 \\
\hline $9 / 13$ & - & 211,584 & 423,168 & $5,924,364$ & $96,437,754$ & 12,800 \\
\hline $9 / 20$ & 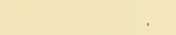 & 634,752 & 317,376 & $2,856,384$ & $15 \vec{i}, 322,752$ & 25,600 \\
\hline $9 / 27$ & & 528,960 & $1,586,8 \mathrm{SO}$ & $2,539,008$ & $99,961,216$ & ......... \\
\hline 4 & & 423,168 & $1,269,504$ & $1,904,256$ & $81,452,672$ & \\
\hline 11 & & 317,376 & 846,336 & $2,221,632$ & $\$ 9,303,502$ & 12,500 \\
\hline 18 & 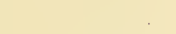 & $7 \pm 0,544$ & 634,752 & $1,692,672$ & $57,291,968$ & \\
\hline$/ 26$ & & 634,752 & 159,688 & 476,064 & $64,325,240$ & 12,500 \\
\hline 1 & & 476,064 & 158,688 & 370,272 & $30,671,584$ & 6,400 \\
\hline $1 / 8$ & 52,896 & 528,960 & 264,480 & 528,960 & $15,042,976$ & \\
\hline$/ 15$ & & 52,896 & $211,58 \pm$ & 158,688 & $6,757,696$ & 3,200 \\
\hline 122 & . & 185,136 & 52,896 & 79,314 & $6,35,421$ & 6,100 \\
\hline$/ 30$ & & 158,688 & 52,896 & 132,240 & $7,324,400$ & 3,200 \\
\hline 6 & 3,200 & 264,480 & .. $\quad \ldots \quad \ldots$ & 290,928 & $13,506,832$ & 3,200 \\
\hline 14 & .. & 105,792 & & 235,032 & $7,003,072$ & 3,200 \\
\hline 20 & ... & $26 \pm, 480$ & 132,240 & 105,792 & $3,890,112$ & $\ldots \ldots$ \\
\hline 127 & . . & 79,314 & 1,600 & 185,136 & $4,581,056$ & \\
\hline
\end{tabular}

\begin{tabular}{|c|c|c|c|c|c|c|}
\hline 1913 & $\begin{array}{l}\text { Closterium } \\
\text { acuminatum }\end{array}$ & $\begin{array}{l}\text { Closterium } \\
\text { rostratum }\end{array}$ & $\begin{array}{c}\text { Cosmarium } \\
\text { sp. }\end{array}$ & $\begin{array}{l}\text { Mougeotia } \\
\text { sp. }\end{array}$ & $\begin{array}{c}\text { Spirogyra } \\
\text { protecta }\end{array}$ & $\underset{A}{\text { Staurastrum }}$ \\
\hline $1 / 11$ & $\ldots \ldots, \ldots \ldots$ & . ............ & & & 1,200 & \\
\hline $1 / 19$ & $\ldots$ & $\ldots \ldots$ & ............. & 1,600 & 6,400 & \\
\hline $1 / 25$ & $\ldots \ldots$ & $\ldots \ldots$ & ........... & 400 & & \\
\hline $2 / 2$ & $\ldots \ldots \ldots \ldots$ & . . $\quad \ldots$ & .......... & $\begin{array}{llll}\ldots \ldots & . .\end{array}$ & 1,600 & \\
\hline$\frac{2}{2 / 15}$ & $\ldots+\cdots$ & $\ldots$ & (........ & $\ldots$ & $\ldots \ldots \ldots$ & 1,600 \\
\hline $\begin{array}{l}2 / 23 \\
3 / 1\end{array}$ & $\begin{array}{l}\ldots,+, \quad \ldots \\
\ldots \ldots\end{array}$ & $\ldots \ldots, \quad \cdots \cdots$ & $\ldots \ldots \ldots \ldots \ldots$ & 1,600 & & 79,344 \\
\hline $3 / 8$ & $\ldots, \quad, \ldots$ & $\ldots \ldots \ldots \ldots \ldots$ & ........ & & & $1 S 5,136$ \\
\hline $\begin{array}{l}3 / 15 \\
3 / 23\end{array}$ & $\cdots, \quad \ldots$ & ............ & .......... & ... & 3,200 & 6,400 \\
\hline $3 / 29$ & $\ldots$ & $\cdots$ & …... & $\ldots$ & & 52,896 \\
\hline 1/5 & $\ldots . .$. & & 1,600 & 1,600 & 6,400 & .. \\
\hline $\begin{array}{l}4 / 13 \\
1 / 19\end{array}$ & $\begin{array}{r}1,600 \\
\ldots \ldots\end{array}$ & (...... & $\ldots, \ldots \ldots$ & 1,600 & ......... & \\
\hline $4 / 26$ & .... & $\ldots \ldots$ & ............. & .. & $\ldots \ldots \ldots$ & 1,600 \\
\hline $\begin{array}{l}5 / 3 \\
5 / 10\end{array}$ & $\ldots$. & $\ldots \ldots$ & …1....... & $\ldots$ & 1,600 & \\
\hline $\begin{array}{l}5 / 17 \\
5 / 24\end{array}$ & $\begin{array}{l}\ldots \ldots \\
\ldots \ldots \\
\ldots \ldots\end{array}$ & $\ldots \ldots \ldots$ & ................ & 3,200 & & \\
\hline
\end{tabular}


Thale 3.-Organisas Plit Cubic Mleter in Plankton of Surtir's Canal in 1913-(Continued)

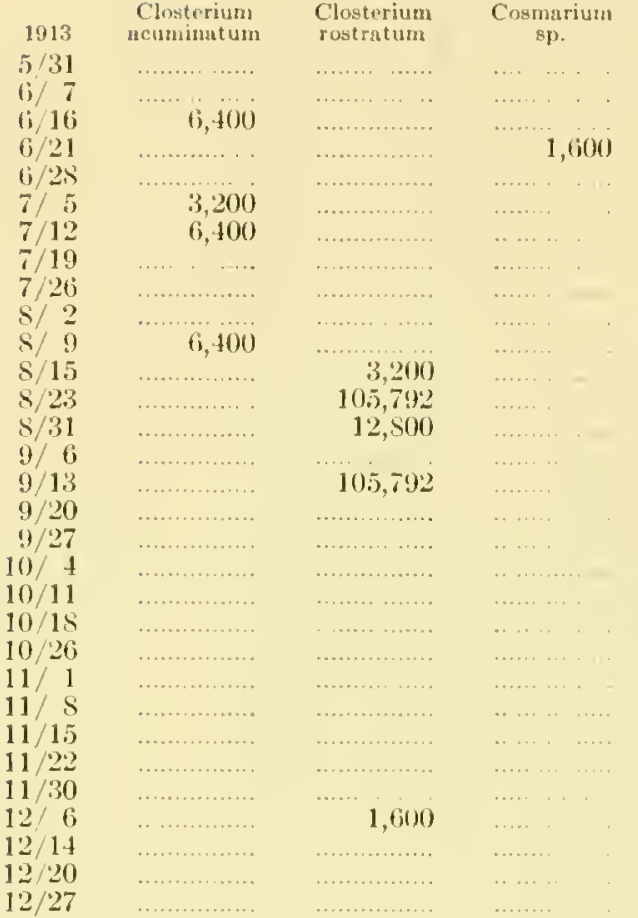

\begin{tabular}{|c|c|c|}
\hline $\begin{array}{c}\text { Mougeotia } \\
\text { sp. } \\
1,600 \\
9,600\end{array}$ & $\begin{array}{c}\begin{array}{c}\text { Spirokyra } \\
\text { protecta }\end{array} \\
\ldots \\
\ldots \ldots\end{array}$ & $\begin{array}{c}\text { Staurastrum } \\
4 \\
. .\end{array}$ \\
\hline . . ....... & $\ldots \ldots, \ldots \ldots$ & .. \\
\hline $\begin{array}{r}\quad \ldots . \cdot \\
1 \ldots . . . .\end{array}$ & $\begin{array}{lll}\ldots \ldots & \ldots & \ldots \\
\ldots \ldots \ldots & \ldots \ldots \ldots\end{array}$ & 52,896 \\
\hline 235,1032 & ……...... & $\begin{array}{l}105,792 \\
132,2+0\end{array}$ \\
\hline $211,5,44$ & ……...... & 12,500 \\
\hline 423,168 & $\ldots \ldots \ldots$ & $10 i, 792$ \\
\hline $26 \cdot 1,4 \times 0)$ & ......... & $10 i, 792$ \\
\hline $1,322,400$ & $\ldots \ldots \ldots, \quad \ldots \ldots$ & 317,376 \\
\hline 3,200 & ........... & 3,2000 \\
\hline $3,967,200$ & $\ldots$ & 105,792 \\
\hline $4,860,432$ & & \\
\hline $1,586,580$ & .. & $211,3 \mathrm{S1}$ \\
\hline 317,376 & 死 & $42: 3,16 \mathrm{~s}$ \\
\hline 105,792 & & $3,067,968$ \\
\hline 105,792 & & 423,168 \\
\hline & ... & 25,600 \\
\hline i2, 896 & .. & $2(j \cdot 1,1 \times)$ \\
\hline & ..... & 12,800 \\
\hline $211,5 \times 1$ & . & \\
\hline 52,896 & & $3,200)$ \\
\hline 1,600 & & 3,200 \\
\hline & 3,200 & 3.200 \\
\hline & 3,200 & 1,600 \\
\hline & 6,400 & \\
\hline
\end{tabular}

\begin{tabular}{|c|c|}
\hline 1913 & $\begin{array}{c}\text { Staurastrun } \\
\text { sp. }\end{array}$ \\
\hline $1 / 11$ & \\
\hline $1 / 19$ & \\
\hline $1 / 25$ & .... \\
\hline $2 / 2$ & \\
\hline 2) 8 & $=1$ \\
\hline $2 / 15$ & \\
\hline $2 / 23$ & $\cdots$ \\
\hline $3 / 1$ & ... \\
\hline $3 / 8$ & $\ldots$ \\
\hline $3 / 15$ & .. \\
\hline $3 / 2.3$ & $\ldots \ldots$ \\
\hline $3 / 29$ & . . . \\
\hline $4 / 5$ & \\
\hline $4 / 13$ & \\
\hline $4 / 19$ & $\cdots$ \\
\hline $4 / 26$ & ..... \\
\hline $5 / 3$ & $\cdots \cdot \cdot$ \\
\hline $\begin{array}{l}5 / 10 \\
5 / 17\end{array}$ & $\cdots$ \\
\hline $5 / 24$ & \\
\hline $5 / 31$ & 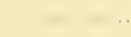 \\
\hline (j) 7 & \\
\hline $6 / 21$ & 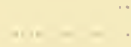 \\
\hline $6 / 28$ & \\
\hline
\end{tabular}

\begin{tabular}{|c|c|}
\hline $\begin{array}{c}\text { Total } \\
\text { Conjugatae }\end{array}$ & $\begin{array}{c}\text { Total } \\
\text { Chlorophyll } \\
\text { bearing }\end{array}$ \\
\hline 1,200 & $999,9 S \mathrm{~S}$ \\
\hline 8,000 & $9,938,504$ \\
\hline 3,600 & 6,50 \\
\hline 4,800 & $9,223,66 t$ \\
\hline 1,600 & $17,480,488$ \\
\hline 4,800 & $10,570,064$ \\
\hline 84,141 & 17,56 \\
\hline 191,536 & $11,030,12 \mathrm{~s}$ \\
\hline & 13,9 \\
\hline 100,000 & $17,035,720$ \\
\hline 52,496 & $25,649,664$ \\
\hline 12,800 & $5,66,9,912$ \\
\hline 3,200 & $11,054,624$ \\
\hline & $12,431,216$ \\
\hline 8,000 & $16,1+1,08 \mathrm{~s}$ \\
\hline & 71 \\
\hline 1,600$)$ & $8,998,528$ \\
\hline 3,20 & $8,5+0,96$ \\
\hline 3,20 & 5,3 \\
\hline 1,600 & $2,57+, 20 \mathrm{~s}$ \\
\hline 9,600$)$ & $9,462,44$ \\
\hline 9,600 & 15,295 \\
\hline 4,800 & $18,320,92 \mathrm{~S}$ \\
\hline 52,596 & $24,406,320$ \\
\hline
\end{tabular}

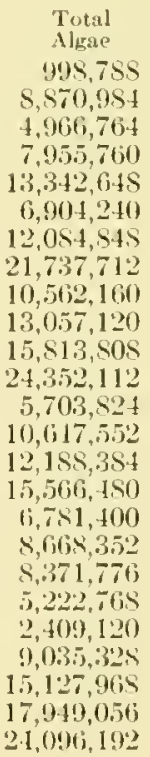

Ceratium

Cercomonns crassicauda ......... 
Table 3.-Organisus Per Cubic Meter in Plankton of Surtu's Canal in 1913-(Continued)

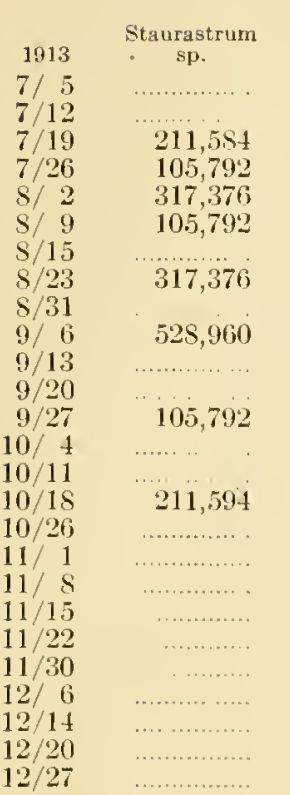

\begin{tabular}{|c|c|c|}
\hline $\begin{array}{l}\text { Tot } \\
\text { onju }\end{array}$ & $\begin{array}{c}\text { Total } \\
\text { Chlorophyll } \\
\text { bearing }\end{array}$ & $\begin{array}{l}\text { Total } \\
\text { Algae }\end{array}$ \\
\hline 92 & $19,267,600$ & $17,929,200$ \\
\hline 353,072 & $33,831,696$ & $31,896,192$ \\
\hline & $36,9 \pm 8,320$ & $28,391,805$ \\
\hline 652,952 & $58,73 S, 174$ & $53,681,254$ \\
\hline 694,048 & 62,336 & $59,710,58 \mathrm{~S}$ \\
\hline 759,365 & 111,133 & $107,0+5,816$ \\
\hline & 161,112 , & $152,120,350$ \\
\hline 60 & 138,24 & $133,585,00 \mathrm{~s}$ \\
\hline & $147,390,46 i^{2}$ & $142,921,59 \mathrm{~S}$ \\
\hline 830,141 & $247,981,772$ & $241,201,676$ \\
\hline$\$ 59,136$ & $114,001,764$ & $108,58 t, 184$ \\
\hline 362 & 177,59 & \\
\hline 423 & 125,26 & 120,05 \\
\hline & 101,54 & $95,957,805$ \\
\hline & & 54 \\
\hline 237 & 65,0 & $62,222,400$ \\
\hline 330 & & $68,147,656$ \\
\hline \multirow[t]{2}{*}{19,200} & & \\
\hline & & $17,137,920$ \\
\hline & $11,703,204$ & $8,382,224$ \\
\hline & & \\
\hline & $11, \mathrm{~S} 0$ & $7,861,712$ \\
\hline 00 & 16,42 & $13,715,96 \mathrm{~S}$ \\
\hline \multirow[t]{2}{*}{11,200} & $10,081,776$ & $7,210,609$ \\
\hline & & $3,912,512$ \\
\hline $6 .+100$ & 1. & 4 \\
\hline
\end{tabular}

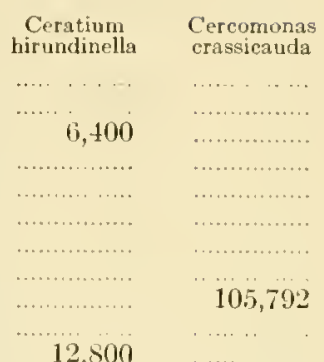

12,800

105,792

52,896

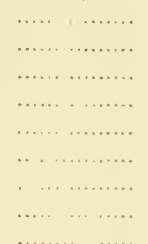

Chlamydomonas Chromulina

$$
\text { sp. }
$$$$
\mathrm{sp.}
$$

Cryptomonas

$$
\text { sp. }
$$

Dinobryon sertularia

$1 / 25$

$2 / 2$

$2 / 8$

2/15

$2 / 23$

$3 / 1$

$3 / 8$

$3 / 15$

$3 / 23$

$3 / 29$

4 . 5

$4 / 13$

$4 / 19$

$4 / 26$

$5 / 3$

$5 / 10$

$5 / 17$

$5 / 24$

$5 / 31$

$6 / 7$

$6 / 16$

$6 / 21$

$6 / 25$

$7 / 5$

$7 / 12$

$7 / 19$

$7 / 26$
$1,005,02 \pm$

$1,500,924$ 952,128

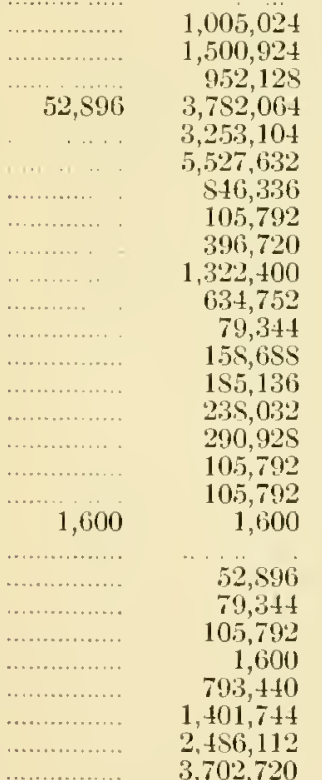

Eu

elegans

1,200
5,000

3,200

105,792

16,000

9,600

32,000

44,500

35,200

60,800

1,000

1,600

1,600

211,584

264,180

3,200

32,000

3,200

12,800

52,896

105,792

6. 400

49,000

52,896

52,896

105,792

16,000

1,600

1,600

3,200

$2 \$, 800$

22,400

$79,3+4$

16,000

6,400
185, 136

51,200

105,792 
Table 3.-Organisms Per Cubic Meter in l'Lankton of Smitu's Canal in 1913 -(Continued)

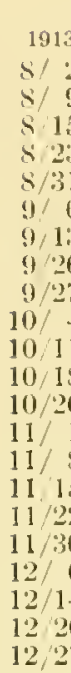

(1)

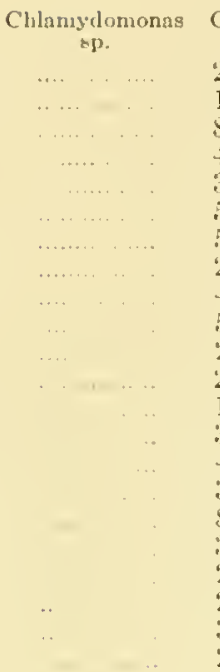

Chromulina

Cryptomonas
ty.

Dinobryon

Eudorinn

$3,3,0,320$

$1,957,1.52$

$5,569,1,52$

4, 2:31,680

$3,270,5,542$

$5,183,808$

$5,075,016$

$2,750,592$

$\{, 453,2634$

$5,501,196$

$2,611,800$

$2,556,354$

$1,6.39,776$

$3,436,240$

$4,601,952$

$3,094,116$

$8,727,840$

$3,623,376$

$2,512,560$

$2,962,176$

$3,253,104$

$2,456,112$

Flagellate

Henidinium nasutum

Mallomonas

$\mathrm{sp}$.

Pandorina

morum

Peridiniun

cinctum

Peridinium

$1 / 11$

119

$1 / 25$

2/ 2

1, 600

1,600

2,400

5) 2,896

22,400

3,200

25,600

$(i, 400$

3.) 000

$1,163,712$

6,100

Fuslenn

$\therefore$

3,200

$10.5,792$

$25,600 \quad 105,-190^{\circ}$

317,376

105,792

25,600

105,792

6,400

211,594

105,793

3,200
22,400

9,600

52,596

52,596

9,600

(i), 400

$$
\begin{array}{r}
9,600 \\
132,240
\end{array}
$$

79,344

105,792

3,200

79,344
79,344

1,600

1, 600

1,600

3.200

52,896

155,136

3,200

6. 400

$: 3.200$

3,200

1,600

3,200

52,896

1,600

105,792

6. 400

3,200

1,600

15s, $6 \mathrm{SS}$

6,400

3,200

$26 \cdot 1,480$

3,200

6,400

105,792

105,792 
Table 3.-Organisms Per Cubic Meter in Plankton of Smith's Canal in 1913 - (Continued)

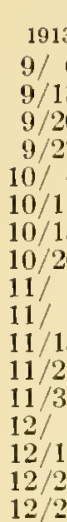

1913

$1 / 11$

$1 / 19$

$1 / 25$

$2 / 2$

$2 / 5$

$2 / 15$

$2 / 23$

$3 / 1$

$3 / 8$

$3 / 15$

$3 / 23$

$3 / 29$

$4 / 5$

$4 / 13$

$4 / 19$

$4 / 26$

$5 / 3$

$5 / 10$

$5 / 17$

$5 / 24$

$5 / 31$

$6 / 7$

$6 / 16$

$6 / 21$

$6 / 28$

$7 / 5$

$7 / 12$

$7 / 19$

$7 / 26$

S/ 2

$8 / 9$

$8 / 15$

$\mathrm{S} / 23$

$8 / 31$

$9 / 6$

$9 / 13$

$9 / 20$

$9 / 27$

$10 / 4$

\begin{tabular}{|c|c|}
\hline $\begin{array}{l}\text { Hemidinium } \\
\text { nasutum }\end{array}$ & $\begin{array}{l}\text { Mallomonas } \\
\text { sp. }\end{array}$ \\
\hline $52 S, 960$ & \\
\hline 105,792 & \\
\hline 105,792 & \\
\hline 105,792 & $\ldots$ \\
\hline ..... & \\
\hline .... & \\
\hline ……......... & ....... \\
\hline ... & .... \\
\hline & 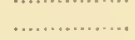 \\
\hline . & $\ldots$ \\
\hline ... & \\
\hline & \\
\hline
\end{tabular}

Phacus

pleuronectes
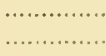

…...........
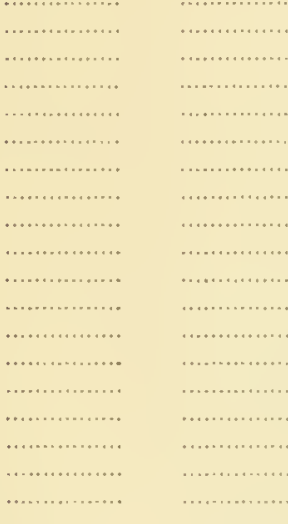

...

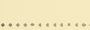

3,200

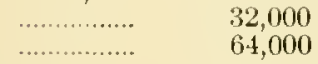

32,000
64,000

25,600

12,800

76,800

12,800

12,800

12,800

Pleodorina

californica
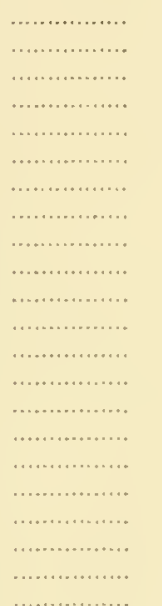

6,400

12,800

105,792

51,200

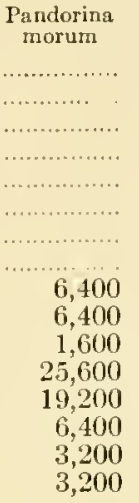

6,400

6,400

1,600

25,600

19,200

6,400

3,200

3,200

Peridinium cinctum

105,792 211,581

317,376

Pleodorina

illinoisensis

Pteromonas

sp.
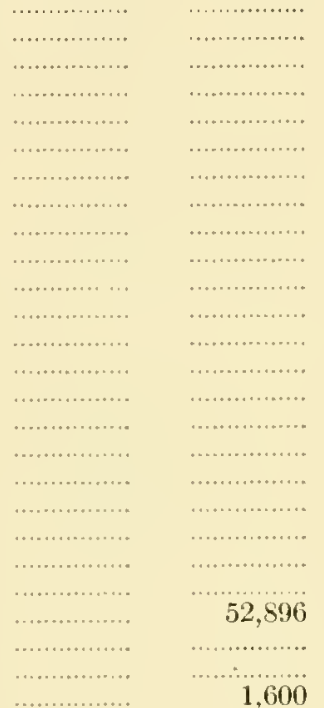

52,896

1,600

25,600
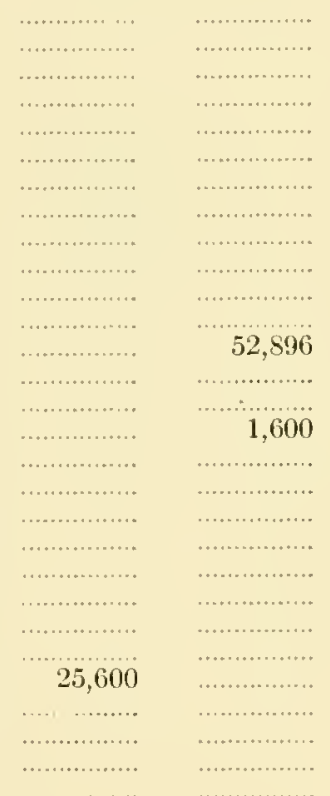

Synerypta

volvox

52,896

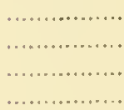

12,800

Peridinium

ap.
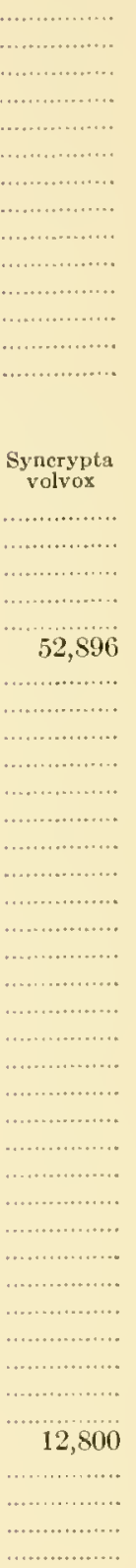
'able 3.-Organisus Per Cobic Meter in Plankton of Saitu's Canai in 1913-(Continued)

\begin{tabular}{|c|c|}
\hline 1913 & $\begin{array}{c}\text { Plancus } \\
\text { pleuronectes }\end{array}$ \\
\hline 1011 & \\
\hline 1018 & $\ldots \ldots$ \\
\hline $10^{\prime \prime 26}$ & $\ldots$ \\
\hline 11 1 & $\cdots$ \\
\hline $11 / 8$ & $\ldots .$. \\
\hline 1115 & \\
\hline $11: 2$ & 52,896 \\
\hline $11 / 30$ & 1,600 \\
\hline $12 / i$ & $\ldots \ldots$ \\
\hline $12 / 1 \cdot 1$ & ....... \\
\hline $\begin{array}{l}12 / 20 \\
12 / 27\end{array}$ & $\begin{array}{rr} & \ldots \\
\ldots \ldots & \ldots\end{array}$ \\
\hline
\end{tabular}

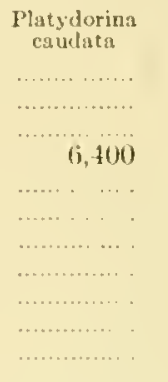

\begin{tabular}{|c|c|}
\hline $\begin{array}{l}\text { Pleodorina } \\
\text { californica }\end{array}$ & $\begin{array}{l}\text { Pleodorina } \\
\text { illinoisensis }\end{array}$ \\
\hline$\ldots \ldots \ldots \ldots \ldots$ & $\cdots$ \\
\hline 12,800 & \\
\hline & $6,-100$ \\
\hline 9,600 & 3,200 \\
\hline$\cdot \ldots \ldots \ldots \ldots$ & 6,100 \\
\hline$\cdot \quad \cdot \quad \cdots$ & $\ldots \ldots, \cdots$ \\
\hline .. & ...... $\cdot$. \\
\hline$\ldots$ & ......... ... \\
\hline & $\ldots$ \\
\hline
\end{tabular}

Synura
uvella
................

\begin{tabular}{|c|c|c|}
\hline $\begin{array}{l}\text { Trachelononas } \\
\text { euchlora }\end{array}$ & $\begin{array}{c}\text { Trachelomonas } \\
\text { volgensis }\end{array}$ & $\begin{array}{l}\text { Trachelomonas } \\
\text { volvocina }\end{array}$ \\
\hline , $\ldots \ldots \ldots$. & $\cdot \cdot \cdot$ & 52,596 \\
\hline 100 & & 33,060 \\
\hline & & 105,792 \\
\hline 52,896 & $\ldots \ldots$ & $211,5 \mathrm{st}$ \\
\hline 52,896 & .. & 290,928 \\
\hline 1,600 & .. & 79,314 \\
\hline 52,896 & ......... & 79,341 \\
\hline & & 317,376 \\
\hline 105,792 & $\ldots \ldots \ldots \ldots \ldots$ & 211,591 \\
\hline 132,210 & .............. & $79,31 t$ \\
\hline 105,792 & ............... & 105,792 \\
\hline 158,688 & 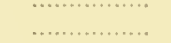 & 52,896 \\
\hline 52,890 & ….............. & 1,600 \\
\hline $132,2+0$ & ………… & 132,240 \\
\hline & ................. & 132,210 \\
\hline & ............... & 105,792 \\
\hline & $\ldots \ldots \ldots \ldots \ldots \ldots$ & 1.600 \\
\hline & ................. & 79,314 \\
\hline & & $10.5,792$ \\
\hline 132,210 & ............... & 52,896 \\
\hline & ................ & 1,600 \\
\hline 52,896 & $\ldots \ldots \ldots \ldots$ & 79,311 \\
\hline $1.32,210$ & n......... & $155,65 S$ \\
\hline ............. & . . . . . . . . . . & 370.272 \\
\hline & ................ & 264,180 \\
\hline 3,200 & $\ldots \ldots$ & \\
\hline 370,272 & $\ldots \ldots \ldots \ldots$ & $5 \$ 1.856^{\circ}$ \\
\hline & ....... & \\
\hline . .. & $\ldots \ldots \ldots \ldots$ & 525,960 \\
\hline ........ & $\ldots .$. & $+23,168$ \\
\hline ....... & .... & 317,376 \\
\hline$\ldots .$. & & 710.514 \\
\hline & $10 i), 792$ & 634,752 \\
\hline$\cdots \cdots$ & $\cdot$ & \\
\hline$\cdots \cdot$ & ... & 317.376 \\
\hline & $\ldots$ & 423,168 \\
\hline & & 317.376 \\
\hline 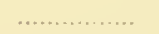 & $10 i, 792$ & 211,554 \\
\hline & .. . & \\
\hline & . $\quad \ldots .$. & $\begin{array}{l}211,58 t \\
211,5 \mathrm{st}\end{array}$ \\
\hline & $105,-792$ & $211,5,5 t$ \\
\hline & ................. & $211,5 \mathrm{St}$ \\
\hline
\end{tabular}

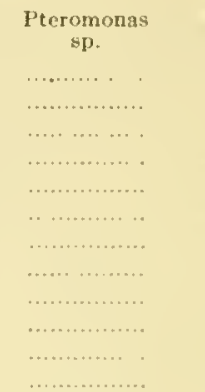

Volvox globutor

Total Mastigophora 1,200

$1,067,5: 20$

$1, \bar{i}+1,9 \backslash 4$

$1,26,9,50+1$

$4,137,010$

$3.665,521$

5), 682,176

$1,0.29,776$

467,968

911,936

$1,82+, 912$

$1,297,5,32$

$16 . \overline{6}, 0 \mathrm{SS}$

407,072

$2+2,5: 32$

$57+605$

(60) 2,800

$3: 30,170$

169,192

$1+1,840$

16.) OSS

427,120

$167,+10$

373,172

310,125

$1,335,400$

$1,937,101$

$2,556,512$

$5,(0,53,920$

$2,625,40 \mathrm{~s}$

$1,087,296$

$5,992,3: 20$

$4,664,41 \mathrm{~S}$

$4,465,861$

$12,800 \quad 0,85.5,5,55$

$5,+17,600$

$3,521,306$

$5,206,60 \mathrm{~s}$

$5,8.56,972$

$3,50: 3,936$

$2,8.56,381$

$1,929.856$

$1,039,2906$

$5,0 \$ 1,416$

$3,32 \cdot 2,600$ 
Table 3.-Organisms Per Cubic Meter in Plankton of SMitu's Canal in 1913-(Continued)

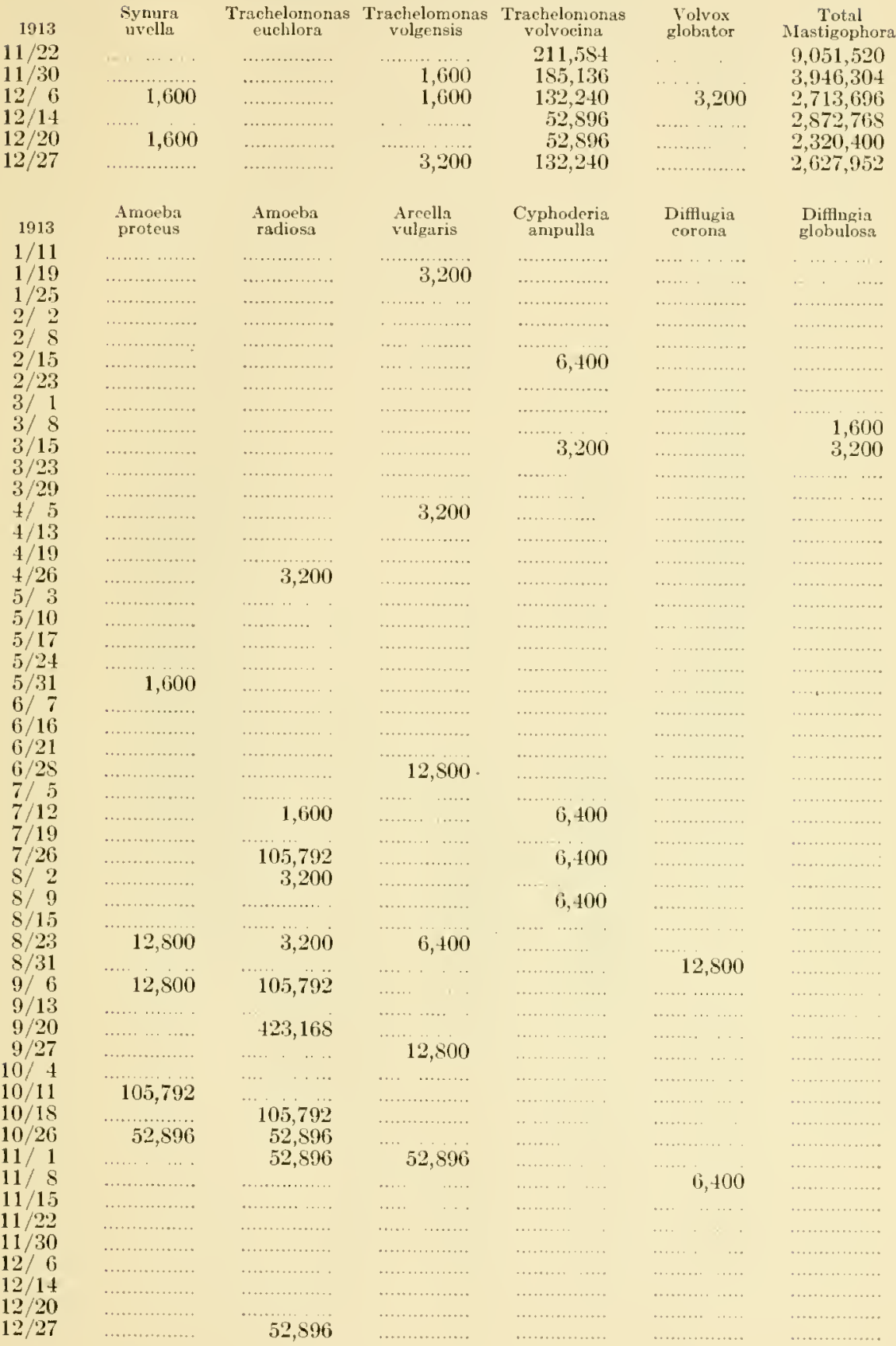


'Table 3.-Organisms l'er Cuhic Meter in Plankton of Smith's Canal in 1913-(Continued)

\section{3}

$1 / 11$

$1 / 19$

$1 / 25$

2/ 2

2/ 8

$2 / 15$

$2 / 23$

$3 / 1$

$3 / 8$

$3 / 15$

$3 / 23$

$3 / 29$

$4 / 5$

$4 / 13$

$4 / 19$

$4 / 26$

$5 / 3$

$5 / 10$

$5 / 17$

$5 / 24$

$5 / 31$

6/ 7

6/16

$6 / 21$

$6 / 28$

$7 / 5$

$7 / 12$

$7 / 19$

$7 / 26$

$8 / 2$

S/ 9

$\mathrm{S} / 15$

$8 / 23$

$\mathrm{S} / 31$

$9 / 6$

$9 / 13$

$9 / 20$

$9 / 27$

10/4

$10 / 11$

$10 / 18$

$10 / 26$

$11 / 1$

11/ $\mathrm{S}$

$11 / 15$

$11 / 22$

$11 / 30$

12/ 6

$12 / 14$

$12 / 20$

$12 / 27$

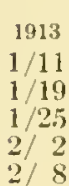

\begin{tabular}{|c|c|}
\hline $\begin{array}{l}\text { Diflusia } \\
\text { pyriformis }\end{array}$ & $\begin{array}{c}\text { Hyalorliscus } \\
\text { sp. }\end{array}$ \\
\hline$\cdots \cdots$ & - \\
\hline 800 & …..... \\
\hline $1,6(1) 0$ & \\
\hline 12,800 & $\ldots \ldots$ \\
\hline $2: 4,400$ & \\
\hline$(i, 400$ & .. \\
\hline 1,600 & $\ldots \ldots \ldots$ \\
\hline$(3,400$ & $+\ldots$ \\
\hline 79,344 & $\ldots \ldots, \ldots \ldots$ \\
\hline 3,200 & $\ldots \ldots \ldots$ \\
\hline 12,800 & $\ldots$ \\
\hline 16,000 & \\
\hline 211,584 & $\ldots$ \\
\hline 235,032 & $\ldots$ \\
\hline 79,344 & $\ldots \ldots \ldots \ldots$ \\
\hline 32,000 & \\
\hline 79,344 & $\ldots$ \\
\hline 140,800 & $\ldots$ \\
\hline $264,4 S 0$ & $\ldots$ \\
\hline 132,240 & ...... \\
\hline 105,792 & $\ldots$ \\
\hline 105,792 & $\ldots$. \\
\hline 317,376 & ....... \\
\hline 238,032 & \\
\hline 105,792 & $\ldots$. \\
\hline 3,200 & (n.......... \\
\hline 6,400 & ........ \\
\hline 6,400 & .............. \\
\hline 6,400 & n............. \\
\hline ....... , , & …............ \\
\hline . & 317,376 \\
\hline ..... & 317,376 \\
\hline & 105,792 \\
\hline N..., & (n........... \\
\hline .. & $211,5 \mathrm{~S} 4$ \\
\hline …n... $\quad$. & ................ \\
\hline . & 105,792 \\
\hline$\ldots \ldots \ldots$ & 52,896 \\
\hline & 52,896 \\
\hline .... & $\cdots, \quad \ldots \ldots$, \\
\hline .... & $\cdot \quad \cdots \cdots$ \\
\hline 1600 & $\cdots+\quad, \quad \cdots$ \\
\hline 3,200 & $\cdots, \quad \cdots$ \\
\hline . $\quad \ldots$ & $\ldots \ldots$ \\
\hline
\end{tabular}

Ileterophrys fockei

Nuclearia

simplex

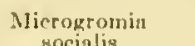

$\ldots \ldots \ldots$
$\ldots \ldots$
$\ldots \ldots$
1,600
1,600
1,600
1,600
1,600
105,792

\section{3,200}

1,600

52,896

3,200

3, 200

3,200

423,168

$1,163,712$

211,581

317,376

105,792

528,960

211,584

105,792

264,480

105,792

52,896

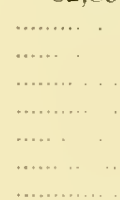

Pinaciophora fluviatilis

R
Trinema
enchely's

Total

Rbizopoda

3, 200

$\mathrm{S} 00$

1,600

12,800

28,800

11,200

$+, 800$

11,200

87,344

6., 400

6,400

16,000

17,600

213, 184

348,624

79,344

32,000

79,344

140,500

266,050

138,640

105,792

105,792

331,776

241,232

220,584

6,400

124,992

12,800

12,800

$5,501,184 \quad 5,501,184$

445.768

647,552

$2,022,848$

422,168

740,544

118,592

753,344

317,376

211,584

476,064

$26+450$

$\begin{array}{rr}105,792 & 105,792 \\ \ldots \ldots \ldots \ldots & 1,600\end{array}$

$\begin{array}{rr}105,792 & 105,792 \\ & 1,600\end{array}$

1,600

1,600

1,600

3,200

3,200

1,600
Actinophrys

sol.

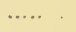

…

6,400

79,314

12,800

3,200

105,792

12.800

211,584

317,376
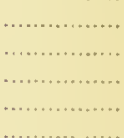

...............
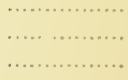

Ciliate

unidentified

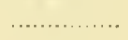

Total
Heliozon

Heliozon

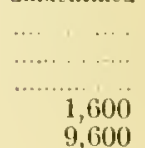


Table 3.-Organisus Per Cubic Meter in Plankton of Smith's Canal in 1913-(Continued)

\begin{tabular}{|c|c|c|c|c|c|c|}
\hline 1913 & $\begin{array}{l}\text { Heterophrys } \\
\text { fockei }\end{array}$ & $\begin{array}{l}\text { Nuclearia } \\
\text { simplex }\end{array}$ & $\begin{array}{l}\text { Pinaciophora } \\
\text { fluviatilis }\end{array}$ & $\begin{array}{c}\text { Raphidiophrys } \\
\text { elegans }\end{array}$ & $\begin{array}{c}\text { Total } \\
\text { Heliozoa }\end{array}$ & $\begin{array}{c}\text { Ciliate } \\
\text { unidentified }\end{array}$ \\
\hline $2 / 15$ & & & & & & 1,600 \\
\hline $2 / 23$ & ..... & ...... & & & 3,200 & 1,600 \\
\hline $3 / 1$ & $\ldots \ldots \ldots \ldots, \quad$. & ……....... & …........... & ............. & …....... & 1,600 \\
\hline $3 / 8$ & ….......... & ......... & ...... & ..... & & \\
\hline $3 / 15$ & $\ldots$. & & ..... & ,.............. & . & 52,896 \\
\hline $\begin{array}{l}3 / 23 \\
3 / 20\end{array}$ & & 1,600 & 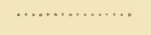 & n.............. & ...... & 9,600 \\
\hline $\begin{array}{l}3 / 29 \\
1 / 5\end{array}$ & n........, & n......, & 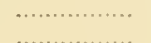 & -... & . & \\
\hline$\pm / 20$ & ……, & $\cdots$ & , $\ldots \ldots \ldots \ldots \ldots \ldots$ & ……............ & .... & 12,800 \\
\hline $1 / 19$ & .... & .... & & & & 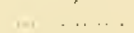 \\
\hline$\pm / 26$ & ......... & …............. & .............. & 1,600 & 1,600 & \\
\hline $5 / 3$ & ........ & ................ & .............. & 79,344 & 79,344 & \\
\hline $5 / 10$ & …............ & …............ & …........... & 1,600 & 1,600 & \\
\hline $5 / 17$ & ............... & ................. & ................ & $\ldots \ldots+\ldots$ & 25,600 & 3,200 \\
\hline $5 / 24$ & $\ldots \ldots$ & …............ & …........... & (n...., , & 6,400 & \\
\hline $5 / 31$ & ……....... & ................. & ............... & 41,600 & 41,600 & \\
\hline $6 / 7$ & ................ & ............... & …............ & & 79,344 & \\
\hline $6 / 16$ & $\ldots$. & …............ & n..., n w & 1,600 & 1,600 & \\
\hline $6 / 21$ & $\ldots .$. & ............... & ......... . . & & 12,800 & \\
\hline $6 / 28$ & $\ldots \ldots \ldots$ & ............... & .............. & 105,792 & 108,992 & \\
\hline $7 / 5$ & ….......... & & ............... & 79,344 & 79,344 & \\
\hline $7 / 12$ & & 52,896 & .............. & 264,480 & $264, \pm 50$ & \\
\hline $7 / 19$ & 211,584 & $\ldots \ldots \quad \ldots \ldots$ & ................ & 423,168 & 634,752 & \\
\hline $7 / 26$ & 211,584 & $\ldots \ldots, \ldots$ & ................. & 317,376 & 528,960 & \\
\hline $8 / 2$ & $211,5 \mathrm{S4}$ & $\ldots \ldots . \ldots$ & ................. & 687,648 & 899,232 & \\
\hline $8 / 9$ & 211,584 & $\ldots, \quad, \ldots$ & n..., & 105,792 & 317,376 & \\
\hline $8 / 15$ & ... & $\ldots \quad \ldots$ & ...... & & & \\
\hline $8 / 23$ & $\cdots$ & $\cdots$ & .... & $1,005,024$ & $1,005,024$ & \\
\hline $8 / 31$ & … $=-0$ & 317,376 & ………… & 211,584 & 211,584 & .. \\
\hline $9 / 6$ & 105,792 & 317,376 & $\ldots \ldots \ldots+\ldots$ & 211,584 & $423,16 \mathrm{~S}$ & \\
\hline $\begin{array}{l}9 / 13 \\
9 / 20\end{array}$ & 423168 & 105,692 & & …,,$\ldots$ & 123 Ifs & \\
\hline $9 / 27$ & 317,376 & $\cdots$ & 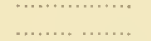 & & 541,760 & \\
\hline $10 / 4$ & $2,962,176$ & 12,800 & & & $3,173,760$ & \\
\hline $10 / 11$ & 211,584 & $\ldots \ldots+\ldots$ & $1,269,504$ & $\ldots \ldots \ldots+\ldots \ldots$ & $1,798,464$ & .. \\
\hline $10 / 18$ & 105,792 & $\ldots . \quad \ldots \ldots$ & 528,960 & .. & 634,752 & \\
\hline $10 / 26$ & 52,896 & $\ldots \ldots \ldots \ldots$ & 423,168 & & 476,064 & \\
\hline $11 / 1$ & - & $\ldots \ldots, \quad, \ldots \ldots$ & 158,688 & 52,896 & 211,581 & \\
\hline $11 / 8$ & n............. & ......, n., & $105,79^{\circ}$ & 687,648 & 799,810 & \\
\hline $11 / 15$ & .............. & ............. & 1,600 & $1,216,608$ & $1,218,208$ & \\
\hline $11 / 22$ & …......... & ….......... & $1=1 ., .$. & $\cdot \quad, \quad \ldots \ldots \ldots$ &,$\quad . \quad \ldots \ldots \ldots$ & \\
\hline $11 / 30$ & ............... & .............. & $\ldots \quad \ldots$ & $\cdot \quad-\ldots \ldots$ & $\ldots, \quad . .$. & .. \\
\hline $12 / 6$ & …, $\ldots \ldots \ldots \ldots$ & …........... & ….... $\quad \ldots$ & $\ldots . \quad \ldots$ & . . ......... & \\
\hline $12 / 14$ & ............... & 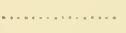 & …n. & $\cdots, \quad \cdots$ & $-\quad \ldots \ldots$ & 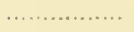 \\
\hline $12 / 20$ & ................ & ….... & n........... & $\begin{array}{lll}\cdots & . & \cdot\end{array}$ & \#....... & n....... \\
\hline $12 / 27$ & ............... & 1,600 & n......... & (n., & .. $\quad \ldots \ldots$ & 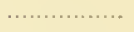 \\
\hline 1913 & $\begin{array}{l}\text { Cyclidium } \\
\text { sp. }\end{array}$ & $\begin{array}{l}\text { Didinium } \\
\text { nasutum }\end{array}$ & $\begin{array}{l}\text { Euplotes } \\
\text { harpa }\end{array}$ & $\begin{array}{l}\text { Euplotes } \\
\text { patella }\end{array}$ & $\begin{array}{l}\text { Halteria } \\
\text { grandinella }\end{array}$ & $\begin{array}{c}\text { Hastatella } \\
\text { radians }\end{array}$ \\
\hline $1 / 11$ & $\ldots \ldots \ldots \ldots \ldots+\ldots$ & …, n, & $\ldots \ldots, \quad \ldots$. & n.w. & .... . & 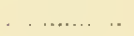 \\
\hline $1 / 19$ & …........... & ............... & .............. & (n........... & …... & $\cdots$. \\
\hline $1 / 25$ & ……........ & ……........ & ……........ & , & ……. $\quad \ldots$ & , \\
\hline $2 / 2$ & … & n..., & ............... & …........... & …..... $\quad \cdots$ & ......... \\
\hline $2 / 8$ & ..... & 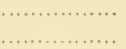 & 6,400 & & 3,200 & \\
\hline $2 / 23$ & & 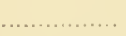 & 3,200 & 9,600 & 3,200 & 3,200 \\
\hline $3 / 1$ & …............ & ........... & 3,200 & s. & $\ldots \ldots \ldots$ & $\ldots \ldots \ldots$ \\
\hline $3 / S$ & ...... & 3,200 & 3,200 & & …........... & \\
\hline $3 / 15$ & - & ......... & 9,600 & 3,200 & .............. & \\
\hline
\end{tabular}


Table 3.-Organisms Per Cubic Meter in plankton of SMtu's Canal in 1913-(Continued)

\begin{tabular}{|c|c|}
\hline \multirow{2}{*}{\multicolumn{2}{|c|}{$\begin{array}{c}\text { clidit } \\
\text { sp. }\end{array}$}} \\
\hline & sp. \\
\hline $3 / 23$ & \\
\hline $3 / 29$ & \\
\hline $4 / 5$ & 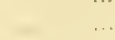 \\
\hline $4 / 13$ & \\
\hline $4 / 19$ & \\
\hline $1 / 26$ & \\
\hline $5 / 3$ & \\
\hline $5 / 10$ & \\
\hline $5 / 17$ & $\ldots$ \\
\hline $5 / 24$ & \\
\hline $5 / 31$ & .. \\
\hline (i) 7 & \\
\hline $6 / 16$ & $\ldots$ \\
\hline $6 / 21$ & . \\
\hline $6 / 29$ & $\ldots$ \\
\hline $7 / 5$ & \\
\hline $7 / 12$ & \\
\hline $7 / 19$ & $\ldots$ \\
\hline $7 / 26$ & ... \\
\hline $8 / 2$ & \\
\hline $8 / 9$ & 3 \\
\hline $8 / 15$ & \\
\hline $8 / 23$ & \\
\hline $8 / 31$ & 105,79 \\
\hline $9 / 6$ & \\
\hline $9 / 13$ & 105, \\
\hline $9 / 20$ & 105 \\
\hline $9 / 27$ & \\
\hline $10 / 4$ & \\
\hline $10 / 11$ & $\ldots$ \\
\hline $10 / 18$ & .. \\
\hline $10 / 26$ & $\ldots .$. \\
\hline $11 / 1$ & $\ldots$ \\
\hline $\begin{array}{l}11 / 8 \\
11 / 15\end{array}$ & \\
\hline $11 / 22$ & \\
\hline $11 / 30$ & \\
\hline $12 / 6$ & \\
\hline $12 / 14$ & \\
\hline $2 / 20$ & \\
\hline 27 & \\
\hline
\end{tabular}

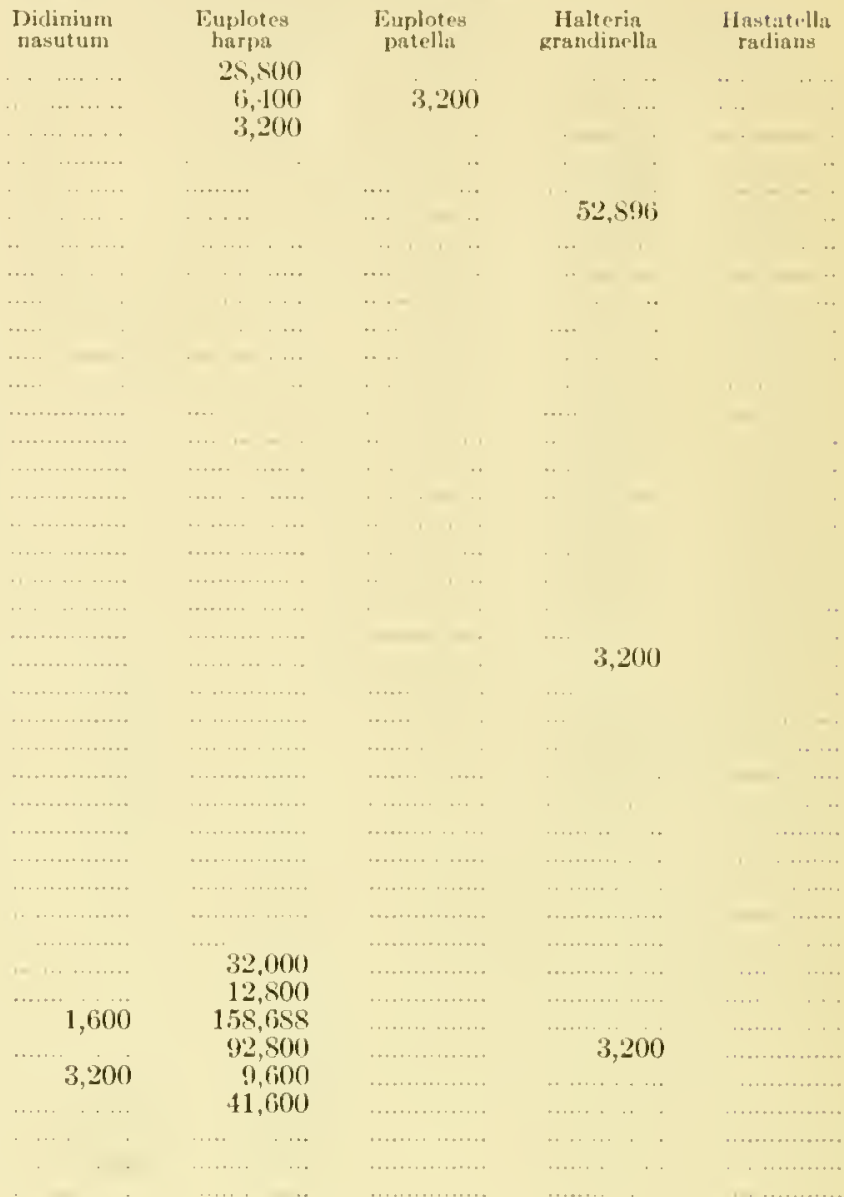

\begin{tabular}{|c|c|c|c|c|c|c|}
\hline 1913 & $\begin{array}{c}\text { Holophrya } \\
\text { sp. }\end{array}$ & $\begin{array}{l}\text { Paramecium } \\
\text { aurelia }\end{array}$ & $\begin{array}{c}\text { Paramecium } \\
\text { bursaria }\end{array}$ & $\begin{array}{c}\text { Prorodon } \\
\text { sp. }\end{array}$ & $\begin{array}{l}\text { Stentor } \\
\text { coeruleus }\end{array}$ & $\begin{array}{l}\text { Stentor } \\
\text { niger }\end{array}$ \\
\hline $\begin{array}{l}1 / 11 \\
1 / 19\end{array}$ & $\begin{array}{lll} & \cdots & \cdots \\
\ldots & \ldots \ldots\end{array}$ & & . & & . . .... & .. \\
\hline $1 / 25$ & $\ldots \ldots \ldots$ & 1,600 & . & 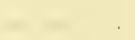 & 800 & \\
\hline $2 / 2$ &.. & .. & . & $\ldots$ & $\ldots$ & . \\
\hline $2 / 8$ & …. & $\ldots \ldots$. & . & $\ldots$ & $\ldots$ & \\
\hline 15 & - & $\ldots$ & & & = & 3,200 \\
\hline $\begin{array}{r}23 \\
1\end{array}$ & $\begin{array}{l}1,600 \\
3,200\end{array}$ & & - & 1,600 & $\cdots$ & \\
\hline $\begin{array}{l}3 / 1 \\
3 / 8\end{array}$ & $\begin{array}{l}3,200 \\
3,200\end{array}$ & 3,200 & .. & 1 & . & 6,400 \\
\hline $3 / 15$ & 3,200 & . . . . & $\begin{array}{ll}\ldots & \ldots\end{array}$ & & & $0,+100$ \\
\hline $3 / 23$ & 3,200 & $\ldots$ & $\ldots \ldots \ldots$ & 1,600 & $=$ & 3,200 \\
\hline 190 & & & & & & 3,200 \\
\hline & $\begin{array}{l}105,792 \\
105,702\end{array}$ & 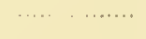 & $\begin{array}{lll}\ldots \ldots \ldots & .\end{array}$ & $\ldots \quad \ldots$. & . & ..... \\
\hline $\begin{array}{l}+13 \\
1 / 19\end{array}$ & $\begin{array}{r}10 i, 792 \\
1,600\end{array}$ & ...... & $\ldots \ldots \ldots$ & 1,600 & & \\
\hline
\end{tabular}


Tabee 3.-Organishs Per Cubic Meter in Plankton of Smith's Canal in 1913-(Continued)

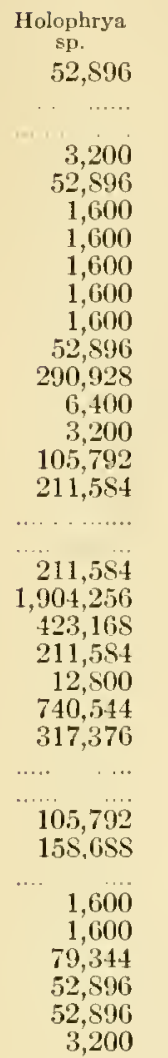

Paramecium
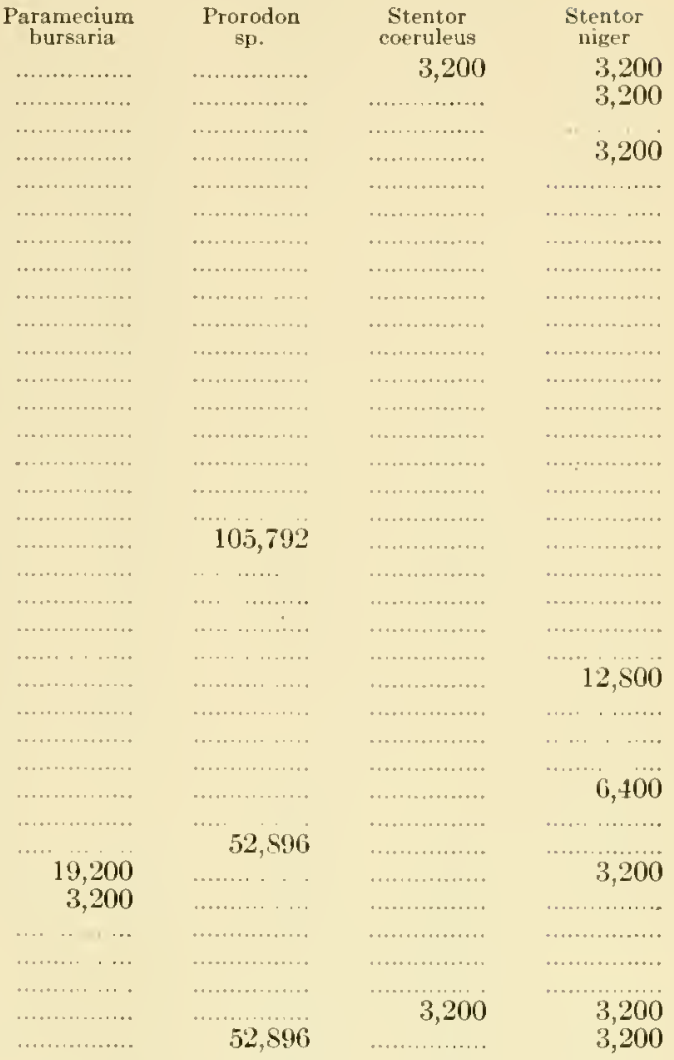

Total fuviatile

longifilum

$$
\text { sp. }
$$

Ciliata

$$
\text { . }
$$

(................
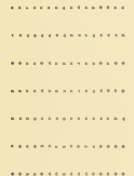

...............

................

................

(................

..............

……...........

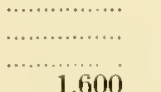

……........

…….....

2,400

1,600

11,200

14,400

28,200

8,000

6,100

25,600

3,200

1,600

…........

2,090

48,000

12,800

108,992

120,192

1,600

6,400

1,600

113,792

1,600

4,800

$105,79^{\circ}$

105,792

158,688

$16 \$, 288$

214,784 
Table 3.-Organisus Pru Cunic Methr in Piankton of SMrtit's Canal in 1913-(Continued)

1913
$5 / 31$
$6 / 7$
$6 / 16$
$6 / 21$
$6 / 25$
$7 / 5$
$7 / 12$
$7 / 19$
$7 / 26$
$8 / 2$
$8 / 9$
$8 / 15$
$8 / 23$
$8 / 31$
$9 / 6$
$9 / 13$
$9 / 20$
$9 / 27$
$10 / 4$
$10 / 11$
$10 / 15$
$10 / 26$
$11 / 1$
$11 / 5$
$11 / 15$
$11 / 22$
$11 / 30$
$12 / 6$
$12 / 14$
$12 / 20$
$12 / 27$

1913
$1 / 11$
$1 / 19$
$1 / 25$
$2 / 2$
$2 / 8$
$2 / 15$
$2 / 23$
$3 / 1$
$3 / 5$
$3 / 15$
$3 / 23$
$3 / 29$
$4 / 5$
$4 / 13$
$4 / 19$
$4 / 26$
$5 / 3$
$5 / 10$
$5 / 17$
$5 / 24$
$5 / 31$
$6 / 7$
$6 / 16$
$6 / 21$
$6 / 25$

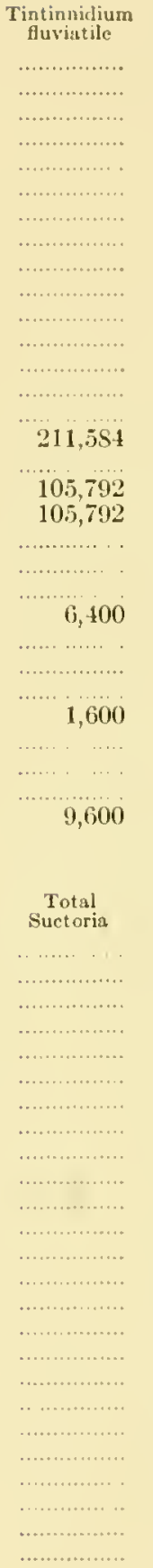

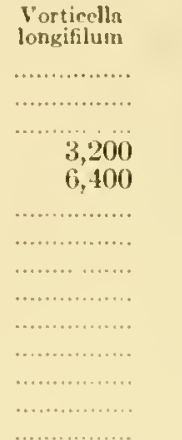

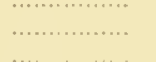

105,792

12,800

25,600

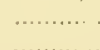

3,200
9,600
3,200
1,600

Total Protoaca
without
Mastigophora 3,200

3,200

3,200

$2+, 000$

43,200

42,600

12,500

36,800

159,440

54,400

19,200

124,992

137,792

$219,5 \mathrm{S4}$

464,016

163,485

139,392

273,232

361,984

547,312

431,168

320,576

573,008

851,536

\begin{tabular}{|c|c|}
\hline $\begin{array}{c}\text { Vorticella } \\
\text { sp. }\end{array}$ & $\begin{array}{c}\text { Total } \\
\text { Ciliata }\end{array}$ \\
\hline 238,032 & 239,632 \\
\hline 211,584 & 213,181 \\
\hline 211,584 & 213,154 \\
\hline 449,616 & 451,416 \\
\hline 423,168 & 440,768 \\
\hline $581,5,56$ & 634,752 \\
\hline 793,440 & $1,084,268$ \\
\hline 581,856 & 588,256 \\
\hline 952,128 & 955,328 \\
\hline $1,5333,984$ & $1,639,776$ \\
\hline 952,128 & $\begin{array}{r}1,166,912 \\
3,200\end{array}$ \\
\hline 105,792 & 211,581 \\
\hline $1,795,464$ & $2,327,424$ \\
\hline 634,752 & $2,551,808$ \\
\hline 211,584 & 952,128 \\
\hline$\$ 46,336$ & $1,269,504$ \\
\hline 634,752 & 804,544 \\
\hline 423,168 & $1,282,304$ \\
\hline 528,960 & 964,928 \\
\hline 740,544 & 740,544 \\
\hline $581,85 t \mathrm{t}$ & 618,856 \\
\hline 105,792 & $249,9 \mathrm{St}$ \\
\hline 158,685 & 408,772 \\
\hline 52,896 & 261,181 \\
\hline 3,200 & 108,800 \\
\hline 132,240 & 148,040 \\
\hline & 130,544 \\
\hline 1,600 & 59,296 \\
\hline 79,344 & 138,640 \\
\hline 1,600 & 73,696 \\
\hline
\end{tabular}

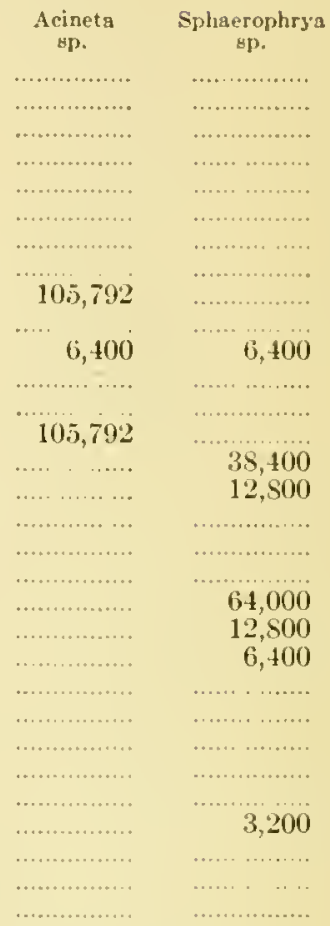

Total Protozoa

Mastigophora

$$
1,200
$$

$1,070,720$

$1,545,184$

$1,272,704$

$4,161,540$

$3,709,024$

$5,724,776$

$1,042,576$

504,768

$1,071,376$

$1,879,312$

$1,316,752$

290,080

544,564

462,416

$1,039,624$

826,285

469,568

442,424

503,824

712,400

\$58,288

488,016

946,480

$1,191,664$
Collotheca egg, attached

Collotheca pelagica

Collotheca 8p. 
Table 3.-Organisms Per Cubic Meter in Plankton of Sirthi's Canal in 1913-(Continued)

\begin{tabular}{|c|c|c|c|c|c|c|}
\hline 1913 & $\begin{array}{c}\text { Total } \\
\text { Suctoria }\end{array}$ & $\begin{array}{l}\text { Total Protozoa } \\
\text { without } \\
\text { Mastigophora }\end{array}$ & $\begin{array}{c}\text { Total Protozoa } \\
\text { with } \\
\text { Mastigophora }\end{array}$ & $\begin{array}{l}\text { Collotheca } \\
\text { egg. attached }\end{array}$ & $\begin{array}{c}\text { Collotheca } \\
\text { pelagica }\end{array}$ & $\begin{array}{c}\text { Collotheca } \\
\text { sp. }\end{array}$ \\
\hline $7 / 5$ & & 955,328 & $2,293,725$ & & & \\
\hline $7 / 12$ & ......... & $\mathbf{1}, 569,432$ & $3,506,536$ & & & \\
\hline $7 / 19$ & & $1,229,408$ & $3,785,920$ & ……1, & ...... & ...... \\
\hline $7 / 26$ & 105,792 & $1,715,072$ & $6,768,992$ & .............. & & $\ldots .$. \\
\hline $8 / 2$ & 44,800 & $2,596,60 \mathrm{~s}$ & $5,222,016$ & …....... & & ..... \\
\hline $8 / 9$ & 12,800 & $1,509,858$ & $5,597,181$ & & & $\ldots$. \\
\hline $8 / 15$ & …............. & $5,504,384$ & $14,496,704$ & & & \\
\hline $8 / 23$ & & $1,665,376$ & $6,329,824$ & 25,600 & 19,200 & \\
\hline $8 / 31$ & 105,792 & $3,292,352$ & $7,761,216$ & $\ldots \ldots \ldots$ & 12,800 & \\
\hline $9 / 6$ & 38,400 & $5,036,224$ & $11,922,112$ & & & \\
\hline $9 / 13$ & 12,800 & $1,387,096$ & $6,904,696$ & 51,200 & 51,200 & \\
\hline $9 / 20$ & 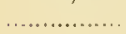 & $2,433,216$ & $6,254,522$ & 38,400 & 51,200 & \\
\hline $9 / 27$ & & $1,464,896$ & $6,671,504$ & & & \\
\hline $10 / 4$ & & $5,209,408$ & $11,066,380$ & 105,792 & 12,800 & $211,58 t$ \\
\hline $10 / 11$ & $6 \pm, 000$ & $3,1 \pm 4,768$ & $6,644,704$ & 423,168 & & 153,600 \\
\hline $10 / 18$ & 12,800 & $1,599,680$ & $4,456,06 \pm$ & 25,600 & 64,000 & ............. \\
\hline $10 / 26$ & 6,400 & $1,577,384$ & $3,507,240$ & 52,896 & 105,792 & \\
\hline $11 / 1$ & & 726,048 & $4,765,34 \pm$ & & 12,800 & \\
\hline $11 / 8$ & & $1,314,404$ & $6,395,820$ & 52,896 & 52,896 & .... \\
\hline $11 / 15$ & & $1,180,992$ & $4,803,592$ & & 3,200 & \\
\hline $11 / 22$ & 3,200 & 112,000 & $9,163,520$ & 6,400 & 3,200 & \\
\hline $11 / 30$ & & 148,040 & $4,094,344$ & & & 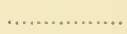 \\
\hline $12 / 6$ & 3,200 & 135,344 & $2,849,040$ & & $\ldots$ & …............ \\
\hline $12 / 1 \frac{1}{4}$ & ....... & 62,496 & $2,935,264$ & & & ........ \\
\hline $12 / 20$ & & 138,640 & $2,459,040$ & …............ & ................ & …........... \\
\hline $12 / 27$ & …............. & 75,296 & $2,703,2 \pm 8$ & & & \\
\hline
\end{tabular}

\begin{tabular}{|c|c|c|c|c|c|c|}
\hline 1913 & $\begin{array}{c}\text { Total } \\
\text { Rhizota }\end{array}$ & $\underset{\text { Reptunia }}{\text { Rotaria }}$ & $\begin{array}{c}\text { Rotaria } \\
\text { rotatoria }\end{array}$ & $\begin{array}{l}\text { Rotifer egg, } \\
\text { winter }\end{array}$ & $\begin{array}{c}\text { Total } \\
\text { Bdelloida }\end{array}$ & $\begin{array}{l}\text { Anuraeopsis } \\
\text { egg, attached }\end{array}$ \\
\hline $1 / 11$ & $\ldots \ldots$ & . $\quad \ldots . .$. & 1,600 & & 1,600 & \\
\hline $1 / 19$ & $\ldots ., \ldots \ldots$ & & 36,800 & ............... & 46,400 & $\ldots$ \\
\hline $1 / 25$ & ................ & 3,200 & 19,836 & & 23,036 & \\
\hline $2 / 2$ & ............... & 1,600 & 11,200 & ... & 22,800 & \\
\hline $2 / 8$ & ................. & $\ldots$ & 35,200 & & 48,000 & $\ldots$ \\
\hline $2 / 15$ & ............... & & 80,000 & 6,100 & 92,800 & \\
\hline $2 / 23$ & .................. & 3,200 & 35,200 & & 44,800 & \\
\hline $3 / 1$ & & & 79,344 & & 98,514 & \\
\hline $3 / 8$ & 3,200 & 3,200 & 185,136 & & 236,336 & \\
\hline $3 / 15$ & .............. & & 28,800 & 3,200 & 38,400 & ...... \\
\hline $3 / 23$ & ................ & 3,200 & 64,000 & $\ldots .$. & 68,800 & …....... \\
\hline $3 / 29$ & …........... & $\ldots$ & 60,800 & . $1 .$. & 60,800 & \\
\hline t/ 5 & ................ & ......... & 16,000 & .......... & 22,400 & $\ldots$ \\
\hline $4 / 13$ & ............... & & 6,400 & ........... & 9,600 & \\
\hline$+/ 19$ & ........... & & 19,200 & .......... & 20,800 & \\
\hline $4 / 26$ & ........... & & & & 6,400 & \\
\hline $5 / 3$ & ............... & .... & 3,200 & 6,100 & 4,800 & \\
\hline $5 / 10$ & ............... & & 1,600 & ..... & 1,600 & .... \\
\hline $5 / 17$ & …........... & 3,200 & 12,800 & & 32,000 & .......... \\
\hline $5 / 24$ & ................. & ..... & & 3,200 & 6,400 & \\
\hline $5 / 31$ & ................. & ...... & 9,600 & $\ldots$. & 168,288 & ........... \\
\hline $6 / 7$ & ………... & ……......... & $\ldots \ldots \ldots$ & ........ & 9,600 & …........... \\
\hline $6 / 16$ & ............... & ..... & & .......... & & \\
\hline $6 / 21$ & ................ & ................ & 6,400 & ................. & 6,400 & ......... \\
\hline $6 / 28$ & ................. & ................. & & & & .. \\
\hline $7 / 5$ & .................. & ................ & 6,400 & 3,200 & 112,192 & .... \\
\hline $7 / 12$ & .................. & ................ & 52,896 & 6,400 & 105,792 & ................ \\
\hline $\begin{array}{l}7 / 19 \\
7 / 26\end{array}$ & .................. & .................. & $\begin{array}{ll}\cdots & . .\end{array}$ & $\cdots$ & $\begin{array}{r}3,200 \\
-800\end{array}$ & $\cdots$ \\
\hline $8 / 2$ & & 12,800 & 6,400 & $\begin{array}{r}0,400 \\
\ldots \ldots \ldots \ldots \ldots\end{array}$ & 177,858 & …........... \\
\hline
\end{tabular}


Table 3.-Organisms Per Cunir Meter in P'Lankton of Simtir's CANaL IN 1913-(Continued)

\begin{tabular}{|c|c|}
\hline \multirow{2}{*}{\multicolumn{2}{|c|}{$\begin{array}{r}1913 \\
8 \quad 9\end{array}$}} \\
\hline & \\
\hline 81.5 & 3,200 \\
\hline 823 & $4+4800$ \\
\hline$\& 31$ & $12, \$ 00$ \\
\hline $9 / 6$ & \\
\hline $9 / 1: 3$ & 102.400 \\
\hline$! 120$ & 89,600 \\
\hline $9 / 27$ & \\
\hline 10/4 4 & 330,176 \\
\hline $10 / 11$ & 576,768 \\
\hline $10 / 18$ & 89,600 \\
\hline $10 / 26$ & 158,688 \\
\hline $11 / 1$ & 12,800 \\
\hline $11 / 8$ & 105,792 \\
\hline $11 / 15$ & 3,200 \\
\hline $11 / 22$ & 9,600 \\
\hline $11 / 30$ & ........... \\
\hline $12 / 6$ & \\
\hline 12,14 & \\
\hline $12 / 20$ & \\
\hline 127 & \\
\hline
\end{tabular}

Rotaria
neptunia
32,000
12,500
$\ldots$.
12,500
12,500
12,800
52,890
12,800
3,200
3,200
3,200
6.
6,400

Rotaria
rotutoria
38,400
19,200
12,800
12,800
12,800
6,400
6,400
6,400
12,800
6,400
6,400
3,200
9,600

Rotifer egg. winter

Total kelloida 76,500

.................

$24 !, 4 \times 4$

25,600

105,792

$211,5 \times 1$

$\begin{array}{rr}105,792 & 22.384 \\ \ldots & 89,600\end{array}$

25,600

51,200

12,800

72,096

59,296

25,600

16,000

9,600

6,400

3,200

3,200

… …….

Anuraeopsis

19

$1 / 11$

$1 / 25$

2/ 2

2) 8

$2 / 15$

$2 / 23$

$3 / 1$

$3 / 8$

$3 / 15$

$3 / 23$

$3 / 29$

$4 / 5$

$+/ 13$

$4 / 19$

$4 / 26$

$5 / 3$

$5 / 10$

$5 / 17$

$5 / 24$

$5 / 31$

$6 / 7$

$6 / 16$

$6 / 21$

$6 / 25$

7/ 5

$7 / 12$

$7 / 1 !$

$7 / 26$

S/ 2

S/ 9

S/15

$S / 23$

$S / 31$

$9 / 6$ fisea

$$
\begin{aligned}
& \text { sp. } \\
& \text { s. }
\end{aligned}
$$

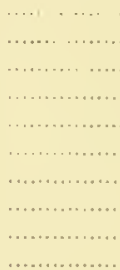

……..........

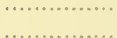

……........

…..............

…….........

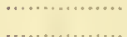

…...........

……........

……......

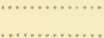

105,792

6.400

211,584

51,200
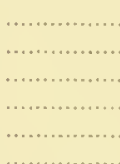

211,581
Asplanchna
brightiwellii

Brachionus

angularis

...............

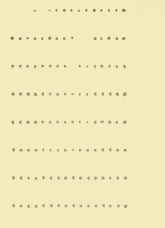

(n.......

…............

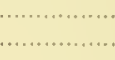

3,200

1,600

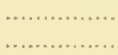

1,600

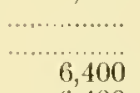

6,400

6,400

3,200
3,200

$$
19,200
$$$$
22,400
$$

3,200

16,000

35,200

45,000

32,000

9,600

9,600

3,200

1,600

6,400

3,200

…..............

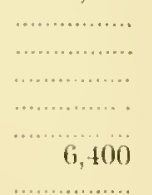
angularis
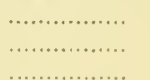

3,200

48,000

3,200

3,200

38,400

105,792

105,792

$6.57,645$

57,600

105,792

370,272

44,800

158,658

740,544

317,376

Brachionus budapestenensis

A nuraeopsis eng, attached

105,792

$.51,200$
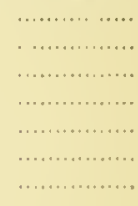

\section{9,600}

$6, \pm 00$

$3 \times, 400$

6,400

6,400 
Table 3.-Organismis Per Cubic Meter in Plankton of Smitu's Canal in 1913-(Contimued)

1913
$9 / 13$
$9 / 20$
$9 / 27$
$10 / 4$
$10 / 11$
$10 / 18$
$10 / 26$
$11 / 1$
$11 / 5$
$11 / 15$
$11 / 22$
$11 / 30$
$12 / 6$
$12 / 14$
$12 / 20$
$12 / 27$

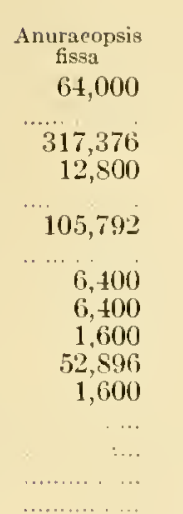

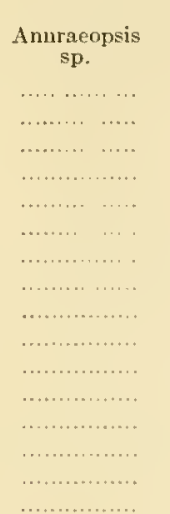

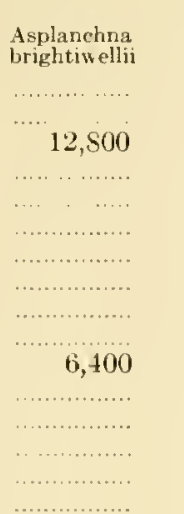

\begin{tabular}{|c|c|}
\hline $\begin{array}{l}\text { Brachionus } \\
\text { angularis }\end{array}$ & $\begin{array}{l}\text { Brachionus } \\
\text { angularis } \\
\text { caudatus }\end{array}$ \\
\hline & 422,400 \\
\hline 12,800 & 25,600 \\
\hline$\ldots$. & 64,000 \\
\hline & 38,400 \\
\hline . & 25,600 \\
\hline$\ldots$ & 211,584 \\
\hline & 6,400 \\
\hline & 19,200 \\
\hline 6,400 & \\
\hline 3,200 & $\ldots$ \\
\hline & \\
\hline$\ldots$ & $\cdots$ \\
\hline & \\
\hline
\end{tabular}

Brachionus budapestenensis 12,800

Brachionus

Brachionus

Brachionus

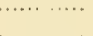

$3 \mathrm{~s}, 400$ capsulifforus

gg; attache

$1 / 11$ calycifforus

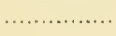

$$
\begin{array}{rr}
\ldots \ldots \ldots \ldots \ldots & 3,200 \\
1,600 & \$ 00 \\
9,600 & \cdots \ldots \ldots \ldots \ldots \\
238,032 & 3,200
\end{array}
$$

3,200

1,600

38,400

185,136

48,000

6,400

38,400

9,600

41,600

6,400

6,400

3,200

$4 / 13$

$4 / 19$

$4 / 26$

$5 / 3$

$5 / 10$

$5 / 17$

1,600

6,400

1,600

25,800

9,600

9,600

6,400

22,400

3,200

$\cdots, 600$
$\cdots$

$5 / 24$

$5 / 31$

6/ 7

$6 / 16$

$6 / 21$

$6 / 28$

$\mathrm{S} / 23$

$\mathrm{s} / 31$

9/ 6

$9 / 13$

$9 / 20$

$9 / 27$

$10 / 4$

$10 / 11$

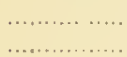

……........

3,200

19,200

6,400

105,792

6,400

3,200

3,200

3,200

3,200

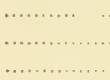

52,896

…............

9,600

3,200

12,800

9,600

3,200

12,800

6,400

22,400

12,800

25,600

$6,400 \quad 19,200$

32,000

317,376

3,200

6,400

12,800

76,800

51,200

25,600

211,584

211,584

12,800

12,800

64,000

25,600

25,600

51,200

317,376

256,000

Brachionus Brachionus

Brachionus female

158,688

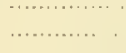

6,400

44,800

1,200

1,600

1,600

3,200

3,200

6,400

3,200

9,600

3,200

9,600

52,890

3,200

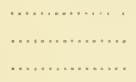

1,600

9,600

$\begin{array}{rrr}\ldots \ldots \ldots \ldots \ldots & 52,896 & \ldots \ldots \ldots \ldots \ldots \\ \ldots \ldots \ldots \ldots \ldots \ldots \ldots & 6,400 & \ldots \ldots \ldots \ldots \ldots \\ \ldots \ldots \ldots \ldots \ldots \ldots \ldots & 1,600 & \ldots \ldots \ldots \ldots \ldots \ldots \\ \ldots \ldots \ldots \ldots \ldots & 1,600 & \ldots \ldots \ldots \ldots \ldots \ldots\end{array}$

$158,6 \mathrm{SS}$

105.792

12,800

$158,6 \mathrm{~s}$

3,200

317,376

105,792

317,376

12,800

$\begin{array}{ll}\ldots \ldots \ldots \ldots \ldots . . . & 211,584 \\ \ldots \ldots \ldots \ldots \ldots \ldots . & 317,376\end{array}$

$\begin{array}{ll}\ldots \ldots \ldots \ldots \ldots \ldots & 211,584 \\ \ldots \ldots \ldots \ldots \ldots . & 317,376\end{array}$

Brachionus egg: free,

...............

.................

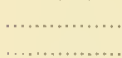

1,600

6,400

……......
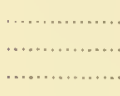

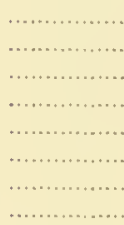

…...........

n...........

(n)

n..............

.................

…............

............... 
Table 3.-Organisma Per Cuib Meter in Plankton of SuItif's Canai, IN 1913-(Conlinued)

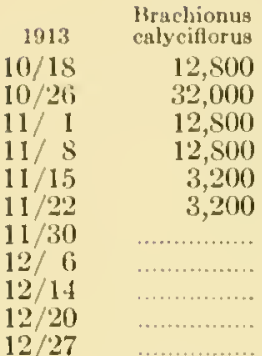

1913

$1 / 11$

$1 / 19$

$1 / 25$

$2 / 2$

/ $\mathrm{S}$

$2 / 15$

$2 / 23$

3) I

$3 / \mathrm{S}$

$3 / 15$

$3 / 23$

$3 / 29$

$4 / 5$

$4 / 13$

$4 / 19$

$4 / 26$

$5 / 3$

$5 / 10$

$5 / 17$

$5 / 24$

31

6/ 7

6/16

(i/21

$6 / 28$

$7 / 5$

$7 / 12$

$7 / 19$

$7 / 26$

$8 / 2$

S/ 9

$8 / 15$

$8 / 23$

$8 / 31$

$9 / 6$

$9 / 13$

$9 / 20$

$9 / 27$

$10 / 1$

$10 / 11$

$10 / 1 \mathrm{~S}$

10/26

$11 / 1$

$11 / 8$

$11 / 15$
Brachionus patulus
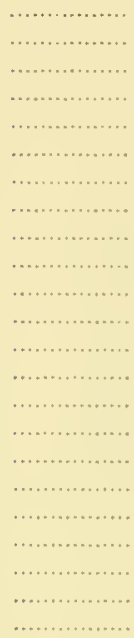

.............

$$
6,400
$$

19,200

12,500

6,400

38,400

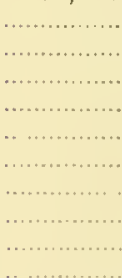

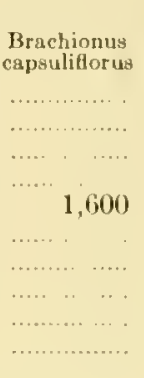

Brachionus

female

105,792

$$
6,400
$$

gR; attache
male

Brachionus

egr: free.
fenule

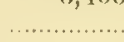

…….

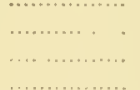

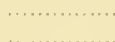

Brachionus plicatilis

40.7

1,600

2,100

Brachionu
urreus

So0

1,600

3,200

9,600

12,800

3,200

3,200

3,200

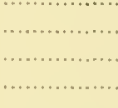

3,200

3,200
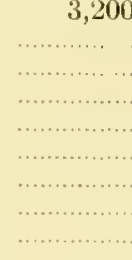

6,400

3,200

3,200

9,600

3.200

6., 400

3,200

12,800

6. 400

6,400

12, 800

12,800

$3 S, 400$
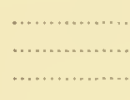

105,792 6,100

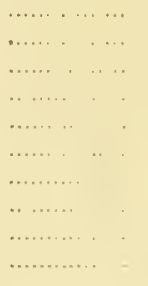

$\quad 1,600$

Diurella egg, free

Epiphanes
clavulata

$132,2 \cdot 10$

3,200

3.200

3,200

$\ldots \ldots$
$\ldots .$.
$\cdots$
$\ldots \ldots$
$\ldots \ldots$
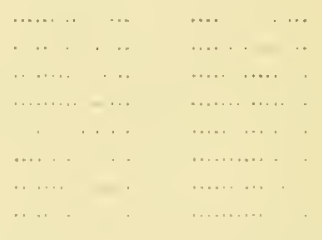

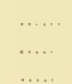

$$
\begin{array}{r}
3,200 \\
22,400 \\
238,032 \\
9,600 \\
22,400 \\
105,792 \\
6,400 \\
555,408 \\
158,688 \\
3,200 \\
317,376
\end{array}
$$$$
370,272
$$

\section{0,544}

$158,68 \mathrm{~S}$

76,800

846,336

128,000

76,800

12,800

25,600

12,800

3,200

52,896

Epiphanes

egig, attached.

female
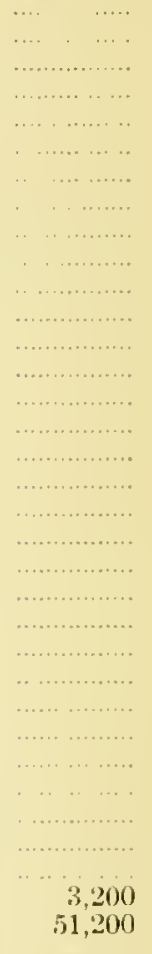

$\begin{array}{lll}528,960 & 128,000 & 12,800\end{array}$

38,400

$528,960 \quad 12,800$

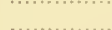

52,89


Table 3.-Organisms Per Cubic Mleter in Plankton of Smitu's Canal in 1913-(Continued)

\begin{tabular}{|c|c|c|c|c|c|c|}
\hline 1913 & $\begin{array}{c}\text { Brachionus } \\
\text { patulus }\end{array}$ & $\begin{array}{c}\text { Brachionus } \\
\text { plicatilis }\end{array}$ & $\begin{array}{l}\text { Brachiopus } \\
\text { urceus }\end{array}$ & $\begin{array}{l}\text { Diurclla } \\
\text { egg, free }\end{array}$ & $\begin{array}{c}\text { Epiphanes } \\
\text { clavulata }\end{array}$ & $\begin{array}{c}\text { Epiphanes } \\
\text { egg; attached, } \\
\text { female }\end{array}$ \\
\hline $11 / 22$ & $\ldots$ & & & & & \\
\hline $11 / 30$ & ........ & $\ldots \ldots$ & $\ldots$ & ...... & ….......... & ... \\
\hline $12 / 6$ & . & & ... & & $\ldots$ & \\
\hline $12 / 14$ & .. & .. & & & & \\
\hline $12 / 20$ & ........ $\ldots$ & ......... & ............... & ............... & ................ & ................. \\
\hline $12 / 27$ & …...... $\quad \ldots$ & ……....... & …............ & ,.............. & …........... & ……........ \\
\hline 1913 & $\begin{array}{c}\text { Filinia } \\
\text { egg, attached, } \\
\text { female }\end{array}$ & $\begin{array}{l}\text { Filinia } \\
\text { egg, attached, } \\
\text { male }\end{array}$ & $\begin{array}{l}\text { Filinia } \\
\text { egg, free }\end{array}$ & $\begin{array}{l}\text { Filinia } \\
\text { longiseta }\end{array}$ & $\begin{array}{l}\text { Feratella } \\
\text { cochlearis }\end{array}$ & $\begin{array}{l}\text { Keratella } \\
\text { egg, attached }\end{array}$ \\
\hline $1 / 11$ & $\ldots \ldots, \ldots, \quad \ldots \ldots$ & $\ldots$. & ................. & 800 & & 400 \\
\hline $1 / 19$ & ............. & . ............... & ……...... & ............... & 4,800 & 4,800 \\
\hline $1 / 25$ & $\ldots \ldots$ & $\ldots \ldots \ldots$ & ............... & $\ldots .$. & & 2,400 \\
\hline $2 / 2$ & ...... & $\ldots \ldots$ & ................. & & 6,400 & 3,200 \\
\hline $2 / 8$ & $\ldots$. & ...... & ......... & 3,200 & 3,200 & 1,600 \\
\hline $2 / 15$ & & $\ldots$ & .. & 1,600 & 35,200 & 19,200 \\
\hline $2 / 23$ & 16,000 & & 6,400 & $92, \mathrm{~S} 00$ & 60,800 & 16,000 \\
\hline 3) 1 & 3,200 & 9,600 & 9,600 & 44,800 & $79,3 \pm 4$ & 9,600 \\
\hline 38 & $\ldots \ldots \ldots$ & 3,200 & 185,136 & 60,800 & $\$ 0,000$ & 12,800 \\
\hline $3 / 15$ & & ........ $\quad \ldots$ & 158,688 & 57,600 & 317,376 & 132,240 \\
\hline $3 / 23$ & 22,400 & .................. & ............ & 99,200 & 634,752 & 370,272 \\
\hline $3 / 29$ & 6,400 & ................ & …............. & 32,000 & 476,064 & 211,584 \\
\hline $4 / 5$ & $\ldots \ldots, \ldots \ldots$ & . $\ldots \ldots \ldots \ldots \ldots \ldots$ & , & 3,200 & 238,032 & 1,600 \\
\hline $4 / 13$ & ............... & ….............. & ................. & 3,200 & 264,480 & 52,896 \\
\hline $4 / 19$ & ................ & …........... & ............... & 6,400 & 502,512 & 238,032 \\
\hline $4 / 26$ & $\ldots$ & ……1...... & & 1,600 & 264,480 & 52,896 \\
\hline $5 / 3$ & …............. & ................ & 79,344 & 9,600 & $423,16 \mathrm{~S}$ & 185,136 \\
\hline $5 / 10$ & .................. & …............... & & 6,400 & 83,200 & 6,400 \\
\hline $5 / 17$ & $\ldots .$. & ................. & 1,600 & 19,200 & 79,344 & 3,200 \\
\hline $5 / 24$ & $\ldots$. & ….............. & 79,344 & 3,200 & 25,600 & 3,200 \\
\hline $5 / 31$ & .................. & ........... & $70-2$ & & 687,648 & 79,344 \\
\hline $6 / 7$ & $\ldots$ & $\ldots \ldots$ & 9,600 & 9,600 & 105,792 & \\
\hline $6 / 16$ & .......... & $\ldots$. & & 3,200 & 32,000 & \\
\hline $6 / 21$ & ....... & …............. & 158,688 & 3,200 & 105,792 & 3,200 \\
\hline $6 / 28$ & & n............. & ............. & $105,79^{2}$ & 264,480 & 105,792 \\
\hline $7 / 5$ & n..., n..., & ................. & & 22,400 & 449,616 & 16,000 \\
\hline $7 / 12$ & …............ & ……....... & 132,240 & 12,800 & $1,824,912$ & 1,600 \\
\hline $7 / 19$ & ….......... & 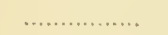 & $\ldots$ & .... & 317,376 & 19,200 \\
\hline $7 / 26$ & ....... & ......... & & 6,400 & 44,800 & 25,600 \\
\hline $8 / 2$ & …............. & …............. & 211,584 & ............... & 19,200 & \\
\hline $8 / 9$ & ............... & 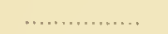 & 211,584 & n............. & & \\
\hline $8 / 15$ & …..... & $\ldots \ldots$. & & …..., & 6,400 & \\
\hline $8 / 23$ & ................ & n...n...n..... & 158,688 & . & *. & \\
\hline $8 / 31$ & ….......... & ….......... & 423,168 & ............... & & \\
\hline $9 / 6$ & n.............. & n.............. & 105,792 & n.............. & 51,200 & \\
\hline $9 / 13$ & , & n............ & ,............... & ............... & ............. & \\
\hline $\begin{array}{l}9 / 20 \\
9 / 27\end{array}$ & …........ & $\cdots$ & 211584 & ... & 25,600 & \\
\hline $10 / 4$ & ……… & 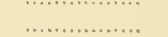 & $10,5,792$ & 12,800 & & 25.600 \\
\hline $10 / 11$ & ................ & ............... & & $\ldots \ldots+\ldots \ldots$ & & $211,5 \mathrm{~S} 4$ \\
\hline $10 / 18$ & ............... & ................ & 211,584 & $\ldots \ldots \ldots$ & $1,269,504$ & 105,792 \\
\hline $10 / 26$ & ................. & ................. & ............... & ................ & $3,173,760$ & 687,648 \\
\hline $11 / 1$ & …............ & ……....... & ,............. & ............. & $4,549,056$ & $1,586,880$ \\
\hline $11 / 8$ & $\ldots$ & ................... & & $\ldots$ & 793,440 & 317,376 \\
\hline $11 / 15$ & & .., $\ldots \ldots, \ldots \ldots$ & & ......... & 317,376 & 79,344 \\
\hline $11 / 22$ & 3,200 & ................. & 1,600 & ......... & 343,824 & 238,032 \\
\hline $11 / 30$ & ....... & ......... & & & 52,896 & 19,200 \\
\hline $12 / 6$ & $\ldots \ldots \ldots \ldots \ldots$ & ................. & & & 52,896 & 16,000 \\
\hline $12 / 14$ & ................. & ................. & $\because$ & $\ldots$ & 3,200 & 52,896 \\
\hline $12 / 20$ & ….......... & ............... & & ............... & $x^{-1}+2+$ & . \\
\hline $12 / 27$ & ................ & $\ldots \ldots \ldots \ldots+\ldots$ & 1,600 & .......... & ..... & $\cdots$ \\
\hline
\end{tabular}


Table 3.-Organisms Per Cubic Meter in Plankton of Swatu's Canal in 1913-(Continued)

\begin{tabular}{|c|c|c|c|c|c|c|}
\hline 1913 & $\begin{array}{l}\text { Keratellh } \\
\text { ckg, free }\end{array}$ & $\begin{array}{l}\text { Keratella } \\
\text { quadrata }\end{array}$ & $\begin{array}{l}\text { Notholcs } \\
\text { striata }\end{array}$ & $\begin{array}{c}\text { Polyarthra } \\
\text { trigla }\end{array}$ & $\begin{array}{l}\text { Polyarthra } \\
\text { trigla rog } \\
\text { at tached, fernale }\end{array}$ & $\begin{array}{c}\text { Synchacts } \\
\text { sp. }\end{array}$ \\
\hline $1 / 11$ & 2,000 & 1,600 & & & & \\
\hline $1 / 19$ & 1,600 & 8,000 & & 3,200 & ……......... & 1,600 \\
\hline $1 / 25$ & 19,836 & 8,000 & 1,600 & 19.836 & $\ldots \ldots$ & 8,000 \\
\hline $2 / 2$ & 70,344 & $(i, 400)$ & 1,600 & 1,600 & & 1,600 \\
\hline $2 / 5$ & 185,136 & 132,240 & & $211,5 \times 1$ & & \\
\hline $2 / 15$ & 185,136 & 25,600 & 6,400 & 132,2410 & & \\
\hline $2 / 23$ & 12,800 & 6,400 & & 12,500 & & $6,-400$ \\
\hline $3 / 1$ & & 6,400 & $\ldots$ & 9,6000 & $\ldots$ & 9,600 \\
\hline $3 / 8$ & & 3,200 & & 3,200 & & $15 t, s 00$ \\
\hline $3 / 15$ & & & 6,400 & & & 3,200 \\
\hline $3 / 23$ & 343,824 & 79,341 & & 12,800 & & 28,800 \\
\hline $3 / 29$ & 211,584 & 9,600 & 1,600 & 1,600 & $\ldots \ldots$ & 12,800 \\
\hline 4.5 & 52,896 & 132,240 & 3,200 & 6,400 & $\ldots \ldots$ & $16,(000$ \\
\hline $4 / 13$ & 79,344 & 25,600 & $\cdots$ & 6.400 & & $(i, 400$ \\
\hline $4 / 19$ & 105,792 & 19,200 & 3,200 & 38,400 & & 22,100 \\
\hline $4 / 26$ & 3,200 & 28,800 & $\ldots$. & 73,600 & & 3,200 \\
\hline $5 / 3$ & 158,658 & 28,800 & & 45,000 & 3,200 & 44,800 \\
\hline $5 / 10$ & 22,400 & 19.200 & ....... & 16.000 & . & 3,200 \\
\hline $\begin{array}{l}5 / 17 \\
5 / 24\end{array}$ & 79,344 & 105,792 & $\ldots \ldots$ & $\begin{array}{r}25,600 \\
3,200\end{array}$ & 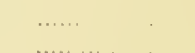 & 108,800 \\
\hline $\begin{array}{l}5 / 24 \\
5 / 31\end{array}$ & 317,376 & 3,200 & $\begin{array}{l}\ldots . . \\
\ldots . .\end{array}$ & $\begin{array}{r}3,200 \\
76,100\end{array}$ & $\begin{array}{l}\ldots . . \\
\ldots . .\end{array}$ & 605,304 \\
\hline $6 / 7$ & 3,200 & 6,400 & & 9,600 & $\ldots \ldots \ldots$ & \\
\hline $\begin{array}{l}6 / 16 \\
6 / 21\end{array}$ & 52,596 & 6,400 & .. & 19,200 & 닫. & 3,200 \\
\hline $6 / 2 S$ & $15 S, 685$ & 185,136 & - & 79.344 & $\cdots$ & 370,272 \\
\hline $7 / 5$ & 264,480 & 3,200 & ................. & 12,800 & & 35,200 \\
\hline $7 / 12$ & 661,200 & 79,344 & & 370,272 & 1,600 & 52,896 \\
\hline $7 / 19$ & 317,376 & 19,200 & ................... & 25,600 & ........ & \\
\hline $7 / 26 i$ & 3,200 & 108,800 & … ............ & 51,200 & $\ldots$ & \\
\hline S/ 2 & & 105,792 & …............... & 211,584 & & 6,400 \\
\hline $8 / 9$ & & 70,400 & & 105,792 & $\ldots .$. & 12,800 \\
\hline $8 / 15$ & & 44,800 & $\ldots .$. & 6,400 & & \\
\hline S/23 & & 25,600 & ……… & 105,792 & & 6,400 \\
\hline $8 / 31$ & 317,376 & 12,800 & & 128,000 & 12,500 & 211,584 \\
\hline $9 / 6$ & & 25,600 & & 38,400 & & 38,400 \\
\hline $9 / 13$ & 317,76 & 51,200 & ... & 153,600 & $\ldots \ldots$ & 12,800 \\
\hline $9 / 20$ & & & & 423,168 & & \\
\hline $9 / 27$ & $\ldots$ & 211,584 & $\ldots$ & 89,600 & $\ldots$ & $211,5 \mathrm{S4}$ \\
\hline $0 / 4$ & & $211,5 \& 4$ & $\ldots$ & & & \\
\hline $10 / 11$ & & 423,168 & ... & 12,500 & & 423,168 \\
\hline $10 / 18$ & 211,554 & 317,376 & & 105,792 & 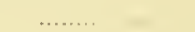 & $211,5 \Omega 4$ \\
\hline $10 / 26$ & 264,480 & 158,685 & 6,400 & 6,400 & (1) & 264,480 \\
\hline $1 / 1$ & 423,165 & 105,792 & 12,800 & $\ldots . .$. & ............ & 211,584 \\
\hline $1 / 8$ & 52,896 & & & ......... & $\ldots$ & 370,272 \\
\hline $1 / 15$ & 52,896 & 3,200 & & & & 52,896 \\
\hline $1 / 22$ & 132,240 & 6,400 & ... & 6,400 & & $105,-92$ \\
\hline $1 / 30$ & 1,600 & 6,400 & $\therefore$ & 12,800 & 3,200 & 105,792 \\
\hline $2 / 6$ & & 1,600 & & 264,450 & 3,201 & 79,344 \\
\hline $2 / 1.1$ & 6,40 & 79,344 & & 6,400 & ............ & 238,032 \\
\hline $12 / 20$ & 6,100 & 6,400 & & 6,400 & .............. & 25,600 \\
\hline $12 / 27$ & 3,200 & 3,200 & & 3,200 & ................ & $1 S 5,136$ \\
\hline 1913 & $\begin{array}{l}\text { Trichocerca } \\
\text { eapucina }\end{array}$ & $\begin{array}{c}\text { Trichocerea } \\
\text { iernis }\end{array}$ & $\begin{array}{c}\text { Total } \\
\text { Ploimal }\end{array}$ & $\begin{array}{c}\text { Total } \\
\text { Rotifera }\end{array}$ & $\begin{array}{c}\text { Bosming } \\
\text { longirost ris }\end{array}$ & $\begin{array}{l}\text { Chydorus } \\
\text { sp. }\end{array}$ \\
\hline $1 / 11$ & $\ldots$ & & 6,500 & $\$, 400$ & & \\
\hline $1 / 19$ & ……....... & ……......... & 36,500 & 83,200 & & \\
\hline $1 / 25$ & & & 71,272 & $91,30 \mathrm{~s}$ & ........ & 800 \\
\hline $2 / 2$ & & $\ldots \ldots$ & 105,144 & 130,944 & ................. & \\
\hline $2 / 8$ & & & $481,5: 20$ & 529,520 & 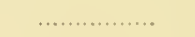 & \\
\hline
\end{tabular}


Table 3.-Organisus Per Cubic Meter in Plankton of Smith's Canal in '1913-(Continued)

\begin{tabular}{|c|c|c|c|c|c|c|}
\hline 1913 & $\begin{array}{l}\text { Trichocerca } \\
\text { capucina }\end{array}$ & $\begin{array}{c}\text { Trichocerca } \\
\text { iernis }\end{array}$ & $\begin{array}{l}\text { Total } \\
\text { Ploima }\end{array}$ & $\begin{array}{c}\text { Total } \\
\text { Rotifera }\end{array}$ & $\begin{array}{c}\text { Bosmina } \\
\text { longirostris }\end{array}$ & $\begin{array}{l}\text { Chydorus } \\
\text { sp. }\end{array}$ \\
\hline $2 / 15$ & & ................ & 841,344 & 934,144 & & \\
\hline $2 / 23$ & & & 324,800 & 369,600 & & \\
\hline $3 / 1$ & ….............. & …............ & 200,944 & $299,48 S$ & & \\
\hline $3 / 8$ & & …............. & 737,424 & 976,960 & & \\
\hline $3 / 15$ & & ................... & 696,304 & 734,704 & & \\
\hline $3 / 23$ & $\ldots$ & …....... & $1,693,792$ & $1,762,592$ & $\therefore, 200$ & \\
\hline $3 / 29$ & ……...... & 다..…… & $1,025,728$ & $1,086,52 \mathrm{~S}$ & & \\
\hline $4 / 5$ & & & 466,368 & 485,768 & $\ldots \ldots \ldots$ & \\
\hline $4 / 13$ & & $\ldots \ldots$ & 441,520 & 451,120 & & \\
\hline $4 / 19$ & ........ & $\ldots \ldots .$. & 958,336 & 979,136 & 6,400 & \\
\hline $4 / 26$ & & & 432,576 & $+38,976$ & ..... & \\
\hline $5 / 3$ & $\ldots \ldots \ldots \ldots$ & …............. & $1,011,136$ & $1,015,936$ & .......... & \\
\hline $5 / 10$ & & & 179,200 & $1 S 0,800$ & …............ & ... \\
\hline $5 / 17$ & 6,400 & & 506,080 & 535,080 & & \\
\hline $\begin{array}{l}5 / 24 \\
5 / 31\end{array}$ & & 12,800 & $\begin{array}{r}204,144 \\
2,377,584\end{array}$ & . 210,544 & ... & \\
\hline $\begin{array}{l}5 / 31 \\
6 / 7\end{array}$ & 3,200 & 12,000 & 179,392 & $\begin{array}{r}2,545,872 \\
185,992\end{array}$ & $\ldots$ & \\
\hline $6 / 16$ & & & 83,200 & 83,200 & & \\
\hline $6 / 21$ & & 6,400 & 434,176 & 440,576 & & \\
\hline $6 / 28$ & 9,600 & 16,000 & $1,540,2 S \mathrm{~S}$ & $1,540,258$ & & \\
\hline $7 / 5$ & 3,200 & 79,344 & $1,022,432$ & $1,134,624$ & 3,200 & \\
\hline $7 / 12$ & 3,200 & 185,136 & $4,896,754$ & $5,002,576$ & 4,800 & $\ldots$ \\
\hline $\begin{array}{l}7 / 19 \\
7 / 26\end{array}$ & & 3,200 & $959,8+0$ & 963,040 & & \\
\hline $\begin{array}{l}7 / 26 \\
8 / 2\end{array}$ & $\begin{array}{l}6,400 \\
6,400\end{array}$ & 19,200 & $\begin{array}{r}544,384 \\
1,466,400\end{array}$ & 703,072 & $\begin{array}{l}6,100 \\
6,400\end{array}$ & \\
\hline $\begin{array}{l}8 / 2 \\
\text { s/ } 9\end{array}$ & 0,400 & 32,000 & $\begin{array}{l}1,466,400 \\
1,398, \$ 16\end{array}$ & $\begin{array}{l}1,644,288 \\
1.475616\end{array}$ & $\begin{array}{r}0,700 \\
12,800\end{array}$ & \\
\hline $8 / 15$ & & & $\begin{array}{r}19,48 S \\
219,40\end{array}$ & 219,488 & 32,000 & \\
\hline $8 / 23$ & $\ldots \ldots$ & 211,584 & $1,604,354$ & $1,899,178$ & & 12,500 \\
\hline $8 / 31$ & .............. & 211,584 & $4,086,720$ & $+125,120$ & 12,800 & \\
\hline $9 / 6$ & ............ & $3 S, 400$ & $1,047,744$ & $1,153,536$ & 38,400 & \\
\hline $9 / 13$ & & 211,584 & $2,412,096$ & $2,726,080$ & 38,400 & \\
\hline $9 / 20$ & 12,800 & 51,200 & 916,352 & $1,230,336$ & 51,200 & \\
\hline $9 / 27$ & & $7 \star 0,544$ & $2,727,626$ & $2,817,226$ & 12,800 & \\
\hline $10 / 4$ & & 423,168 & $2,269,450$ & $2,625,226$ & 12,800 & \\
\hline $10 / 11$ & .............. & 105,792 & $2,217,472$ & $2,845,440$ & 25,600 & \\
\hline $10 / 18$ & & 12,800 & $3,000,576$ & $3,102,976$ & & \\
\hline $10 / 26$ & …..... & 6,400 & $4,725,24 \mathrm{~s}$ & $4,956,032$ & $\cdots$ & \\
\hline $11 / 1$ & ..... & .... & $7,006,176$ & $7,075,272$ & ........... & 52,896 \\
\hline $11 / 8$ & & $\ldots$ & $1,565,984$ & $1,697,376$ & …........... & ... \\
\hline $11 / 15$ & ....... & $\ldots .$. & 515,312 & 534,512 & $\cdots$ & 9600 \\
\hline $11 / 22$ & & $\ldots$. & $1,091,520$ & $1,110,720$ & ..... & 9,000 \\
\hline $\begin{array}{l}11 / 30 \\
12 / 6\end{array}$ & & … & $\begin{array}{l}209,858 \\
420,720\end{array}$ & 216,285 & .... & \\
\hline $\begin{array}{l}12 / 6 \\
12 / 14\end{array}$ & $\ldots$ & …............. & $\begin{array}{l}420,720 \\
389,472\end{array}$ & $\begin{array}{r}423,920 \\
392,072\end{array}$ & & 3,200 \\
\hline $12 / 20$ & & & $\begin{array}{r}309,462 \\
44,800\end{array}$ & $\begin{array}{r}392,012 \\
+4,500\end{array}$ & & \\
\hline $12 / 27$ & .......... & ……...... & 197,936 & 197,936 & & \\
\hline 1913 & $\begin{array}{l}\text { Sida } \\
\text { sp. }\end{array}$ & $\begin{array}{l}\text { Total } \\
\text { Cladocera }\end{array}$ & $\begin{array}{c}\text { Canthocaniptus } \\
\text { sp. }\end{array}$ & $\begin{array}{l}\text { Cyclops } \\
\text { sp. }\end{array}$ & $\begin{array}{l}\text { Nauplius } \\
\text { sp. }\end{array}$ & $\begin{array}{c}\text { Total } \\
\text { Copepoda }\end{array}$ \\
\hline $\begin{array}{l}1 / 11 \\
1 / 19\end{array}$ & & 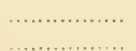 & ............. & 1,000 & & \\
\hline $\begin{array}{l}1 / 19 \\
1 / 25\end{array}$ & . & & & 1,600 & 1,600 & 3,200 \\
\hline $\begin{array}{l}1 / 25 \\
2 / 2\end{array}$ & & 800 & $\ldots$ & $? 000$ & 3,200 & 3,200 \\
\hline $2 / 8$ & ........... & ....... & ….... & $\begin{array}{l}3,200 \\
3,200\end{array}$ & $\begin{array}{l}6,400 \\
3200\end{array}$ & 9,600 \\
\hline $2 / 15$ & $\ldots \ldots$ & ... & 3,200 & . & 3. & $\begin{array}{l}6,400 \\
3,200\end{array}$ \\
\hline $\begin{array}{l}2 / 23 \\
3 / 1\end{array}$ & . & …… & $\cdots$ & ………… & 3,200 & 3,200 \\
\hline $3 / 1$ & . $\ldots \ldots \ldots \ldots \ldots$ & …............ & (................. & …........... & $\ldots \ldots$ & . \\
\hline $3 / 15$ & ……......... & ……...... & 3,200 & & ㄱ...…… & 3,200 \\
\hline
\end{tabular}


Table 3.-Organisus Per Cubic Meter in l'lankton of Smiti's Canal in 1913-(Continued)

1913
$3 / 23$
$3 / 29$
$4 / 5$
$4 / 13$
$4 / 19$
$4 / 26$
$5 / 3$
$5 / 10$
$5 / 17$
$5 / 24$
$5 / 31$
$6 / 7$
$6 / 16$
$6 / 21$
$6 / 25$
$7 / 5$
$7 / 12$
$7 / 19$
$7 / 26$
$8 / 2$
$5 / 9$
$8 / 15$
$8 / 23$
$8 / 31$
$9 / 6$
$9 / 13$
$9 / 20$
$9 / 27$
$10 / 4$
$10 / 11$
$10 / 18$
$10 / 26$
$11 / 1$
$11 / 5$
$11 / 15$
$11 / 22$
$11 / 30$
$12 / 6$
$12 / 14$
$12 / 20$
$12 / 27$
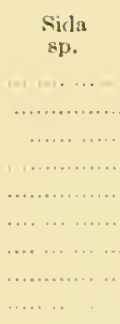

6,400

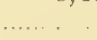

3,200

19,600

6,400

12,500

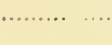

12,800
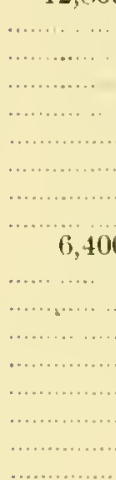

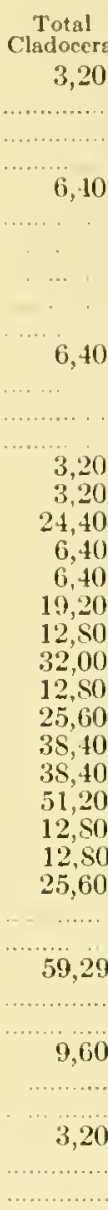
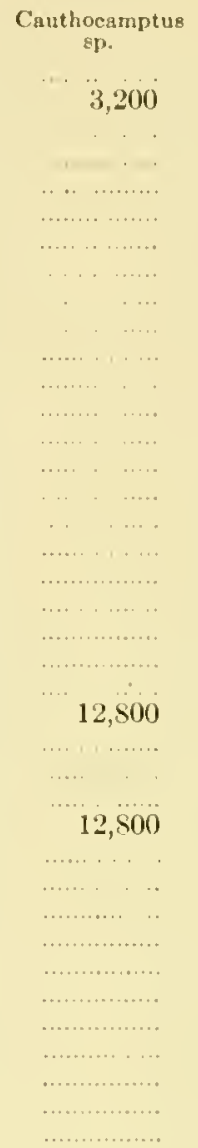

\section{5,792}
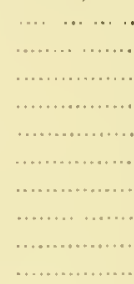

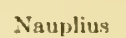

...........

1,600

3,200

...............

9,600

12,800
$-3,200$

9,600

9,600

16,000

3,200

9,600

6,400

(i., 400

25,600

6,400

19,200

12,800

25,600

12,800

25,600

1) 500

12,800

6,400

1,600

1,600

3,200

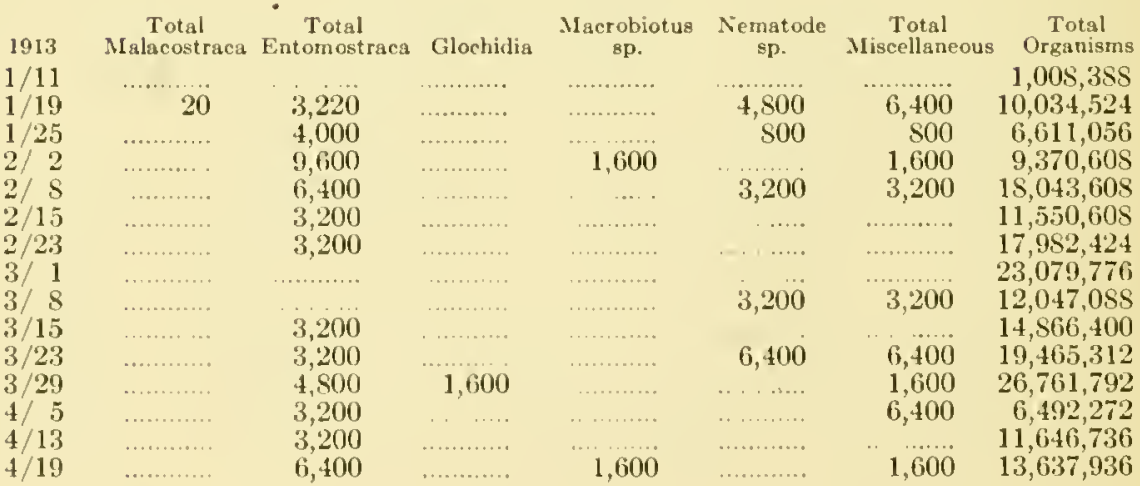


Table 3.-Organisms Pir Cubic Meter in Plankton of Smith's Canal in 1913-(Concludd)

\begin{tabular}{|c|c|c|c|c|c|c|c|}
\hline 1913 & $\begin{array}{c}\text { Total } \\
\text { Malacostraca }\end{array}$ & $\begin{array}{c}\text { Total } \\
\text { Entomostraca }\end{array}$ & Glochidia & $\begin{array}{c}\text { Macrobiotus } \\
\text { sp. }\end{array}$ & $\begin{array}{c}\text { Nematode } \\
\text { sp. }\end{array}$ & $\begin{array}{c}\text { Total } \\
\text { Miscellaneou }\end{array}$ & $\begin{array}{c}\text { Total } \\
\text { Organisms }\end{array}$ \\
\hline $4 / 26$ & $\ldots$ & & & ............ & ............ & & $17,044,080$ \\
\hline $5 / 3$ & ..... & 12,800 & & ............ & & & $8,636,424$ \\
\hline $5 / 10$ & $\ldots \ldots$ & 3,200 & .. & ............ & ... & $\ldots$ & $9,321,920$ \\
\hline $5 / 17$ & $\ldots \ldots$ & & ............ & ............ & ..... & $\ldots$ & $9,352,280$ \\
\hline $5 / 24$ & ...... & 12,800 & ............. & .............. & ............. & & $5,949,936$ \\
\hline $5 / 31$ & $\ldots \ldots$ & 19,200 & $\ldots \ldots$ & ............ & $\ldots \ldots$ & . & $5,686,592$ \\
\hline (i) 7 & $\ldots . .$. & 19,200 & $\ldots \ldots$ & .............. & $\cdots$ & $\cdots$ & $10,101,808$ \\
\hline $6 / 16$ & $\ldots$. & 9,600 & ............. & .............. & & & $15,708,784$ \\
\hline $6 / 21$ & $\ldots$. & 16,000 & ..... & ............. & ........... & & $19,352,112$ \\
\hline $6 / 28$ & ...... & 12,800 & ...... & ............. & ..... & & $26,840,944$ \\
\hline & ...... & 6,400 & & ............. & $\ldots .$. & & $21,363,952$ \\
\hline $7 / 12$ & ..... & 55,240 & 3,200 & ... & 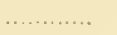 & 3,200 & $40,626,45 S$ \\
\hline $7 / 19$ & ...... & 12,800 & & .... & $\ldots$ & & $39,153,56 \mathrm{~S}$ \\
\hline $7 / 26$ & $\ldots \ldots$ & 57,600 & 6,400 & & & 6,100 & $61,220,318$ \\
\hline $8 / 2$ & $\ldots$ & 35,400 & & 6,400 & & 6,400 & $66,621,792$ \\
\hline $8 / 9$ & ..... & 76,800 & 6,400 & $\ldots \ldots$ & & 6,400 & $114,201,816$ \\
\hline $8 / 15$ & $\ldots .$. & 32,000 & & . . & & & $166,868,542$ \\
\hline $8 / 23$ & ..... & 32,000 & 6,400 & $\ldots \ldots$ & & 6,100 & $141,852,410$ \\
\hline $\mathrm{S} / 31$ & ..... & 90,600 & ........... & ........ & 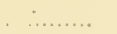 & & $154,898,534$ \\
\hline $9 / 6$ & $\ldots$ & 51,200 & $\ldots$. & & & & $254,328,524$ \\
\hline $9 / 13$ & (.......... & 64,000 & .......... & $\cdots \cdot$ & & & $118,178,940$ \\
\hline $9 / 20$ & .......... & 51,200 & .......... & ............ & ............. & $\ldots$ & $181,305,952$ \\
\hline 27 & ..... & 131,392 & .......... & ........... & . . ......... & & $129,678,426$ \\
\hline 4 & ..... & 38,400 & ............ & ......... & . ......... & & $109,717,814$ \\
\hline 11 & $\ldots \ldots$ & 35,100 & …..... & .. ......... & .......... & 105,792 & $110,191,392$ \\
\hline 18 & $\ldots$ & & .. ......... & $\ldots \ldots \ldots \ldots$ & ......... & & $69,781,440$ \\
\hline 26 & $\ldots \ldots$ & 6,400 & ............. & ............. & & & $76,617,328$ \\
\hline 1 & ........ & 59,296 & ........... & ........... & $\ldots \ldots \ldots$ & ...... & $46,179,728$ \\
\hline & $\ldots .$. & & ............. & ............ & . . ........ & ....... & $25,234,116$ \\
\hline & $\ldots$. & & ........... & $\ldots \ldots \ldots \ldots$ & ........... & ....... & $13,720,308$ \\
\hline 22 & ....... & 9,600 & ............. & ............. & ............ & ............. & $17,451,856$ \\
\hline &,$\quad \ldots$. & n. ... & ........... & $\ldots \ldots \ldots$ & . ......... & ............. & $12,172,344$ \\
\hline 6 & $\ldots$ & & ............ & $\ldots \ldots \ldots$ & .......... & $\ldots . .$. & $16,985,928$ \\
\hline 14 & 1...... & 3,200 & ............ & ........... & .......... & $\cdots$ & $10,538,544$ \\
\hline & $\ldots \ldots$ & 3,200 & ............ & ........... & ............ & & $6,416,352$ \\
\hline & $\ldots$. & . $\quad$. & ............ & ............. & ............ & 3,200 & $7,757,568$ \\
\hline
\end{tabular}


Table 1.- l'lankton Onginis.as P'er Cubic Meter in S'tockton Channel, DAILY SERIES IN 1913 .

\begin{tabular}{|c|c|}
\hline 1913 & $\begin{array}{c}\text { Spirillumu } \\
\text { undula }\end{array}$ \\
\hline $7 / 5$ & 105,792 \\
\hline$\frac{7}{7}, \frac{6}{1}$ & \\
\hline $7 / 8$ & \\
\hline $7 / 9$ & . \\
\hline 7,10 & $\ldots$ \\
\hline $7 / 11$ & \\
\hline $7 / 12$ & . \\
\hline $\begin{array}{l}7 / 13 \\
7 / 14\end{array}$ & \\
\hline $\begin{array}{l}7 / 14 \\
7 / 15\end{array}$ & \\
\hline $\begin{array}{l}7 / 15 \\
7 / 16\end{array}$ & \\
\hline $\begin{array}{l}7 / 16 \\
7 / 17\end{array}$ & \\
\hline $\begin{array}{l}7 / 17 \\
7 / 18\end{array}$ & \\
\hline $\begin{array}{l}7 / 18 \\
7 / 19\end{array}$ & 3,200 \\
\hline $\begin{array}{l}7 / 19 \\
-/ 20\end{array}$ & \\
\hline $\begin{array}{l}7 / 20 \\
7 / 21\end{array}$ & \\
\hline $\begin{array}{l}7 / 21 \\
7 / 22\end{array}$ & \\
\hline $\begin{array}{l}7 / 22 \\
7: 33\end{array}$ & 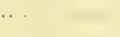 \\
\hline $7 \quad 24$ & - \\
\hline 725 & 3,200 \\
\hline $7 / 26$ & \\
\hline $7 / 27$ & 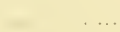 \\
\hline $7 / 28$ & \\
\hline $7 / 29$ & \\
\hline $7 / 30$ & \\
\hline $7 / 31$ & \\
\hline S/ 1 & \\
\hline $\begin{array}{ll}8 & 2 \\
8 & 3\end{array}$ & 3,200 \\
\hline$s / 4$ & ...... \\
\hline
\end{tabular}

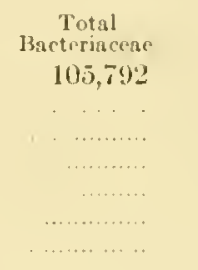

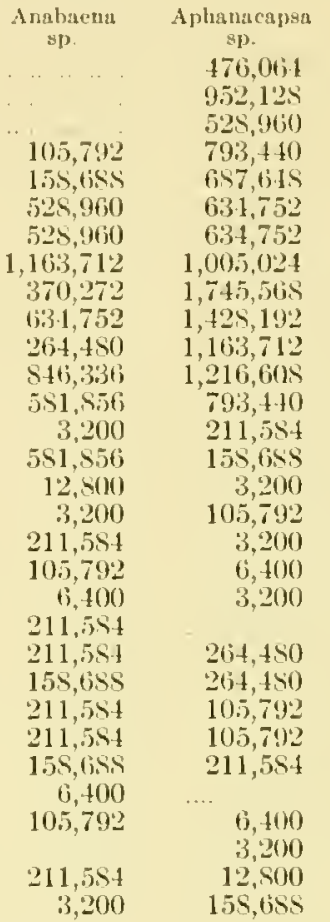

Gloeocepen conglomerata conglonertiat

Gloeorapss sp

264,480

3,200

370,272

$528,900 \quad 211,581$

$36,400 \quad 370,272$

$846,336 \quad 156,658$

$740,514 \quad 476,061$

$899,232 \quad 5 \$ 1,856$

$1,005,024 \quad 476064$

$5 \$ 1,856, \quad 1,639,776$

$899,232 \quad 1,586,850$

$156,658 \quad 1,375,996$

$7,30,544$

$211,2 \mathrm{~s}+$

$3,200 \quad 525,960$

476,064

264,480

264,480

204,480

$3,200 \quad 158,658$

6, $400 \quad 317,376$

$1,005,024$

$211,554 \quad 1,057,920$

6:34,7.52

793,440

$3,200 \quad 317,376$

$423,16 \mathrm{~s}$

317,376

105,792

$63+, 752$

105,792

Gomphosphacra Merismopedium Microcystis aponina glaucun

sp

Nostoc

sp.

12,800

$7 / 5$

158,658

3,200

$7 / 7$

7/ 8

$7 / 9$

$7 / 10$

$7 / 11$

712

$7 / 13$

$7 / 14$

$7 / 15$

$7 / 16$

$7 / 17$

$7 / 18$

7.19

$7 / 20$

$7 / 21$

72

$7 / 23$

724

$7 / 25$

$7 / 26$

$7 / 27$

$7 / 28$

7.29

317,376

105,792

$211,5 \$ 1$

26,150

264,490

$26+4 \times 0$

370,272

317,376

$26,4,480$

$264.4 \times 0$

3,200

3,200

$211,5 \mathrm{~S} 1$

3,200

$24 i 4,4 \leqslant 0$

15), $68 \mathrm{SS}$

3,200

3,200

$2(i+4,4)$

1(1), 792

317,376

6,400

105,792

793,440

320,576

$7+3,7+4$

$1,425,19^{2}$

687,649

740,541

$476,0 t \mathrm{i}$

373,472

793,440

$1,057,920$

793,140

$1,375,296$

$423.16 \mathrm{~s}$

$740,5+4$

214,734

317.376

261,450

171,455

740,514

525 (5)

$52+960$

330,176

716,3364

Oscillatoria

sp.

Oscillatoria tenuis

12,800

105,792

105,792

155,658

211,584

$3,200 \quad 370,272$

$470,064 \quad 3,200$

$105,792 \quad 370,272$

$370,272 \quad 3,200$

$211,5 \mathrm{S4}$

317,376

370,272

370,272

$211.5 \mathrm{~s}$

$1,26 \div, 501$

370,272

317.376

$15 \mathrm{~s}, \mathrm{tis} 5$

370,272

476,014

317,376

$524,(9)$

$5.91,856$

$1,110,816$

105,792

$1(5,792$

46,061

370,272

3,200

105,792

470,064 
Table 4.-Plankton Organisms Per Cubic Meter in stockton Channel, Daily Series in 1913-(Continued)

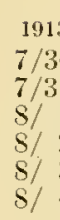

1913

$7 / 5$

7) 6

$7 / 7$

7) 9

7/ 10

$T / 11$

7/12

$7 / 13$

$7 / 14$

$7 / 15$

i) 16

i/17

$7 / 18$

$7 / 19$

$7 / 20$

$7 / 21$

$7 / 22$

$7 / 23$

$7 / 24$

$7 / 25$

$7 / 26$

$7 / 27$

$7 / 28$

$7 / 29$

$7 / 30$

$7 / 31$

S/ 1

S/ 2

S/ 3

S/ 4

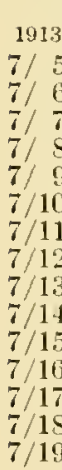

Gomphosphaera Merismopedium Microcystis

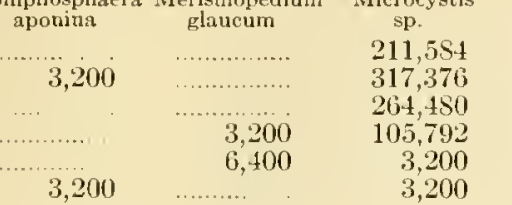

Phormidium spp.

\section{1,584}

$211,5 \mathrm{St}$

370,272
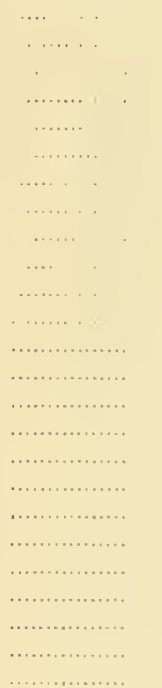

Lagerheimia wratislaviense

\begin{tabular}{|c|c|}
\hline \multirow[t]{2}{*}{$\begin{array}{l}\text { Pediastrum } \\
\text { boryamum }\end{array}$} & $\begin{array}{l}\text { Pediastrum } \\
\text { duplex }\end{array}$ \\
\hline & $+76,064$ \\
\hline & 846,336 \\
\hline & 528,960 \\
\hline & $1,269,504$ \\
\hline 6,400 & $1,005,024$ \\
\hline 105,792 & 793,440 \\
\hline & $1,110,816$ \\
\hline & $1,269,504$ \\
\hline 105,792 & 899.232 \\
\hline & 793,440 \\
\hline & $7 \mathfrak{1}(0,5) \pm$ \\
\hline . & 793,440 \\
\hline$\ldots$ & $1,005,024$ \\
\hline & $63 \pm, 752$ \\
\hline 12,800 & 740,544 \\
\hline
\end{tabular}

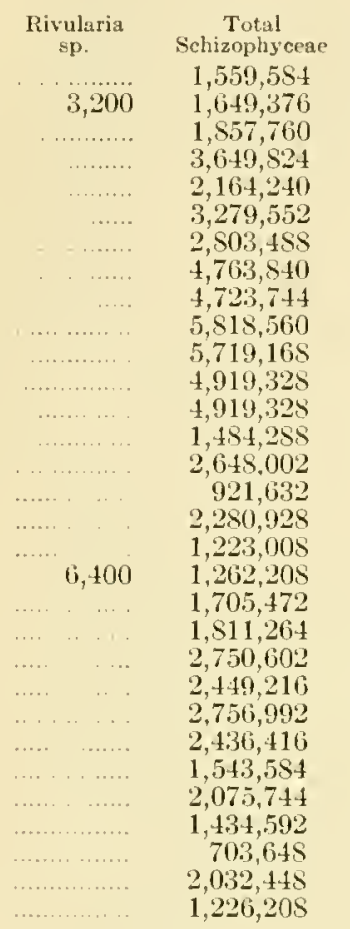

Nostoc
sp.
323,776
267,680
261,480
3,200
581,856
264,480

Oscillatoria
sp.
317,376
740,544
317,376
476,064
370,272
476,064

Oscillatoria tenuis

317,376

158,688

3,200

211,584

211,584

Actinastrum

Actinastrum

(large)

Coelastrum hantzschii

3,200

3,200

…..........

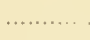

6,400

3,200

12,800

3,200

6,400

105,792

211,584

19,200

19,200

6,400

105,792

105,792

6,400

3,200

6., 100

105,792

105,792

19,200

$211,5 \mathrm{S4}$

6,400

3,200

12,500

6,400

19,200

mieroporum

105,792

158,658

$26+480$

$15 \mathrm{~S}, 6 \mathrm{SS}$

3,200

105,792

158,688

423,168

211,584

$15 \mathrm{~S}, 6 \mathrm{SS}$

$10.5,792$

158,688

3,200

105,792

105,792

105,792

$211,5 \mathrm{st}$

105,792

476,064

$15 \mathrm{~S}, 6 \mathrm{SS}$

6.400

$158,6,98$

$211,55 \pm$

$26 \pm,+80$

105,792

211,584

6,400

3,200

211,584

\begin{tabular}{|c|c|c|}
\hline $\begin{array}{l}\text { Pediastrum } \\
\text { simplex }\end{array}$ & $\begin{array}{l}\text { Raphidium } \\
\text { polymorphum }\end{array}$ & $\begin{array}{c}\text { Raphidium } \\
\text { pyrenogerum }\end{array}$ \\
\hline $\begin{array}{r}\omega,-10 \\
\ldots \ldots \ldots \ldots\end{array}$ & & 3.200 \\
\hline & & 105,792 \\
\hline$\ldots$. & 264,180 & 370,272 \\
\hline …............ & 105,792 & 3,200 \\
\hline ....... & & $15 \mathrm{~S}, 6 \mathrm{SS}$ \\
\hline ….,$\ldots \ldots \ldots$ & 3,200 & ........ \\
\hline 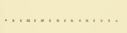 & 3,200 & ......... \\
\hline ... & $264, \pm .80$ & \\
\hline & $211,58 \mathrm{st}$ & 158,688 \\
\hline & & 105,792 \\
\hline 12,800 & 105,792 & 158.688 \\
\hline $1=\ldots \ldots$ & 6,400 & . 3200 \\
\hline & 3,200 & 3,20 \\
\hline
\end{tabular}




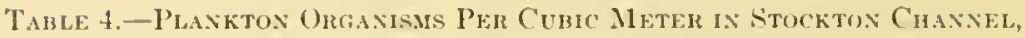
DALY SERES IN 1913-(C'ontinued)

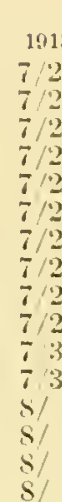

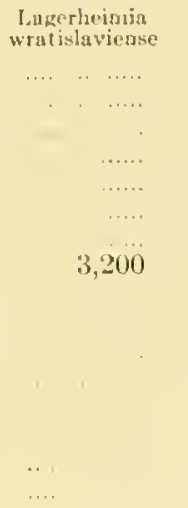
obliquus

150,68

3,200

476,064

370,272

211,581

$370,2,2$

211,584

211,584

$5,35,960$

264,180

$42: 3,165$

264,480

317,376

528,960

$\therefore 200$

$15 \mathrm{~S}, 6 \mathrm{SS}$

476,064

105,792

317,376

211,584

$687,64 \mathrm{~S}$

740.544

370,272

476,064

317,376

3,200

(i3) 1,752

105, 792

264,480

$26+4,480$

Bacillaria paradoxa

\begin{tabular}{|c|c|}
\hline $\begin{array}{c}\text { Pecliastrum } \\
\text { boryanum }\end{array}$ & $\begin{array}{l}\text { Pediastrum } \\
\text { duplex }\end{array}$ \\
\hline & $211,5 \mathrm{~s}$ \\
\hline 12,800 & 211,584 \\
\hline & 476,06 i4 \\
\hline$(i, 400)$ & $(i 34,752$ \\
\hline 105,792 & 523,960 \\
\hline & 317,376 \\
\hline$(i, 400)$ & 793,440 \\
\hline & $793,4-40$ \\
\hline & 634,752 \\
\hline 19,200 & $740,5+4$ \\
\hline . & 740,544 \\
\hline & 526,960 \\
\hline & $+23,168$ \\
\hline 3,200 & 476,064 \\
\hline & 634,752 \\
\hline 6,100 & 740,544 \\
\hline
\end{tabular}

Scenedesmus quadricaudi

370,272

687,618

(ii) 4,752

$1,163,712$

634,752

$1,057,9^{\circ} 20$

$1,005,024$

476,064

$1,005,024$

$1,0,57,920$

264,150

$1,375,206$

899,232

423,168

952,128

264,450

$158,68 \mathrm{~s}$

123,165

$5 \mathrm{~S} 1,856$

793,440

899,232

$1,00,0,024$

$1,6992,672$

$1,481,085$

657,648

(ii) 4,752

581,556

$1,005,024$

899,232

$423,16 \mathrm{~S}$

846,336

Cyclotella

370,272

740,544

$211,5 \mathrm{S4}$

$1,005,024$

264.480

581,856
Schroederia

setigera

3,200

.

3,200

105,792

15S,6SS

$15 \mathrm{~S}, 6 \mathrm{~S} \mathrm{~S}$

264,450

15S,6SS

3 . 200

105,792

3,200

158,658

105,792

105,792

3,200

3,200

3,200

3,200)

3,200

Cyclotella

operculata

$13,911,648$

$\$, 780,730$

$11,901,600$

$12,906,624$

$12,060,2 \mathrm{sS}$

$13,558,752$
Pedinatrum 6,400

3,200

12,800

$15 S$, GSS

105,792

19,200

19,200

6,400

25,600

12,800

3,200

105,792

6,400

6,400

12,800

........

Total

Chlorophyceae

$1,021,024$

$1,649,376$

$1,907,456$

$3,702,720$

$2,131,840$

2, 459,202

2,228,032

$2,135,232$

$3,014,072$

$2,971,776$

$1,699,072$

$3,050,768$

$2,704,096$

$1,665,576$

$2,462,624$

597,556

$\$ 19,040$

$1,655,776$

$1,817,664$

$1,963,5.52$

$1, \$ S 0,160$

$3,470,240$

$3,715,520$

$2,5.50,102$

$2,306,528$

$1,919,256$

$1,229,408$

$2,617,504$

$1,710,572$

$2,101,344$

$2,337,0^{\circ}+4$

Asterionclla Amphiprora

eracillima alata

3,200

105,792

3,200

3,200

3,200

3,200

3,200

3,200

3,200

6,400

3,200

3,200

10.5,792

6,100

3,200

105,792

3,200

Cymbella

affinis

Cymbella

Cymbella 
Table 4.-Plankton Organishs Per Cubic Meter in Stockton Channel, Daily Series in 1913-(Continued)

\begin{tabular}{|c|c|c|}
\hline $\begin{array}{l}\text { Bacillaria } \\
\text { paradoxa }\end{array}$ & $\begin{array}{l}\text { Cyelotella } \\
\text { kützingii }\end{array}$ & $\begin{array}{l}\text { Cyclotella } \\
\text { operculata }\end{array}$ \\
\hline & 370,272 & $13,118,208$ \\
\hline & 211,581 & $16,556,44 \mathrm{~s}$ \\
\hline 12,800 & 476,064 & $26,448,000$ \\
\hline 158,688 & $5 \pm 6,336$ & $37,291,680$ \\
\hline 3,200 & $634,75^{\circ}$ & $36,022,176$ \\
\hline 12,800 & 423,168 & $45,331,572$ \\
\hline 6,400 & 528,960 & $46,178,208$ \\
\hline & 317,376 & $31,949,184$ \\
\hline 57,600 & 264,480 & $24,014,784$ \\
\hline 6,400 & 105,792 & $14,070,336$ \\
\hline 12,800 & 105,792 & $16,133,280$ \\
\hline 6,400 & 105,792 & $18,672,288$ \\
\hline & $158,68 \mathrm{~S}$ & $11,584,224$ \\
\hline & 105,792 & $13,647,168$ \\
\hline 6,400 & 211,584 & $13,964,544$ \\
\hline 211,584 & 581,856 & $16,768,032$ \\
\hline 51,200 & 793,410 & $15,1 \pm 3,328$ \\
\hline & 952,128 & $16,820,928$ \\
\hline & 317,376 & $16,397,760$ \\
\hline & 952,128 & $14,916,672$ \\
\hline 12,800 & 740,544 & $17,032,512$ \\
\hline 12,800 & $1,163,712$ & $16,186,176$ \\
\hline 32,000 & $1,692,672$ & $13,224,000$ \\
\hline 32,000 & $1,692,672$ & $12,271,872$ \\
\hline 158,688 & $1,269,50 \pm$ & $10,579,200$ \\
\hline
\end{tabular}
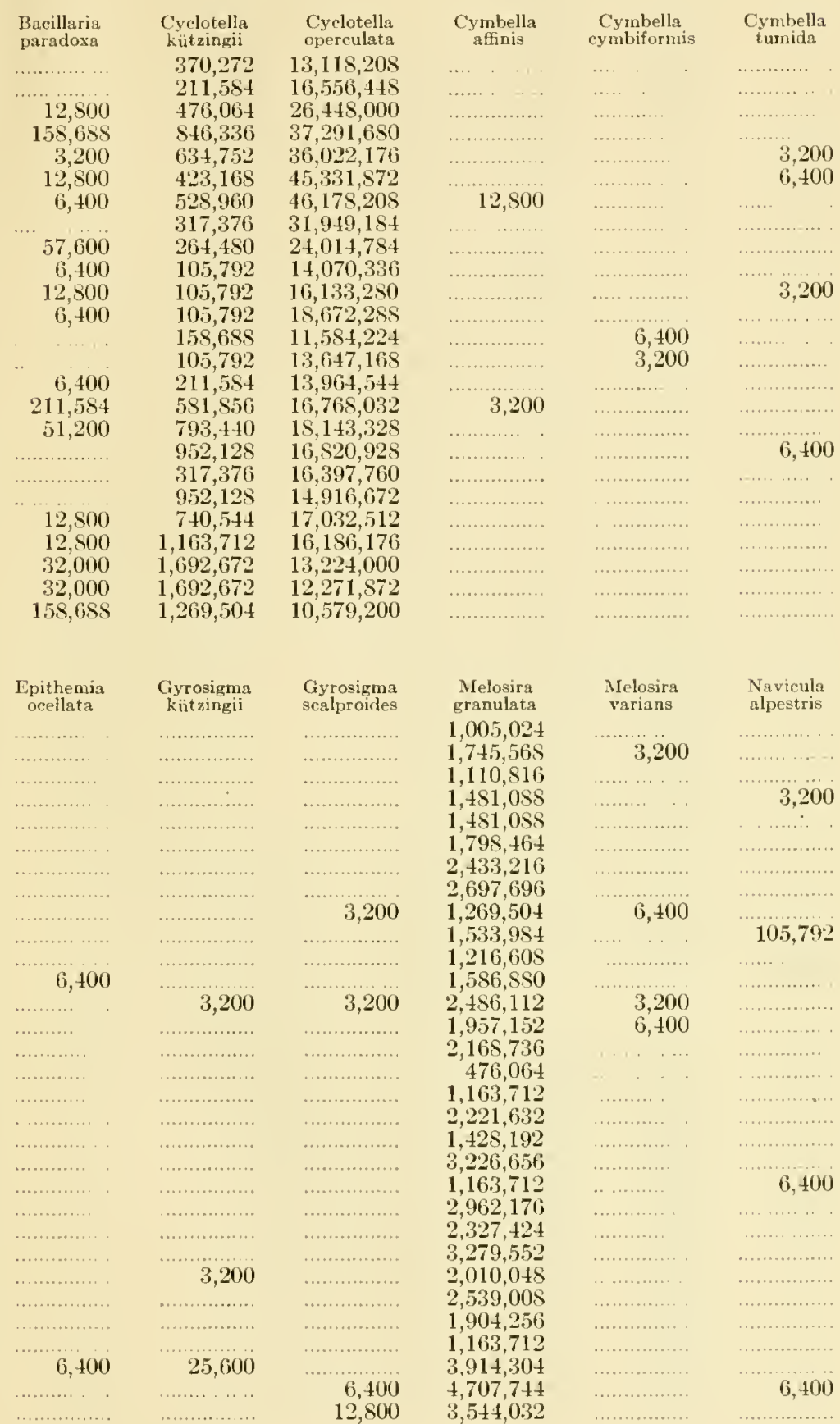

\begin{tabular}{|c|c|c|c|c|c|c|}
\hline 1913 & $\begin{array}{l}\text { Epithemia } \\
\text { ocellata }\end{array}$ & $\begin{array}{c}\text { Cyyrosigma } \\
\text { kitzingii }\end{array}$ & $\begin{array}{l}\text { Gyrosigma } \\
\text { sealproides }\end{array}$ & $\begin{array}{l}\text { Melosira } \\
\text { granulata }\end{array}$ & $\begin{array}{l}\text { Melosira } \\
\text { varians }\end{array}$ & $\begin{array}{l}\text { Navicula } \\
\text { alpestris }\end{array}$ \\
\hline $7 / 5$ & & ............. & & $1,005,024$ & & \\
\hline $7 / 6$ & & ................. & .. & $1,745,56 \mathrm{~s}$ & 3,200 & \\
\hline $7 / 7$ & .... & ............... & $\ldots \ldots$ & $1,110,816$ & & \\
\hline $7 / 8$ & & ................. & ................ & $1,481,088$ & & 3,200 \\
\hline $7 / 9$ & & ................... & ................... & $1,481,0 S 8$ & .... & 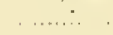 \\
\hline $7 / 10$ & . . & ............... & …........... & $1,798,464$ & & \\
\hline $7 / 11$ & & .......... & ... & $2,433,216$ & & \\
\hline $7 / 12$ & ......... & ................ & & $2,697,696$ & & \\
\hline $7 / 13$ & ......... & .............. & 3,200 & $1,269,504$ & 6,400 & \\
\hline $7 / 14$ & $\ldots$ & ......... & …............. & $1,533,9 S \pm$ & $\cdots \ldots$ & 105,792 \\
\hline $7 / 15$ & & & & $1,216,608$ & & \\
\hline $7 / 16$ & 6,400 & & & $1,586,8 \mathrm{S0}$ & & \\
\hline $7 / 17$ & ……. & 3,200 & 3,200 & $2,486,112$ & 3,200 & \\
\hline $7 / 18$ & $\ldots$ & …............ & ...... & $1,95 \overline{7}, 152$ & 6,400 & \\
\hline $7 / 19$ & & ................. & $\ldots .$. & $2,168,736$ & $\cdots$ & ... \\
\hline $7 / 20$ & & .... & ... & 476,064 & & \\
\hline $7 / 21$ & & ............... & .... & $1,163,712$ & . & \\
\hline $7 / 22$ & . & ............... & ........ & $2,221,632$ & $\ldots$ & \\
\hline $7 / 23$ & & ......... & ........ & $1,428,192$ & .... & \\
\hline $7 / 21$ & ..... . & ................ & .......... & $3,226,656$ & & \\
\hline $7 / 25$ & ….. . & .............. & ........ & $1,163,712$ & & 6,400 \\
\hline $7 / 26$ & $\cdots$ & ,................ & …….... & $2,962,176$ & & \\
\hline $7 / 27$ & & .............. & .......... & $2,327,424$ & & \\
\hline $7 / 28$ & & & .... & $3,279,552$ & & \\
\hline $7 / 29$ & & 3,200 & ......... & $2,010,0 \pm 8$ & & \\
\hline $7 / 30$ & ....... & .................. & $\ldots$ & $2,539,008$ & & \\
\hline $7 / 31$ & $\ldots \ldots$ & ................ & $\ldots$. & $1,904,256$ & & \\
\hline $8 / 1$ & & & & $1,163,712$ & & \\
\hline $8 / 2$ & 6,400 & 25,600 & & $3,914,304$ & & \\
\hline $8 / 3$ & .... & $\ldots \ldots$ & 6,400 & $4,707,744$ & & 6,400 \\
\hline $8 / 4$ & .................. & .................. & 12,800 & $3,544,032$ & & \\
\hline
\end{tabular}


Tamle 1.-Plankton Organisus Per Conic Meter in stockton Cilannel, DaILY SERIES IN 1913-(Continued)

\begin{tabular}{|c|c|c|c|}
\hline 1913 & $\begin{array}{l}\text { Navicula } \\
\text { bacillum }\end{array}$ & $\begin{array}{l}\text { Navicula } \\
\text { stacilis }\end{array}$ & $\begin{array}{l}\text { Nitzschia } \\
\text { acicularis }\end{array}$ \\
\hline $7 / 5$ & 3,200 & & $4,264,576$ \\
\hline $7 / 6$ & 3,200 & 3,200 & $2,750,592$ \\
\hline $7 / 7$ & & & $4,337,172$ \\
\hline $7 / S$ & . & 105,792 & $3,967.200$ \\
\hline $7 / 9$ & & 3,200 & $2,909,280$ \\
\hline $7 / 10$ & & $155,0 \mathrm{SS}$ & $4,760,640$ \\
\hline $7 / 11$ & & 3,200 & $5,448,288$ \\
\hline $7 / 12$ & 3,200 & & $4,666,132$ \\
\hline $7 / 13$ & $\ldots$ & 155,088 & $6,0 \times 3,040$ \\
\hline $7 / 14$ & $\ldots \ldots \quad \ldots$ & 264,480 & $5,130,912$ \\
\hline $7 / 15$ & & 105,792 & $4,496,160$ \\
\hline $7 / 16$ & 105,792 & 370,272 & $5,025,120$ \\
\hline $7 / 17$ & 1.58, 688 & 370,272 & 5,183, sos \\
\hline $7 / 18$ & & & $3,914,301$ \\
\hline $7 / 19$ & & 211,581 & $4,125,858$ \\
\hline $7 / 20$ & & 3,200 & $2,062,944$ \\
\hline $7 / 21$ & & 3,200 & $2,697,696$ \\
\hline $7 / 22$ & & $158,68 \mathrm{~s}$ & $2,697,696$ \\
\hline $7 / 23$ & & 3,200 & $2,380,320$ \\
\hline $7 / 21$ & & 105,792 & $2,9(199,280$ \\
\hline $7 / 25$ & & 105,792 & $4,231,680$ \\
\hline $7 / 26$ & & $423,16 \mathrm{~S}$ & $6,982,272$ \\
\hline $7 / 27$ & 105,792 & 176,061 & $9,309,696$ \\
\hline $7 / 28$ & & 370,272 & $7,085,064$ \\
\hline $7 / 29$ & 3,200 & 317,376 & $6,030,144$ \\
\hline $7 / 30$ & & 370,272 & $3,755,616$ \\
\hline $7 / 31$ & & 264,450 & $4,813,536$ \\
\hline $8 / 1$ & 105,792 & $211,5 \mathrm{S1}$ & $3,541,032$ \\
\hline$s / 2$ & 3,200 & $264,4 \$ 0$ & $3,385,344$ \\
\hline S/ 3 & 3,200 & 3,200 & $3,220,656$ \\
\hline $8 / 4$ & 3,200 & 317,376 & $3,702,720$ \\
\hline
\end{tabular}
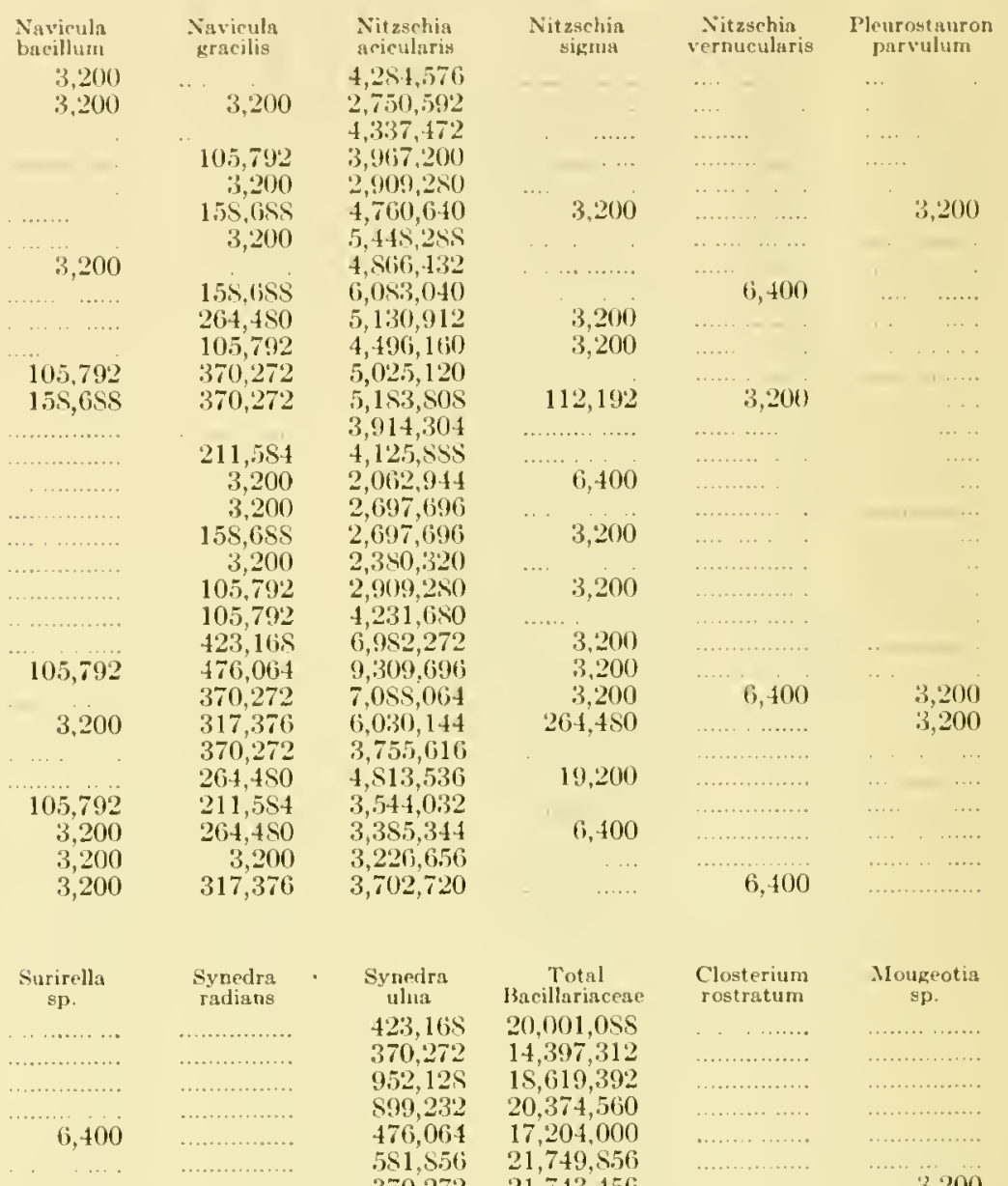

$5,501,184$

$5,765,664$

$3,200 \quad 4,284,576$

$3,200 \quad 1,496,160$

$19,200 \quad 3,279,552$

$6,400 \quad 1,322,400$

634,752

12,500

3,200

12,800

3.200

12,500

6,400

105,792

12,800

6,400

12,800

528,960

528,960

793,440

581,856

370,272

476,064

899,232

657,648

476.064

Synedra

Synedra
ulua

423,168

370,272

$952,12 \mathrm{~s}$

$\$ 99,232$

476,064

581,856

370,272

423,168

740,544

637,952

846,336

634,752

$1,110,816$

317,376

317,376

264,450

476,064

370,272

528,960

476,064

$211,5 \$ 4$

657,645

793,440

899,232

899,232

Total
Ibacillariacese
$20,001,088$
$14,397,312$
$18,619,392$
$20,374,560$
$17,204,000$
$21,749,856$
$21,743,456$
$24,761,728$
$40,709,024$
$51,741,888$
$47,625,600$
$58,002,816$
$59,463,008$
$39,790,592$
$31,801,600$
$17,543,776$
$21,127,904$
$25,045,408$
$16,675,040$
$20,863,424$
$20,387,360$
29637,760
$32,509,824$
$29,918,240$
$27,263,810$

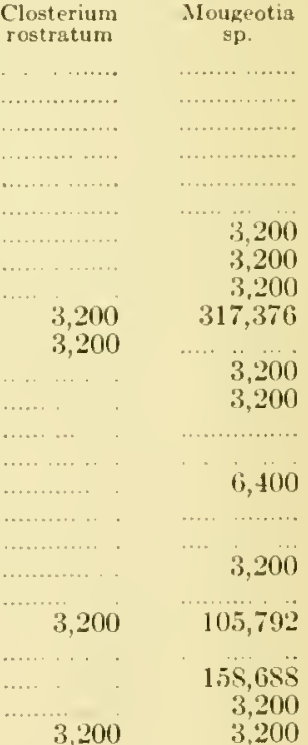


Table 4.-Plankton Organisms Per Cubic Meter in Stockton Channel, DAILY SERIES IN 1913-(Continued)

$\begin{array}{lc} & \text { Surirella } \\ 1913 & \text { sp. } \\ 7 / 30 & 6,40 \\ 7 / 31 & 6,400 \\ \text { S/ } 1 & 105,79 \\ \text { S/2 } & \ldots \ldots \ldots \ldots \\ 8 / 3 & 12.80 \\ \text { S/ } 4 & 25,600\end{array}$

1913

$7 / 5$

$7 / 6$

7/ 7

$7 / 8$

7) 9

$7 / 10$

$7 / 11$

$7 / 12$

$7 / 13$

$7 / 14$

$7 / 15$

$7 / 16$

$7 / 17$

$7 / 18$

$7 / 19$

$7 / 20$

$7 / 21$

$7 / 22$

$7 / 23$

$7 / 24$

$7 / 25$

$7 / 26$

$7 / 27$

$7 / 28$

$7 / 29$

$7 / 30$

$7 / 31$

8/ 1

S/ 2

S/ 3

8/ 4

1913

$7 / 5$

7/ 6

7) 7

$7 / 8$

7/ 9

$7 / 10$

$7 / 11$

$7 / 12$

$7 / 13$

$7 / 14$

$7 / 15$

$7 / 16$

$7 / 17$

$7 / 18$

$7 / 19$

\begin{tabular}{|c|c|c|c|}
\hline Staurastrum $_{A}$ & $\begin{array}{c}\text { Staurastrum } \\
\text { sp. }\end{array}$ & $\begin{array}{c}\text { Total } \\
\text { Conjugatae }\end{array}$ & $\begin{array}{c}\text { Total } \\
\text { Chlorophyll } \\
\text { bearing }\end{array}$ \\
\hline 3,200 & & 6,400 & $24,657,440$ \\
\hline & 3,200 & 3,200 & $20,518,752$ \\
\hline$\ldots \ldots$ & $\cdots \quad \ldots$ & $\ldots \ldots$ & $25,811,552$ \\
\hline 6,400 & & 6,400 & $24,516,656$ \\
\hline & 3,200 & 3,200 & $31,763,090$ \\
\hline & & 3,200 & $30,378,304$ \\
\hline & $\ldots$. & 3,200 & $37,862,232$ \\
\hline & ....... & 3,200 & $56,860,504$ \\
\hline .......... & .............. & 320,576 & $68,840,096$ \\
\hline & & 3,200 & $62,210,896$ \\
\hline 6,400 & $\ldots .$. & 9,600 & $71,364,608$ \\
\hline & & 3,200 & $72,392,032$ \\
\hline 3,200 & 3,200 & 6,400 & $48,292,352$ \\
\hline$\ldots$ & $\cdots$ & 6,400 & $22,560,800$ \\
\hline & & & $27,722,208$ \\
\hline 6,400 & ........... & 6,400 & $30,423,104$ \\
\hline & & 3,200 & $23,041,054$ \\
\hline 3,200 & 3,200 & 6,400 & $27,956,192$ \\
\hline & & 105,992 & $27,893,696$ \\
\hline & 3,200 & 6,400 & $44,063,882$ \\
\hline & & 158,688 & $45,490,368$ \\
\hline 6,400 & …....... & 9,600 & $42,223,606$ \\
\hline 6,400 & & 12,800 & $39,375,328$ \\
\hline & ........ & 9,600 & $31,213,344$ \\
\hline & ...... & 6,400 & $33,447,776$ \\
\hline .... & …............ & 3,200 & $34,225,216$ \\
\hline & 3,200 & 3.200 & $\begin{array}{l}30,601,496 \\
32774,432\end{array}$ \\
\hline 6,400 & 3,200 & 118,592 & $31,681,322$ \\
\hline
\end{tabular}

Synedra radians

476,061

- $\$ 46,336$

370,272

370,272

793,440

$\begin{gathered}\text { Synedra } \\ \text { ulna }\end{gathered}$
528,960
370,272
423,168
423,168
634,752
211,584

Total

riacen

$5,-15,56$

$23,766,304$

$23,354,240$

$22,967,96 \mathrm{~S}$

$20,630,944$

3,200

Tota

$22,693,888$

$17,699,264$

$22,384,608$

$27,727,104$

$21,506,480$

$27,521,810$

$26,778,176$

$31,667,000$

$48,450,040$

$60,552,800$

$55,017,040$

$66,012,512$

$67,059,632$

$42,953,056$

$36,912,226$

$19,069,66$

$24,227,872$

$27,930,592$

$19,758,112$

$24,538,848$

$24,190,976$

$35,865,002$

$39,133,248$

$35,234,934$

$32,019,581$

$26,967,864$

$29,057,408$

$27,821,600$

$25,771,960$

$27,104,960$

$24,312,778$

elegans

sp.

634,752

$1,428,192$

$2,221,632$

$3,385,344$

$2,486,112$

$3,596,928$

$3,120,564$

$4,919,32 \mathrm{~S}$

$6,664,896$

$7,088,064$

$6,188,932$

$5,183,808$

$4, \$ 66,432$

105,792

$4,760,640$

$6,929,376$
....

6,400

6,400

57,600

19,200

3,200

3,200

6,400

158,688

6,400

6,400
Euglena

$$
3,200
$$

3,200

105,792

211,584

3,200

105,792

793,440

$1,057,920$

370,272

634,752

158,688

423,168

476,06 .

6,400
105,792

Mougeotia sp.

…..........

\section{Cercomonas}

crassicauda

...............
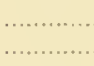

................
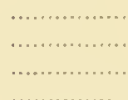

3,200

Hemidinium nasutum

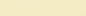


'Mable 4,-Plankton Organisug Per Cubic Meter in Stochton Channel, Dally SERIES IN 1913-(Continued)

$\begin{gathered}\text { Chilononas } \\ \text { sp. }\end{gathered}$
Chlunydomonis
sp.

Chromulinu
sp.
$3,015,072$
$2,5,56,384$
$2,274,528$
$3,173,760$
$2,750,592$
$2,803,488$
$7,299,614$
$5,395,392$
$6,347,520$
$4,496,160$
$3,279,552$
$3,385,344$
$3,649,524$
$3,967,200$
$4,919,324$
$5,130,912$

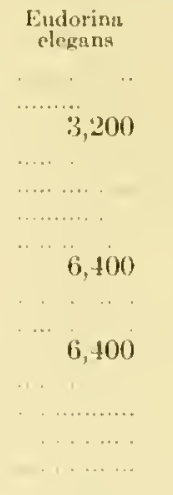

Euglen viridis $176,06 \% 1$ …...... $2,5,56,3,34$ (n............

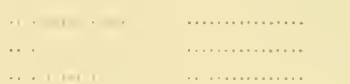

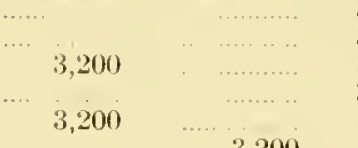

$5,130,912$

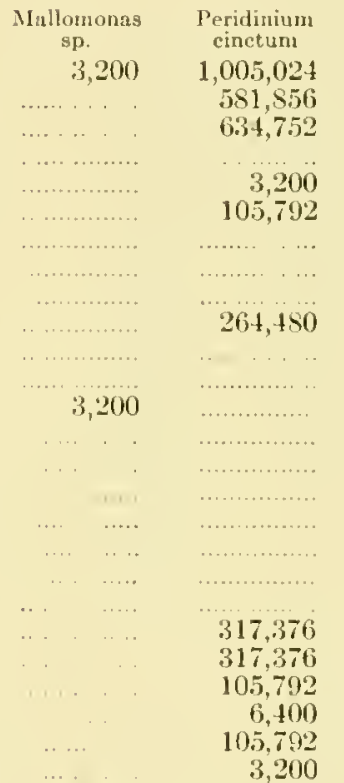

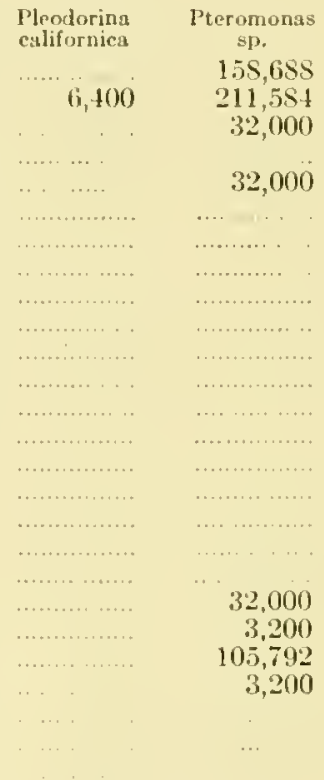

(i, 100

$2.327,424$

528,960

$\begin{array}{lr}159,6 \mathrm{~S} & \mathrm{~S} 1 \mathrm{~S}, 336 \\ 26 \cdot 1,+80 & 2,456,112\end{array}$

$105,792 \quad 6 i 34,752$

$: 3,200 \quad 6: 34,7.52$

$12,500 \quad 1,639,776$

$\begin{array}{ccc}1913 & \begin{array}{c}\text { Trachelomonas } \\ \text { volvocina }\end{array} & \begin{array}{c}\text { Total } \\ \text { Mastigophora }\end{array} \\ 7 / 8 & 261,480 & 2,069,344 \\ 7 / 6 & 317,376 & 2,819,455 \\ 7 / 7 & 528,360 & 3,426,944 \\ 7 / 8 & 211,584 & 3,760,320 \\ 7 / 9 & 264,450 & 3,016,576 \\ 7 / 10 & 528,960 & 4,241,280\end{array}$

\begin{tabular}{|c|c|}
\hline $\begin{array}{l}\text { Amoeba } \\
\text { radiosa }\end{array}$ & $\begin{array}{c}\text { Difllugia } \\
\text { pyriformis }\end{array}$ \\
\hline & 211,591 \\
\hline 3,200 & 476,064 \\
\hline & $26+4,450$ \\
\hline 3,200 & 12,800 \\
\hline$=$ & $264,4 \mathrm{~S} 0$ \\
\hline
\end{tabular}

3,200 socialis

Symura uvell:1

$1.58,685$

\section{Trachelemon} ruchlora e

3,200

3,200

211,584

Total

$2: 24,381$

479,264

$3,200 \quad 267,680$

1!), 200

270,880

3,200 
Table 4.-Plankton Organisus Per Cubic Meter in Stockton Channel, DaIlY Series IN 1913-(Continued)

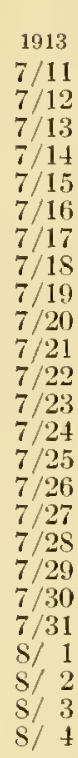

1913

$7 / 5$

$7 / 6$

$7 / 7$

7) $\mathrm{s}$

$7 / 9$

$7 / 10$

$7 / 11$

$7 / 12$

$7 / 13$

$7 / 14$

$7 / 15$

$7 / 16$

$7 / 17$

$7 / 18$

$7 / 19$

$7 / 20$

$7 / 21$

$7 / 22$

$7 / 23$

$7 / 24$

$7 / 25$

726

$7 / 27$

$7 / 28$

$7 / 29$

$7 / 30$

$7 / 31$

8/ 1

S/ 2

S/ 3

S/ 4

\begin{tabular}{|c|c|}
\hline $\begin{array}{c}\text { Trachelomonas } \\
\text { volvocina }\end{array}$ & $\begin{array}{c}\text { Total } \\
\text { Mastigophora }\end{array}$ \\
\hline 370,272 & $3,600,128$ \\
\hline 476,064 & $6,195,232$ \\
\hline 657,648 & $8,410,464$ \\
\hline 105,792 & $7,987,296$ \\
\hline 370,272 & $7,193,556$ \\
\hline .... & $5,352,096$ \\
\hline & $5,302,400$ \\
\hline$\ldots$ & $5,342,496$ \\
\hline & $7,041,568$ \\
\hline & $3.491,136$ \\
\hline 3,200 & $3,494,336$ \\
\hline & $2,492,512$ \\
\hline 3,200 & $3,285,952$ \\
\hline 158,688 & $3,417,344$ \\
\hline 158,688 & $3,705,920$ \\
\hline 105,792 & $8,198,880$ \\
\hline 211,581 & $6,357,120$ \\
\hline 211,581 & $6,988,672$ \\
\hline 3,200 & $7,35.5,744$ \\
\hline tren & $4,244,480$ \\
\hline$\ldots$ & $4,390,36 \mathrm{~S}$ \\
\hline & $6,403,616$ \\
\hline 105,792 & $4,832,736$ \\
\hline 105,792 & $5,669, \pm 72$ \\
\hline 370,272 & $7,368,544$ \\
\hline
\end{tabular}

Heterophrys Raphidiophrys fockei

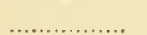

(n.............

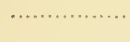

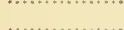
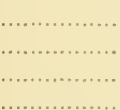

................
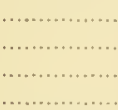

6,400

105,792

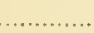

n............

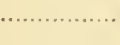

105,792

44,800 105,792

6,400 528,960 528,960 317,376

476,064

$1,269,504$

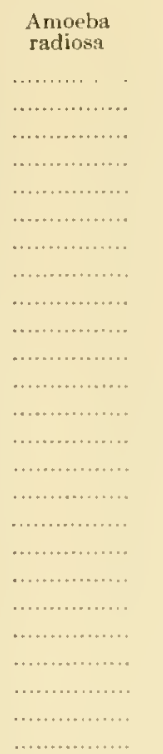

Difflugia pyriformis

\begin{tabular}{|c|c|}
\hline $\begin{array}{l}\text { Microgromia } \\
\text { socialis }\end{array}$ & $\begin{array}{c}\text { Total } \\
\text { Rhizopoda }\end{array}$ \\
\hline & 3200 \\
\hline & 3,200 \\
\hline 3,200 & 6,400 \\
\hline & 3,200 \\
\hline 3,200 & 112,192 \\
\hline & 12,800 \\
\hline & 9,600 \\
\hline & 6,400 \\
\hline & 108,992 \\
\hline 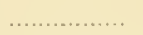 & 6,400 \\
\hline
\end{tabular}

6. 400

105,792

6,400

Total

Heliozoa

528,960

740,544

846,336

$1,110,816$

$8 \pm 6,336$

370,272

423,168

158,688

$1,110,816$

$1,005,0^{2} 24$

370,272

528,960

$158,6 \mathrm{ss}$

$211,5 \mathrm{St}$

370,272

112,192

310,272

317,376

317,376

317,376

105,792

370,272

476,064

528,960

525,960

$\pm 15,072$

581,856

694,048

$1,798,46$

740,5414

$952,12 \mathrm{~S} \quad 1,269,501$
105,792

$1.5 \mathrm{~S}, 68 \mathrm{~S}$

264,450

211,584

6,400

105,792

3,200

\begin{tabular}{|c|c|}
\hline \multirow{3}{*}{$\begin{array}{l}105,792 \\
105,792\end{array}$} & 105,792 \\
\hline & 370,272 \\
\hline & $158,68 \mathrm{~s}$ \\
\hline & 267.650 \\
\hline 3,200 & 217,984 \\
\hline 3,200 & 12,800 \\
\hline & 211,584 \\
\hline 3,200 & 3,200 \\
\hline & 6,400 \\
\hline & \\
\hline $158,68 \mathrm{~s}$ & 155,68 \\
\hline 105,792 & 105,792 \\
\hline
\end{tabular}

\begin{tabular}{|c|c|c|}
\hline $\begin{array}{l}\text { Holophrya } \\
\text { sp. }\end{array}$ & $\begin{array}{l}\text { Prorodon } \\
\text { sp. }\end{array}$ & $\begin{array}{l}\text { Tintinnidium } \\
\text { fluviatile }\end{array}$ \\
\hline $158,69 \mathrm{~S}$ & & \\
\hline 105,792 & $\ldots .$. & $\cdots$ \\
\hline 158,688 & …..... & …..... \\
\hline 105,792 & ....... & $\ldots \ldots \ldots \ldots$ \\
\hline 211,584 & ......... & . \\
\hline $211,5 \mathrm{S4}$ & ......... & $\ldots \ldots \ldots$ \\
\hline 423,165 & ......... & \\
\hline 3,200 & ........ & \\
\hline 211,584 & ......... & . \\
\hline $10.5,792$ & $\ldots . .$. & \\
\hline 528,960 & .......... & \\
\hline 6,400 & .......... & \\
\hline & …..... & \\
\hline & n......., & \\
\hline 3,200 & & \\
\hline 264,480 & .... & \\
\hline 3,200 & ….............. & \\
\hline 3,200 & 3,200 & \\
\hline 264,480 & $\ldots$. & \\
\hline 211,584 & .... & \\
\hline 317,376 & ................ & \\
\hline $158,68 \mathrm{~S}$ & ................ & \\
\hline $158,68 \mathrm{~s}$ & , ...... & \\
\hline 105,792 & & 105,792 \\
\hline 105.792 & 3,200 & $105,79^{\circ}$ \\
\hline 264,480 & $\ldots$ & 3,200 \\
\hline 105,792 & ............... & \\
\hline 3,200 & & 6,400 \\
\hline $158,6 \mathrm{SS}$ & & 6,400 \\
\hline
\end{tabular}


Table 4-Plankton Organisms Per Cuhr Metej in Stockton Chanyel, DAILY SERIES 1N 1913-(Conlinued)

\begin{tabular}{|c|c|c|c|c|c|c|}
\hline 1913 & $\underset{b}{\text { Vorticella }}$ & $\begin{array}{l}\text { Vorticclla } \\
\text { longifilum }\end{array}$ & $\begin{array}{c}\text { Vorticella } \\
\text { sp. }\end{array}$ & $\begin{array}{c}\text { Total } \\
\text { Ciliata }\end{array}$ & $\begin{array}{l}\text { Total, l'rotozoa } \\
\text { witlout } \\
\text { Mastigophora }\end{array}$ & $\begin{array}{l}\text { Total, Protozoa } \\
\text { with } \\
\text { Mastigophora }\end{array}$ \\
\hline $7 / 5$ & 3,200 & .................. & $2,6.11,800$ & $2,806,689$ & $3,560,032$ & $5,629,376$ \\
\hline $7 / 6$ & & & $1,375,296$ & $1,490,688$ & $2,707,496$ & $5,526,981$ \\
\hline $7 / 7$ & $1.58,6 \times 8$ & ........ & $1,0,37,920$ & $1,216,608$ & $2,330,62 \cdot 1$ & $5,757,56 \mathrm{~s}$ \\
\hline $7 / 8$ & 211,584 & …… & $1,110,810$ & $1,216,608$ & $2,346,632+$ & $6,106,944$ \\
\hline $7 / 9$ & 370,272 & …............ & $476,06 \mathrm{i}-1$ & $687,6.18$ & $1,804,864$ & $4,521,440$ \\
\hline $7 / 10$ & 634,752 & ....... & $1,322,400$ & $1,533,984$ & $1,907,456$ & $6,145,736$ \\
\hline $7 / 11$ & 105,792 & ....... & $846,336 i$ & $1,269,504$ & $1,692,672$ & $5,292,800$ \\
\hline $7 / 12$ & $158,6 S S$ & . $\ldots \ldots \ldots \ldots$ & 740,541 & 743,744 & $905,6,32$ & $7,100,86,4$ \\
\hline $7 / 13$ & & & 634,752 & 816,336 & $1,960,35.2$ & $10,370,816$ \\
\hline $7 / 14$ & 105,792 & & $1,163,712$ & $1,269,504$ & $2,240,1325$ & $10,265,224$ \\
\hline $7 / 1.5$ & & & $\$ 46,336$ & $1,375.296$ & $1,7+8,768$ & 8.942 .624 \\
\hline $7 / 16$ & 3,200 & & $1,110,816$ & $1,116,216$ & $1,757,368$ & $7,109,464$ \\
\hline $7 / 17$ & & & $1,163,712$ & $1,163,712$ & $1,335,200$ & $(i, 6,37,600)$ \\
\hline $7 / 18$ & & & 370,272 & 370,272 & 5) 91,456 & $5,933,952$ \\
\hline $7 / 19$ & & $\ldots$ & $1,057,920$ & $1,057,920$ & $1,434,592$ & $8,476,160$ \\
\hline $7 / 20$ & & ...... & 476,064 & 476,064 & 697,445 & $1,158,5 \mathrm{~S} 1$ \\
\hline $7 / 21$ & . & ...... & 370,272 & (i. 34,752 & $9.51,+24$ & $4,445,760$ \\
\hline $7 / 22$ & & & $1,005,024$ & $1,008,224$ & $1,325,600$ & $3, \$ 18,112$ \\
\hline $7 / 23$ & & $\ldots$ & 476.064 & 476,064 & 899,232 & $4,185,184$ \\
\hline $7 / 24$ & & & $\$ 99,232$ & $90.5,632$ & $1,593,2 \mathrm{~S} 0$ & $5,010,(124$ \\
\hline $7 / 25$ & & ..... & 793,440 & $1,163,712$ & $1,425,192$ & $5,134,112$ \\
\hline $7 / 26$ & $\ldots$ & …............ & $1,269,504$ & $1,487,488$ & $2,125,440$ & $10,324,320$ \\
\hline $7 / 27$ & & .......... & $1,957,152$ & $2,274,52 \mathrm{~s}$ & $2,96 \varsigma, 576$ & $9,325,696$ \\
\hline $7 / 28$ & & & $1,586,880$ & $1.745,568$ & $2,287,328$ & 9.276 .000 \\
\hline $7 / 29$ & 476,064 & 3,200 & $2,010,048$ & $2,171,936$ & $2,912,480$ & $10,265,224$ \\
\hline $7 / 30$ & & 6.400 & 899,232 & 1.117 .216 & $1,535,4 \times S$ & $5,779,966$ \\
\hline $7 / 31$ & & $\ldots \ldots$ & $1,533,984$ & $1,748,768$ & $2,337,024$ & $6,727,392$ \\
\hline S/ 1 & & & $1,269,504$ & $1,537,184$ & $2,231,232$ & $8,634,845$ \\
\hline $8 / 2$ & . & ....... & $1,639,776$ & $1,748,768$ & $3,547,232$ & $8,379,968$ \\
\hline $8 / 3$ & & & $1,957,152$ & $1,966,752$ & $4,394,944$ & $10,064,416$ \\
\hline 8/ 4 & & 3,200 & $1,692,672$ & $1,860,950$ & $4,231,246$ & $11,604,790$ \\
\hline 1913 & $\begin{array}{c}\text { Rotaria } \\
\text { neptunia }\end{array}$ & $\begin{array}{c}\text { Rotaria } \\
\text { rotatoria }\end{array}$ & $\begin{array}{c}\text { Rotifer } \\
\text { uniclentified }\end{array}$ & $\begin{array}{c}\text { Total } \\
\text { Bdelloida }\end{array}$ & $\begin{array}{l}\text { Anuraeopsis } \\
\text { fissa }\end{array}$ & $\begin{array}{l}\text { Asplanchua } \\
\text { brightwelli }\end{array}$ \\
\hline $7 / 5$ & & 19,200 & 155,688 & $177, \mathrm{SSS}$ & & 158,688 \\
\hline $7 / 6$ & & 25,600 & $211,5 \mathrm{~S} 1$ & 237,184 & & 57,600 \\
\hline 7) 7 & 6,400 & 6,400 & 3,200 & 16,000 & 3,200 & 70,400 \\
\hline $7 / 8$ & & 12,800 & 6,400 & 19,200 & 6,400 & 19,200 \\
\hline $7 / 9$ & . & 6,400 & 3,200 & 9,600 & & 19,200 \\
\hline $7 / 10$ & & 25,600 & & 25,600 & 6.400 & $\$ 9,600$ \\
\hline $7 / 11$ & 12,800 & 3,200 & & 16,000 & & 51,200 \\
\hline $7 / 12$ & & 211,584 & 3,200 & 214,784 & & 44.800 \\
\hline $7 / 13$ & & 38,400 & 159,695 & $196,08 \mathrm{~s}$ & 3,200 & 76,800 \\
\hline $7 / 14$ & 3,200 & 264,480 & 158.685 & 426,368 & 3,200 & $158,6 \mathrm{ss}$ \\
\hline $7 / 15$ & & 6,400 & 3,200 & 9,600 & & 64,000 \\
\hline $7 / 16$ & $\ldots$. & 19,200 & 19,200 & $3 \varsigma, 400$ & & 12,800 \\
\hline $7 / 17$ & & 317,376 & 264,480 & 581,856 & & 19.200 \\
\hline $7 / 1 \mathrm{~s}$ & & 6,400 & 3,200 & 9,600 & & $10 . \overline{5}, 792$ \\
\hline $7 / 19$ & 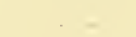 & & 158,688 & 159,685 & & 6,400 \\
\hline $7 / 20$ & & 6,400 & 3,200 & 9,600 & 6,400 & 12,800 \\
\hline $7 / 21$ & $\ldots$ & 19,200 & & 19,200 & 6,400 & 19,200 \\
\hline $7 / 22$ & & 19,200 & 3,200 & 22,400 & & 25,600 \\
\hline $7 / 23$ & & 317,376 & & 317,376 & 6,400 & 3,200 \\
\hline $7 / 24$ & $6, \frac{1}{2} 00$ & 105,792 & 3,200 & 115,392 &, 200 & 12,800 \\
\hline $7 / 25$ & & 6,400 & 105,792 & 112,192 & & \\
\hline $7 / 26$ & & 12,800 & 25,600 & 38,400 & 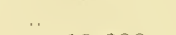 & 19,200 \\
\hline $7 / 27$ & 19,200 & 6,400 & 105,792 & 131,392 & 19,200 & 38,400 \\
\hline $7 / 28$ & - & & 211,584 & 211.584 & 6,400 & $12, \$ 00$ \\
\hline $7 / 29$ & & & 105,792 & 105,792 & & 32,000 \\
\hline
\end{tabular}


Table 4.-Plankton Organisms Per Cubic Meter in Stockton Channel, Daily Series in 1913-(Continued)

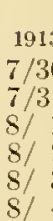

1913

$7 / 5$

$7 / 6$

7. 8

7 . 9

$7 / 10$

$7 / 11$

$7 / 12$

$7 / 13$

$7 / 14$

$7 / 15$

$7 / 16$

$7 / 17$

$7 / 18$

$7 / 19$

$7 / 20$

$7 / 21$

$7 / 22$

$7 / 23$

$7 / 24$

$7 / 25$

$7 / 26$

$7 / 27$

$7 / 2 S$

$7 / 29$

$7 / 30$

$7 / 31$

$8 / 1$

$8 / 2$

$8 / 3$

8/ 4

1913

$7 / 5$

$7 / 6$

$7 / 7$

$7 / 8$

$7 / 9$

$7 / 10$

$7 / 11$

$7 / 12$

$7 / 13$

$7 / 14$

$7 / 15$

$7 / 16$

$7 / 17$

$7 / 18$
Rotaria
rotatoria

Rotaria

6,400

6,400

$\begin{array}{rr}\ldots . \ldots . & 12,800 \\ \ldots & 3,200\end{array}$

32,000

158,688

6,400

Brachionus

angularis

3,200

3,200

3,200

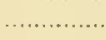

$158,6 S S$

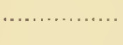

3,200

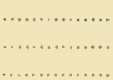

6,400

158,688

3,200
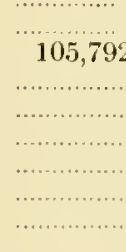

6,400

Brachionus egg; attached male

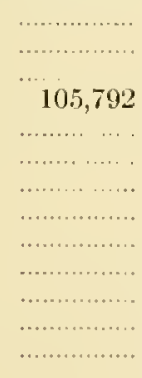

Brachionus angularis

476,064

423,168

264,480

$1,269,504$

$1,163,712$

$5 \$ 1,856$

$1,005,024$

$1,375,296$

581,856

$\$ 46,336$

740,544

793,440

$1,057,920$

$-93,410$

476,064

370,272

528,960

317,376

740,544

$1,216,608$

$1,481,088$

$3,755,616$

$1,851,360$

581,856

423,168

264,480

$5 \mathrm{S1,856}$

211,584

211,564

264,480

$1,269,504$

\$46,336

$1,005,024$

740,544

528,960

687,648

370,272

476,064

$\begin{array}{rr}\begin{array}{c}\text { Rotifer } \\ \text { unidentified }\end{array} & \begin{array}{c}\text { Total } \\ \text { Bdelloida }\end{array} \\ 3,200 & 16,000 \\ 158,68 S & 19,200 \\ 3,200 & 161,888 \\ 3,200 & 11,600 \\ 105,792 & 11,688 \\ & 112,192\end{array}$

$\begin{gathered}\text { Anuraeopsis } \\ \text { fissa }\end{gathered}$
6,400
$\ldots \ldots \ldots$
$\ldots \ldots \ldots$
$\ldots \ldots \ldots \ldots$

$1,110,816$

Brachionus
budapestenensis

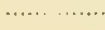

…........

...

3,200

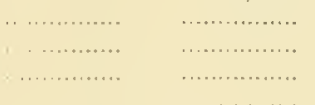
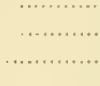

...............

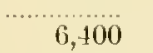

6,400
$6 . \ldots \ldots \ldots$

…...........

……..........

$\ldots \ldots+\ldots, \ldots, \ldots$

.................

…...........

n..............

patulus

...............

$1,005,024$
Brachionus

calyciflorus

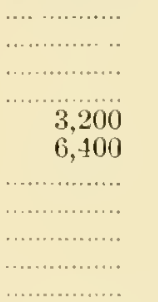

Brachionus capsuliflorus

...............

Brachionus egg attached,

158,688

105,792

105,792

$52 \mathrm{~S}, 960$

$687,64 \mathrm{~S}$

264,480

317,376

528,960

317,376

687,648

423,168

$8+6,336$

264,480

$\begin{array}{ll}19,200 & 264,180 \\ & 370,272\end{array}$

476,064

158,688

$211,5 S 4$

$5 \$ 1,856$

$6,400 \quad 158,688$

476,061

$\$ 46,336$

370,272

$1,42 \mathrm{~S}, 192$

634,752

211,581

$6,100 \quad 12,800$

$6,400 \quad 211,584$

370,272

264,480

$6,400 \quad 105,792$

158,688

Brachionus
plicatilis

6,400

urceus

44,800

6,400

12,800

19,200

44,500

211,584

$\mathbf{1 5 8 , 6 8 8}$

528,960

370,272

$5 \$ 1,856$

528,960

528,960

47,064

$1,216,608$
Diurella

egg

3,200

3,200

3,200

3,200 
Tahe 4.-Plankton Organisus Per Cubic Meter in stockton Cuandel, DAILY SkIRES IN 1913-(Continued)

\begin{tabular}{|c|c|c|c|c|c|c|}
\hline 1913 & $\begin{array}{c}\text { Brachionus } \\
\text { egg; attached, } \\
\text { male }\end{array}$ & $\begin{array}{l}\text { Brachionus } \\
\text { "gg: free", } \\
\text { female }\end{array}$ & $\begin{array}{l}\text { Brachionus } \\
\text { patulus }\end{array}$ & $\begin{array}{l}\text { IBrachionus } \\
\text { plicutilis }\end{array}$ & $\begin{array}{l}\text { Braclionus } \\
\text { ureceus }\end{array}$ & $\begin{array}{l}\text { Diurella } \\
\text { egg }\end{array}$ \\
\hline $7 / 19$ & $\ldots$. & $26+, 480$ & & & 370,272 & \\
\hline $7 / 20$ & ............. & $423,16 \mathrm{~s}$ & & & 740,514 & \\
\hline $7 / 21$ & ............... & 846,336 & ..... & $\ldots \ldots \ldots$ & $(3 i 34,752$ & .. \\
\hline $7 / 22$ & n............. & $1,057,920$ & & & 634,752 & .. . . . . \\
\hline $7 / 23$ & . . . . . & 740,544 & & & 6.400 & \\
\hline $7 / 2 \cdot 1$ & . $\ldots \ldots \ldots \ldots \ldots$ & 528,960 & .... .......... & ............. & 211,581 & $\ldots$ \\
\hline $7 / 25$ & ............... & $1,057,920$ & ................. & …............ & 370,272 & \\
\hline $7 / 26 j$ & ............... & 476,064 & & $\ldots \ldots \ldots \ldots \ldots$ & 423,166 & \\
\hline $7 / 27$ & ................... & $1,8.51,360$ & .................... & ............. & 526,960 & - \\
\hline $7 / 28$ & $\ldots \ldots \ldots+\ldots$ & 528,960 & & $\ldots \ldots$ & 528,900 & 6,400 \\
\hline $7 / 29$ & . ............... & 952,128 & 3,200 & & 370,272 & $\ldots$. \\
\hline $7 / 30$ & . ............. & 423,168 & ............. & $\ldots$ & 105,792 & $\ldots .$. \\
\hline $7 / 31$ & ................... & $423,16$. & ............. & & $158,68 \mathrm{~s}$ & \\
\hline S/ 1 & ................ & 528,960 & ................. & ... & 423,168 & 6,400 \\
\hline $8 / 2$ & ................. & 423,168 & ............... & & 370,272 & $10.5,792$ \\
\hline S/ 3 & & 158,685 & & & 423168 & 6,400 \\
\hline $8 / 4$ & 25,600 & 317,376 & ............... & 6,400 & 317,376 & ..... \\
\hline 1913 & $\begin{array}{c}\text { Filinia } \\
\text { brachiatu }\end{array}$ & $\begin{array}{l}\text { Filinia egg; } \\
\text { attached, } \\
\text { female }\end{array}$ & $\begin{array}{l}\text { Filinia } \\
\text { egg, free }\end{array}$ & $\begin{array}{l}\text { Filinia } \\
\text { longiseta }\end{array}$ & $\begin{array}{l}\text { Keratella } \\
\text { cochlearis }\end{array}$ & $\begin{array}{l}\text { Keratella egg. } \\
\text { attached }\end{array}$ \\
\hline $7 / 5$ & 3,200 & $158,68 \mathrm{~S}$ & 370,272 & $1,375,296$ & 793,410 & 211,584 \\
\hline $7 / 0$ & & 105,792 & 528,960 & 370,272 & $211,55 t$ & .... : \\
\hline $7 / 7$ & 3,200 & 105,792 & 317,376 & 317,376 & 476.064 & 3,200 \\
\hline 7) 8 & ......... & 3,200 & 528,960 & 264,480 & $211,5 \mathrm{St}$ & 3,200 \\
\hline $7 / 9$ & $1, \ldots \ldots$ & 3,200 & 476,064 & 12,500 & 211,584 & 3,200 \\
\hline $7 / 10$ & ............. & & 476,064 & 44,800 & $423,16 \mathrm{~s}$ & 105,792 \\
\hline $7 / 11$ & n............ & $6, \pm 00$ & 423,165 & $158,6 S 5$ & $5 \mathrm{~S} 1,8,56$ & 3,200 \\
\hline $7 / 12$ & ................ & ................... & 370,272 & 105,792 & 423,168 & 3,200 \\
\hline $7 / 13$ & ……....... & & 3,200 & 158,685 & 470,064 & 105,792 \\
\hline $7 / 1.1$ & ................. & 3,200 & 105,792 & 211,584 & 476,064 & 3,200 \\
\hline$\tau / 15$ & n..., & …........ & 158,685 & ...... & $158,6 \mathrm{SS}$ & 3,200 \\
\hline $7 / 16$ & …........... & ...... & & 25,600 & 12,800 & 105,792 \\
\hline $7 / 17$ & $\ldots \ldots \ldots \ldots \ldots$ & $\cdots \cdot$ & $10.5,792$ & 25,600 & 32,000 & ........ \\
\hline $7 / 18$ & $\ldots \ldots+\ldots \ldots+\cdots$ & ........... & 211,584 & & 25,600 & \\
\hline $7 / 19$ & n........... & 6,400 & $10.5,792$ & 6,400 & 32,000 & 211,584 \\
\hline $7 / 20$ & $\ldots \ldots \ldots \ldots, \ldots$ & .......... & 105,792 & 19,200 & 158,683 & 2000 \\
\hline $7 / 21$ & 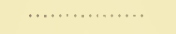 & $\cdots$ & 3,200 & 6,400 & $155,6.88$ & 3.200 \\
\hline $7 / 22$ & (............. & ............... & $10.5,792$ & 6,400 & 105,792 & 317,376 \\
\hline $7 / 23$ & ............... & & 105,792 & $\ldots \ldots$ & 38,400 & 211,584 \\
\hline $7 / 24$ & ................ & n............ & 158,685 & ….......... & 19,200 & 264,480 \\
\hline $7 / 25$ & ……....... & .............. & 211,584 & $\ldots \ldots \ldots$ & 12,800 & 264,480 \\
\hline $7 / 26$ & …............. & & 211,584 & $\ldots \ldots \ldots+\ldots$ & 6,400 & 264,480 \\
\hline$T / 2 T$ & .............. & $\ldots \ldots$ & 105,792 & . & & 423,168 \\
\hline $7 / 2 \mathrm{~S}$ & . ............... & , $\ldots \ldots \ldots \ldots \ldots$ & $15 \mathrm{~S}, 68 \mathrm{~S}$ & & 6,400 & 264,480 \\
\hline $7 / 29$ & . . .............. & .......... & 105,792 & ............ & 19,200 & 687,648 \\
\hline $7 / 30$ & ........ & ............ & $15 \mathrm{s,688}$ & & 12,800 & $10 ;, 792$ \\
\hline $7 / 31$ & . $\ldots \ldots \ldots \ldots \ldots$ & n.............. & 158,688 & ................ & 3,200 & 317.376 \\
\hline $8 / 1$ & .. & .. & .. & ............... & .... . & 158,688 \\
\hline $8 / 2$ & ……...... & . & & .. . & & 158,685 \\
\hline $8 / 3$ & ,.............. & .......... & $211,5 \mathrm{St}$ & & 12,500 & 3,200 \\
\hline $8 / 4$ & & & $15 \mathrm{~S}, 6 \mathrm{SS}$ & $\ldots \ldots$ & $\ldots+\cdots$ & $15 \mathrm{~S}, 6 \mathrm{SS}$ \\
\hline 1913 & $\begin{array}{l}\text { Keratella } \\
\text { egg, free }\end{array}$ & $\begin{array}{l}\text { Keratella } \\
\text { quadruta }\end{array}$ & $\begin{array}{c}\text { Polyartlara } \\
\text { trigla }\end{array}$ & $\begin{array}{l}\text { Polyarthra } \\
\text { trigla egg. } \\
\text { attached }\end{array}$ & $\begin{array}{l}\text { Syuchaeta } \\
\text { sp. }\end{array}$ & $\begin{array}{c}\text { Trichocerea } \\
\text { capueina }\end{array}$ \\
\hline $7 / 5$ & $476,06.1$ & $1,163,712$ & $15 \mathrm{~S}, \mathrm{BSS}$ & …......... & 528,960 & . $\quad \cdots$ \\
\hline $7 / 6$ & 264,480 & 317,376 & 211,584 & $\ldots$ & 19,200 & $. \quad \ldots . \ldots$ \\
\hline 7) 7 & 105,792 & 317,376 & 528,960 & .............. & $\ldots \ldots \ldots$ & $\ldots \ldots, \quad \ldots \ldots$ \\
\hline $7 / \mathrm{S}$ & 158,688 & $657,64 \mathrm{~S}$ & 740,544 & & & 000 \\
\hline $7 / 9$ & $211,5 \mathrm{~S} .1$ & 264,480 & 899,232 & 3,200 & 12,500 & 3,200 \\
\hline
\end{tabular}


Table 4.-Plankton Organisms Per Cubic Meter in Stockton Channel, DAILY SERIES IN 1913-(Continued)

\begin{tabular}{|c|c|c|c|c|c|c|}
\hline 1913 & $\begin{array}{l}\text { Keratella } \\
\text { egg, free }\end{array}$ & $\begin{array}{l}\text { Keratella } \\
\text { quadrata }\end{array}$ & $\begin{array}{c}\text { Polyarthra } \\
\text { trigla }\end{array}$ & $\begin{array}{l}\text { Polyarthra } \\
\text { trigla egg. } \\
\text { attached }\end{array}$ & $\begin{array}{c}\text { Synchaeta } \\
\text { sp. }\end{array}$ & $\begin{array}{c}\text { Trichocerca } \\
\text { capucina }\end{array}$ \\
\hline $7 / 10$ & 317,376 & 528,960 & $1,745,568$ & 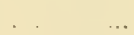 & & \\
\hline $7 / 11$ & 370,272 & 687,648 & $1,798,464$ & & & \\
\hline $7 / 12$ & 657,648 & $1,322,400$ & $1,692,672$ & 3,200 & 3,200 & 3,200 \\
\hline $7 / 13$ & & $1,110, \$ 16$ & $1,004,256$ & & & \\
\hline $7 / 14$ & 3,200 & $1,057,920$ & $1,163,712$ & . & . & \\
\hline $7 / 15$ & & $1,110,816$ & 370,272 & …...... & 3,200 & \\
\hline $7 / 16$ & & 952,128 & 687,648 & & 6,400 & \\
\hline $7 / 17$ & $211,58 t$ & 687,618 & 38,100 & $\ldots$ & ..... & 3,200 \\
\hline $7 / 18$ & 105,792 & $1,322,400$ & 76,800 & $\ldots$ & ….... $\quad \ldots$ & \\
\hline $7 / 19$ & 105,792 & 846,336 & 158,688 & & .......... & \\
\hline$\vec{r} / 20$ & 105,792 & $1,0.57,020$ & 89,600 & & & \\
\hline $7 / 21$ & 158.685 & 846,336 & 158,688 & & & \\
\hline $7 / 22$ & 211,581 & $1,110,816$ & 101,400 & & 12,800 & \\
\hline $7 / 23$ & & $1,692,672$ & 134,400 & & 6,400 & \\
\hline $7 / 24$ & 105,792 & $1,163,712$ & 211,581 & & 3,200 & \\
\hline $7 / 25$ & 3,200 & $2,010,04 \mathrm{~S}$ & 476,064 & & & \\
\hline $7 / 26$ & & $2,062,944$ & 634,752 & & & \\
\hline $7 / 27$ & $158,68 \mathrm{~S}$ & $5,554,0 \mathrm{SO}$ & $1,216,608$ & 3,200 & 6,400 & \\
\hline $7 / 28$ & 3,200 & $2,644,800$ & $5 \$ 1,856$ & & 6,400 & \\
\hline $7 / 29$ & 3,200 & $4,601,052$ & 846,336 & 3,200 & & 3,200 \\
\hline $7 / 30$ & 3,200 & $2,010,048$ & 952,128 & & & \\
\hline $7 / 31$ & 105,792 & $2,856,384$ & 846,336 & & 6,400 & \\
\hline $8 / 1$ & & $2,909,280$ & 793,410 & & & \\
\hline $8 / 2$ & 105,792 & $1,110,816$ & 793,440 & 3,200 & & \\
\hline s/ 3 & & 423,168 & 264,480 & 6,100 & & \\
\hline $5 / 4$ & . & $1,057,920$ & 264,480 & . & & \\
\hline 1913 & $\begin{array}{c}\text { Trichocerca } \\
\text { iernis }\end{array}$ & $\begin{array}{c}\text { Total } \\
\text { Ploima }\end{array}$ & $\begin{array}{c}\text { Total } \\
\text { Rotifera }\end{array}$ & $\begin{array}{c}\text { Bosmina } \\
\text { longirostris }\end{array}$ & Sida & $\begin{array}{c}\text { Total } \\
\text { Cladocera }\end{array}$ \\
\hline $7 / 5$ & 19,200 & $7,111,968$ & $7,289,956$ & & 6,400 & 6,400 \\
\hline $7 / 6$ & 19,200 & $3,229,664$ & $3,466,848$ & ......... & 32,000 & 32,000 \\
\hline $7 / 7$ & 158,688 & $3,590,336$ & $3,606,336$ & & 6,400 & 6,400 \\
\hline $7 / 8$ & 317,376 & $5,921,656$ & $5,940,856$ & & .. & 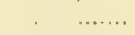 \\
\hline $7 / 9$ & 211,581 & $5,127,720$ & $5,137,320$ & & & \\
\hline $7 / 10$ & 370,272 & $6,415,024$ & $6,470,624$ & & 6,400 & 6,400 \\
\hline $7 / 11$ & 476,061 & $6,884,384$ & $6,900,384$ & & 12,800 & 12,800 \\
\hline $7 / 12$ & 317.376 & $8,578,056$ & $8,792,840$ & & 6,400 & 6,400 \\
\hline $7 / 13$ & 264,480 & $6,113,344$ & $6,309,132$ & & 12,800 & 12,800 \\
\hline $7 / 14$ & 105,792 & $5,940,352$ & $6,367,720$ & & & \\
\hline $7 / 15$ & ....... & $4,252,384$ & $4,261,984$ & & 6,400 & 6,400 \\
\hline $7 / 16$ & 6,400 & $4,348,576$ & $4,386,976$ & & & \\
\hline $7 / 17$ & 3,200 & $3, \pm 19,552$ & $4,001,408$ & 6,400 & 6,400 & $12, \mathrm{~S} 00$ \\
\hline $7 / 18$ & 6,400 & $5,557,088$ & $5,566,688$ & ........ & 12,800 & 12,800 \\
\hline $7 / 19$ & 6,400 & $3,390,048$ & $3,548,736$ & & 12,800 & 12,800 \\
\hline $7 / 20$ & 12,800 & $3,373,856$ & $3,383,156$ & 12,800 & r & 12,800 \\
\hline $7 / 21$ & 158,688 & $3,588,832$ & $3,608,032$ & & & \\
\hline $7 / 22$ & 6,400 & $4,966,136$ & $4,988,536$ & 12,800 & 12,800 & 25,600 \\
\hline $7 / 23$ & .. . & $3,428,256$ & $3,745,632$ & & & \\
\hline $7 / 24$ & & $3,010,176$ & $3,125,568$ & & 12,800 & 12.800 \\
\hline $7 / 25$ & 158,688 & $6,069,000$ & $6,181,192$ & & 6,400 & 6,400 \\
\hline $7 / 26$ & 12.800 & $5,972,352$ & $6,010,752$ & & 6,400 & 6,400 \\
\hline $7 / 27$ & 3,200 & $15,098,656$ & $15,230,048$ & & 6,400 & 6,400 \\
\hline $7 / 28$ & $6, \pm 00$ & $7,241,956$ & $7.453,440$ & & & \\
\hline $7 / 29$ & 6,400 & $8,434,368$ & $8,540,160$ & & & \\
\hline $7 / 30$ & 19,200 & $4,255,784$ & $4,271,754$ & 6,400 & & 6,400 \\
\hline $7 / 31$ & 25,600 & $5,384,096$ & $5,403,296$ & & & \\
\hline $8 / 1$ & 25,600 & $5,816,864$ & $5,978,752$ & & & \\
\hline $8 / 2$ & 19,200 & $3,639,032$ & $3,680,632$ & 6,400 & 6,400 & 12,800 \\
\hline $8 / 3$ & 12,800 & $1,95 \overline{8}, 656$ & $2,133,314$ & 6,400 & & 6,400 \\
\hline $8 / 4$ & 6,400 & $2,859,085$ & $2,971,280$ & , n........ & 6,400 & 6,400 \\
\hline
\end{tabular}


'Table 4,-Plankton Organisms l'me Cubic Meter in Stockton Channel, DatLY SEntes iN 1913 - (Comeluded)

\begin{tabular}{|c|c|c|c|c|c|c|}
\hline 1913 & Cyclops & Nauplius & $\begin{array}{c}\text { Total } \\
\text { Coprpoda }\end{array}$ & $\begin{array}{c}\text { Total } \\
\text { Entonostraca }\end{array}$ & Glochidia & $\begin{array}{c}\text { Total } \\
\text { Organisms }\end{array}$ \\
\hline $7 / 5$ & $26,8,800$ & $1,057,920$ & $1,326,720$ & $1,333,120$ & & $36,9+6,240$ \\
\hline $7 / 6$ & $3: 32,800$ & 631,752 & 9677,552 & 999,552 & & $27,692,64 \mathrm{~s}$ \\
\hline $7 / 7$ & 317,376 & - $\quad 528,960$ & 846,3336 & $8.52,736$ & & $32,601,215$ \\
\hline i) 8 & 317,376 & 793,440 & $1,110,816$ & $1,110,51+j$ & $\ldots$ & $40,65,5,720$ \\
\hline 7) 9 & 370,272 & $1,163,712$ & $1,533,9,9.1$ & $1,533,984$ & & $32,9: 2,824$ \\
\hline $7 / 10$ & $2: 30,400$ & 793,440 & $1,023,840$ & $1,0.30,240$ & & $41,171,-110$ \\
\hline $7 / 11$ & $35 \mathrm{~S}, 400$ & 740,544 & $1,09,1,944$ & $1,111,744$ & & $40,0.83,104$ \\
\hline $7 / 12$ & $740,5+4$ & 856,336 & $1,5 \mathrm{~S} 6 \mathrm{i}, \mathrm{S} \mathrm{SO}$ & $1,593,2 \times 0$ & & $49,15: 3,984$ \\
\hline $7 / 13$ & 265,500 & $1,375,296$ & $1,6 \cdot 1+, 096$ & $1,6.56,596$ & . & $60,7,7,184$ \\
\hline $7 / 11$ & $6 \mathrm{ST}, 6+\mathrm{S}$ & $1,428,192$ & $2,115,840$ & $2,115,8+0$ & & $79,601,581$ \\
\hline $7 / 15$ & 476,064 & $1,057,920$ & $1,533,984$ & $1,540,354$ & & $69,792,032$ \\
\hline $7 / 16$ & 454,400 & $793,+40$ & $1,247,5.10$ & $1,247,540$ & & $78.756,792$ \\
\hline $7 \quad 17$ & $26,4,480$ & $740,5+4$ & $1,005,021$ & $1,017,524$ & & $78,7 \pm 6,464$ \\
\hline $7 / 18$ & 581,556 & $5 \$ 1,856$ & $1,16: 3,712$ & $1,176,512$ & ( & $55,(0.30,208$ \\
\hline 7,19 & $6 \times 7,6.15$ & 740,544 & $1,426,19^{2}$ & $1,440,992$ & $6, \pm 00$ & $50,284,514$ \\
\hline 720 & 581,856 & 899,232 & $1,481,0 \$ s$ & $1,493,8,5$ & . . & $25,135,592$ \\
\hline $7 / 21$ & $5 \$ 1,856$ & $1,745,568$ & $2,327,424$ & $2,327,424$ & & $34,609,058$ \\
\hline $7 / 22$ & $3,173,760$ & $1,692,672$ & $4,866,4: 32$ & $4,892,032$ & 3,200 & $41,632,472$ \\
\hline $7 / 2: 3$ & 264,450 & $1,110,81 \mathrm{i}$ & $1,375,296$ & $1,375,296$ & & $29,064,214$ \\
\hline 724 & $26,4,480$ & 899,2332 & $1,170,112$ & $1,182,912$ & & $33,557,952$ \\
\hline 725 & $423,16 \mathrm{~s}$ & 952,125 & $1,375,296$ & $1,3,41,696$ & & $36,857,976$ \\
\hline 7.26 & 264,450 & 657,645 & 952,125 & $9.5,528$ & & $53,155,60^{\circ}$ \\
\hline T 27 & 176,0 it & 952.128 & $1,428,192$ & $1,434,592$ & & $4.5,123,5 \mathrm{St}$ \\
\hline 7.24 & $5: 28,960$ & 793,440 & $1,322,400$ & $1,322,400$ & & 53.290 .774 \\
\hline $7 / 29$ & 634,752 & $1,269,504$ & $1,904,256$ & $1,904.256$ & 3,200 & $52,735,424$ \\
\hline $7 / 30$ & 317,376 & 740,541 & $1,057,920$ & $1,064,320$ & 3,200 & $35,0,58,136$ \\
\hline $7 / 31$ & 423,165 & $581,5.56$ & $1,005,024$ & $1.005,024$ & 6,400 & $42,199,520$ \\
\hline$s / 1$ & $516,3: 36$ & $\$ 99,232$ & $1,7+5,568$ & $1,745,56 \mathrm{~s}$ & & $44,1 \mathrm{~S} 0,76 \mathrm{~s}$ \\
\hline 812 & 581,856 & $1,322,400$ & $1,904,256$ & $1,917,056$ & & $39,7+9,616$ \\
\hline $5 / 3$ & 264,480 & 846,336 & $1,110,816$ & $1,117.216$ & & $40,419,936$ \\
\hline $8 / 4$ & 317,376 & $1,163,712$ & $1,4 \mathrm{~s} 1,0 \mathrm{SS}$ & $1,487,488$ & ........... & $40,376,336$ \\
\hline
\end{tabular}


Table 5.-Plankton Organisms Per Cubic Meter in Simith's Canal, Hourly Series in 1913

\begin{tabular}{|c|c|c|c|c|c|c|}
\hline $\begin{array}{l}1913 \\
8 / 11\end{array}$ & $\begin{array}{l}\text { Lamprocystis } \\
\text { sp. }\end{array}$ & $\begin{array}{c}\text { Total } \\
\text { Bacteriaceae }\end{array}$ & $\begin{array}{l}\text { Anabaena } \\
\text { sp. }\end{array}$ & $\begin{array}{c}\text { Aphanocapsa } \\
\text { sp. }\end{array}$ & $\begin{array}{c}\text { Coelosphaerium } \\
\text { kutzingianum }\end{array}$ & $\begin{array}{c}\text { Gloeoeapsa } \\
\text { conglomerata }\end{array}$ \\
\hline 7 A.M. & & & 105,792 & 264,480 & & 52,596 \\
\hline S A.M. & $\cdots$ & & 343,821 & $15 \mathrm{~S}, 6 \mathrm{SS}$ & & 6,400 \\
\hline 9 A.M. & 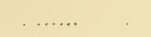 & & 52,596 & 6,400 & $\therefore \ldots \ldots$ & \\
\hline 10 A.M. & & $\cdots \cdot$ & 396,720 & 52,896 & & 105,792 \\
\hline $11 \mathrm{~A} . \mathrm{M}$. & & & 449,616 & $211,5 \mathrm{~s} 4$ & 52,896 & 52,896 \\
\hline $12 \mathrm{M.}$ & & $\cdots$ & 449.616 & 343,824 & & 6,400 \\
\hline 1 P.M. & .... & .... & 502,512 & 158,688 & & 105,792 \\
\hline 2 P.M. & & & $1,163,712$ & 105,792 & & 52,896 \\
\hline 3 P.м. & & & $1,719,120$ & 502,512 & & 52,896 \\
\hline 4 P.MI. & 52,896 & 52,896 & $1,666,224$ & 211,554 & . & $52,890^{\circ}$ \\
\hline 5 Р.M. & 52,896 & 52,896 & $3,861,408$ & 158,689 & & \\
\hline 5:48 р.м. & & & $3,967,200$ & 105,792 & & \\
\hline $6: 40$ P.AI. & 6,400 & 6.400 & $5,236,70 \frac{1}{2}$ & 155,655 & 22,896 & 155,658 \\
\hline $\begin{array}{l}1913 \\
8 / 11\end{array}$ & $\begin{array}{c}\text { Glococapsa } \\
\text { sp. }\end{array}$ & $\begin{array}{l}\text { Gomphosphaera } \\
\text { aponina }\end{array}$ & $\begin{array}{l}\text { Mierocystis } \\
\text { sp. }\end{array}$ & $\begin{array}{l}\text { Nostoc } \\
\text { sp. }\end{array}$ & $\begin{array}{l}\text { Oscillatoria } \\
\text { sp. }\end{array}$ & $\begin{array}{c}\text { Oscillatoria } \\
\text { tenuis }\end{array}$ \\
\hline 7 A.M. & $343, \Omega 24$ & 52,896 & $211,50 \mathrm{~S}$ & 211,581 & & \\
\hline 8 A.M. & 343,524 & & $3+3,524$ & 52.896 & & \\
\hline 9 A.MI. & 261,480 & & 449,616 & 52.896 & & \\
\hline 10 A.M. & 343,524 & & $158,6 \times S$ & 396,720 & & \\
\hline 11 A.M. & 343,824 & & 105,792 & 105,792 & 158,685 & . \\
\hline $12 \mathrm{~m}$ & 158,658 & 159,688 & 661,200 & 459,616 & & \\
\hline 1 P.M. & 766,992 & & 264,480 & 52,896 & & . \\
\hline 2 р.и. & 661,200 & 15.658 & $3+3,82 \pm$ & $3,120,864$ & & \\
\hline 3 р.и. & 608,304 & & $343, \times 24$ & $4,522,60 \mathrm{~s}$ & & 105,792 \\
\hline \pm P.M. & 605,304 & & 396,720 & $5,448,288$ & & 52.896 \\
\hline 5 Р.з1. & 925,680 & & 502,512 & $3.91+, 304$ & $4+9,610$ & एट. \\
\hline $5: 4 S$ P.M. & 1. 714,096 & & 502,512 & $2,697,696$ & 502,512 & \\
\hline $6: 10$ P.И. & 925,680 & $105,7 !+2$ & 449,616 & $3,306,000$ & $26+480$ & \\
\hline $\begin{array}{l}1913 \\
8 / 11\end{array}$ & $\begin{array}{l}\text { Phormidium } \\
\text { foveolarum }\end{array}$ & $\begin{array}{l}\text { Stigonema } \\
\text { ocellatum }\end{array}$ & $\begin{array}{c}\text { Total } \\
\text { Schizophyceae }\end{array}$ & $\begin{array}{l}\text { Actinastrum } \\
\text { hantzschii }\end{array}$ & $\begin{array}{l}\text { Actinastrum } \\
\text { hantzsehii } \\
\text { (Jarge) }\end{array}$ & $\begin{array}{l}\text { Coelastrum } \\
\text { microporum }\end{array}$ \\
\hline 7 A.M. & 211,584 & & $1,454,644$ & & 105,792 & $10.5,792$ \\
\hline 8 A.MI. & $158,68 \mathrm{~s}$ & 52.596 & $1,461,0+0$ & & 158,698 & 105,792 \\
\hline 9 A.M. & 158,688 & & 944,976 & & $26+4<0$ & 105,792 \\
\hline 10 A.M. & & & $1,454,6+0$ & & $3+3,821$ & 52,896 \\
\hline 11 A.M. & 52,896 & & $1,533,984$ & 52,596 & 502,512 & 105,792 \\
\hline $12 \mathrm{M}$. & 264,450 & 52,596 & $2,5+5,40 \mathrm{~s}$ & 6,400 & 211,584 & 158,685 \\
\hline 1 P.M. & $26+480$ & & $2,115,5+0$ & 52,896 & 449,616 & 52,896 \\
\hline 2 P.M. & 343,524 & & $5,871,456$ & 52,896 & $3+3,824$ & 6,400 \\
\hline 3 P.M. & 211,584 & . & $8,096,6 \pm 0$ & 52,896 & 661,200 & 19,200 \\
\hline 4 р.м. & 264,480 & & $8,701,394$ & 52,896 & 264,450 & 158,655 \\
\hline 5 р.м. & 264,450 & 6,400 & $10,0 \$ 3,0 \mathrm{~S} 5$ & & 396,720 & 52,896 \\
\hline $5: 48$ P.M. & & 52,896 & $8,542,704$ & 52,896 & 502,512 & 211,584 \\
\hline $6: 40$ P.M. & & & $12,0+40,250$ & 6,400 & 608,304 & $26-1,4 \$ 0$ \\
\hline $\begin{array}{l}1913 \\
8 / 11\end{array}$ & $\begin{array}{l}\text { Pediastrum } \\
\text { boryanum }\end{array}$ & $\begin{array}{l}\text { Pediastrum } \\
\text { duplex }\end{array}$ & $\begin{array}{l}\text { Pediastrum } \\
\text { simplex }\end{array}$ & $\begin{array}{c}\text { Raphidium } \\
\text { polymorphum }\end{array}$ & $\begin{array}{c}\text { Raphidium } \\
\text { pyrenogerutm }\end{array}$ & $\begin{array}{l}\text { Scenedesmus } \\
\text { obliquus }\end{array}$ \\
\hline 7 A.M. & & $+49,616$ & 6,400 & & & 52,596 \\
\hline S A.M. & 12,800 & 766,992 & $52,890^{\circ}$ & & & $264,4>0$ \\
\hline 9 А.ม. & & 396,720 & & & & 52,896 \\
\hline 10 A.M. & & 449,616 & 105,792 & & & 211,554 \\
\hline $11 \mathrm{~A} . \mathrm{M}$. & & 661,200 & 158,689 & & & 52,896 \\
\hline $12 \mathrm{k.}$ & 12,800 & 605,304 & $52, \$ 96$ & & & \\
\hline 1 P.M. & 52,896 & $1,216,608$ & 6,400 & & 52,836 & 52,896 \\
\hline 2 р...1. & 19,200 & $1,163,712$ & 52,596 & 105,792 & & 34,824 \\
\hline 3 P.M. & 12,800 & $1,110,816$ & 105,792 & 52,890 & & $3+3,824$ \\
\hline t P.MI. & 105,792 & (0.6) & $52<06$ & 6,400 & & 211.584 \\
\hline $50 \%$ & $1.58,659$ & $1, \therefore \cdots n<1$ & $12 \mathrm{k00}$ & & & 264,480 \\
\hline $5: 18$ Р & 105,792 & $1+1, \mathrm{RSS}$ & 25.600 & & & $158,68 \mathrm{~s}$ \\
\hline $6: 40$ P.M. & 6,400 & 1211,605 & 6.409 & $52,59 \mathrm{i}$ & 105.792 & $15 \mathrm{~S}, 6 \mathrm{SS}$ \\
\hline
\end{tabular}


Tarle 5.-Plankton Organisme P'rr Cubic Meter to Simtís Cayal, IIOURLY SERHE IN 1913-(Continued)

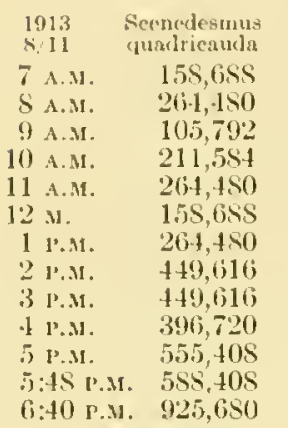

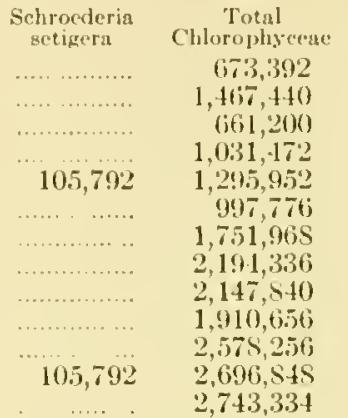

\begin{tabular}{|c|c|}
\hline $\begin{array}{l}\text { Astcrionclla } \\
\text { gracillinia }\end{array}$ & $\begin{array}{c}\text { Amphiprora } \\
\text { alata }\end{array}$ \\
\hline 52,596 & 15S,liss \\
\hline & $261,-180$ \\
\hline 52,506 & $5(12,512$ \\
\hline & 5()$^{2}, 512$ \\
\hline & $50^{\circ}, 512$ \\
\hline 1 & $211,5 \mathrm{4}$ \\
\hline$\cdots$ & 343,524 \\
\hline .. & $211,5 \$ 4$ \\
\hline & $211,5 \times 4$ \\
\hline 52,896 & $10.5,792$ \\
\hline 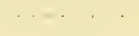 & 52,896 \\
\hline & $15 \mathrm{~s}$, \\
\hline & 261, \\
\hline
\end{tabular}

Lacillaria paracloxa 264,480

211,581

$15 \mathrm{~S}, 6 \mathrm{SS}$

211,584

60,500

343,824

211,581

$396,-20$

449,616

343,824

155,658

$3-13,824$

$15 \mathrm{~S}, 6 \mathrm{SS}$

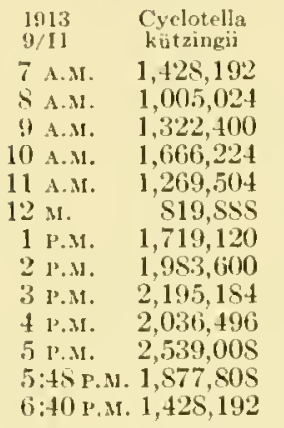

Cyclotella

Cymbella

perculata

$3,508,572$

$4,311,024$

$4,178,784$

$3,464,698$

$2,750,592$

$2,697,696$

$3,623,376$

$4,178,784$

$2,856,384$

$3,702,720$

$4.072,992$

$+, 072,992$

$5,395,392$

\begin{tabular}{|c|c|}
\hline $\begin{array}{l}1913 \\
8 / 11\end{array}$ & $\begin{array}{l}\text { Fragillaria } \\
\text { capucina }\end{array}$ \\
\hline 7 A.M. & 6,400 \\
\hline S A.M. & $\cdots$ \\
\hline $\begin{array}{l}9 \text { A.M. } \\
10 \text { A.M. }\end{array}$ & \\
\hline $\begin{array}{l}10 \mathrm{A.M} \text {. } \\
11 \mathrm{A.M} .\end{array}$ & \\
\hline $12 \mathrm{M}$ & \\
\hline 1 P.M. & \\
\hline 2 P.M. & 52,896 \\
\hline 3 Р.м. & 6,400 \\
\hline 4 P.M. & ... $\quad \ldots .$. \\
\hline 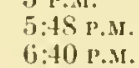 & 52,896 \\
\hline
\end{tabular}

Gomphonema

constrictum

Gyrosigma

Cymbella

cymbiformis

Cymbella

Epithemia ocellata

…............

$$
6,400
$$

minidia

52,896

52,896

$6,+100$

52,596

52,596

52,896

105,792

$52, \$ 96$

$\begin{array}{lr}\ldots \ldots \ldots \ldots & 6,400 \\ \ldots \ldots \ldots \ldots \ldots & \\ \ldots \ldots \ldots \ldots \ldots \ldots & 12,800\end{array}$

\[ \ldots \ldots \]
$\ldots \ldots$
$\ldots$
$\ldots$
$\ldots \ldots$
$\ldots \ldots$
$\ldots 2, \$ 96$

Gyrosigma Gyrosigma

Melosira 52,896

$\begin{array}{lll}52,596 & 155,658 & 10,790,754 \\ 52,596 & 343,824 & 10,526,304\end{array}$

........... $52,896 \quad 343,82$

$15 \mathrm{~S}, 6 \mathrm{SS} \quad \mathrm{S}, 436,912$

$3 \cdot 13,824 \quad 8,198,880$

$15 \$, 68 \mathrm{~S} \quad \$, 489,808$

$52,896^{\circ}$

52,896

343,524

$9,56,5,38$

$211.5 \mathrm{St}$ 449,616

$10.5,792$

$15 \mathrm{~s}, 6 \mathrm{SS}$

819,555

6,400

52,896

52,896

52, 596

52,596

396,720

766,992

$925,6 \mathrm{SO}$

$1,0.57,920$

105,702

661,200

\begin{tabular}{|c|c|c|}
\hline $\begin{array}{l}191.3 \\
8 / 11\end{array}$ & $\begin{array}{l}\text { Melosira } \\
\text { varians }\end{array}$ & $\begin{array}{l}\text { Navicula } \\
\text { alpestris }\end{array}$ \\
\hline 7 A.M. & & \\
\hline A A.M. & & 6,400 \\
\hline 9 А.М. & & \\
\hline A.M. & $5^{2}, 896$ & 105,792 \\
\hline A.M. & 52,896 & 12,800 \\
\hline $2 \mathrm{M}$ & .... & 52,896 \\
\hline 1 P... & . . ........... & 12,50 \\
\hline $\begin{array}{l}2 \text { р..и. } \\
3 \text { ғ.м. }\end{array}$ & & \\
\hline 1 t?... & & $158,6 \mathrm{~s}$ \\
\hline 5 P... & 6,400 & $10.5,79$ \\
\hline $5: 48 \mathrm{P}$. & & 158,68 \\
\hline$: 40 \mathrm{P} . \mathrm{.}$ & & $52, \mathrm{~S}$ \\
\hline
\end{tabular}

Navicula

bacillum

1.58, GSS

105,792

Navicula

didyma

52,896

$15 \$, 6 \mathrm{~s}$

52,896

Navicula

12,6 f 8,592

$19,853,104$

$20,655,888$

$24,067,690$

$34,990,704$

$31,737,600$

$35,563,458$

Navicula

$1,26,9,504$

$1,163,712$

12,800

766,992

$1,005,024$

$1,163,712$

\$19,5SS

105,792

872,784

$1,163,712$

872,784

$1,269,504$

$1,5,86,8 \times 0$

$1,216,608$

105,792

52,896 
Table 5.-Plankton Organisms Per Cubic Mejer in Smith's Canal, Hodrly SERIES IN 1913--(Continued)

\begin{tabular}{|c|c|c|c|c|c|c|}
\hline $\begin{array}{l}1913 \\
8 / 11\end{array}$ & $\begin{array}{l}\text { Navicula } \\
\text { viridis }\end{array}$ & $\begin{array}{l}\text { Nitzschia } \\
\text { acicularis }\end{array}$ & $\begin{array}{l}\text { Nitzschia } \\
\text { signa }\end{array}$ & $\begin{array}{c}\text { Nitzschia } \\
\text { vernicularis }\end{array}$ & $\begin{array}{l}\text { Pleurostauron } \\
\text { parvulun }\end{array}$ & $\begin{array}{c}\text { Stauroneis } \\
\text { phoenicenteron }\end{array}$ \\
\hline$T$ A.M. & & 449,616 & 52,896 & & & \\
\hline S A.M. & & 502,512 & 52,896 & 52,896 & & \\
\hline 9 A.MI. & & 343,824 & 158,688 & 52,896 & & \\
\hline 10 A.M. & ....... & 158,688 & & 6,400 & 52,896 & \\
\hline 11 A.M. & & 396,720 & 343,824 & & & \\
\hline $12 \mathrm{M.}$ & & 105,792 & $15 S, 68 S$ & & & \\
\hline 1 P.M. & ...... & 264,480 & & & & 52,896 \\
\hline 2 P.M. & & 502,512 & $158,68 \mathrm{~S}$ & 52,896 & 52,896 & \\
\hline 3 P.M. & $\cdots$ & 661,200 & 59,296 & 105,792 & 105,792 & \\
\hline 4 P.M. & & 343,824 & $158,6 \mathrm{SS}$ & 52,896 & tom, & \\
\hline 5 P.M. & & 572,784 & 211,584 & 52,596 & 52,896 & 52,896 \\
\hline $5: 48$ P.M. & 6,400 & $1,322,400$ & & & 52,896 & \\
\hline $6: 40$ P.M. & 6,400 & $1,877,80 \mathrm{~S}$ & 158,688 & $\ldots$ & 52,896 & 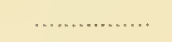 \\
\hline $\begin{array}{l}1913 \\
8 / 11\end{array}$ & $\begin{array}{l}\text { Surirella } \\
\text { sp. }\end{array}$ & $\begin{array}{l}\text { Synedra } \\
\text { ulna }\end{array}$ & $\begin{array}{l}\text { Synedra } \\
\text { radians }\end{array}$ & $\begin{array}{c}\text { Total } \\
\text { Bacillariaceae }\end{array}$ & $\begin{array}{c}\text { Closterium } \\
\text { accuminatum }\end{array}$ & $\begin{array}{l}\text { Closterium } \\
\text { acerosum }\end{array}$ \\
\hline 7 A.M. & 158,685 & 158,688 & 343,824 & $29,525,024$ & 6,400 & 6,400 \\
\hline S A.M. & 343,524 & 211 & $158,6 S 8$ & $17,451,424$ & 6,400 & 6,400 \\
\hline 9 А.M. & 211,584 & 396,720 & 264,480 & $17,289, \mathrm{~S} 44$ & ........... & 6,400 \\
\hline 10 A.M. & 60,500 & 608,304 & 264,480 & $17,866,704$ & & \\
\hline 11 A.M. & 211,584 & 396,720 & 555,408 & $17,179,664$ & & 6,400 \\
\hline $12 \mathrm{M}$ & 80,000 & 343,824 & 105,792 & $15,688,528$ & & \\
\hline 1 P.M. & 15 & 158,688 & $50^{2}$ & $21,719,160$ & & \\
\hline 2 P.M. & 396,720 & $211,5 S 4$ & 714,096 & $31,129,904$ & & 19,200 \\
\hline 3 P.u. & 608,304 & 211,584 & 502,512 & $31,307,184$ & & 25,600 \\
\hline 4 P.M. & $50^{\circ}, 512$ & 52 & 714 & 34 & & 6,400 \\
\hline 5 P.м. & 449 & 10 & 26 & 47, & & 52,896 \\
\hline 5:48 P.M. & . 396,720 & 396,720 & 555,408 & $44,121,664$ & ................... & 12,500 \\
\hline 6:40 Р.M. & . 396,720 & 714,096 & $1,375,296$ & $51,818,032$ & 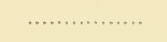 & . \\
\hline $\begin{array}{l}1913 \\
8 / 11\end{array}$ & $\begin{array}{l}\text { Closterium } \\
\text { rostratum }\end{array}$ & $\begin{array}{l}\text { Mougcotia } \\
\text { sp. }\end{array}$ & Staurastrum & $\begin{array}{c}\text { Staurastrum } \\
\text { sp. }\end{array}$ & $\begin{array}{c}\text { Total } \\
\text { Conjugatae }\end{array}$ & $\begin{array}{c}\text { Total } \\
\text { Chlorophyll } \\
\text { bearing }\end{array}$ \\
\hline 7 A.M. & 6,400 & 264,480 & 6,400 & $52, \$ 96$ & 342,966 & $35,677,850$ \\
\hline S P.M. & 6,400 & & 52,896 & & 680,400 & 7,312 \\
\hline 9 A.M. & & & 6,400 & & 621,104 & $24,220,324$ \\
\hline 10 A.M. & 52,896 & 608,304 & 52,896 & ………… & 714,096 & $25,405,888$ \\
\hline 11 A.M. & 6,400 & 84 & 105,792 & & 330,176 & $23,936,704$ \\
\hline $12 \mathrm{~N}$. & & 661,200 & 12,800 & 52,896 & 726,896 & $25,301,712$ \\
\hline 1 P.M. & 6,400 & 766,992 & 52,896 & & 826,285 & $29,217,400$ \\
\hline 2 P.м. & 52,896 & 34 & 264,480 & $x^{-}$ & 528,960 & $42,512,800$ \\
\hline 3 P.M. & 52,596 & $1,057,920$ & 105 & ........ & $1,242,208$ & 7,248 \\
\hline 4 P.M. & 52,896 & 872,784 & $15 \mathrm{~S}, 6 \mathrm{SS}$ & & $1,090,758$ & $49,945,672$ \\
\hline 5 P.M. & 105,792 & $60 \mathrm{~s}$ & 52,896 & & 192 & $65,839,858$ \\
\hline $5: 48$ P.M. & 52,896 & 1,11 & 158,688 & & $1,335,200$ & $60,499,184$ \\
\hline $6: 40$ P.M. & & $2,059,392$ & 105,792 & 52,896 & $2,248,080$ & $73,644,689$ \\
\hline $\begin{array}{l}1913 \\
8 / 11\end{array}$ & $\begin{array}{l}\text { Total } \\
\text { Algae }\end{array}$ & $\begin{array}{l}\text { Cercomonas } \\
\text { crassicauda }\end{array}$ & $\begin{array}{c}\text { Cercomonas } \\
\text { sp. }\end{array}$ & $\begin{array}{c}\text { Chlamydomonas } \\
\text { sp. }\end{array}$ & $\begin{array}{l}\text { Chromulina } \\
\text { sp. }\end{array}$ & $\begin{array}{l}\text { Eudorina } \\
\text { elegaus }\end{array}$ \\
\hline 7 A.M. 3 & $31,996,026$ & & .............. & & $2,750,592$ & 211,584 \\
\hline S A.M. 2 & $21,060,304$ & & & (n......... & $2,539,008$ & 343,824 \\
\hline 9 A.M. 1 & $19,557,124$ & & & & $2,750,592$ & 396,720 \\
\hline 10 A.M. 2 & $21,066,912$ & & & 211,584 & $2,591,904$ & 396,720 \\
\hline 11 A.M. 2 & $20,339,776$ & $\cdots . .$. & 52,896 & 105,792 & $1,719,120$ & 105,792 \\
\hline $12 \mathrm{M}$. & $19,95 \mathrm{~S}, 608$ & & 52,896 & & $3,147,312$ & 502,512 \\
\hline 1 P.M. 2 & $26,413,256$ & 52,896 & .............. & ...... & $1,719,120$ & 211,584 \\
\hline 2 Р.м. 3 & $39,724,656$ & 52,896 & . & .............. & $1,877,808$ & 396,720 \\
\hline 3 P.M. & $42,793,872$ & & & & $2,142,285$ & $555,40 \mathrm{~S}$ \\
\hline 4 P.M. 4 & $46,524,776$ & 96 & & & $1,824,912$ & 264,480 \\
\hline 5 P.M. 6 & 61,6 & 52,896 & 96 & 555,405 & $2,089,392$ & 608,304 \\
\hline 5:48Р.и. & & & 105,792 & 10 & 3,080 & 555,408 \\
\hline 6:40p.м.t & $6 S, S 56,096$ & $52, \$ 96$ & & 502,512 & $2,850,384$ & 343,824 \\
\hline
\end{tabular}


Table 5.-Plankton Organisus 1'er Cubic Meter in Simtis's Canal, Hovrly Series ix 1913-(Continued)

\begin{tabular}{|c|c|c|c|c|c|c|}
\hline $\begin{array}{l}1913 \\
s / 11\end{array}$ & $\begin{array}{c}\text { Euglena } \\
\text { viridis }\end{array}$ & $\begin{array}{c}\text { Goniurn } \\
\text { pectorale }\end{array}$ & $\begin{array}{l}\text { IIcmidinium } \\
\text { nasatum }\end{array}$ & $\begin{array}{c}\text { Mallomonas } \\
\text { sp. }\end{array}$ & $\begin{array}{l}\text { Pandorina } \\
\text { morum }\end{array}$ & $\begin{array}{l}\text { Periditium } \\
\text { cinctum }\end{array}$ \\
\hline TA.s. & & 6,400 & 201,480 & & 52,896 & \\
\hline S A.M. & 6,400 & & 105,792 & & 105,792 & 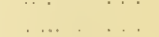 \\
\hline 9 A.M. & & & 502,512 & & 158,688 & \\
\hline $10 \mathrm{~A} . \mathrm{M}$. & $158,6,58$ & & $608,30 \cdot 1$ & & 52,596 & \\
\hline $11 \mathrm{~A} . \mathrm{M}$ & & & 396,720 & 52,896 & 396,720 & \\
\hline $12 \mathrm{~N}$ & 52,896 & 6,100 & 396,720 & & 264,480 & 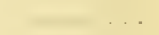 \\
\hline 1 P.M. & 52,896 & 12,800 & 158, (iss & & $158,6.55$ & \\
\hline 2 P.M. & & & 158,659 & & 6,400 & \\
\hline 3 P.M. & $\ldots \ldots \ldots$ & 52,896 & 105,792 & ….......... & 52,896 & $52, \$ 96$ \\
\hline 4 P.M. & ..... & & $+49,616$ & & 6,400 & \\
\hline 5 P.M. & & & $15 S, 6 \Omega S$ & 105,792 & 52,896 & 52,896 \\
\hline $5: 4 S$ P... & 105,792 & & 52,896 & ........ & 19,200 & \\
\hline $6: 40 \mathrm{p} \ldots \mathrm{M}$ & & …....... & $4 \cdot 19,616$ & ...... & & 52,896 \\
\hline $\begin{array}{l}1913 \\
8 / 11\end{array}$ & $\begin{array}{l}\text { Platydorina } \\
\text { caurlata }\end{array}$ & $\begin{array}{l}\text { Pleodorina } \\
\text { californica }\end{array}$ & $\begin{array}{l}\text { Pleodorina } \\
\text { illinoisensis }\end{array}$ & $\begin{array}{l}\text { Trachelomonas } \\
\text { cuchlora }\end{array}$ & $\begin{array}{l}\text { Trachelomonas } \\
\text { valvocina }\end{array}$ & $\begin{array}{c}\text { Total } \\
\text { Mastigophora }\end{array}$ \\
\hline 7 A.M. & 105,792 & 25,600 & & 52,896 & $211,5.54$ & $3,681,821$ \\
\hline S.A.M. & 12,800 & 52,596 & 6,400 & & 714,096 & $3,887,00 \mathrm{~s}$ \\
\hline 9 А.M. & 6,400 & 32,000 & $6,-400$ & 105,792 & $55.5,405$ & $4,663,200$ \\
\hline 10 А.м. & 54,400 & 52,896 & 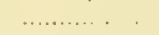 & 211,554 & 605,304 & $4,335,976$ \\
\hline $11 \mathrm{~A} . \mathrm{M}$. & 105,792 & 158,685 & $\cdots$ & & 449,616 & $3,596,92 \mathrm{~S}$ \\
\hline $12 \mathrm{M}$ & 105,792 & 60,800 & & & 502,512 & $5,343,104$ \\
\hline 1 P.M. & 105,792 & 67,200 & $\ldots$. & 52,896 & 211,554 & $2,804,1+4$ \\
\hline 2 p.M. & 19,200 & 158,688 & $\ldots$ & & 396,720 & $2,785,144$ \\
\hline 3 Р.M. & 48,000 & 32,000 & $\ldots$. & 105,792 & $555,40 \mathrm{~s}$ & $3,703,376$ \\
\hline 4 p.... & 32,000 & 25,600 & & 52,596 & 714,096 & $3,473,792$ \\
\hline 5 P.M. & 19,200 & 112,000 & 6,400 & $158,6 \mathrm{Ss}$ & 264,450 & $4,236,336$ \\
\hline 5:4S р.м. & & 54,400 & & & 555,408 & $3,50^{\circ}, 765$ \\
\hline $6: 40$ г.... & 12,800 & $4 S, 000$ & & $\ldots .$. & 925,680 & $4,794,992$ \\
\hline $\begin{array}{l}1913 \\
8 / 11\end{array}$ & $\begin{array}{l}\text { Amoeba } \\
\text { proteus }\end{array}$ & $\begin{array}{l}\text { Amoeba } \\
\text { radiosa }\end{array}$ & $\begin{array}{l}\text { Cyphoderia } \\
\text { ampulla }\end{array}$ & $\begin{array}{c}\text { Difflugia } \\
\text { pyriformis }\end{array}$ & $\begin{array}{l}\text { Hyalodiscus } \\
\text { sp. }\end{array}$ & $\begin{array}{l}\text { Microgromia } \\
\text { socialis }\end{array}$ \\
\hline 7 A.M. & $\cdots$ & $\ldots \ldots \ldots$ & …........... & 105,792 & & \\
\hline $\begin{array}{l}8 \text { А.м. } \\
9 \text { А.м. }\end{array}$ & $\ldots$ & 52,896 & 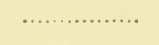 & $\cdots .$. & .. . & $10.5,792$ \\
\hline $\begin{array}{r}9 \text { А.м. } \\
10 \text { А.м. }\end{array}$ & … ……. & 52,590 & 52,596 & 52,896 & $\cdots \quad \ldots$ & \\
\hline 11 A.M. & …… & ………… & 52,896 & 105,792 & $\begin{array}{ll}\ldots & \ldots \\
\ldots & \ldots\end{array}$ & \\
\hline $12 \mathrm{M}$ & ……........ & .......... & & & $\ldots, \ldots$ & $\begin{array}{l}10.5,792 \\
105,792\end{array}$ \\
\hline 1 P.M. & ……… & $\ldots \ldots \ldots$ & & 52,896 & 105,792 & \\
\hline $\begin{array}{l}2 \text { р.м. } \\
3 \text { р... }\end{array}$ & ............... & ............. & …...... &.$\quad \ldots$ & 52,596 & 158,658 \\
\hline $\begin{array}{l}3 \text { р.м. } \\
4 \text { г.м. }\end{array}$ & ............. & 105,792 & $\begin{array}{l}\ldots \ldots \ldots \\
\ldots \ldots \ldots\end{array}$ & 52,896 & & 158,688 \\
\hline 5 P.M. & & ......... & & & 396,720 & \\
\hline $5: 4 S$ P.M. & - 396,720 & ….. $\quad \ldots$ & $\ldots$ & .. & 396,720 & 105,792 \\
\hline 6:40 r... & . 396,720 & ...... & .. & . & 925,650 & 52,896 \\
\hline $\begin{array}{l}1913 \\
8 / 11\end{array}$ & $\begin{array}{l}\text { Nebela } \\
\text { sp. }\end{array}$ & $\begin{array}{l}\text { Nuclearia } \\
\text { simplex }\end{array}$ & $\begin{array}{c}\text { Total } \\
\text { Rhizopoda }\end{array}$ & $\begin{array}{l}\text { Actinophrys } \\
\text { sol. }\end{array}$ & $\begin{array}{l}\text { Hetcrophrys } \\
\text { fockei }\end{array}$ & $\begin{array}{l}\text { Ileterophrys } \\
\text { sp. }\end{array}$ \\
\hline $7 \mathrm{A.M.}$ & & ............. & 158,688 & & 211,584 & \\
\hline 8 А.M. & & & $211,5 \mathrm{~S}+1$ & & $211,5 \mathrm{~S} 4$ & \\
\hline 9 А.м. & 105,792 & 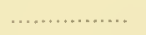 & 158,688 & 52,896 & 52,896 & . \\
\hline 10 A.M. & $\cdots$ & & 105,792 & 52596 & & $\ldots$ \\
\hline $\begin{array}{l}11 \mathrm{~A} . . \mathrm{H} . \\
12 \mathrm{M.}\end{array}$ & & $158,6 \mathrm{SS}$ & $\begin{array}{l}264,480 \\
264,480\end{array}$ & 52,896 & $\begin{array}{r}105,792 \\
52.596\end{array}$ & $\ldots$ \\
\hline 1 Р.M. & . …… & 52,896 & $\begin{array}{l}264,480 \\
214,584\end{array}$ & & 52,896 &... \\
\hline 2 p... & . . . . & & 211,584 & & 396,720 & \\
\hline 3 P.M. & $\ldots \ldots \ldots$ & 105,792 & 211,584 & $15 \mathrm{~S}, 68 \mathrm{~S}$ & 343,524 & 502,512 \\
\hline 4 P.M. & ... & 52,890 & 370,272 & & 502,512 & $50^{2}, 512$ \\
\hline 5 P... & & & 396,720 & 105,792 & 449,616 & 766,992 \\
\hline $5: 15$ P... & & 211,584 & $1,110,816$ & -. & $158,68 \mathrm{~S}$ & $343,52 \cdot 1$ \\
\hline 6:40 P.M. & . 105,792 & ...... & $1,4 \$ 1,0 \$ 8$ & & 158,688 & 396,720 \\
\hline
\end{tabular}


Table 5.-Plankton Organisas Per Cubic Meter in Simth's Canal, Hourly Series in 1913-(Continued)

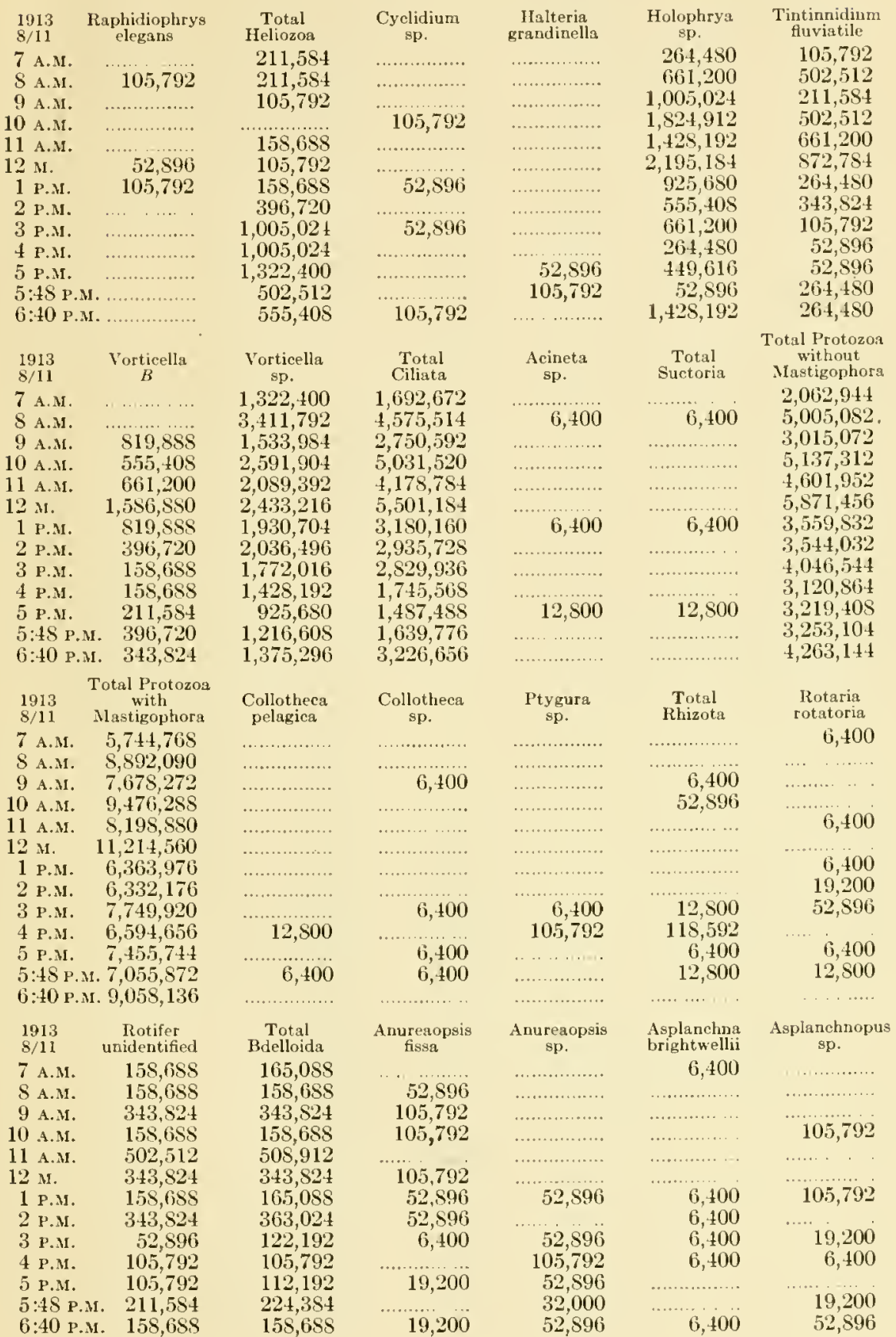


Table 5.-Planktux Oriansus l'er Cuhe Meter ix Suth's Caxal, HoURAY SERs iN 1913-(Contimued)

\begin{tabular}{|c|c|c|}
\hline $\begin{array}{l}1913 \\
611\end{array}$ & $\begin{array}{c}\text { Brachionus } \\
\text { angularis }\end{array}$ & $\begin{array}{l}\text { Brarliomus } \\
\text { angublaris } \\
\text { raudatus }\end{array}$ \\
\hline $\begin{array}{l}7 \text { А.м. } \\
\text { A...1. }\end{array}$ & 6.400 & $1,216,608$ \\
\hline 9 А.u. & $11, \mathrm{~T}=0$ & $2,3 \times 0,320$ \\
\hline $10 \mathrm{~A}$. & & $1,930,704$ \\
\hline $11 \mathrm{AM}$ & 52,596 & $1,163,712$ \\
\hline $\begin{array}{l}12 \mathrm{M} . \\
1 \mathrm{p} . \mathrm{u} .\end{array}$ & 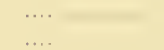 & $\begin{array}{l}3,253,104 \\
1,666,224\end{array}$ \\
\hline 2 p.... & 52,896 & $\begin{array}{r}1,0000,24 \\
925,680\end{array}$ \\
\hline 3 Р... & & 555,408 \\
\hline 4 P.M. & $\cdots$ & 714,096 \\
\hline 5 P.M. & $\ldots \ldots, \ldots$ & 766,992 \\
\hline $5: 48$ P.M & ......... & $1,163,712$ \\
\hline $6: 40$ P.M & 1. … $\ldots \ldots$ & $1,586,880$ \\
\hline $\begin{array}{l}1913 \\
\$ 111\end{array}$ & $\begin{array}{l}\text { Brachionus } \\
\text { egr; attucheal, } \\
\text { male }\end{array}$ & $\begin{array}{l}\text { Brachionus } \\
\text { egk: frec. } \\
\text { female }\end{array}$ \\
\hline 7 A.M. & & 608,304 \\
\hline S A.M. & 105,792 & $1,0.57,920$ \\
\hline 9) A.M. & 52,896 & 343,824 \\
\hline $10 \mathrm{~A}$.M. & & 61,200 \\
\hline 11 A.M. & ............ & 343,524 \\
\hline $12 \mathrm{M.}$ & ..... & 766,992 \\
\hline 1 P.... & …........ & 158,658 \\
\hline 2 г.м. & ... & 105,792 \\
\hline $\begin{array}{l}3 \text { P.M. } \\
4 \text { P.M. }\end{array}$ & ......... & 52,896 \\
\hline 5 P.... & 32,000 & 105,792 \\
\hline $5: 4 \mathrm{P}^{\mathrm{P}}$ & 52,896 & 608,304 \\
\hline $6: 40 \mathrm{P.s}$ & 52,896 & 313,824 \\
\hline
\end{tabular}

\begin{tabular}{|c|c|}
\hline $\begin{array}{l}1913 \\
5 / 11\end{array}$ & $\begin{array}{l}\text { Brachionus } \\
\text { urceus }\end{array}$ \\
\hline T A.M. & \\
\hline S A.M. & 25,600 \\
\hline 9 A.M. & 6,400 \\
\hline $10 \mathrm{~A}$.M. & $\ldots$ \\
\hline $11 \mathrm{~A} . \mathrm{M}$. & \\
\hline $\begin{array}{rl}12 & \mathrm{M} . \\
1 & \text { p.... }\end{array}$ & 6,400 \\
\hline 2 P.M. & 158,688 \\
\hline 3 P.M. & 52,896 \\
\hline 4 P.M. & 6,400 \\
\hline 5 Р... & 45,000 \\
\hline $5: 4 S \mathrm{P}$. & 12,800 \\
\hline
\end{tabular}

6:40 P.M. 15S,6SS

\begin{tabular}{|c|c|c|}
\hline $\begin{array}{l}1913 \\
\$ / 11\end{array}$ & $\begin{array}{l}\text { Kicratella } \\
\text { egg, altached }\end{array}$ & $\begin{array}{l}\text { Keratella } \\
\text { equ, free }\end{array}$ \\
\hline F A.M. & 52,896 & 396,720 \\
\hline S A.M. & & 396,720 \\
\hline 9 А.M. & 52,896 & 502,512 \\
\hline 10 A.M. & ....... & 766,992 \\
\hline 11 A...I. & $\ldots \ldots$ & 449,616 \\
\hline $12 \mathrm{~s}$ & & S19,S8S \\
\hline 1 P.M. & $\ldots$ & 502,512 \\
\hline 2 р.м. & & S19,8S5 \\
\hline 3 P.M. & & 661,200 \\
\hline 4 P.M. & & $26 \cdot 4,480$ \\
\hline 5 P.... & 6,400 & 605,304 \\
\hline $5: 48$ P.A. & $5 \operatorname{son}$ & 714,096 \\
\hline $6: 10 \mathrm{P} . . \mathrm{M}$ & $.52,890$ & 925,000 \\
\hline
\end{tabular}

Brachionus with parasites 6,400

105,792

…................

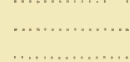

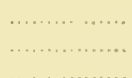

\begin{tabular}{|c|c|}
\hline $\begin{array}{l}\text { Brachionus } \\
\text { udapestinensis }\end{array}$ & $\begin{array}{l}\text { Brachionus } \\
\text { calyciflorus }\end{array}$ \\
\hline 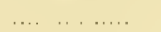 & $155,6 \mathrm{SS}$ \\
\hline \multirow{3}{*}{$(;, 400$} & 396,720 \\
\hline & $26,4,480$ \\
\hline & $2(j-1,4 \leqslant 0$ \\
\hline 6,400 & $\begin{array}{l}158,65 i \\
211,584\end{array}$ \\
\hline $52, \$ 96$ & $s 0,0(0)$ \\
\hline & $140,8() 0$ \\
\hline & 15,688 \\
\hline & $10.5,792$ \\
\hline & 80,000 \\
\hline 6,400 & 105,792 \\
\hline 52,596 & $158,6 \mathrm{SS}$ \\
\hline
\end{tabular}

Brachionus Brachionus egg, winter

$\begin{array}{ll}261,480 & \ldots \ldots \\ 1195,792 & \ldots\end{array}$

$\ldots \ldots \ldots \quad 52,896$

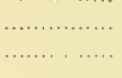

(n)

$\begin{array}{ll} & 158,658 \\ \ldots \ldots \ldots & 264,480 \\ 211,584\end{array}$

heratella quadrata

211,584 396,720 343,824

$.502,512$ 264,480 $2(34,480$ 60,800 211,584 1.7. 200 52,596

52,596

158,698 264,480

Polyarthra

$$
\begin{gathered}
\text { Brarhionus } \\
\text { crpsuliflorus } \\
25,600 \\
12,600 \\
41,600 \\
10,79,792 \\
67,200 \\
105,792 \\
12,400 \\
19,200 \\
6,400 \\
52,896 \\
25,600 \\
25,600 \\
25,600
\end{gathered}
$$

Brachionus Nge: attached, female 52,596 261,440 52.596 52,596 52,596 1iss,6ss $211,5 \mathrm{S1}$ $211,5 \mathrm{~s}$ $26,4,4,80$ 396,720

Brachiouns patulus $6,-100$

Brachionus plicatilis

$$
\text { 6, } 100
$$$$
12,500
$$$$
12,800
$$

$52, \$ 96$

52,896

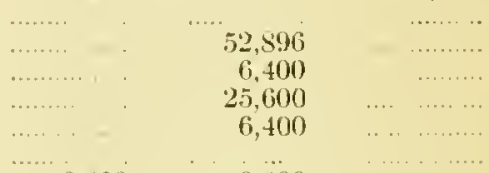

(i, 400

6,400

Filinia

661,200

714,096

$55.5,408$

555,408

396,720

766,992

502,512

449,616

105,792

158,688

396,720

449,616

608,304 trigla

766,992

$1,586,880$

$2,248,080$

$1,322,400$

$1,877,808$

$1,824,912$

$1,005,024$

$1,269,504$

$1,269,504$

608,304

766092

$1,057,920$ 872,784
Filinia

ongiset?

52,896

6,400

Keratella cochlearis

$52, \$ 96$

12,500

6,400

6,400

6,400

Polyarthra trigla egg: attached, Rotifer egg, female

6,400

105,792

105,792

52,896

$52,596 \quad 264,480$

$10.3,792$

52,896

$105,792 \quad 158,68 \mathrm{~S}$

$155,685 \quad 52,896$

$52.896 \quad 52,896$

10:5, $792 \quad 52,896$ winter

$52,896 \quad 25,600$ 
Table 5.-Plankton Organisms Per Cubic Meter in Simth's Canal, Hourly Series ix 1913-(Concluded)

\begin{tabular}{|c|c|c|c|c|c|c|c|}
\hline $\begin{array}{l}1913 \\
8 / 11\end{array}$ & $\begin{array}{c}\text { Synchaeta } \\
\text { sp. }\end{array}$ & \multicolumn{2}{|c|}{$\begin{array}{c}\text { Trichacerca } \\
\text { capucinat }\end{array}$} & $\begin{array}{c}\text { Trichocerea } \\
\text { ieruis }\end{array}$ & $\begin{array}{c}\text { Total } \\
\text { Ploima }\end{array}$ & $\begin{array}{c}\text { Total } \\
\text { Rotifera }\end{array}$ & $\begin{array}{c}\text { Bosmina } \\
\text { longirostris }\end{array}$ \\
\hline 7 A.AI. & & \multicolumn{2}{|c|}{... . .............. } & 158,688 & $4,564,560$ & $4,729,6+5$ & 52,896 \\
\hline S A.M. & 52,896 & \multicolumn{2}{|c|}{. . ............ } & \multirow{2}{*}{$\begin{array}{l}155,685 \\
343,824\end{array}$} & $7, \pm 66,640$ & $7,615,328$ & \\
\hline 9 А.м. & 52,896 & \multirow{2}{*}{\multicolumn{2}{|c|}{$52, \$ 96$}} & & \multirow{2}{*}{$\begin{array}{l}4.846,384 \\
7.199 .408\end{array}$} & $5,196,60 \mathrm{~s}$ & \multirow[t]{2}{*}{52,596} \\
\hline 10 A.M. & & & & 264,480 & & $7,410,992$ & \\
\hline 11 А.S. & 52,596 & \multirow{3}{*}{\multicolumn{2}{|c|}{12,800}} & \multirow{2}{*}{$\begin{array}{l}714,096 \\
766,992\end{array}$} & $5,759,920$ & $6,268,832$ & \multirow{3}{*}{52,896} \\
\hline $12 \mathrm{Mr}$. & 6,400 & & & & \multirow{2}{*}{$\begin{array}{l}9,612,576 \\
4,979,936\end{array}$} & $9,956,400$ & \\
\hline 1 P.M. & & & \multicolumn{2}{|c|}{343,924} & & $5,145,024$ & \\
\hline 2 Р.м. & 6,400 & & & 584 & $4,817,607$ & 5,1 So,631 & \\
\hline 3 P.м. & 6,400 & & & 594 & $8 \pm 0$ & 3,70 & \\
\hline 4 P.M. & & & & 000 & $2,721,600$ & $2,852,992$ & 6,400 \\
\hline 5 р.м. & & 52,5 & & 600 & $3,512,752$ & $3,631,344$ & 6,400 \\
\hline 5:48 р.м. & . 158.688 & & & 584 & $5,471,152$ & $5,708,336$ & \\
\hline $6: 40$ Р.м. & & & & 480 & $6,199,188$ & $7,357,876$ & 6,400 \\
\hline $\begin{array}{l}1913 \\
8 / 11\end{array}$ & Sida & $\begin{array}{c}\text { Total } \\
\text { Cladocera }\end{array}$ & Cyclops & Nauplius & $\begin{array}{c}\text { Total } \\
\text { Copepoda }\end{array}$ & $\begin{array}{c}\text { Total } \\
\text { Entomostraca }\end{array}$ & $\begin{array}{c}\text { Total } \\
\text { Organisms }\end{array}$ \\
\hline 7 A.M. & 52,896 & 105,792 & 158,688 & 158,688 & 317,376 & $423,16 \mathrm{~s}$ & $42,893,610$ \\
\hline 8 A.M. & 12,800 & 12,800 & 86,400 & 158,688 & $245,08 S$ & 257,858 & $37, \$ 25,610$ \\
\hline 9 A.M. & $12, S 00$ & 65,696 & 86,400 & 105,792 & 192,192 & 257,888 & $32,689,892$ \\
\hline 10 A.M. & 25,600 & 25,600 & 54,400 & 158,688 & 213,058 & 238,685 & $38,192,880$ \\
\hline 11 A.M. & $6,40)$ & 6,400 & 73,600 & 80,000 & 153,600 & 160,000 & $34,967,488$ \\
\hline $12 \mathrm{M}$ & 19,200 & 19,200 & 54,400 & 211,584 & 265,984 & 285,184 & $41,414,752$ \\
\hline 1 P.M. & & 52,896 & 25,600 & $\$ 6,400$ & 112,000 & 164,896 & $38,0 \times 7,152$ \\
\hline 2 P.M. & 19,200 & 19,200 & 80,000 & 92,500 & 172,800 & 192,000 & $51,429,463$ \\
\hline 3 р.... & 52,896 & 52,896 & 60,800 & 12,800 & 73,600 & 126,496 & $54,374,720$ \\
\hline 4 Р.м. & 52,896 & $52, \$ 96$ & 60,800 & 52,896 & 113,696 & 172,992 & $56,092,520$ \\
\hline 5 Р... & & 6,400 & 99,200 & 105,792 & 204,992 & $211,58+$ & $72,902,032$ \\
\hline 5:48 р.м. & 0 & 6,400 & 99,200 & 52,896 & 152,096 & $15 S, 496$ & $69,619,120$ \\
\hline 6:40 P... & 12,800 & 19,200 & 140,800 & 105,792 & 216,592 & 265,792 & $85,531,500$ \\
\hline
\end{tabular}


Tabee 6.-Vonumes of Catches, 1913

\begin{tabular}{|c|c|c|c|c|c|c|c|c|c|c|c|c|}
\hline \multirow{2}{*}{$\begin{array}{l}\text { Date } \\
1013\end{array}$} & \multicolumn{3}{|c|}{$\begin{array}{l}\text { Volume in cubic } \\
\text { centimeter per } \\
\text { eubie meter }\end{array}$} & \multicolumn{3}{|c|}{$\begin{array}{l}\text { Dsstimated } \\
\text { percentage of } \\
\text { plankton }\end{array}$} & \multicolumn{3}{|c|}{$\begin{array}{c}\text { Number } \\
\text { of } \\
\text { hauls }\end{array}$} & \multicolumn{3}{|c|}{$\begin{array}{l}\text { Number of } \\
\text { formus } \\
\text { reforded }\end{array}$} \\
\hline & I & II & III & I & II & III & I & II & III & I & II & III \\
\hline $1 / 5$ & 0.5 & 0.4 & & $50 \%$ & $40 \%$ & & 13 & 7 & & 30 & 31 & \\
\hline $1 / 8$ & 0.55 & & 0.55 & $50^{\circ}$ & & $40 \%$ & 13 & & 25 & 28 & & 24 \\
\hline $1 / 12$ & 0.35 & 0.25 & & $30 \%$ & 50 & & 13 & 7 & & 30 & 37 & \\
\hline $1 / 15$ & 0.8 & & & $60 \%$ & & & & & & 42 & & \\
\hline $1 / 19$ & $\begin{array}{l}0.55 \\
0.6\end{array}$ & 0.35 & 0.55 & $60 \%$ & $60 \%$ & $40 \%$ & $\$$ & 7 & 13 & 43 & 45 & 41 \\
\hline $\begin{array}{l}1 / 22 \\
1 / 25\end{array}$ & 06 & 0.65 & & & $70 \%$ & & 9 & 6 & & 56 & 60 & f) \\
\hline $1 / 26$ & 1.0 & & & & & 6010 & 9 & 0 & & 39 & & 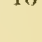 \\
\hline $1 / 29$ & 0.8 & & & $90 \%$ & & & 8 & & & 46 & & \\
\hline $\begin{array}{l}2 / 2 \\
2 / 5\end{array}$ & $\begin{array}{ll}0 & 85 \\
0 & 95\end{array}$ & 0.65 & 0.6 & $\begin{array}{l}8.5^{\circ} \\
8.5 \%\end{array}$ & $75 \%$ & $80 \%$ & $\begin{array}{l}9 \\
9\end{array}$ & 7 & 13 & 45 & 50 & 51 \\
\hline $2 / 8$ & 10 & 0.85 & 0.6 & $80^{r y}$ & $70 \%$ & $80 \%$ & 9 & $T$ & 13 & 46 & 49 & 45 \\
\hline $2 / 12$ & 17 & & & $85 \%$ & & & 10 & & & 50 & & \\
\hline $\begin{array}{l}2 / 15 \\
2 / 19\end{array}$ & 1.0 & 0.75 & 0.65 & $80^{4}$ & $60^{C}$ & $80 \%_{c}$ & 9 & 7 & 13 & 54 & 50 & 59 \\
\hline $\begin{array}{l}2 / 19 \\
2 / 23\end{array}$ & 0.85 & & & $60 \%$ & & & 9 & & & 61 & & \\
\hline $\begin{array}{l}2 / 23 \\
2 / 26\end{array}$ & $\begin{array}{l}155 \\
165\end{array}$ & 0.65 & 0.6 & $707 \mathrm{c}$ & $60 \%$ & $70 \%$ & 9 & 7 & 13 & 60 & 62 & 64 \\
\hline $3 / 1$ & $\begin{array}{l}1.32 \\
1.4\end{array}$ & 0.65 & 0.75 & $85 \%$ & $40^{\circ}$ & $50 \%$ & $\begin{array}{r}13 \\
9\end{array}$ & 7 & 13 & $\begin{array}{l}59 \\
55\end{array}$ & 52 & 57 \\
\hline 35 & 395 & & & 850 & & & 13 & & & 46 & & \\
\hline $3 / 8$ & 52 & 1.4 & 0.65 & 85 & $10^{c}$ & $50 \%_{0}$ & 9 & 7 & 13 & 48 & 52 & 60 \\
\hline $3 / 12$ & $6 \mathrm{~s}$ & & & $80 \%$ & & & 16 & & & 43 & & \\
\hline 315 & 1.8 & 1.95 & 0.8 & $90^{\circ}$ & $15 \%$ & $50 \%$ & 10 & 7 & 13 & $5 \overline{5}$ & 58 & 70 \\
\hline $3 / 19$ & 2.1 & & & $\mathrm{SOC}_{0}$ & & & 13 & & & 56 & & \\
\hline $\begin{array}{l}3 / 23 \\
3 / 26\end{array}$ & $\begin{array}{ll}1 & 9 \\
1 & 8\end{array}$ & 0.8 & 0.8 & $\begin{array}{l}85 \\
85\end{array}$ & $10 \%$ & $60 \%$ & $\begin{array}{r}9 \\
13\end{array}$ & 7 & 13 & $\begin{array}{l}63 \\
51\end{array}$ & 74 & 70 \\
\hline $3 / 29$ & 18.5 & 0.7 & 1.0 & $80 \%$ & $15 \%$ & $40 \%$ & 9 & 7 & 13 & 54 & $7 S$ & 72 \\
\hline $4 / 2$ & 2.5 & & & 90 & & & 9 & & & 57 & & \\
\hline $4 / 5$ & 2.7 & 1.7 & 0.55 & $90 \%$ & $15 \%$ & $40 \%$ & 9 & 5 & 13 & $5 s$ & 75 & 71 \\
\hline 49 & 24 & & & $95 \%$ & & & 9 & & & 54 & & \\
\hline 413 & 1. 85 & 05 & 0.75 & $\begin{array}{l}95 \% \\
80 c \%\end{array}$ & $1.5 \%$ & $20 \%$ & $\begin{array}{r}9 \\
10\end{array}$ & 5 & 12 & 62 & 70 & 67 \\
\hline $\begin{array}{l}4 / 16 \\
4 / 19\end{array}$ & 265 & 1.85 & 0.7 & $90 \%$ & $10 \%$ & $75 C_{0}$ & 13 & 5 & 13 & $\begin{array}{l}56 \\
47\end{array}$ & 58 & 61 \\
\hline $4 / 23$ & 2.2 & & & & & & 9 & & & 6.5 & & \\
\hline $4 / 26$ & 31 & 0.8 & 0.55 & $90 \%$ & $20 \%$ & $25 \%$ & 13 & 5 & 13 & 70 & 68 & 71 \\
\hline $4 / 30$ & 2.3 & & & $80 \%$ & & & 9 & & & 51 & & \\
\hline $5 / 3$ & 21 & 3.05 & 0.65 & $6.5 \%$ & $4 \%$ & $50 \%$ & 9 & 5 & 13 & 53 & $5 S$ & $6: 3$ \\
\hline $\begin{array}{l}5 / 7 \\
5 / 10\end{array}$ & $\begin{array}{l}2.6 \\
3.0\end{array}$ & 66 & 0.55 & $\begin{array}{l}90 \\
95 \%\end{array}$ & 40 & $\mathrm{SO}_{\mathrm{N}}$ & $\begin{array}{l}9 \\
9\end{array}$ & 6 & 12 & $\begin{array}{l}5.5 \\
64\end{array}$ & $4 \pi$ & 56 \\
\hline & $2 \mathrm{~s}$ & & & 90 & & & 9 & & & 51 & & \\
\hline $5 / 17$ & 34 & 56 & 0.6 .5 & 10 & $4{ }^{\prime} c$ & $55 \%$ & 9 & 6 & 13 & 6.5 & 6.4 & 70 \\
\hline $5 / 21$ & 2.25 & & & $85^{\circ} \%$ & & & 9 & & & 49 & & \\
\hline $5 / 24$ & 2.75 & 6.0 & 0.6 & 50 & $5 \%$ & $50 \%$ & S & 5 & 9 & 50 & 59 & 58 \\
\hline $5 / 27$ & 2.95 & & & & & & 9 & & & 58 & & \\
\hline $\begin{array}{l}5 / 31 \\
6 / 3\end{array}$ & $\begin{array}{l}3.6 \\
2.9\end{array}$ & 6.7 & 0.7 & $\begin{array}{l}80 \% \\
95\end{array}$ & $2 \%$ & 9 & $\begin{array}{l}9 \\
9\end{array}$ & 3 & 13 & $\begin{array}{l}53 \\
5.9\end{array}$ & 52 & 46 \\
\hline $6 / 7$ & 24 & 3.15 & 0.5 & 95 & $5 \%$ & $45 \%$ & 9 & 3 & 9 & 54 & 60 & $66^{\circ}$ \\
\hline $6 / 11$ & 28 & & & & & & 9 & & & 50 & & \\
\hline & $\begin{array}{ll}1 & 85 \\
2 & 65\end{array}$ & 1. & 0 & $65 c^{\circ}$ & $4 \%$ & $50 \%$ & 9 & 6 & 13 & 65 & 63 & 61 \\
\hline $6 / 21$ & 28 & 1.2 & 0.6 & $90 \%$ & $10 \%$ & $60 \%$ & $\begin{array}{l}9 \\
9\end{array}$ & 7 & 13 & $\begin{array}{l}56 \\
57\end{array}$ & $6 S$ & $7 S$ \\
\hline $6 / 25$ & 3.45 & & & & & & 13 & & & 72 & & \\
\hline $6 / 28$ & 3.1 & 195 & 0.75 & $92 \%$ & $15 \%$ & $05 \%$ & $1: 3$ & 9 & $13^{\circ}$ & 61 & 77 & 72 \\
\hline $7 / 5$ & 305 & 0.95 & 07 & $93 \%$ & $30 \%$ & $65 \%$ & 9 & 9 & 13 & 63 & 60 & 72 \\
\hline $7 / 9$ & 2.7 & & & $\mathrm{Si}^{\circ} \mathrm{C}_{\mathrm{C}}$ & & & 9 & & & 59 & & \\
\hline $\begin{array}{l}7 / 12 \\
7 / 16\end{array}$ & $\begin{array}{l}3.85 \\
3.9\end{array}$ & 2.1 & 1.7 & $\begin{array}{l}90 \% \\
92 \%\end{array}$ & $40 \%$ & $8.5 \%$ & $\begin{array}{l}9 \\
9\end{array}$ & 9 & 13 & $\frac{55}{57}$ & 82 & 94 \\
\hline
\end{tabular}


Tarle 6.-Volumes of Catches, 1913-(Concluded)

\begin{tabular}{|c|c|c|c|c|c|c|c|c|c|c|c|c|}
\hline \multirow{2}{*}{$\begin{array}{l}\text { Date } \\
1913\end{array}$} & \multicolumn{3}{|c|}{$\begin{array}{l}\text { Volume in cubic } \\
\text { centimeter per } 1 / 4 \\
\text { cubic meter }\end{array}$} & \multicolumn{3}{|c|}{$\begin{array}{l}\text { Estimated } \\
\text { percentage of } \\
\text { plankton }\end{array}$} & \multicolumn{3}{|c|}{$\begin{array}{c}\text { Number } \\
\text { of } \\
\text { hauls }\end{array}$} & \multicolumn{3}{|c|}{$\begin{array}{l}\text { Number of } \\
\text { forms } \\
\text { recorded }\end{array}$} \\
\hline & I & II & III & I & II & III & I & II & III & I & II & III \\
\hline & 4.1 & 1.7 & 0.95 & $85 \%$ & $60 \%$ & $80 \%$ & 9 & 9 & 13 & 50 & 66 & 60 \\
\hline $7 / 26$ & 43 & 1.4 & 165 & $90 \%$ & $90 \%$ & $50 \%$ & $\begin{array}{l}9 \\
9\end{array}$ & 10 & 13 & $\begin{array}{l}52 \\
63\end{array}$ & 70 & 83 \\
\hline $7 / 30$ & 4.5 & & & $92 \%$ & & & 9 & & & 61 & & \\
\hline 8/2 2 & 4. 2 & 2.3 & 1.35 & $90 \%$ & $80 \%$ & $90 \%$ & 9 & 9 & 13 & 66 & 88 & 76 \\
\hline $\begin{array}{l}8 / 6 \\
8 / 9\end{array}$ & $\begin{array}{l}4.5 \\
4.7\end{array}$ & 2. & & $\begin{array}{l}93 \% \\
95 \%\end{array}$ & $75 \%$ & & $\begin{array}{l}9 \\
9\end{array}$ & 9 & 13 & $\begin{array}{l}52 \\
63\end{array}$ & 83 & 98 \\
\hline $8 / 13$ & 4.75 & 2. & 2 & $75 \%$ & 807 & 3 & 9 & $y$ & 10 & 75 & 83 & Is \\
\hline $8 / 15$ & 5.1 & 2.3 & 1.4 & $80 \%$ & $\mathrm{~s} 0 \%$ & $70 \%$ & 9 & 9 & 13 & 72 & 98 & 44 \\
\hline $8 / 20$ & 6.1 & & & $60^{\circ} \mathrm{C}$ & & & 9 & & & 68 & & \\
\hline $\begin{array}{l}8 / 23 \\
S / 27\end{array}$ & $\begin{array}{l}4.1 \\
4.6\end{array}$ & 2.0 & 4.6 & $\begin{array}{l}80 \\
95\end{array}$ & $85 \%$ & $80 \%$ & $\begin{array}{l}9 \\
9\end{array}$ & S & 13 & $\begin{array}{l}71 \\
65\end{array}$ & 86 & 92 \\
\hline $\mathrm{S} / 31$ & 5.2 & 2.9 & 1.7 & $85 \%$ & $90 \%$ & $80 \%$ & 9 & 8 & 13 & 58 & $8 t$ & 78 \\
\hline $9 / 2$ & 4. & & & $85 \%$ & & & 9 & & & 71 & & \\
\hline $\begin{array}{l}9 / 6 \\
0 / 0\end{array}$ & 3.8 & 2.0 & 2.8 & $\begin{array}{l}55 \% \\
55 \%\end{array}$ & $90 \%$ & $80 \%$ & 9 & 8 & 13 & 67 & 66 & 85 \\
\hline $9 / 13$ & $\begin{array}{l}3.9 \\
3.9\end{array}$ & 2.5 & 1.75 & $75 \%$ & $55 \%$ & $85 \%$ & $\begin{array}{l}9 \\
9\end{array}$ & 9 & 13 & $\begin{array}{l}68 \\
63\end{array}$ & 81 & 79 \\
\hline $9 / 17$ & 3.2 & & & so\% & & & 9 & & 10 & 63 & or & 8 \\
\hline $9 / 20$ & 2.0 & 1.9 & 1.9 & $95 \%$ & $85 \%$ & $95 \%$ & 9 & 9 & 13 & 58 & 78 & 67 \\
\hline $9 / 24$ & 1.8 & & & $95 \%$ & & & 9 & & & 73 & & \\
\hline $9 / 27$ & 3.15 & 2.5 & 1.55 & $95 \%$ & $30 \%$ & $90 \%$ & 9 & 9 & 13 & 63 & 70 & 76 \\
\hline $\begin{array}{l}10 / 4 \\
10 / 4\end{array}$ & 2. & 16 & & $\begin{array}{l}80 \% \\
85 \%\end{array}$ & & & 9 & & & 69 & & \\
\hline $\begin{array}{l}10 / 4 \\
10 / 8\end{array}$ & $\begin{array}{l}2.0 \\
2.7\end{array}$ & 1. & 1.8 & $\begin{array}{l}85 \% \\
75 \%\end{array}$ & $30 \%$ & $55 \%$ & $\begin{array}{l}9 \\
9\end{array}$ & 7 & 13 & $\begin{array}{l}67 \\
79\end{array}$ & 74 & 72 \\
\hline $10 / 11$ & 2.45 & 2.1 & 1.55 & $85 \%$ & $30 \%$ & $40 \%$ & 9 & 8 & 13 & 70 & 74 & 73 \\
\hline $10 / 15$ & 4.6 & & & $20 \%$ & & & 9 & & & 78 & & \\
\hline $10 / 18$ & 17 & 1.25 & 1. 45 & $50 \mathrm{c}$ & $30 \%$ & $40 \%$ & 9 & S & 13 & 57 & 68 & 53 \\
\hline $10 / 22$ & 2.3 & & & $50 \%$ & & & 9 & & & 69 & & \\
\hline $\begin{array}{l}10 / 26 \\
10 / 29\end{array}$ & $\begin{array}{l}1.65 \\
1.6\end{array}$ & 1. & 1 & $\begin{array}{l}60 \% \\
60 \%\end{array}$ & $25 \%$ & 40 & $\begin{array}{l}9 \\
9\end{array}$ & 9 & 13 & $\begin{array}{l}57 \\
78\end{array}$ & 62 & 75 \\
\hline $11 / 2$ & 1.1 & 1.2 & 1.2 & $60 \%$ & $30 \%$ & $50 \%$ & 9 & 9 & 13 & 64 & 76 & 71 \\
\hline $11 / 5$ & 0.9 & & & 250 & & & 9 & & & 54 & & \\
\hline $11 / \mathrm{s}$ & 0.5 & 1.3 & 1.5 & $40 \%$ & $20 \%$ & $15 \%$ & 9 & 9 & 19 & 44 & 57 & 66 \\
\hline $11 / 12$ & 1.25 & & & $30 \%$ & & & 9 & & & 69 & & \\
\hline $11 / 19$ & $\begin{array}{l}0.6 \\
1.35\end{array}$ & 0 & & $\begin{array}{l}30 \% \\
15 \%\end{array}$ & $25 \%$ & $45 \%$ & $\begin{array}{r}9 \\
13\end{array}$ & 9 & 13 & $\begin{array}{l}56 \\
83\end{array}$ & 64 & 65 \\
\hline $11 / 22$ & 1.3 & 0.7 & 0.95 & $15 \%$ & $15 \%$ & $20 \%$ & 9 & 9 & 13 & 77 & 67 & 81 \\
\hline$/ 26$ & 1.15 & & & $40 \%$ & & & 9 & & & 64 & & \\
\hline $11 / 30$ & 1.35 & 1.1 & 0.6 & $15 \%$ & $45 \%$ & $25 \%$ & 12 & 9 & 13 & 73 & 57 & 62 \\
\hline & 1.3 & & & & & & 13 & & & 72 & & \\
\hline $\begin{array}{l}12 / 6 \\
12 / 10\end{array}$ & $\begin{array}{l}0.9 \\
0.9\end{array}$ & 0 . & 1. & $\begin{array}{l}50 \% \\
15 \%\end{array}$ & $50 \%$ & $35 \%$ & $\frac{9}{7}$ & 8 & 13 & 64 & 46 & 61 \\
\hline $\begin{array}{l}12 / 10 \\
12 / 14\end{array}$ & 0.7 & 0.8 & 0.85 & $15 \%$ & $25 \%$ & $25 \%$ & 12 & 7 & 17 & 71 & 49 & 52 \\
\hline $12 / 17$ & 0.8 & & & $20 \%$ & & & 7 & & & 63 & & \\
\hline $12 / 20$ & 1.9 & 0.5 & 0.65 & $15 \%$ & $25 \%$ & $20 \%$ & 9 & 7 & 17 & 67 & 56 & 40 \\
\hline $12 / 24$ & 0.55 & & & $25 \%$ & & & 7 & & & 78 & & \\
\hline $\begin{array}{l}12 / 27 \\
12 / 31\end{array}$ & $\begin{array}{l}1.0 \\
0.95\end{array}$ & 1.30 & 0.7 & $\begin{array}{l}15 \% \\
20 \%\end{array}$ & $15 \%$ & $10 \%$ & $\begin{array}{l}9 \\
9\end{array}$ & 7 & 13 & $\begin{array}{l}71 \\
59\end{array}$ & 54 & 51 \\
\hline
\end{tabular}




\begin{tabular}{|c|c|c|c|c|c|c|c|c|c|}
\hline \multicolumn{5}{|c|}{ DALY, STATION I. } & \multicolumn{5}{|c|}{ Hourly, station IIIa. } \\
\hline $\begin{array}{l}\text { Date } \\
1913\end{array}$ & 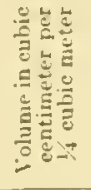 & 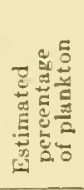 & 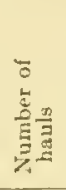 & 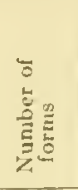 & $\begin{array}{l}\text { Date } \\
1913 \\
\text { s/11 }\end{array}$ & 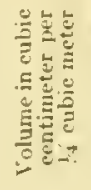 & 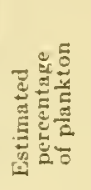 & 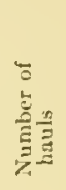 & 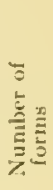 \\
\hline $\begin{array}{ccc}7 & 5 \\
7 & 6 \\
7 & 7 \\
7 & 9 \\
7 & 9 \\
7 & 11 \\
7 & 12 \\
7 & 13 \\
7 & 14 \\
7 & 15 \\
7 & 16 \\
7 & 18 \\
7 & 19 \\
7 & 20 \\
7 & 21 \\
7 & 22 \\
7 & 24 \\
7 & 25 \\
7 & 26 \\
7 & 27 \\
7 & 28 \\
7 & 29 \\
7 & 30 \\
7 & 31 \\
8 / 1 \\
8 & 2 \\
8 & 2 \\
8 & 4\end{array}$ & $\begin{array}{l}3.05 \\
2.5 \\
3.2 \\
3.6 \\
2.7 \\
3.4 \\
1.1 \\
3.85 \\
5.05 \\
4.35 \\
4.40 \\
3.9 \\
4.65 \\
6.4 \\
4.1 \\
49 \\
4.3 \\
4.2 \\
3.9 \\
3.35 \\
3.85 \\
4.3 \\
5.8 \\
4.45 \\
4.3 \\
4.5 \\
4.2 \\
3.8 \\
4.2 \\
3.7 \\
3.6\end{array}$ & $\begin{array}{l}93 \% \\
70 \% \\
75 \% \\
80 \% \\
85 \% \\
90 \% \\
85 \% \\
90 \% \\
92 \% \\
50 \% \\
90 \% \\
92 \% \\
50 \% \\
90 \% \\
85 \% \\
92 \% \\
92 \% \\
92 \% \\
85 \% \\
95 \% \\
92 \% \\
90 \% \\
95 \% \\
95 \% \\
95 \% \\
92 \% \\
90 \% \\
92 \% \\
90 \% \\
95 \% \\
95 \%\end{array}$ & $\begin{array}{r}9 \\
9 \\
9 \\
9 \\
9 \\
9 \\
9 \\
9 \\
12 \\
9 \\
10 \\
9 \\
10 \\
13 \\
9 \\
9 \\
9 \\
13 \\
9 \\
9 \\
9 \\
9 \\
13 \\
9 \\
9 \\
9 \\
9 \\
9 \\
9 \\
9 \\
9\end{array}$ & $\begin{array}{l}63 \\
57 \\
54 \\
55 \\
59 \\
54 \\
45 \\
55 \\
56 \\
64 \\
55 \\
57 \\
50 \\
50 \\
50 \\
52 \\
54 \\
56 \\
52 \\
64 \\
57 \\
63 \\
67 \\
62 \\
64 \\
61 \\
59 \\
53 \\
66 \\
64 \\
65\end{array}$ & 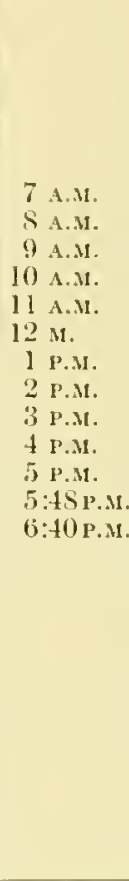 & $\begin{array}{l}2.4 \\
2.3 \\
2.3 \\
2.5 \\
2.4 \\
2.4 \\
2.07 \\
2.07 \\
2.07 \\
2.07 \\
2.3 \\
2.3 \\
2.5\end{array}$ & $\begin{array}{l}50 \% \\
60 \% \\
70 \% \\
50 \% \\
50 \% \\
75 \% \\
80 \% \\
75 \% \\
85 \% \\
85 \% \\
80 \% \\
85 \% \\
80 \%\end{array}$ & $\begin{array}{l}6 \\
6 \\
6 \\
6 \\
6 \\
6 \\
6 \\
6 \\
6 \\
6 \\
6 \\
6 \\
6\end{array}$ & $\begin{array}{l}76 \\
74 \\
75 \\
73 \\
79 \\
79 \\
81 \\
80 \\
91 \\
86 \\
94 \\
86 \\
93\end{array}$ \\
\hline
\end{tabular}


TABLE 7.

\begin{tabular}{|c|c|c|c|c|c|c|c|c|c|c|c|}
\hline \multirow{2}{*}{$\begin{array}{l}\text { Date } \\
1913\end{array}$} & \multirow{2}{*}{$\begin{array}{l}\text { Time of } \\
\text { first } \\
\text { collection }\end{array}$} & \multicolumn{4}{|c|}{$\begin{array}{l}\text { Temperature } \\
\text { centigrade }\end{array}$} & \multirow{2}{*}{$\begin{array}{l}\text { Air } \\
\text { conditions }\end{array}$} & \multirow{2}{*}{$\begin{array}{l}\text { Water } \\
\text { conditions }\end{array}$} & \multirow{2}{*}{$\begin{array}{c}\text { Anchor } \\
\text { or } \\
\text { drift }\end{array}$} & \multicolumn{3}{|c|}{$\begin{array}{l}\text { Nuniber } \\
\text { of hauls }\end{array}$} \\
\hline & & & I & II & III & & & & 1 & II & III \\
\hline $1 / 1$ & 3:30 P.M. & Air & & & & Clear & & $\mathrm{a}$ & 13 & & \\
\hline $1 / 5$ & 4:00 P.M. & Air & & 4.5 & & High wind; clear & Rough & $\mathbf{a}$ & & 7 & \\
\hline $1 / \mathrm{s}$ & 5:00 P.M. & $\begin{array}{l}\text { Air } \\
\text { Water }\end{array}$ & $\begin{array}{l}2.5 \\
5.5\end{array}$ & & & Wind; sleet & Choppy & a & 13 & & \\
\hline $1 / 11$ & 3:00 P.M. & $\begin{array}{l}\text { Air } \\
\text { Water }\end{array}$ & & & $\begin{array}{l}6.5 \\
4\end{array}$ & Wind; cloudy & Choppy & $a$ & & & 25 \\
\hline $1 / 12$ & 2:00 P...M. & Air. & 13 & 15 & & Wind; clear & Choppy & a & 13 & 7 & \\
\hline $1 / 15$ & 4:00 P.M. & $\begin{array}{l}\text { Air } \\
\text { Water }\end{array}$ & $\frac{9}{7}$ & & & Cloudy & & a & 13 & & \\
\hline $1 / 19$ & $11: 00$ A.... & $\begin{array}{l}\text { Air } \\
\text { Water }\end{array}$ & 8 & 11 & $\begin{array}{l}9.5 \\
8\end{array}$ & Wind; clear & Choppy & d & 8 & 7 & 13 \\
\hline $1 / 22$ & 4:00 P.M. & $\begin{array}{l}\text { Air } \\
\text { Wrater }\end{array}$ & $\begin{array}{c}9.5 \\
10\end{array}$ & & & No wind; rain & Smooth & $\mathrm{d}$ & 9 & & \\
\hline $1 / 25$ & 2:00 p.x. & & & 17 & $\begin{array}{l}19 \\
10\end{array}$ & No wind; clear & Smooth & d & & fi & 25 \\
\hline $1 / 26$ & 10:00 A.M. & $\begin{array}{l}\text { Mir } \\
\text { Water }\end{array}$ & $\begin{array}{l}14 \\
10\end{array}$ & & & No wind; clear & Smooth & $\mathrm{d}$ & 9 & & \\
\hline $1 / 29$ & 4:00 P.M. & $\begin{array}{l}\text { Air } \\
\text { Water }\end{array}$ & $\begin{array}{l}17.5 \\
11.5\end{array}$ & & & Light wind; clear & Wavy & d & 8 & & \\
\hline $2 / 2$ & $11: 30$ A.M. & Air & 14 & 17.5 & $5 \begin{array}{l}17 \\
10\end{array}$ & Breeze; clear & Ripply & d & 9 & 7 & 13 \\
\hline $2 / 5$ & 4:00 P.M. & $\begin{array}{l}\text { Air } \\
\text { ITater }\end{array}$ & $\begin{array}{l}16.5 \\
12.5\end{array}$ & & & No wind; cloudy & Simooth & d & 9 & & \\
\hline $2 / 8$ & $10: 30$ A.M. & $\begin{array}{l}\text { Air } \\
\text { WTater }\end{array}$ & $\begin{array}{l}15 \\
14.5\end{array}$ & $\begin{array}{l}15 \\
10.5\end{array}$ & $\begin{array}{l}16 \\
511.5\end{array}$ & Light wind; rain & Wavy & $d$ & 9 & 7 & 13 \\
\hline $2 / 12$ & 4:00 P.M. & $\begin{array}{l}\text { Air } \\
\text { WTater }\end{array}$ & $\begin{array}{ll}19 \\
15 & 5\end{array}$ & & & Breeze; clear & Ripply & $\mathrm{d}$ & 10 & & \\
\hline $2 / 15$ & 10:00 A.M. & $\begin{array}{l}\text { Air } \\
\text { Trater }\end{array}$ & $\begin{array}{l}18 \\
15\end{array}$ & $\begin{array}{l}19 \\
13.5\end{array}$ & $\begin{array}{l}15.5 \\
513\end{array}$ & No wind; clear & Smooth & $\mathrm{d}$ & 9 & 7 & 13 \\
\hline $2 / 19$ & 4:00 P.M. & $\begin{array}{l}\text { Air } \\
\text { IVater }\end{array}$ & $\begin{array}{ll}14 & 5 \\
12 & 5\end{array}$ & & & High wind; clear & Rough & a & 9 & & \\
\hline $2 / 23$ & 9:00 A.MI. & $\begin{array}{l}\text { Air } \\
\text { Water }\end{array}$ & 10 & 5 & $\begin{array}{r}13 \\
9\end{array}$ & $\begin{array}{l}\text { High wind; } \\
\text { part cloudy }\end{array}$ & Rough & a & 9 & 7 & 13 \\
\hline $2 / 26$ & 4:00 P.M. & $\begin{array}{l}\text { Air } \\
\text { Water }\end{array}$ & $\begin{array}{l}13 \\
12\end{array}$ & & & High wind; cloudy & Rough & a & 13 & & \\
\hline $3 / 1$ & 1:00 P.M. & $\begin{array}{l}\text { Air } \\
\text { Wiater }\end{array}$ & $\begin{array}{l}13.5 \\
13\end{array}$ & $\begin{array}{l}515 \\
10\end{array}$ & $\begin{array}{l}15 \\
10\end{array}$ & Light wind; cloudy & Wavy & a & 9 & 7 & 13 \\
\hline $3 / 5$ & 4:00 P.M. & $\begin{array}{l}\text { Air } \\
\text { WTater }\end{array}$ & $\frac{23.5}{15}$ & & & Light wind; clear & Wavy & a & 13 & & \\
\hline $3 / 8$ & $9: 30$ A.M. & $\begin{array}{l}\text { Air } \\
\text { Water }\end{array}$ & 23 & $\frac{21.5}{15}$ & $\begin{array}{l}522.5 \\
15\end{array}$ & Light wind; clear & Wavy & a & 9 & 7 & 13 \\
\hline $3 / 12$ & 4:00 P.M. & $\begin{array}{l}\text { Air } \\
\text { Water }\end{array}$ & $\begin{array}{ll}17.5 \\
16 & 5\end{array}$ & & & Light wind; clear & Wavy & a & 16 & & \\
\hline $3 / 15$ & $9: 00$ A.Mr. & $\begin{array}{l}\text { Air } \\
\text { Water }\end{array}$ & $\begin{array}{l}145 \\
14.5\end{array}$ & $5 \begin{array}{l}12 \\
12\end{array}$ & $\begin{array}{l}11.5 \\
12\end{array}$ & Breeze; clear & Ripply & a & 10 & 7 & 13 \\
\hline $3 / 19$ & $4: 00$ P.M. & $\begin{array}{l}\text { Air } \\
\text { Water }\end{array}$ & $\begin{array}{l}17.5 \\
14.5 \\
14.5\end{array}$ & & & $\begin{array}{l}\text { High wind; } \\
\text { part eloudy }\end{array}$ & Rough & a & 13 & & \\
\hline $3 / 23$ & $9: 00$ A.M. & Air & $\begin{array}{l}12 \\
14\end{array}$ & 9.5 & $\begin{array}{ll}5 & 13 \\
12 & 5\end{array}$ & Wind; cloudy & Choppy & a & 9 & 7 & 13 \\
\hline $3 / 26$ & $4: 30$ P...I. & $\begin{array}{l}\text { Air } \\
\text { Water }\end{array}$ & $1 \mathrm{~s}$ & & & Breeze; clear & Ripply & $a$ & 13 & & \\
\hline $3 / 29$ & $9: 00$ A.M. & $\begin{array}{l}\text { Air } \\
\text { Water }\end{array}$ & $\begin{array}{l}20 \\
12\end{array}$ & $\begin{array}{l}17 \\
13\end{array}$ & $\begin{array}{l}18.5 \\
14.5\end{array}$ & Wind; clear & Choppy & a & 9 & 7 & 13 \\
\hline $4 / 2$ & $4: 30$ P.M. & $\begin{array}{l}\text { Air } \\
\text { Water }\end{array}$ & $\begin{array}{l}18 \\
17\end{array}$ & & & Light wind; clear & Wary & a & 9 & & \\
\hline
\end{tabular}


Ta13Le 7.-(Continued)

\begin{tabular}{|c|c|c|c|c|c|c|c|c|c|c|c|}
\hline \multirow{2}{*}{$\begin{array}{l}\text { Date } \\
1913\end{array}$} & \multirow{2}{*}{$\begin{array}{c}\text { Time of } \\
\text { first } \\
\text { collection }\end{array}$} & \multicolumn{4}{|c|}{$\begin{array}{l}\text { Temperature } \\
\text { contigrade }\end{array}$} & \multirow{2}{*}{$\begin{array}{l}\text { Air } \\
\text { conditions }\end{array}$} & \multirow{2}{*}{$\begin{array}{l}\text { Watex } \\
\text { conditions }\end{array}$} & \multirow{2}{*}{$\begin{array}{l}\text { Anchor } \\
\text { or } \\
\text { drift }\end{array}$} & \multicolumn{3}{|c|}{$\begin{array}{l}\text { Number } \\
\text { of hauls }\end{array}$} \\
\hline & & & I & II & III & & & & I & II & III \\
\hline $4 / 5$ & $9: 00$ A.M. & Air & 15.5 & 13.5 & 15 & Wind; cloudy & Choppy & a & 9 & 5 & 13 \\
\hline $4 / 9$ & $12: 00 \mathbf{x}$ & $\begin{array}{l}\text { Water } \\
\text { Air }\end{array}$ & 24 & 14.5 & 15 & Breeze; clear & Ripply & a & 9 & & \\
\hline $4 / 13$ & 9:00 A.M. & Wir & 18.5 & 16.5 & 17 & 13reeze; part eloudy & Ripply & a & 9 & 5 & 12 \\
\hline $4 / 16$ & 4:00 P.M. & $\begin{array}{l}\text { Water } \\
\text { Air }\end{array}$ & 24 & & 16.5 & Breeze; elear & Ripply & a & 10 & & \\
\hline $4 / 19$ & $9: 00$ A.M. & $\begin{array}{l}\text { Water } \\
\text { Air }\end{array}$ & 21 & 18 & 19 & IBreezc; clear & Ripply & a & 13 & 5 & 13 \\
\hline $4 / 23$ & 4:00 P.м. & Air & 25 & & & Breeze; clear & Ripply & a & 9 & & \\
\hline $4 / 26$ & 9:00 A.M. & $\begin{array}{l}\text { Wirer } \\
\text { Wir } \\
\text { Water }\end{array}$ & $\begin{array}{l}20 \\
26.5 \\
20\end{array}$ & 23.5 & 24.5 & Вreene; clear & Ripply & a & 13 & 5 & 13 \\
\hline $4 / 30$ & $4: 00 \mathrm{P} \cdot \mathrm{M}$ & Air & 20 & & & Wind; clear & Choppy & a & 9 & & \\
\hline $5 / 3$ & S:45 A.M. & Air & $\begin{array}{l}18 \\
23 \\
18\end{array}$ & 21 & 22 & Light wind; clear & Wavy & a & 9 & 5 & 13 \\
\hline $5 / 7$ & $11: 00$ A.M. & $\begin{array}{l}\text { Air } \\
\text { Water }\end{array}$ & $\begin{array}{l}18 \\
22 \\
20\end{array}$ & & & Light wind; clear & Wary & a & 9 & & \\
\hline $5 / 10$ & 9:00 А.м. & $\begin{array}{l}\text { Air } \\
\text { Wrater }\end{array}$ & $\begin{array}{l}22 \\
21\end{array}$ & 21.5 & $21.5|20.5|$ & Wind; part cloudy & Choppy & a & 9 & 6 & 12 \\
\hline $5 / 14$ & 4:00 P...1. & $\begin{array}{l}\text { Air } \\
\text { Water }\end{array}$ & $\begin{array}{l}26 \\
21\end{array}$ & & & Wind; clear & Choppy & $\mathrm{a}$ & 9 & & \\
\hline $5 / 17$ & $12: 00 \mathrm{M}$ & $\begin{array}{l}\text { Air } \\
\text { Water }\end{array}$ & $\left|\begin{array}{l}26 \\
21\end{array}\right|$ & $\begin{array}{l}25 \\
19\end{array}$ & $\begin{array}{l}26 \\
19\end{array}$ & Wind; cloudy & Choppy & a & 9 & 6 & 13 \\
\hline $5 / 21$ & 4:00 P.M. & $\begin{array}{l}\text { Air } \\
\text { Water }\end{array}$ & 27.5 & & & $\begin{array}{l}\text { Light wind; } \\
\text { part eloudy }\end{array}$ & Way & a & 9 & & \\
\hline $5 / 24$ & $9: 00$ A.M. & Air & $\frac{26.5}{23}$ & 27 & 25.5 & Light wind; clear & Wary & a & 8 & 5 & 9 \\
\hline $5 / 27$ & 4:00 P.MI. & $\begin{array}{l}\text { Air } \\
\text { Water }\end{array}$ & 18 & & & Light wind; rain & Wavy & a & 9 & & \\
\hline $5 / 31$ & $12: 00 \mathrm{M}$ & $\begin{array}{l}\text { Air } \\
\text { Water }\end{array}$ & $\begin{array}{l}31 \\
27\end{array}$ & $\begin{array}{l}30.5 \\
19.5\end{array}$ & 32 & Brecze; clear & Ripply & a & 9 & 3 & 13 \\
\hline 13 & 5:30 P.M. & $\begin{array}{l}\text { Air } \\
\text { Wrater }\end{array}$ & 22.5 & & & Breeze; cloudy & Ripply & a & 9 & & \\
\hline $6 / 7$ & 9:00 A.M. & $\begin{array}{l}\text { Air } \\
\text { Water }\end{array}$ & $\mid 23$ & $\begin{array}{l}23.5 \\
20.5\end{array}$ & 22.5 & Wind; part eloudy & Choppy & a & 9 & 3 & 9 \\
\hline $6 / 11$ & 4:00 P.M. & $\begin{array}{l}\text { Air } \\
\text { Water }\end{array}$ & $\begin{array}{l}29 \\
23\end{array}$ & & & Wind; clear & Choppy & a & 9 & & \\
\hline $6 / 16$ & $6: 45$ A.M. & $\begin{array}{l}\text { Air } \\
\text { Water }\end{array}$ & $\begin{array}{l}21 \\
20\end{array}$ & & & No wind; clear & Smooth & d & 9 & & \\
\hline $6 / 16$ & 4:00 P.M. & $\begin{array}{l}\text { Air } \\
\text { Wrater }\end{array}$ & & 27 & $\begin{array}{l}24 \\
21\end{array}$ & Wind; clear & Choppy & d & & 6 & 13 \\
\hline $6 / 1 \mathrm{~s}$ & 1:00 P.M. & $\begin{array}{l}\text { Air } \\
\text { Water }\end{array}$ & $\begin{array}{l}25 \\
22\end{array}$ & & & Breeze; cloudy & Ripply & $\mathrm{d}$ & 9 & & \\
\hline $6 / 21$ & $9: 00$ A.M. & Air & 30 & 28.5 & 28 & Wind; elear & Choppy & $d$ & 9 & 7 & 13 \\
\hline 25 & $1: 30$ P.M. & $\begin{array}{l}\text { Air } \\
\text { Water }\end{array}$ & $\begin{array}{l}22 \\
22.5\end{array}$ & & & $\begin{array}{l}\text { Iligh wind; } \\
\text { part eloudy: }\end{array}$ & Rough & d & 13 & & \\
\hline $6 / 28$ & $9: 00$ A.M. & $\begin{array}{l}\text { Air } \\
\text { Water }\end{array}$ & $\begin{array}{l}23.5 \\
23\end{array}$ & $\begin{array}{l}21 \\
20\end{array}$ & $\begin{array}{l}22.5 \\
20.5\end{array}$ & Wind; clear & Choppy & d & 13 & 9 & 13 \\
\hline 7 & $9: 00$ A.M. & Air & 24 & & & Wind; clear & Choppy & d & 9 & & \\
\hline $7 /$ & 9:00 A.M. & Air & 32 & 28.5 & 30.5 & No wind; lutzy & Smooth & d & 9 & 9 & 13 \\
\hline 7/ & $10: 30$ A.M. & $\begin{array}{l}\text { Air } \\
\text { Water }\end{array}$ & $\begin{array}{l}31 \\
26\end{array}$ & & & Light wind; clear & Ripply & $d$ & 9 & & \\
\hline
\end{tabular}


TABLE 7.-(Continued)

\begin{tabular}{|c|c|c|c|c|c|c|c|c|c|c|c|}
\hline \multirow{2}{*}{$\begin{array}{l}\text { Date } \\
1913\end{array}$} & \multirow{2}{*}{$\begin{array}{l}\text { Time of } \\
\text { first } \\
\text { collection }\end{array}$} & \multicolumn{4}{|c|}{$\begin{array}{c}\text { Temperature } \\
\text { centigrade }\end{array}$} & \multirow{2}{*}{$\begin{array}{l}\text { Air } \\
\text { conditions }\end{array}$} & \multirow{2}{*}{$\begin{array}{l}\text { Water } \\
\text { conditions }\end{array}$} & \multirow{2}{*}{$\begin{array}{c}\text { Anchor } \\
\text { or } \\
\text { drift }\end{array}$} & \multicolumn{3}{|c|}{$\begin{array}{l}\text { Number } \\
\text { of hauls }\end{array}$} \\
\hline & & & I & II & III & & & & I & II & III \\
\hline $7 / 12$ & S:40 A.M. & $\begin{array}{l}\text { Air } \\
\text { Water }\end{array}$ & $\begin{array}{l}32 \\
27\end{array}$ & $\begin{array}{l}32 \\
25\end{array}$ & & No wind; elear & Smooth & $d$ & 9 & 9 & 13 \\
\hline $7 / 16$ & $10: 45$ A.M. & $\begin{array}{l}\text { Air } \\
\text { Water }\end{array}$ & 28 & & & Breeze; clear & Ripply & a & 9 & & \\
\hline $7 / 19$ & $10: 00$ A.M. & Air & 29 & 26 & 27.5 & Breeze; hazy & Ripply & $\mathrm{a}$ & 9 & 9 & 13 \\
\hline $7 / 23$ & $10: 30$ A.M. & $\begin{array}{l}\text { Air } \\
\text { Water }\end{array}$ & 27 & & & Breeze; light rain & Ripply & a & 9 & & \\
\hline $7 / 26$ & $9: 00$ A.M. & $\begin{array}{l}\text { Air } \\
\text { Water }\end{array}$ & $\begin{array}{l}26.5 \\
26\end{array}$ & $\begin{array}{l}22.5 \\
23\end{array}$ & $\left|\begin{array}{l}24.5 \\
24.5\end{array}\right|$ & Breeze; part eloudy & Ripply & d & 9 & 10 & 13 \\
\hline $7 / 30$ & 10:40 A.M. & $\begin{array}{l}\text { Air } \\
\text { Water }\end{array}$ & 27.5 & & & Breeze; hazy & Ripply & a & 9 & & \\
\hline S/ 2 & S:45 A.M. & $\begin{array}{l}\text { Air } \\
\text { IVater }\end{array}$ & $\begin{array}{l}27.5 \\
26\end{array}$ & 25.5 & $\begin{array}{l}26.5 \\
25\end{array}$ & No wind; elear & Smooth & a & 9 & 9 & 13 \\
\hline $8 / 6$ & $10: 30$ A.M. & $\begin{array}{l}\text { Air } \\
\text { WTater }\end{array}$ & 33 & & & Breeze; elear & Ripply & $\mathrm{a}$ & 9 & & \\
\hline $8 / 9$ & S:45 A.M. & $\begin{array}{l}\text { Air } \\
\text { Water }\end{array}$ & $\begin{array}{l}29 \\
27\end{array}$ & 24.5 & 25.5 & Breeze; part eloudy & Ripply & a & 9 & 9 & 13 \\
\hline $8 / 13$ & $11: 00$ A.M. & & 24 & & & Light wind; elear & Wavy & a & 9 & & \\
\hline & 9:00 A.M. & $\begin{array}{l}\text { Air } \\
\text { Water }\end{array}$ & $\begin{array}{l}22.5 \\
23.5\end{array}$ & 23.5 & $\left\{\begin{array}{l}24 \\
24\end{array}\right.$ & Breeze; hazy & Ripply & a & 9 & 9 & 13 \\
\hline $8 / 20$ & $11: 30$ A.M. & $\begin{array}{l}\text { Air } \\
\text { Water }\end{array}$ & $\begin{array}{l}32.5 \\
26\end{array}$ & & & Breeze; hazy & Ripply & a & 9 & & \\
\hline $8 / 23$ & 8:10 A.M. & $\begin{array}{l}\text { Air } \\
\text { Water }\end{array}$ & $\begin{array}{l}33 \\
25\end{array}$ & $\begin{array}{l}29 \\
24.5\end{array}$ & $\begin{array}{l}32.5 \\
25\end{array}$ & Breeze; hazy & Ripply & a & 9 & 8 & 13 \\
\hline $8 / 27$ & $11: 00$ A.M. & $\begin{array}{l}\text { Air } \\
\text { Water }\end{array}$ & $\begin{array}{l}32.5 \\
27\end{array}$ & & & No wind; eloudy & Smooth & $\mathrm{a}$ & 9 & & \\
\hline $\mathrm{s} / 30$ & $8: 45$ A.M. & $\begin{array}{l}\text { Air } \\
\text { Water }\end{array}$ & $\begin{array}{l}33 \\
28\end{array}$ & $\begin{array}{l}30.5 \\
26\end{array}$ & $\begin{array}{l}31.5 \\
27\end{array}$ & Breeze; hazy & Ripply & a & 9 & 8 & 13 \\
\hline $9 / 2$ & $12: 00 \mathrm{M}$ & $\begin{array}{l}\text { Air } \\
\text { Water }\end{array}$ & $\begin{array}{l}24 \\
26.5\end{array}$ & & & Breeze; part cloudy & Ripply & a & 9 & & \\
\hline & 9:15 A.M. & $\begin{array}{l}\text { Air } \\
\text { Water }\end{array}$ & $\begin{array}{l}30 \\
26\end{array}$ & $\begin{array}{ll}26 & 5 \\
24 & \end{array}$ & $27 \cdot 5$ & Breeze; hazy & Ripply & a & 9 & 8 & 13 \\
\hline $9 / 9$ & $12: 40$ P.M. & $\begin{array}{l}\text { Air } \\
\text { Water }\end{array}$ & $\begin{array}{l}28 \\
26\end{array}$ & & & Breeze; hazy & Ripply & a & 9 & & \\
\hline $9 / 13$ & 9:00 A.M. & $\begin{array}{l}\text { Air } \\
\text { WTater }\end{array}$ & $\begin{array}{l}24.5 \\
25\end{array}$ & $\begin{array}{l}21 \\
23.5\end{array}$ & 23 & Breeze; elear & Ripply & a & 9 & 9 & 13 \\
\hline $9 / 17$ & 5:00 P.M. & $\begin{array}{l}\text { Air } \\
\text { Wrater }\end{array}$ & $\begin{array}{l}33.5 \\
27\end{array}$ & & & No wind; elear & Smooth & a & 9 & & \\
\hline $9 / 20$ & $9: 00$ A.M. & $\begin{array}{l}\text { Air } \\
\text { Water }\end{array}$ & $\begin{array}{l}23.5 \\
26\end{array}$ & $\begin{array}{l}22.5 \\
23.5\end{array}$ & 23 & Breeze; eloudy & Ripply & a & 9 & 9 & 13 \\
\hline $9 / 24$ & 5:00 P.M. & $\begin{array}{l}\text { Air } \\
\text { Water }\end{array}$ & $\begin{array}{l}24.5 \\
22.5\end{array}$ & & & Breeze; elear & Ripply & a & 9 & & \\
\hline $9 / 27$ & 7:30 A.M. & $\begin{array}{l}\text { Air } \\
\text { Water }\end{array}$ & $\begin{array}{l}23.5 \\
22\end{array}$ & $\begin{array}{l}21.5 \\
20.5\end{array}$ & 20.5 & Breeze; elear & Ripply & $a$ & 9 & 9 & 13 \\
\hline $10 / 1$ & 4:15 P.M. & $\begin{array}{l}\text { Air } \\
\text { Water }\end{array}$ & $\begin{array}{l}29 \\
22\end{array}$ & & & Breeze; clear & Ripply & a & 9 & & \\
\hline $10 / 4$ & S:00 A.M. & $\begin{array}{l}\text { Air } \\
\text { Water }\end{array}$ & 20 & $\begin{array}{l}19 \\
20\end{array}$ & $\begin{array}{l}17 \\
20\end{array}$ & Breeze; elear & Ripply & a & 9 & 7 & 13 \\
\hline $10 / 8$ & 5:00 P.M. & $\begin{array}{l}\text { Air } \\
\text { Water }\end{array}$ & $\begin{array}{l}18.5 \\
19 \\
19\end{array}$ & & & Wind; clear & Choppy & a & 9 & & \\
\hline $10 / 11$ & 7:00 A.MI & $\begin{array}{l}\text { Air } \\
\text { Water }\end{array}$ & $\begin{array}{l}22 \\
19.5\end{array}$ & $\frac{21}{17} \cdot 5$ & $\begin{array}{l}14 \\
17\end{array}$ & No wind; elear & Sinooth & a & 9 & S & 13 \\
\hline $10 / 15$ & 5:00 Р.u. & $\begin{array}{l}\text { Air } \\
\text { Water }\end{array}$ & $\begin{array}{l}21 \\
18.5\end{array}$ & & & No wind; clear & Smooth & a & 9 & & \\
\hline $10 / 18$ & S:00 A.M. & $\begin{array}{l}\text { Air } \\
\text { Water }\end{array}$ & $\begin{array}{l}23.5 \\
19\end{array}$ & $\begin{array}{l}19.5 \\
17.5 \\
\end{array}$ & $\begin{array}{l}19 \\
17\end{array}$ & No wind; elear & Smooth & a & 9 & S & 13 \\
\hline
\end{tabular}


TABLE: $7 .-($ Conduded $)$

\begin{tabular}{|c|c|c|c|c|c|c|c|c|c|c|c|}
\hline \multirow{2}{*}{$\begin{array}{l}\text { Date } \\
1913\end{array}$} & \multirow{2}{*}{$\begin{array}{l}\text { Time of } \\
\text { first } \\
\text { collection }\end{array}$} & \multicolumn{4}{|c|}{$\begin{array}{l}\text { Temperature } \\
\text { centigrade }\end{array}$} & \multirow{2}{*}{$\begin{array}{l}\text { Air } \\
\text { conditions }\end{array}$} & \multirow{2}{*}{$\begin{array}{l}\text { Winter } \\
\text { conditions }\end{array}$} & \multirow{2}{*}{$\begin{array}{c}\text { Auchor } \\
\text { or } \\
\text { drift }\end{array}$} & \multicolumn{3}{|c|}{$\begin{array}{l}\text { Number } \\
\text { of hauls }\end{array}$} \\
\hline & & & I & II & III & & & & I & II & III \\
\hline $10 / 22$ & 5:00 P.u. & $\begin{array}{l}\text { Air } \\
\text { Water }\end{array}$ & $\begin{array}{l}25 \\
20\end{array}$ & & & No wind; clear & Smooth & ¿ & 9 & & \\
\hline $10 / 26$ & 2:00 р.и. & $\operatorname{lir}_{W_{\text {ittor }}}$ & $\begin{array}{l}2.2 .5 \\
19\end{array}$ & 27 & 24 & Hrecze; clear & Ripply & d & 9 & 9 & 13 \\
\hline $10 / 29$ & $4: 30$ 1.... & $\begin{array}{l}\text { Air } \\
\text { Whater }\end{array}$ & $\begin{array}{l}16 \\
19\end{array}$ & & & Breeze; cloudy & Ripply & a & 9 & & \\
\hline $11 / 2$ & $10: 00$ A.M. & & $\begin{array}{l}19 \\
19,5\end{array}$ & 19.5 & $\begin{array}{l}17.5 \\
17\end{array}$ & No wind; cloudy & Simooth & $\mathbf{a}$ & 9 & 9 & 13 \\
\hline $11 / 5$ & $4: 30$ P.Mr. & $\begin{array}{l}\text { Air } \\
\text { Water }\end{array}$ & 17.5 & & & No wind; cloudy & smooth & a & 9 & & \\
\hline $11 / 8$ & $10: 00$ A.M. & Air & $\begin{array}{l}20 \\
19\end{array}$ & 17 & $\frac{18}{17}$ & No wind; cloudy & Sinooth & a & 9 & 9 & 19 \\
\hline $11 / 12$ & $4: 45$ P...1. & $\begin{array}{l}\text { dir } \\
\text { IVater }\end{array}$ & 13.5 & & & Wind; cloudy & Choppy & a & 9 & & \\
\hline $11 / 15$ & S: 45 A.M. & $\begin{array}{l}\text { Air } \\
\text { Water }\end{array}$ & 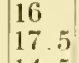 & 12 & $\begin{array}{l}13 \\
15\end{array}$ & No wind; fog & Sinooth & at & 9 & 9 & 13 \\
\hline $11 \quad 19$ & $5: 45$ P...1 & $\begin{array}{l}\text { Air } \\
\text { Water }\end{array}$ & $\begin{array}{l}145 \\
16\end{array}$ & & & Wind; cloudy & Choppy & : & 13 & & \\
\hline $11 / 22$ & $11: 00$ A.M. & $\begin{array}{l}\text { Nir } \\
\text { Water }\end{array}$ & $\begin{array}{l}15 \\
15\end{array}$ & $\begin{array}{l}13 \\
12\end{array}$ & $\begin{array}{l}12.5 \\
13\end{array}$ & Breeze; clear & Ripuly & $a$ & 9 & 9 & 13 \\
\hline $11 / 26$ & $7: 30$ A.M. & & $\begin{array}{r}9 \\
13\end{array}$ & & & No wind; cloudy & Smooth & $a$ & 9 & & \\
\hline $11 / 30$ & 1:00 P.M. & $\begin{array}{l}\text { Air } \\
\text { Water }\end{array}$ & $\begin{array}{l}13 \\
13\end{array}$ & $\begin{array}{l}14 \\
10\end{array}$ & 13 & Wind; cloar & Choppy & at & 12 & 9 & 13 \\
\hline & $4: 45$ P.M. & $\begin{array}{l}\text { Air } \\
\text { Water }\end{array}$ & $\begin{array}{l}14 \\
10\end{array}$ & & & No wind; clear & Smooth & $a$ & 13 & & \\
\hline $12 / 6$ & $11: 00$ A.M. & $\begin{array}{l}\text { Air } \\
\text { wilter }\end{array}$ & 11 & $\begin{array}{l}4.5 \\
7.5\end{array}$ & $\begin{array}{l}6 \\
5\end{array}$ & No wind; fog & Smooth & ia & 9 & 8 & 13 \\
\hline$[2 / 10$ & $4: 30$ P.M. & & $\begin{array}{c}8 \\
9 \\
13\end{array}$ & & & No wind; fog & Smooth & $\mathrm{a}$ & 7 & & \\
\hline $12 / 1+$ & $11: 00$ A.M. & $\begin{array}{l}\text { Air } \\
\text { liviter }\end{array}$ & $\begin{array}{l}13.5 \\
12\end{array}$ & $\begin{array}{r}14 \\
9\end{array}$ & $\begin{array}{c}14 \\
95\end{array}$ & Wind; clenr & Choply & it & 12 & 7 & 16 \\
\hline $12 / 17$ & $4: 30$ P.M. & $\begin{array}{l}\text { Air } \\
\text { IIter }\end{array}$ & $\begin{array}{l}10 \\
12\end{array}$ & & & No wind; cloudy & Snooth & a & 7 & & \\
\hline $12 / 20$ & $2: 00$ r.... & $\begin{array}{l}\text { Air } \\
\text { Water }\end{array}$ & $\begin{array}{c}9 \\
11.5\end{array}$ & $\begin{array}{l}9.5 \\
8.5\end{array}$ & $\begin{array}{l}9.5 \\
9\end{array}$ & No wind; cloudy & Smooth & $a$ & 9 & 7 & 17 \\
\hline $12 / 24$ & 2:00 P.... & $\begin{array}{l}\text { Air } \\
\text { WVater }\end{array}$ & $\begin{array}{l}12 \\
13\end{array}$ & & & Light wind; cloudy & $\mathrm{W}_{\mathrm{ary}}$ & a & 7 & & \\
\hline $12 / 27$ & $10: 00$ A.s. & $\begin{array}{l}\text { Air } \\
\text { IViter }\end{array}$ & $\begin{array}{c}9 \\
11.5\end{array}$ & $\begin{array}{l}9.5 \\
9\end{array}$ & $\begin{array}{l}9 \\
9\end{array}$ & Light wind; cloudy & Wayy & a & 9 & 7 & 13 \\
\hline $12 / 31$ & $11: 00$ A.M. & $\begin{array}{l}\text { Air } \\
\text { Viater }\end{array}$ & $\begin{array}{l}16 \\
11.5\end{array}$ & & & High wind ; cloudy & Rough & a & 9 & & \\
\hline \multicolumn{2}{|c|}{$\begin{array}{c}\text { Average for } \\
\text { the year }\end{array}$} & $\begin{array}{l}\text { Air } \\
\text { Wiater }\end{array}$ & $\begin{array}{l}20.6 \\
19 \\
\end{array}$ & $\begin{array}{l}19.5 \\
16.7\end{array}$ & $\begin{array}{l}19.6 \\
17.3 \\
\end{array}$ & & & & & & \\
\hline
\end{tabular}


Table S.-Daily Collections Station I

\begin{tabular}{|c|c|c|c|c|c|c|c|}
\hline $\begin{array}{l}\text { Date } \\
1913\end{array}$ & $\begin{array}{l}\text { Time } \\
\text { of first } \\
\text { eollection }\end{array}$ & $\begin{array}{r}\text { Temper } \\
\text { centig }\end{array}$ & & $\begin{array}{l}\text { Air } \\
\text { conditions }\end{array}$ & $\begin{array}{l}\text { Water } \\
\text { conditions }\end{array}$ & $\begin{array}{c}\text { Anehor } \\
\text { or } \\
\text { drift }\end{array}$ & $\begin{array}{c}\text { Number } \\
\text { of } \\
\text { hauls }\end{array}$ \\
\hline $7 / 5$ & $11: 20$ A.M. & $\begin{array}{l}\text { Air } \\
\text { Water }\end{array}$ & $\begin{array}{l}32 \\
26\end{array}$ & No wind; hazy & Smooth & $d$ & 9 \\
\hline $7 / 6$ & $9: 30$ A.M. & $\begin{array}{l}\text { Air } \\
\text { Water }\end{array}$ & $\begin{array}{l}32.5 \\
26\end{array}$ & No wind; elear & Simooth & d & 9 \\
\hline $7 / 7$ & S:30 A.M. & $\begin{array}{l}\text { Air } \\
\text { Water }\end{array}$ & $\begin{array}{l}29.5 \\
26\end{array}$ & Breeze; clear & Ripply & d & 9 \\
\hline $7 / 8$ & $1: 30$ Р...1. & $\begin{array}{l}\text { Air } \\
\text { Water }\end{array}$ & $\begin{array}{l}34.5 \\
27\end{array}$ & Wind; hazy & Choppy & d & 9 \\
\hline $7 / 9$ & $10: 30$ A.M. & $\begin{array}{l}\text { dir } \\
\text { Water }\end{array}$ & $\begin{array}{l}31 \\
26\end{array}$ & Light wind; elear & Wavy & d & 9 \\
\hline $7 / 10$ & $10: 45$ A.M. & $\begin{array}{l}\text { Air } \\
\text { llater }\end{array}$ & $\begin{array}{l}32 \\
26\end{array}$ & Wind; hazy & Choppy & d & 9 \\
\hline $7 / 11$ & $10: 45$ A.M. & $\begin{array}{l}\text { Air } \\
\text { WTater }\end{array}$ & $\begin{array}{l}35 \\
26.5\end{array}$ & Breeze; clear & Ripply & d & 9 \\
\hline $7 / 12$ & $10: 55$ A.M. & $\begin{array}{l}\text { Air } \\
\text { Water }\end{array}$ & $\begin{array}{l}32 \\
27\end{array}$ & No wind; elear & Smooth & d & 9 \\
\hline $7 / 13$ & 12:00 M. & $\begin{array}{l}\text { Air } \\
\text { Water }\end{array}$ & $\begin{array}{l}29.5 \\
27\end{array}$ & Wind; elear & Choppy & d & 12 \\
\hline $7 / 14$ & $10: 30$ A.M. & $\begin{array}{l}\text { Air } \\
\text { Water }\end{array}$ & $\begin{array}{l}26 \\
26\end{array}$ & So wind; elear & Smooth & d & 9 \\
\hline $7 / 15$ & $10: 45$ A.M. & $\begin{array}{l}\text { Air } \\
\text { Water }\end{array}$ & $\begin{array}{l}25.5 \\
26\end{array}$ & No wind; elear & Smooth & d & 10 \\
\hline $7 / 16$ & 10:45 A.MI. & $\begin{array}{l}\text { Air } \\
\text { Water }\end{array}$ & $\begin{array}{l}28 \\
26\end{array}$ & Breeze; elear & Ripply & a & 9 \\
\hline $7 / 17$ & $10: 45$ A.M. & $\begin{array}{l}\text { Air } \\
\mathbb{W}^{\mathrm{T}} \mathrm{ater}\end{array}$ & $\begin{array}{ll}30 & 5 \\
26 & \end{array}$ & Breeze; clear & Ripply & a & 10 \\
\hline $7 / 18$ & 2:00 P.M. & $\begin{array}{l}\text { Air } \\
\text { Water }\end{array}$ & $\begin{array}{l}32 \\
26.5\end{array}$ & Breeze; part cloudy & Ripply & a & 13 \\
\hline $7 / 19$ & $11: 50$ A.M. & $\begin{array}{l}\text { Air } \\
\text { Water }\end{array}$ & $\begin{array}{l}29 \\
27\end{array}$ & Breeze; hazy & Ripply & a & 9 \\
\hline $7 / 20$ & $10: 00$ A.M. & $\begin{array}{l}\text { Air } \\
\text { Water }\end{array}$ & $\begin{array}{l}26 \\
26\end{array}$ & Breeze; part cloudy & Ripply & $\mathbf{a}$ & 9 \\
\hline $7 / 21$ & $10: 45$ A.M. & $\begin{array}{l}\text { Air } \\
\text { Water }\end{array}$ & $\begin{array}{l}27 \\
26.5\end{array}$ & $\begin{array}{l}\text { No wind; } \\
\text { part eloudy }\end{array}$ & Smooth & a & 9 \\
\hline $7 / 22$ & $10: 30$ A.M. & $\begin{array}{l}\text { Air } \\
\text { Water }\end{array}$ & 23 & No wind; rain & Smooth & a & 13 \\
\hline $7 / 23$ & $10: 30$ A.M. & $\begin{array}{l}\text { Air } \\
\text { Water }\end{array}$ & $\begin{array}{l}27 \\
25\end{array}$ & Breeze; rain & Ripply & a & 9 \\
\hline $7 / 24$ & $10: 30$ A..II. & $\begin{array}{l}\text { Air } \\
\text { Water }\end{array}$ & $\begin{array}{l}26 \\
25.5\end{array}$ & Breeze; hazy & Ripply & at & 9 \\
\hline $7 / 25$ & $11: 30$ A.M. & $\begin{array}{l}\text { Air } \\
\text { Water }\end{array}$ & 24 & Breeze; part cloudy & Ripply & a & 9 \\
\hline $7 / 26$ & $12: 30$ P.M. & $\begin{array}{l}\text { Air } \\
\text { Water }\end{array}$ & $\begin{array}{l}26.5 \\
26\end{array}$ & Breeze; part eloudy: & Ripply & d & 9 \\
\hline $7 / 27$ & $10: 40$ A.11. & $\begin{array}{l}\text { Air } \\
\text { Wiater }\end{array}$ & $\begin{array}{l}2 \pm .5 \\
25\end{array}$ & Breeze; clear & Ripply & a & 13 \\
\hline $7 / 28$ & 10:50 A.M. & $\begin{array}{l}\text { Air } \\
\text { Water }\end{array}$ & 25 & Breeze; hazy & Ripply & a & 9 \\
\hline $7 / 29$ & 10:45 A.य. & $\begin{array}{l}\text { Air } \\
\text { Water }\end{array}$ & 25.5 & Breeze; hazy & Ripply & a & 9 \\
\hline $7 / 30$ & 10:10 A.M. & $\begin{array}{l}\text { Air } \\
\text { Water }\end{array}$ & $\begin{array}{l}27.5 \\
25.5\end{array}$ & Breeze; hazy & Ripply & a & 9 \\
\hline $7 / 31$ & $11: 00$ A.M. & $\begin{array}{l}\text { Air } \\
\text { Water }\end{array}$ & $\begin{array}{l}26.5 \\
26.5\end{array}$ & Breeze; hazy & Ripply & a & 9 \\
\hline $8 / 1$ & $11: 00$ A.M. & $\begin{array}{l}\text { Air } \\
\text { Water }\end{array}$ & $\begin{array}{l}24.5 \\
26\end{array}$ & Breeze; part eloudy & Ripply & a & 9 \\
\hline $8 / 2$ & $11: 07$ A.M. & $\begin{array}{l}\text { Air } \\
\text { Water }\end{array}$ & 27.5 & No wind; elear & Smooth & a & 9 \\
\hline $8 / 3$ & $10: 50$ A.M. & $\begin{array}{l}\text { Air } \\
\text { Water }\end{array}$ & $\begin{array}{l}28.5 \\
25.5\end{array}$ & Breeze; hazy & Ripply & a & 9 \\
\hline $8 / 4$ & 10:30 A.M. & $\begin{array}{l}\text { Air } \\
\text { Water }\end{array}$ & $\begin{array}{l}27 \\
25.5 \\
\end{array}$ & Breeze; part eloudy & Ripply & a & 9 \\
\hline
\end{tabular}


Tanle 9.-IIourly Collections, Station III $a$

\begin{tabular}{|c|c|c|c|c|c|c|c|}
\hline $\begin{array}{l}\text { Date } \\
1913\end{array}$ & $\begin{array}{l}\text { Time } \\
\text { of first } \\
\text { collection }\end{array}$ & \multicolumn{2}{|c|}{$\begin{array}{l}\text { Temperature } \\
\text { centigrade }\end{array}$} & $\begin{array}{l}\text { Air } \\
\text { conditions }\end{array}$ & $\begin{array}{l}\text { Water } \\
\text { conditions }\end{array}$ & $\begin{array}{l}\text { Anchor } \\
\text { or } \\
\text { drift }\end{array}$ & $\begin{array}{c}\text { Number } \\
\text { of } \\
\text { hauls }\end{array}$ \\
\hline $8 / 11$ & 7:00 A.M. & $\begin{array}{l}\text { Air } \\
\text { Water }\end{array}$ & $\begin{array}{l}19.5 \\
24\end{array}$ & Breeze; hazy & Ripply & d & 6 \\
\hline $8 / 11$ & 8:00 А.м. & $\begin{array}{l}\text { Air } \\
\text { Water }\end{array}$ & $\begin{array}{l}20.5 \\
24.5\end{array}$ & l3reeze; hazy & Ripply & d & 6 \\
\hline $8 / 11$ & $9: 00$ A.s. & $\begin{array}{l}\text { Air } \\
\text { Water }\end{array}$ & 22.5 & light wind; hazy & Wavy & d & 6 \\
\hline $8 / 11$ & $10: 00$ A.M. & $\begin{array}{l}\text { Nir } \\
\text { Water }\end{array}$ & $\begin{array}{l}24 \\
25.5\end{array}$ & light wind; hazy & Wavy & $d$ & 6 \\
\hline $8 / 11$ & $11: 00$ A.s. & & & Light wind; hazy & Wavy & d & 6 \\
\hline $8 / 11$ & $12: 00 \mathrm{Mr}$ & $\begin{array}{l}\text { Air } \\
\text { Water }\end{array}$ & 26 & Light wind; hazy & Wavy & a & 6 \\
\hline $8 / 11$ & 1:00 P.M. & $\begin{array}{l}\text { Air } \\
W^{r} \text { ater }\end{array}$ & $\begin{array}{l}29.5 \\
26\end{array}$ & Wind; hazy & Choppy & a & 6 \\
\hline $8 / 11$ & 2:00 P.MI. & $\mathrm{NW}_{\text {Water }}$ & $\begin{array}{l}29.5 \\
26\end{array}$ & Wind; hazy & Choppy & a & 6 \\
\hline $8 / 11$ & $3: 00$ P.M. & $\begin{array}{l}\text { Air } \\
\text { Water }\end{array}$ & $\begin{array}{l}30 \\
26\end{array}$ & Wind; hazy & Choppy & a & 6 \\
\hline$S / 11$ & 4:00 P.M. & $\begin{array}{l}\text { Air } \\
\text { Water }\end{array}$ & $\begin{array}{l}29.5 \\
26\end{array}$ & High wind; hazy & lough & $\mathrm{a}$ & 6 \\
\hline $8 / 11$ & $5: 00$ P.M. & $\begin{array}{l}\text { Air } \\
\text { Water }\end{array}$ & $\begin{array}{l}26 \\
25.5\end{array}$ & High wind; hazy & lough & a & 6 \\
\hline $8 / 11$ & 5:48 P.M. & $\begin{array}{l}\text { Air } \\
\text { Water }\end{array}$ & $\begin{array}{l}25.5 \\
25.5\end{array}$ & High wind; hazy & Rough & a & 6 \\
\hline $8 / 11$ & 6:40 P.M. & $\begin{array}{l}\text { Air } \\
\text { Water }\end{array}$ & $\begin{array}{l}20.5 \\
25\end{array}$ & High wind; hazy & Rough & $a$. & 6 \\
\hline
\end{tabular}




\section{LITERATURE CITED}

(Owing to lack of time tle writer is unable to present an exhaustive bibliography. Only those references are named in the following list which were most constantly in use, all of them being in the writer's immeliate possession. The writer also made frequent use of the extensive private library of Professor C. A. Kofoicl, as well as the library of the University of California.)

BIRGE, E. A., and JUDAY, C.

1911. The inland lakes of Wisconsin. Wisconsin Survey Bull., no. 22.

Brauer, A.

1912. Süsswasserfauna Deutschlands. XIV, Rotatoria and Gastrotricha, Jena.

ChOdAT, R.

1901. Beiträge zur Kryptogamenflora iler Schweiz. Band I, Heft 3. Algues vertes de la Suisse, Berne, Wyss.

Ctapp, W. B., and llenshaw, F. F.

1911. Surface water supply of the United States, 1909. XI, California, U. S. Geol. Surv., Water Supply Paper mo. 271.

Cons, II. IV.

1905. Preliminary report on the Protozoa of the fresh waters of Connecticut. Conn. St. Geol. Nat. Hist. Surv., Bull. no. 2.

Harring, H, K.

1913. Synopsis of the Rotatoria. U. S. Nat. Mus., Bull. no. 81.

HERRICK, C. L.

1895. Entomostraca of Minnesota. Geol. Nat. Hist. Surv. Minn., 2d Rep. St. Zoologist.

Hudson, C. T, and Gosse, P. H.

1589. The Rotifera, or Wheel-aninalcules, both British and foreign. 2 vols. with supplement. London, Longuans.

Tzquierdo $\mathrm{Y}$ SANFUentes, V.

1906. Ensayo sobre los protozoos de las aguas dulces de Chile. Santiago, Cervantes.

JENNINGS, H. S.

1901. Rotatoria of the United States, with special reference to those of the Great Lakes. Bull. U. S. Fish Comm., 19, 1899.

1901. Synopses of North Anerican iuvertebrates. XVII, The Rotatoria. Am. Nat., 35, 795-777.

1904. Rotatoria of the United States. II, Monograph of the Rattulidae, Bull. U. S. Fish Comm., 22, 1902.

KENT, W. S.

1850. Manual of the Infusoria, inclucling a leseription of all known fla gellate, ciliate, aud tentaculiferous Protozoa, British and foreign. 3 vols., Lonilon, Bogue.

KofoId, C. A.

1903. Plankton of the Illinois River, 1894-1899. Bull. 11l. State Lab. Nat.

Hist., 6, no. 2.

1908. Ibid., 8, no. 1 . 
1,EIDY, JOSEPH

1879. Fresh-water rhizopols of North America. U. S. Geol. Surv. Terr., 12. PAScIiER, A.

1913. Süswasserflora Deutschlands, Oesturreichs und Jer Schweiz. Hefte 1-2, Flagellatae; Heft 3, Dinoflagellatae: Heft 9, Zygnenales; Heft 10, Bacillariales. Jena, Fischer.

Pritcifard, i.

1561. A Ilistory of the Infusoria, including the Desmidiaceae and Diatonaceac, British and foreign; ed. 4. London.

REIGIIARD, J. E.

1594. Biological examination of Lake St. Clair. Bull. MFich. Fish Comm., no. 4 .

Schoenicien, W., and Kalbertai, A.

1909. B. Eyferth's Einfachste Lebensformon des Tier-und Ptanzenreiches: el. 4. Braunsehweig, Goeritz.

Stohes, Alfred C.

1557. Mieroscoly for beginners. New Fork, Harper.

Tildex, Josephine

1910. Minnesota Algae. Geol. Nat. Hist. Surv. Minn., Botanical series, 8.

UNited States ENGMEerixg DEPARTMENT

1908. Survey of San Joaquin River, Stoekton Channel, ete. House loe. 1124,60 cong., 2 sess., serial no. 5435.

WARD, II. B.

1597. Biologieal examination of Lake Michigan. Bull. Mich. Fish Comm.. no. 6.

TEBER, E. F.

1895. Faune rotatorienue du bassin du Léman. Rev. suisse Zool., 5, 263-785. 


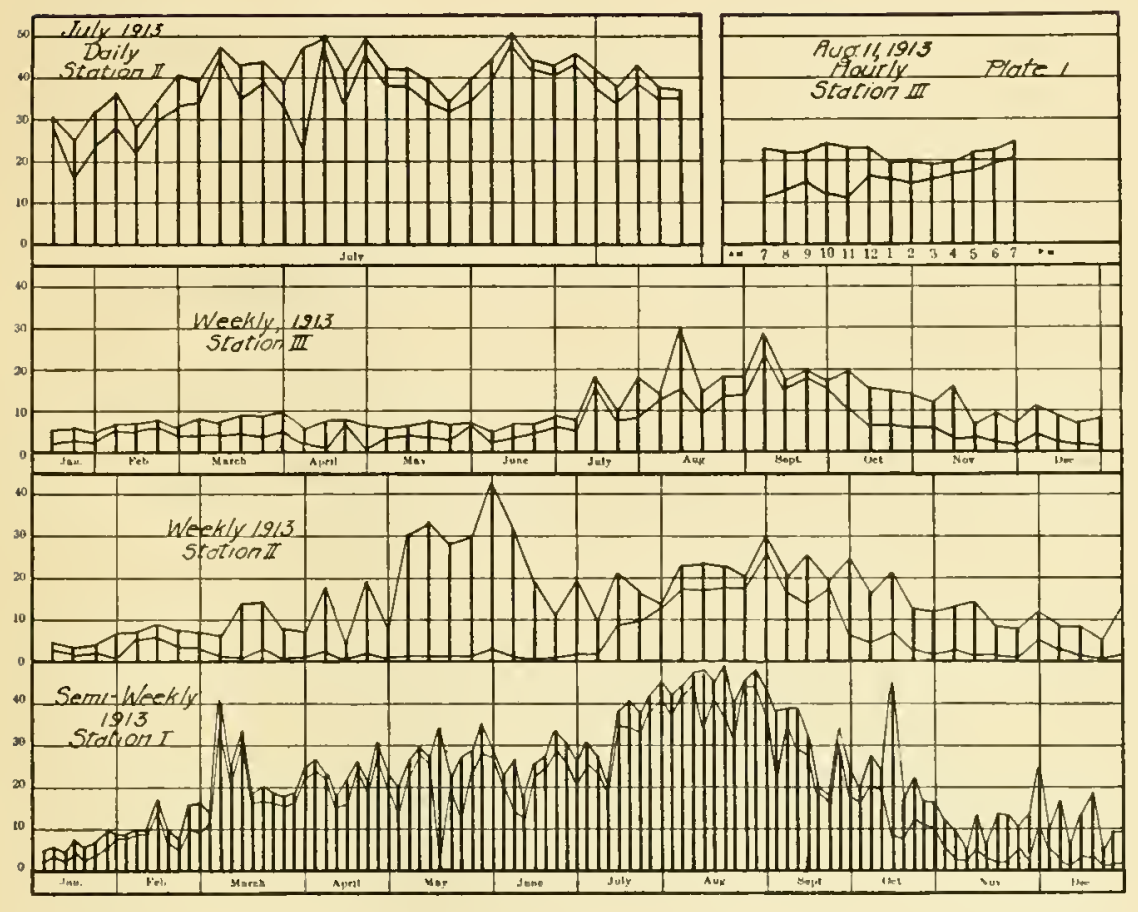





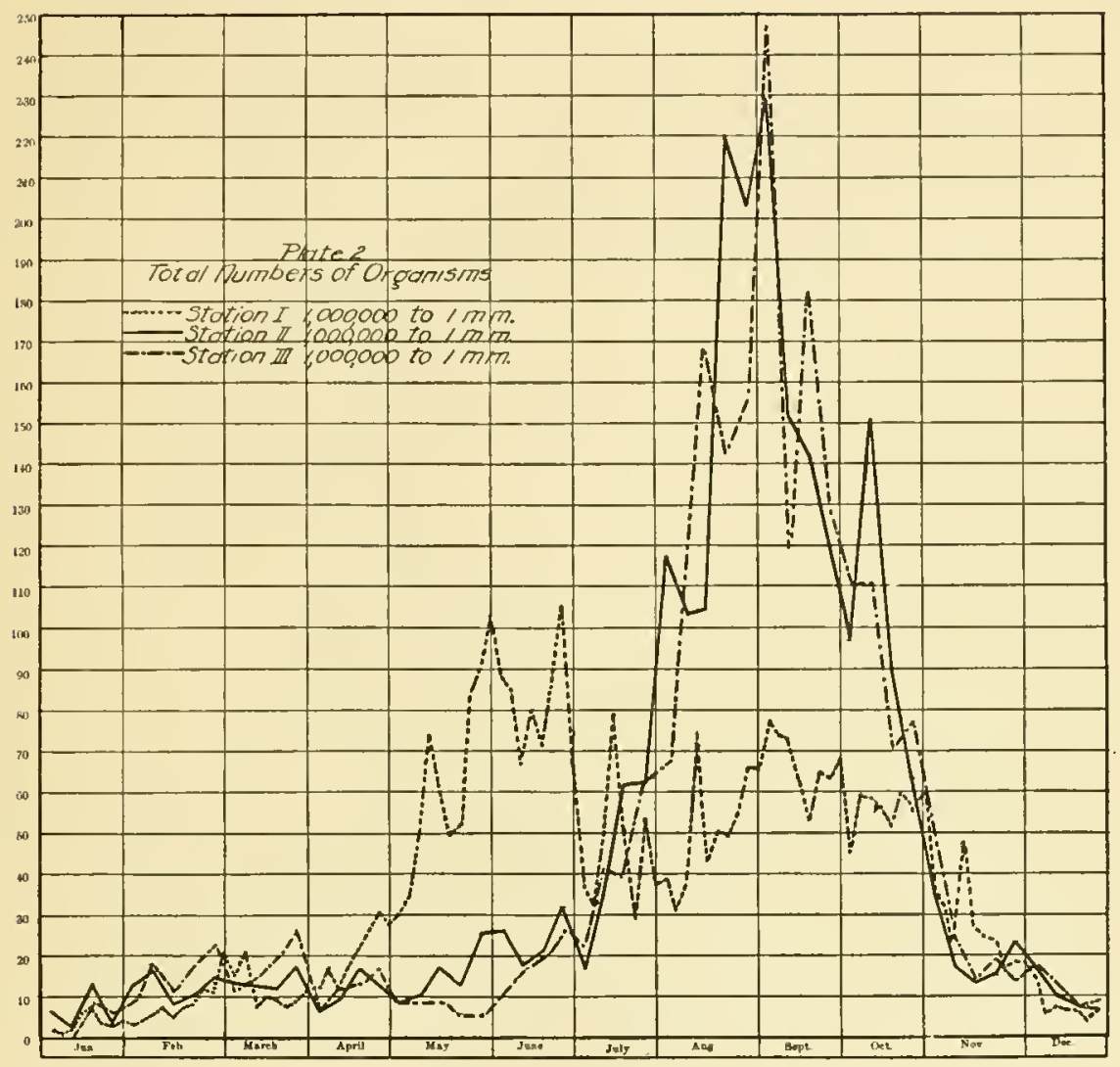





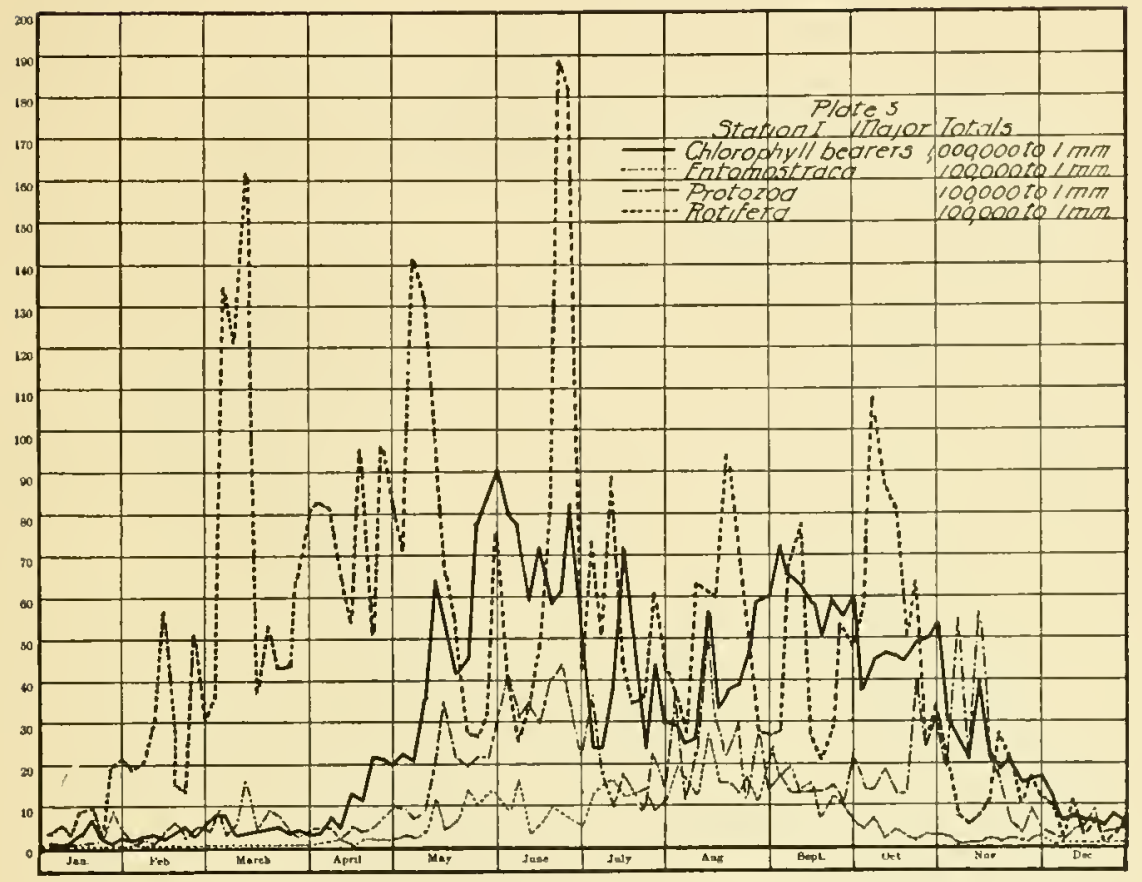





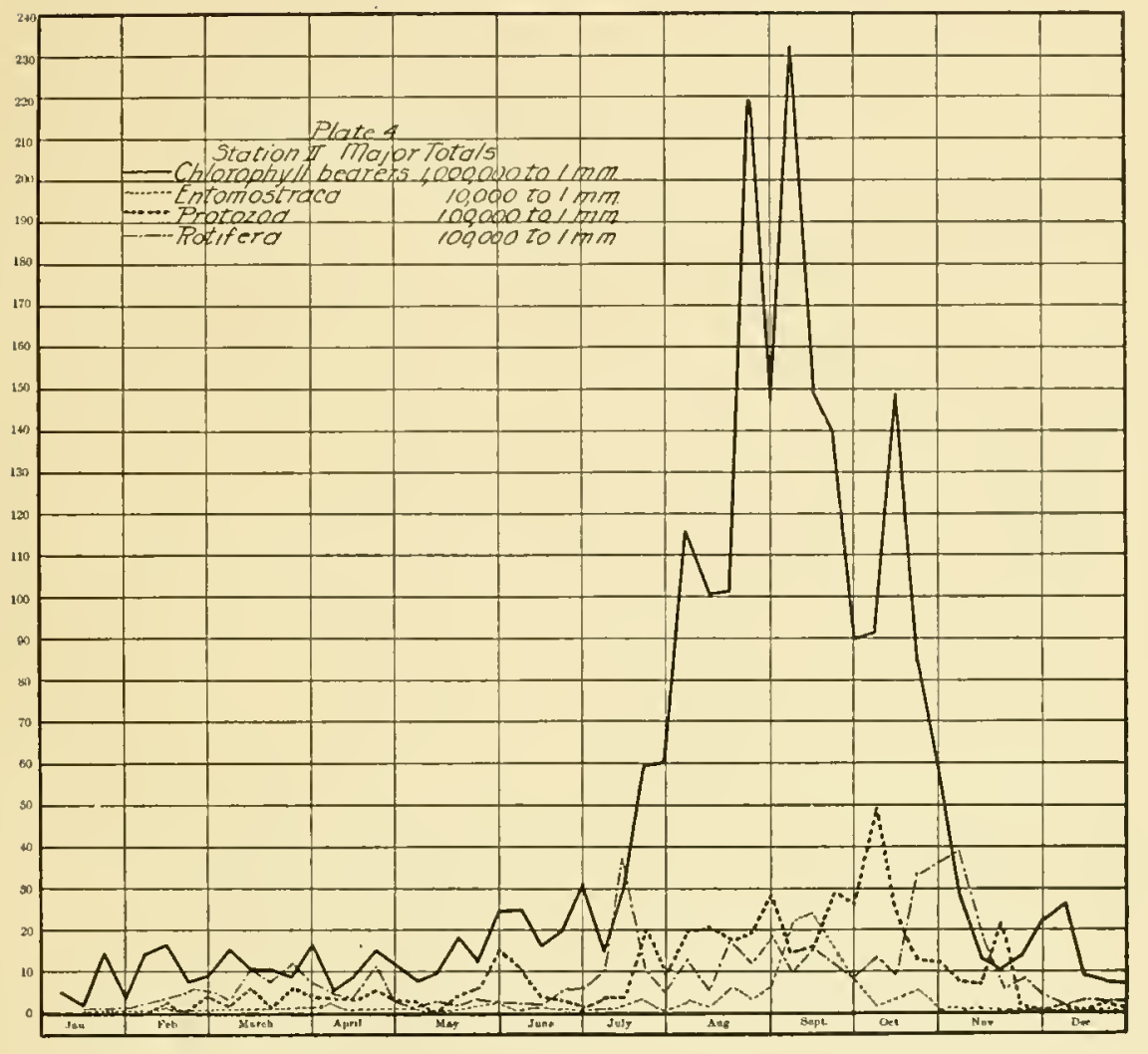





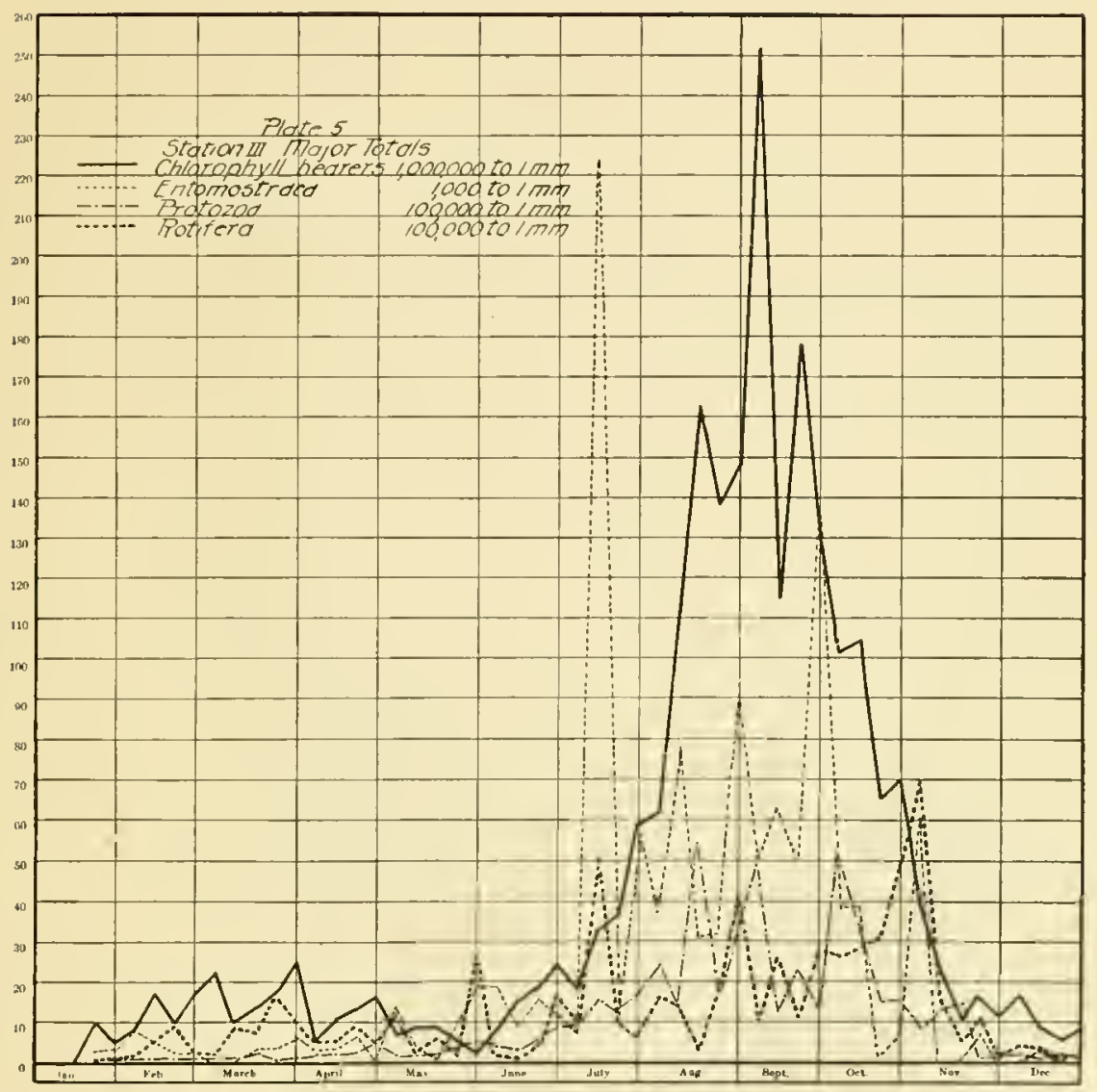





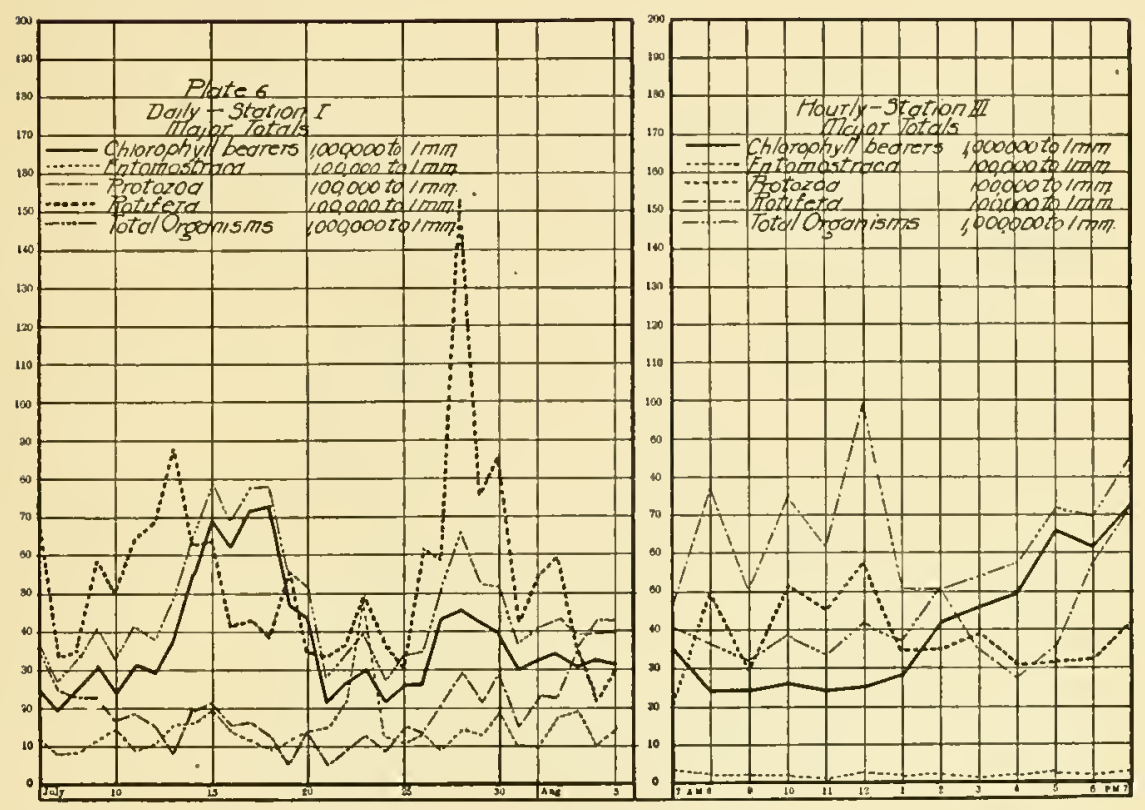



UNIV, CALIF, PUBL, ZOOL, VOL, 22

[ALLEN] PLATE 7

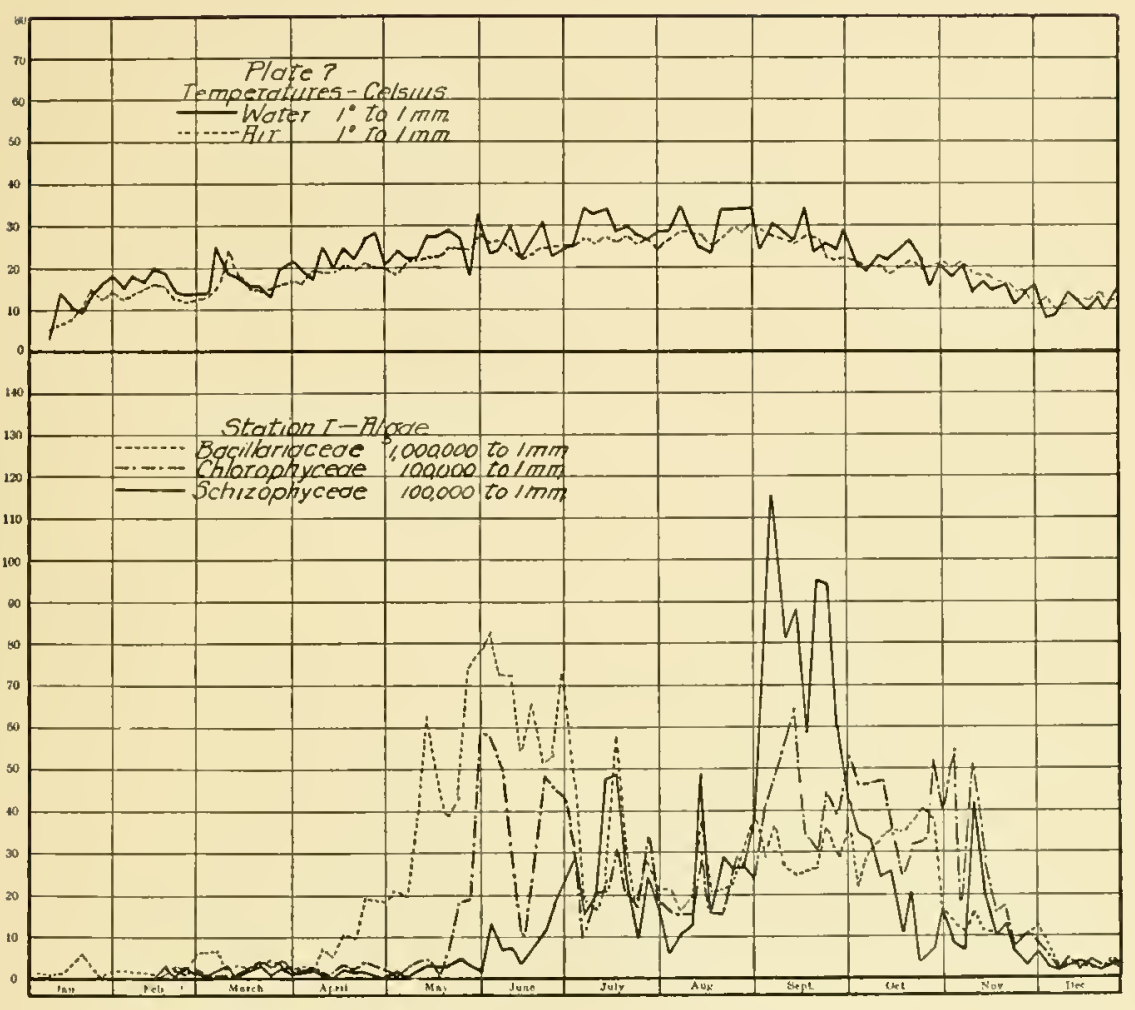





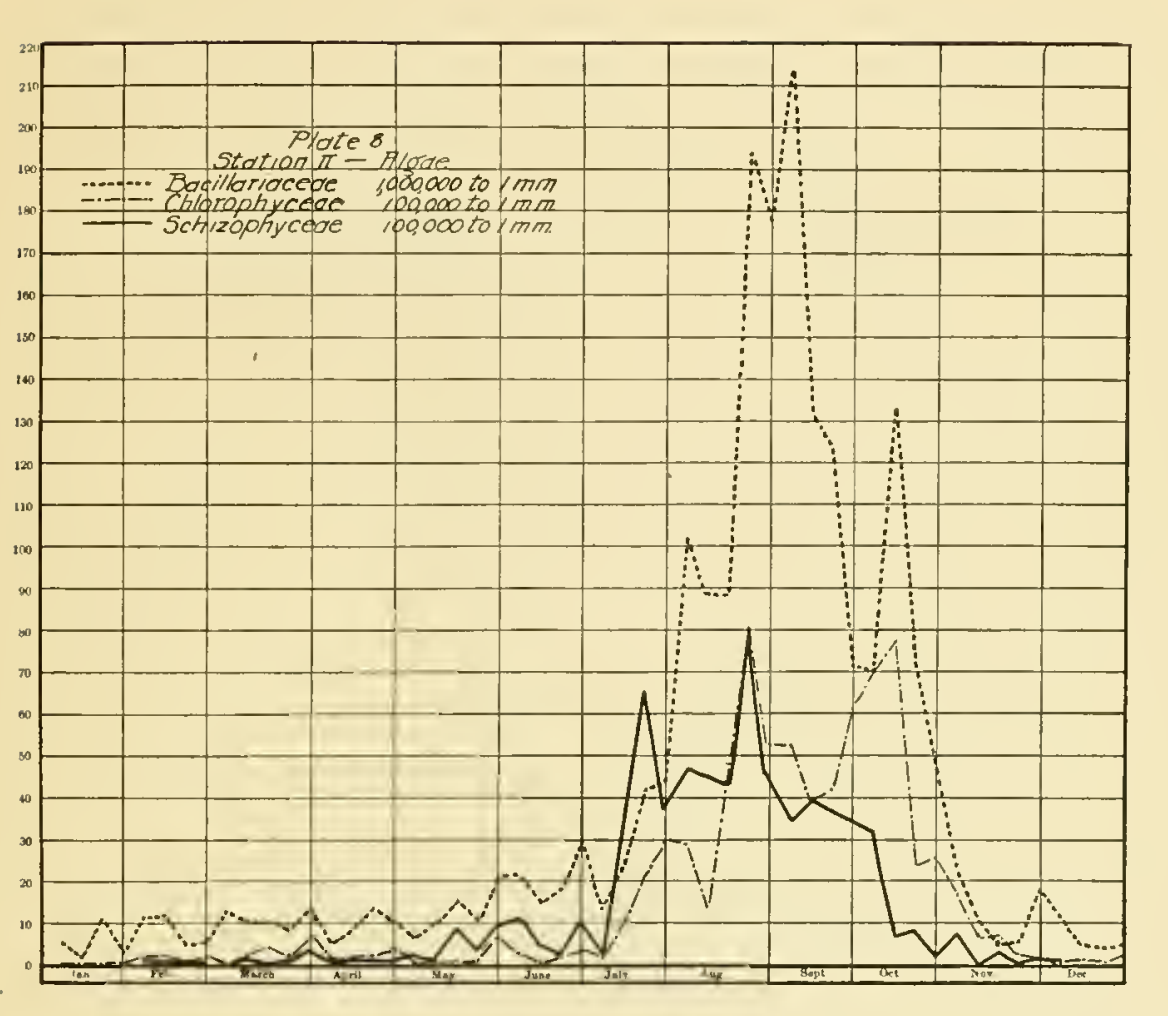





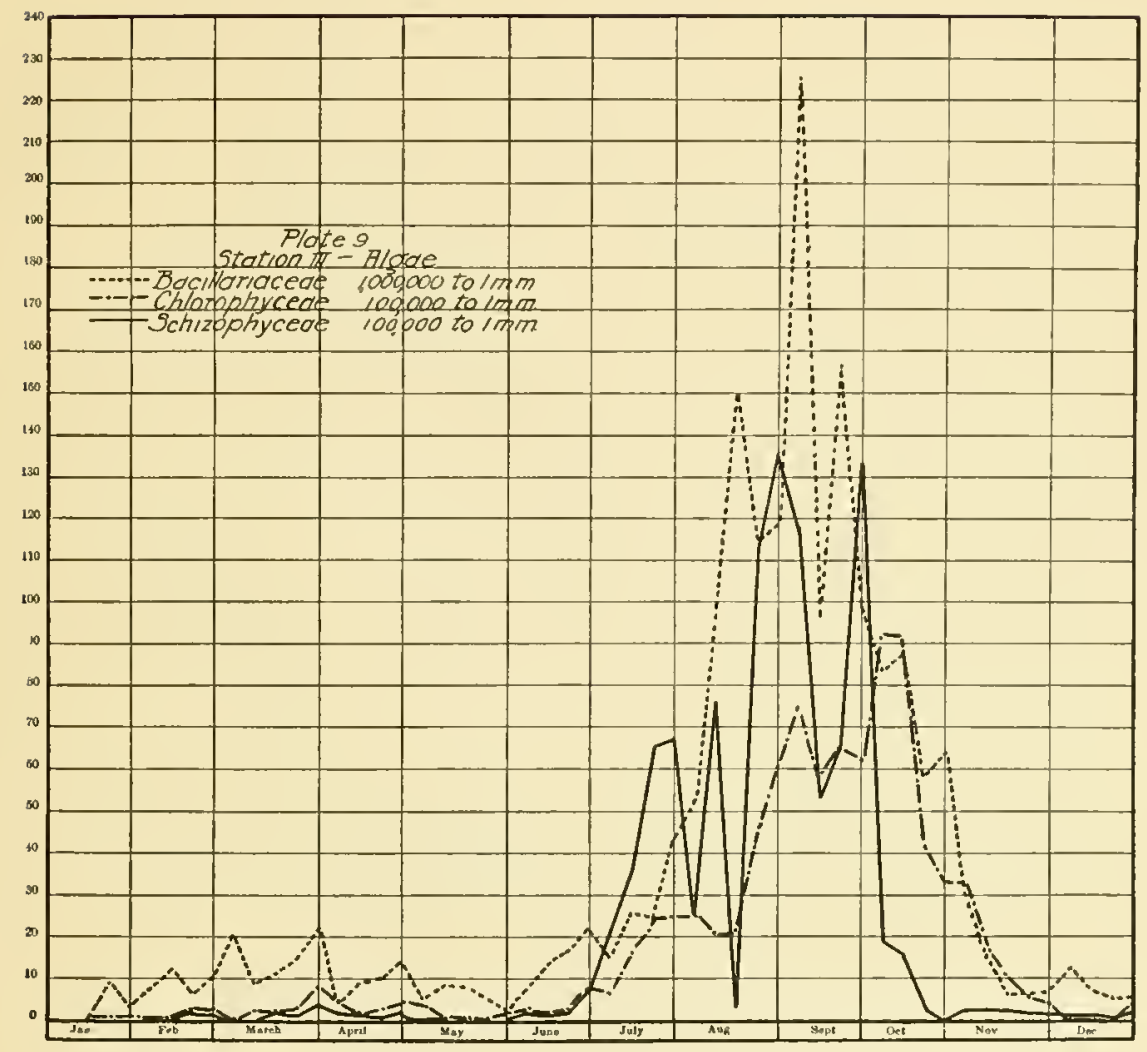





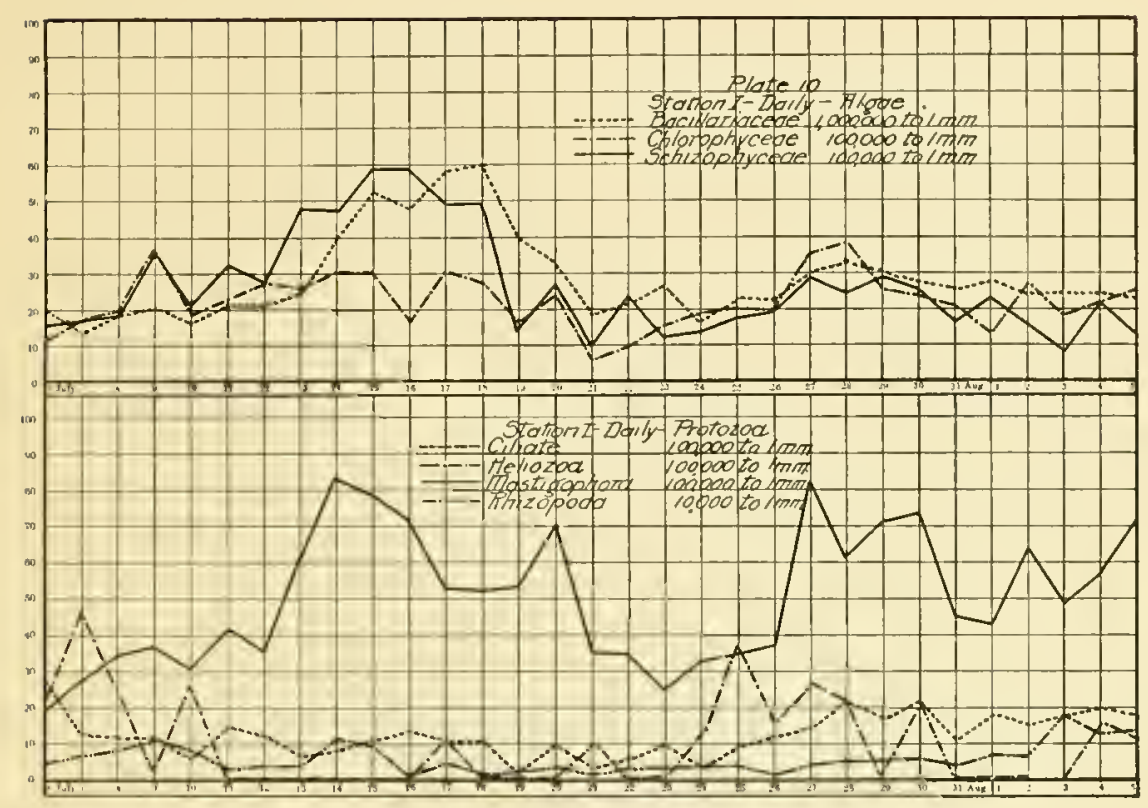





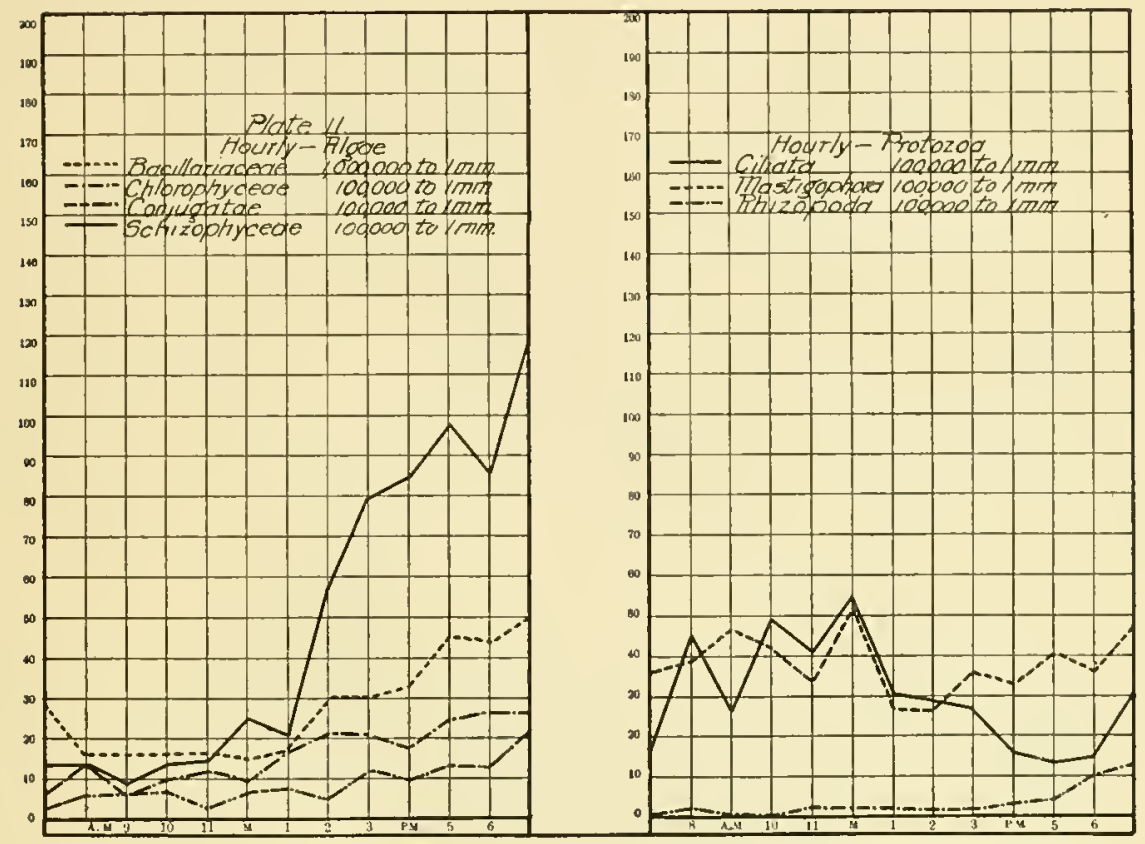





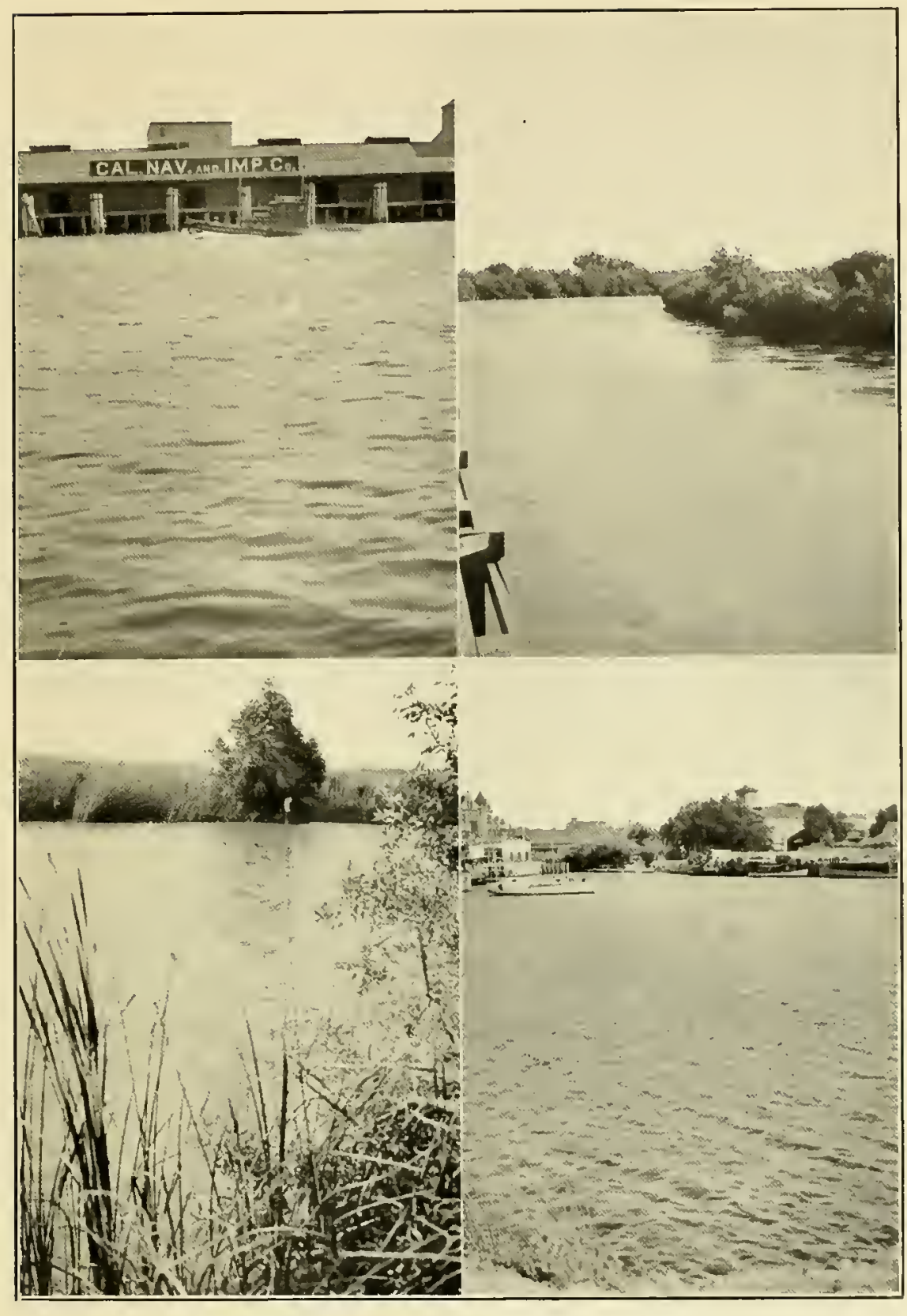

Station III

Station IV

San Joaquin Plankton collecting Stations 

UNIVERSITY OF CALIFORNLA PUBLICATIONS-(Continned)

11. A Study of tre Races of the White-Fronted Goose (Anser albifrons) occurring in California, by $\mathbf{H}$. S. Swarth and HaroId C. Bryant. Pp. 209-222, 2 figures in text, plate 13. October, 1917

12. A Synopsis of the Bats of California, hy Hilda Wood Grinnell. Pp. 223-404, plates 14-24, 24 text figures. January 31, 1918

13. The Pacific Coast Jays of the Genus Aphelocoma, by H. S. Swarth. Pp. 405-422, I figure in text. February 23, 1918

14. Six New Mammais from the Mohave Desert and Inyo Reginns of California, by Joseph Grinnell. Pp. $423-430$.

15. Notes on Some Bats from Alaska and British Columbia, by Hilda Wood Grinuell. Pp. 431-433.

Nos. 14 and 15 in one cover. April, 1918

16. Revision of the Rodent Genus Aplodontia, by Waiter P. Tayior. Pp. 435. 504, piates 25-29, 16 text figures. Maj, 1918

17. The Subspecies of the Mountain Chickadee, by Joseph Grinnell. Pp. 505515, 3 text figures. MaJ, 1918 the Habits of the Animal, hy Charies Lewis Camp. Pp. 517-536, 6 figures in text. June, 1918

Index, pp. 537-545.

Vol. 18. 1. Mitosis in Giardia microti, hy William C. Boeck. Pp. 1-26, piato 1. October, 1917

2. An Unusuai Extension of the Distribution of the Shipworm in San Fran. cisco Bay, California, by Albert L. Barrows. Pp, 27-43. December, 1917.

3. Description of Some New Species of Polynoidae from the Coast of Callfornia, by Christine Essenberg. Pp. 45-60, piates 2-3. October, 1917 ......

4. New Species of Amphinomidae from the Pacific Coast, by Christine Essenberg. Pp. 61-74, piates 4-5. October, 1917

5. Crithidia euryophtholmi, sp. nov., from the Hemipteran Bug, Euryophthalmus convivus Stål, by Irene McCulloch. Pp. 75-88, 35 text figures. December, 1917

6. On the Orientation of Erythropsis, by Charies Atwood Kofold and Olive Swezy. Pp. 89-102, 12 figures in text. December, 1917

7. The Transmission of Nervous Impulses in Reiation to Irocomotion in the Earthworm, by John F. Bovard. Pp. 103-134, 14 figures in text. January, 1918

8. The Function of the Giant Fibers in Earthworns, by John F. Bovard. Pp. 135-144, 1 figure in text. January, 1918

9. A Rapid Method for the Detection of Protozoan Cysts in Mammalian Faeces, hy Willam C. Boeck. Pp. 145-149. December, 1917

10. The Musculature of Heptanchus maculatus, by Pirie Davidson... Pp. 151-170, 12 figures in text. March, 1918

11. The Factors controlling the Distribution of the Polynoidae of the Pacific Coast of North America, by Christine Essenberg. Pp. 171-238, piates 6-8, 2 figures in text. March, 1918....

12. Differentiais in Behavior of the Two Generations of Salpa democratica Relative to the Temperature of the Sea, by Ellis I. MIchael. Pp. 239-298, plates 9-11, 1 figure in text. March, 1918

13. A Quantitative Anaiysis of the Molluscan Fauna of San Francisco Bay, by E. I. Packard. Pp. 299-336, plates 12-13, 6 figs. in text. Aprll, 1918...

14. The Neuromotor Apparatus of Euplotes patella, by Harry B. Yocom. Pp. 337-396, plates 14-16. September, 1918

15. The Significance of Skeletal Variations in the Genus Peridinium, by A. I. Barrows. Pp. 397-478, piates 17-20, 19 figures in text. June, 1918 ............

16. The Subciavian - Vein and its Reiations in Elasmobranch Fishes, by $J$. Frank Daniel. Pp. 479-484, 2 figures in text. August, 1918

17. The Cercaria of the Japanese Blood Fluke, Schistosomn japonicum Katsurada, by William W. Cort. Pp. 485-507, 3 figures in text.

18. Notes on the Eggs and Miracidia of the Human Schistosomes, by William W. Cort. Pp. 509-519, 7 figures in text.

Nos. 17 and 18 in one cover. January, 1919. Index in preparation. 


\section{UNIVERSITY OF CALIFORNLA PUBLICATIONS-(Oontinued)}

Vol. 19. 1. Reaction of Various Plankton Animals with Reference to their Diurnal Migrations, by Oalvin O. Esterly. Pp. 1-83. April, 1919.

2. The Pteropod Desmopterus pacificus (sp. nov.), by Christine Essenberg. Pp. 85-88, 2 figures in text. May, 1919

3. Studies on Giardia microti, by Wlllam C. Boeck. Pp. 85-136, plato 1,18 flgures in text

4. A Comparison of the Life Cycle of Crithidia with that of Trypanosoma in the Invertebrate Host, by Irene McCulloch. Pp. 135-190, plates 2-6, 3 figures in text. October, 1919

5. A Muscid Larva of the San Francisco Bay Region which sucks the Blood of Nestling Birds, by O. E. Plath. Pp. 191-200. February, 1919

6. Binary Fission in Collodictyon triciliatum Carter, by Robert Clinton Rhodes. Pp. 201-274, plates 7-14, 4 figures in text. December, 1919

7. The Excretory System of a Stylet Cercarla, by Wlllam W. Cort. Pp. 275 281, . f figure in text. August, 1919

8. A New Distome from Rana aurora, by William W. Cort. Pp. 283-298, 5 figures in text. November, 1919.

9. The Occurrence of a Rack-Boring Isopod along the Shore of San Francisco Bay, Califormia, by Albert L. Barrows. Pp. 299-316, plates 15-17. December, 1919

10. A New Morphological Interpretation of the Structure of Noctiluca, and its Bearing on the Status of the Cystofiagellata (Haeckel), by Charies A. Kofold. Pp. 317-334, plate 18, 2 figures in text. February, $1920 \ldots . .$.

11. The Life Cycle of Echinostoma revolutum (Froelich), by John C. Johnson. Pp. 338-388, plates 19-25, 1 text figure. May, 1920

.85

.05

.60

.60

.10

1.00

.10

.25

.60 Plymastigote Flagte with a Linear Plasmodial Phase, by Charles Atwood Kofold and Olive Swezy. Pp. 1-20, plates 1-2, 1 figure in text. July, 1919

2. Studies on the Parasites of the Termites. II. On Trichomitus termitidis, a Polymastlgote Flagellate with a Highly Developed Neuromotor System, oy Charles Atwood Kofoid and OLve Swezy. Pp. 21-40, plates 3-4, 2 figures in text. July, 1919

3. Studies on the Parasites of the Termites. III. On Trichonympha campanula Sp. Nov., by Charles Atwood Fofold and Ouve Swezy. Pp. 41-98, plateo 5-12, 4 figures in text. July, 1919

4. Studies on the Parasites of the Termites. IV. On Leidyopsis sphaerica gen. nov., sp. nov., by Charles Atwood Kofold and Olive Swezy. Pp. 99-116, plates 13-14, 1 figure in text. July, 1919.

5. On the Morshology and Mitosis of Chilomastix mesnili (Wenyon), a Common Flagellate of the Human Intestine, by Charles A. Kofoid and Olive Swezy. Pp. 117-144, plates 15-17, 2 figures in text. April, 1920

6. A Critical Review of the Nomenclature of Human Intestinal Flagellates, Cercomonas, Chilomastix, Trichomonas, and Giardia, by Charles A. Kofold. Pp. 145-168, 9 figures in text. June, 1920

Vol. 21. 1. A Revision of the Microtus californicus Group of Meadow Mice, by Rem. ington Kellogg. Pp. 1-42, 1 figure in tost. December, 1918

2. Five Now Five-toed Kangaroo Rats from California, by Joseph Grinnell. Pp. 43-47. March, 1919

3. Notes on the Natural History of the Bushy-Tailed Wood Rats of Callfornia, by Joseph Dixon. Pp. 49-74, plates 1-3, 3 figures in text. Decomber, 1919

4. Revision of the Avian Genus Passerella, with Special Reference to the Distribution and Migration of the Races in Califorwia, by H. S. Swarth. Pp. 75-224, plates 4-7, 30 flgures in text. 1920

5. A Study of the Californta Jumping Mice of the Genus Zapus, by A. Brazter Howell. Pp. 225-238, 1 text figure. May, 1920

Vol. 22. 1. A Quantitative and Statistical Study of the Plankton of the San Joaquin Rlver and its Tributarics in and Near Stockton, California, in 1913, by Winfred Emory Allen. Pp. 1-292, plates 1-12, 1 text figure. July, 1920 

(
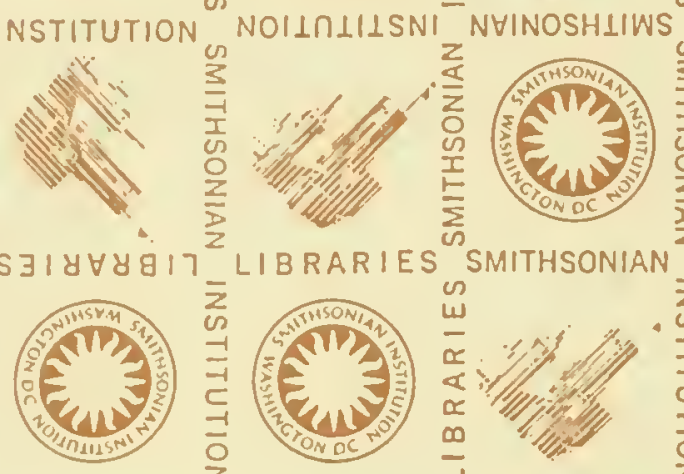

(O)
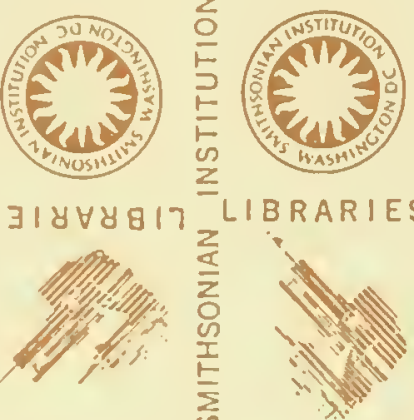

(noner

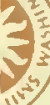
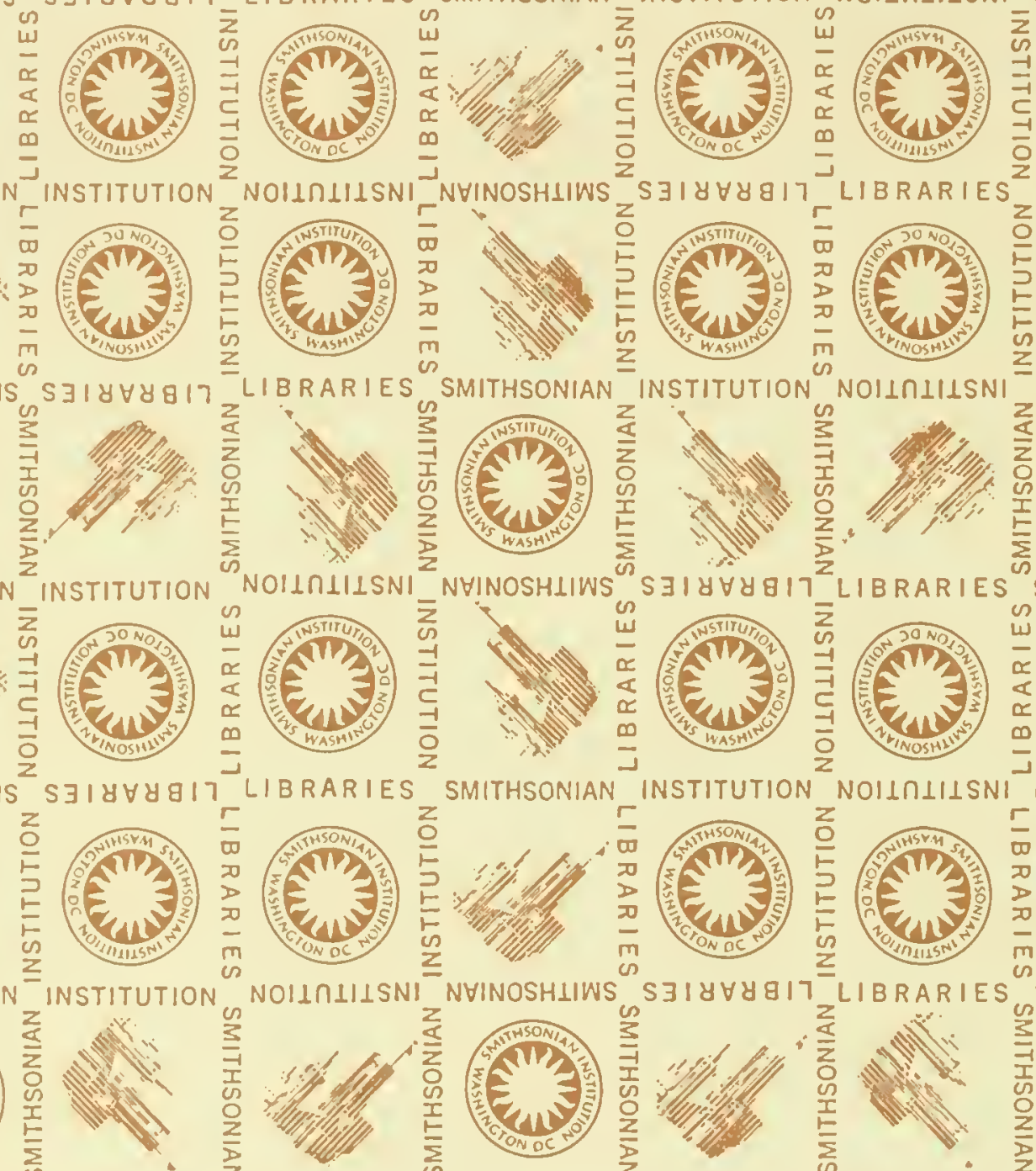
SMITHSONIAN

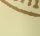

INSTI?

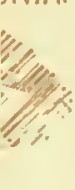

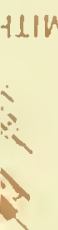
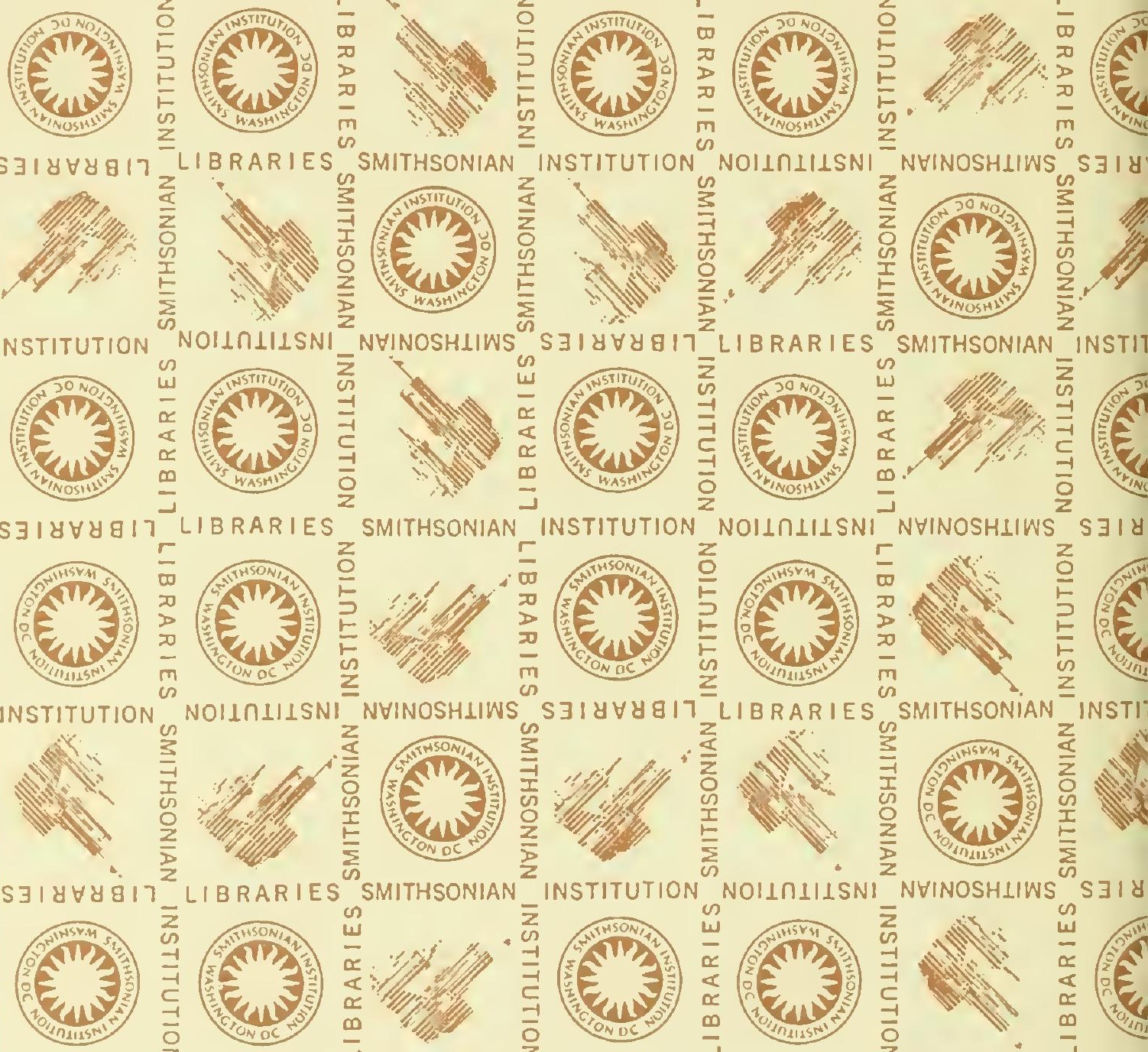

INSTI

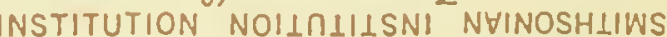

S 318
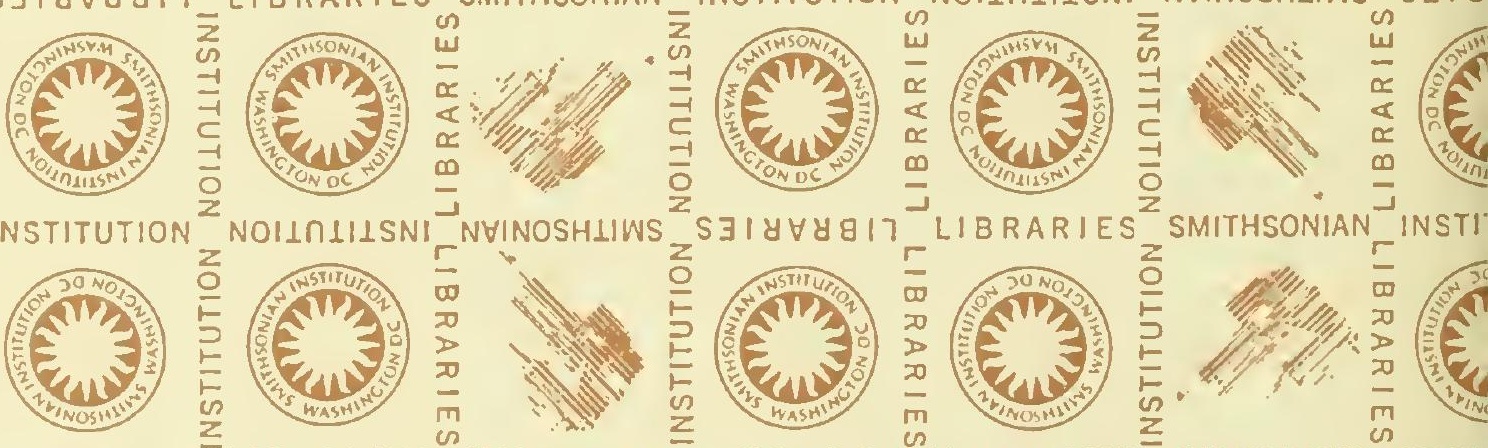

NSTI
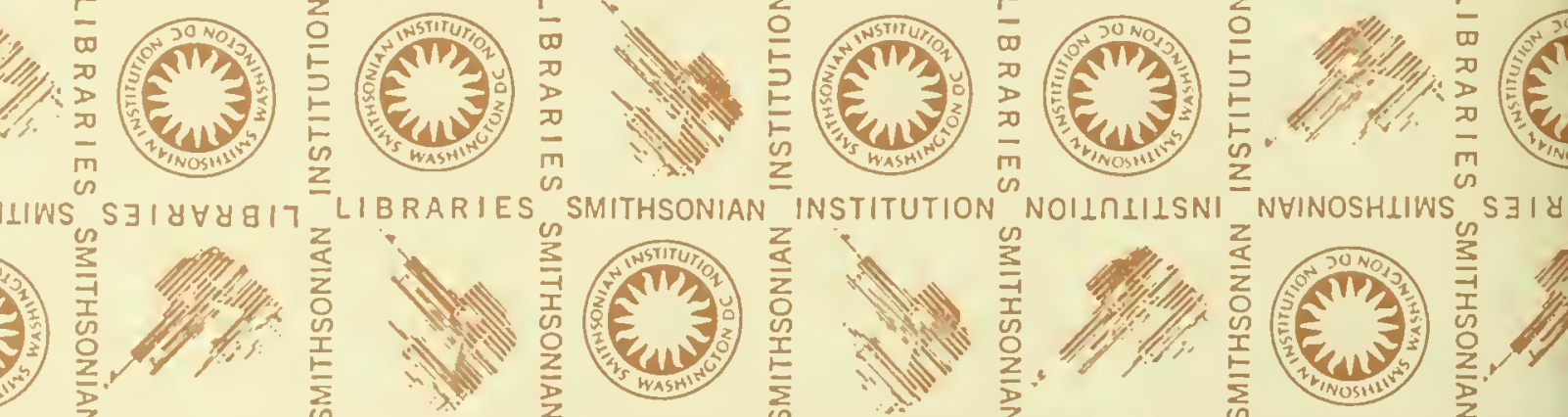

$S$ S $\exists 1$ d

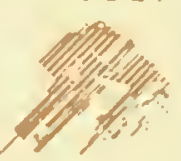


